Urologe $2021 \cdot 60$ (Suppl 1):S6-S114

https://doi.org/10.1007/s00120-021-01626-1

(c) Springer Medizin Verlag GmbH, ein Teil von

Springer Nature 2021

\section{Abstracts des 73. Kongresses der Deutschen Gesellschaft für Urologie e.V.}

\section{V01 - Infektionen und entzündliche Erkrankungen des Harntraks}

15.09.2021, H2, 10:30-12:00

V01.1

Contemporary practice patterns in the treatment of Fournier's gangrene in German academic medicine and their implications for planning a register study

L. Schneidewind ${ }^{1 *}$, J. Kranz ${ }^{2}$, J. Steffens ${ }^{2}$, F. M.E. Wagenlehner ${ }^{3}$, O.W. Hakenberg ${ }^{1}$

'Universitätsmedizin Rostock, Urologische Klinik und Poliklinik, Rostock, Germany; ${ }^{2}$ St.-Antonius Hospital gGmbH, Klinik für Urologie und Kinderurologie, Eschweiler, Germany; ${ }^{3}$ Justus-Liebig-Universität-Gießen, Klinik für Urologie, Kinderurologie und Andrologie, Gießen, Germany

Background and objectives: Fournier's gangrene (FG) is a sporadic and life-threatening disease, but the outcome has not improved in recent years. Primary aim of this study was the description of current practice patterns in German academic medicine. The secondary aim was the identification of factors associated with a higher mortality rate. Furthermore, we attempted to use the data for planning a register study.

Material and methods: A 29-item non-validated questionnaire was sent out to the German University Medical Centers (Dept. of Urology), including three reminders from April until June 2020. Data management and analysis was performed with SPSS 26.0.

Results: The response rate was $88.9 \%$. Median five patients per year with a median age of 60.0 years were treated in German University Medical Centers. The contemporary practice patterns are very heterogenous, especially in terms of empiric antibiotic treatment. Only one significant risk factor for a mortality rate higher than $20.0 \%$ was identified-intensive care treatment for 10 or more days $(p=0.039)$. 50.0\% stated that outcome of FG has not improved over the recent years. Furthermore, the majority of the respondents think that mortality is still too high. Consequently, $84.4 \%$ would support a register study. From open questions we received a variety of suggestions for planning such a study, like histological confirmation of the disease.

Conclusion: The contemporary practice patterns in FG are very heterogenous, but the outcome is still worrisome and the disease is difficult to predict.
V01.2

Vergleichende Analyse der Leitlinienadhärenz zwischen Deutschland und Österreich am Beispiel der unkomplizierten Harnwegsinfektionen

J. Kranz ${ }^{1 * 2,2}$, C. Wiesinger ${ }^{3}$, J. Pfuner ${ }^{3}$, J. Nagler', J. Steffens' ${ }^{1}$, F. Wagenlehner ${ }^{4}$, L. Schneidewind ${ }^{5}$

'St.-Antonius Hospital gGmbH, Klinik für Urologie und Kinderurologie, Eschweiler, Deutschland; ${ }^{2}$ Universitätsklinikum Halle (Saale), Universitätsklinik und Poliklinik für Urologie, Halle, Deutschland; ${ }^{3}$ Klinikum Wels-Grieskirchen $\mathrm{GmbH}$, Abteilung für Urologie, Wels-Grieskirchen, Österreich; ${ }^{4}$ Universitätsklinikum Gießen und Marburg GmbH, Justus-Liebig-Universität Gießen, Klinik und Poliklinik für Urologie, Kinderurologie und Andrologie, Gießen, Deutschland; ${ }^{5}$ Universitätsmedizin Rostock, Urologische Klinik und Poliklinik, Rostock, Deutschland

Einleitung: Unkomplizierte Harnwegsinfektionen zählen den häufigsten ambulanten Infektionen. Da die Entwicklung multiresistenter Erreger ein zunehmendes globales Problem darstellt, ist die Leitlinienadhärenz auf diesem Gebiet besonders relevant. Ziel der Arbeit ist es, mögliche Gründe für eine Abweichung von Leitlinienempfehlungen - im Vergleich zweier benachbarter Länder - zu identifizieren und Lösungsansätze zu definieren.

Material und Methoden: Nach Entwicklung eines 19-Item Fragebogens, der zwischen Arzt- und Patienten-bezogenen Faktoren differenziert, erfolgte der Versand an die Mitglieder der Deutschen und Österreichischen Gesellschaft für Urologie. Nur vollständig ausgefüllte Fragebögen wurden berücksichtigt und analysiert.

Ergebnisse: Insgesamt wurden 563 (D: 307, Ö: 256) Fragebögen analysiert. Zu den Arzt-bezogenen Barrieren der Leitlinienadhärenz zählen vorrangig persönliche Erfahrungen, mangelnde Anwendbarkeit auf den individuellen komplexen Patienten sowie Zeitmangel. Die häufigsten Patienten-bezogenen Faktoren sind die schlechte Erfahrung mit dem empfohlenen Antibiotikum, Angst vor Nebenwirkungen und fehlende Informationen über die Erkrankung und Therapie. Es gab keine signifikanten länderspezifischen Unterschiede. Interessanterweise nutzen die Österreicher neben der deutschen AWMF S3 Leitlinie zu unkomplizierten Harnwegsinfektionen $(52,17 \%)$ zudem überwiegend die europäische Leitlinie zu urologischen Infektionen (58,14\%).

Schlussfolgerung: Die vergleichende Untersuchung der Leitlinienadhärenz bei unkomplizierten Harnwegsinfektionen zwischen Deutschland und Österreich ergibt ein übereinstimmendes Bild. Die Resultate können nun konkret genutzt werden, um die Adhärenz der derzeit in Überarbeitung befindlichen AWMF S3 Leitlinie zu steigern. 
V01.3

Die Bedeutung der Booster Injektion in der Prophylaxe von rezidivierenden Harnwegsinfekten der Frau mittels StroVac

\author{
S. Nestler ${ }^{1 *}$, B. Grüne ${ }^{2}$, L. Schilchegger ${ }^{3}$, A. Suna ${ }^{1}$, A. Neisius ${ }^{4}$ \\ 'UroGate Bad Vilbel, Urologische Praxis, Bad Vilbel, Deutschland; ${ }^{2}$ Universitätsmedi- \\ zin Mannheim, Urologie, Mannheim, Deutschland; ${ }^{3}$ Hochtaunusklinik, Urologie, Bad \\ Homburg, Deutschland; ${ }^{4}$ Krankenhaus der Barmherzigen Brüder Trier, Urologie, Trier, \\ Deutschland
}

Einleitung: Angesichts steigender Resistenzen gegen Antibiotika steigt die Bedeutung nicht-antibiotischer Prophylaktika. StroVac bietet eine effektive Prophylaxe, nach 12 Monaten wird die Injektion eines Boosters empfohlen. Wir haben die Compliance der Patientinnen bezüglich des Boosters sowie die Erfolgsraten mit und ohne Boosterinjektion im zweiten Jahr nach Grundimmunisierung mit StroVac betrachtet.

Material und Methoden: Alle Patientinnen mit einem Follow-up von mindestens 24 Monaten nach StroVac Grundimmunisierung wurden nach zeitgerechter Boosterinjektion oder Verzicht auf selbige eingeteilt. Beschwerden in den folgenden 12 Monaten wurden dokumentiert und mittels Urinkultur objektiviert. Als Erfolg wurde maximal ein Infekt in $12 \mathrm{Mo}$ naten akzeptiert. Eine Therapie andernorts wurde ausgeschlossen.

Ergebnisse: Insgesamt konnten 120 Patientinnen eingeschlossen werden. Im ersten Jahr war die Prophylaxe bei 102 Patientinnen erfolgreich (85\%). In der Folge entschieden sich 76 Patientinnen für den Booster (Gruppe 1, 63,3\%), 44 dagegen (Gruppe 2, 36,7\%), meist bei noch bestehender Infektfreiheit. In Gruppe 1 waren 69 Patientinnen (90,8\%) erfolgreich, in Gruppe 2 zeigten sich bei 18 Patientinnen $(40,9 \%, p<0,005)$ erneut rezidivierende Infekte. Wurde in der Folge der Booster nachgeholt, zeigte er sich bei allen Patientinnen ( $n=12)$ erfolgreich in den nun folgenden Monaten (Follow-up nach Booster median 10 Monate).

Schlussfolgerung: StroVac ist eine effektive Therapieoption zur Behandlung von rezidivierenden Harnwegsinfektionen der Frau, der Booster sollte allerdings nach 12 Monaten injiziert werden, um den guten initialen Erfolg der Therapie zu erhalten. Bei Verzicht auf den Booster und einem Rezidiv kann der Booster mit sehr gutem Erfolg nachgeholt werden.

\section{V01.4 \\ Der natürliche Verlauf der Urindiagnostik nach Harnableitung}

\section{G. Magistro", J. Marcon, J.-N. Mumm, C. G. Stief}

Ludwig-Maximilians-Universität (LMU), Medizinische Fakultät, München, Deutschland

Fragestellung: Im präsentierten Projekt wird der Einfluss der Harnableitung auf Parameter der Urindiagnostik untersucht und nach Risikofaktoren für die Entwicklung von Infektkomplikationen gescreent.

Methoden: In einer retrospektiven, monozentrischen Studie wurden 429 Patienten evaluiert. Dabei erhielten 185 Patienten eine orthotope llemneoblase (NB) und 244 Patienten ein lleumkonduit (IC). Die Patienten wurden über ein Follow-Up von 12 Monaten zu drei definierten Zeitpunkten anhand kompletter Urindiagnostik (Urinteststreifen, Mikroskopie, Urinkultur) analysiert.

Ergebnisse: Zwei Wochen nach OP wies der Urinstix positive Reaktionen für Leukozyten und Hämoglobin in 80,7\% nach IC und in $80 \%$ nach NB auf. Ein Jahr nach OP waren beide Testfelder in beiden Kohorten für alle Patienten stets positiv. Entsprechend zeigte die Mikroskopie zwei Wochen post-OP in hohem Maße Leukozyten ( $84 \%$ vs. 85,4\%), Erythrozyten $(82,8 \%$ vs. $83,8 \%)$ und Bakterien ( $94,3 \%$ vs. $96,8 \%)$ in Urinproben aus IC und NB. Nach einem Jahr war auch dies unabhängig von der Harnableitung stets positiv. Die Urinkultur 2 Wochen nach OP war in $50 \%$ positiv für IC und in $60,5 \%$ für NB $(p>0,05)$. Allerdings konnten mehr polymikrobielle Ergebnisse nach NB $(81,3 \%)$ als nach IC $(67,2 \%)$ festgestellt werden $(p=0,018)$. Den einzigen Parameter, der nach univariater $(p=0,006)$ und multivariater Analyse (OR 4,2; Cl $95 \%$ 1,525-11,569; $p=0,006$ ) mit einer fieberhaften Harnwegsinfektion/Uroepsis assoziiert war, stellte die Harntransportstörung mit Hydronephrose.

Schlussfolgerung: Eine positive Urindiagnostik ist nach Harnableitung ein häufiger Normalbefund. Eine Harntransportstörung ist ein Risikofaktor für symptomatische Harnwegsinfektionen. Der Befund einer positiven Urindiagnostik rechtfertigt keine standardmäßige antibiotische Therapie.

\section{V01.5}

\section{High-throughput antibiotic susceptibility testing of} uropathogenic bacteria using Raman spectroscopy

\author{
G. Magistro ${ }^{1 *}$, C. Haisch ${ }^{2}$, C. G. Stief ${ }^{1}$ \\ 'Ludwig-Maximilians-Universität (LMU), Medizinische Fakultät, München, Germany; \\ ${ }^{2}$ Technical University Munich, Munich, Germany
}

Objective: Antimicrobial resistance (AMR) has emerged as one of the most challenging and threatening problems to public health on a global scale. The antibiotic treatment of UTI was always an easy and safe matter, but the rising AMR renders the management more and more challenging today. In order to assure effective treatment of patients, rapid, automated, and reliable antibiotic susceptibility testing (AST) of bacterial pathogens is essential. Here, we developed and evaluated a novel extended Ramanbased antibiotic susceptibility test.

Materials and methods: Raman spectroscopy as a non-destructive technique providing chemical-specific information was employed to monitor the deuterium uptake of metabolically active bacteria during antibiotic treatment, enabling fast and reliable AST. In this feasibility study, a bulk sample-preparation method was developed, allowing a high-throughput analysis of a collection of 51 clinical isolates.

Results: With our Raman-based assay, we currently cover typical Grampositive and Gram-negative uropathogens in combination with various antibiotic substances. The applicability of the assay was demonstrated for 51 clinical isolates with good performance compared to reference methods such as the E-test. Furthermore, we demonstrated the high potential of this assay to detect heteroresistant bacteria down to an estimated frequency of 10-6 resistant bacteria.

Conclusions: We introduce a Raman-based AST assay that exhibits good correlation in comparison with state-of-the-art reference analytics, but reduces the total analysis time (sample preparation, measurement, and evaluation) to $3.5 \mathrm{~h}$.

\section{V01.6}

Bakterielle Besiedlung und Resistenzlage auf Ureterschienen nach prolongierter Liegedauer vor elektiver Steinsanierung

\author{
A. Eder*, A. Henning, K. Eredics, C. Wehrberger, M. Marszsalek \\ Klinik Donaustadt, Urologie, Wien, Österreich
}

Einleitung: Limitierte OP-Kapazitäten angesichts der COVID-19-Pandemie verzögern die Steinsanierung nach akuter Einlage einer Ureterschiene (DJ) bei Urolithiasis. Die verlängerte Liegedauer der DJs kann zu einem divergierenden Keimspektrum an den DJ-Enden und einer vermehrten Besiedlung mit multiresistenten Erregern führen. Trotz resistenzgerechter antibiotischer Abschirmung kann es dadurch im Rahmen der Steinsanierung zu septischen Komplikationen kommen.

Methodik: Bei 38 Patienten ( $23 \hat{\jmath}, 15$ + $)$ wurde die Liegedauer der DJs, die bakterielle Besiedlung der DJ-Enden, des präoperativen Spontanharns sowie die perioperative Antibiose vor Steinsanierung erhoben.

Resultate: Die mittlere Liegedauer der DJs betrug 81d (21-255 d), das mittlere Alter der Patienten 49a (16-81a). Die mittlere OP-Dauer war 42 min (5-108 min). Von den Bakterienkulturen der DJ-Enden sowie den präoperativen Harnkulturen waren je $45 \%$ (17/38), $34 \%$ (13/38) und $66 \%$ 
(25/38) positiv. In $63 \%$ (24/38) der Fälle zeigte sich eine Diskrepanz zwischen Harnkultur und Kultur der DJ-Enden. In $21 \%$ (8/38) war die Harnkultur negativ bei positiver Kultur am DJ-Ende (proximal/distal oder beide). In $13 \%$ (5/38) war die perioperative Antibiose bei negativer Harnkultur und positiver Kultur des DJ nicht resistenzgerecht. Eine Patientin verstarb postoperativ an Urosepsis, in 5 Fällen traten postoperative Komplikationen (Clavien-Dindo Grad 2) auf.

Schlussfolgerung: Im Vergleich der präoperativen Harnkultur mit der bakteriellen Besiedlung der DJs zeigen sich teils erhebliche Differenzen, sodass ein Teil der Patienten vor Steinsanierung nicht resistenzgerecht antibiotisch abgeschirmt zu sein scheint. Dies könnte insbesondere nach verlängerter Liegedauer der DJs zu einer erhöhten perioperativen Komplikationsrate führen.

\section{V01.7}

\section{Prophylaxe für wiederkehrende Harnwegsinfekte bei} Frauen mittels StroVac - Effektivität und Compliance in einem 2 Jahres Follow-up

\author{
S. Nestler ${ }^{1 *}$, B. Grüne ${ }^{2}$, L. Schilchegger ${ }^{3}$, A. Suna ${ }^{1}$, A. Neisius ${ }^{4}$ \\ 'UroGate Bad Vilbel, Urologische Praxis, Bad Vilbel, Deutschland; ' 2 Universitätsmedi- \\ zin Mannheim, Urologie, Mannheim, Deutschland; ${ }^{3}$ Hochtaunusklinik, Urologie, Bad \\ Homburg, Deutschland; ${ }^{4}$ Krankenhaus der Barmherzigen Brüder Trier, Urologie, Trier, \\ Deutschland
}

Einleitung: Rezidiveriende Harnwegsinfekte (rHWI) betreffen $30 \%$ aller Frauen. Angesichts steigender Antibiotikaresistenzen werden nicht-antibtioische Prophylaktika interessanter. Daher haben wir einen Vergleich zwischen StroVac und einer dreimonatigen Prophylaxe mit Nitrofurantoin $100 \mathrm{mg}$ einmal täglich in einem 2 Jahres Follow-up initiiert und unser Augenmerk auf Effektivität und Compliance gelegt.

Material und Methoden: Allen Patientinnen mit rHWI wurde eine Prophylaxe mit StroVac oder Nitrofurantoin angeboten. Bei erneuten Beschwerden wurden diese dokumentiert und mittels Urinkultur diagnostiziert. Als Erfolg wurde ein Infekt in 12 Monaten akzeptiert. Nach 12 und 24 Monaten wurde mittels Telefoninterview eine Therapie andernorts ausgeschlossen. In der StroVac Gruppe wurde nach 12 Monaten an die Boosterinjektion erinnert und nach Patientenwunsch injiziert.

Ergebnisse: Wir konnten 124 Patientinnen in die StroVac Gruppe und 49 Patientinnen in die Nitrofurantoin Gruppe einschließen. In der StroVac Gruppe waren im ersten Jahr $85 \%$ der Patientinnen erfolgreich, in der Nitrofurantoin Gruppe $91 \%(p=0,33)$. Im zweiten Jahr war StroVac in 77,4\% der Patientinnen erfolgreich. Im zweiten Jahr nach Prophylaxe mit Nitrofurantoin zeigte sich nur in 57,1 \% der Fälle ein weiterhin bestehender Effekt $(p<0,05)$.

Bei Patientinnen mit immunmodulatorischer Medikation zeigte sich StroVac signifikant weniger effektiv (Erfolg $33 \%$ im ersten und 37,5\% im zweiten Jahr). Unter Nitrofurantoin war die Erfolgsrate vergleichbar mit der Gesamtgruppe.

Schlussfolgerung: StroVac stellt eine effektive und anhaltende Prophylaxe für Frauen mit rezidivierenden Harnwegsinfekten dar, bei Patientinnen mit immunsuppressiver Medikation ist die Erfolgsrate geringer.

\section{V01.8}

Blasenspülung mit elektrochemisch aktivierter Lösung als individueller Heilversuch bei Patienten mit neurogener Dysfunktion des unteren Harntraktes (NLUTD) und rezidivierenden Harnwegsinfektionen

\section{A. K. Jaekel ${ }^{1 *}$, M. Weyler ${ }^{1}$, S. Knüpfer ${ }^{1}$, R. Kirschner-Hermanns ${ }^{1,2}$}

'Universitätsklinikum Bonn, Sektion Neuro-Urologie, Klinik für Urologie und Kinderurolo-

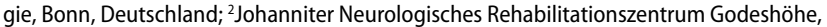
Neuro-Urologie, Bonn, Deutschland
Hintergrund: Ein Hauptproblem von Patienten mit neurogener Dysfunktion des unteren Harntraktes (NLUTD) stellt die rezidivierende katheterassoziierte Harnwegsinfektion (CAUTI) dar.

Ziel: Unter der zunehmenden Bedeutung von Antibiotic Stewardship war Ziel der Studie, eine alternative Therapiemaßnahme zur Antibiotikaeinnahme für Patienten mit NLUTD und rezidivierenden Harnwegsinfektionen zu finden. Die Behandlung sollte lokal anwendbar und gut verträglich sein. Gleichzeitig sollte die Entwicklung einer Antibiotika-Resistenz vermieden werden.

Studiendesign und Methodik: Retrospektive Analyse von individuellen Heilversuchen bei 12 Patienten mit NLUTD und CAUTI (Ethikvotum des UK Bonn EK183/20). Alle Patienten befanden sich stationär in einer neurologischen Rehabilitationseinrichtung. Die Therapieentscheidung wurde individuell zur temporären Keimeliminierung vor einer diagnostischen oder therapeutischen Intervention getroffen. Dazu wurde elektrochemisch aktivierte Lösung (ECAS) als Blasenspülung verwendet. Es wurden jeweils Urinkulturen mit Antibiogramm vor und nach der Behandlung angelegt, das Ausmaß von Leukozyt- und Erythrozyturie bestimmt und klinische Parameter erhoben.

Ergebnisse: Eine Keimeliminierung oder die Zunahme der sensibel getesteten Antibiotika wurde bei $50-70 \%$ der Patienten beobachtet. Nebenwirkungen traten nicht auf.

Limitationen: Aufgrund der Durchführung als individueller Heilversuch war die Teilnehmerzahl limitiert und es gab keine Kontrollgruppe.

Schlussfolgerung: Bei Patienten mit NLUTD und rezidivierenden Harnwegsinfektionen scheint die Anwendung von ECAS als Blasenspülung zur temporären Keimeliminierung vor invasiven Maßnahmen eine viel versprechende Alternative zur Antibiotikaeinnahme zu sein. Eine randomisierte kontrollierte Studie ist erforderlich.

\section{V01.9}

Phage therapy in the treatment of urinary tract infections-In vitro testing of commercial phage preparations using isothermal microcalorimetry

M. Max ${ }^{12}$, A. P. Sigg ${ }^{1 a}$, A. Grütter ${ }^{1}$, T. Lafranca', M. Rieken ${ }^{1,2}$, O. Braissant ${ }^{1,3}$, G. Bonkat ${ }^{*}, 2,3$

'Faculty of Medicine, University of Basel, Basel, Switzerland; 'alta uro AG, Basel, Switzerland; ${ }^{3}$ Department of Biomedical Engineering, University of Basel, Allschwil, Switzerland

Background \& Objectives: Antimicrobial resistance is drastically increasing worldwide. As the antibiotic pipeline is rather narrow, valuable alternatives are desperately needed. Phage therapy might be such an alternative. However, the efficacy of phage therapy for urinary tract infections (UTIS) has not sufficiently been investigated yet. We used isothermal microcalorimetry (IMC) to assess the efficacy of commercial phage preparations against $E$. coli and P. mirabilis in sterile filtered and artificial urine. Material and methods: A microcalorimetry instrument (TAM48, TA Instruments, New Castle, DE) equipped with 48 channels was used to follow bacterial growth (or its absence). Bacteria were incubated in sterile filtered urine and artificial urine together with different dilutions (1\% and $5 \%$ ) of bacteriophage solution (E. coli/Proteus bacteriophage solution, NPO Microgen, 44, Gruzinskaya str., Nizhny Novgorod, Nizhny Novgorod region, 603950 Russia). Positive controls were performed using $3 \mathrm{~mL}$ of inoculated urine and negative (sterility) controls were prepared using uninoculated urine (i. e., filter sterilized urine). Measurement started after thermal equilibration procedure as recommended by the manufacturer and lasted until the signal rose and returned to baseline or for at least $120 \mathrm{~h}$.

Results: A clear drop of metabolic activity-representing bacterial deathwas visible for each concentration (1\% and $5 \%$ ) of phage solution used. The metabolic heat rate of E. coli returned after to baseline after $3-4 \mathrm{~h}$. The growth of Proteus mirabilis growth was strongly reduced (growth rate decreased by $50 \%$ and lag phase increased by $4.6 \mathrm{~h}$ ) but not fully suppressed. Conclusions: The commercial phage product used in our study was very effective in inducing bacterial death in E. coli and P. mirabilis in sterile fil- 
tered urine and artificial urine, respectively. IMC provides valuable additional information such as kinetics of bacterial death as well as preypredator behavior. Furthermore, a phagogram might be obtained within 4-7 h. In conclusion, IMC confirmed the potential of bacteriophages to induce death in uropathogens in urine.

aFirst both authors contributed equally

\section{V02 - Qualität in der deutschen Urologie: Aus Sicht von Patienten und Ärzten}

\author{
16.09.2021, C5.2, 08:00-09:30
}

\section{V02.1}

\section{Biopsie des Prostatakarzinoms: Antworten aus der VERSUS-Studie von d-uo}

R. Schönfelder ${ }^{{ }^{*}}$, M. Johannsen², J. Klier ${ }^{3}$, R. Eichenauer ${ }^{4}$, F. König' ${ }^{5}$, J. Schröder ${ }^{5}$, E. Hempel ${ }^{6}$, C. Doehn ${ }^{7}$

'Urologie Schönfelder \& Straßer, Hamburg, Deutschland; ${ }^{2}$ Urologische Facharztpraxis Johannsen \& Laux, Berlin, Deutschland; ' ${ }^{3}$ rrologische Partnerschaft Köln, Köln, Deutschland; ${ }^{4}$ Urologikum Hamburg, Hamburg, Deutschland; ${ }^{5}$ ATURO, Berlin, Deutschland; ${ }^{6}$ SMG Forschungsgesellschaft, Berlin, Deutschland; ${ }^{7}$ Urologikum Lübeck, Lübeck, Deutschland

Einleitung: Seit 5/2018 dokumentieren Mitglieder von d-uo urologische Tumorerkrankungen im Rahmen der prospektiven VERSUS-Studie. In der vorliegenden Arbeit wurde die Prostatabiopsie (PBx) bei Patienten mit der Erstdiagnose Prostatakarzinom (PCa) untersucht.

Material und Methoden: Bis 12/2020 wurden 7469 Patienten mit der Erstdiagnose einer urologischen Tumorerkrankung dokumentiert. Bei 4703 Patienten (63\%) lag ein PCa vor.

Ergebnisse: Bei 3121 Patienten waren Daten zur Anzahl entnommener PBx verfügbar. Die Zahl lag im Median bei 12 (Spannweite 1-37). Bei 2267 Patienten (72,6\%) wurden zwischen 10 und $12 \mathrm{PBx}$, in $11,6 \%$ der Fälle weniger als $10 \mathrm{PBx}$ und in 15,8\% der Fälle mehr als $12 \mathrm{PBx}$ entnommen. Die mediane Zahl positiver PBx lag bei 5 (Spannweite 0-28). Bei 2967 Patienten waren Daten zum Anteil tumortragender PBx verfügbar: bei 969 Patienten (32,7\%) lag dieser zwischen 0 und $25 \%$, bei 839 Patienten $(28,3 \%)$ zwischen 26 und $50 \%$, bei 430 Patienten $(14,5 \%)$ zwischen 51 und $75 \%$ und bei 729 Patienten (24,6\%) zwischen 76 und $100 \%$.

Bei 1656 Patienten lagen Daten zum höchsten Tumoranteil in einer PBx vor: dieser lag in 560 Fällen $(33,8 \%)$ bei $0-25 \%$, in 379 Fällen $(22,9 \%)$ bei $26-50 \%$, in 258 Fällen (15,6\%) bei $51-75 \%$ und in 459 Fällen (27,7 \%) bei 76-100\%.

Bei 3467 Patienten waren Informationen zur Gleason-Score (GS) bzw. Gradgruppe (GG) in der PBx verfügbar: GG1 (GS 6), GG2 (GS 7a), GG3 (GS 7b), GG4 (GS 8) und GG5 (GS 9 oder 10) waren wie folgt verteilt: $26,2 \%$, $26,3 \%, 16,3 \%, 14,9 \%$ und $16,3 \%$.

Schlussfolgerung: Bei 3 von 4 Patienten mit einem PCa lag die Anzahl entnommener PBx zwischen 10 und 12. Die knappe Hälfte der entnommenen PBx waren tumortragend. Die günstigste und die ungünstigste Gleason-Gradgruppe waren jeweils bei einem Viertel der Patienten nachweisbar.

\section{V02.2}

\section{Einfluss soziokultureller Faktoren auf Patientenselbsteinschätzung nach offener und robotergestützter Prostatektomie}

M. Maas", K. Funk, J. Hennenlotter, V. Stühler, S. Walz, S. Aufderklamm, J. Bedke, A. Stenzl, S. Rausch

Uniklinik Tübingen, Urologie, Tübingen, Deutschland
Einleitung: Beim Vergleich von Prostatektomie-(Px)-techniken werden neben onkologischen Kriterien auch funktionelle und qualitative Parameter der Selbsteinschätzung herangezogen. Bekannte Zusammenhänge des sozioökonomischen Status mit Patientenselbsteinschätzungen sollen bezüglich ihres Einflusses auf den Vergleich offener (off-) mit daVinci-gestützter Px (daV-Px) geprüft werden.

Material \& Methoden: An einem Kollektiv von 177 off-Px und 150 daV-Px Patienten wurden postoperativer Schmerzmittelbedarf und nach 24 Monaten Kontinenz-, Potenz-, Lebensqualität und Gesundheitszustand erhoben. Parallel wurden sozioökonomische Faktoren und Parameter der Lebenssituation ermittelt. Für alle einflussnehmenden Faktoren wurde anschließend mittels bivariater Effekt-Modelle ihr Einfluss auf die Auskünfte im Vergleich zur OP-Technik nach log-Wertigkeit ( $p$-Wert) gelistet.

Ergebnisse: Die daV-Px zeigt bessere Ergebnisse für Lebensqualität, Kontinenz und postoperativen Schmerzmittelbedarf (je $p<0,05$ ). Stärkeren Einfluss als die OP-Technik auf die Lebensqualität nehmen dabei geringeres Alter, IIEF, ICIQ (je $\mathrm{p}^{\text {Einfluss }}<0,05$, $\mathrm{p}^{\text {OP-Technik }}>0,05$ ), fehlende Vorerkrankungen und Hypertonie sowie, verheiratet oder verwitwet sein' (je $p^{\text {Einfluss }}<$ $\left.\mathrm{p}^{\text {op-Technik }}\right)$. Stärkeren Einfluss auf die Kontinenz nehmen ,keine psychische Belastung' ( $p^{\text {Einfluss }}<0,05, p^{\text {OP-Technik }}>0,05$ ), geringer ICSO und hoher ISEI

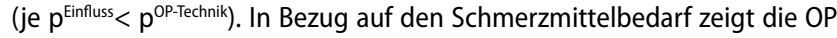
Technik den stärksten Einfluss.

Diskussion: Die Selbstbewertung von funktioneller Situation und Gesundheitszustand nach Px wird von soziodemografischen Faktoren beeinflusst. Eine Berücksichtigung dieser Momente kann individuelle Behandlungen verbessern. Off- und daV-Px können damit valider bezüglich ihres Outcomes verglichen werden.

\section{V02.3}

Multizentrische Validierung eines komprehensiven geriatrischen Assessments zur Prädiktion von funktionellem Outcome und Mortalität nach uroonkologischen Operationen C. Fiebig ${ }^{1 *}$, A. Kahlmeyer ${ }^{1}$, H. Bannert ${ }^{1}$, H. Taubert ${ }^{1}$, S. Wach' ${ }^{1}$, L. Koneval2
S. Graf

'Universitätsklinikum Erlangen, Urologische und Kinderurologische Klinik, Erlangen, Deutschland; ${ }^{2}$ Universitätsklinikum Würzburg, Klinik und Poliklinik für Urologie und Kinderurologie, Würzburg, Deutschland; ${ }^{3}$ Kepler Universitätsklinikum, Klinik für Urologie und Andrologie, Linz, Österreich; ${ }^{2}$ Zentralkrankenhaus Bozen, Klinik für Urologie, Bozen, Italien; ${ }^{5}$ SHG-Kliniken Völklingen, Klinik für Urologie, Kinderurologie und urologische Onkologie, Völklingen, Deutschland; ${ }^{6}$ Klinikum Neumarkt, Medizinische Klinik III, Neumarkt i. d.OPf., Deutschland; ${ }^{7}$ Malteser Waldkrankenhaus St. Marien, Geriatrie-Zentrum Erlangen, Erlangen, Deutschland

Einleitung: Durchgeführt wurde eine multizentrische Ausweitung (Würzburg, Linz, Bozen, Völklingen) einer laufenden, bislang monozentrischen Studie zur Validierung eines geriatrischen Assessments. Ziel ist die Prädiktion des postoperativen funktionellen Outcomes und der Mortalität von geriatrischen Tumorpatienten.

Material und Methoden: Prospektive Untersuchung von Patienten $\geq 70$ Jahren, welche einer elektiven Zystektomie, Prostatektomie oder Tumornephrektomie unterzogen werden. Präoperativ erfolgt ein geriatrisches Assessment zur Identifizierung von Hochrisikopatienten bezüglich des funktionellen Outcomes und der Mortalität. Diese Untersuchung erfolgt neben der in Erlangen laufenden Studie in vier weiteren Zentren zur Validierung des so genannten Erlangen Index (EI).

Ergebnisse: Eingeschlossen wurden in der Referenzkohorte (Erlangen) 159 Patienten, in den Validierungszentren 106 Patienten. In der Referenzkohorte zeigte der El eine Korrelation der Hochrisikopatienten (EI $\geq 4)$ mit der funktionellen Verschlechterung nach 30 Tagen, 180 Tagen sowie mit einer erhöhten Mortalität. Bezüglich der Verschlechterung des Outcomes nach 30 Tagen (Würz.: Sen $=91 \%$, Spe $=42 \%$; Linz: Sen $=74 \%$, Spe: $40 \%$ ) und nach 180 Tagen (Würz.: Sen $=50 \%$, Spe $=91 \%$ ) zeigten sich bereits in den Validierungszentren ähnliche Ergebnisse. Dies bestätigt sich in einer signifikant reduzierten Überlebensrate der Hochrisikopatienten sowohl 
in der Referenzkohorte $\left(X^{2}(1)=16,944, p<0,001\right)$ als auch in den Validierungszentren $\left(X^{2}(1)=4,594, p=0,032\right)$.

Schlussfolgerungen: Das bereits in Erlangen entwickelte geriatrische Assessment mit dem so genannten Erlangen Index als Risikoparameter lässt sich auch in einer ersten Zwischenauswertung in externen Zentren zur präoperativen Identifizierung von Hochrisikopatienten anwenden.

\section{V02.4}

Einfluss der SARS-CoV-2-Pandemie auf die Erstdiagnose Prostatakarzinom. Monozentrische Auswertung der Fallvorstellungen im Prostatakarzinomzentrum der Universitätsklinik Regensburg

\section{S. Hammer*, I. Gebhard, J. Breyer, M. Burger, M. Schnabel}

Caritas Krankenhaus St. Josef, Universiät Regensburg, Urologie, Regensburg, Deutschland

Fragestellung: Durch die SARS-CoV-2-Pandemie kam es ab März 2020 zu Einschränkungen im täglichen Leben und Veränderungen in der medizinischen Versorgung. Vorsorgeuntersuchungen könnten durch diese Ausnahmesituation in den Hintergrund gerückt worden sein. Hatte die SARS-CoV-2-Pandemie einen Einfluss auf die Erstdiagnose eines Prostatakarzinoms?

Material und Methoden: Es erfolgte eine retrospektive, monozentrische Analyse der Fallvorstellungen im Prostatakarzinomzentrum der Universitätsklinik Regensburg. Ausgewertet wurden der Zeitraum vor der Pandemie (Z0: 10/2019-03/2020), 1. Lockdown (Z1:04/2020-05/2020), freies Intervall (Z2: 06/2020-10/2020) und 2. Lockdown (Z3: 11/2020-02/2020). Einschlusskriterium war die stanzbioptisch-gesicherte Erstdiagnose Prostatakarzinom.

Ergebnisse: 816 Patienten wurden in die Analyse eingeschlossen. Medianer PSA ( $8 \mathrm{ng} / \mathrm{ml}, p=0,47)$, Alter MW: 67 Jahre, $p=0,29)$ und Anteil karzinombefallener Stanzen (MW: $36 \%, p=0,31$ ) unterschieden sich über den gesamten Zeitraum nicht. Es zeigte sich ein signifikanter Anstieg im WHO Grading $(p=0,018)$ bzw. Gleason Score $(p=0,019)$, welcher mit zeitlicher Verzögerung ab Z2 (WHO MW: 2,78) bzW. Z3 (WHO MW: 2,71) im Vergleich zu Z0 (WHO MW: 2,51) und Z1 (WHO MW: 2,42) sichtbar wurde. Die mittlere Anzahl an Erstdiagnosen pro Monat erwies sich im Verlauf als tendenziell rückläufig (Z0: 49,5, Z1: 55,5, Z2: 52,4, Z3: 36,2; $p=0,20)$.

Schlussfolgerung: Im zeitlichen Verlauf der SARS-CoV-2-Pandemie kam es bei der Erstdiagnose eines Prostatakarzinoms zu einer signifikanten Erhöhung des Gradings. Zudem zeigte sich ein Trend zu weniger Erstdiagnosen im Verlauf des zweiten Lockdowns. Patienten sollten verstärkt über die Notwendigkeit von Vorsorgeuntersuchungen auch während der aktuellen Pandemie aufgeklärt werden.

\section{V02.5}

Vergleich dreier Komorbidität-Indizes bezüglich ihrer Vorhersagekraft von Morbidität und Mortalität chirurgischer Eingriffe

\section{Häuser ${ }^{1,2}$, P. Herzog², A. Ayub², J. Noldus', , M. Mossanen², Q.-D. Trinh²}

'Marien Hospital Herne, Ruhr-Universität Bochum, Klinik für Urologie und Neuro-Urologie, Herne, Deutschland; ${ }^{2}$ Brigham and Women's Hospital, Division of Urologic Surgery and Center for Surgery and Public Health, Boston, Vereinigte Staaten von Amerika

Einleitung: Das Erfassen des perioperativen Risikos ist ein wesentlicher Aspekt der chirurgischen Entscheidungsfindung. Ziel dieser Studie war es, weit verbreitete Komorbidität-Indizes hinsichtlich ihrer Prädiktionsfähigkeit von Morbidität und Mortalität zu vergleichen.

Material und Methoden: Wir analysierten NSQIP, eine amerikanische nationale Datenbank, die das Outcome sämtlicher chirurgischer Eingriffe beinhaltet, und wählten 16 Operationen unterschiedlicher Disziplinen. Für jeden Patienten wurden der American Society of Anesthesiologists (ASA) score, Charlson Comorbidity Index (CCI) und der modifizierte Frailty Index
(mFl) bestimmt. Anschließend wurden Modelle mit jedem Komorbiditätsindex für die Vorhersage von Morbidität, Mortalität, verlängerter Krankenhausaufenthalt ( $p L O S,>75$. Perzentile) erstellt. Area under the curve (AUC) Werte und Decision Curve Analysis (DCA) wurden benutzt, um die Effektivität jedes Modells zu messen.

Ergebnisse: $11,7 \%, 17,0 \%$ und $0,75 \%$ der insgesamt 650.437 Patienten erfuhren eine Komplikation, pLOS und Mortalität, respektive. Jeder der Komorbiditätsindizes war ein unabhängiger Prädiktor für Morbidität, Mortalität und pLOS (alle $p<0,05$ ). Für jeden Index galt, dass die Modelle, die Mortalität vorhersagten, am besten abschnitten, während die Modelle, die pLOS vorhersagten, am schlechtesten abschnitten. Während alle Indizes gleichwertig in DCA Morbidität und pLOS vorhersagten, zeigte der ASA eine bessere Prädiktion der 30-Tages-Mortalität.

Schlussfolgerung: Die bekannten Komorbiditätsindizes ASA, CCI und $\mathrm{mFI}$ zeigen vergleichbare Exaktheit in der Vorhersage von Morbidität und pLOS nach chirurgischen Eingriffen. Der ASA, welcher am einfachsten zu kalkulieren ist, weist jedoch eine bessere Genauigkeit bei der Mortalität auf.

\section{V02.6}

\section{Gleason Wert Übereinstimmung von Biopsie und pathologischem Präparat vor und nach Einführung der} MRT-Fusionsbiopsie. Eine multizentrische Registerstudie

K. Boehm ${ }^{1 * 2,}$, T. Ebert ${ }^{3,4}$, R. Dotzauer ${ }^{1,2}$, J. Jones ${ }^{5}$, E. Khaljani ${ }^{4}$, M. Schmid ${ }^{2,6}$, W. Schulze-Seemann ${ }^{4,7}$, P. Weib ${ }^{4,8}$, J. Herden ${ }^{4,9,10}$

'Klinik und Poliklinik für Urologie und Kinderurologie der Universitätsmedizin Mainz, Mainz, Deutschland; ${ }^{2}$ GeSRU-Academics, Frankfurt, Deutschland; ${ }^{3}$ Prostatazentrum Metropolregion Nürnberg, Nürnberg, Deutschland; ${ }^{4}$ URO-Cert e. V., Berlin, Deutschland; ${ }^{5}$ Klinik für Urologie Krankenhaus Bad Homburg, Hochtaunus-Kliniken gGmH, Bad Homburg vdH, Deutschland; ${ }^{6}$ Klinik für Urologie der Universitätsmedizin Göttingen, Göttingen, Deutschland; ${ }^{7}$ Prostatazentrum Freiburg, Freiburg, Deutschland; ${ }^{8}$ Kompetenznetz Prostata Siegen, Siegen, Deutschland; ${ }^{9}$ Prostatazentrum Köln, Köln, Deutschland; ${ }^{10}$ Klinik für Urologie der Uniklinik Köln, Köln, Deutschland

Einleitung: Seit 2016 ist die MRT Fusionsbiopsie der Prostata in der S3 Leitlinie implementiert. Zunächst wurde die MRT-Fusionsbiopsie nur für die Wiederholungsbiopsie empfohlen und wurde sukzessive Standard in Deutschland.

Ziel: Evaluation der Übereinstimmung von Biopsie- und ProstatapräparatGleasonwert vor 2016 vs $\geq 2016$

Patienten und Methoden: Insgesamt wurden 4584 Patienten der UroCert Datenbank eingeschlossen, welche einer radikalen Prostatektomie zwischen 2000 und 2019 unterzogen wurden. Prä- und posttherapeutische Daten wurden ermittelt. Posttherapeutische Gleasonwerte wurden im Vergleich zu den Biopsie-Gleasonwerten als "Korrekt", "Unterschätzt ${ }^{\prime}$ und "Überschätzt" klassifiziert und nach OP Datum < 2016 vs $\geq 2016$ stratifiziert. Zudem wurde die Rate an signifikantem Upgrading (Gleason $3+3$ oder $3+4$ auf Gleason $\geq 4+3$ ) evaluiert.

Ergebnisse: Insgesamt wurde bei 1398 (28,9\%), 1424 (29,4\%), 793 $(16,4 \%)$ und 969 (20\%) ein Gleasonwert von $3+3,3+4,4+3$ und $\geq 4+4$ in der Biopsie festgestellt. Der pathologische Gleasonwert wurde in $54,7 \%$ korrekt eingeschätzt, in 12,3\% überschätzt und in $27,7 \%$ unterschätzt. Es zeigte sich ein signifikanter Unterschied vor und nach 2016 in Deutschland ( $50,6 \%$ vs $61,8 \%$ korrekt; 11,3 vs $14,1 \%$ unterschätzt; $29,7 \%$ vs $24,2 \%$ überschätzt; $p<0,001)$. Ein signifikantes Gleason-Upgrading zeigte sich vor 2016 in $27,3 \%$ vs $\geq 2016$ in $20,3 \%(p<0,001)$.

Schlussfolgerungen: Seit Einführung des MRTs in Deutschland hat sich die Übereinstimmung von Biopsie-Gleasonwert und pathohistologsichem Gleasonwert signifikant gebessert. Dies spricht für eine flächendeckend bessere Versorgung der Patienten durch die Leitlinienänderung. Informationen über die Genauigkeit der MRT-Fusionsbiopsie können in dieser Studie nicht getroffen werden. 
V02.7

Weiterbildungs- und Arbeitsbedingungen urologischer Assistenzärzt:innen in Deutschland: Ergebnisse der zweiten GeSRU-Weiterbildungsumfrage von 2020

C. Siech ${ }^{1 *}$, J. König ${ }^{2}$, A. Mattigk ${ }^{3}$, L. Bellut ${ }^{4}$, A. Beck ${ }^{5}$, F.-M. Wundrack ${ }^{6}$, M. Fassbach ${ }^{7}$, H. Arnold ${ }^{8}$

'Universitätsklinikum Frankfurt, Frankfurt am Main, Deutschland; ${ }^{2}$ Asklepios Stadtklinik Bad Tölz, Bad Tölz, Deutschland; ${ }^{3}$ Universitätsklinikum Ulm, Ulm, Deutschland; ${ }^{4}$ Universitätsklinikum Erlangen, Erlangen, Deutschland; ${ }^{5}$ Katholisches Marienkrankenhaus Hamburg, Hamburg, Deutschland; ${ }^{6}$ Helios Klinikum Berlin-Buch, Berlin, Deutschland; ${ }^{7}$ Helios Klinikum Duisburg, Duisburg, Deutschland; ${ }^{8}$ Urologische Facharztpraxis, Senden, Deutschland

Einleitung: Die Zeit der Weiterbildung ist einer der prägendsten Abschnitte des ärztlichen Werdegangs. Bereits 2015 konnte die German Society of Residents in Urology (GeSRU) mit der ersten nationalen Befragung Herausforderungen der urologischen Weiterbildung in Deutschland aufzeigen. Mit der Folgebefragung soll der Status Quo der Arbeits- und Weiterbildungsbedingungen erhoben, Veränderungen analysiert und Vorschläge zur Verbesserung formuliert werden.

Material und Methoden: In der zweiten Jahreshälfte 2020 wurde basierend auf der Vorbefragung von 2015 eine Online-Umfrage mit insgesamt 82 Fragen unter den Ärztinnen und Ärzten in Weiterbildung (ÄiW) für Urologie in Deutschland durchgeführt. Schwerpunkte dieser Auswertung bildeten die Arbeitsbedingungen im Berufsalltag, die Fort- und Weiterbildung, die Vereinbarkeit von Beruf und Familie und der Einfluss ökonomischer Erwägungen. Zusätzlich wurde die Kurzfassung des validierten Fragebogens zum Gratifikationskrisenmodell nach Siegrist eingesetzt. Ergebnisse: Die Hälfte der 332 Teilnehmenden der Befragung sind mit ihrer beruflichen Situation zufrieden. $63 \%$ empfinden, dass sich der wirtschaftliche Druck negativ auf ihre Weiterbildung auswirke. Die Vereinbarkeit von Familie und Beruf wird mit der Note 3,6 bewertet. Bei $86 \%$ der Teilnehmenden lag eine Gratifikationskrise mit einem Effort-Reward (ER)-Ratio $>1$ vor. Im Vergleich zur Vorbefragung zeigt sich im Mittel ein höheres ER-Ratio $(1,79 \pm 1,45$ vs. $1,37 \pm 0,42)$ und eine geringere Verausgabung, Belohnung und Verausgabungsneigung.

Schlussfolgerung: Urologische ÄiW sind mit ihrem Beruf mehrheitlich zufrieden, geben jedoch erneut eine hohe psychosoziale Arbeitsbelastung an. Im Berufsalltag besteht ein deutlicher ökonomischer Druck, adäquate Weiterbildungs- und Arbeitsbedingungen kommen zu kurz.

\section{V02.8}

Die berufliche Zufriedenheit von Urologinnen und Urologen mit Migrationshintergrund (UKMH) tätig an deutschen Kliniken - Ergebnisse der Querschnittstudie EUTAKD

\section{May ${ }^{1 *}$, M. Shaar ${ }^{1}$, K.-P. Braun², S. Lebentrau ${ }^{3}$}

'St. Elisabeth-Klinikum Straubing, Straubing, Deutschland; ${ }^{2} \mathrm{MVZ}$ Dr. Braun GmbH, Cottbus, Deutschland; ${ }^{3}$ Ruppiner Kliniken $\mathrm{GmbH}$, MHB Theodor Fontane, Urologische Klinik, Neuruppin, Deutschland

Es liegen keine gesicherten Erkenntnisse darüber vor, ob es für UKMH eine Korrelation der beruflichen Zufriedenheit mit dem Wunsch gibt, die Fachrichtung bzw. das Land ihrer gegenwärtigen Tätigkeit wieder verlassen zu wollen. Erstmalig sollen diese Daten in Deutschland mittels Survey erhoben werden.

Material und Methoden: Ein Survey-Monkey ${ }^{\circledast}$ mit 101 Items zu charakterisierenden Kriterien des Studienteilnehmers und Fragen zur beruflichen Zufriedenheit ( $n=39$ ) wurde zwischen 8-10/2020 für UKMH geöffnet. Der Einfluss verschiedener Dimensionen beruflicher Zufriedenheit auf den Wunsch, die urologische Tätigkeit u/o Deutschland ggf. verlassen zu wollen, wurde analysiert (Gr. A: möchte nicht die urologische Tätigkeit und ebenfalls nicht Deutschland verlassen, und Gr. B: kann sich das Verlassen der urologischen Tätigkeit u/o Deutschlands zumindest vorstellen).

Ergebnisse: 81 UKMH verteilten sich in den Gr. A (50,6\%) und B (49,4\%) nahezu paritätisch. Die berufliche Zufriedenheit war in mehreren Dimensionen höher in der Gr. A. Aus drei im Gruppenvergleich signifikant unterschiedlichen Dimensionen beruflicher Zufriedenheit: (1) Verhältnis zu den Vorgesetzten $(p=0,014)$, (2) Karrieremöglichkeiten in der Klinik $(p<0,001)$, und (3) Möglichkeiten zur Weiterentwicklung der chirurgischen Fähigkeiten $(p=0,006)$ wurde ein Summenscore mit einer Range von 3-15 Pkt. gebildet. Pro Punktwert dieses Summenscores nahm der Wunsch des UKMH, die Urologie u/o Deutschland verlassen zu wollen (bzw. zumindest unsicher in dieser Frage zu sein) um 34,6\% ab (OR 0,654, $95 \%$-Cl: 0,496-0,861, $p=0,002$ ).

Schlussfolgerungen: Es wurden verschiedene Dimensionen beruflicher Zufriedenheit identifiziert, deren Verbesserung zu einer langfristigen Tätigkeit der UKMH an deutschen urologischen Kliniken beitragen könnte.

\section{V02.9}

Einfluss graphisch-radiologischer Annotierung suspekter Läsionen auf die Ergebnisse der zielgerichteten MRT/ Ultraschall-Fusionsbiopsie der Prostata

P. Krausewitz ${ }^{1 *}$, N. Klümper ${ }^{1}$, J. Stein ${ }^{1}$, U. Attenberger², J. Luetkens², G. Kristiansen ${ }^{3}$, J. Ellinger ${ }^{1}$, M. Ritter ${ }^{1}$

'Universitätsklinikum Bonn, Klinik für Urologie und Kinderurologie, Bonn, Deutschland; 2Universitätsklinikum Bonn, Klinik für Diagnostische und Interventionelle Radiologie, Bonn, Deutschland; ${ }^{3}$ Universitätsklinikum Bonn, Institut für Pathologie, Bonn, Deutschland

Strukturierte Berichterstattung von Ergebnissen multiparametrischer Magnetresonanztomographien der Prostata (mpMRT) verbessert die interdisziplinäre Kommunikation und Detektion von Prostatakarzinomen (PCA). Wir analysierten den Einfluss der zusätzlichen graphischen Annotierung auffälliger Läsionen in der mpMRT auf die Ergebnisse gezielter MRT/Ultraschall-Fusionsbiopsien der Prostata (TB).

268 biopsie-naive und 84 vorbiopsierte Männer mit Verdacht auf ein PCA wurden untersucht. Erfahrene Uroradiologen bewerteten und berichteten MRT-Ergebnisse von 106 Patienten gemäß dem PI-RADS-Standard Version 2.1. In der Vergleichsgruppe wurden die Läsionen in den MRT-Bildern (Markierung in T2-gewichteten und diffusionsgewichteten Sequenzen) für 246 Männer zusätzlich annotiert. Läsionen der PI-RADS Kategorie $\geq 3$ wurden biopsiert. Prostatakarzinome mit ISUP-Werten (International Society of Urological Pathology) $\geq 2$ wurde als klinisch signifikant (cSPCA) definiert. Die Daten wurden prospektiv erhoben und die Gesamt-PCA-Detektionsrate (CDR) und Erkennungsrate von csPCA verglichen.

Die Verteilung der PIRADS-Bewertung war in beiden Gruppen vergleichbar. Die CDR der TB gemäß dem Standardansatz, basierend auf den PIRADS-Kategorien 3, 4 und 5, betrug $5 \%, 39 \%$ und $72 \%$ für PCA bzw. $5 \%, 36 \%$ und $68 \%$ für csPCA. Durch zusätzliche Annotierung der Ziele in den MRT-Sequenzen verbesserte sich die CDR auf $17 \%, 53 \%$ und $93 \%$. Hervorzuheben ist, dass sich die CDR von CSPCA signifikant erhöhte (PPCA $\left.<0,021 ; \mathrm{P}_{\text {cSPCA }}<0,001\right)$.

Die radiologische Berichterstattung mitsamt Annotation suspekter Areale in MRT-Bildern führt zu signifikant besseren diagnostischen Ergebnissen der TB. Wir schlussfolgern daher, dass diese multimodale Befundung in die nächste PI-RADS-Version integriert werden sollte. 


\section{V03 - Nierenkarzinom - Experimentell}

16.09.2021, C7.2, 08:00-09:30

\section{V03.1}

Dissecting the mechanistic role of PBRM1 loss to inflammatory signals within the tumor microenvironment of clear cell renal cell carcinoma

N. Klümper ${ }^{*}, 2$, J. Linxweiler ${ }^{3}$, P. Zeuschner ${ }^{3}$, S. Leonardelli ${ }^{2}$, J. Albrecht ${ }^{1,2}$, A. Bamarni ${ }^{2}$, T. Lindenberg ${ }^{4}$, B. Odermatt ${ }^{4}$, G. Kristiansen ${ }^{5}$, M. Ritter' ${ }^{1}$, J. Ellinger', A. Alajati', K. Junker ${ }^{3}$, M. Toma', M. Hölzel ${ }^{2}$

'Universitätsklinikum Bonn, Klinik und Poliklinik für Urologie und Kinderurologie, Bonn, Germany; ${ }^{2}$ Universitätsklinikum Bonn, Institut für Experimentelle Onkologie, Bonn, Germany; ${ }^{3}$ Universitätsklinikum des Saarlandes, Klinik für Urologie und Kinderurologie, Homburg, Germany; ${ }^{4}$ Universitätsklinikum Bonn, Institut für Neuroanatomie, Bonn, Germany; ${ }^{5}$ Universitätsklinikum Bonn, Institut für Pathologie, Bonn, Germany

Introduction: PBRM1-mutations were associated with therapeutic response to VEGFR-targeting tyrosine kinase inhibitors as well as immune checkpoint blockade in clear cell renal carcinoma (ccRCC). The exact molecular basis of how PBRM1 loss mediates these responses is, however, still poorly understood. Here, we propose that PBRM1 loss influences the response to inflammatory signals within the tumor microenvironment (TME).

Material and methods: We established matched pairs of PBRM1 pro- and deficient Caki1 and 7860 ccRCC cell lines using CRISPR-Cas9. We investigated the influence of PBRM1 loss on growth as well as the transcriptional response to a cytotoxic cytokine environment modelled by exposure to IFNY, TNFa, or T cell-conditioned using 3'RNAseq. To characterize the influence of PBRM1 loss on the cCRCC cells behavior in vivo, we xenografted fluorescently-labeled Caki1 wildtype versus PBRM1-knockout cells (KO) into the yolk sac of KDR-EGFP zebrafish larvae and under the renal capsule in a well-established orthotopic xenograft mouse model.

Results: In vitro, PBRM1-KO did not affect cell growth but exposures to IFN $\gamma$ and TNFa revealed a uniform picture showing that PRBM1 loss potently enhanced transcriptional responses. Hyperinduction of angiogenic or T cell-attracting chemokines like CXCL5 or CXCL10, respectively, was validated by qRT-PCR and ELISA. In vivo, first results revealed that PBRM1 loss led to a reduced xenograft success rate in the subcapsular orthotopic mouse model, whereas, interestingly, in the zebrafish larvae model, PBRM1-deficient Caki1 showed increased migratory capacity and tumor cell-vessel interaction.

Conclusions: PBRM1 loss confers hyperresponsiveness to inflammatory signals from the TME, which then shapes ccRCC tumor cell behavior and therapy response.

\section{V03.2}

\section{Inhibition der Autophagie als therapeutisches Konzept} beim Nierenzellkarzinom

V. Stühler ${ }^{*}$, S. Rausch', S. Winter ${ }^{2}$, C. Schmees ${ }^{3}$, A. Stenzl', J. Bedke', M. Schwab ${ }^{2,4}$, E. Schaeffeler ${ }^{2}$

'Universitätsklinik Tübingen, Urologie, Tübingen, Deutschland; ${ }^{2}$ Dr. Margarete FischerBosch - Institut für Klinische Pharmakologie, Stuttgart, Deutschland; ${ }^{3} \mathrm{NMI}$ Naturwissenschaftliches und Medizinisches Institut, Reutlingen, Deutschland; ${ }^{4}$ Departments of Clinical Pharmacology, Pharmacy and Biochemistry, University of Tuebingen, Tübingen, Deutschland

Fragestellung: Autophagie verknüpft zelluläre Abbauprozesse mit dem Stoffwechsel und stellt eine innovative therapeutische Strategie in der Tumortherapie dar.

Material und Methoden: Für diese Studie wurde Tumor- $(n=324)$, Normal- und Metastasengewebe $(n=164)$ von Patienten mit Nierenzellkarzinom (NZK) verwendet. Es wurden Analysen der Transkriptomdaten von
Autophagie-Kandidatengenen ( $n=129)$ durchgeführt und die Expression für ATG5, ATG7, LC3B \& SQSTM1 untersucht. In Zellkulturexperimenten wurde die Wirkung des neuen Autophagie-Inhibitors ROC-325 allein und in Kombination mit Metformin auf die Zellviabilität, Genexpression und mitochondriale Atmung in etablierten und primären NZK-Zelllinien untersucht.

Ergebnisse: Die 4 untersuchten Proteine zeigten eine höhere Expression im Metastasen- verglichen zum Primärtumorgewebe. Aktivierte Autophagie Signalwege fanden sich im Primärtumor und Metastasen vom klarzelligen NZK sowie in primären NZK-Zelllinien. Am höchsten exprimiert waren CTSD und RAB7A. In der TCGA-Vergleichskohorte waren CTSD und RAB7A ebenfalls hoch exprimiert, zusätzlich aber auch SQSTM1 und LAMP1\&2. Die Behandlung mit ROC-325 zeigte konzentrationsabhängig sowie in Kombination mit Metformin eine signifikant geringere Viabilität in den Zellexperimenten. Die Wirkung von ROC-325 auf die mitochondriale Atmung ergab widersprüchliche Ergebnisse. Die Fähigkeit der Zellen auf einen energetischen Bedarf zu reagieren, wurde bei Kombination von ROC-325 mit Metformin reduziert.

Schlussfolgerung: Die Inhibition der Autophagie im Tumormicroenvironement des NZK ist eine neue therapeutische Strategie in der Beeinflussung metabolischer Signalwege.

Gefördert durch ein Ferdinand Eisenberger-Forschungsstipendium der DGU, Fördernummer StV1/FE-19 und durch die Robert Bosch Stiftung, Stuttgart

\section{V03.3}

\section{Zirkuläre RNA: Bedeutung als Biomarker für Patienten mit einem klarzelligen Nierenzellkarzinom}

L. Frey ${ }^{1 *}$, N. Klümper ${ }^{1}$, D. Schmidt ${ }^{1}$, G. Kristiansen ${ }^{2}$, M. Toma ${ }^{2}$, M. Ritter ${ }^{1}$, A. Alajati ${ }^{1}$, J. Ellinger ${ }^{1}$

'Universitätsklinikum Bonn, Urologie, Bonn, Deutschland; '2Universitätsklinikum Bonn, Pathologie, Bonn, Deutschland

Fragestellung: Zirkuläre RNAs spielen eine bedeutende Rolle in der Karzinogenese verschiedener Tumorentitäten. Da sie mutmaßlich eine hohe Tumor- und Gewebespezifität besitzen, haben sie großes Potenzial als Biomarker. Vor dem Hintergrund, dass das Wissen über zirkuläre RNAs im klarzelligen Nierenzellkarzinom (ccRCC) begrenzt ist, haben wir das Expressionsprofil von sieben zirkulären RNAs (circCOL5A1, circEHD2, circEDEM2, circEGNL3, circNETO2, circSCARB1, circSOD2) in einer Kohorte von Patienten mit einem cCRCC untersucht.

Material und Methoden: Prospektiv wurde das Gewebe von Patienten mit einem $c c R C C$, die sich einer radikalen/partiellen Nephrektomie unterzogen, in der Biobank des Universitätsklinikum Bonn gesammelt. Die Gesamt-RNA wurde von 121 Tumorgeweben und 91 normalen Nierengeweben isoliert und das Expressionsprofil der zirkulären RNAs durch eine quantitative real-time PCR bestimmt.

Ergebnisse: Die Expression von circEHD2, circENGLN3 und circNETO2 war im ccRCC im Vergleich zum normalen Gewebe signifikant erhöht, wobei die circEGLN3 Expression mit einer hohen Genauigkeit (Sensitivität $87 \%$, Spezifität $78 \%$ ) zwischen Tumor- und Normalgewebe unterscheiden konnte. Keine der zirkulären RNAs war mit klinisch-pathologischen Parametern korreliert. Eine hohe circEHD2 und eine niedrige circNETO2 Expression konnten unabhängig von klinisch-pathologischen Parametern (pT, cM, Grading) ein verkürztes progressionsfreies, krebsspezifisches und Gesamtüberleben bei Patienten mit ccRCC vorhersagen.

Schlussfolgerungen: Die Analyse von zirkulären RNAs kann diagnostische und prognostische Informationen liefern und so möglicherweise helfen, die individuelle Behandlung und letztendlich das Überleben von Patienten mit einem Nierenzellkarzinom zu verbessern. 
V03.4

\section{PD-L1 Expression auf extrazellulären Vesikeln von Nierenzellkarzinom-Patienten}

P. Zeuschner*, G. Jaschkowitz, D. Himbert, J. Sonnleithner, A. Zaccagnino, M. Stöckle, K. Junker

Universitätsklinikum des Saarlandes, Klinik für Urologie und Kinderurologie, Homburg/ Saar, Deutschland

Einleitung: Extrazelluläre Vesikel (EVs) gewinnen eine zunehmende Bedeutung als Biomarker. Für einige Tumorentitäten konnte gezeigt werden, dass PD-L1 auf EVs eine prognostische und prädiktive Wertigkeit hat. Ziel dieser Studie ist die Untersuchung der PD-L1 Expression auf EVs bei Patienten mit klarzelligem Nierenzellkarzinom (NZK).

Material \& Methoden: EVs wurden aus 9 primären Tumorgeweben mittels Ultrazentrifugation mit Dichtegradient und aus Blutplasma mittels Kit isoliert. PD-L1 auf EVs wurde mit Western Blot analysiert, die Quantifizierung von PD-L1 im Plasma erfolgte mittels ELISA. An Gewebeschnitten wurde PD-L1 immunhistochemisch untersucht. Qualität und Quantität der EVIsolation wurden mittels Elektronenmikroskopie, Nanotracking Analyse und Western Blot bewertet.

Ergebnisse: EVs konnten aus allen Tumorgeweben isoliert werden. PD-L1 war in 8/9 Tumoren und deren EVs nachweisbar und unterschied sich patientenabhängig. In 5/9 Fällen war PD-L1 in Tumor-EVs im Vergleich zum Gewebe angereichert. Im umgebenden Normalgewebe (2 Fälle) war die PD-L1 Expression in EVs und Zellen niedriger. Immunhistochemisch fanden sich in 8/9 Tumoren PD-L1 positive Tumorzellen, in 7/8 Fällen waren aber nur wenige Tumorzellen schwach gefärbt. Alle Tumore hatten PD-L1 positive Immunzellen, 2/8 große Immunzellinfiltrate. Bei allen Patienten waren PD-L1 positive EVs im Blut nachweisbar, die Menge an PD-L1 war in der EV-Fraktion höher als im Gesamtplasma.

Schlussfolgerung: In dieser Arbeit konnte erstmals die PD-L1 Expression auf EVs aus primärem NZK-Gewebe gezeigt werden. PD-L1 war auf den EVs im Vergleich zu den Tumorzellen angereichert, dessen funktionelle Rolle wird nun weiter untersucht. PD-L1 auf den EVs könnte darüber hinaus einen vielversprechenden Biomarker im Blut darstellen.

\section{V03.5}

IFNp-vermittelte Stimulation der PD-L1 Expression auf Zellen und extrazellulären Vesikeln von Nierenzellkarzinom-Zelllinien

G. Jaschkowitz ${ }^{1 *}$, P. Zeuschner ${ }^{1}$, D. Himbert ${ }^{1}$, A. Zaccagnino ${ }^{1}$, M. Stöckle ${ }^{1}$, E. Noessner ${ }^{2}$, K. Junker ${ }^{1}$

'Universitätsklinikum des Saarlandes, Klinik für Urologie und Kinderurologie, Homburg, Deutschland; ${ }^{2} \mathrm{Helmholtz} \mathrm{Zentrum} \mathrm{München,} \mathrm{German} \mathrm{Research} \mathrm{Center} \mathrm{for} \mathrm{Environmental}$ Health, IMA Immunoanalytics, München, Deutschland

Einleitung: PD-L1 spielt eine wichtige Rolle bei der Regulation der tumorgerichteten Immunantwort. Die Kommunikation zwischen Tumorzellen und Immunzellen wird auch durch extrazelluläre Vesikel (EV) vermittelt. Ziel dieser Studie ist die Evaluation der PD-L1 Expression auf EVs von Nierenzellkarzinom (NZK)-Zelllinien und deren immunmodulatorische Effekte auf CD8+T-Zellen.

Material und Methoden: EVs wurden aus Zellkulturüberständen von 6 NZK-Zelllinien (Caki1, Caki2, 786-O, RCC26, RCC53, KTCTL26) durch serielle Ultrazentrifugation gewonnen. Qualität und Quantität der EVs wurden mittels NanoTracking Analyse, Elektronenmikroskopie und Western Blot geprüft, PD-L1 Expression in Zellen und EVs semiquantitativ mittels Western Blot bestimmt. Die Zellen wurden repetitiv mit verschiedenen Dosen Interferon-Gamma (IFN $\gamma$ ) an 5 und 3 Tagen vor Isolation stimuliert.

Ergebnisse: Alle Zelllinien exprimieren PD-L1, jedoch in unterschiedlicher Intensität. In korrespondierenden EVs ist die Expression schwächer. Die basale Expression von PD-L1 ist am höchsten in RCC53, am niedrigsten in KTCTL26 und 786-O. Die repetitive Stimulation mit IFN $\gamma$ führt zu erhöhter
PD-L1 Expression in Zellen und EVs in 4/6 Zelllinien (RCC53, RCC26, 786O, KTCTL26), in Abhängigkeit von IFNY-Dosis und Zeit. KTCTL26 zeigt nach Stimulation die stärkste Anreicherung von PD-L1 in Zellen sowie EVs. Schlussfolgerung: NZK-Zelllinien exprimieren PD-L1 in Zellen und deren EVs. Die basale Expression ist relativ gering. Nicht alle Zelllinien sind stimulierbar, jedoch kann IFNY-Gabe die PD-L1 Expression in Abhängigkeit vom individuellen zellulären Kontext hochregulieren. Wir konnten somit ein in vitro Modell entwickeln, um PD-L1-abhängige Effekte, die durch EVs vermittelt werden, in dieser laufenden Studie weiter zu untersuchen.

\section{V03.6}

Ring finger protein 34 (RNF34) is a prognostic biomarker in clear cell renal cell carcinoma

N. Klümper', D. Ralser', A. Cox' , M. Toma ${ }^{3}$, G. Kristiansen', A. Alajati', M. Ritter', J. Ellinger', J. Stein ${ }^{*}$

'Urologie/Universitätsklinikum Bonn, Bonn, Germany; ${ }^{2}$ Gynäkologie/Universitätsklinikum Bonn, Bonn, Germany; ${ }^{3}$ Pathologie/Universitätsklinikum Bonn, Bonn, Germany

Introduction: Ring finger proteins play pivotal roles in diverse cellular processes and are implicated in contribution to cancer. Ring finger protein 34 (RNF34) has antiapoptotic and oncogenic properties. RNF34 is upregulated during carcinogenesis and tumor progression in the colorectal adenoma-carcinoma sequence and was already described to mediate chemoresistance. Thus, RNF34 is a promising target for oncology research. In clear cell renal cell carcinoma (ccRCC), however, the role and expression pattern of RNF34 is unknown. Therefore, our study aimed to comprehensively investigate RNF34 in ccRCC.

Materials and methods: First, we investigated the association of RNF34 mRNA expression with clinicopathological parameters and survival using data obtained from The Cancer Genome Atlas (TCGA) cCRCC cohort $(N=533)$. To assess RNA34 protein expression, we performed immunohistochemical (IHC) staining of an established ccRCC cohort (University of Bonn) in tissue microarray format (TMA). This validation cohort contains $N=109$ primary ccRCC samples. IHC data were associated with clinicopathological parameters and overall survival.

Results: In the ccRCC TCGA cohort, increased RNF34 mRNA expression was associated with advanced $\mathrm{pT}$-stage and metastatic spread. Further, high mRNA expression (Cutoff median RNF34 expression) was associated with unfavorable overall survival (log rank: $p<0.001)$. On the protein level, RNF34 showed expression in different cell compartments (cell membrane, cytoplasm and nucleus). RNF34 staining was associated with a significantly shorter overall survival.

Conclusion: Our data support the role of RNF34 as a novel prognostic marker in ccRCC. Thus, RNF34 represents a promising object for further research.

\section{V03.7}

The in vitro activity of Cabozantinib as first- and secondline agent in metastatic renal cell carcinoma

\section{A. Zaccagnino*, B. Vynnytska-Myronovska, M. Stöckle, K. Junker}

Universität des Saarlandes, Klinik für Urologie und Kinderurologie, Homburg/Saar, Germany

Introduction: Cabozantinib (Cbz) is applied as first- and second-line agent for selective metastatic renal cell carcinoma (mRCC) patients. We investigated the efficacy of $\mathrm{Cbz}$ after a chronic Sunitinib (Sun) treatment in vitro. Material and method: The response to $\mathrm{Cbz}$ was assessed by the $\mathrm{IC}_{50}$ method in the Sun-resistant cells (786-O/S and Caki-2/S) and their counterparts (786-O/WT and Caki-2/WT). The signaling pathways were analyzed by using immunoblotting.

Results: The drug response was different between the two cell lines: 786O/WT were slightly more sensitive to $\mathrm{Cbz}$ than Caki-2/WT ( $\mathrm{IC}_{50}$ of $10.8 \mu \mathrm{M}$ and $13.6 \mu \mathrm{M}$, singly). In 786-O/WT, Cbz $>10 \mu \mathrm{M}$ caused a late onset of the 
activated receptor MET and the coupled proteins, Src and STAT3, followed by an impairment of Erk $1 / 2$ and FAK. Under the same conditions MET was efficiently inhibited in Caki-2/WT cells, along with the mTOR markers, AKT and S6. As second-line drug, Cbz had lower efficacy in 786-O/S cells $\left(\mathrm{IC}_{50}\right.$ of $13 \mu \mathrm{M}, p$ value 0.02$)$, but no in Caki-2/S (IC $C_{50}$ of $\left.12.6 \mu \mathrm{M}\right)$. The Sun-pretreatment enhanced the level of MET only in 786-O/S. After the $\mathrm{Cbz}$ treatment a delayed inhibition of MET ( $72 \mathrm{~h}$ ) was compensated by the boost of Src and STAT3 in 786-O/S. By contrast, Cbz impaired MET in Caki-2/S, as in the Caki2/WT. In both Sun-pretreated cell lines, the endogenous activation of FAK was not affected by $\mathrm{Cbz}$. Still, the drug altered mTOR, especially in Caki-2/ $\mathrm{S}$. Finally, the anti-apoptotic protein $\mathrm{BCl}-2$ was enhanced at the maximum inhibition of MET, notably in 786-O/S and Caki-2/WT.

Conclusions: Following MET inhibition, the activation of Src-FAK protein axis and $\mathrm{BCl}-2$ might suggest a synergy that could weaken Cbz's antitumor activity. This ongoing work will provide a better knowledge of cellular signaling in mRCC therapy sequencing.

\section{V03.8}

\section{CMTM6 expression as a potential biomarker for immunotherapy in metastatic renal cell Carcinoma}

G. Tulchiner ${ }^{1 *}$, A. Brunner ${ }^{2}$, M. Schmidinger ${ }^{3}$, N. Staudacher ${ }^{2}$, J. J. Orme ${ }^{4}$, M. Thurnher ${ }^{2}$, W. Horninger ${ }^{2}$, Z. Culig' ${ }^{2}$, R. Pichler ${ }^{2}$

${ }^{1}$ Med. Universität Innsbruck, Urologie, Innsbruck, Austria; ${ }^{2}$ Med. Universität Innsbruck Innsbruck, Austria; ${ }^{3}$ Medical University of Vienna, Vienna, Austria; ${ }^{4}$ Mayo Clinic Cancer Center, Rochester, Vereinigte Staaten von Amerika

Recently human chemokine-like factor (CKLF)-like MARVEL transmembrane domain containing family member 6 (CMTM6) has been identified as a key regulator of PD-L1 cell surface expression across various cancer entities. Thus, CMTM6 is supposed not only to refine the prognostic value of PD-L1, but also to play an independent role as a predictive factor for response to immune checkpoint inhibition.

For the first time we evaluated expression of CMTM6 within the tumour microenvironment TME (tumour cells (TC) and tumour-infiltrating immune cells (IC)) of RCC and its predictive role when compared to PD-L1 in primary tumours of sixteen patients with metastatic RCC patients receiving nivolumab.

A high intratumoural heterogeneity of both CMTM6 and PD-L1 expression, with a significantly higher expression of both markers on IC compared to TC (CMTM6: $p<0.001$; PD-L1: $p=0.008$ ) was found. Focusing on IC, CMTM6 expression was significantly higher compared to PD-L1 $(p=0.0016)$. Moreover, CMTM6 expression was positively correlated with PD-L1 on TC $\left(r_{s}=0.441 ; p=0.047\right)$ and IC $\left(r_{s}=0.487 ; p=0.057\right)$. Further, patients with CMTM6-IC high scores (CMTM6-IChigh) had a significantly shorter PFS on nivolumab when compared to patients with CMTM6-IC low scores (CMTM6-IClow), (median, low vs. high: 24 vs. 7 months; $p=0.032$ ).

Our data suggest that CMTM6 plays an important role in the RCC tumour microenvironment. Although both markers CMTM6 and PD-L1 were more frequently expressed on IC than on TC, CMTM-IC expression was significantly higher compared to PD-L1. Moreover, in contrast to PD-L1, CMTM6IC expression appears to predict PFS in patients receiving nivolumab. Thus, PD-L1 IHC may be supplemented by IHC measurement of CMTM6 to increase its prognostic role as predictive biomarker.
V03.9

Fluoreszenz-In-Situ-Hybridisierung zur Differenzierung zwischen Onkozytomen und chromophoben Nierenzellkarzinomen

S. Schaffner ${ }^{*}$, F. Erlmeier ${ }^{2}$, C. Stöhr ${ }^{2}$, S. Steffens ${ }^{3}$, M. Authenrieth ${ }^{4}$, J. Gschwend ${ }^{4}$, H. Zitzelsberger ${ }^{5}$, W. Weichert ${ }^{6}$, A. Hartmann ${ }^{2}$, K. Junker ${ }^{7}$

'Klinik für Urologie und Kinderurologie, Universität des Saarlandes, Homburg, Deutschland; ${ }^{2}$ Institut für Pathologie der Universität Erlangen-Nürnberg, Erlangen, Deutschland; ${ }^{3}$ Medizinische Hochschule Hannover (MHH), Hannover, Deutschland; ${ }^{4}$ Klinik für Urologie, Klinikum rechts der Isar, TU München, München, Deutschland; ${ }^{5}$ Helmholtz Zentrum München, Abteilung für Strahlenzytogenetik, München, Deutschland; ${ }^{6}$ Institut für Pathologie, TU München, München, Deutschland; ${ }^{7}$ Universitätsklinikum des Saarlandes, Homburg, Deutschland

Die eindeutige Diagnose von Onkozytomen (OZ) ist eine wichtige Voraussetzung für die Therapieentscheidung und Nachsorge, insbesondere bei kleinen Nierentumoren. Die Differenzierung zwischen Onkozytomen (OZ) und chromophoben Nierenzellkarzinomen (chrNZK) ist jedoch durch alleinige Histopathologie nicht immer möglich. Ziel dieser Studie war die Analyse chromosomaler Alterationen von OZ vergleichend zu chrNZK mittels FISH.

Es wurden Tissue Microarrays (TMA) von 59 chrNZK und 36 Onkozytomen mit je 2 Tumorarealen und z. T. Normalgeweben verwendet. Die FISH wurde auf Schnitten der TMAs unter Verwendung von Zentromersonden für die Chromosomen (Chr) 1, 2, 6, 10 und 17 durchgeführt. Pro Gewebestanze wurden 100 Zellkerne ausgewertet. Die Cut-off-Werte wurden für jede Sonde an 10 Normalgeweben definiert.

Die chrNZK wiesen Verluste der Chr 1, 2, 10 und 17 in je $100 \%$ und von Chr 6 in $94 \%$ der Proben auf. In allen Fällen waren mindestens 4 Chromosomen verändert. Bei den OZ fanden sich Verluste von 1 in $100 \%$, von 2 in $26 \%$, von 6 in $11 \%$, von 10 in $8 \%$ und von 17 in $12 \%$ der Proben. Jedoch war der Anteil veränderter Zellen für die Chr 2, 6, 10 und 17 bei den OZ signifikant geringer (6-11\% vs. $52-85 \%$ ). Es bestand keine Korrelation zur Tumorgröße. Für die chrNZK wurde eine hohe (Korrelationskoeffizient $>0,86$ ) und für die $\mathrm{OZ}$ eine mittlere bis hohe Übereinstimmung (Korrelationskoeffizient 0,34-0,89) der Veränderungen zwischen 2 Tumorarealen festgestellt.

Während Onkozytome durch den Verlust des Chr 1 charakterisiert sind, weisen chrNZK immer kombinierte Verluste von mindestens 4 Chromosomen auf. Diese Ergebnisse belegen, dass die FISH an Schnittpräparaten eine wichtige Technik zur Absicherung der histopathologischen Diagnose und damit zur individuellen Therapieentscheidung darstellt.

\section{V04 - Operationstechniken: aktuelle Entwicklungen}

$$
\text { 16.09.2021, C4.2, 08:00-09:30 }
$$

\section{V04.1}

Präoperative Ankerdraht-Markierung vor robotischer Salvage-Lymphadenektomie bei "in-field“ Lymphknotenrezidiven nach radikaler Prostatektomie: erste Erfahrungen

\section{J. Linxweiler ${ }^{1 *}$, P. Fries ${ }^{2}$, S. Siemer ${ }^{1}$, M. Stöckle ${ }^{1}$, M. Saar ${ }^{1}$}

'Universitätsklinikum des Saarlandes, Klinik für Urologie und Kinderurologie, Homburg Saar, Deutschland; ${ }^{2}$ Universitätsklinikum des Saarlandes, Klinik für diagnostische und interventionelle Radiologie, Homburg Saar, Deutschland

Einleitung: Die minimal-invasive Salvage-Lymphadenektomie (sLND) stellt eine innovative Therapieoption bei Lymphknotenrezidiv nach radikaler Prostatektomie (RP) dar. Insbesondere bei „in-field“ Rezidiven ist es intraoperativ jedoch häufig schwierig versteckt gelegene Lymphknoten- 
metastasen in einem voroperierten Areal aufzufinden. Daher haben wir begonnen bei selektierten Fällen vor robotischer sLND eine CT-gesteuerte Ankerdrahtmarkierung durchzuführen.

Material \& Methoden: 8 Patienten haben zwischen März 2020 und Februar 2021 bei PSMA-PET/CT-gesichertem Lymphknotenrezidiv nach RP eine robotische sLND erhalten. In allen Fällen war das Rezidiv bildgebend im Gebiet einer typischen pelvinen LND lokalisiert. Die periinterventionellen- bzw. operativen und histologischen Resultate wurden analysiert.

Ergebnisse: 8 Patienten mit einem medianen Alter von 67,5 Jahren [range $57 ; 75]$ unterzogen sich 50,3 Monate $[4,1 ; 121,6]$ nach ihrer RP einer robotischen sLND. Der PSA-Wert vor sLND lag bei $2,07 \mathrm{ng} / \mathrm{ml}[0,74 ; 4,32]$, in allen Fällen waren die im PET/CT auffälligen Lymphknoten im Abflussgebiet der A. iliaca interna lokalisiert. Die Ankerdrahtmarkierung wurde in Lokalanästhesie über einen ventralen $(n=5)$ bzw. dorsal-parasakralen Zugang $(n=3)$ komplikationslos durchgeführt. Im Rahmen der SLND (OP-Dauer 136 min [84;228], Blutverlust $48 \mathrm{ml}[20 ; 70])$ gelang es in allen Fällen den tumorbefallenen Lymphknoten zu entfernen. In einem Fall musste eine Blasenläsion intraoperativ übernäht werden, ansonsten traten keine Komplikationen auf. Die Patienten konnten nach einem Aufenthalt von 4 Tagen $[1 ; 6]$ entlassen werden.

Schlussfolgerung: Insbesondere bei „in-field" Rezidiven hat sich die präoperative Ankerdrahtmarkierung vor robotischer Salvage-Lymphadenektomie als äußert hilfreich erwiesen.

\section{V04.2}

\section{Roboterassistierte radikale Prostatektomie (RARP): to Flap or not to Flap?}

S. Homann, N. Harz , A. Kress, N. Kreutzer, M.C. Truß

Klinikum Dortmund, Urologie, Dortmund, Deutschland

Einleitung: Lymphozelen (LZ) sind die häufigste postoperative (p.o.) Komplikation nach RARP mit pelviner Lymphadenektomie (PLAE). Die Reduktion symptomatischer LZ durch Etablierung eines Peritonealflaps (PF) wird in der Literatur kontrovers diskutiert. Wir untersuchten deshalb den Wert des PF prospektiv.

Material und Methoden: Im Zeitraum von April bis Dezember 2020 erfolgte monozentrisch bei der RARP mit bilateralen PLAE alternierend ein PF als Zwei-Punkt-Fixierung an der endopelvinen Faszie. Von insgesamt 115 Patienten mit RARP erhielten 90,4\% (104/115) simultan eine PLAE, bei 11 Patienten wurde auf diese bei low-risk-Konstellation verzichtet und diese von der Studie ausgeschlossen.

Patienten mit/ohne PF wurden systematisch erfasst und primär in Hinblick auf die Rate an sympt. LZ mit der Notwendigkeit der stat. Behandlung analysiert. Ergänzend wurde die mediane Operationszeit, die Kontinenzsituation (Vorlagenverbauch/24 h), p.o. Komplikationsrate vergleichend erfasst.

Ergebnisse: 49 \% (51/104) der Patienten erhielten einen PF. Zwischen den Kollektiven mit/ohne PF gab es keine signifikanten Unterschiede hinsichtlich klinischer $u$. onkologischer Kriterien. Im Median erfolgte die Entfernung von 9,5 Lymphknoten (2-30). 10,5\% der Patienten (11/104) entwickelten innerhalb von 90 Tagen p.o. eine interventionsbedürftige symp. LZ, davon $3,9 \%$ des Kollektivs mit PF $(2 / 51)$ vs. $16,9 \%$ ohne PF $(9 / 53)$ $(p=0,416)$.

Ein Unterschied zwischen den Kollektiven bezüglich der Operationszeit $(p=0,426)$, der p.o. Komplikationsrate $(p=0,941)$ und der Kontinenzsituation der Patienten $(p=0,884)$ bestand nicht.

Schlussfolgerung: Der PF führte im untersuchten Kollektiv zur Reduzierung von symptomatischen LZ, bisher jedoch ohne statistische Signifikanz im untersuchten Kollektiv.
V04.3

Roboter-assistierte Nierenteilresektion unterschiedlich komplexer Nierentumore unter Verwendung von Fluoreszenz - Imaging mit Firefly ${ }^{\mathrm{TM}}$ - Technik

R. Ganzer*, W. Brummeisl, A. Mangold, J. König, L. M. Szyper

Asklepios Stadtklinik Bad Tölz, Klinik für Urologie, Bad Tölz, Deutschland

Fragestellung: Hilft der standardisierte Einsatz der Firefly ${ }^{\mathrm{TM}}$ - Technik bei der Roboter - assistierten Nierenteilresektion (NTR) bei Nierentumoren unterschiedlicher Komplexität?

Material und Methoden: Prospektive Analyse von Patienten nach NTR ab 07/2017. Zur Überprüfung der Ischämie des Exzisionsbereichs wurde nach Ausklemmen der Nierenarterie(n) eine Fluoreszenzdiagnostik mit Indocyaningrün - Firefly ${ }^{\mathrm{TM}}$ - Technik durchgeführt. Bei persistierender Perfusion erfolgte eine weitere Präparation der Gefäßversorgung. Die Einteilung der Nierentumore erfolgte anhand des R. E. N. A. L. Scores. Komplikationen wurden nach der Clavien-Dindo Klassifikation erfasst.

Ergebnisse: 117 Patienten wurden untersucht. In 77,7 \% lagen Tumore intermediärer $(n=71)$ und hoher $(n=20)$ Komplexität vor (multifokal $n=5$, Einzelniere $n=3$ ). In den Gruppen mit niedrigem, intermediärem und hohem R.E.N.A.L. Score lagen die mittleren Tumorgrößen bei jeweils 28 (12-62), 40 (12-96) und 52 (24-103) mm. In 19,2\%, 33,8\% und $45 \%$ fanden sich $\geq 2$ Nierenarterien. Die mittlere (partielle) Ischämiezeit betrug 14 (0-22), $16(0-28)$ und 21 (9-35) Minuten. Eine postoperative Bluttransfusion erfolgte in $0 \%, 2,8 \%(2 / 71)$ und $10 \%(2 / 20)$. Interventionspflichtige Clavien IIIb Komplikationen traten in 4/71 (5,6\%) auf. Der mittlere Krankenhausaufenthalt betrug 7,1 (5-15), 7,2 (5-19) und 6,6 (5-8) Tage. Es erfolgte keine intraoperative Konversion.

Schlussfolgerungen: Der Einsatz der Firefly ${ }^{\mathrm{TM}}$ Technik ist eine einfache technische Erweiterung, um bei der Roboter-assistierten NTR eine Ischämie des Exzisionsbereiches zu gewährleisten. Mit dieser Technik zeigte sich an unserem Patientenkollektiv mit Tumoren überwiegend intermediärer und hoher Komplexität eine niedrige Komplikationsrate ohne intraoperative Konversion und ohne Nierenverlust.

\section{V04.4}

Der kardiale Notfall (kN) während roboterassistierter (RA) Eingriffe: Simulationstraining verbessert die Teamkoordination

J. Moellers*, K. Wenker, J. H. Witt

St. Antonius Hospital Gronau GmbH, Gronau, Deutschland

Fragestellung: Bei RA Eingriffen im kleinen Becken kann es durch die Lagerung und den angedockten Roboter während eines kN zu einem Zeitverlust zwischen Herzstillstand und Beginn der Wiederbelebung kommen. Ziel der Arbeit war es, die Zeit vom Eintritt des kN bis zur Defibrillation (DEF) zu verkürzen.

Material und Methoden: Ein multidisziplinäres Team wurde in die Notfallschritte eingewiesen. Die einzelnen Teams wurden in einem mit komplettverkabelten und OP-üblich abgedecktem Kunststofftorso in $30^{\circ}$ Trendelenburglagerung präparierten OP gebracht. Der Anästhesist gibt das Stichwort "Stopp Notfallabdocken". Gemessen wurden folgende Zeiten: erste Herzdruckmassage (HDM), Zurückziehen des Roboters und der ersten DEF. Zusätzlich wurde die Selbsteinschätzung (SE) des Handelns im kN vor und nach dem Training abgefragt.

Ergebnisse: 2019 haben 42, im folgenden Jahr 35 Personen (P) teilgenommen und insgesamt 35 Durchgänge absolviert. Mediane Zeiten in Sekunden (s) 2019: HDM 39s, Zurückziehen des Roboters 37s, DEF 125s. Mediane Zeiten 2020: HDM 29s, Zurückziehen des Roboters 37s, DEF 134s. SE 2019 vor Training: 32 von $42 \mathrm{P}$ schätzen ihre Fähigkeit korrekt zu Handeln "sehr gut" bis ",befriedigend" ein. Nach Training schätzen sich alle Teilnehmer so ein. SE 2020 vor Training: 22 von 35 schätzen ihre Fähigkeiten „sehr gut" 
bis „befriedigend“ ein. Nach Training haben wieder alle Teilnehmer eine entsprechende Einschätzung.

Schlussfolgerung: Um eine schnelle und effektive Reanimation während RA Eingriffen zu gewährleisten, ist ein praktisches Notfalltraining sinnvoll. Die gleichartige Selbsteinschätzung vor und nach dem Training nach 1 Jahr legt nahe dass derartige Simulationen in kürzeren Abständen erfolgen sollten.

\section{V04.5}

\section{Ergebnisse der Harnröhrenplastik mit} Mundschleimhaut bei penilen Strikturen mit und ohne Meatusrekonstruktion

M. Borisenkov", G. Ivanov, J. Beier, A. Pandey

Sana Klinikum Hof, Klinik für Urologie, Hof, Deutschland

Einleitung: Strikturrezidive (SR) nach Urethraplastik (UP) mit Mundschleimhaut (OMG) treten in ca. 15-20\% auf. Wir untersuchten die SRRate bei penilen UP mit \& ohne Meatusrekonstruktion (MR).

Methode: 04/94-04/20 wurden 1575 Urethrastrikturen (US) mittels OMG (ventral onlay) rekonstruiert. Bei MR erfolgte Glans-Untertunnelung. Pat. mit einzeitiger UP bei peniler US $(\leq 10 \mathrm{~cm}$ lang, Abstand zum Sphinkter $\geq 5 \mathrm{~cm}$ ) ohne anamn. Hypospadiekorrektur wurden ausgewertet. FU: Flow \& Restharn (prosp., stand. 3-mon. in ersten 2 J. \& dann 6-mon.) \& „Patient self reported"-Fragebögen zu Lebensqualität, Morbidität \& Zufriedenheit. Bei Flow $<20 \mathrm{ml} / \mathrm{sec}$, Restharn $>50 \mathrm{ml}$ oder HWI empfahlen wir Urethroskopie u./o. Urethrographie. Jegliche Instrumentation an der Urethra während FU wurde als SR bewertet.

Ergebnisse: Bei 6,7\% (106/1575) lag eine penile US vor, davon bei 43,4\% (46/106) mit MR (Gruppe 1, G1) und bei 43,4\% (46/106) ohne (Gruppe 2, G2). Bei $13,2 \%(14 / 106)$ Pat. Beteiligung des Meatus unbekannt. Mittl. Strikturlänge 5,7 cm (med. 5,5; Range 2-10) vs. 5,5 cm (med. 5,5; R. 1,5$10), p=0,99$. Die Pat. der $\mathrm{G} 1$ waren junger: 54,6 vs. $62,5 \mathrm{~J}$., $p=0,01$. Mittl. Anzahl der Vor-OP's: G1 4,1 vs. G2 4,9 ( $p=0,01)$. Med. FU in G1 war kürzer (med. 6,5 Mo., R. 1-131) vs. G2 (med. 20 Mo., R. 1-168), aber nicht signifikant, $p=0,06$.

Ein SR trat in G1 bei 3 (6,5\%) vs. 6 (13\%) Pat. in G2, $p>0,05$.

Komplikationen: G1 bei 7 Pat. - 2 Fisteln, 3 Wundheilungsstörungen (WS), 2 TBVT. G2 bei 9 Pat. - 1 Fistel, 3 WS, 2 TBVT, 3 OMG-Abstoßung, 1 Penisdeviation und 1 Lungenembolie.

Schlussfolgerung: Die MR bei peniler UP mit OMG scheint keinen Einfluss auf die SR-Rate zu haben. Die wichtigsten Komplikationen unabhängig von MR sind Fistelbildung, WS und TBVT und sollen in Patientenberatung eingeschlossen werden.

\section{V04.6}

Neue TRUS-geführte Hydrospacing-Technik erleichtert die Präparation des Neovaginalkanals bei genitalangleichenden Operationen von Mann zu Frau

C. Kaspar*, A. Henkel, A. Panic, U. Krafft, J. P. Radtke, B. A. Hadaschik, S. Tschirdewahn, J. Heß

Universitätsmedizin Essen, Klinik und Poliklinik für Urologie, Uroonkologie und Kinderurologie, Essen, Deutschland

Einleitung: Die Etablierung des Scheidenkanals ist einer der heikelsten Schritte bei Mann-zu-Frau (MzF) genitalangleichenden Operationen (GAO). Es wird eine neue Hydrospacing-Technik (HST) zur Hydrodistension des Vaginalkanals vorgestellt.

Material \& Methoden: Zwischen 06/2018 und 06/2020 erhielten 54 Transfrauen eine GAO mit HST. Unter transrektaler Ultraschallkontrolle (TRUS) wurde der Raum dorsal der Denonvillier'schen Faszie mit einer TSK-Supranadel $(20 \mathrm{G}, 120 \mathrm{~mm})$ transperineal punktiert. Durch Injektion von $\mathrm{NaCl}$ wurde ein artifizieller Raum zwischen Rektum und Prostata geschaffen.
Zur intraoperativen Visualisierung wurde der hydrodistendierte Raum mit $2 \mathrm{ml}$ Methylenblau gefärbt. Die erhobenen Daten wurden retrospektiv mit einer klinisch und demographisch vergleichbaren Serie von 84 Transfrauen, die zwischen 06/2016 und 06/2018 eine GAO ohne HST (Kontrollgruppe, KG) erhielten, gegenübergestellt. Alle Eingriffe wurden vom selben Chirurgen durchgeführt. Das perioperative Setting war vergleichbar. Ergebnisse: Beide Gruppen unterschieden sich nicht bezüglich der Ausgangscharakteristika wie Alter $(p=0,44)$ und Body-Mass-Index $(p=0,73)$. Vaginale Tiefe und Breite waren in der HST-Gruppe signifikant größer $(14,4 \mathrm{~cm}$ vs. $13,5 \mathrm{~cm}, p=0,01$ und $4,2 \mathrm{~cm}$ vs. $3,8 \mathrm{~cm}, p<0,001)$. Beide Gruppen unterschieden sich nicht bzgl. intraoperativer Rektumverletzungen $(p=0,26)$ und postoperativer Komplikationen $(p=0,55)$. Die mediane Gesamt-OP-Zeit war ähnlich in beiden Gruppen ( $211 \mathrm{~min}$ vs. $218 \mathrm{~min}$; $p=0,19)$.

Schlussfolgerung: HST ist ein minimalinvasives und leicht anzuwendendes Verfahren zur sicheren Präparation des Scheidenkanals während der MzF-GAO. Der zusätzliche operative Schritt vereinfacht die folgende Präparation, führt nicht zu einer Verlängerung der OP-Zeit und verbessert das Outcome.

\section{V04.7}

Modifikation der bulbären Harnröhrenplastik bei segmental hochobliterativen Strikturen: Technik und Ergebnisse der ventralen Mucomucosal Anastomotic Non-Transecting Augmentation (MANTA) Urethroplastik

P. Marks*', R. Dahlem, M. Khonsari, L. Kühnke, F. König, M. Fisch, M.W. Vetterlein Universitätsklinikum Hamburg-Eppendorf, Klinik und Poliklinik für Urologie, Hamburg, Deutschland

Längere, segmental obliterative Urethrastrikturen bedürfen beidseitiger Rekonstruktionen, prinzipiell einhergehend mit der Durchtrennung des Spongiosums und damit Beeinträchtigung der urethralen Perfusion. Diese Techniken wurden zuletzt i.S. weniger invasiver Methoden (nontransecting) verfeinert (End-zu-End-Anastomose + dorsales Transplantat). Wir präsentieren Technik und Ergebnisse unserer Modifikation mit dorsaler mukomukosaler Anastomose und ventraler Augmentation.

Patienten mit bulbärer Striktur und hoch obliterativem Segment $(\leq 2 \mathrm{~cm})$ wurden mittels MANTA-Technik zwischen 2016-2019 rekonstruiert. Nach ventraler Inzision erfolgt hierüber die dorsale Exzision des obliterativen Segments und Anastomose der Mukosa. Ventrale Augmentation mit Mundschleimhaut. Prospektive Erfassung perioperativer Charakteristika inkl. Uroflowmetrie und validierter PROMs. Analyse postoperativer Verbesserung objektiver und funktioneller Parameter. Ein Rezidiv wurde definiert als Re-Intervention.

Insgesamt 54 Patienten (medianes Alter $51 \mathrm{~J})$. Voreingriffe: $\geq 1$ Urethrotomie bei $83 \%$, Urethroplastik bei $26 \%$. Die mittlere Transplantatlänge betrug $4 \mathrm{~cm}$. Uroflowmetrisch zeigte sich eine signifikante Besserung des medianen Qmax von 7,7 ml/s auf $31 \mathrm{ml} / \mathrm{s}$ postoperativ $(p<0,001)$. Die funktionellen Ergebnisse von 50 (93\%) Patienten nach medianem Follow-up von 40 Monaten zeigen eine signifikante Verbesserung des medianen 6-item LUTS Scores von 12 (IQR 8-14) auf postoperativ 1 (IQR 0-3; $p<0,001)$. Die Gesamterfolgsrate betrug $93 \%, 4 / 54$ Patienten erlitten ein Rezidiv.

Die ventrale Urethroplastik mit dorsaler mukomukosaler Anastomose ohne Durchtrennung des Spongiosums (MANTA Urethroplastik) zeigt eine exzellente Erfolgsrate in der komplexen Rekonstruktion bulbärer Harnröhrenstrikturen mit hochobliterativem Segment. 
V04.8

Offene Behandlung von Harnröhrenstrikturen bei Patienten mit einer Hypospadie in der Vorgeschichte

I. Kunz ${ }^{1 *}$, C. Peters ${ }^{2}$, R. Baschek², S. Krege ${ }^{2}$, D. Kröpfl

'Paracelsus-Klinik Golzheim Düsseldorf, Urologie, Düsseldorf, Deutschland; ${ }^{2}$ Evang. Huyssens-Stiftung Essen-Huttrop (KEM), Klinik für Urologie, Kinderurologie \& Urologische Onkologie, Essen, Deutschland

Fragestellung: Auch jahrelang nach der Hypospadie (Hyp) Operation (OP) kann es zu Strikturen (ST) der Neourethra kommen. Wir beschreiben hier die Behandlung von Harnröhrenstrikturen (HS) in einer oder zwei Sitzungen bei Patienten mit vorausgegangener Hyp-OP.

Material und Methodik: Wir führten eine monozentrische retrospektive Studie bei 57 Patienten mit einer HS durch, die zwischen Februar 1996 und Juli 2017 einer Rekonstruktion unterzogen wurden.

Ergebnisse: Das Follow-up der Patienten im Alter von 4-58 Jahre (Median 33 Jahren) betrug im Median 48 Monate.

22 Patienten $(38,6 \%)$ mit einer einzeitigen OP (Gruppe I) hatten ein mittleres Follow-up von 43 Monaten. 35 Patienten $(61,4 \%)$ mit einer zweizeitigen OP (Gruppe II) hatten ein mittlers Follow-up of 55 Monaten. Von den letzteren Gruppe haben sich 7 Patienten der zweiten Sitzung nicht unterzogen.

Die Länge der Striktur war in der Gruppe I zwischen 1 und 7,56 cm (Median 3,5 cm) und in der Gruppe II zwischen 2 und $16 \mathrm{~cm}$ (Median $5 \mathrm{~cm}$ ). Bei 5 Patienten der Gruppe I waren die Strikturen ausserhalb der Neourethra lokalisiert. 9 Patienten der Gruppe II hatten ein Lichen sclerosus.

Die Neourthra wurde gebildet aus Mundschleimhaut bei 53, innerem Vorhautblatt bei 2 und als composite Graft bei 1 Patienten.

Clavien III Komplikationen wurden bis 90 Tage nach der OP bei 7 Patienten beobachtet. Bei einer mittleren Beobachtungszeit von 48 Monaten traten in beiden Gruppen je 3 Rezidive auf.

Weiterhin traten eine ventral penile Deviation und eine Störung der Sensibilität des Mundwinkel auf.

Zusamenfassung: Die Rekonstruktion der Harnröhrenstrikturen nach vorausgegangener Hyp-OP bedarf einer Beherrschung des kompletten operativen Spektrums. Bei einem kurzen mittleren Follow-up war die Rate der Komplikationen vertretbar.

\section{V04.9}

Interdisziplinärer Behandlungsansatz der totalen Exenteration und Defektdeckung mittels vertikaler Rectus-abdominis-Muskel-Haut-Lappenplastik (VRAM) bei ausgedehnten urogenitalen Tumoren am Beispiel des Vulvakarzinoms

J. Hammes ${ }^{1 *}$, S. Aufderklamm 1 , S. Kommoss², J. Kolbenschlag ${ }^{3}$, E. Oberlechner², R. Ladurner', J. Bedke', A. Stenzl', B. Amend'

'Universitätsklinikum Tübingen, Klinik für Urologie, Tübingen, Deutschland; ${ }^{2}$ Universitätsklinikum Tübingen, Department für Frauengesundheit, Universitäts-Frauenklinik, Tübingen, Deutschland; ${ }^{3} B$ K Klinik Tübingen, Klinik für Hand-, Plastische, Rekonstruktive und Verbrennungschirurgie, Tübingen, Deutschland; ${ }^{4}$ Universitätsklinikum Tübingen, Klinik für Allgemeine, Viszeral- und Transplantationschirurgie, Tübingen, Deutschland

Einleitung: Lokal fortgeschrittene Vulvakarzinome sind häufig mit Lebensqualitätsminderung mit Schmerzen bis hin zur Geruchsbildung verbunden. Therapeutisch kann eine radikale Resektion mit totaler Exenteration sinnvoll sein. Zur Deckung der lokalen Defekte kommen dabei gestielte Lappenplastiken zum Einsatz. Hier stellen wir den interdisziplinären Ansatz dieser Operation an einer Serie von Vulvakarzinomen vor.

Material und Methoden: Bei vier Fällen wurde zwischen 2018 und 2020 eine Ano-/Vulvektomie mit totaler Exenteration sowie lleum conduit- und Colostoma-Anlage bei fortgeschrittenem Vulvakarzinom interdisziplinär (Gynäkologie/Urologie/Chirurgie) durchgeführt. Die Defektdeckung er- folgte mittels VRAM-Lappenplastik und Bauchwandrekonstruktion mit Netz (Plastische Chirurgie).

Ergebnisse: Das mittlere Alter betrug 71,25 Jahre (70-73). Karzinome lagen als Primärbefund oder Rezidiv nach Radiatio vor. Die lokale Ausbreitung umfasste urethrale und rektale Infiltration. Postoperativ wurden die Patientinnen bis zur Einheilung des Urostomas erst im Mittel 13,5 Tage (12-15 Tage) urologisch, anschließend 20 Tage (6-34 Tage) gynäkologisch betreut. Die Kontrolle des VRAM-Lappens erfolgte regelmäßig durch die Plastische Chirurgie. In allen 4 Fällen gelangen eine makroskopische Tumorkomplettresektion $(3 \times p R 0,1 \times p R 1)$ sowie das vollständige Einwachsen der Lappenplastik.

Schlussfolgerung: Durch enge interdisziplinäre Kooperation kann die ausgedehnte Resektion mit Harn- und Stuhlableitung sowie Defektdeckung mit gestieltem Lappen erfolgreich umgesetzt werden. Die en bloc Vulvektomie mit Exenteration ermöglicht eine vollständige Tumorresektion mit Erhalt der Lebensqualität. Die VRAM-Lappenplastik kann auch bei vorbestrahltem Gewebe adäquat zum Wundverschluss angewendet werden.

\section{V05 - Prostatakarzinom: Therapie lokal begrenzter Tumoren}

$16.09 .2021, C 1.2 .1,13: 30-15: 00$

V05.1

Spatium Retzii-erhaltende (rsRARP) vs. konventionelle roboterassistierte radikale Prostatektomie (cRARP) Kontinenz-Ergebnisse einer prospektiv, randomisierten, einseitig verblindeten Studie

V. Schütz*, J. Nyarangi-Dix, M. Güttlein, D. Würkner, P. Reimold, L. Hofer, M. Görtz, S. Dieffenbacher, K. Kaltenecker, G. Tosev, M. Hohenfellner

Universitätsklinikum Heidelberg, Urologische Universitätsklinik, Heidelberg, Deutschland

Hintergrund: Seit 2010 die rsRARP publiziert wurde, wurde die Technik nun in drei prospektiven RCT gegen die CRARP untersucht. Zur Vertiefung der Evidenz wurde von uns eine prospektiv, randomisierten, einseitig verblindete Studie durchgeführt.

Patienten/Methoden: 202 Prostatakarzinom (PCa) Patienten (Alter $64,2 \pm 6,9 \mathrm{~J}$.) wurden in die Studie eingeschlossen und 1:1 randomisiert. Präoperativ sowie 1, 4 und 12 Wochen nach Katheterentfernung wurden funktionelle Daten (Kontinenz, Sexualfunktion) mittels Fragebögen (ICIQ-UI SF, IPSS, IIEF-5, QoL) erhoben.

Ergebnisse: 3 Monate postoperativ liegen komplette Datensätze zu 186 Patienten (cRARP $n=92$, rsRARP $n=94$ ) vor. Präoperative Charakteristika waren in den Gruppen gleich verteilt. Der stationäre Aufenthalt $(4,1 \pm 0,9$ vs. $5,4 \pm 5,8 \mathrm{~d} ; p=0,037$ ) und Konsolenzeit (Prostatektomie $36,8 \pm 8,8$ vs. $46,8 \pm 12,8$ Min; $p=0,017$ ) waren in der rsRARP Gruppe signifikant kürzer. Patienten nach rsRARP zeigten ein signifikant schnelleres Wiedererlangen der Kontinenz ( 1 Woche $p=0.003,3$ Monate $p=0,022$ ), einen geringeren Vorlagenverbrauch $(p=0.001,0,011,0,019)$ und eine geringere Beeinträchtigung der Lebensqualität durch ungewollten Urinverlust $(p=0,001$, $0,002,0,005$ ) als Patienten nach cRARP. Onkologische Follow-up-Daten liegen zu diesem Kollektiv noch nicht vor. Nach rsRARP an unserer Klinik liegt die Rate der BCR gesamt bei 5,9\%, bei R1-Resektion bei $4,1 \%$.

Zusammenfassung: Die technisch deutlich aufwändigere rsRARP ist mit einem signifikant höheren Erhalt bzw. früheren Wiedererlangung der Kontinenz, geringerem Vorlagenvebrauch und einer höheren Lebensqualität verbunden. Gleichzeitig geht die rsRARP mit einer niedrigen BCR-Rate und somit gutem onkologischem Outcome einher. 


\section{V05.2}

Continence recovery at 3, 6 and 12 months following robotic-assisted vs laparoscopic surgery: outcome from the first multicentre randomised patient blinded controlled trial in radical prostatectomy (LAP-01)

S. Holze ${ }^{1 *}$, M. Mende ${ }^{2,3}$, M. C. Truss ${ }^{4}$, C. M. Haney ${ }^{1}$, P. Neuhaus ${ }^{2}$, C.I. Grzella ${ }^{4}$, M. Hohenfellner ${ }^{5}$, D. Teber ${ }^{5,6}$, P. Albers ${ }^{7}$, R. Rabenalt ${ }^{7,8}$, J.-U. Stolzenburg' ${ }^{1}$

'Universität Leipzig, Klinik und Poliklinik für Urologie, Leipzig, Germany; ${ }^{2}$ Universität Leipzig, Zentrum für Klinische Studien Leipzig, Leipzig, Germany; ${ }^{3}$ Universität Leipzig, Institut für Medizinische Informatik, Statistik und Epidemiologie, Leipzig, Germany; ${ }^{4}$ Klinikum Dortmund, Klinik für Urologie, Dortmund, Germany; ${ }^{5}$ Universität Heidelberg, Klinik für Urologie, Heidelberg, Germany; ${ }^{6}$ Städtisches Klinikum Karlsruhe, Klinik für Urologie, Karlsruhe, Germany; ' Universität Düsseldorf, Klinik für Urologie, Düsseldorf, Germany;

${ }^{8}$ Marien Hospital Düsseldorf, Klinik für Urologie, Düsseldorf, Germany

Objectives: The LAP-01 trial was designed to address the lack of highquality literature comparing robotic-assisted (RARP) and laparoscopic (LRP) radical prostatectomy. We present the results of the 12-month follow-up data.

Materials and methods: 782 patients from four clinical sites in Germany were randomised in the ratio of 3:1 (RARP: LRP). Follow-up was carried out at 1, 3, 6, 12, 24, 36 months. Frequencies in crosstabs were calculated and compared by chi-squared tests. Continence state was multiply modelled in logistic regression.

Results: 576 and 185 patients underwent RARP and LRP. Data at 12 months were available for $n=701$ (92\%) patients. The baseline characteristics, nerve-sparing rates and all other perioperative parameters were comparable between the groups. At 3 months, the difference in continence rates (0 pads or safety pad) significantly favoured $\operatorname{RARP}(p=0.027)$. At 6 months the rates were higher (RARP: $69 \%$ vs. LRP: $62 \%, p=0.068$ ) but the differences were no longer significant. The difference further decreased at 12 months of follow up ( $80 \%$ vs. $75 \%, p=0.18$ ). Regression analysis revealed that continence was significantly correlated with baseline continence, study arm and nerve-sparing procedure and not significantly with age and Rocco stitch at 12 months. Wide excision (non-nerve sparing) patients had no difference in continence between the two groups throughout the whole follow up period.

Conclusion: RARP only improves the early continence rate compared to conventional LRP in nerve sparing procedure.

\section{V05.3}

Reduzierte Symptome des unteren Harntraktes nach roboterassistierter radikaler Prostatektomie: Resultate eines high-volume Zentrums

N. Liakos", S.-R. Leyh-Bannurah, M. Mendrek, T. Karagiotis, C. Wagner, A. Schuette, K. Urbanova, M. Oelke, J. H. Witt

Prostatazentrum Nordwest, Klinik für Urologie, Kinderurologie und Urologische Onkologie, St. Antonius-Hospital Gronau, Gronau (Westf.), Deutschland

Ziel: Beurteilung der klinisch signifikanten Verbesserung der präoperativen Symptome des unteren Harntrakts(LUTS) und der damit verbundenen Lebensqualität(QoL) nach roboterassistierter radikaler Prostatektomie (RARP) bei Prostatakarzinompatienten.

Methoden: Wir identifizierten 6866 RARP Patienten mit präoperativ moderaten (IPSS 8-19) vs. schweren (IPSS 20-35) LUTS. Eine deutliche klinische Verbesserung wurde als eine negative IPSS-Differenz von 8 Punkten definiert. Multivariable logistische Regressionsanalysen (LRM) zur Prädiktion von $\triangle I P S S \leq-8$ beinhalteten das Alter, präoperatives PSA, präoperative LUTS (moderat [REF.] vs. schwer), Drüsengewicht (g), CAPRA-S-Score, Nervenschonung (keine vs. uni- vs. bilateral) und Blasenhalsrekonstruktionsbreite $(1-5 \mathrm{~cm})$.

Resultate: Präoperative LUTS wurden bei $37 \%(n=2556)$ bzw. $5,8 \%(n=400)$ als moderat und schwer eingestuft. Hier wurde eine post- operative Verbesserung ( $\triangle$ IPSS $\leq-8$ ) bei $36 \%$ bzw. $89 \%$ berichtet, was mit einer Score-Veränderung von $-2,0$ vs. $-15,1$ einherging $(p<0,001)$. Ein $\triangle \mathrm{IPSS} \leq-8$ vs. $>-8$ ging mit einer Score-Veränderung der Lebensqualität von $+0,28$ vs. $-1,5$ einher $(p<0,001)$. In der LRM waren der präoperative LUTS-Grad (OR 14; $95 \% \mathrm{Cl} 10-19 ; p<0,001)$ und das Drüsengewicht (pro

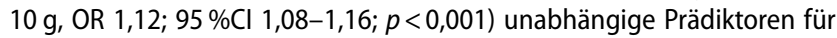
klinisch signifikante LUTS-Verbesserung.

Schlussfolgerungen: In unserer Kohorte mit präoperativen LUTS zeigte den großen Anteil von Patienten eine klinisch signifikante Verbesserung der LUTS-Beschwerden bereits 6 Monate nach RARP. Dies wirkt sich zudem auf eine verbesserte Lebensqualität aus. LRM zeigte den größten Vorteil bei Patienten mit präoperativer schwerer LUTS und großvolumiger Drüse. Diese Parameter sind bei der Therapieberatung neben onkologischen Variablen zu berücksichtigen.

V05.4

Onkologische Ergebnisse und Tumorcharakteristika von Prostatakarzinompatienten im Alter von $\geq 75$ Jahren nach roboter-assistierten radikalen Prostatektomie

M. Mendrek*, S.-R. Leyh-Bannurah, C. Wagner, A. Schuette, N. Liakos, K. Urbanova, M. Oelke, J. H. Witt

Prostatazentrum Nordwest, Klinik für Urologie, Kinderurologie und Urologische Onkologie, St. Antonius-Hospital Gronau, Gronau (Westf.), Deutschland

Fragestellung: Wir untersuchen den Einfluss des Alters $\geq 75$ Jahre auf das progressionsfreie Überleben(PFS) nach roboter-assistierter radikaler Prostatektomie(RARP). Es ist kontrovers, ob das Alter per se das onkologische Outcome beim Prostatakarzinom negativ beeinträchtigt.

Methoden: Wir analysierten 8159 RARP-Patienten, eingeteilt in zwei Gruppen: $<70(n=7578)$ vs. $\geq 75$ Jahren $(n=581)$. Das Alter wurde in multivariablen Cox-Regressionsanalysen(MVA) untersucht, die auch initiales PSA, neoadjuvante Androgendeprivation, Charlson Comorbidity Index, Jahr der Operation, pathologischer Gleason-Score, Tumor-, Lymphknotenund Tumorrand-Status beinhalteten. Die Analysen wurden nach Propensity Score Matching(PSM) wiederholt, welche die gleichen Variablen beinhaltete.

Ergebnisse: Die Senior-Patienten $\geq 75$ Jahren wiesen im Vergleich zu den jüngeren Patienten $<70$ Jahren folgende onkologische Unterschiede auf: ISUP Grade $\geq 3$ ( 55 vs. $35 \% ; p<0,001$ ), $\geq$ pT3 ( 53 vs. $34 \% ; p<0,001$ ), pN1 ( 13 vs. $7,6 \% ; p<0,001)$ und R1 ( 13 vs. $10 \%, p=0,04)$. Das mediane FollowUp war 60 (IQR 25-97) vs. 36 Monate (IQR 5,9-68). Das 3-Jahres PFS war $84(95 \% \mathrm{Cl} 83-85)$ vs. $77 \%(95 \% \mathrm{Cl} 74-81 ; p<0,001)$. Nach PSM wurden keine statistisch signifikanten Unterschiede bei den pathologischen Variablen bei Gruppen $\geq 75$ vs. $<70$ Jahren beobachtet. In der MVA war das Alter kein statistisch signifikanter Risikofaktor für kürzeres PFS, weder vor noch nach der PSM.

Schlussfolgerungen: Die Patienten im Alter von $\geq 75$ weisen nach der RARP ungünstigere pathologische PCa-Parameter als jüngere Patienten auf. Das Alter selbst ist jedoch kein negativer Risikofaktor für eine kürzere PFS nach der RARP. Basierend auf unseren onkologischen Daten sollte ein fortgeschrittenes Patientenalter alleine kein Ausschlusskriterium für RARP darstellen.

\section{V05.5}

Ändert die Zweitbeurteilung des Probenmaterials der Erstdiagnose eines Prostatakrebses durch einen spezialisierten Pathologen die Therapieplanung?

\section{S. Knipper ${ }^{1 *}$, C. Arnold ${ }^{1}$, H. Heinzer ${ }^{1}$, F. Lutz ${ }^{2}$, G. Sauter ${ }^{2}$, M. Graefen ${ }^{1}$}

${ }^{1}$ Martini-Klinik am Universitätsklinikum Hamburg-Eppendorf, Hamburg, Deutschland; ${ }^{2}$ Institut für Pathologie, Universitätsklinikum Hamburg-Eppendorf, Hamburg, Deutschland 
Einleitung: Die aktive Überwachung (AS) ist eine primäre Therapieoption des Niedrig-Risiko Prostatakarzinoms (PCa). Um bestmögliche onkologische Sicherheit zu gewährleisten, sind ursprünglich strikte Einschlusskriterien ( $\leq$ Gleason $3+3$ in $\leq 2$ Biopsien mit $<50 \%$ Tumoranteil/Biopsie, $\mathrm{PSA} \leq 10 \mathrm{ng} / \mathrm{ml}$ und $\leq \mathrm{CT} 2 \mathrm{a}$-Tumor) definiert worden. Dabei ist die pathologische Diagnose entscheidend und wirft die Frage auf, inwiefern eine Zweitbeurteilung der Histologie durch einen spezialisierten Uropathologen hilfreich sein könnte.

Material und Methoden: Hierfür wurden 95 PCa-Patienten, die zwischen 2010 und 2018 in die AS eingeschlossen wurden, evaluiert. Das Erstdiagnose-Biopsiematerial wurde von den externen Pathologien angefordert und durch unsere spezialisierten Uropathologen zweitbefundet. Diskrepanzen wurden evaluiert.

Ergebnisse: In der externen Befundung war bei $89(93,7 \%)$ und $3(3,2 \%)$ Patienten ein Gleason $3+3$ bzw. Gleason $3+4$ PCa diagnostiziert worden. In der Zweitbefundung wurde bei 66 (69,5\%) und 16 (16,8\%) der Patienten ein Gleason $3+3$ bzw. Gleason $3+4$ PCa beschrieben. Zudem zeigte sich bei einem Patienten ein Gleason 3 + 5 PCa und 12 (12,6\%) Patienten hatten lediglich high grade PIN Läsionen. Bezüglich der Anzahl positiver Stanzbiopsien gab es bei 31 (32,6\%) Patienten diskrepante Ergebnisse. Bei 24 (25,3\%) Patienten wäre nach S3-Leitlinienkriterien keine AS empfohlen worden. Hauptlimitation der Arbeit sind potenziell unvollständige Befundungen, da nicht bei allen Patienten alle histologischen Schnitte der Erstdiagnose zur Verfügung standen.

Schlussfolgerung: Etwa ein Viertel der Patienten hätten nach Zweitbeurteilung keine Empfehlung zur AS erhalten. Insbesondere bei jüngeren Patienten kann eine Zweitbefundung daher die Möglichkeit einer zusätzlichen Sicherheit bieten.

\section{V05.6}

Beurteilung von Harninkontinenz und erektiler Dysfunktion durch Patienten und UrologInnen: Ergebnisse aus einer randomisierten kontrollierten Studie bei nicht-metastasiertem Prostatakarzinom

J. Huber ${ }^{1 *}$, P. Karschuck', R. Koch' ', A. Ihrig' ${ }^{2}$, T. Krones ${ }^{3}$, A. Neisius', S. von Ahn', C. Klopf ${ }^{5}$, S. Weikert ${ }^{5}$, M. Siebels ${ }^{6}$, N. Haseke ${ }^{6}$, C. Weißflog ${ }^{7}$, M. Baunacke ${ }^{1}$, P. Liske ${ }^{8}$, G. Tosev ${ }^{9,10}$, T. Benusch ${ }^{11}$, M. Schostak ${ }^{12}$, J. Stein ${ }^{13}$, P. Spiegelhalder ${ }^{14}$, C. Thomas' ${ }^{1}$, C. Groeben' ${ }^{1}$ EvEnt-PCA-Studiengruppe

'Universitätsklinikum Carl Gustav Carus, TU Dresden, Dresden, Deutschland; ${ }^{2}$ Universitätsklinikum Heidelberg, Sektion Psychoonkologie, Klinik für Allgemeine Innere Medizin und Psychosomatik, Heidelberg, Deutschland; ${ }^{3}$ Universitätsspital Zürich, Klinische Ethik, Zürich, Schweiz; ${ }^{4}$ Krankenhaus der Barmherzigen Brüder Trier, Klinik für Urologie, Trier, Deutschland; ${ }^{5}$ Huk-Vivantes Humboldt Klinikum, Klinik für Urologie, Berlin, Deutschland; ${ }^{6}$ Gemeinschaftspraxis Urologie Pasing, München, Deutschland; ${ }^{7}$ Urologische Gemeinschaftspraxis Dr. med. Christian Weißflog \& Dr. med. Ulrich Gerhardt am Weißen Hirsch, Dresden, Deutschland; ${ }^{8}$ Urologische Praxis Dr. Gnann und Dr. Liske, Stuttgart, Deutschland; ${ }^{9}$ Urologische Praxis, Mannheim, Deutschland; ${ }^{10}$ Universitätsklinikum Heidelberg, Urologische Klinik, Heidelberg, Deutschland; ${ }^{1}$ Urologische Praxis, Neustadt in Sachsen, Deutschland; ${ }^{12}$ Universitätsklinikum Magdeburg, Magdeburg, Deutschland; ${ }^{13} \mathrm{KRH}$ Klinikum Großburgwedel, Urologische Klinik, Burgwedel, Deutschland; ${ }^{14}$ Überörtliche Gemeinschaftspraxis „Urologie Neandertal“, Dr. Langhorst/Dr. Spiegelhalder/Dr. Winter, Mettmann, Deutschland

Einleitung: Differenzen zwischen subjektiven Beschwerden und der ärztlichen Wahrnehmung können die Versorgungsqualität verschlechtern. Ziel der Studie war es, vom Patienten berichtete Ergebnisparameter (PROMs) mit der ärztlichen Einschätzung zu vergleichen.

Material und Methoden: Aus einer multizentrischen randomisierten kontrollierten Studie zur Evaluierung einer Online-Patienten-Entscheidungshilfe (EvEnt-PCA; $n=1114$ ) analysierten wir die Ergebnisse ein Jahr nach der ersten Behandlungsentscheidung bei nicht-metastasiertem Prostatakarzinom. Wir evaluierten Harninkontinenz $(\mathrm{HI})$ und erektile Dysfunktion (ED) mit dem EPIC-26.

Ergebnisse: Von $n=356$ Patienten mit 1-Jahres-Follow-up hatten $63 \%$ eine radikale Prostatektomie, $17 \%$ eine Strahlentherapie, und $19 \%$ ein zuwartendes Vorgehen gewählt. Die tägliche Vorlagenzahl gaben die Pa- tienten mit 0 in $67 \%, 1$ in $21 \%, 2$ in $8 \%$ und $>2$ in $5 \%$ an. Die ärztliche Einschätzung stimmte in $69 \%$ mit diesen Angaben überein, überschätzte die $\mathrm{HI}$ in $23 \%$ und unterschätzte sie in $8 \%$. Die Belastung durch die $\mathrm{HI}$ wurde in $43 \%$ richtig eingeschätzt, in $21 \%$ überschätzt und in $37 \%$ unterschätzt. Die von den Patienten angegebene ED war in $75 \%$ schwer oder sehr schwer. Die ärztliche Einschätzung stimmte in $56 \%$ hiermit überein, überschätzte die ED in $12 \%$ und unterschätzte sie in $32 \%$. Die Belastung durch die ED wurde in $32 \%$ korrekt eingeschätzt, in $27 \%$ überschätzt und in $41 \%$ unterschätzt.

Schlussfolgerung: Die Belastung der Patienten durch HI und ED wurde bei 4 von 10 Patienten unterschätzt. Der konsequente Einsatz von PROMs sollte UrologInnen helfen, den Behandlungsbedarf ihrer Patienten besser zu erkennen.

Finanzierung: Innovationsfonds des G-BA

\section{V05.7}

\section{Entscheidungszufriedenheit und Lebensqualität nach fokaler Therapie mit TOOKAD ${ }^{\circledR}$}

\section{Flegar", B. Bürk, R. Proschmann, S. Propping, J. Huber, C. Thomas,} A. Borkowetz

Universitätsklinikum Carl Gustav Carus, Technische Universität Dresden, Poliklinik und Klinik für Urologie, Dresden, Deutschland

Einleitung: Die vaskulär-zielgerichtete photodynamische Therapie (VTP) stellt eine fokale Therapieoption für das unilaterale Niedrigrisiko-Prostatakarzinom (PCa) dar. Wir untersuchten die Entscheidungszufriedenheit und -beteiligung sowie die Lebensqualität (QoL) nach der Behandlung mit VTP. Materialien und Methoden: Patienten, die sich zwischen Mai 2018 und Dezember 2020 an unserer Einrichtung einer VTP für unilaterales Niedrigrisiko-PCa unterzogen, erhielten validierte Fragebögen zur Erfassung der QoL (EORTC-QLQ-C30 \& QLQ-PR25). Die Entscheidungsbeteiligung wurde mittels Control Preferences Scale und die Zufriedenheit mittels Decisional Regret Scale ermittelt.

Ergebnisse: Von 43 Patienten konnten insgesamt 36 Patienten eingeschlossen werden und $29(81 \%)$ antworteten. $76 \%$ der Patienten $(n=22)$ waren mit der Therapieentscheidung zufrieden. Der mittlere Decision Regret-Score betrug 6,6 (SD 18,0). 19 Patienten (65,5\%) waren aktiv an der Entscheidungsfindung beteiligt und $72,4 \%$ der Patienten $(n=21)$ entschieden gemeinsam mit ihrem Arzt. Der mittlere globale Gesundheitszustand betrug 79,5 (SD 18,8). Die Harnsymptome (EORTC PRURI) blieben nach der Behandlung mit 17,1 (SD 15,5) gering. In der Biopsie 12 Monate post-op wiesen $19,4 \%$ der Patienten $(n=7)$ ein Lokalrezidiv auf und bei $13,8 \%$ der Patienten $(n=5)$ wurde eine Progression zu einem höheren Gleason-Score festgestellt. Diese Gruppe zeigte tendenziell ein höheres Maß an Entscheidungsreue $(p=0,3309)$.

Schlussfolgerungen: Die Lebensqualität war nach fokaler Therapie mit VTP stabil. 12 Monate nach VTP bereuten nur $24 \%$ der Patienten $(n=7)$ die Behandlung. Eine längere Nachbeobachtung dieser Patienten ist erforderlich, um die langfristigen Auswirkungen der Therapie auf die QoL und Behandlungszufriedenheit nach VTP zu untersuchen.

\section{V05.8}

Quality of life after laparoscopic and robotic-assisted radical prostatectomy: Results of a multicentre patientblinded, randomised controlled trial (LAP-01)

E. Lemaire ${ }^{1 *}$, S. Holze ${ }^{1}$, M. Mende ${ }^{2,3}$, M.C. Truss ${ }^{4}$, M. Hohenfellner ${ }^{5}$, P. Albers ${ }^{6}$, J.-U. Stolzenburg ${ }^{1}$

'Universität Leipzig, Klinik und Poliklinik für Urologie, Leipzig, Germany; ${ }^{2}$ Universität Leipzig, Zentrum für Klinische Studien, Leipzig, Germany; ${ }^{3}$ Universität Leipzig, Institut für Medizinische Informatik, Statistik und Epidemiologie, Leipzig, Germany; ${ }^{4}$ Klinikum Dortmund, Urologische Klinik, Dortmund, Germany; ${ }^{5}$ Universität Heidelberg, Urologische Klinik, Heidelberg, Germany; ${ }^{6}$ Universität Düsseldorf, Klinik für Urologie, Düsseldorf, Germany 
Objectives: To date, no multicentre randomised trial has compared robotic-assisted (RARP) and laparoscopic radical prostatectomy (LRP) in terms of quality of life (QoL). This study provides high-quality data on healthand prostate cancer-related QoL for both surgical techniques.

Materials and methods: 782 patients were recruited at four German hospitals and randomly assigned to either RARP or LRP in a 3:1 ratio. Patient-reported outcomes were prospectively collected before and 1, 3, 6, 12 months after radical prostatectomy using validated questionnaires to assess general (EORTC QLQ-C30) and prostate-specific (QLQ-PR25) QoL. Cross-sectional and longitudinal contrasts were analysed by linear modelling.

Results: In terms of general QoL, cross-sectional analysis showed only minimal differences between study arms, whereas longitudinal comparison indicated an advantage of RARP on recovery: RARP patients reported an earlier return to baseline in global health status ( 3 vs. 6 months) and social functioning ( 6 vs. 12 months). Only the RARP arm regained baseline scores in role functioning, whilst cognitive functioning only returned to baseline in the LRP arm. With regard to prostate-specific QoL, LRP patients experienced more urinary symptoms. Mean scores of the LRP arm were 3.2 points $(95 \% \mathrm{Cl} 0.4,6 ; p=0.024)$ higher at 1 -month follow-up and 2.9 points $(0.1,5 ; p=0.042)$ higher at 3 -month follow-up than for RARP. There were no other significant differences between treatment groups. Urinary symptoms, sexual activity and sexual function remained significantly worse at all timepoints in both arms.

Conclusion: Compared to LRP, robotic assistance led to an earlier return to baseline in several domains of general health-related QoL and a better short-term recovery of urinary symptoms.

\section{V05.9}

Die symptomatische Lymphozele nach offener und robotisch-assistierter Prostatektomie: Eine RisikoAnalyse

\section{G. Magistro", Y. Volz, A. Becker, C. G. Stief}

Ludwig-Maximilians-Universität (LMU), Medizinische Fakultät, München, Deutschland

Fragestellung: Im vorliegenden Projekt werden die Prävalenz und Prädiktoren für eine symptomatische Lymphozele nach offener retropubischer radikaler Prostatektomie (RRP) und nach robotisch-assistierter radikaler Prostatektomie (RARP) untersucht.

Methoden: In dieser retrospektiven, monozentrischen Studie wurden 472 Patienten evaluiert, die nach RRP $(n=241)$ und RARP $(n=231)$ für zwei Jahre nachgesorgt wurden. Demographische und histopathologische Parameter wurden verglichen und mittels univariater und multivariater logistischer Regression wurde nach Prädiktoren für das Auftreten einer symptomatischen Lymphozele gescreent.

Ergebnisse: Nach RRP wurden insgesamt signifikant weniger Lymphozelen beobachtet als nach RARP $(8,2 \%$ vs. $16,7 \% ; p=0,049)$, wobei für symptomatische Verläufe kein relevanter Unterschied festgestellt wurde (7,4\% vs. $11,7 \%, p=0,315)$. Obwohl die Lymphadenektomie häufiger für die RARP erfolgte $(70,1 \%$ vs. $50,6 \% ; p<0,001)$, zeigte sich ein L1 Status häufiger nach RRP ( $18 \%$ vs. $6,2 \%, p=0,002)$. Die mediane Lymphknotenzahl betrug 11 für die RRP und 10 für die RARP $(p=0,381)$. In der multivariaten Regression erwiesen sich die Lymphknotenzahl (mind. 11) (OR $1,1 ; 95 \% \mathrm{Cl} 1,055-1,147 ; p=0,001)$, der Gleason-Score $\geq 8$ (OR 4,7; $95 \%$ $\mathrm{Cl} 2,365-9,363 ; p=0,001)$ und der präoperative PSA-Wert $\geq 10 \mathrm{ng} / \mathrm{ml}$ (OR $1,05 ; 95 \% \mathrm{Cl} 1,02-1,074 ; p=0,001)$ als unabhängige Prädiktoren für das Auftreten von symptomatischen Lymphozele.

Schlussfolgerung: Das Ausmaß der Lymphadenektomie und das Vorliegen einer high-grade Disease sind unabhängig vom technischen OP-Verfahren mit einem erhöhten Risiko für symptomatische Lymphozelen assoziiert. Dies ist eine wichtige Information für die Evaluation und Beratung von Patienten vor einer operativen Behandlung des Prostatakarzinoms.

\section{V06 - Funktionsstörungen und Komplikationen des} oberen Harntraktes

\author{
16.09.2021, C5.2, 13:30-14:30
}

\section{V06.1}

KIM-1 shows potential to be predictive of re-perfusion damage in porcine kidneys during normothermic whole-blood machine perfusion

\section{Steinhauser ${ }^{1 *}$, J. Putz', A. E. Yakac' ', S. Füssel', S. Kromnik², W. Markgraf², R. Mühle², P. Talhofer ${ }^{2}$, W. Löffler ${ }^{2}$, H. Malberg ${ }^{2}$, C. Thiele ${ }^{2}$, C. Thomas ${ }^{1}$}

${ }^{1} T e c h n i s c h e$ Universität Dresden, Department of Urology, Dresden, Germany; ${ }^{2} T e c h n i s c h e$ Universität Dresden, Institute of Biomedical Engineering, Dresden, Germany

Introduction: Normothermic machine perfusion (NMP) using oxygenated whole-blood is a currently investigated tool to combat the scarcity of usable kidneys for transplantation by assessing marginal organs under physiological conditions. Establishing markers predicting the transplantability of those organs during NMP is necessary. Kidney injury marker 1 (KIM-1), a marker for tubule damage, mediates phagocytosis of necrotic/apoptotic debris.

Materials and methods: Kidneys obtained from slaughterhouse pigs were perfused for $4 \mathrm{~h}$. They were grouped based on their morphology (hemorrhagic infarction) after NMP into "good" $n=7$ and "injured" $n=3$. Tissue samples were taken before and after NMP; urine and plasma samples were taken at the start and after $1 \mathrm{~h}, 2 \mathrm{~h}$ and $4 \mathrm{~h}$. KIM- 1 was assessed in tissue using $\mathrm{QPCR}$ and IHC; liquid samples were analyzed with ELISA.

Results: Good Kidneys experienced no change in relative KIM-1-mRNA levels over the course of $4 \mathrm{~h}$ NMP $\left(1,7 \cdot 10^{-4} \pm 6,9 \cdot 10^{-5}\right.$ vs $1,6 \cdot 10^{-4} \pm 7,5 \cdot 10^{-}$ 5; ns), injured kidneys showed a slight decrease $\left(1,5 \cdot 10^{-4} \pm 3,3 \cdot 10^{-5}\right.$ vs $\left.0,7 \cdot 10^{-4} \pm 3,5 \cdot 10^{-5} ; \mathrm{ns}\right)$. Staining intensity and distribution of KIM-1-protein was slightly increased in good kidneys after NMP. No change was observed in injured kidneys. Relative KIM-1 levels in plasma increased in injured kidneys but remained stable in good kidneys, but did not differ significantly after $4 \mathrm{~h}(p=0,067)$. Urinary KIM-1 increased in both groups to similar levels.

Conclusion: Injured kidneys shed higher levels of KIM-1 into the bloodstream than uninjured ones, although KIM-1 is increased within tissues of good kidneys to help clear cell debris. As plasma levels rise within $1 \mathrm{~h}$ of NMP, KIM-1 has, in conjunction with further markers, the potential to predict the outcome of NMP.

Funding: Funded by EFRE \& SAB; project no. 100382963

\section{V06.2}

\section{Identifizierung des Myofibroblasten-Ursprungs bei der Nierenfibrose}

\author{
J. Kranz ${ }^{* * 2,3}$, C. Kuppe ${ }^{3}$, J. Steffens ${ }^{1}$, R. Kramann ${ }^{3}$
}

'St.-Antonius Hospital gGmbH, Klinik für Urologie und Kinderurologie, Eschweiler, Deutschland; ' 2 Universitätsklinikum Halle (Saale), Universitätsklinik und Poliklinik für Urologie, Halle, Deutschland; ${ }^{3}$ Uniklinik RWTH Aachen, Institut für Experimentelle Innere Medizin und Systembiologie, Aachen, Deutschland

Einleitung: Chronische Nierenerkrankungen betreffen $>10 \%$ der Weltbevölkerung und führen zu einer konsekutiven Nierenfibrose. Derzeit gibt es keine zugelassene antifibrotische Therapie. Grund dafür ist, dass der Ursprung, die funktionelle Heterogenität und Regulation der narbenbildenden Zellen nur unvollständig verstanden und erforscht sind.

Methodik: Mittels Einzelzelltranskriptom-Sequenzierung erfolgte die Analyse verschiedener Nieren-Zelltypen bei Patienten mit und ohne Nierenfibrose. Das hierzu verwendete Gewebe stammt aus der EschweilerAachener-Biobank. Zudem führten wir im transgenen Mausmodell Ab- 
stammungsexperimente (Lineage-Tracing) sowie Validierungen mittels in-situ Färbungen durch.

Ergebnisse: Mithilfe der o.g. Technik wurde ein hochauflösender Atlas der Matrix-produzierenden Zellen humaner Nieren erstellt. Die Abstammungsexperimente in der Maus zeigten die höchste Matrixproduktion in intrarenalen PDGFR- $/^{+}$mesenchymalen Zellen. Unsere humanen Einzelzelltranskriptomdaten zeigten eine Differenzierung von Perizyten und Fibroblasten in Myofibroblasten. Mittels in-situ Hybridisierung konnten wir diese beiden Differenzierungswege validieren. NKD2 wurde als wichtiger Regulator der Matrixproduktion in der humanen Nierenfibrose identifiziert.

Schlussfolgerungen: Erstmals gelang die Kartierung aller matrixproduzierenden Zellen des humanem Nierengewebes. Perizyten und Fibroblasten wurden als wichtigste Ursprungszellen der Myofibroblasten identifiziert. In einem „Proof-of-Concept" konnten wir die Relevanz eines WNT-Signalwegregulators, NKD2, demonstrieren. Wir erhoffen mit den o.g. Daten weitere Regulatoren der Matrixproduktion in humanen mesenchymalen Zellen identifizieren und eine gezielte antifibrotische Therapie entwickeln zu können.

\section{V06.3}

\section{Tumor Stent for chronic ureteral obstruction: Which are} predictors of stent failure?

A. Gu*, L. Oyo, N. C. Grossmann, M. S. Wettstein, B. Kaufmann, U. Bieri, C. Poyet, T. Hermanns, T. Sulser, D. Eberli, E.X. Keller

Universitätsspital Zürich, Zürich, Switzerland

Introduction: The UROSOFT ${ }^{\circledR}$ Tumor Stent is a reinforced ureteral stent available for treatment of chronic ureteral obstruction. According to the manufacturer, it has a maximal dwell time of 6 months. Under certain conditions, stent failure may negatively impact on this theoretical maximal dwell time. Aim of this study was to evaluate predictors of stent failure.

Material and methods: All patients undergoing Tumor Stent insertion in our institution between 2010 and 2018 were analyzed. Exclusion criteria were planned temporary stent dwell time or refusal to participate in the study. Primary endpoint was time to stent failure after first-time Tumor Stent insertion. Only the first 5 months after insertion were considered for analysis, since planned Tumor Stent exchange was usually undertaken within 1 month prior to maximal dwell time.

Results: 182 patients were available for analysis. Failure free survival estimates at 1, 2, 3, 4 and 5 months were $89 \%, 83 \%, 76 \%, 65 \%$ and $52 \%$, respectively. We found bilateral insertion, intrinsic ureteral obstruction, and prolonged postoperative antibiotic therapy to be significant and independent predictors of stent failure $(p<0.04)$. Patients with stent failure had significantly higher grade of hydronephrosis, higher urinary culture bacterial growth, higher serum WBC, higher CRP and lower eGFR at the time of re-intervention, compared to patients with timely stent exchange. Conclusions: The Tumor Stent has a high operation success rate in the presence of chronic ureteral obstruction. Predictors of stent failure are bilateral insertion, intrinsic ureteral obstruction, and the need of prolonged postoperative antibiotic therapy. Patients should be closely monitored for infectious signs or impaired kidney function, which may suggest stent failure.

V06.4

\section{Diagnostik und Therapie der uretero-iliakalen Fistel}

T. Klein*, J. Aich, F. Distler, J. Ell, C. Hüttenbrink, S. Pahernik

Paracelsus Medizinische Privatuniversität Klinikum Nürnberg, Klinik für Urologie, Nürnberg, Deutschland

Einleitung: Die uretero-iliakale Fistel (UIF) kann aufgrund der massiven Blutung eine lebensgefährliche Notfallsituation darstellen. Die Versor- gung dieser Patienten über eine interventionelle oder operative Therapie stellt eine Herausforderung dar.

Methoden: Seit 2017 stellten sich insgesamt vier Patienten mit einer UIF vor, wobei drei Patienten interventionell und ein Patient operativ behandelt wurden. Bei allen lag eine Makrohämaturie vor, die zu einer transfusionswürdigen Anämie führte. Drei Patienten hatten zuvor eine DJ-Versorgung erhalten, beim vierten Patienten lag eine ehemalige DJ-Versorgung bei Harnleiterstenose vor. Bei einem Patienten bestand ein Aneurysma der A. iliaca communis mit einem Durchmesser von ca. $4 \mathrm{~cm}$. Drei Patienten waren zuvor bestrahlt worden und hatten eine Beckenoperation (Y-Prothesen-Anlage oder Rectumresektion).

Ergebnis: Die Verifizierung der Diagnose erfolgte über eine retrograde Pyeloureterographie (RUG) in drei Fällen sowie über CT-Angiographie in zwei Fällen. In allen Fällen wurde ein DJ gelegt. In drei Fällen erfolgte die Versorgung interventionell, indem ein Stent in die A. iliaca externa gelegt wurde. In einem Fall wurde aufgrund eines zusätzlichen Aneurysma operativ eine Gefäßprothese implantiert, da hier technisch eine interventionelle Therapie nicht möglich war.

Schlussfolgerung: Die Therapieentscheidung über ein interventionelles oder operatives Vorgehen bleibt individuell und muss insbesondere bei akuter Blutung schnell getroffen werden und hängt von der Infrastruktur des Standorts ab. Ein wichtiger Faktor in der Therapieentscheidung ist der Durchmesser des zu versorgenden lliakalabschnittes.

\section{V06.5}

\section{Harnleiterersatz durch Ureter-Ileum-Interponat bei langstreckigen Ureterstenosen - eine retrospektive unizentrische Kohortenstudie}

\section{J. Nolting*, D. Dräger, O. Hakenberg}

Universitätsmedizin Rostock, Klinik und Poliklinik für Urologie, Rostock, Deutschland

Fragestellung: Die häufigsten Ursachen für Harnleiterengen sind: Morbus Ormond, Tumoren (intra- und extraluminal) und retroperitoneale Operationen und Bestrahlung sowie deren Komplikationen. Ein Ureter-Ileum-Interponat ist bei langstreckiger Denudierung und narbiger Obliteration des Harnleiters indiziert. Dieses rekonstruktive Verfahren dient dem Erhalt der Nierenfunktion, als Verhinderung einer drohenden Dialysepflichtigkeit bei vorbestehender Niereninsuffizienz, sowie dem Erhalt der Lebensqualität durch Vermeidung regelmäßiger Schienenwechsel. Ziel der Studie war der Vergleich der prä- und postoperativen Nierenfunktion und Lebensqualität sowie die Darstellung der intra- und postoperativen Komplikationen. Material und Methoden: Ausgewertet wurden Patienten mit Urothelkarzinom des Harnleiters $(n=11)$, posttherapeutischen Harnleiterstenosen anderer Tumorentitäten $(n=12)$ sowie benignen Ureterstrikturen $(n=5)$. Als Auswertungskriterien wurden die prä- und postoperative Nierenfunktion (GFR und Kreatinin) sowie die Komplikationsrate (Clavien-DindoKlassifikation) ermittelt. Die Lebensqualität wurde postoperativ mit dem EORTC-C30-Fragebogen erhoben.

Ergebnisse: In allen Gruppen zeigte sich die Nierenfunktion stabil. Schwere operative Komplikationen (Clavien-Dindo Grad III-V) traten vor allem bei Urothelkarzinompatienten (5/11) auf. Es erfolgte bei vier Patienten mit Urothelkarzinom innerhalb der nächsten zwei Jahre eine radikale Nephroureterektomie bei Rezidiv. Die postoperative Lebensqualität war nicht eingeschränkt.

Schlussfolgerung: Der Harnleiterersatz durch ein Ureter-Ileum-Interponat ist ein rekonstruktives Verfahren zur Protektion der Nierenfunktion sowie der Lebensqualität und sollte Patienten ohne schwerwiegende Komorbiditäten angeboten werden. 


\section{V06.6}

Einsatz der künstlichen Intelligenz als erster Schritt in der Automatisierung der Diagnose und Therapie der Hydronephrose

\section{R. Alexa*, S. Siemer, M. Stöckle, M. Saar}

Universitätsklinikum des Saarlandes, Klinik für Urologie und Kinderurologie, Homburg/ Saar, Deutschland

Einleitung: Hier bauten wir ein neuronales Netzwerk für Nierenechographien auf und bewerteten dessen diagnostische Genauigkeit für den Nachweis einer Hydronephrose.

Material und Methoden: Normale und hydronephrotische Ultraschallbilder der menschlichen Niere wurden anonym aus unserer Ambulanzdatenbank gesammelt.

Zentrierte, sagittale echographische Bilder wurden auf 96×96 Pixel reduziert.

Anschließend wurden diese Bilder mit 2 unterschiedlichen Schärfegraden und aus 4 verschiedenen Winkeln multipliziert. Danach wurde ein sequentielles Modell mit 3 Hauptfaltungsschichten trainiert, getestet und zur Auswertung neuer Bilder verwendet. Zur Programmierung wurden Python 3.8.3 (Python Software Foundation, Wilmington, DE), Keras-Framework, Tensorflow 2.2 (Google Brain Team, Mountain View, Kalifornien) und Jupyter Notebooks (Fernando Perez, Open-Source-Software) verwendet. Ergebnisse: Es wurden 68 sonographische Nierenbilder von 34 normalen und 34 hydronephrotischen Nieren gesammelt. Nach Datenerweiterung (Bildrotation und Unschärfeeffekte) konnten 4352 Bilder erzeugt werden. Daraus wurde das Faltungsnetzwerk mit 3047 Bildern in 15 Zyklen trainiert und mit 1305 Bilder validiert. Mit einer Endgenauigkeit von 98,8\% wurde unser Modell zur Auswertung von 60 neuen sonographischen Nierenbildern ( 30 normale und 30 hydronephrotische Nieren) verwendet. Es wurden $86 \%$ der hydronephrotischen und $90 \%$ der normalen Nieren korrekt zugeordnet. Die Genauigkeit unseres Modells betrug $88 \%$.

Schlussfolgerung: Wir haben gezeigt, dass unser automatisiertes echographisches Modell trainiert und verwendet werden kann, um echografische Bilder mit hoher Genauigkeit zu interpretieren. Diese Methode wird in Zukunft als automatisiertes Werkzeug im Diagnosealgorithmus des akuten Nierenversagens dienen.

\section{V07 - Onkologie/seltene Tumoren}

\author{
16.09.2021, C7.2, 13:30-14:30
}

\section{V07.2}

CTLA4 promoter hypomethylation correlates with lymphocyte infiltration and predicts response to antiPD-1 based immunotherapy in metastatic renal cell carcinoma

N. Klümper ${ }^{1 * 2,}$, D. J. Ralser ${ }^{3}$, R. Zarbl ${ }^{4}$, K. Schlack ${ }^{5}$, A. J. Schrader ${ }^{5}$, M. Rehlinghaus ${ }^{6}$, M. J. Hoffmann 6 , G. Niegisch 6 , A. Uhlig ${ }^{7}$, L. Trojan 7 , J. Steinestel ${ }^{8}$, K. Steinestel ${ }^{9}$, R.M. Wirtz ${ }^{10,11}$, G. Kristiansen ${ }^{12}$, M. Toma ${ }^{12}$, M. Hölzel' ${ }^{2}$ M. Ritter', S. Strieth', J. Ellinger', D. Dietrich ${ }^{4}$

'Universitätsklinikum Bonn, Klinik und Poliklinik für Urologie und Kinderurologie, Bonn, Germany; ${ }^{2}$ Universitätsklinikum Bonn, Institut für Experimentelle Onkologie, Bonn, Germany; ${ }^{3}$ Universitätsklinikum Bonn, Klinik für Gynäkologie und Gynäkologische Onkologie, Bonn, Germany; ${ }^{4}$ Universitätsklinikum Bonn, Klinik und Poliklinik für Hals-NasenOhren-Heilkunde, Bonn, Germany; ${ }^{5}$ Universitätsklinikum Münster, Klinik für Urologie und Kinderurologie, Münster, Germany; ${ }^{6}$ Universitätsklinikum Düsseldorf, Klinik für Urologie, Düsseldorf, Germany; ${ }^{7}$ Universitätsklinikum Göttingen, Klinik für Urologie, Göttingen, Germany; ${ }^{8}$ Universitätsklinikum Augsburg, Klinik für Urologie, Augsburg, Germany; ${ }^{9}$ Bundeswehrkrankenhaus UIm, Institut für Pathologie, Ulm, Germany; ${ }^{10}$ St. Elisabeth Krankenhaus Köln, Institut für Pathologie, Köln, Germany; ${ }^{11}$ STRATIFYER Molecular Pathology GmbH, Köln, Germany; ${ }^{12}$ Universitätsklinikum Bonn, Institut für Pathologie, Bonn, Germany

Introduction: In advanced and metastatic clear cell renal cell carcinoma (ccRCC), different combination therapies, each including anti-PD-1 immune checkpoint blockade (ICB), are applied as the first-line treatment. Robust predictive biomarkers for rational upfront therapy decisions are still pending, although they are urgently needed. Recently, we showed that CTLA4 promoter methylation (mCTLA4) predicts response to ICB in melanoma. Here, we aimed to investigate the epigenetic regulation of CTLA4 in CCRCC and its utility as a predictive biomarker in a multicenter ICB-treated RCC cohort.

Materials and methods: $m C T L A 4$ was analyzed with regard to transcriptional gene activity, intratumoral immune cell composition, and clinical course in two cCRCC cohorts obtained from The Cancer Genome Atlas (TCGA, $N=533$ ) and the University Medical Center Bonn (UKB, $N=116$ ). In addition, $m C T L A 4$ was evaluated in pre-treatment samples from a multicenter ICB-RCC cohort $(N=36)$ treated with anti-PD-1 monotherapy or anti-PD-1/CTLA-4 combination therapy with regard to treatment response according to RECIST and progression-free survival (PFS) following treatment initiation.

Results: $m C T L A 4$ was significantly correlated with CTLA4 mRNA expression (Spearman's $\rho=-0.54, P<0.001)$, lymphocyte infiltration $(\rho=-0.56$, $P<0.001$ ), and poor overall survival in both cohorts (TCGA: $P<0.001$; UKB: $P=0.043)$. Of note, CTLA4 promoter was significantly hypomethylated in ICB-responders compared to non-responders $(P<0.001)$ and associated with prolonged PFS after ICB-treatment initiation $(P=0.008)$.

Conclusions: Our study suggests MCTLA4 as a surrogate for RCC immunogenicity and as a predictive biomarker for response to ICB in metastatic ccRCC.

V07.3

Kidney cancer urine marker

M. Von Brandenstein, B. Köditz", J. Herden, M. Huerta, T. Nestler, A. Heidenreich', J. Fries

Universitätsklinikum Köln, Köln, Germany

Introduction: Recently, our group showed that Vim3 is overexpressed in tissue samples of renal oncocytomas and Mxi- 2 in clear cell renal carcinoma (ccRCCs). The mechanism leading to the truncation of both proteins 
is known and involves with two miRs, both detectable in urine. Since the analysis of miRs is time consuming, our aim was to identify the truncated proteins in urine instead. Furthermore, urine samples from small renal cancers (SRM) $(n=45,<4 \mathrm{~cm})$ were analyzed to get a pre-surgical differentiation of the cancer subtypes.

Methods: Urines were accessed from the urological biobank $(n=350)$. Proteins were isolated from urine samples, and Western blots were performed. Each sample was analyzed with ELISA for the expression of Vim3 and Mxi-2. A lateral flow assay was established. For the detection of SRMs, the miRs were isolated and qRT-PCR was performed.

Results: A significant increase of Vim3 in urines from patients with oncocytoma $(n=20)$ was detectable with ELISA compared to all other subtypes of RCCs (chromophobe $(n=50)$, papillary $(n=40)$, cCRCC $(n=200)$, and controls $\left.(n=40)\left({ }^{* * *} p<0.0001\right)\right)$. Mxi-2 was predominantly overexpressed in ccRCCs $\left({ }^{* * *} p<0.0001\right)$. Lateral flow assay of Vim3 and Mxi2 shows two bands in the case of oncocytoma and cCRCC indicating the specificity of this test. For SRMs, an overexpression of miR-15a/Mxi2 was detectable in urine samples from cCRCC and chromoRCC patients. In contrast to that miR-498/Vim3 were predominantly overexpressed in oncocytoma patients.

Conclusion: Both proteins (Vim3 and Mxi-2) were detectable in patients' urines and can be used for the non-invasive differentiation of kidney cancers.

\section{V07.4}

\section{Association of DNA methylation of P-Cadherin (CDH3) with adverse histopathology and shortened survival in renal cell carcinoma}

P. Faraj Tabrizi ${ }^{*}$, N. Dubrowinskaja ${ }^{1}$, H. Tezval' ${ }^{1}$ O. Katzendorn' ${ }^{1}$, C. von Klot ${ }^{1}$, J. Hennenlotter' ${ }^{2}$ M. Lafos ${ }^{3}$, M. A. Kuczyk', J. Serth', I. Peters'

'Medizinische Hochschule Hannover, Klinik für Urologie und Urologische Onkologie, Hannover, Germany; ${ }^{2}$ Universitätsklinikum Tübingen, Klinik für Urologie und Urologische Onkologie, Tübingen, Germany; ${ }^{3}$ Medizinische Hochschule Hannover, Institut für Pathologie, Hannover, Germany

Background: The potential impact of cadherins $(\mathrm{CDH})$, known as cell-cell adhesion molecules, in the development of human malignant diseases including renal cell carcinoma (RCC) has become a matter of growing interest.

Methods: The present study investigated $\mathrm{CpG}$ island (CGI) methylation and epigenetic silencing of the $p$-cadherin $(C D H 3)$ gene in tissue specimens of RCC patients. Results were correlated to histopathological and clinical characteristics of the patients. In addition, protein expression of $\mathrm{CDH} 3$ was examined using immunohistochemistry in specimens of cancerous and adjacent non-malignant (normal) renal tissue. DNA extracted from tissue samples was subjected to pyrosequencing.

Results: Analysis revealed a tumor-specific CGI hypermethylation of the $\mathrm{CDH} 3$ gene in comparison to normal tissue $(p=0.0002)$ of all RCC. The degree of methylation was associated with a loss in differentiation and a higher tumor stage. Cox regression demonstrated an association between an increase in methylation and a reduction in recurrence-free survival of patients. $\mathrm{CDH} 3$ protein expression was detected in $100 \%$ of non-malignant renal tissue specimens whereas a loss in $\mathrm{CDH} 3$-immunoreactivity was detected in $35 \%$ of the cancerous specimens.

Conclusion: The results indicate that hypermethylation of $\mathrm{CDH} 3$ and loss of protein expression may contribute to the pathogenesis of a subset of RCC. Further studies to characterize in more detail the functional and clinical effects of epigenetic alterations of $\mathrm{CDH} 3$ in RCC are indicated.
V07.5

Primär renale Sarkome: Bildmorphologische Eigenschaften und Unterscheidungsmöglichkeiten von nicht-Sarkomen

A. Uhlig ${ }^{1 *}$, J. Uhlig' ${ }^{2}$, S. Bachanek², M. Ruhi Onur ${ }^{3}$, S. Kinner ${ }^{4}$, D. Geisel', M. Köhler ${ }^{6}$, H. Preibsch ${ }^{7}$, M. Puesken ${ }^{8}$, D. Schramm ${ }^{9}$, M. May ${ }^{10}$, P. De Visschere ${ }^{11}$, M. A. Weber ${ }^{12}$, A. Surov $9,13,14$

'Universitätsmedizin Göttingen, Göttingen, Deutschland; ${ }^{2}$ Universitätsmedizin Göttingen, Institut für Diagnostische und Interventionelle Radiologie, Göttingen, Deutschland; ${ }^{3}$ Hacettepe University, Department of Radiology, Ankara, Türkei; ${ }^{4}$ Universitätsklinikum Essen, Institut für Diagnostische und Interventionelle Radiologie und Neuroradiologie, Essen, Deutschland; ${ }^{5}$ Charité - Universitätsmedizin Berlin, Klinik für Radiologie, Berlin, Deutschland; ${ }^{6}$ Universitätsklinikum Münster, Klinik für Radiologie, Münster, Deutschland; ${ }^{7}$ Universitätsklinikum Tübingen, Department für Radiologie, Tübingen, Deutschland; ${ }^{8}$ Uniklinik Köln, Institut für Diagnostische und Interventionelle Radiologie, Köln, Deutschland; ${ }^{9}$ Martin-Luther-University Halle-Wittenberg, Klinik und Poliklinik für Radiologie, Halle (Saale), Deutschland; ${ }^{10}$ Universitätsklinikum Erlangen, Radiologisches Institut, Erlangen, Deutschland; ${ }^{1}$ Ghent University Hospital, Department of Radiology and Nuclear Medicine, Gent, Belgien; ${ }^{12}$ Universitätsmedizin Rostock, Institut für Diagnostische und Interventionelle Radiologie, Kinder- und Neuroradiologie, Rostock, Deutschland ${ }^{13}$ Otto-von-Guericke Universität Magdeburg, Universitätsklinik für Radiologie und Nuklearmedizin, Magdeburg, Deutschland; ${ }^{14}$ Universität Leipzig, Klinik und Poliklinik für Diagnostische und Interventionelle Radiologie, Leipzig, Deutschland

Fragestellung: Welche bildmorphologischen Eigenschaften besitzen primär renale Sarkome (PRS) und wie können sie von anderen Nierentumoren unterschieden werden?

Material und Methoden: Aus 11 europäischen Institutionen wurden $\mathrm{Pa}$ tienten eingeschlossen, welche 1995-2018>18 Jahre alt waren und ein CT/MRT bei einem PRS erhalten hatten. Als Vergleich dienten randomisierte Patienten mit nicht-Sarkom-Nierentumor. Mittels 21 prädefinierten Bildgebungsparametern sowie auf Basis klinischer Daten wurde ein random forest (RF) machine learning Modell trainiert, zwischen PRS und anderen Nierentumoren zu unterscheiden.

Ergebnisse: Insgesamt wurden $n=34$ PRS mit $n=136$ nicht-Sarkomen verglichen (klarzelliges Nierenzellkarzinom (NCC) $n=81$, papilläres NCC $n=21$, chromophobes NCC $n=10$, sarkomatoides NCC $n=7$, Onkozytom $n=9$, Angiomyolipom $n=8$ ). PRS traten häufiger bei jüngeren Patienten auf (med. 55 vs. 67 Jahre, $p<0,01$ ) und waren komplexer (hoher RENALScore $79,4 \%$ vs. $25,7 \%$; $p<0,01$ ). PRS waren im Vergleich zu nicht-Sarkomen größer (med. Durchmesser 108 vs. 43 mm; $p<0,01$ ), eher irregulär geformt sowie unscharf berandet und zeigten häufiger eine Infiltration von Vena renalis oder Vena cava, Tumornekrosen, Organinvasion und Kontakt zur Nierenarterie (je $p<0,05$ ). Der RF Algorithmus erzielte in der Prädiktion eines PRS eine mediane Area Under the Curve (AUC) $=93,8 \%$, sowie Sensitivität $=90,4 \%$, Spezifität $=76,5 \%$, und positiv prädiktiven Wert $=93,9 \%$.

Schlussfolgerungen: PRS sind seltene Tumore, die sich als vergleichsweise große Neoplasien bei eher jüngeren Patienten manifestieren. Ein anhand von bildmorphologischen und klinischen Parametern trainierter RF Algorithmus zur Unterscheidung zeigte eine hervorragende diagnostische Genauigkeit und könnte klinische Entscheidungsprozesse unterstützen. 


\section{V07.6}

Primär renale Sarkome des Erwachsenen:

Bevölkerungsweite Untersuchungen zu Epidemiologie, Therapie und Überleben

A. Uhlig ${ }^{1 *}$, J. Uhlig' ${ }^{2,3}$, H. Deshpande ${ }^{4}$, P. Ströbel ${ }^{5}$, L. Trojan', J. Lotz ${ }^{2}$, M. Hurwitz ${ }^{4}$, O. Hafez ${ }^{6}$, P. Humphrey ${ }^{6}$, V. Grünwald ${ }^{7}$, H. S. Kim ${ }^{8}$

${ }^{1}$ Universitätsmedizin Göttingen, Urologie, Göttingen, Deutschland; ${ }^{2}$ Universitätsmedizin Göttingen, Institut für Diagnostische und Interventionelle Radiologie, Göttingen, Deutschland; ${ }^{3} Y a l e$ School of Medicine, Section of Interventional Radiology, New Haven, Vereinigte Staaten von Amerika; ${ }^{4}$ Smilow Cancer Hospital, New Haven, Vereinigte Staaten von Amerika; ${ }^{5}$ Universitätsmedizin Göttingen, Institut für Pathologie, Göttingen Deutschland; ${ }^{6}$ Yale School of Medicine, Department of Pathology, New Haven, Vereinigte Staaten von Amerika; ${ }^{7}$ Universitätsklinikum Essen, Essen, Deutschland; ${ }^{8}$ University of Maryland School of Medicine, Department of Diagnostic Radiology and Nuclear Imaging, Baltimore, Deutschland

Fragestellung: Wie verhalten sich Epidemiologie, Therapie und Gesamtüberleben (OAS) von erwachsenen Patienten mit primär renalen Sarkomen?

Material und Methoden: Aus den US-amerikanischen SEER (Surveillance Epidemiology and End Results)- und NCDB (National Cancer Database)Daten der Jahrgänge 2004-2016 wurden Patienten >18 Jahre mit primär renalen Sarkomen (PRS) eingeschlossen. Die epidemiologischen Maßzahlen ", average annual age-adjusted incidence rates (AAIR) " und ", average annual percentage change (AAPC)" wurden anhand der SEER-Daten berechnet. Cox-Modelle untersuchten tumorspezifische Parameter und OAS an den NCDB-Daten.

Ergebnisse: Die PRS-Inzidenz der 1279 NCDB-Patienten blieb 2004-2016 stabil (Mittel 0,53 Fälle/1 Mio. Einwohner/a; $\mathrm{AAPC}=0,7, p=0,6$ ). Unter 43 PRS-Subtypen waren das Leiomyosarkom (AAIR 0,14 Fälle/1 Mio.) und der maligne rhabdoide Tumor (0,06 Fälle/1 Mio.) am häufigsten. Demographie und Tumorvariablen der PRS-Subtypen waren ausgesprochen heterogen. Ein relevanter PRS-Anteil war bei Diagnose lokal fortgeschritten (T3 33,3\%; T4 14,2\%) oder metastasiert (29,1\%). Die Therapie bestand meist aus primär chirurgischer Resektion (81,6\%); 32,1\% der Patienten erhielten eine systemische Therapie. Ein multivariabel längeres OAS hatten junge, weibliche Patienten mit wenigen Komorbiditäten und lokalisierten Leiomyosarkomen ohne Tumornekrosen in der RO-Situation. Die Effektivität einer Systemtherapie war abhängig vom PRS-Subtyp (Interaktion $p<0,001$ ).

Schlussfolgerungen: PRS des Erwachsenen machen ca. 0,25 \% aller Nierentumoren aus und unterscheiden sich relevant in Epidemiologie, klinischer Manifestation, Systemtherapie-Sensitivität und OAS. Sie ähneln Weichteilsarkomen anderer Lokalisation, werden jedoch häufig gemäß der Nierenzellkarzinom-Leitlinien therapiert.

\section{V08 - Urolithiasis: klinisch und experimentell}

$$
16.09 .2021, C 6.1,16: 00-17: 30
$$

\section{V08.2}

\section{Outcome und Survival von geriatrischen Patienten mit therapiewürdiger Urolithiasis}

\section{R. Mager", C. Brauers, M. Kurosch, A. Haferkamp}

Universitätsmedizin Mainz, Klinik und Poliklinik für Urologie und Kinderurologie, Mainz, Deutschland

Einleitung: Durch den demographischen Wandel nehmen Patienten $\geq 70$ Jahren einen festen Platz unter den Steinpatienten ein. Das Ziel der Arbeit ist die Untersuchung von Outcome und Survival nach Steintherapie für die besonders vulnerable Gruppe der $\geq 80$-jährigen im Vergleich zur jüngeren Gruppe der 70-79-jährigen Patienten.
Material und Methoden: Nach Zustimmung der Ethikkommission erfolgte für 2013-2018 eine retrospektive Analyse symptomatischer Urolithiasis-Patienten $\geq 70$ Jahre bei denen eine therapeutische Intervention indiziert war $(\mathrm{N}=325)$. Nach Alter wurden die Gruppen 1 ( $\geq 80$ Jahre, $N=84)$ und 2 (70-79 Jahre, $N=241$ ) gebildet und hinsichtlich Outcome und Survival verglichen.

Ergebnisse: Das mediane Alter in Gruppe 1 und 2 lag bei 83 (IQR 81-86) bzw. 75 (IQR 73-77) Jahren. Bei Erstdiagnose war der Anteil infizierter Harnstauungsnieren in Gruppe 1 signifikant größer $(p<0,05)$, während sich die mediane Steinlast und der Charlson comorbidity index nicht signifikant unterschieden. Eine aktive Steintherapie erfolgte in Gruppe 1 und 2 in 85 bzw. $88 \%$ der Fälle $(p>0,05)$, wobei in 15 bzw. $29 \%$ SWL $(p<0,05)$, in 60 bzw. $52 \%$ URS und 17 bzw. $23 \%$ der Fälle eine PNL durchgeführt wurden $(p>0,05)$. Ergebnisparameter wie Steinfreiheits- ( 81 vs. $83 \%)$ und Komplikationsrate (11 vs. $10 \%$ ) zeigten keinen signifikanten Unterschied zwischen den Gruppen. Das 2-Jahres-Gesamtüberleben lag für Gruppe 1 und 2 bei 0,91 (95\%-Cl 0,75-1) bzw. 0,97 (95\%-Cl 0,88-1).

Schlussfolgerung: In Anbetracht des exzellenten 2-Jahres-Überlebens von Steinpatienten $\geq 80$ mit gleichwertigen Steinfreiheits- und Komplikationsraten im Vergleich mit den 70-79-jährigen Patienten erweitert unsere Arbeit die Evidenz für die aktive Steintherapie dieser Patientenpopulation.

\section{V08.3}

\section{Einflussfaktoren für spontanen Steinabgang bei} einliegender Harnleiterschiene

Y. Trachsel", B. Foerster, H. John, C. Schregel

Kantonsspital Winterthur, Urologie, Winterthur, Schweiz

Einführung: Bei Patienten mit Ureterolithiasis erfolgt häufig die Harnleiterscheinung. Hierunter kommt es teilweise zu einem spontanen Steinabgang, die Literatur zur Abgangsrate ist jedoch rar. Wir wollten die Häufigkeit und prädiktive Faktoren für die Passage von Steinen mit einliegendem Ureterstent identifizieren.

Methoden: Alle Patienten von Januar 2015 bis August 2020 mit Ureterolithiasis wurden auf die spontane Abgangsrate nach Einlage einer Harnleiterschiene untersucht. Wir analysierten Retrospektiv die Daten von präoperativen CT und Ergebnissen aus der sequentiellen Ureterorenoskopie. Es erfolgte eine multivariate logistische Regressionsanalyse zur Identifikation von prädiktiven Faktoren.

Resultate: Insgesamt wurden 401 Patienten untersucht. Die spontane Abgangsrate betrug $23,7 \%(n=95)$ bei einem mittleren Steindurchmesser von 4,7 mm (IQR 3,3-5,6 mm). Die Abgangsrate bei einem Durchmesser von 0 bis $2,9 \mathrm{~mm}$, 3 bis $4,9 \mathrm{~mm}, 5$ bis $6,9 \mathrm{~mm}, 7$ bis $8,9 \mathrm{~mm}$ und $>9 \mathrm{~mm}$ betrug jeweils $75 \%, 37,1 \%, 19,1 \%, 10,3 \%$ bzw. 8,2 \%. Die Steinlokalisation (OR 1,63, Cl 1,31-2,06, $p<0,001$ ), der maximale Steindurchmesser (OR $1,31, \mathrm{Cl} 1,11-1,55, p=0,002$ ) und das Steinvolumen (OR 1,01, $\mathrm{Cl} 1,00-1,02$, $p=0,008$ ) waren unabhängige Prädiktoren für die Passage. Die Durchgangsrate der Steine im distalen, medialen und proximalen Ureter betrug $70,8 \%, 12,5 \%$ bzw. $16,7 \%$.

Konklusion: Fast die Hälfte der Steine mit einem maxikmalen Durchmesser von $<5 \mathrm{~mm}$ zeigten einen Spontanabgang (42,6\%). Aufgrund der Daten unterstützen wir die Einlage einer Harnleiterschiene bei Ureterolithiasis auch bei kleinem Steinenvolumen. Bei ausgewählten Patienten sollte eine wiederholte Bildgebung vor der operativen Behandlung in Betracht gezogen werden, um weitere Behandlungsentscheidungen richtig treffen zu können. 
V08.4

Nephrolithiasis der unteren Kelchgruppe - Klinische Ergebnisse beim Einsatz von flexiblen single use und reuseable Ureterorenoskopen im Vergleich zur perkutanen Nephrolitolapaxie

E. Erne ${ }^{1 *}$, S. Deininger ${ }^{2}$, A. Reeb ${ }^{1}$, S. Aufderklamm¹, B. Amend ${ }^{1}$, M. Pallauf ${ }^{2}$, P. Törzsök ${ }^{2}$, A. Stenzl' ${ }^{1}$, S. Rausch ${ }^{1}$

'Universitätsklinik für Urologie Tübingen, Tübingen, Deutschland; ${ }^{2}$ Universitätsklinik für Urologie und Andrologie Salzburg, Salzburg, Österreich

Das optimale Management von Unterpolsteinen wird kontrovers diskutiert. Wir evaluierten klinische Ergebnisse von Patienten mit Unterpolsteinen unter dem Eindruck der verwendeten OP-Technik der flexiblen Ureterorenoskopie (fURS) mit single use (s-fURS) und reuseable Ureterorenoskopen ( $r$-fURS) und der mini-perkutanen Nephrolitolapaxie (mPCNL). Methoden: In die Studie wurden Patienten eingeschlossen, welche sich im Zeitraum von 2017-2020 an den Universitätskliniken Tübingen und Salzburg einer operativen Steinsanierung bei Unterpolsteinen unterzogen. Patientencharakteristika, Op-Zeit, Steinfreiheitsrate (SFR) und Komplikationen nach Clavien-Dindo wurden evaluiert.

Ergebnisse: Die Kohorte umfasste 375 Patienten (medianes Alter 56 Jahre, 40,5\% Frauen und 59,5\% Männer, 48,5\% Rezidivsteinbildner). Es erfolgte eine mPCNL bei 102, eine s-fURS bei 100 und eine r-fURS bei 173 Patienten. Der mittlere Durchmesser des Unterpolsteines betrug 0,85 cm, bei $52 \%$ der Pat. war mehr als ein Stein nachweisbar. Die SFR betrug $90,1 \%$ und unterschied sich nicht in Abhängigkeit der OP-Methode. Die OP-Zeit war signifikant länger bei der mPCNL im Vergleich zur fURS ( 91 vs. $58 \mathrm{~min} ; p<0,001)$. Es resultierte eine signifikant kürzere OP-Dauer beim Einsatz der s-fURS im Vergleich zur r-fURS (53,3 vs $61,8 \mathrm{~min} ; p=0,016$ ). Die Steingröße war signifikant höher beim Einsatz eines s-fURS im Vergleich zur r-fURS $(0,89$ vs $0,68 \mathrm{~cm} ; p=0,018)$. Insgesamt lag die Komplikationsrate bei 7,7 \% (Grad I-II:24 Pat.; Grad III-IV:5 Pat.) und war erwartungsgemäß höher in der mPCNL-Gruppe.

Zusammenfassung: Das Management von Unterpolsteinen ist sicher und praktikabel unter Anwendung von mPCNL, s-fURS und r-fURS. Während sich die Steinfreiheitsraten nicht unterschieden, deutet sich eine Zeitersparnis beim Einsatz der Single-use fURS an.

\section{V08.5}

Kurzfristige Mono-J Einlage: Eine Alternative zur DoppelJ-Schienen Einlage nach Ureterorenoskopie

A. Reicherz ${ }^{*}$, V. Maas², M. Brehmer ${ }^{1}$, M. Reike' ${ }^{1}$, J. Noldus ${ }^{1}$, P. Bach ${ }^{1}$

Marien Hospital Herne, Ruhr-Universität Bochum, Herne, Deutschland; ${ }^{2}$ Augusta Kliniken Bochum, Bochum, Deutschland

Fragestellung: Obwohl deutsche und europäische Leitlinien keine routinemäßige Harnleiterschienung nach unkomplizierter URS empfehlen, wird in der Praxis in Deutschland bei der Mehrheit der Patienten eine Doppel-J-Schiene eingelegt; laut der europäischen Leitlinie sind die Ergebnisse bei kurzfristiger Harnleiterschieneneinlage vergleichbar.

Profitieren Patienten nach unkomplizierter URS und Steinextraktion uneingeschränkt von einer 6-stündigen Mono-J-Einlage?

Material und Methoden: Eingeschlossen wurden Patienten aus den FaSTStudien, prospektiv randomisierte Studien zur postoperativen Harnableitung, die nach sekundärer Ureterorenoskopie einen Mono-J für $6 \mathrm{~h}$ eingelegt bekamen. Endpunkte waren Schienen-assoziierte Beschwerden, die zu zwei Zeitpunkten mittels validiertem Fragebogen (USSQ) erhoben wurden. Es erfolgte eine Analyse der Korrelation zwischen USSQ-Ergebnissen und klinischen Parametern, Steincharakteristika und Operationsdetails.

Ergebnisse: Zwischen August 2014 und April 2018 wurden 108 von 156 initial randomisierten Patienten eingeschlossen. Miktionsbeschwerden und Schmerzen waren einen Tag vor Ureterorenoskopie und Steinextraktion signifikant höher als 3-5 Wochen nach der Intervention. USSQ Er- gebnisse vor und nach Steinsanierung korrelierten nicht mit der Steingröße oder Operationszeit, und waren unabhängig von der Lokalisation, der Erfahrung des Operateurs und dem Instrument, das benutzt wurde $(p>0,05)$. Bei 6 Patienten war eine operative Re-Intervention erforderlich (5\%).

Schlussfolgerungen: Patienten nach sekundärer Ureterorenoskopie und kurzfristiger Mono-J Einlage profitieren von einer hohen Lebensqualität. Diese ist unabhängig von der Steingröße und -lokalisation, der Operationszeit, der Erfahrung des Operateurs und dem verwendeten URS-Instrument.

\section{V08.6}

Gepulster Thulium:YAG-Laser: Erste klinische Ergebnisse während der perkutanen Nephrolitholapaxie

J. Bergmann*, C. Netsch, C. M. Rosenbaum, A.J. Gross, B. Becker

Asklepios Klinik Hamburg Barmbek, Urologie, Hamburg, Deutschland

Einleitung: Bei der Steinsanierung durch die Mini-PCNL spielt die Laserlithotripsie eine tragende Rolle. Innovative gepulste Thulium Laser versprechen umfangreiche Möglichkeiten, um den Eingriff mit hoher Präzision und Effektivität durchzuführen. Diese Studie wurde zur Überprüfung der Sicherheit und Effektivität eines neuen RevoLix-HTL 150 W Hybrid Thulium Laser (Lisa Laser Products GmbH) während der Mini-PCNL durchgeführt.

Material und Mehtode: Die Rekrutierung der Patienten erfolgte prospektiv. Es wurden sämtliche Patienten, die sich einer Mini-PNL unter der Anwendung des gepulsten Thulium Lasers unterzogen, eingeschlossen. Dokumentiert wurden Lasereinstellungen, Operations- sowie Laserzeiten und die Steingröße.

Zur Ermittlung der Steinfreiheitsrate erfolgte postoperativ die Durchführung eines Röntgenbildes und einer Sonographie. Die Clavien-Dindo Klassifikation wurde zur objektiven Dokumentation der Komplikationen angewandt.

Ergebnisse: Das durchschnittliche Alter der 40 eingeschlossenen Patienten lag bei 50 Jahren. 24 Patienten (60\%) waren männlich. $248 \mathrm{~mm}^{2}$ betrug die mittlere Steingröße mit einer durchschnittlichen Dichte von 830 ( \pm 337) HU. Die mittlere Operationszeit betrug $23( \pm 10,3)$ Minuten. Die dokumentierte Laserzeit betrug 06:04 ( \pm 07:18) Minuten. Folgende Lasereinstellungen wurden am häufigsten genutzt: 0,4 J, 46 W, $115 \mathrm{~Hz}$. Die Gesamtenergie für die Steinablation betrug im mittel 13.573 ( \pm 16.753) $\mathrm{kJ}$. Die Steinfreiheitsrate betrug insgesamt 82,5\%. Die Gesamtkomplikationsrate betrug 34,5\% (Clavien-Dindo-Klassifikation Grad $1 n=8$, Grad 2 $n=3$, Grad 4a $n=1$ ).

Zusammenfassung: Der gepulste RevoLix HTL ermöglicht eine sichere und effiziente Lithotripsie während der Mini-PCNL mit hohen Steinfreiheitsraten und kurzen Operationszeiten.

\section{V08.7}

Multi-tract vs. Single-tract perkutane Nephrolithotomie: Retrospektive Analyse von Wirksamkeit und Sicherheit

\section{R. Mager*, O. Savko, M. Kurosch, A. Haferkamp}

Universitätsmedizin Mainz, Klinik und Poliklinik für Urologie und Kinderurologie, Mainz, Deutschland

Einleitung: Die Erweiterung der PNL zum Multi-tract Eingriff kommt zunehmend in Fällen mit ausgeprägter Steinlast zum Einsatz. Bei limitierten Daten zum Multi-tract Vorgehen ist das Ziel der Arbeit dessen Wirksamkeit und Sicherheit gegenüber dem Standard der Single-tract PNL zu untersuchen.

Material und Methoden: Retrospektiv wurden 391 konsekutive PNL, die von 2016 bis 2020 in unserer Klinik durchgeführt wurden, untersucht. Klinische Ergebnis-Parameter wie die Steinfreiheits- und Komplikationsrate, 
OP-Zeit, Länge des stationären Aufenthalts und die Zeit bis zum therapiewürdigen ipsilateralen Rezidiv wurden verglichen.

Ergebnisse: Es wurden 37 (9\%) Multi-tract und 354 (91\%) Single-tract PNL durchgeführt. Bei Erstdiagnose waren Multi-tract gegenüber Single-tract Fällen durch eine signifikant größere Steinlast $\left(2,62\right.$ vs. $\left.0,97 \mathrm{~cm}^{3}\right)$, einen höheren S.T.O.N.E. score und durch einen größeren Anteil an Hoch-Risiko Steinbildnern (59 vs. $19 \%$ ) charakterisiert $(p<0,01)$. Bei den Ergebnissen zeigten sich beim Multi-tract Vorgehen signifikant längere OP-Zeiten ( $2 \mathrm{~h}: 48 \mathrm{~min}$ vs. $1 \mathrm{~h} 54 \mathrm{~min}$ ) und längere stationäre Aufenthalte (4d vs. $3 d)(p<0,01)$, aber kein Unterschied bei den Steinfreiheits- $(92 \%$ vs. $88 \%$ ) und Komplikationsraten (43 vs $28 \%$ ) und der Zeit bis zur erneuten ipsilateralen Steintherapie aufgrund Urolithiasis-Rezidiv (42 vs 45 Monate bei 8 vs. $4 \%)(p>0,05)$.

Schlussfolgerung: In dieser monozentrischen retrospektiven Analyse stellte sich die Multi-tract PNL als sichere und wirksame Erweiterung einer PNL bei Patienten mit komplexer Steinlast dar. Zukünftige prospektive Forschung ist erforderlich, um das Potenzial der Multi-tract PNL zur Reduktion der Eingriffsanzahl bis Steinfreiheit erreicht ist, bei Patienten mit massiver komplexer Steinlast zu ermitteln.

\section{V08.8}

Klinische Validierung einer CT Textur Analyse Software (CTTA) zur Prädiktion des Outcomes nach perkutaner Nephrolithotomie (PCNL)

\section{Stellwag", R. Umbach, J. Dlugosch, J. Jessen, N. Atassi, T. Knoll \\ Klinikum Sindelfingen, Urologische Klinik, Sindelfingen, Deutschland}

Einleitung: Das CT ist der Standard für Steindiagnostik und Therapieplanung. Obwohl es eine Vielzahl von Informationen enthält, beschränkt sich die Analyse meist auf Steinanzahl, -durchmesser und -lokalisation. Eine neue, für die Auswertung von Steinen modifizierte CTTA-Software ermöglicht eine automatisierte CT Analyse, welche auch weitere Faktoren wie Steinheterogenität mit einbezieht. Diese korrelieren mit dem Erfolg einer ESWL Behandlung. Unklar ist bislang jedoch, ob eine solche Analysen auch hilfreich für die Planung einer PCNL sind.

Material und Methoden: Eingeschlossen wurden 96 Pat., die mittels PCNL (24F/18F, Karl Storz; ballistisch/Laser, EMS, Schweiz, Dornier Medtech, Deutschland) behandelt wurden. Präop. Parameter wurden einschl. des Guy's Stone Scores (GSS) erfasst. Die präop. CT wurden mittels CTTA (StoneChecker, Imagingbiometrics, UK) analysiert (Texturmuster, Entropie, Kurtosis).

Ergebnisse: Die mittl. OP-Zeit betrug 73 min. (41-349 min). Die Steinfreiheitsrate (SFR) betrug $79,2 \%$. Beide Parameter korrelierten mit Anzahl $(p=0,001 ; p=0,002)$ und Volumen $(p<0,001 ; p=0,006)$ der Steine. Komplikationen zeigten keine Korrelationen. Der GSS hatte einen signifikanten Einfluss auf SFR $(p=0,012)$, jedoch nicht auf OP Dauer. Alter, Geschlecht, Steinlokalisation und- dichte $(\mathrm{HU})$ zeigten keine Korrelationen. Für die CTTA zeigte nur die Kurtosis eine Korrelation zur OP Dauer $(p=0,007)$, aber nicht zur Steinfreiheit. In der multiplen logistischen Regression war der addierte max. Steindiameter die wichtigste Einflussgröße $(p<0,001)$. Zusammenfassung: Die PCNL Ergebnisse korrelieren mit Steinvolumen und dessen assoziierten Parametern. Weitere Analysen der Steinstruktur scheinen jedoch anders als bei der ESWL keinen Einfluss zu haben.
V08.9

Der hydrostatische Nierenbeckendruck als strahlenfreie Alternative zur Fistelfüllung nach PCNL

S. Degener ${ }^{1 *}$, D. Stapelmann ${ }^{2}$, N. M. Dreger ${ }^{1}$, A. S. Brandt ${ }^{3}$, P. Rebacz $^{4}$,
F.-C. von Rundstedt ${ }^{1}$, S. Roth ${ }^{1}$

'Helios Universitätsklinik Wuppertal, Klinik für Urologie, Wuppertal, Deutschland; ${ }^{2}$ St. Franziskus-Hospital, Radiologie, Münster, Deutschland; ${ }^{3}$ Urologisches Zentrum Euregio, Simmerath, Deutschland; ${ }^{4}$ Universität Witten/Herdecke, Lehrstuhl für Lehrstuhl für Didaktik und Bildungsforschung im Gesundheitswesen, Witten, Deutschland

Hintergrund: Evaluation des hydrostatischen Nierenbeckendrucks (NBD) als strahlenfreie Alternative zur radiologischen Beurteilung des ureteralen Abflusses (Fistelfüllung) nach PCNL.

Material und Methode: Retrospektive Analyse (2007-2015) von 248 PCNL $(86$ P /162 3̂) mit Nierenbeckendruckmessung an Tag 2 nach OP. Ein Nanometer wurde $\mathrm{NaCl}$-gefüllt (analog zur Messung des zentralvenösen Drucks) an die einliegende Nephrostomie angeschlossen und der NBD über die Höhe der oszillierenden Wassersäule $\left(\mathrm{CmH}_{2} \mathrm{O}\right)$ gemessen.

Der primäre Endpunkt war die Beurteilung des NBD in Abhängigkeit von der Durchgängigkeit des Ureters und dem Erfolg der Nephrostomieentfernung.

Der sekundäre Endpunkt war die Bewertung der oberen Grenze des normalen NBD von $<20 \mathrm{cmH}_{2} \mathrm{O}$ als Indikator für einen ungestörten ureteralen Abfluss.

Ergebnisse: Die mediane Eingriffsdauer betrug $141 \mathrm{~min}(112-171,5) \mathrm{mit}$ einer Steinfreiheitsrate von $82 \%(n=202)$. Der NBD war signifikant höher bei Patienten mit obstruktivem Nephrostogramm $\left(25 \mathrm{~cm} \mathrm{H}_{2} \mathrm{O}\right.$ [21-32] vs. $\left.20 \mathrm{cmH}_{2} \mathrm{O}[16-24] ; p<0,001\right)$.

Der Druck war bei Patienten mit erfolgreicher Nephrostomieentfernung niedriger als in der Gruppe mit persistierender Urinfistel $\left(18 \mathrm{cmH}_{2} \mathrm{O}[15-\right.$ 21 ] vs. $23 \mathrm{cmH} 2 \mathrm{O}$ [20-29]; $p<0,001)$. Die Analyse eines Cut-off-Wertes von $<20 \mathrm{cmH} 2 \mathrm{O}$ zeigte eine Sensitivität von 76,9\% (95\% Cl: [60,7\%; 88,9\%]) und eine Spezifität von $61,5 \%$ (95\% Cl: [54,6\%; 68,2\%]). Der negative prädiktive Wert betrug $93,4 \%$ (95\% Cl: $[87,9 \% ; 97,0 \%])$ und der positive prädiktive Wert 27,3\% (95\% Cl: [19,2\%; 36,6\%]). Die Genauigkeit des Modells zeigte eine AUC $=0,795$ (95\% Cl: $[0,668 ; 0,862])$.

Fazit: Die Messung des hydrostatischen Nierenbeckendrucks scheint ein einfaches und geeignetes bedside-Verfahren zur Beurteilung des ureteralen Abflusses nach PCNL zu sein.

\section{V09 - Geschichte der Urologie}

16.09.2021, C5.1.1, 16:00-17:30

V09.2

KultUROlogie zwischen Sakkara und Nittenau - die künstlerische Rezeption der Zirkumzision aus ritueller Indikation vom Alten Unterägypten bis in die moderne Oberpfalz

W. Otto ${ }^{1 *, 2}$

'Universität Regensburg, Regensburg, Deutschland; '2Urologie im Gesundheitsforum, Regensburg, Deutschland

Es ist unstrittig, dass die Zirkumzision zu den ältesten Eingriffen der Menschheitsgeschichte gehört. Sicher nachgewiesen, weil in bildender Kunst und Schrifttum klar adressiert, ist die Zirkumzision seit dem 3. Jahrtausend vor der Zeitenwende. Man denke hier etwa an die weltbekannten Reliefs aus Sakkara in Unterägypten, wo um 2300 vor Christus die erste bekannte Darstellung einer rituellen Beschneidung, wohl nach dem so genannten "Schlangenkult", ins Werk gesetzt wurde. Die Beschneidung war aber keine ägyptische Exklusivität, sondern ist in der Bronzezeit für 
viele Völkerschaften auch auf dem Gebiet des "fruchtbaren Halbmonds" nachweisbar. Neben den Ägyptern übten sie auch die benachbarten Moabiter, Ammoniter, Edomiter und Israeliten aus. Die bildliche Darstellung religiöser Inhalte ist im jüdischen ebenso wie im islamischen Kulturkreis unüblich, dennoch hat sich unter dem Einfluss der abendländischen Buchmalerei auch eine Szene von der Beschneidung Isaaks im jüdischen „Regensburger Pentateuch" aus dem späten 13. Jahrhundert erhalten. In den darauffolgenden Jahrhunderten hielt die Darstellung der Beschneidung von Jesus Christus auch in die christliche bildende Kunst Einzug. Aber auch, nachdem die „Beschneidung des Herrn“ (1. Januar) im Zweiten Vatikanischen Konzil aus dem katholischen Feiertagskalender gestrichen worden war, blieb die Beschneidung ein Sujet für die sakrale Kunst. Im Vortrag über die Darstellung der Beschneidung wird ein Bogen von der Reliefkunst des Alten Ägyptens über die mittelalterliche Buchmalerei und neuzeitliche bildende Kunst bis zur modernen Kunst gespannt.

\section{V09.3}

\section{„Für jede Krankheit den richtigen Heiligen“ - Heilige und die Urologie}

\section{F. Moll ${ }^{1 * 2}$, I. Schwarzburger ${ }^{1,3}$, F. Söhner ${ }^{1}$}

'Heinrich-Heine-Universität Düsseldorf, Medizinische Fakultät, Centre for Health and Society, Institut für Geschichte, Theorie und Ethik der Medizin, Düsseldorf, Deutschland; ${ }^{2}$ Kliniken der Stadt Köln gGmbH, Urologische Klinik, Urologischer Arbeitsplatz Krankenhaus Merheim, Köln, Deutschland; ${ }^{3}$ Heinrich-Heine-Universität Düsseldorf, Lehrstuhl für Mittelalterliche Geschichte, Düsseldorf, Deutschland

Fragestellung: Untersuchungen zur Urologie- und Medizingeschichte haben sich hin zu einer Kulturgeschichte des Medikalen geweitet. Das Interesse gilt auch Einstellungen und Praktiken, die mit Gesundheit und Krankheit, zu tun haben. In der fachkulturellen Erinnerung der Urologie sind beim Harnsteinleiden neben der Heiligenvita des HI. Liborius die des HI. Apollinaris oder die des HI. Rasso von Grafrath (Andechs) in Bayern bekannt. Für dem Erkrankungskomplex der Geschlechtskrankheiten (,Widerfahrnis") sind zumeist der HI. Dionys(ius), der HI. Georg, im Rheinland wieder der HI. Apollinaris von Ravenna oder der HI. Rochus von Montpellier in Tradition und als Stationsbezeichnung aktiv in Gebrauch. Bei den Heiligen wechseln die Zuschreibungen der Erkrankungen (Syphilis, Geschlechtskrankheiten; Nieren-Gallensteine etc.).

Material und Methode: Wir gehen der Frage nach, wie sich in zwei verschiedenen Kulturräumen, im Rheinland sowie Schwaben, anhand von Patrozinien Heilige mit Bezug zur Urologie nachweisen lassen und ggf. ein besonderer Kultus vorliegt. Anhand von primären und sekundären Quellen aus lokalen und regionalen Archiven (u.a. HStA D, HAEbK, HStASt) wurden Patrozinien zweiter Regionen (Rheinland-Schwaben) analysiert.

Ergebnisse: Es ließen sich Kultusschwerpunkte mit Bezug zur Urologie in einzelnen, ausgewählten Regionen nachweisen, wobei Heilige mit Bezug zur Urologie nicht immer das Hauptpatronat inne hatten.

Schlussfolgerung: Bei den Erkrankungen sind für die Urologie das Harnsteinleiden und die Geschlechtskrankheitenteils eine antropomorphe Konstante, was sich bis in die Hippokratischen Schriften zurückverfolgen lässt. Daher lassen sich Patrozinien in zwei deutschen Regionen nachweisen.

\section{V09.4}

\section{Kastration und "Entmannung" in der Deutschen Zeitschrift für die gesamte gerichtliche Medizin, 1922 1943}

\section{Krischel*, F. Moll}

Heinrich-Heine-Universität Düsseldorf, Medizinische Fakultät, Centre for Health and Society, Institut für Geschichte, Theorie und Ethik der Medizin, Düsseldorf, Deutschland

Fragestellung: Die Deutsche Zeitschrift für die gesamte gerichtliche Medizin erschien ab 1922 und stellt eine zentrale Quelle zur Geschichte der
Gerichtsmedizin in Deutschland dar. Seit der Gründung der Zeitschrift wurden Fragen der Kastration und "Entmannung" in der Zeitschrift thematisiert, welche auf Grund des betroffenen organischen Bereichs - insb. beim Mann - einen engen Zusammenhang zur Urologie, Andrologie, Sexualmedizin und Sexualwissenschaft aufweisen.

Material und Methode: Die Deutsche Zeitschrift für die gesamte gerichtliche Medizin (heute: International Journal of Legal Medicine) wurde auf die Stichworte "Kastration", "Castration" und "Entmannung" untersucht. Die Treffer wurden elektronisch gesichert, in Orginalia und Rezensionen kategorisiert und inhaltlich ausgewertet.

Ergebnisse: Zwischen 1922 und 1943 finden sich 291 Beiträge in der Zeitschrift, in denen mindestens eines der gesuchten Stichworte vorkommt. Eine zentrale Frage stellt hierbei die "Entmannung" von Sittlichkeitsverbrechern dar, die bereits seit den 1920er Jahren als Therapie in Betracht gezogen und ab 1934 durch das nationalsozialistische „Gesetz gegen gefährliche Gewohnheitsverbrecher und über Maßregeln der Sicherung und Besserung" legalisiert wurde.

Schlussfolgerung: Fragen der Kastration und „Entmannung" spielen in der Deutschen Zeitschrift für die gesamte gerichtliche Medizin eine wichtige Rolle. Aus der disziplinären und geographischen Breite der Rezensionen lässt sich ablesen, dass die Frage nach dem Zusammenhang von Keimdrüsen, Sexualität und Verhalten im Untersuchungszeitraum intensiv diskutiert wurde. Durch die nationalsozialistische Gesetzgebung in den 1930er Jahren erhielt das Thema eine noch größere Bedeutung.

\section{V09.5}

Samuel Jessner (1859-1929) „Arzt für Haut-, Haar-, und Harnleiden" in Königsberg Urologie und Sexualmedizin zu Beginn des 20. Jahrhunderts

\section{F. H. Moll ${ }^{1 * 2}$, T. Halling ${ }^{3}$, N. Hansson ${ }^{1}$, M. Krischel ${ }^{1}$}

'Heinrich-Heine-Universität Düsseldorf, Medizinische Fakultät, Centre for Health and Society, Institut für Geschichte, Theorie und Ethik der Medizin, Düsseldorf, Deutschland;

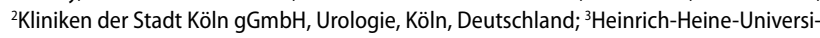
tät Düsseldorf, Medizinische Fakultät, Centre for Health and Society, Geschichte, Theorie und Ethik der Medizin, Düsseldorf, Deutschland

Fragestellung: Die Urologie konstituierte sich im letzten Viertel des 19. Jhds. aus verschiedenen Gruppen, in der neben Operateuren der "Harnund Geschlechtsorgane", Endoskopikern, Venerologen-Dermatologen, Gynäkologen und Internisten auch an der Sexualmedizin Interessierte ihre wissenschaftliche Heimat fanden. Während in der Erinnerungskultur des Faches Urologie hier besonders auf Carl Posner (1854-1928), Leopold Casper (1859-1959) oder im „Kaiserthum Österreich“ auf Viktor Ultzmann (1842-1889) fokussiert wird, geriet S. Jessener in Vergessenheit, trotz volkstümlicher Publikationen sowie einem Lehrauftrag für "Sexualkunde" an der Albertina in Königsberg.

Material und Methode: Anhand von Primärquellen wie Nekrologen, seinen Publikationen in der Fachpresse und Zitationen, wird initial eine ergo-biographische Skizze erstellt. In vergleichender Perspektive werden weitere allgemeine Aspekte der Fachentwicklung an der Grenze zu Venero-Dermatologie und Sexualmedizin analysiert im Rahmen eines größer angelegten Forschungsprojektes zur Sexualmedizin und Erinnerungskultur in Medizin und Urologie.

Ergebnisse: Samuel Jessner gehört unbestritten zu den frühen nationalen Promotoren innerhalb der Venero-Dermatologie und Sexualmedizin. Auf wissenschaftlicher Ebene befasset er sich besonders mit den zu dieser Zeit Sexualpädagogik.

Schlussfolgerung: Erst langsam konnte sich - besonders ab Ende des Ersten Weltkrieges und zu Beginn der Weimarer Republik - die Therapie sexueller Funktionsstörungen innerhalb der Urologie verbessern. Die Urologie konnte sich als eigenständiges Fachgebiet, das während der Weimarer Republik den Facharztstatus erlangte, mit einem eigenen Therapiekanon auch im Bereich der akademisch nicht abgegrenzten Sexualerkrankungen und Neurasthenie ihre Angebote ausweiten. 


\section{V09.6}

\section{Urologiegeschichte im Archiv: Die Nachlässe von F.} Eisenberger und H.-J. Reuter

\section{T. Halling*, M. Krischel, F. Moll, H. Fangerau}

Heinrich-Heine-Universität, Institut für Geschichte, Theorie und Ethik der Medizin, Düsseldorf, Deutschland

Fragestellung: Ferdinand Eisenberger (1937-2009) gehört als Mitentwickler der ESWL zu den bekanntesten deutschen Urologen der Nachkriegszeit, Hans-Joachim Reuter (1923-2003) begründete eine der umfangreichsten Privatsammlungen zur Geschichte der Endoskopie. Beide verbindet nicht nur eine langjährige klinische Tätigkeit in Stuttgart, sondern vor allem, dass ihre Nachlässe im Archiv der Deutschen Gesellschaft für Urologie e.V. verwahrt werden. Ausgehend von der unterschiedlichen Bedeutung der Lebensläufe für die deutsche Urologie, stellt der Beitrag die überlieferten Quellengattungen vor und analysiert die zentrale Bedeutung von Nachlässen für die fachkulturelle Erinnerung sowie die Geschichtsschreibung der Urologie.

Material und Methode: Die Nachlässe im Historischen Archiv der DGU wurden systematisch erschlossen und ausgewählte Korrespondenzbestände unter Berücksichtigung der Schutzfristen für personenbezogenes Archivgut gemäß dem Landesarchivgesetz NRW qualitativ analysiert. Ergebnisse: Der Nachlass von Ferdinand Eisenberger vermittelt wichtige Einsichten in eine zentrale wissenschaftliche Innovation in der Urologie des 20. Jahrhunderts. Der noch wesentlich umfangreichere Nachlass von Hans-Joachim Reuter ermöglicht durch die systematisch überlieferte Korrespondenz umfassende netzwerkanalytische Untersuchungen zum deutsch-deutschen Wissenschaftsaustausch während des Kalten Kriegs. Schlussfolgerung: Nachlässe stellen eine zentrale Quelle zur Erforschung der Fachgeschichte dar. Urologinnen und Urologen, die nicht hauptamtlich an Universitäten wirken (hier sind die Universitätsarchive zuständig) sollten die dauerhafte Sicherung Ihres wissenschaftlichen Nachlasses im Archiv der DGU sicherstellen.

\section{V09.7}

Das Mediziner-Porträt im Spiegel seiner Zeit am Beispiel des anglo-amerikanischen Porträtmalers John Singer Sargent (1856-1925)

\section{Schultheiss}

Praxis für Urologie und Dermatologie, Gießen, Deutschland

Einleitung: John Singer Sargent hat zwei ikonographische Mediziner-Porträts geschaffen, die unterschiedlicher in Stimmung und Ausdruck nicht sein könnten.

Material und Methoden: Sargent gilt als ein Hauptvertreter des "Gilded Age" in Amerika, obwohl er vorwiegend in Europa lebte und arbeitete. Mit seinen Porträtbildern war er auf beiden Kontinenten enorm erfolgreich und führend in seinem Metier.

Ergebnisse: „Dr. Pozzi at Home“ von 1881 zeigt den dandyhaften Gynäkologen Samuel Jean Pozzi (1846-1918) in einen roten Hausmantel gekleidet in den Privaträumen seiner Pariser Wohnung. 1884 begründete er den ersten Lehrstuhl für Gynäkologie in Paris und führte ein illusteres Leben in der angesehenen Pariser Gesellschaft. Pozzi behielt das Porträt zu seinen Lebzeiten und es gelangte erst 1991 aus Privatbesitz in eine öffentlich-private Kunstsammlung in Los Angeles.

„The Four Doctors" von 1906 ist ein konventionelles Gruppenporträt der vier Gründer der Johns Hopkins Medical School in Baltimore Sir William Osler (1849-1919), William S. Halsted (1852-1922), William H. Welch (1850-1934) and Howard A. Kelly (1858-1943) in ihren akademischen Roben. Osler war seit 1905 in Oxford tätig und alle reisten im Juni 1905 nach London um Singer Sargent in seinem Studio Portrait zu sitzen. 1906 wurde das Bild in London ausgestellt und ist seit 1907 an seinem endgültigen Bestimmungsort an der Johns Hopkins University.
Schlussfolgerung: Die beiden Gemälde versinnbildlichen die unterschiedliche Ikonographie und Rezeption von Medizinerporträts aus der Hand eines Künstlers. Das eine Bild mit einer privaten und intimen Darstellung des Porträtierten erregte erst in den letzten 3 Jahrzehnten das Interesse der Öffentlichkeit. Das andere Porträt dient seit über 100 Jahren der offiziellen Repräsentation.

\section{V10 - Prostatakarzinom - Prognose und Prädiktion}

$$
\text { 17.09.2021, C5.2, 08:15-09:45 }
$$

\section{V10.1}

Lymphangioinvasion als negativer Prädiktor in pNO Prostatakarzinompatienten nach radikaler Prostatektomie

R.M. Pose ${ }^{* *}$, C. Würnschimmel ${ }^{1,2}$, F. Stolzenbach ${ }^{1,3}$, S. Knipper', P. Tennstedt ${ }^{1}$, M. Wenzel ${ }^{2,4}$, G. Sauter ${ }^{5}$, M. Graefen $^{1}$

'Universitätsklinikum Hamburg-Eppendorf, Martini-Klinik Prostatakarzinomzentrum, Hamburg, Deutschland; ${ }^{2}$ University of Montreal Health Centre, Cancer Prognostics and Health Outcomes Unit, Montreal, Kanada; ${ }^{3}$ Fachabteilung Urologie, Kantonspital 2, Luzern, Schweiz; ${ }^{4}$ Goethe Universität Frankfurt, Klinik für Urologie, Frankfurt, Deutschland 5Universitätsklinikum Hamburg-Eppendorf, Klinik für Pathologie, Hamburg, Deutschland

Fragestellung: Einfluss von L1 auf die krebsspezifische Mortalität (CSM) in N0 Patienten.

Material und Methoden: Innerhalb unserer prospektiven Datenbank wurden 23.798 Patienten ermittelt, die sich zwischen 04/2005 und 12/2017 einer radikalen Prostatektomie (RP [offen oder robotisch-assistiert]) unterzogen. Von diesen wurden 21.452 konsekutive Patienten mit nachgewiesener immunhistochemischer Lymphgefäßinvasionsanalyse analysiert. Der Einfluss von L1 wurde gemessen. Der primäre Endpunkt war CSM. Für alle Time-to-Event-Analysen wurden uni- und multivariable Cox'sche Proportional-Hazards-Modelle und univariable Kaplan-Meier-Analysen stratifiziert angewendet, mit einer Signifikanzschwelle von $p<0,05$.

Ergebnisse: Im Median betrug das Alter 64 Jahre (IQR: 59-69 Jahre) und der PSA-Wert vor der RP 8,1 ng/ml (IQR: 5,8-12,2 ng/ml). Eine pelvine Lymphknotendissektion wurde bei 14.907 Patienten (69,5\%) durchgeführt. Im Median wurden 13 Lymphknoten entnommen (IQR: 8-20) und im Median war einer der dissezierten Lymphknoten positiv (IQR: 1-3). 2449 Patienten $(11,4 \%)$ waren pN1 und 3180 Patienten $(14,8 \%)$ hatten einen L1-Status. Die mediane Nachbeobachtungszeit betrug 60,7 Monate (IQR: 36,4-96,2). Wir identifizierten 1516 pN0-L1-Patienten (7,0\%) und 149 pNX-L1-Patienten (0,7\%), die keinen signifikanten Unterschied im CSM aufwiesen. Sie wurden für die Analysen zusammengeführt. In uni- und multivariablen Cox-Regressionsmodellen war L1 ein unabhängiger Prädiktor für CSM (Hazard ratio: 1,54, 95 \%-Konfidenzintervall: 1,072,$23 ; p=0,02$ ).

Schlussfolgerung: L1 hat einen Einfluss auf die Prognose bei pNO-Patienten. Daher könnte es einen Einfluss auf die klinische Behandlungsentscheidung wie die Behandlungsplanung haben (z. B. durch Erweiterung des Bestrahlungsfeldes). 
V10.2

Positive Familienanamnese und postoperatives Upgrading und Upstaging beim low-risk und favorableintermediate-risk Prostatakarzinom nach radikaler Prostatektomie: Bedeutung für die Active Surveillance

V. H. Meissner ${ }^{1 *}$, N. Maier ${ }^{1}$, S. Schiele ${ }^{1}$, D.P. Ankerst ${ }^{2}$, J. E. Gschwend ${ }^{1}$, K. Herkommer ${ }^{1}$

'Universitätsklinikum rechts der Isar der TU München, Klinik und Poliklinik für Urologie, München, Deutschland; ${ }^{2}$ Fakultät für Mathematik der TU München, Lehrstuhl für Mathematische Modelle biologischer Systeme, München, Deutschland

Fragestellung: Ist eine positive Familienanamnese (FA) ein Risikofaktor für ein postoperatives Upgrading oder Upstaging beim low-risk (LR) und favorable-intermediate-risk (FIR) Prostatakarzinom (PCa)?

Material und Methoden: In vorliegende Studie wurden 4091 Patienten nach radikaler Prostatektomie (RP) (1994-2019) aus der Datenbank „Familiäres Prostatakarzinom" mit einem LR (Gleason Grade Group (GG) 1, cT1c-2a, Prostata-spezifisches Antigen (PSA) $<10 \mathrm{ng} / \mathrm{ml}(n=2607))$, Gleason GG 1 FIR (GG 1, cT1c-2a, PSA 10-20 ng/ml $(n=630))$ und Gleason GG 2 FIR (GG 2, cT1c-T2a, PSA < $10 \mathrm{ng} / \mathrm{ml}(n=854))$ PCa eingeschlossen. In multiplen Regressionsmodellen wurde der Einfluss der FA auf das Upgrading (Gleason GG $\geq 3$ ) bzw. Upstaging ( $\geq \mathrm{pT} 3 / \mathrm{pN} 1$ ) untersucht.

Ergebnisse: In der LR Gruppe hatten 7,2\% ein Upgrading, 12,0\% ein Upstaging. Prädiktoren für ein Upgrading waren ein höheres Alter bei RP (OR $1,06[1,03-1,08])$ und ein höherer PSA-Wert (OR 1,14 [1,05-1,23]), für ein Upstaging ein höherer PSA-Wert (OR 1,18 [1,11-1,26]). In der Gleason GG 1 FIR Gruppe hatten 10,6\% ein Upgrading und 24,1\% ein Upstaging. Die Regressionsanalyse zeigte keine signifikanten Prädiktoren. In der Gleason GG 2 FIR Gruppe hatten 13,8\% ein Upgrading, 16,6 \% ein Upstaging. Prädiktoren für ein Upgrading waren ein höherer PSA-Wert (OR 1,14 [1,03$1,26]$ ) sowie ein suspekter Tastbefund (OR 1,73 [1,08-2,78]), für ein Upstaging ein höherer PSA-Wert (OR 1,16 [1,05-1,27]). In keiner Gruppe zeigte sich eine Assoziation zwischen einer positiven FA und einer erhöhten Rate an postoperativem Upgrading bzw. Upstaging.

Schlussfolgerungen: Die PCa FA hatte in den untersuchten Gruppen keinen Einfluss auf das Risiko des postoperativen Upgrading oder Upstaging und sollte somit kein Grund sein, auf eine Active Surveillance zu verzichten.

\section{V10.3}

\section{Eine PSMA PET positive regionale} Lymphknotenmetastasierung korreliert mit einem verminderten biochemischen-rezidiv ( $\mathrm{BCR}$ )-freien und therapiefreien Überleben nach radikaler Prostatektomie (RP)

T. Amiel ${ }^{*}$, C. Würnschimmel ${ }^{2}$, M. Heck³, T. Horn ${ }^{3}$, N. Nguyen ${ }^{3}$, L. Budäus², S. Knipper ${ }^{2}$, M. Wenzel ${ }^{4}$, I. Raucher ${ }^{5}$, M. Eiber ${ }^{3}$, H. Wang ${ }^{5}$, T. Maurer $^{2}$

${ }^{1}$ Klinikum Rechts der Isar der TU München, Urologie, München, Deutschland; ${ }^{2}$ MartiniKlinik Prostate Cancer Center, Universitätsklinikum Hamburg-Eppendorf, Hamburg, Deutschland; ${ }^{3}$ Klinikum Rechts der Isar der TU München, München, Deutschland; ${ }^{4}$ Universitätsklinikum Frankfurt, Urologie, Frankfurt, Deutschland; ${ }^{5}$ Klinikum Rechts der Isar der TU München, Nuklearmedizin, München, Deutschland

Einleitung: Die PSMA PET kann eine lymphogene Metastasierung früher als die konventionelle Bildgebung nachweisen. Bisher ist jedoch nicht geklärt, ob im Primärstaging vor RP der Nachweis einer lymphogenen Metastasierung auch prognostisch hinsichtlich des BCR-freien bzw. therapiefreien Überleben korreliert.

Material und Methoden: Zw. 2013 und 2017 erhielten insgesamt 230 Patienten mit Prostatakarzinom (64 mit mittlerem und 166 mit hohen Risikoprofl) eine ${ }^{68} \mathrm{Ga}-\mathrm{PSMA}-11$ PET Bildgebung gefolgt von einer RP mit PLND. Das BCR sowie das therapiefreie Überleben wurden bestimmt. Für alle Zeit-zu-Ereignis-Analysen wurden uni- und multivariable Cox-Propor-
tional-Hazard-Modelle und univariable Kaplan-Meier-Analysen mit einem Signifikanzwert von $p<0,05$ angewendet.: Ergebnisse: Die Sensitivität, Spezifität sowie der positive und negative prädiktive Wert der PSMA PET für pN1 betrugen $48,5 \%, 95,7 \%, 82,1 \%$ bzw. $82,2 \%$. Das mediane Follow-up betrug 30,2 Monate. Ein BCR trat bei 50,4\% $(n=116)$ der Patienten auf und bei $46,5 \%(n=107)$ wurde eine adjuvante oder Salvage-Therapie durchgeführt. Das geringste freie BCR- und therapiefreie Überleben wurde bei pN1 Patienten beobachtet, die ebenfalls PSMA PET positive Lymphknoten zeigten, gefolgt von pN1 mit unauffälligem PSMA PET sowie pN0 mit unauffälligem PSMA PET (medianes freies BCR Überleben 1,7 vs. 7,5 vs. $>36$ Monate, medianes therapiefreies Überleben 2,6 vs. 8,9 vs. > 36 Monate).

Schlussfolgerung: Patienten mit positivem Lymphknotennachweis in der PSMA PET vor RP müssen trotz gründlicher PLND mit einem früheren $B C R$ und einer früheren adjuvanten/Salvage-Therapie rechnen. Die PSMA PET könnte somit für die präoperative Beratung, für strengere Nachsorgen als auch für die Planung einer neo-/adjuvanten Therapien dieser Patienten von Nutzen sein.

\section{V10.4}

\section{AR-V7 in granulären Strukturen ist ein unabhängiger Prognostischer Faktor beim Prostatakarzinom}

S. Wach' , P. König' ${ }^{1}$, M. Eckstein², G. Serrero ${ }^{3}$, C. Geppert², R. Stöhr², A. Hartmann ${ }^{2}$, B. Wullich ${ }^{1}$, H. Taubert', V. Lieb ${ }^{1}$

'Urologische und Kinderurologische Klinik, Universitätsklinikum Erlangen, Erlangen, Deutschland; ${ }^{2}$ Pathologisches Institut, Universitätsklinikum Erlangen, Erlangen, Deutschland; ${ }^{3} \mathrm{~A} \& \mathrm{G}$ Pharmaceutical, Columbia, Vereinigte Staaten von Amerika

Einleitung: Spleißvarianten des Androgenrezeptors, insbesondere AR-V7, haben einen bedeutenden Einfluss auf die Tumorbiologie. Die klinische Anwendung ist aktuell fokussiert auf den Nachweis von AR-V7 mRNA oder Protein in zirkulierenden Tumorzellen. Die prognostische Aussagekraft von $A R$ und $A R-V 7$ in primärem Tumorgewebe ist hingegen noch nicht ausrteichend geklärt.

Patienten und Methoden: Wir verwendeten einen tissue microarray mit Gewebeproben von 410 radikalen Prostatektomiepräparaten aus dem Zeitraum von 1999-2010. Der immunhistochemische Nachweis erfolgte für AR (AR411, Dako) und für AR-V7 (AG10008, A\&G). Ein immunoreaktiver score (AR, AR-V7) sowie ein Prozentsatz positiver Tumorzellen (AR-V7 granulär) kam zum Einsatz.

Ergebnisse: Mehr als $80 \%$ der Gewebeproben zeigten einen positiven Nachweis von zytoplasmatischem AR-V7. Sowohl ein positiver Nachweis von AR als auch AR-V7 (IRS $>2$ ) in den Tumorzellen ist korreliert mit einem höherem Tumorstadium, einem höheren Gleason score und der Anwesenheit von Perineuralscheidenkarzinose. Die Färbemuster von AR waren ohne Assoziation zum Gesamtüberleben, dem tumorspezifischen Überleben oder dem rezidivfreien Überleben (RFS). AR-V7 hingegen zeigte eine Assoziation mit RFS. Hierbei erwies sich der AR-V7 Nachweis im Zytoplasma als negativer Prädiktor für das RFS, wohingegen ein vermehrtes Auftreten von AR-V7 in granulären Strukturen ( $\geq 5 \%$ der Tumorzellen) ein positiver Prädiktor für ein längeres RFS war.

Schlussfolgerung: Es besteht keine Assoziation zwischen AR-V7 im Primärtumor und dem Gesamtüberleben oder dem tumorspezifischen Überleben. Für das rezidivfreie Überleben erscheint die Lokalisation von AR-V7 relevant zu sein. AR-V7 im Zytoplasma ist assoziiert mit einem kürzeren, in granulären Strukturen mit einem längeren RFS. 


\section{V10.5}

Induzierte Kristallbildung im Urin als leicht zugänglicher Indikator für ossäre Metastasen, Tumorstadium oder paraneoplastische Hyperkalziämie? - Eine interdisziplinäre explorative Studie

\section{N. Laube ${ }^{1 *}$, F. Klein $^{2}$, C. Fisang ${ }^{3}$}

${ }^{1}$ Regen Lab SA, Le Mont-sur-Lausanne, Schweiz; ${ }^{2} \mathrm{FH}$ Aachen, Jülich, Deutschland; ${ }^{3}$ Marienhaus Kliniken GmbH, Krankenhaus Maria Hilf, Urologie, Bad Neuenahr-Ahrweiler, Deutschland

Fragestellung: Die Neoplasie-assoziierten Stoffwechselprodukte können im Urin Indikatoren für die Aktivität von Tumoren sein. Da diese Substanzen konzentrationsabhängig die Übersättigung des Urins verändern, beeinflussen sie die Bildung von Kristallen im Urin. Die BONN-Risk-Index (BRI)-Methode der induzierten Kristallisation von Ca-Oxalat (CaOx) in nativem Urin ist für die Überwachung des Urolithiasisrisikos etabliert. Prinzipiell kann der BRI Krankheiten detektieren, welche durch renale Ausscheidung spezifischer Substanzen die CaOx-Ausfällung systematisch beeinflussen. Diese explorative Studie untersucht das Potenzial dieses Ansatzes als neue Strategie für die Überwachung des Krankheitsverlaufs (uro-)onkologischer Erkrankungen durch Vergleich von BRI und Tumormarkerkonzentrationen und Bildgebung bei Krebspatienten.

Material und Methoden: BRI und Ca-Ausscheidung wurden routinemäBig aus Urinproben von Tagespatienten mit verschiedenen Primärtumoren bestimmt. 14 Patienten hatten Prostatakarzinome (PC), 29 Patienten neuroendokrine Tumore (NET). In jedem PC und in 13 NET wurden Knochenmetastasen nachgewiesen. Bei PC wurde die Serumaktivität der knochenspezifischen alkalischen Phosphatase (BSAP) analysiert.

Ergebnisse: Die BRI-Verteilung von NET ermöglicht es, die Patienten in drei Gruppen aufzuteilen; mit niedrigem $\left({ }^{*}\right)$, mittlerem und hohem BRI. Es ergibt sich eine Korrelation zwischen BRI und der Knochenmetastasenanzahl. Nur NET $\left.{ }^{*}\right)$ zeigt keine diffuse Knochenmetastasierung. In PC korrelieren $\log 2$ (BRI) und BSAP invers $(r=0,71)$.

Schlussfolgerungen: Die Ergebnisse zeigen vielversprechende Korrelationen zwischen dem BRI (Kalziumabhängigen Kristallisationspotential) und dem tumormarkerbasierten Krankheitsbild; weitere Studien mit angepassten Untersuchungsstrategien werden durchgeführt.

\section{V10.6}

Unterschiede in der prognostischen Bedeutung von Komorbidität und sozioökonomischen Parametern bei radikaler Prostatektomie und radikaler Zystektomie M. Fröhner ${ }^{*}$, R. Koch², U. Heberling ${ }^{3}$, A. Borkowetz ${ }^{4}$, M. Hübler ${ }^{5}$, V. Novotny ${ }^{6}$,
M. Wirth ${ }^{2}$, C. Thomas

'Zeisigwaldkliniken Bethanien, Klinik für Urologie, Chemnitz, Deutschland; ${ }^{2}$ Technische Universität Dresden, Klinik für Urologie, Dresden, Deutschland; ${ }^{3}$ Zeisigwaldkliniken Bethanien, MVZ Mittweida, Chemnitz, Deutschland; ${ }^{4}$ Technische Universität Dresden, Dresden, Deutschland; ${ }^{5}$ St. Joseph Stift Dresden, Anesthesiologie, Dresden, Deutschland; ${ }^{6}$ Städtisches Klinikum Görlitz, Görlitz, Deutschland

Einleitung: Ziel war der Vergleich der prognostischen Bedeutung von Prädiktoren der konkurrierenden Sterblichkeit nach radikaler Prostatektomie (RPE) und radikaler Zystektomie (RCX).

Material und Methoden: Verglichen wurden konsekutive Patienten, die sich einer RPE (1992-2016, $n=6809)$ oder einer RCX (1993-2018, $n=1419$ ) unterzogen. Mittels proportionalen Hazard-Modellen für konkurrierende Risiken wurde der Zusammenhang zwischen Operation, Alter, Komorbidität, Body-Mass-Index, sozioökonomischen Parametern, OP-Jahr und der konkurrierenden Mortalität untersucht.

Ergebnisse: Während bei gemeinsamer Analyse alle untersuchten Parameter (Alter, Charlson-Score, ASA-Klasse, Body-Mass-Index, OP-Jahr, Raucherstatus, Familienstand, Bildungsabschluß) mit Ausnahme der Art der Operation (RCX versus RPE: Hazard-Ratio, HR, 0,897, $95 \%$-Konfidenzin- tervall, Kl, 0,761-1,058, $p=0,20$ ) signifikante Prädiktoren der konkurrierenden Sterblichkeit waren, erreichte bei den RCX-PatientInnen allein nur Alter, Charlson-Score, OP-Jahr und Raucherstatus das Signifikanzniveau, während bei den RPE-Patienten nur der Familienstand (verheiratet versus nicht, HR 0,817, 95 \%-KI 0,660-1,012, $p=0,06$ ) dieses knapp verfehlte. Ein auf den genannten Variablen basierender Score war hinsichtlich der Vorhersage der 10-Jahres-Sterblichkeit bei den RPE-Patienten dem altersadjustierten Charlson-Score überlegen (Area under the ROC curve, AUC, 0,68 versus $0,64, p<0,0001$ ), nicht jedoch bei den RCX-PatientInnen (AUC 0,67 versus $0,68, p=0,35$ ).

Schlussfolgerung: Zur Vorhersage der konkurrierenden Mortalität unterscheidet sich die prognostische Bedeutung die untersuchten Parameter nach RPE und RCX, während die Art der Operation nach Korrektur der Risikofaktoren nur eine marginale Rolle spielt.

\section{V10.7}

\section{The effect of primary urological cancers on survival in men with secondary prostate cancer}

\section{Wenzel ${ }^{1 *}$, C. Würnschimmel' ${ }^{2}$, B. Hoeh', D. Tilki', M. Graefen'2, F. Roos',} P. Mandel', A. Becker', L. Kluth', F. Chun', P. Karakiewicz ${ }^{3}$

'Department of Urology, University Hospital Frankfurt, Frankfurt, Germany; ${ }^{2}$ MartiniKlinik Prostate Cancer Center, University Hospital Hamburg-Eppendorf, Hamburg, Germany; ${ }^{3}$ Cancer Prognostics and Health Outcomes Unit, Division of Urology, University of Montréal Health Center, Montreal, Canada

Background: To test the effect of urological primary cancers (bladder, kidney, testis, upper tract, penile, urethral) on overall mortality (OM) after secondary prostate cancer (PCa).

Material and methods: Within the Surveillance, Epidemiology and End Results (SEER) database, patients with urological primary cancers and concomitant secondary PCa (diagnosed 2004-2016) were identified and were matched in 1:4 fashion with primary PCa controls. OM was compared between secondary and primary PCa patients and stratified according to primary urological cancer type, as well as to time interval between primary urological cancer vs. secondary PCa diagnoses.

Results: We identified 5987 patients with primary urological and secondary PCa (bladder, $n=3287$; kidney, $n=2127$; testis, $n=391$; upper tract, $n=125$; penile, $n=47$; urethral, $n=10$ ) vs. 531,732 primary PCa patients. Except for small proportions of Gleason grade group and age at diagnosis, PCa characteristics between secondary and primary PCa were comparable. Conversely, proportions of secondary PCa patients which received radical prostatectomy were smaller ( 29.0 vs. $33.5 \%)$, while no local treatment rates were higher (34.2 vs. $26.3 \%$ ). After 1:4 matching, secondary PCa patients exhibited worse OM than primary PCa patients, except for primary testis cancer. Here, no OM differences were recorded. Finally, subgroup analyses showed that the survival disadvantage of secondary PCa patients decreased with longer time interval since primary cancer diagnosis.

Conclusion: After detailed matching for PCa characteristics, secondary PCa patients exhibit worse survival, except for testis cancer patients. The survival disadvantage is attenuated, when secondary PCa diagnosis is made after longer time interval, since primary urological cancer diagnosis.

\section{V10.8}

Head-to-head comparison of Proclarix and Prostate Health Index to predict any and significant prostate cancer on biopsy

\author{
T. Steuber ${ }^{1 *}$, A. Haese ${ }^{1}$, P. Tennstedt ${ }^{1}$, A. Athanasiou ${ }^{2}$, R. Schiess ${ }^{2}$ \\ 'Universitätsklinikum Hamburg-Eppendorf, Martini-Klinik, Hamburg, Germany; ${ }^{2}$ Proteo- \\ medix AG, Zürich-Schlieren, Switzerland
}

Background: Proclarix ${ }^{\circledast}$ is based on novel biomarkers, PSA and age. An algorithm returns a risk score to identify clinically significant prostate can- 
cer (csPCa GG $\geq 2$ ). Prostate Health Index (phi) is a formula that provides a probability of prostate cancer (PCa), combining PSA, free PSA, p2PSA. We performed a head-to-head comparison of Proclarix versus phi to predict any and significant $\mathrm{PCa}$ on biopsy.

Methods: We evaluated Proclarix and phi performance in 185 patients undergoing TRUS-guided prostate biopsy. Among those, 90 men with $\mathrm{PCa}$ on biopsy underwent radical prostatectomy ( $\mathrm{rP})$. All men had a PSA 2-10 ng/mL, normal DRE and an enlarged prostate ( $\geq 35 \mathrm{~mL}$ ). Comparison of AUC and performance at predefined cut-offs was performed to predict $\mathrm{PCa}$ and csPCa.

Results: Proclarix was more accurate than phi for predicting PCa (AUC 0.79 vs $0.62, p<0.01$ ) and csPCa (AUC 0.73 vs $0.66, p=0.31$ ) based on TRUS-biopsy. Taking Gleason GG derived from rP from biopsy positive men into account, Proclarix was significantly more accurate than phi for predicting PCa (AUC 0.79 vs $0.61, p<0.01$ ) and csPCa (AUC 0.81 vs $0.63, p<0.01$ ). At predefined cut-offs, Proclarix outperformed phi with specificity and positive predictive value $(p<0.01)$, which results in avoiding a higher number of unneeded biopsies. On decision curve analysis the highest net benefit was observed with Proclarix.

Conclusions: Proclarix outperformed phi in terms of AUC, specificity and clinical net benefit. Limitations of the study include the retrospective design, the use of biobanked samples and the exclusion of men with small prostate volume, which may negatively impact the analytical validity of PSA und PSA derived subfractions included in phi. Prospective studies are warranted to substantiate our findings.

Funding: Sponsored by Proteomedix

\section{V10.9}

Identifikation pathogener Mutationen durch die mpMRT beim lokalisierten Hoch-Risiko Prostatakarzinom

\author{
A. Borkowetz ${ }^{1 *}$, U. Sommer ${ }^{2}$, F. Fahlteich ${ }^{2}$, S. Zeugner' ${ }^{2}$, I. Platzek ${ }^{3}$, S. Füssel', \\ K. Erdmann' ${ }^{1}$, T. Todenhöfer ${ }^{4}$, H. Erb' ${ }^{1}$, C. Thomas'
}

'Technische Universität Dresden, Urologie, Dresden, Deutschland; ${ }^{2}$ Technische Universität Dresden, Pathologie, Dresden, Deutschland; ${ }^{3}$ Technische Universität Dresden, Radiologie, Dresden, Deutschland; ${ }^{4}$ Studienpraxis Urologie, Nürtingen, Deutschland

Fragestellung: Spezifische Alterationen in tumor-assoziierten Genen sind mit der Aggressivität und der Prognose beim Prostatakarzinom (PCa) assoziiert. Es sollen Gensignaturen, die das Progressionsrisiko beim lokalbegrenzten Hoch-Risiko PCa (hr-PCa) hervorsagen können, identifiziert und mit der multiparametrischen MRT (mpMRT) verglichen werden.

Material und Methoden: 17 Patienten mit hr-PCa $(\geq \mathrm{pT} 3, \geq \mathrm{pN} 1$, Gleason Score (GS) $\geq 8$ ), die mit einer Prostatektomie (RP) behandelt wurden, wurden untersucht. RP-Präparate wurden direkt mit der mpMRT verglichen, wobei der Index-Tumor (Tumor mit dem höchsten GS oder größter Durchmesser) und Index-Läsion (Läsion mit dem höchsten PI-RADS oder größten Durchmesser) identifiziert wurden. Mittels eines Genpanels, welches 328 Gene inkludiert (QIAseq Targeted DNA V3 Panel, Qiagen), erfolgten gezielte DNA-Sequenzierungen. Die Varianten-Evaluierung erfolgte mittels Varsome.

Ergebnisse: Tumor-assoziierte Mutationen wurden in 32 unterschiedlichen Genen bei $88 \%$ der Patienten identifiziert. 16 pathogene Mutationen (37 Allele), 14 Mutationen unsicherer Signifikanz (24 Allele) und 6 wahrscheinlich benigne Mutationen (7 Allele) wurden identifiziert. $54 \%$, $77 \%$ bzw. $23 \%$ der pathogenen Mutationen waren mit einem GS $\geq 8$, einer PI-RADS 4 bzw. 5 Läsion assoziiert.

Neben Mutationen in BRCA2, PTEN oder CK12 wurden auch weniger bekannte Mutationen beim PCa wie IDH1 oderNTRK3 nachgewiesen. Patienten mit Nachweis mehrerer pathogener Mutationen $(\geq 1)$ zeigten ein tendenziell kürzeres Rezidiv-freies Überleben (75Mo (95\%-KI 64-84 Mo) vs. 49Mo (95\%-KI 31-67Mo); $p=0,172)$ ).

Schlussfolgerung: Die frühe Identifikation pathogener Mutationen in aggressiven PCa ist ein Marker für die Prognose. Über die mpMRT können Regionen, die diese pathogenen Mutationen aufweisen, identifiziert werden.

\section{V11 - Operative Therapie der Inkontinenz/ Neurourologie}

\author{
17.09.2021, C7.2, 08:15-09:45
}

V11.1

OnabotulinumtoxinA Detrusorinjektionen: trotz
höherer Schmerzbelastung wird die Durchführung in
Lokalanästhesie der in Vollnarkose bevorzugt

H. Schulte-Baukloh ${ }^{1 * 2, \text { D. Höppner }}{ }^{1}$, C. Waskow' ${ }^{1}$, K. Mala $^{2}$, T. Schlomm², S. Weinberger ${ }^{2}$

'Urologische Gemeinschaftspraxis Turmstraße, Berlin, Deutschland; ${ }^{2}$ Charité Universitätsmedizin Berlin, Klinik für Urologie, Berlin, Deutschland

Einleitung: Gibt es Unterschiede im Schmerzscore und in der Bevorzugung der OnabotulinumtoxinA Detrusorinjektion bei Anwendung unter Lokalanästhesie (LA) vs Vollnarkose (VN)?

Material und Methoden: PatientInnen, die zu einer OnabotA-DI anstanden, entschieden selbst das Anästhesieverfahren. Zur Evaluation der Unterschiede bzgl. anästhesiologischem Vorgehen und Ergebnissen der Therapie kamen zur Anwendung: der Amsterdam Preoperative Anxiety and Information Scale (APAIS), ein Schmerzscore, der UDI-6, der IIQ-7, der Symptom Severity Index SSI, der Symptom Impact Index SII sowie ein postoperativer Zufriedenheitsfragebogen.

Ergebnisse: 50 PatientInnen (46w, 4 m; Alter $\varnothing 64$ (34-80) Median 66,5 Jahre) konnten ausgewertet werden. Die OnabotA-DI wurde bei 36 PatientInnen in LA und bei 14 in VN durchgeführt. Jeweils Vergleich der LA- mit der VN Gruppe: Der präoperative Angstscore (APAIS) wies keine signifikanten Unterschiede aus (5,91 vs. 5,07, $p=0,383)$. Indes zeigte sich im Schmerzscore während des Eingriffs ein signifikanter Unterschied: 3,55 vs. $1,08, P<0,001)$. Die Inkontinenzfragebögen 4 Wochen nach dem Eingriff zeigten alle hochsignifikante $(p<0,001)$ Verbesserungen, jedoch ohne signifikante Unterschiede zwischen den beiden Gruppen. 80,0\% vs. 92,3\% $(p=1,00)$ der PatientInnen gaben an, dass sie sich erneut für diese Therapie ihrer Blasenfunktionsstörungen entscheiden würden. Von Patientlnnen, die angaben, den Eingriff in der Vergangenheit mit beiden Anästhesieverfahren durchgeführt haben zu lassen, gaben 17 an, die LA der VN vorzuziehen, 6 würden hingegen der VN vor der LA den Vorzug geben.

Schlussfolgerung: Die Therapiequalität der OnabotA-DI scheint unabhängig vom Anästhesieverfahren zu sein. Trotz höherer Schmerzbelastung wird der LA der VN der Vorzug gegeben.

\section{V11.2}

The effect of sacral neuromodulation (SNM) on nocturia in patients with overactive bladder syndrome (OAB)

P. Daemi Attaran 1* J. Janssen², G. van Koeveringe², D. Vrijens², J. Heesakkers', T. A. Vögeli', M. S. Rahnama'i ${ }^{4}$

'Sana Kliniken Duisburg, Duisburg, Germany; ${ }^{2}$ Maastricht University Medical Centre, Maastricht, The Netherlands; ${ }^{3}$ Radboud University Medical Centre Nijmegen, Nijmegen The Netherlands; ${ }^{4}$ Uniklinik RWTH Aachen, Aachen, Germany

Introduction: Sacral neuromodulation (SNM) is often applied for Patients with idiopathic overactive bladder $(\mathrm{OAB})$, refractory to conservative treatment. The effect of SNM on nocturia is unknown. The aim of our Multicenter study was to study the effect of SNM on nocturia episodes retrospectively.

Materials and methods: Sensation-related bladder diaries (SR-BDs) were assessed in all our patients who underwent SNM for idiopathic OAB between January 2014 and July 2020. SNM was performed following a two-phased tined lead procedure under local or general anesthesia. The SR-BDs were collected prospectively. Patients filled out a SR-BD, for 3 con- 
secutive days at baseline and after 2 weeks, during a 4-week test phase. Bedtime and times of voiding, as well as intake and output were noted. Results: A total of 84 (males and females) patients with $O A B$, with and without incontinence ( 95 and $5 \%$ respectively), were included. 5340 voids were analyzed. 61 patients had a successful test phase $(>50 \%$ reduction of OAB symptoms). In patients with a successful test phase $(\mathrm{T}+)$, the number of nocturia episodes changed significantly from $3.03( \pm 2.4)$ to $1.55( \pm 1.4)$ $P=0.000$. Also, the mean volume voided at night was significantly fewer $(P=0.000)$. The total number of voids frequency over 3 days was significantly reduced between baseline and during the test-phase $(12+/-5$ vs $9+/-3, P=0.000$ ). There was no significant difference in fluid in intake prior versus during SNM test phase. There was no significant decrease in nocturia episodes in patients with a negative tined lead test, $2.8 .1 \pm 1.2 \mathrm{vs}$ $2.7 \pm 1.5 P=0.109$. ( $<50 \%$ reduction in OAB symptoms).

Conclusion: Our results show that SNM significantly modifies nocturia in patients with $O A B$, during a successful test phase.

\section{V11.3}

Der paraurethrale zystische Befund bei der Frau: Ergebnisse der operativen Therapie im eigenen Krankengut

\author{
A. Katzenwadel ${ }^{*}$, C. Fahr, M. Grabbert, C. Gratzke \\ Urologie/Universitätsklinikum Freiburg, Freiburg, Deutschland
}

Ziel: Paraurethrale zystische Befunde bei Patientinnen sind in der urologischen Praxis ein eher seltenes Krankheitsbild. Symptome wie Miktionsbeschwerden oder Fremdkörpergefühl können zur primären Vorstellung beim Urologen führen. In einer retrospektiven Studie sollen die Untersuchungs- und operativen Behandlungsergebnisse am eigenen Krankengut dargestellt werden.

Patienten und Methode: Von 5/2000 bis $2 / 2021$ wurden 39 Patientinnen wegen einer paraurethralen zystischen Raumforderung operativ therapiert. An diagnostischen Maßnahmen kamen die transvesicale Sonographie, die vaginale oder Introitus-Sonographie, die Urethrozystoskopie und in manchen Fällen die MRT-Schnittbildgebung zur Anwendung. Die operative Therapie erfolgte in allen Fällen über einen transvaginalen $\mathrm{Zu}$ gang.

Ergebnisse: Das Alter der Patientinnen betrug im Mittel 36 Jahre (16-78 J). Bis auf 5 Fälle war bei lokaler Beteiligung der Urethra eine Eröffnung der Urethra und Versorgung mit Naht notwendig. In 2 Fällen wurde bei sehr distaler Lokalisation eine Rekonstruktion des Ostium externum urethrae erforderlich. Bei 30 Patientinnen (77\%) ließ sich intraoperativ eine Divertikelgangverbindung zur Urethra und somit ein Urethradivertikel nachweisen. Histopathologisch wurden plattenepitheliale Anteile in 30 (77\%), urotheliale Anteile in 27 (69\%) Fällen nachgewiesen. Es traten keine intra-/perioperativen Komplikationen sowie keine de-novo-Harninkontinenz auf. In keinem Fall war eine Rezidivoperation erforderlich.

Schlussfolgerung: Am häufigsten liegt ein Harnröhrendivertikel als Ursache für einen zystischen Befund an der Vaginalvorderwand vor. Die operative transvaginale Behandlung durch den Urologen ist eine sichere und sehr effektive Maßnahme.

\section{V11.4}

The role of partially absorbable midurethral slings for the treatment of stress urinary incontinence in a realworld study

T. Hüsch ${ }^{1 *}$, C. Fünfgeld ${ }^{2}$, N. Ng-Stollmann ${ }^{2}$

'Universitätsmedizin der Johannes Gutenberg-Universität Mainz, Mainz, Germany; ${ }^{2}$ Klinikum Tettnang GmbH, Tettnang, Germany
Introduction: To evaluate the performance of retropubic midurethral sling procedure for female stress urinary incontinence (SUI) in a real-world setting and to identify risk factors for sling failure in this cohort.

Methods: This was a single center cohort study including women who underwent retropubic midurethral sling procedure for stress or mixed urinary incontinence between 2012 and 2019 with a follow-up of 12 months. Primary endpoint was cure of SUI assessed by the severity categorization of the International Consultation of Incontinence Questionnaire-Urinary Incontinence-Short Form (ICIQ-UI-SF). Univariate and multivariate analysis was applied to identify risk factors for failure. Wilcoxon signed-rank tests were used as paired samples tests. The significance level was set at $5 \%$.

Results: A total of 662 women with a median age of 65 (IQR 19) were included in the investigation. $79.0 \%$ presented with complicated SUI. Cure was reported by $32.2 \%$ and cure or improvement (COI) by $76.3 \%$ of patients. Independent predictors for decreased odds for cure or $\mathrm{COI}$ were obesity, pharmacotherapy for overactive bladder (OAB), postoperative sling tailing and the utilization of partially absorbable mesh. The utilization of partially absorbable mesh was correlated with a $56 \%$ and $46 \%$ decrease in the odds for achieving cure or COI respectively.

Conclusions: The current investigation emphasizes the impact of the patient heterogeneity on the success of midurethral sling procedure in clinical daily practice. Furthermore, amongst several risk factors for failure, partially absorbable mesh and the pharmacotherapy of OAB were associated with decreased success rates. The role of partially absorbable mesh for SUI treatment should be evaluated in further prospective trials.

\section{V11.5}

Biofeedback mittels Videocontrolling verbessert die Ergebnisse des Beckenbodentrainings bei Patienten nach radikaler Prostatektomie: eine randomisierte Pilotstudie

\author{
M. Kässer1 , K.-D. Sievert'², A. Stenzl ${ }^{3}$, B. Amend ${ }^{3 *}$
}

'Universitätsklinikum Tübingen, TherapieZentrum, Tübingen, Deutschland; ${ }^{2}$ Klinikum Lippe, Klinik für Urologie, Detmold, Deutschland; ${ }^{3}$ Universitätsklinikum Tübingen, Klinik für Urologie, Tübingen, Deutschland

Einleitung: Harninkontinenz ist eine relevante Komplikation nach Prostatektomie, die die Lebensqualität einschränkt. Beckenbodentraining (BBT) wird zur postoperativen Rehabilitation empfohlen. Hierbei ist BBT mit professioneller Anleitung dem selbständigen BBT überlegen. Leitlinien empfehlen konventionelles Biofeedback, das nur bei Patienten mit guter Compliance hilfreich ist. Diese randomisierte Pilotstudie untersucht Auswirkungen eines videokontrollierten BBT (vBT) durch Visualisierung des Perineums mit Anleitung zur Wiedererlangung der Kontinenz nach retropubischer radikaler Prostatektomie (RRP) gegenüber konventionellem $\mathrm{BBT}(\mathrm{kBT})$.

Material und Methoden: Die Studie wurde von der Ethikkommission genehmigt und mit 50 Pat. in 1:1-Random. geplant. Nur Pat. nach nervschonender RRP wurden eingeschlossen. Alle Pat. erhielten Anleitung für bis zu 26 Wo. Kontinenz wurde anhand eines 24-h-Pad-Tests bestimmt. Erfolg wurde definiert mit weniger als $5 \mathrm{~g}$ Verlust/24 $\mathrm{h}$ und dem präoperativen Blasenvolumen (oder $500 \mathrm{ml}$ ). Primärer Endpunkt war die Zeit bis zur Wiederherstellung der Kontinenz. Die Daten wurden mittels Log-Rank-Test analysiert.

Ergebnisse: 23 Pat. wurden rekrutiert (12 vBT, 11 kBT). Es gab keine Nebenwirkungen durch das BBT und keinen signifikanten Unterschied der Komplikationen nach RRP. Nach 26 Wo. zeigte nur die Gruppe mit vBT bei allen Probanden gemäß Protokoll eine Wiedererlangung der Kontinenz. Pat. mit kBT erholten sich ebenfalls von der Inkontinenz, allerdings war hierfür mehr Zeit erforderlich $(p=0,005)$.

Schlussfolgerungen: Unsere Pilotstudie zeigt die Wirksamkeit von Videocontrolling um die Zeit bis zur Kontinenz nach RRP im Vergleich zu kBT zu 
verkürzen. Die Rekrutierung war trotz der Chancen erschwert. Die Ergebnisse ermutigen zur Durchführung einer Folgestudie.

\section{V11.6 \\ Der adjustierbare artifizielle Sphinkter VICTO: Ergebnisse nach 104 Implantationen}

G. Ameli", P. Weibl, J. Vendl, M. Rutkowski, W. A. Hübner

Landeskliniken Korneuburg, Urologie, Korneuburg, Österreich

Hintergrund: Diese Arbeit dient der Evaluierung der Ergebnisse des VICTO Systems nach 104 Implantationen.

Methode: Zwischen 12/16 und 12/20 wurde bei 104 Patienten mit einer Stressinkontinenz die Indikation für ein VICTO-System gestellt. Wir konnten die Daten von insgesamt 96 Pat. einem medianen Follow-up (FU) von $24,3 \mathrm{Mo}$ (Intervall 0,7-48) einschließen. Patienten mit $\geq 3$ vorangegangenen Inkontinenz-Operationen wurden ausgeschlossen $(n=8)$. Postoperativ wurde ein standardisiertes $24-S t u n d e n-P a d t e s t ~(p / d)$ durchgeführt, Patienten mit $\leq 1 \mathrm{p} / \mathrm{d}$ wurden dabei als „,socially dry" bewertet.

Ergebnisse: Nach einem medianen FU von 24 Mo $(n=88)$, reduzierte sich der p/d von $6( \pm 3,1)$ auf $1,2( \pm 1,1)$ und es waren durchschnittlich $1,7(\mathrm{IQR}=1,8)$ Adjustierungen für ein suffizientes Ergebnis notwendig. 65 (74\%) Patienten waren „socially dry“, zusätzlich berichteten $13,6 \%$, über eine Reduktion des $\mathrm{p} / \mathrm{d}$ um $>50 \%$. In der Subgruppenanalyse zeigten Patienten mit vorangegangener Radiotherapie $(n=36)$ oder Inkontinenzchirurgie $(n=25)$ keinen signifikanten Unterschied bzgl. postoperativer Kontinenz zu Indexpatienten $(p=0,23)$. Insgesamt wurden 10 Optimierungseingriffe durchgeführt (kleinere Manschette, Pumpenreposition). Eine Explantation des Systems aufgrund von Arrosion, Infektion oder persistierende Inkontinenz war in 7 Fällen notwendig. In einem Fall sind die blanden Systemkomponenten im Rahmen der Conduitanlage explantiert wurden.

Conclusio: In unserem Patientenkollektiv hat sich die Kontinenz bei $88 \%$ der Patienten um $\geq 50 \%$ verbessert und die Zufriedenheitsrate lag bei $87 \%$. Diese vielversprechende Ergebnisse müssen in zukünftigen Studien mit Langzeit-follow-ups belegt werden.

\section{V11.7}

Langzeitergebnisse des adjustierbaren suburethralen Schlingensystems Argus ${ }^{\circledast}$, mit einem durchschnittlichem Beobachtungszeitraum von 10 Jahren

G. Ameli", P. Weibl, L. Prüger, J. Vendl, M. Rutkowski, W. A. Hübner

Landeskliniken Korneuburg, Urologie, Korneuburg, Österreich

Hintergrund: Die adjustierbare Argus-Schlinge bietet eine gute Therapieoption zur Behandlung der männlichen Belastungsinkontinenz (SUI).

Methode: Zwischen 3/2005-9/2020 wurde bei insgesamt 122 Patienten mit einer mittelgradigen/schwereren SUI, die Indikation für einer Argus-Schlinge gestellt. 25 Pat. hatten eine vorangegangene Radiotherapie (21\%), bei $24(20 \%)$ war eine und bei $20(16 \%)$ mehr als eine Operation zur Therapie der Inkontinenz durchgeführt worden. Präoperative Daten umfassten Harnkultur, Zystoskopie und Anzahl der Vorlagen in $24 \mathrm{~h}(\mathrm{p} / \mathrm{d})$. Postoperativ sind Restharnvolumen, VAS-Schmerzskala und $\mathrm{p} / \mathrm{d}$ sowie $\mathrm{Pa}-$ tientenzufriedenheit erfasst worden. Kontinenz ist als „,socialy dry“ mit $\leq 1$ $\mathrm{p} / \mathrm{d}$ definiert worden.

Resultate: Insgesamt sind 115 Pat. in einem durchschnittlichen Beobachtungszeitraum (FU) von 95 ( \pm 60 ) Mo eingeschlossen worden. 75(65\%) der Pat. benötigten $\leq 1 \mathrm{p} / \mathrm{d}$, weitere $11 \%$ gaben eine Reduktion von $>50 \%$ der $\mathrm{p} / \mathrm{d}$ an. Adjustierungen waren in 53 Fällen notwendig und die Zufriedenheitsrate lag bei $96 \%$. Insgesamt sind 12 intraoperative Blasenperforationen aufgezeichnet worden, in allen Fällen wurde die Operation nach Reposition der Nadel vollendet und der transurethrale Katheter für 5 Tage in situ belassen. Komplikationen umfassten Hämatome $(n=12)$, transien- te perineale oder skrotale Schmerzen $(n=11)$. Nach einer medianen FU von 40,7 Mo sind 39 Explantationen aufgezeichnet worden - meist aufgrund von persistierender Harninkontinenz $(n=16)$ oder Harnröhrenarrosion $(n=10)$. Insgesamt erhielten 33 dieser Patienten im Intervall eine erfolgreiche Inkontinenztherapie (30 artifizielle Sphinkter, 3 Argus Reimplantation).

Conclusio: Das Argus-Schlingensystem ist eine effektive Behandlungsmethode, mit guten Langzeitergebnissen in Behandlung der männlichen Belastungsinkontinenz.

\section{V11.8}

\section{WaterJet: A novel needle-free injection technique for} cell therapy of stress urinary incontinence

R. Geng ${ }^{1}{ }^{*}$, J. Knoll' ${ }^{1}$, N. Harland ${ }^{1}$, T. Abruzzese ${ }^{1}$, A. Stenzl' ${ }^{1}$, W. Linzenbold ${ }^{2}$, M. Enderle ${ }^{2}$, W. K. Aicher ${ }^{1}$

'Eberhard Karls University of Tübingen, Klinik für Urologie, Tübingen, Germany; ${ }^{2}$ Erbe Medizintechnik GmbH, Tübingen, Germany

Introduction: Cell based therapies are a promising tool for the treatment of Stress urinary incontinence (SUI). Cell injection by needle may cause misplacement of cells. Therefore, a novel WaterJet (WJ) technology was developed to deliver cells precisely into the urethral sphincter.

Methods: Porcine muscle-derived cells (pMDC) were expanded and characterized by expression of marker genes, labeled and injected by William's needle (WN) or WJ (Erbe) in porcine urethral cadaveric samples (CS) $(n \geq 24)$ and in living animals $(\mathrm{LA})(n=24)$. From CS, cells were retrieved and expanded in vitro. The distribution of cells in tissues targeted including their distributions in X-depth, Y-width, Z-height (3D) and areas of cell clusters were analyzed.

Results: The pMDC expressed specific markers on transcript and protein levels. Upon CS, viable cells were retrieved in all samples investigated injection by WJ $(n=8)$ and by WN $(n=5)$. Due to channels generated by the $\mathrm{WN}$, the distribution of cells was significantly higher in the Z-axis $(p<0.002)$ when compared to WJ injections. After transurethral WJ injection of cells in pigs, in $95.83 \%$ of injections labelled, intact appearing cells were detected. There was a significant difference for the X-depth $(p<0.0001)$ and Z-height $(p<0.0002)$ between WJ injections in CS vs. LA with a wider MDCs distribution in LA urethra samples.

Conclusion: In vitro tests confirmed that WN injection punched visible channel in the tissue while WJ injections resulted in no visible tissue defects in cryosections. The novel WJ is a way to inject living cells in tissues with wider and diffuse distribution and less disintegration of the tissue targeted.

Supported by grants from BMBF, DFG, EU 


\section{V11.9}

Intermittierender Selbstkatheterismus bei Personen mit Querschnittlähmung - Gold-Standard für alle? - Eine retrospektive Kohortenstudie

\author{
J. Wöllner ${ }^{1 *}$, J. Krebs'², F. Rademacher ${ }^{1}$, J. Pannek ${ }^{1}$ \\ 'Schweizer Paraplegiker Zentrum, Neuro-Urologie, Nottwil, Schweiz; ${ }^{2}$ Schweizer Paraple- \\ giker Zentrum, Clinical Trial Unit, Nottwil, Schweiz
}

Fragestellung: Gemäss Leitlinien soll die Blase von Personen mit einer akuten Querschnittlähmung in der Primärrehabilitation möglichst frühzeitig durch intermittierendes Katheterisieren (IK) entleert werden. Wie wird diese Leitlinie in der klinischen Realität umgesetzt?

Material und Methoden: Im klinischen Informationssystem des Schweizer Paraplegiker-Zentrums Nottwil wurden alle Personen identifiziert, welche zwischen Januar 2015 und Dezember 2017 eine Primärrehabilitation wegen einer Querschnittlähmung absolviert hatten. Es wurden Daten zur Person, Querschnittlähmung und zum Blasenmanagement gesammelt. Ergebnisse: Die Daten von 255 Männern (74,3\%) und 88 Frauen $(25,7 \%)$ mit einem Durchschnittsalter von $54 \pm 19$ Jahren wurden analysiert. Die Dauer der Rehabilitation betrug durchschnittlich 5,8 $\pm 2,8$ Monate. $\mathrm{Zu}$ Beginn der Primärrehabilitation waren die meisten Patienten $(58,0 \%$, 199/343) mit einem transurethralen (TUK) oder suprapubischen (SPK) Dauerkatheter versorgt, und nur 14,3\% (49/343) entleerten die Blase mittels IK. Das Blasenmanagement veränderte sich während der Rehabilitation, und bei Entlassung verwendeten die meisten Patienten eine Reflexentleerung (48,4\%, 166/343); 28,8\% (99/343) der Patienten entleerten die Blase mittels IK. Knapp $20 \%$ (66/343) waren mit einem SPK versorgt. Ältere Patienten ( $\geq 60$ Jahre) wurden im Vergleich zu jüngeren häufiger $(p<0,002)$ mit einem SPK oder TUK entlassen. Unzureichende Handfunktion war der häufigste Grund, weshalb IK nicht möglich war.

Schlussfolgerungen: Nur ca. $30 \%$ der Patienten entleerten nach der Erstrehabilitation die Blase mittels IK. Das Ziel eines ganzheitlichen Blasenmanagements ist die Erhaltung der Nierenfunktion und der Lebensqualität, und somit sind verschiedene Faktoren relevant für die Wahl des Blasenmanagements.

\section{V12 - Hodentumoren - Fortgeschrittene Tumoren und Platinresistenz}

$$
\text { 17.09.2021, C4.2, 08:15-09:45 }
$$

\section{V12.2}

\section{Discordant histology of abdominal and thoracic post chemotherapy residual tumor resection in patients with metastatic germ cell tumor}

C. Buddensieck ${ }^{1 *}$, V. Besser ${ }^{1}$, Y. Che' ${ }^{1}$, P. Albers' ${ }^{1}$, J. Schirren$^{2}$, S. Sponholz ${ }^{2}$, M. Schirren², A. M. Schauer ${ }^{3}$, W.T. Knoefel ${ }^{3}$, A. Hiester ${ }^{1}$

'Department of Urology, University of Duesseldorf, Medical Faculty, Heinrich-HeineUniversity, Düsseldorf, Germany; ${ }^{2}$ Department of Thoracic Surgery, Agaplesion Markus Hospital Frankfurt, Frankfurt am Main, Germany; ${ }^{3}$ Division of Thoracic Surgery, Department of General and Visceral Surgery, University of Duesseldorf, Medical Faculty, Heinrich-Heine-University, Düsseldorf, Germany

Objectives: Post chemotherapy residual tumor resection (PC-RTR) is a crucial part of treatment in patients (pts) with metastatic non-seminomatous germ cell tumor (NSGCT). In case of retroperitoneal and thoracic metastases, multiple surgeries are necessary. This study compares histologies after abdominal and thoracic PC-RTR in order to predict thoracic histology. Material and methods: From 2008 to 2020, 537 retroperitoneal RTRs have been performed at a single center. We identified 54 pts who had under- gone retroperitoneal and thoracic PC-RTR after first line or salvage chemotherapy (CTx).

Results: All pts presented with stage III NSGCT. 42 (78\%) and 12 (22\%) pts had first line and salvage CTx, respectively. Pts were classified as good, intermediate and poor prognosis according to IGCCCG in $17 \%, 22 \%$, and $61 \% .49$ (91\%) pts received retroperitoneal RTR first, followed by thoracic RTR. 3 (5\%) pts had thoracic before retroperitoneal RTR and 2 (4\%) pts underwent simultaneous surgery.

Overall, histology of retroperitoneal and thoracic RTR matched in 35 (65\%) pts. In 19 (35\%) pts histology was discordant.

Discordant histologies showed retroperitoneal necrosis in 7 (37\%), teratoma in $9(47 \%)$ and vital tumor other than teratoma in $3(16 \%)$ pts. Of 21 pts with retroperitoneal necrosis 7 (33\%) showed vital cancer or teratoma in the thorax.

After first line CTx discordance of histology was $29 \%$ (12/42), after salvage CTx 58\% (7/12) (not significant, $p=0.087$ ).

Conclusion: This data underlines that sequential PC-RTR in all locations is mandatory, since discordance of histology is up to $35 \%$. Comparing findings after first line and salvage CTx, discordance increase from 29 to $58 \%$. Thus, thoracic surgery should be performed in all pts after salvage CTx independent on tumor volume.

\section{V12.3}

Post-chemotherapy residual tumor resection in patients with elevated tumor markers

\author{
Y. Che ${ }^{1 *}$, P. Albers' ${ }^{1}$ C. Winter', R. große Siemer' ${ }^{2}$, A. Hiester ${ }^{1}$ \\ 'Uni Düsseldorf, Düsseldorf, Germany; ${ }^{2}$ Helios Universitätsklinikum Wuppertal, Wupper- \\ tal, Germany
}

Objectives: The benefit of post-chemotherapy residual tumor resection (PC-RTR) in patients with germ cell tumors and elevated serum tumor markers (STM) remains undefined. This retrospective analysis aims to define patients who benefit from surgery in this setting.

Patients and methods: Of 575 PC-RTR (07/2008-07/2019) 153 were performed in patients with elevated STM (B-HCG $>2 \mathrm{mlU} / \mathrm{ml}$, AFP $>7 \mu \mathrm{g} / \mathrm{l}$ ), 55 patients after first- and 98 after salvage chemotherapy. Analysis was performed to determine predictors for RTR histology and oncological outcome.

Results: Viable cancer was more frequent in the salvage group than in the first-line group, $48.98 \%$ vs. $16.36 \%(p=0.00019)$ and was a predictor for survival. AFP $\geq 30 \mu \mathrm{g} / \mathrm{l}$ was a predictor for viable cancer in first-line and salvage setting, $55.56 \%(p=0.0157)$ and $66.67 \%(p=0.0017)$, respectively. In the salvage group compared to the first-line, the relapse-free rate $(22.7 \%$ and $50 \%, p=0.00032)$ and survival rate $(37.8 \%$ and $65 \%, p=0.0058)$ were significantly poorer. AFP $\geq 30 \mu \mathrm{g} / \mathrm{l}$ and $\mathrm{HCG} \geq 20 \mathrm{mU} / \mathrm{ml}$ were significant factors for survival in the first-line group.

Conclusion: If preoperative AFP is $\geq 30 \mu \mathrm{g} / \mathrm{l}$ after first-line chemotherapy, chances for viable GCT are high and survival is poor. For these patients PC-RTR is probably not beneficial and salvage chemotherapy should be the preferred treatment. In turn, for patients with AFP $<30 \mu \mathrm{g} / \mathrm{l}$ and HCG $<20 \mathrm{mlU} / \mathrm{ml}$ after first-line chemotherapy, PC-RTR yields favorable results and should be the primary treatment. After salvage chemotherapy prognosis is poor regardless of STM status. In this group, AFP $\geq 30 \mu \mathrm{g} / \mathrm{l}$ is associated with a higher risk for viable GCT. So called "desperation surgery" in this situation is justified if complete resection is possible since two-year survival approaches $40 \%$. 
V12.4

Skeletal surgery during postchemotherapy retroperitoneal lymphadenectomy (PC-RPLA): management and outcome

K. Zimmermann ${ }^{1 *}$, P. Paffenholz ${ }^{1}$, D. Pfister ${ }^{1}$, T. Nestler ${ }^{1}$, A. Hiester ${ }^{2}$, Y. Che ${ }^{2}$, P. Albers ${ }^{2}$, A. Heidenreich ${ }^{1}$

${ }^{1}$ Uniklinik Köln, Köln, Germany; ${ }^{2}$ Uniklinik Düsseldorf, Düsseldorf, Germany

Objective: to report oncological and functional outcomes of skeletal surgery during PC-RPLA and to identify patient characteristics, surgical approaches and diagnostic algorithms associated with an increased risk of skeletal surgery.

Patients and methods: 29 pts underwent RPLA plus resection of 1-2 vertebral bodies. In 25 and in 4 pts, primary and redo-PC-RPLND was performed, resp. All pts were marker negative or had plateauing markers; 3 pts. had late relapse. We assessed progression-free and overall survival. We assessed surgery related complications according to the Clavien-Dindo classification.

Results: Mean age was 24.5 (18-52) years. All pts had primary nonseminomas. 6 and 23 pts underwent thoracoabdominal or retroperitoneal approach, resp.. In 22 pts complete resection of the vertebra with replacement was performed. 7 patients were managed with partial resection of the vertebral body. Mean surgical time was 8.7 (7-11) hours, mean intraoperative blood loss was 950 (600-2500) ml. Vascular, renal, or hepatic surgery was necessary in 10 (34.5\%) pts. Mean hospitalization was 12 (832) days. Pathohistology revealed teratoma in 15 , embryonal carcinoma in 3 , yolk sac tumor in 2, malignant somatic transformation in 2, and necrosis in 7 patients. Mean follow-up is 27 (12-43) months, overall survival and progression-free survival is $83 \%$ and $66.6 \%$, respectively. Teratoma had the best long-term prognosis and only patients with vital cancer relapsed. Conclusion: Combined resection of vertebral bodies and residual tumor masses is feasible with a low rate of treatment related complications. Only Teratoma patients will benefit from this procedure. Preoperative biopsy should be performed to exclude viable cancer.

\section{V12.5}

Der Einfluss des Tumormikromilieus auf die CisplatinSensitivität und das Transkriptom von Keimzelltumoren in vitro

M. A. Skowron ${ }^{*}$, G. Ludwig' , K. Eul', P. Petzsch², K. Raba ${ }^{3}$, G. Poschmann ${ }^{4}$, A. Stephan' ${ }^{1}$, G. A. Wakileh ${ }^{1,5}$, K. Stühler ${ }^{4}$, K. Köhrer ${ }^{2}$, P. Albers ${ }^{6}$, D. Nettersheim ${ }^{1}$

${ }^{1}$ Klinik für Urologie, Urologisches Forschungslabor, Translationale UroOnkologie, Medizinische Fakultät und Universitätsklinikum Düsseldorf, Heinrich-Heine-Universität Düsseldorf, Düsseldorf, Deutschland; ${ }^{2}$ Genomics and Transcriptomics Laboratory, Biologisch-Medizinisches Forschungszentrum (BMFZ), Medizinische Fakultät und Universitätsklinikum Düsseldorf, Heinrich-Heine-Universität Düsseldorf, Düsseldorf, Deutschland; ${ }^{3}$ Institut für Transplantationsdiagnostik und Zelltherapeutika (ITZ), Medizinische Fakultät und Universitätsklinikum Düsseldorf, Heinrich-Heine-Universität Düsseldorf, Düsseldorf, Deutschland; ${ }^{4}$ Molecular Proteomics Laboratory, Biologisch-Medizinisches Forschungszentrum (BMFZ), Medizinische Fakultät und Universitätsklinikum Düsseldorf, HeinrichHeine-Universität Düsseldorf, Düsseldorf, Deutschland; ${ }^{5}$ Universitätsklinikum Ulm, Klinik für Urologie und Kinderurologie, Ulm, Deutschland; ${ }^{6} \mathrm{Klinik}$ für Urologie, Medizinische Fakultät und Universitätsklinikum Düsseldorf, Heinrich-Heine-Universität Düsseldorf, Düsseldorf, Deutschland

Fragestellung: Keimzelltumoren (KZT) treten vorwiegend bei jungen Männern auf und sprechen bedeutend auf die Standard Cisplatin-basierte Therapie an. Ein Grund jedoch für die häufig entstehende Resistenz kann der Einfluss des Tumormikromilieus (TM) sein, welches proliferative und anti-apoptotische Signalwege fördern kann. Diese Studie untersucht die Interaktion zwischen KZT und ihrem TM, sowie den Einfluss auf die Cisplatin-Sensitivität.

Methoden und Ergebnisse: XTT-Zellviabilitäts-Assays verdeutlichten, dass in TM-Medium kultivierte KZT-Zelllinien eine verminderte Cisplatin-
Sensitivität aufwiesen. Massenspektrometrische Analysen identifizierten aus dem TM sekretierte Proteine, die als mögliche Mediatoren dieser Cisplatin-Resistent in Frage kommen. Die Transduktion der KZT- und TM-Zellen mit fluoreszierenden Proteinen ermöglichte die durchflusszytometrische Sortierung der einzelnen Populationen aus 3D-Co-Kulturen und anschließende RNA-Sequenzierung. Analog zu den Sekretom-Daten verdeutlichte die bioinformatische Auswertung der Transkriptom-Daten, dass die Co-Kultur von KZT mit M2-Makrophagen zu einer erhöhten Expression von Chemokin-assoziierten Signalwegsmolekülen in den Tumorzellen führte. Die Co-Kultur mit T-Zellen hingegen führte in KZT zu einer Hochregulation von Genen, die in der Regulation der Immunantwort involviert sind. Umgekehrt wurden in TM-Zellen nach Co-Kultur mit KZTZellen Gene, die für die Zelladhäsion und Zell-Zell-Kontakte relevant sind, hochreguliert.

Fazit: Diese Studie konnte die Interaktion zwischen dem TM und KZT molekularbiologisch aufschlüsseln und so einen Zusammenhang zwischen einer Tumor-Mikromilieu-Interaktion und der Entwicklung einer CisplatinResistenz in KZTs aufzeigen.

\section{V12.6}

Targeted therapy in patients with chemorefractory, metastatic progressing testicular germ cell tumors (mTGCT)

\section{A. Heidenreich ${ }^{*}$, P. Paffenholz, T. Nestler, D. Pfister}

Uniklinik Köln, Köln, Germany

Purpose: $10-15 \%$ of patients with mTGCT will develop chemorefractory disease of which about $50 \%$ will die. We report on the integration of next generation sequencing in daily clinical practice to identify druggable mutations.

Patients and methods: 3 consecutive patients with chemorefractory mTGCT ( $n=1$ extragonadal YST, $n=1$ seminoma and $n=1$ nonseminoma with retroperitoneal and pulmonary metastases) were included. All patients underwent CT-guided biopsies of progressing metastatic lesions. Biopsy samples were immediately shipped to the molecular biology lab, processed and analyzed.

40 ng DNA was quantified with the Qubit dsDNA HS Assay on the Qubit 2.0 Fluorometer and sheared on the Covaris E220 Focused-ultrasonicator using the 8 microTUBE-50 Strip AFA Fiber V2. For DNA library preparation and enrichment the TruSight Oncology 500 Kit was used. Post-enriched libraries were quantified, pooled and sequenced on a NextSeq 500. Sequencing data are analyzed with the TruSight Oncology 500 Local App Version 1.3.0.39. Besides mutational data, microsatellite status and tumor mutational load can be analyzed from sequencing data. Differential expression of targetable genes on mRNA level is determined using a customized NanoString Panel.

Results: Mutational analysis revealed KIT D820G, TP53, and NPM1 mutations as well as MMR deficiency with loss of MSH2 and MSH6 proteins so that targeted therapy with sunitinib $(n=2)$ or pembrolizumab $(n=1)$ was initiated. Targeted therapy resulted in remarkable partial remissions for a duration of $9,12+$, and 15 months.

Conclusion: Although rare, identification of druggable mutations might be an option in chemorefractory TGCT following all sequences of approved treatment options. 


\section{V12.7}

\section{Entwicklung neuer HDAC-BET-Dualinhibitoren als epigenetische Therapieoption für urogenitale Tumoren}

\author{
A. Burmeister ${ }^{1 *}$, A. Stephan ${ }^{1}$, M. A. Skowron' ${ }^{1}$, P. Petzsch², K. Köhrer ${ }^{2}$, \\ L. A. Alves-Avelar ${ }^{3}$, T. Kurz ${ }^{3}$, P. Albers ${ }^{4}$, D. Nettersheim ${ }^{1}$
}

${ }^{1}$ Klinik für Urologie, Medizinische Fakultät und Universitätsklinikum Düsseldorf, HeinrichHeine-Universität Düsseldorf, Urologisches Forschungslabor, Translationale UroOnkologie, Düsseldorf, Deutschland; 'Biologisch-Medizinisches Forschungszentrum (BMFZ), Medizinische Fakultät und Universitätsklinikum Düsseldorf, Heinrich-Heine-Universität Düsseldorf, Genomics \& Transcriptomics Labor, Düsseldorf, Deutschland; ${ }^{3}$ Institut für Pharmazeutische und Medizinische Chemie, Heinrich-Heine-Universität Düsseldorf, Düsseldorf, Deutschland; ${ }^{4}$ Klinik für Urologie, Medizinische Fakultät und Universitätsklinikum Düsseldorf, Heinrich-Heine-Universität Düsseldorf, Düsseldorf, Deutschland

Zielsetzung: Die Inhibition von Schlüsselfaktoren der Epigenetik kann eine therapeutische Alternative in der Behandlung urogenitaler Malignitäten (Urothel-, Nierenzell-, Prostatakarzinom, Keimzelltumoren (KZT)) darstellen. Diese Studie identifizierte aus einer Wirkstoff-Bibliothek neuartige Histon-Deacetylase (HDAC)- und Bromodomänen-Protein (BET)-Inhibitoren, um die wirksamsten Kandidaten zu HDAC-BET-Dualinhibitoren zu fusionieren.

Methoden: Die Zytotoxizität von 35 HDAC- und BET-Inhibitoren wurde anhand XTT-Zellviabilitäts-Assays, sowie Apoptose- und Zellzyklusanalysen in 22 urogenitalen Karzinom- und 7 Kontrollzelllinien bestimmt. Mit Hilfe von ATAC-, RNA-Seq, qRT-PCR, Western Blot-Analysen und Enzym-Assays wurden die Wirkmechanismen aufgeschlüsselt.

Ergebnisse: Basierend auf den wirksamsten HDAC- $\left(\mathrm{LD}_{50} 0,1-5 \mu \mathrm{M}\right)$ und BET- (1-10 $\mu \mathrm{M})$-Inhibitoren wurden drei HDAC-BET-Dualinhibitoren synthetisiert. Sowohl die HDAC- und BET-Inhibitoren als auch die Dual-Inhibitoren induzierten Apoptose und einen Zellzyklusarrest in den urogenitalen Karzinomzelllinien. Der Wirkungsbereich der Dual-Inhibitoren lag zwischen dem der Monoinhibitoren. Die Isoformprofile der Monoinhibitoren stellen eine selektive Inhibition von HDAC Klasse I/llb, bzw. BRD2/3/4 dar und eine Zunahme der Histonacetylierung nach HDAC-Inhibitor-Behandlung validierte den Wirkmechanismus. Die Genexpression von Schlüsselgenen nach HDAC-Inhibitor-Behandlung ähnelte den Effekten des HDAC-Inhibitors Romidepsin. ATAC- und RNA-Seq.-Analysen identifizierten Gene, die nach Behandlung zugänglicher/weniger zugänglich vorlagen und häufiger/seltener transkribiert wurden.

Fazit: Die HDAC-BET-Dualinhibitoren könnten, vor allem für Cisplatin-resistente Tumoren, einen vielversprechenden Ansatz in der Behandlung urogenitaler Tumoren bieten.

\section{V12.8}

\section{The new tumour biomarker miRNA-371-3p influences cisplatin sensitivity of testicular germ cell tumour cell lines}

R. Weiten ${ }^{1 *}$, T. Engler ${ }^{1}$, H. Schorle ${ }^{2}$, J. Ellinger ${ }^{1}$, A. Alajati ${ }^{1}$, M. Ritter ${ }^{1}$, D. Nettersheim ${ }^{3}$, I. Syring-Schmandke

'Universitätsklinik Bonn, Urologie, Bonn, Germany; ${ }^{2}$ Universitätsklinik Bonn, Pathologie, Bonn, Germany; ${ }^{3}$ Uniklinik Düsseldorf, Urologie, Düsseldorf, Germany

Introduction: Cisplatin resistance remains a major obstacle in the standard chemotherapeutic approach in late-stage and metastatic testicular germ cell tumour patients. MiRNA-371a-3p (miR-371), the novel serum biomarker of TGCTs, shows significantly increased expression in cisplatin-resistant TGCT cell lines compared to the parental cell lines. However, the influence of miR-371 on cisplatin-sensitivity has not yet been investigated. Materials and methods: In three non-seminomatous TGCT cell lines and their respective cisplatin-resistant subclones, the expression of miR-371 was determined by qPCR. By using two different antagomirs, we inhibited miR-371, leading to a decreased miR-371 expression (>95\%). To measure cytotoxic impacts of chemotherapeutic drugs, miR-371-inhibited and control cells were exposed to different concentrations of cisplatin for 24-72 h.
Afterwards, changes in viability were measured by crystal violet assay. Additionally, the effects on cell cycle phase distribution and apoptosis rates were measured by flow cytometry ( $\mathrm{PI}, \mathrm{AnnexinV/PI)}$.

Results: In the cisplatin-resistant and corresponding parental TGCT cell lines, cisplatin-sensitivity was significantly raised after the miR-371 inhibition, indicated by a strongly reduced viability and increased apoptosis after cisplatin application in miR371-inhibited cells as compared to controls. These data suggest that miR-371 might contribute to the acquisition of cisplatin-resistance.

Conclusion: In summary, our results show that the miR-371 has a decisive influence on the development of cisplatin-resistance in TGCT, i. e. interfering with the miR-371-expression can increase the cisplatin-sensitivity of the tumours cells. This may represent a promising approach for the treatment of patients with cisplatin-resistant TGCTs.

\section{V12.9}

Die pharmakologische Interferenz mit der

epigenetischen Landschaft als Alternative zur

Standardtherapie für (Cisplatin-resistente)

\section{Keimzelltumoren}

\section{R. Müller ${ }^{1 *}$, M. A. Skowron', P. Petzsch², K. Köhrer², P. Albers', D. Nettersheim}

'Klinik für Urologie, Urologisches Forschungslabor, Translationale UroOnkologie, Medizinische Fakultät und Universitätsklinikum Düsseldorf, Heinrich-Heine-Universität Düsseldorf, Düsseldorf, Deutschland; ${ }^{2}$ Biologisch-Medizinisches Forschungszentrum (BMFZ), Medizinische Fakultät und Universitätsklinikum Düsseldorf, Heinrich-Heine-Universität Düsseldorf, Düsseldorf, Deutschland, ${ }^{3}$ Klinik für Urologie, Medizinische Fakultät und Universitätsklinikum Düsseldorf, Heinrich-Heine-Universität Düsseldorf, Düsseldorf, Deutschland

Fragestellung: Keimzelltumoren (KZT) besitzen eine sehr niedrige $\mathrm{Mu}$ tationslast, daher wird eine Disregulation der epigenetischen Landschaft als Treiber der Tumorigenese diskutiert. Dabei wird die Genexpression auf epigenetischer Ebene durch posttranslationale Modifikationen (PTM) an Histonen, z. B. Acetylierungen und Methylierungen, reguliert. Ziel dieser Studie ist es durch Modulation von PTM neue Therapieoptionen für Cisplatin-resistente KZT und nebenwirkungsärmere Alternativen zur Standardtherapie zu finden.

Material und Methoden: Die zytotoxischen Effekte von 16 epigenetisch wirkenden Agenzien wurden in KZT- sowie nicht-malignen Kontrollzelllinien mittels Zellviabilitäts- (XTT), Zellzyklus- und Apoptose-Assays (Propidium-lodid (PI)- bzw. Annexin V/PI-Färbung) nachgewiesen. Die molekularen Wirkmechanismen wurden mittels Massenspektrometrie von Histon-PTM, Western Blot, RNA-Seq, qRT-PCR und DNA-MethylierungQuantifizierungskit analysiert.

Ergebnisse: Aufgrund ihres stark zytotoxischen Effekts wurden sieben „epi-drugs" ausgewählt. Alle Agenzien induzierten Apoptose und/oder Zellzyklusarrest in den KZT-Zelllinien inklusive Cisplatin-resistenter Subklone, jedoch nicht in den Kontrollzellen. Außerdem führte die Inhibition einzelner PTM zu weitreichenden Veränderungen der epigenetischen Landschaft (auf DNA- und Histon-Ebene), jenseits des erwarteten Wirkspektrums. Des Weiteren zeigten sich deutliche Veränderungen im Transkriptom.

Fazit: In dieser Studie konnte gezeigt werden, dass sich die Modulation von PTM aufgrund des zytotoxischen Effekts eine vielversprechende Therapieoption für (Cisplatin-)resistente KZTs darstellt. Als wirksamster Kandidat zeigte sich dabei der Histondeacetylase-Inhibitor Quisinostat, welcher bereits in Phase-II-Studien bei Ovarialkarzinomen eingesetzt wird. 


\section{V13 - Andrologie - Sexuelle Dysfunktion, Männergesundheit und Hypogonadismus}

$17.09 .2021, C 6.2,08: 15-09: 45$

V13.1

Applying an unbiased clustering approach to subclassify a cohort of unexplained infertile men reveals FSHB genotype as most prominent segregation marker

\section{Schubert ${ }^{1 *}$, H. Krenz ${ }^{2}$, M. Dugas², S. Kliesch¹, J. Gromoll ${ }^{3}$}

${ }^{1}$ Centrum für Reproduktionsmedizin und Andrologie (CeRA), Universitätsklinik Münster, Abteilung für Klinische und Operative Andrologie, Münster, Germany; ${ }^{2}$ Institut für Medizinische Informatik, Universität Münster, Münster, Germany; ${ }^{3}$ Centrum für Reproduktionsmedizin und Andrologie (CeRA), Universitätsklinik Münster, Institut für Reproduktive and Regenerative Biologie, Münster, Germany

Objectives: About $65 \%$ of infertile men are still diagnosed with unexplained infertility, lacking major factors sufficient to explain the fertility status. The aim was to identify subgroups of similar patients in a cohort of unexplained infertile men by an unbiased clustering approach.

Patients and methods: We retrospectively (2008-2018) selected patients with unexplained male infertility from our database Androbase ${ }^{\circledast}$ (exclusion: obstructive, genetic, other known causative factors; inclusion: total sperm count $\geq 1$ mill./ejac., FSH $\geq 1 \mathrm{lU} / \mathrm{l}$, Testosterone $\geq 8 \mathrm{nmol} / \mathrm{l})$.

For the 2422 patients somatic, semen, and hormonal parameters as well as testicular volumes (TV) were included, supplemented by genotyping of the FSHB c.-211G >T (rs10835638) single nucleotide polymorphism.

For the cluster analysis, partitioning around medoids method was employed for 2 to 20 medoids based on Gower distance between patients. Quality of clustering was evaluated by average silhouette widths.

Results: Separation of patients into two clusters resulted in the best average silhouette width ( 0.12); sign. different distributions were evident for: total sperm count, sperm motility, TV, FSH, and FSHB genotype. The clusters each contained the majority of either men carrying the Wildtype (GG) or men carrying a T-allele in the $F S H B(>98 \%$ Cluster 1, $>92 \%$, Cluster 2 ). Conclusion: In this unbiased approach an evident separation by genotype in the FSHB was most prominent. Consequently, genotyping should be implemented as diagnostic routine in these men. Potential therapeutic consequences have to be investigated. Still, a large fraction remains unexplained infertile, showing the necessity of new assays and genetic markers for further classification.

Funding: Supported by the German Research Foundation (CRU326)

\section{V13.2}

\section{Einfluss der Lagerungsdauer kryokonservierter Spermien auf deren Vitalität und Motilität}

\footnotetext{
S. Bier ${ }^{1 *}$, D. Hanke ${ }^{1}$, M. Zitzmann¹, V. Nordhoff ${ }^{2}$, S. Kliesch
}

'Universitätsklinikum Münster (UKM), Abteilung für Klinische und Operative Andrologie, Centrum für Reproduktionsmedizin und Andrologie (CeRA), Münster, Germany; ${ }^{2}$ Universitätsklinikum Münster (UKM), Centrum für Reproduktionsmedizin und Andrologie (CeRA), Münster, Germany

Die Kryokonservierung von Spermien ist Standard der Fertilitätsprotektion. Kurzzeitige Effekte der Lagerung auf die Qualität der Spermien sind in Studien nicht beobachtet worden (Kläver et al. 2012, J Assist Reprod Genet 29, 943-950), bei Langzeitlagerung ist bei Samenspendern eine Abnahme der Qualität nach 10 Jahren berichtet (Huang et al. Fertil Steril 112:663-669, 2019). Tumorpatienten lagern ihre Proben über lange Zeiträume und es fehlen hier gesicherte Daten über Effekte der Langzeitlagerung auf die Spermienqualität.

Im Zeitraum von 2001-2019 wurden in unserem Centrum für 6022 Patienten Kryodepots angelegt. 294 dieser Patienten stellten ihr Depot zu For- schungszwecken zur Verfügung. Zur Beurteilung der Qualität der Spermien nach dem Einfriervorgang wird 3 Tage später ein Aliquot der Probe aufgetaut und die Motilität und die Vitalität der Spermien bestimmt. Im Rahmen unserer Studie wurde von allen zur Verfügung stehenden Forschungsproben wiederum ein Aliquot zur erneuten Beurteilung der Spermien analysiert.

Zum Zeitpunkt der Auswertung waren die Proben im Mittel 9,4 $\pm 3,6$ Jahre eingefroren. Nach Unterteilung der Einfrierdauer in drei Gruppen (1: $\leq 5$ Jahre, 2: 6-14 Jahre, 3: $\geq 15$ Jahre) zeigte sich kein signifikanter Einfluss der Einfrierdauer auf Motilität oder Vitalität. Es zeigte sich ein signifikanter Zusammenhang zwischen Vitalität in der Kontrolle drei Tage nach Kryokonservierung und der Spermienvitalität nach der Langzeitlagerung $(p=0,001)$. Den selben Effekt zeigte sich für die Spermienmotilität $(p<0,001)$.

Die Kryokonservierung stellt ein sicheres Verfahren zur langfristigen Fertilitätsprotektion vor gonadenschädigender Therapie dar. Patienten, die nach langer Lagerungsdauer ihr Kryospermadepot verwenden wollen, müssen nicht mit Qualitätseinschränkungen rechnen.

\section{V13.3}

\section{Die Rolle von Pornographie im Sexleben junger}

Erwachsener - eine retrospektive Kohortenstudie an Medizinstudierenden

M. Jahnen'", L. Zeng' ', V. Meissner', A. Korte' ${ }^{2}$, A. Dichtl' ${ }^{3}$, S. Schiele', H. Schulwitz' ${ }^{1}$ J. Gschwend' ${ }^{1}$ K. Herkommer ${ }^{1}$

'Klinik und Poliklinik für Urologie, Klinikum rechts der Isar, Fakultät für Medizin, Technische Universität München, München, Deutschland; ${ }^{2}$ Klinik und Poliklinik für Kinder- und Jugendpsychiatrie, Psychosomatik und Psychotherapie der Universität München, München, Deutschland; ${ }^{3}$ Klinik und Poliklinik für Psychosomatische Medizin und Psychotherapie, Klinikum rechts der Isar, Fakultät für Medizin, Technische Universität München, München, Deutschland

Fragestellung: Durch den einfachen Zugriff auf unbegrenzte Mengen an pornografischem Material (PM) über das Internet ist der Konsum von PM unter Jugendlichen und jungen Erwachsenen gängig. Ziel dieser Arbeit war es, Informationen zum Pornokonsumverhalten von Medizinstudierenden (MS) zu erheben und Assoziationen mit vermehrtem Pornokonsum zu identifizieren.

Material und Methoden: MS wurden per Fragebogen bezüglich ihres Pornokonsum- und Sexualverhaltens befragt. 98,8\% der MS nahmen teil $(N=468)$. Die erhobenen Daten wurden mittels multivariater Poisson Regression analysiert.

Ergebnisse: $86,8 \%$ der männlichen MS konsumierten in den letzten 4 Wochen vor Befragung mindestens 4-mal PM, während 93,5\% der weiblichen MS in diesem Zeitraum 0-4-mal PM konsumierten. 93,6\% der männlichen MS masturbierte meistens oder immer während des Konsums von PM. 43,5\% der weiblichen MS berichtete solch ein Verhalten. Männliche und weibliche MS, die angaben durch Pornos inspiriert worden zu sein $(74,6 \%)$ und die schon einmal Analverkehr hatten $(33,7 \%)$ konsumierten häufiger PM. Weibliche MS die bereits Erfahrungen mit einem „Dreier" hatten $(9,0 \%)$, die erotische Bilder von sich selbst verschickt haben $(33,5 \%)$ und die schon einmal eine Geschlechtskrankheit hatten (14,7\%), konsumierten häufiger PM. (alles $p<0,05$ )

Schlussfolgerung: Der Konsum von pornografischem Material (PM) unter Medizinstudierenden, insbesondere männlichen, ist weit verbreitet. PM ist für viele junge Erwachsene eine Inspiration für ihre eigene Sexualität, so dass sich Assoziationen zwischen vermehrten Konsum von PM und einem ausgefalleneren Sexualleben zeigen. Der Umgang mit Pornographie und die Einordnung der dargestellten Sexualität sollte Jugendlichen und jungen Erwachsenen frühzeitig beigebracht werden. 


\section{V13.4}

Less mortality and less major adverse cardiovascular events (MACE) under long-term testosterone therapy (TTh): 15-year data from a prospective controlled registry study

M. Alwani ${ }^{*}$, M. Salman², K. Haider ${ }^{2}$, A. Al-Qudimat ${ }^{3}$, R.M. Al-Zoubi ${ }^{3}$, F. Saad ${ }^{4}$, A. Yassin 3,4

'Jordan University of Science and Technology, Irbid, Jordan; ${ }^{2}$ Center of Urology and Andrology, Norderstedt, Germany; ${ }^{3}$ Hamad Medical Corporation, Doha, Qatar; ${ }^{4}$ Dresden International University, Dresden, Germany

Introduction: We have previously demonstrated improvements in cardiometabolic risk factors in hypogonadal men on long-term TTh.

Methods: Cumulative registry study to investigate long-term effectiveness and safety of 3-monthly TU to treat hypogonadism was established in 2004 in a urological setting. Of 805 hypogonadal men, 412 received parenteral TU $1000 \mathrm{mg} / 12$ weeks (T-group) for up to 12 years. 393 men opted against TTh and served as controls (CTRL). 10-year data are reported. Confounders including age, BMI, smoking, alcohol, total and HDL cholesterol, systolic blood pressure, and type 2 diabetes were assessed and considered in statistical modeling.

Results: Baseline age was $57.7 \pm 7.4$ in the T-group and $63.7 \pm 4.8$ years in CTRL $(p<0.001)$. The absolute follow-up time comprised approximately 6500 patient-years.

The mean Framingham risk score at baseline was 15.5 in the T-group and 15.8 in CTRL $(p<0.05)$. The mean 10 -year risk was $22.7 \%$ in the T-group and $23.5 \%$ in CTRL $(p=0.11)$.

Mean and median observation time in the T-group was 8 years. There were 16 deaths (3.9\%) but no myocardial infarctions or strokes.

Mean observation time in CTRL was 8 , median 9 years. There were 74 deaths (18.8\%), $70 \mathrm{Mls}(17.8 \%)$ and 59 strokes (15\%).

All classical cardiovascular risk factors including obesity, glycaemic control, lipid pattern, and C-reactive protein improved in the T-group and worsened in CTRL.

The reduction of cardiovascular events by TTh after applying a linear mixed effect model was $24.7 \%$ and $15.5 \%$ after applying a random effect longitudinal model.

Conclusions: In hypogonadal men, long-term TTh reduces cardiovascular events and mortality.

\section{V13.5}

Miktionsfunktion und Prostata-Sicherheit der LangzeitTestosterontherapie bei Männern mit funktionalem Hypogonadismus

\section{K. S. Haider ${ }^{*}$, A. Haider', G. Doros ${ }^{2}$, A. Traish ${ }^{3}$}

'Praxis Dr. Haider, Bremerhaven, Deutschland; 'B Boston University School of Public Health, Department of Epidemiology and Statistics, Boston, Vereinigte Staaten von Amerika; ${ }^{3}$ Boston University School of Medicine, Department of Biochemistry and Department of Urology, Boston, Vereinigte Staaten von Amerika

Einleitung: Laut aktueller Leitlinien gibt es keine Evidenz für ein erhöhtes Risiko von Prostata-Erkrankungen infolge einer Testosterontherapie (TTh). Dennoch sind diesbezügliche Bedenken weit verbreitet.

Material und Methoden: In unserer Hypogonadismus-Registerstudie analysierten wir 779 Männer mit funktionalem Hypogonadismus. 386 Männer erhielten TTh (Testosteron-Undecanoat-Injektionen $1000 \mathrm{mg} / 12$ Wochen mit 6 Wochen-Anfangsintervall) (T-Gruppe), 393 Männer entschieden sich gegen TTh (KTRL). Die Unterschiede über die Beobachtungszeit wurden anhand eines gemischten Effektmodells für wiederholte Messungen verglichen, welches für Alter, Gewicht, Bauchumfang, Blutdruck, nüchtern Blutzucker, Lipide und Lebensqualität an der Baseline bereinigt wurde. Ergebnisse: Mittleres Follow-Up: 8,9 $\pm 2,6$ (T-Gruppe), 9,6 $6 \pm 2,3$ Jahre (KTRL). Gesamtbeobachtungszeit: T-Gruppe 3431, KTRL 3765 Jahre.
Baseline Alter:

$58,4 \pm 6,4$ (T-Gruppe), 63,1 $\pm 4,8$ Jahre (KTRL). Medikation:

Alpha-Blocker: 44,3 \% (T-Gruppe), 50,4 \% (KTRL); 5-a-Reduktase-Inhibitor: 2,6\% (T-Gruppe), 8,4 \% (KTRL); PDE5-Inhibitor: 25,9\% (T-Gruppe), 22,1 \% (KTRL).

IPSS sank um 5,1 $\pm 0,1$ (T-Gruppe) und stieg um 4,1 $1 \pm 0,1$ (KTRL). Geschätzte adjustierte Differenz zw. Gruppen (adj. Diff.): $-9,2$.

Prostatavolumen stieg um 3,1 $\pm 0,2$ (T-Gruppe) bzw. 3,9 $\pm 0,2 \mathrm{ml}$ (KTRL), adj. Diff.: $0,8 \mathrm{ml}(p<0,01)$.

PSA stieg um 0,06 $\pm 0,1$ (T-Gruppe) bzw. 1,1 $\pm 0,1 \mathrm{ng} / \mathrm{ml}$ (KTRL), adj. Diff. $1,0(p<0,0001)$.

Bei 12 Patienten (3,1\%) in der T-Gruppe und 50 (12,7\%) in KTRL wurde ein Prostata-Karzinom diagnostiziert $(p<0,0001)$. Bei 18 Patienten in KTRL kam es zu einem biochemischen Rezidiv.

Beurteilung: Langzeit-TTh bei Männern mit funktionalem Hypogonadismus verbesserte die Miktionsfunktion. Prostata-Karzinome wurden viermal so häufig in der Kontrollgruppe diagnostiziert.

\section{V13.6}

\section{Der Frenulumeinriss - eine prospektive Kohortenstudie}

F. Dittmar ${ }^{1 *}$, F. Wagenlehner ${ }^{1}$, U. Schagdarsurengin ${ }^{1}$, I. Hoffmann ${ }^{2}$, A. Pilatz ${ }^{1}$

'Justus-Liebig-Universität Gießen, Klinik für Urologie, Kinderurologie und Andrologie, Giessen, Deutschland; ${ }^{2}$ Kinderwunschzentrum Dres. Hoffmann, Berlin, Deutschland

Einleitung: Verletzungen am äußeren Genitale gehören zu den typischen urologischen Notfällen. Die Gruppe von Patienten mit Einriss des Frenulums ist bisher jedoch nicht charakterisiert.

Material und Methoden: Im Rahmen einer prospektiven Studie haben wir seit 2017 Patienten evaluiert, die sich als Notfall mit einem Frenulumeinriss vorstellten.

Ergebnisse: Das mediane Alter betrug 22 Jahre. Die höchste Inzidenz zeigte sich am Wochenende (54\%). Der Arztkontakt fand im Median $14 \mathrm{~h}$ nach dem Trauma statt. Hauptgründe waren Blutung (54\%), Angst/Unsicherheit (50\%) und Schmerzen (46\%). Die Mehrzahl der Patienten war heterosexuell (90\%) und vollführte Vaginalverkehr (90\%) mit der Langzeitpartnerin (97\%). Bei Erstvorstellung waren zu $80 \%$ keine aktiven Blutungszeichen mehr nachweisbar. $83 \%$ der Männer hatten einen partiellen Einriss des Penisbändchens. Die Therapie bestand vorwiegend aus Gespräch und Aufklärung (97\%). Eine notfallmäßige Frenulumnaht war nicht notwendig. Im Rahmen der 3-monatigen Nachbeobachtung $(n=16)$ erhielten 6 Patienten (34\%) bereits eine Frenulumplastik oder Zirkumzision, 2 Patienten (14\%) strebten eine zukünftige operative Versorgung an. Die erste sexuelle Aktivität wurde im Median nach 11 Tagen wieder aufgenommen. Die Zufriedenheit des Sexuallebens wurde auf einer Skala von 1-10 vor als auch nach dem Frenulumeinriss mit 8 bewertet.

Schlussfolgerung: Die erstmalige Beschreibung einer Kohorte von Männern mit penilen Frenulumeinriss zeigt, dass diese mit durchschnittlich 22 Jahren jung sind. Das Trauma findet typischerweise zum Wochenende beim vaginalen Geschlechtsverkehr statt. Während initial eine konservative Beratung ausreichend ist, erfolgt bei $50 \%$ der Patienten im Follow-Up eine operative Therapie. Die sexuelle Zufriedenheit ist im Verlauf unverändert hoch. 
V13.7

Ist das Peptidhormon Vasopressin ein endogener Mediator der Erektilen Dysfunktion (ED)? Eine klinische Studie

\author{
S. Ückert ${ }^{1 *}$, A. J. Becker ${ }^{2}$, A. Bannowsky ${ }^{3}$, D. Tsikas ${ }^{4}$, M. A. Kuczyk ${ }^{1}$
}

${ }^{1}$ Medizinische Hochschule Hannover (MHH), Klinik für Urologie \& Urologische Onkologie, Hannover, Deutschland; ${ }^{2}$ Ludwig-Maximilians-Universität (LMU), Medizinische Fakultät, Klinik für Urologie, München, Deutschland; ${ }^{3}$ Imland Klinik GmbH, Klinik für Urologie, Rendsburg, Deutschland; ${ }^{4}$ Medizinische Hochschule Hannover (MHH), Zentrum Pharmakologie \& Toxikologie, Hannover, Deutschland

Einleitung: Vasopressin (VP/ADH = Antidiuretisches Hormon) wird im Hypothalamus gebildet und nach einem neuronalen Reiz in die Zirkulation sezerniert. Vasokonstriktorische Effekte von VP auf isoliertes Corpus cavernosum penis (CC) sind beschrieben, dennoch ist wenig über die Rolle von VP in der Kontrolle des erektilen Gewebes bekannt. Wir haben in gesunden Männern und in Patienten mit ED die Plasmakonzentrationen des Peptidhormons im systemischen und cavernösen Blut über verschiedene Stadien sexueller Erregung gemessen.

Methoden: 41 gesunden Probanden (Durchschnittsalter 25 Jahre) und 45 Patienten mit ED (Durchschnittsalter 52 Jahre) wurde während der penilen Stadien Flakzidität, Tumeszenz, Rigidität (wurde nur von den gesunden Probanden erreicht) und Detumeszenz Vollblut aus einer Cubitalvene und dem CC entnommen. Die Quantifizierung von VP (ng/ml Plasma) erfolgte mit radioimmunchemischen Methoden (RIA).

Ergebnisse: Der mittlere VP Plasmaspiegel im systemischen Blut des Normalkollektivs reduzierte sich von der Flakzidität zur Tumeszenz und Rigidität (5.4/3.4/2.9), der Plasmaspiegel im cavernösen Blut blieb de facto konstant. Während der Flakzidität und Tumeszenz lag die systemische VP Plasmakonzentration über dem Wert im CC. In der Gruppe der Patienten erhöhte sich die cavernöse VP Konzentration mit der Einleitung der Tumeszenz leicht (2.0 auf 2.8), der systemische VP-Plasmaspiegel zeigte keine markante Dynamik (2.5/2.1).

Schlussfolgerung: Die Verringerung der VP-Konzentration im Blut der gesunden Probanden könnte eine Voraussetzung für die Dilatation der Penisarterien sein. Dass im Kollektiv der Patienten mit dem Beginn der sexuellen Erregung keine Abnahme des VP beobachtet wurde, könnte ein Hinweis auf eine Dysregulation der Sezernierung/Degradierung des Peptids sein.

\section{V13.8}

\section{Six-injections of collagenase clostridium histolyticum: the impact on patients with Peyronie's disease}

R. Talib' ${ }^{1 *}$, M. Abdelkareem', M. Alwani², A. Al-Qudimat', S. Karbech', M. Rejeb', F. Abdelwahab' ${ }^{1}$, K. Alkubaisi', A. Alansari' ${ }^{1}$

${ }^{1}$ Hamad Medical Corporation, Surgical Department, Division of Andrology, Doha, Qatar; 2Jordan University of Science and Technology, School of Medicine, Faculty of Medicine, Irbid, Jordan

Objectives: To evaluate mixed approach between the trials to 6 or 8 injection achieve the most possible outcomes and patient satisfaction.

Methods: Prospective registry study for PD patients who underwent Collagenase Clostridium Histolyticum (CCH) treatment. Inclusion Criteria were any Peyronie's disease patient with penile curvature $>300$ and $<90$ o. Exclusion criteria were any ventral curvature and calcified plaque. Data with follow up to 2 years. International Index of Erectile Function (IIEF), and Penile ultrasound with induced erection for plaque size and curvature determination pre and post-treatment.

Group 1 (G1) was patients who received 6 injections while Group 2 (G2) was patients who received 8 injections. A Pearson Chi-Square and T-test $(P<0.05)$ was used to figure out the statistical significance.

Results: 80 patients (G1 $n=31$ and G2 $n=49$ ) suffer from PD underwent $0.58 \mathrm{mg} \mathrm{CCH}$ injections, Age (mean \pm standard deviation) $56.7 \pm 8.4$ years for $\mathrm{G} 1$, and $55.3 \pm 10$ years for $\mathrm{G} 2$. The mean size of the plaque was $1.7 \pm 0.6 \mathrm{~cm}$ for each group.

Baseline mean curvature degree was $47.30 \pm 10.20$ and $48.60 \pm 11.70$ for $\mathrm{G} 1$ and $\mathrm{G} 2$, respectively $(p>0.05)$. The mean change in degree after treatment was $21.60 \pm 12.10$ and $17.30 \pm 13.40$ for each $\mathrm{G} 1$ and $\mathrm{G} 2(p>0.05)$. Almost, $83.9 \%$ and $81 \%$ have more than or equal to $20 \%$ reduction in curvature for $\mathrm{G} 1$ and $\mathrm{G} 2$, sequentially $(p>0.05)$. A mean improvement in IIEF score after treatment by 3.25 points and 1.59 points for $G 1$ and G2, respectively.

Conclusion: No significant difference between the two groups ( 6 and 8 injections). Ccustomizing the treatment plan for PD patients greatly advised by considering the number of injections in relation to curvature reduction and patient satisfaction, reducing inessential costs and ensuring a satisfactory outcomes.

V13.9

Ist es möglich, die erektile Funktion nach nervenschonender radikaler Prostatektomie durch Verdoppelung der Dosis von täglichen PDE5-Hemmern zu verbessern? - 2 Jahre Follow-up

\section{A. Bannowsky ${ }^{1 *}$, V. Märker ${ }^{2}$, C. Wedel ${ }^{1}$, F. Armbrust ${ }^{1}$, D. Osmonov ${ }^{3}$, S. Ückert ${ }^{4}$ \\ 'Imland Klinik Rendsburg, Klinik für Urologie, Rendsburg, Deutschland; ${ }^{2}$ UKE Hamburg- Eppendorf, Institut für Sexualforschung, Sexualmedizin und forensische Psychiatrie, Hamburg, Deutschland; ${ }^{3}$ Universitätsklinikum Schleswig-Holstein, Campus Kiel, Klinik für Urologie, Kiel, Deutschland; ${ }^{4}$ Medizinische Hochschule Hannover (MHH), Hannover, Deutschland}

Einleitung: Verschiedene Behandlungsschemata zur Rehabilitation der erektilen Funktion (EF) nach nervenschonender radikaler Prostatektomie (nsRP) werden derzeit diskutiert. Die „optimale“ Dosis von PDE5-Hemmern zur Rehabilitation der EF ist jedoch nicht bekannt.

Material und Methoden: Bei 36 Patienten führten wir eine nsRP durch. Die EF wurde bei allen Patienten mittels IIEF-5 Fragebogen evaluiert. Gruppe 1 ( $n=12$ Patienten) erhielt täglich Vardenafil $5 \mathrm{mg} / \mathrm{d}$, im Vergleich zu Gruppe 2 ( $n=12$ ), die Vardenafil $10 \mathrm{mg} / \mathrm{d}$ zur Nacht erhielten. Eine Kontrolle von 12 Patienten wurde ohne PDE-5-Hemmer weiterverfolgt. Die Evaluierung der EF mittels IIEF-5 erfolgte präoperativ sowie 3, 6, 12, 18 und 24 Monate nach nsRP.

Ergebnisse: In der Gruppe mit 5 mg Vardenafil (Gruppe 1) verringerte sich der IIEF-5-Score von präoperativ 22,4 auf 4,2 nach 3 Monaten, 8,9 nach 6 Mo., 13,4 nach 12 Mo., 15,2 nach 18 Mo. und 18,3 nach 24 Mo. nach nsRP. In Gruppe 2 zeigte der IIEF-5-Score präoperative 22,8 sowie 4, 1 nach 3 Mo., 7,9 nach 6 Mo., 12,8 nach 12 Mo., 14,9 nach 18 Mo. und 18,4 nach 24 Mo. Der präoperative IIEF-5-Score in der Kontrollgruppe von 21,9 sank auf 3,8 nach 3 Mo., 6,1 nach 6 Mo., 8,9 nach 12 Mo., 10,2 nach 18 Mo. und 11,3 nach $24 \mathrm{Mo}$. Die statistische Auswertung ergab signifikante Unterschiede im IIEF-5 im zeitlichen Verlauf der EF zwischen den Gruppen 1 und 3 und zwischen den Gruppen 2 und $3(p<0,05)$. Es wurden keine Unterschiede zwischen den Gruppen 1 und 2 festgestellt.

Schlussfolgerung: Täglich niedrig dosierte PDE-5-Inhibitoren führen zu einer signifikanten Verbesserung der Wiederherstellung der EF nach nsRP. In dieser Studie konnte gezeigt werden, dass die Verdoppelung der täglichen Dosis nicht zu einer weiteren Verbesserung der EF nach 2 Jahren führt. 


\section{V14 - Wie verändern urologische Eingriffe die Lebensqualität?}

$$
\text { 17.09.2021, C1.2.2, 13:30-15:00 }
$$

\section{V14.1}

The Autonomy Preference Index-Uronocology (APIUro) to assess patients' participation preference in uroonocological decision making

\section{B. Büdenbender ${ }^{1 *}$, A. K. Köther', M. C. Kriegmair², B. Grüne'², M. S. Michel²,} G.W. Alpers'

'Universität Mannheim, Lehrstuhl für Klinische Psychologie und Biologische Psychologie und Psychotherapie, Mannheim, Germany; ${ }^{2}$ Universität Heidelberg, Universitätsmedizin Mannheim, Klinik für Urologie und Urochirurgie, Mannheim, Germany

Introduction: Urooncological guidelines highlight the need for patient involvement in medical decision making. Little is known about patients' desire for autonomy specifically in urooncological decisions. Therefore, we introduce the API-Uro, a tool to measure participation preference in patients with urological cancers.

Methods: We recruited 460 urological outpatients (42\% urooncological) at a university hospital. Participation preference was assessed with the $\mathrm{Au}-$ tonomy Preference Index (API), its generic case vignettes, and six novel urooncological case vignettes describing 12 medical decisions of varying severity (API-Uro). A polychoric principal component analysis (PCA) was used to reduce items.

Results: PCA revealed two components for the API-Uro: diagnostic and treatment decisions. Internal consistency was good for both components (as $\geq 0.8$. Two vignettes were removed due to substantial cross-loadings. Convergent validity of the API-Uro is documented in high correlations with the API $(r=0.45)$ and the generic API case vignettes $(r=0.64)$. The combined sumscore for the API-Uro was in the moderate range $(M=35$, $S D=13$, Range $=[0-100])$. More patients desired active participation for treatment decisions (78\%) then for diagnostic decisions $(22 \%), \chi^{2}(1)=20.8$, $p \leq 0.001$. Oncological patients did not differ in their participation preference from non-oncological patients in any measure (all $p s \geq 0.14$ ).

Conclusion: The API-Uro is an efficient and valid instrument to assess participation preference in patients facing medical decisions for urological cancers. We found considerable differences in the desired involvement in treatment vs. diagnostic decisions. This highlights the importance of assessing participation preference with a specific rather than a generic measures.

\section{V14.2}

\section{Patient-reported-Outcome-Messung (PROM) der gesundheitsbezogenen Lebensqualität von Patienten mit oberflächlichem Urothelkarzinom der Harnblase}

\section{L. Dräger ${ }^{*}$, B. Kunz, L. Schneidewind, J. Nolting, O. Hakenberg \\ Universitätsmedizin Rostock, Klinik und Poliklinik für Urologie, Rostock, Deutschland}

Fragestellung: Das Harnblasenkarzinom ist die zweithäufigste Tumorerkrankung in der Urologie. Die oberflächliche Variante ist durch eine hohe Rezidivrate charakterisiert, so dass eine engmaschige Nachsorge notwendig ist, die die Lebensqualität beeinflusst. Zur Untersuchung der gesundheitsbezogenen Lebensqualität $(\mathrm{Q} \mathrm{OL})$ beim oberflächlichen Harnblasenkarzinom steht derzeit ein ergänzendes Modul zum EORTC-QLQ-C30 das QLQ-NMIBC-24 zur Verfügung. Ziel der Studie war die Patient-ReportedOutcome-Messung der QoL von Patienten mit einem oberflächlichen Harnblasenkarzinom.

Material und Methoden: Evaluation von Patienten mit oberflächlichem Blasenkarzinom $(n=141)$ mittels EORTC-QLQ-C30 und -QLQ-NMIBC-24.
Diese geben Auskunft über Lebensqualität, funktionalen Skalen (physische, emotionale, kognitive, soziale Funktionsfähigkeit und Rollenfunktion), allgemeine Symptomskalen, 6 Einzelitems (u. a. Inappetenz, Insomnie) und krebsspezifischen Funktions- und Symptomskalen (u.a. Miktion, Sexualität).

Ergebnisse: Die untersuchten Patienten wiesen eine schlechte emotionale, soziale und Rollenfunktion auf. Ferner berichteten sie häufiger von Inappetenz, Fatigue, Schlaflosigkeit und Miktionsbeschwerden. Patienten, die eine intravesikale Instillationstherapie erhielten, zeigten eine schlechtere gesundheitsbezogene QoL als Patienten ohne intravesikale Rezidivprophylaxe.

Schlussfolgerungen: Patienten mit einem oberflächlichen Harnblasenkarzinom weisen eine eingeschränkte Lebensqualität auf. Zu berücksichtigen ist der sog. „Response shift", der bei konstanter QoL zu Verschiebungen innerhalb der Funktions- und Symptomskalen führt, d. h. es kommt zur Neu-Ordnung der Prioritäten mit zeitlichem Abstand zur Operation.

\section{V14.3}

\section{Different patients-different preferences? Exploring patient-reported treatment preferences in uro-oncology}

\author{
A. K. Köther ${ }^{1 *}$, B. Büdenbender', M.C. Kriegmair², B. Grüne², S. Holbach³, \\ P. Karschuck ${ }^{4}$, M. S. Michel ${ }^{2}$, N. von Landenberg ${ }^{5}$, J. Lenk ${ }^{6}$, T. Martini $^{7}$, \\ G.W. Alpers ${ }^{1}$
}

'Universität Mannheim, Fakultät für Sozialwissenschaften, Lehrstuhl für Klinische und Biologische Psychologie und Psychotherapie, Mannheim, Germany; ${ }^{2}$ Universität Heidelberg, Medizinische Fakultät Mannheim, Mannheim, Germany; ${ }^{3}$ Caritas Krankenhaus St. Josef, Universiät Regensburg, Regensburg, Germany; ${ }^{4}$ Universitätsklinikum Carl Gustav Carus, Dresden, Germany; ${ }^{5}$ Marien Hospital Herne, Ruhr-Universität Bochum, Herne, Germany; ${ }^{6}$ Urologische Klinik München-Planegg, Planegg, Germany; ${ }^{7}$ Universitätsklinikum Ulm, Ulm, Germany

Research Questions: Patient-centered care and shared decision making (SDM) are recognized as the gold-standard for medical consultations, especially for preference-sensitive decisions. While medical conditions that influence the choice of urinary diversion (UD) are well known, the impact of psychological patient factors on this decision remains unclear. We set out to explore the role of anxiety and personality in the choice of UD after radical cystectomy and determine if anxiety predicts patients' participation preferences.

Methods: We recruited a multi-center sample of bladder cancer patients ( $N=143$, primarily male, retired) before their medical consultation regarding radical cystectomy. Patients filled in a set of self-report questionnaires, including preferred UD, personality, anxiety, and participation preference (generic and uro-oncological case vignettes), as well as socio-demographic characteristics.

Results: More patients preferred continent UD (43\%) than incontinent UD (32\%). A quarter of patients did not indicate a preference. Patients who preferred incontinent UD were significantly older than patients who preferred continent UD. Their personality profile showed lower conscientiousness and less openness to new experiences. Most patients expressed a low participation preference. Almost a third of patients (29\%) reported clinically relevant anxiety (scores $\geq 55$ ). Anxiety predicted higher uro-oncological participation preference.

Conclusion: Our findings provide insight into the role of psychological patient characteristics for SDM. Patients who reported less openness and conscientiousness were more likely to prefer less invasive treatment methods. Moreover, anxiety may drive the motivation to be more involved in consultations. 
Tab. 1 | V14.4 Urinverlust 24hPT nach Neoblasen-Anlage in den Jahren 2010-2020

\begin{tabular}{|l|l|l|l|l|l|l|l|l|l|}
\hline Jahr & $\mathbf{N}$ & $\begin{array}{l}\text { Urinver- } \\
\text { lust/24 } \mathbf{h}(\mathbf{g}) \\
\text { Mittelwert }\end{array}$ & $\begin{array}{l}\text { Verände- } \\
\text { rung zu } \\
\mathbf{2 0 1 0}(\mathbf{\%})\end{array}$ & $\begin{array}{l}\text { Verände- } \\
\text { rung zum } \\
\text { Vorjahr (\%) }\end{array}$ & Jahr & $\mathbf{N}$ & $\begin{array}{l}\text { Urinver- } \\
\text { lust/24 } \mathbf{h}(\mathbf{g}) \\
\text { Mittelwert }\end{array}$ & $\begin{array}{l}\text { Verände- } \\
\text { rung zu } \\
\mathbf{2 0 1 0}(\%)\end{array}$ & $\begin{array}{l}\text { Verände- } \\
\text { rung zum } \\
\text { Vorjahr (\%) }\end{array}$ \\
\hline 2010 & 68 & 587,1 & 0 & 0 & 2016 & 61 & 609,4 & 3,8 & 13,6 \\
\hline 2011 & 57 & 617 & 5,1 & 5,1 & 2017 & 62 & 567,3 & $-3,4$ & $-6,9$ \\
\hline 2012 & 51 & 395,3 & $-32,7$ & $-35,9$ & 2018 & 66 & 538,1 & $-8,3$ & $-5,2$ \\
\hline 2013 & 63 & 517,9 & $-11,8$ & 31,0 & 2019 & 46 & 661,6 & 12,7 & 22,9 \\
\hline 2014 & 53 & 573,2 & $-2,4$ & 10,7 & 2020 & 36 & 434,5 & $-25,9$ & $-34,3$ \\
\hline 2015 & 58 & 536,5 & $-8,6$ & $-6,4$ & & & & & \\
\hline
\end{tabular}

V14.4

Historische Entwicklung der Harnverlustmengen nach Anlage einer Neoblase von 2010-2020

M. Heydenreich*, D.-H. Zermann

Vogtland-Klinik Bad Elster, Bad Elster, Deutschland

Fragestellung: Die Überwindung der Harninkontinenz nach Anlage einer Neoblase stellt eine besondere Herausforderung dar. Ziel der Studie war es, die Entwicklung der Kontinenzsituation nach Neoblasen-Anlage von 2010 bis 2020 zu bewerten.

Material und Methoden: 621 Neoblasen-Patienten führten den 24hPT am Anfang einer fachspezifischen uro. Rehabilitation durch. Für die statistische Auswertung wurde eine SQL-Abfrage der Daten der Jahre 20102020 durchgeführt.

Ergebnis: Der postoperative $24 \mathrm{~h}$-Urinverlust liegt im Mittel bei $552,8 \mathrm{~g}$ (min. $2 \mathrm{~g}$ und max. $3170 \mathrm{~g}$ ).

Schlussfolgerung: Die Ergebnisse zeigen, dass die postoperativen Urinverlustmengen nach Neoblasen-Anlage von 2010 bis 2020 Schwankungen unterliegen. Eine Tendenz zur Reduktion über die letzten zehn Jahre, wie bei Z.n. radikaler Prostatektomie [1], ist nicht nachweisbar. Dies ist sehr wahrscheinlich auf die komplexen anatomischen und physiologischen Veränderungen zurückzuführen, die sich durch die Neoblasen-Anlage ergeben. Dies unterstreicht die Notwendigkeit einer zielgerichteten rehabilitativen Behandlung, die durch eine Kombination von Kontinenzund Koordinationstraining zeitnahe Fortschritte erlaubt [2].

\section{Literatur}

1. Heydenreich et al., Historische Entwicklung der Harnverlustmengen nach radikaler Prostatektomie von 2010-2019, Der Urologe; 2020

2. Heydenreich et al., Harninkontinenz nach Anlage einer Neoblase - Effizienz eines sensomotorischen Trainings, Der Urologe; 2020

\section{V14.5}

Der Einfluss von riesigem Prostatavolumen auf Healthrelated quality of life nach radikaler Prostatektomie eine Propensity-score matched Analyse

T. Westhofen", A. Becker, A. Buchner, B. Schlenker, M. Chaloupka, C. G. Stief, A. Kretschmer

Klinik für Urologie, Ludwig-Maximilians-Universität München, München, Deutschland

Einleitung: Der Einfluss riesiger Prostatavolumina (PV) auf das Outcome nach radikaler Prostatektomie (RP) ist umstritten. Der aktuellen Literatur mangelt es an Daten zum Einfluss von PV auf die Health-related quality of life (HRQOL). Ziel war es den Einfluss riesiger PV auf funktionelle Ergebnisse und HRQOL nach RP zu untersuchen.
Methoden: Riesiges PV wurde basierend auf dem $95 \%$-Perzentil des PV von 3929 Patienten definiert, die sich zwischen 2013 und 2018 mittels RP operiert wurden. Eine Propensity-Score gematchte Analyse von 929 Männern wurde durchgeführt ( $n=184$ mit $\mathrm{PV} \geq 100 c c, n=745$ mit $\mathrm{PV}<100 c c)$. Primärer Endpunkt: HRQOL (basierend auf dem EORTC QLQ-C30). Sekundärer Endpunkt: onkologisches Outcome und funktionelles Outcome (ICIQ-SF- und IIEF-5-Scores)

Ergebnisse: Medianes Follow-up betrug 24 Monate. Das mediane PV betrug $58 \mathrm{cc}$. Wir fanden keine signifikanten Unterschiede hinsichtlich HRQOL für beide Gruppen $(p=0,183)$. In der multivariablen Analyse war riesiges PV nicht signifikant mit einer guten $\mathrm{HRQOL}$ assoziiert (OR 1,54, $95 \% \mathrm{Cl} 0,96-2,47, p=0,075)$. Es gab keine signifikante Korrelation zwischen PV und HRQOL (Korrelationskoeffizient 0,028, $p=0,571$ ). Es wurden keine signifikanten Unterschiede hinsichtlich Kontinenzraten (HR 0,956 $95 \% \mathrm{Cl} 0,771-1,185, p=0,682)$, der medianen ICIQ-SF-Scores $(p=0,062)$ oder der Potenzraten $(p=0,151)$ gefunden. Riesiges PV zeigte keine signifikanten Einfluss auf biochemisches rezidivfreies Überleben (HR 0,968 $95 \% \mathrm{Cl} 0,651-1,439, p=0,871)$.

Schlussfolgerungen: Für Patienten nach RP zeigte riesiges PV keinen negativen Einfluss auf die HRQOL-Ergebnisse. PV beeinträchtigt nicht die Kontinenzraten, Potenzraten und das biochemische rezidivfreie Überleben, daher ist die RP eine effiziente Behandlungsoption für Männer mit riesiger PV.

\section{V14.6}

Die Angst vor einem Rezidiv nach radikaler Zystektomie bei Patienten mit Urothelkarzinom - vorläufige Ergebnisse einer prospektiven Studie (NCT04535921)

Y. Volz'1*, J. Troost', L. Eismann', P. Pfitzinger', J.-F. Jokisch', G. Schulz', R. Waidelich', S. Böck², A. Buchner', B. Schlenker', C. Stief', S. Rodler'

'Urologische Klinik und Poliklinik, Klinikum der Universität München, LMU München, München, Deutschland; ${ }^{2}$ Ludwig-Maximilians-Universität (LMU), Medizinische Fakultät, Hämatoonkologie, München, Deutschland

Die Angst vor einem Krebsrezidiv (FCR) ist eine herausfordernde und oft nicht adressierte Sorge bei Patienten mit Urothelkarzinom. Weiter sind prädiktive Faktoren für die FCR unbekannt und Patienten mit einem hohen FCR-Risiko werden oft nicht entsprechend beraten und behandelt. Wir haben Patienten vor radikaler Zystektomie prospektiv in eine laufende Studie (NCT4535921) eingeschlossen. Baseline FCR und Patientencharakteristika wurden am Tag vor der Operation und nach Erhalt der endgültigen Histologie nach der Zystektomie erhoben. Wir verwendeten den validierten FCR-7-Fragebogen. Die statistische Analyse erfolgte mit dem Chi-Quadrat-Test für kategorische Variablen und der Mann-Whitney-U/ Wilcoxon-Test für kontinuierliche Variablen durchgeführt.

Bis Ende Januar 2021 wurden 74 Patienten eingeschlossen. 47 Patienten (64\%) hatten sowohl prä- als auch postoperative FCR-Scores. 29 Patienten ( $39 \%$ ) hatten eine lokal fortgeschrittene Erkrankung ( $\geq$ pT3) in der endgültigen Histologie. 


\begin{tabular}{|l|l|l|l|l|l|}
\hline Tab. 1 | V14.7 Überblick des Einflusses des Schweregrades der Harninkontinenz auf die Lebensqualität \\
$\begin{array}{l}\text { Schweregrad der } \\
\text { Harninkontinenz }\end{array}$ & $\mathbf{N}$ & $\begin{array}{l}\text { körperliches Wohlbe- } \\
\text { finden }\end{array}$ & Funktionsfähigkeit & FACT-P & $\begin{array}{l}\text { Seelisches Wohlbe- } \\
\text { finden }\end{array}$ \\
\hline$<=10 \mathrm{~g}$ & 50 & $24,1(3,6)$ & $19,4(5,1)$ & $32,9(5,6)$ & $19,9(3,3)$ \\
\hline$>=11 \mathrm{~g}$ & 42 & $22,5(3,3)$ & $18,4(5,4)$ & $29,1(6,7)$ & $20,2(3,3)$ \\
\hline $\begin{array}{l}p \text {-Wert innerhalb der } \\
\text { Gruppe nach 21 Tagen } \\
\text { Reha }\end{array}$ & $p=0,03$ & $p=0,69$ & $p=0,003$ & $p=0,35$ \\
\end{tabular}

Die FCR vor der Zystektomie (Median: 16, Bereich 6-34) änderte sich nicht signifikant nach Erhalt der endgültigen Histologie (Median: 14,5, 6-28, $p=0,171)$. Variablen wie familiäre Unterstützung, Familienstand, Beschäftigung, Bildung, Religiösität hatten keinen Einfluss auf die FCR. Ebenso histologische Variablen wie Organbegrenzung, Lymphknotenstatus und Resektionsstatus.

Nach unserem Wissen ist dies die größte Studie zu FCR bei Patienten mit Urothelkarzinom. Die Patienten zeigen relevante FCR. Allerdings scheint die Tatsache der Erkrankung selbst die FCR am meisten zu beeinflussen und familiäre Unterstützung oder histologische Variablen haben keinen Einfluss auf die Rezidivangst.

\section{V14.7}

\section{Einfluss der postoperativen Frühkontinenz nach} radikaler Prostatektomie auf die Lebensqualität

M. Heydenreich*, D.-H. Zermann

Vogtland-Klinik Bad Elster, Bad Elster, Deutschland

Fragestellung: Die postop. Harninkontinenz bleibt trotz deutlich verbesserter operativer Ergebnisse in den letzten Jahren nicht ohne Auswirkungen auf die psychosoziale Gesundheit. Ziel der Studie war es zu überprüfen, welchen Einfluss die frühe Kontinenzsituation auf die gesundheitsbezogene Lebensqualität (LQ) der Betroffenen hat.

Material und Methoden: 92 Patienten ( 6 64,0 Jahre) nach radikaler Prostatektomie nahmen an der Studie teil. Die gesundheitsbezogene LQ (FACT-G) und Prostata spezifischen Funktionseinschränkungen (FACT-P) wurde mittels Fragebogen (Functional Assessment of Cancer Therapy) am Anfang einer AHB (MW - 14,8 d p.o.) erhoben. Die Bestimmung des Schweregrades der Harninkontinenz erfolgte mit Hilfe des 1-h-Pad Test. Ergebnisse: Es zeigen sich signifikante LQ-Unterschiede beim körperlichen Befinden und im FACT-P zwischen geringen und höheren Urinverlustmengen.

Schlussfolgerungen: Die Studienergebnisse zeigen, dass bei Patienten mit höherem Urinverlust ( $>50 \mathrm{~g} / 1$-h-Pad-Test) die gesundheitsbezogene Lebensqualität (körperliches Wohlbefinden, FACT-P Fragebogen) negativ beeinflusst wird. Demzufolge sollten diese Patienten neben der therapeutischen Behandlung der Harninkontinenz eine zielgerichtete fachärztlich urologische Beratung und psychologische Unterstützung im Rahmen der Uro-AHB erhalten.

\section{V14.8}

Harn- und stuhlkontinenzbezogene Lebensqualität bei Jugendlichen und Erwachsenen mit kloakaler Ekstrophie

\footnotetext{
M. Himmler ${ }^{1 *, 2}$, J. Mühlbauer ${ }^{1}$, N. Schwarzer ${ }^{3}$, M. Grilli ${ }^{4}$ R. Stein ${ }^{2}$, N. Younsi ${ }^{2}$

'Universitätsmedizin Mannheim, Klinik für Urologie und Urochirurgie, Mannheim, Deutschland; ${ }^{2}$ Universitätsmedizin Mannheim, Zentrum für Kinder-, Jugend- und Rekonstruktive Urologie, Mannheim, Deutschland; ${ }^{3}$ SoMA e.V., München, Deutschland; ${ }^{4}$ Bibliothek der Universitätsmedizin Mannheim, Mannheim, Deutschland
}

Einleitung: Ziel dieser Studie war die Evaluation der Harn- und Stuhlkontinenz bei jugendlichen und erwachsenen Patienten mit kloakaler Ekstro- phie (CE) in Deutschland sowie die Evaluation der inkontinenzbezogenen Lebensqualität (QoL).

Materialien und Methoden: CE-Patienten eines tertiären Versorgungszentrums und der Selbsthilfegruppe für Anorektal-Fehlbildungen (SoMA e.V.) wurden mittels 18 unabhängigen Fragen sowie dem validierten King's health questionnaire (KHQ) und dem Questionnaire on Quality of Life in Fecal Incontinence (FLQAI) auf Deutsch bezüglich der Prävalenz und der QoL bei bestehender Harn- und Stuhlinkontinenz befragt.

Ergebnisse: Insgesamt wurden 23 Patienten eingeschlossen. 14 von 19 Patienten mit kontinenter Harnableitung berichteten über ungewollte Urinverluste. Harnableitung und ungewollter Urinverlust (hier mit Ausnahme von "Umgang mit der Inkontinenz" und "Nächtliche Inkontinenz") hatten im KHQ keinen signifikanten Einfluss auf die QoL. Von 18 Patienten mit und 5 ohne Anus präter gaben 5 bzw. 3 einen ungewollten Stuhlverlust an. Weder die Art der Darmentleerung noch ungewollter Stuhlverlust zeigten im FLQAI signifikanten Einfluss auf die QoL. Im Vergleich mit bereits publizierten Referenzgruppen zeigten die meisten KHQ-Domänen signifikante Unterschiede, die FLQAI-Items nur bei einer der zwei Vergleichsgruppen. Die QoL war in fast allen KHQ-Domains niedriger als in der Referenzgruppe.

Schlussfolgerung: Dies ist die erste Studie zur inkontinenzbezogenen QoL von CE-Patienten mit validierten Fragebögen. Die Versorgung ist hinsichtlich der Kontinenzraten optimierbar. Die inkontinenzbezogene QoL wurde kaum durch die Inkontinenz und die Art der Harnableitung/Stuhlentleerung beeinflusst, war jedoch im Vergleich zu publizierten Referenzgruppen reduziert.

\section{V14.9}

Die Kurzform des Qualiveen@ Fragebogens ist ein valides Instrument für die Erfassung der blasenbezogenen Lebensqualität von Personen mit einer chronischen neurogenen Blasenfunktionsstörung

J. Wöllner ${ }^{1 *}$, J. Pannek1 ${ }^{1}$ A. Widmer ${ }^{1}$, J. Krebs²

${ }^{1}$ Schweizer Paraplegiker Zentrum, Neuro-Urologie, Nottwil, Schweiz; ${ }^{2}$ Schweizer Paraplegiker Zentrum, Clinical Trial Unit, Nottwil, Schweiz

Fragestellung: Der Qualiveen® Fragebogen zur Erfassung der blasenbezogenen Lebensqualität von Personen mit einer neurogenen Blasenfunktionsstörung (NBFS) umfasst 30 Fragen und ist zu umfangreich, um im klinischen Alltag standardisiert eingesetzt zu werden. Die existierende Kurzform, ist in deutscher Sprache nicht validiert.

Material und Methoden: Personen mit einer chronischen ( $>1$ Jahr) neurogenen Blasenfunktionsstörung, wurden im Rahmen der ambulanten Kontrolle in der Neuro-Urologie des Schweizer Paraplegiker-Zentrums Nottwil, eingeschlossen. Die Studienteilnehmer füllten zweimal, im Abstand von 14-30 Tagen, die Voll- und Kurzversion des Qualiveen॰ Fragebogens aus. Patientencharakteristika (Höhe, Ausprägung der Querschnittlähmung, Blasenmanagement, Inkontinenz, Harnweginfekte) wurden erhoben. Zur Beurteilung der Validität und Test-Retest-Zuverlässigkeit der Kurzversion wurde der Intraklassen-Korrelationskoeffizient berechnet. Ergebnisse: Das Durchschnittsalter ( $n=50$ Studienteilnehmer, 35/70\% Männer und $15 / 30 \%$ Frauen) war $53 \pm 14$ Jahre und die Dauer der NBFS $19,3 \pm 14,0$ Jahre. Eine Tetraplegie zeigte sich bei $26 \%$ (13/50) der Patien- 
ten. Die Mehrzahl entleerte die Blase durch intermittierendes Katheterisieren (30/60\%). $40 \%$ (20/50) berichteten über Inkontinenz und $36 \%$ (18/50) über Harnweginfekte. 35 (70\%) Teilnehmer füllten die Fragebogen nach 38,0 $\pm 32,6$ Tagen ein zweites Mal aus.

Die Kurzversion zeigte an beiden Zeitpunkten eine sehr gute Validität im Vergleich zur Vollversion $(0,91 / 0,62-0,97$ und $0,93 / 0,64-0,98)$ und eine sehr gute Zuverlässigkeit in der Testwiederholung $(0,94 / 0,89-0,97)$.

Schlussfolgerungen: Die Kurzform des Qualiveen $\odot$ Fragebogens in deutscher Sprache ist valide und kann zur Erfassung der Lebensqualität im klinischen Alltag eingesetzt werden.

\section{V15 - Rekonstruktion und Regeneration des unteren Harntrakts}

\section{$17.09 .2021, C 7.2,13: 30-15: 00$}

\section{V15.1}

Thalidomide-analogue lenalidomide inhibits human prostate smooth muscle contraction: a therapeutic option in male LUTS?

A. Tamalunas'", C. Sauckel', A. Ciotkowska', R. Huang', C. Gratzke'2, C. Stief', M. Hennenberg

'Urologische Klinik und Poliklinik, Klinikum der Universität München, LMU München, München, Germany; ${ }^{2}$ Albert-Ludwigs-Universität Freiburg, Urologie, Freiburg, Germany

Introduction: Medical treatment for LUTS/BPO includes reduction of smooth muscle tone in the prostate. Recently we could show that thalidomide inhibits prostate smooth muscle contraction and that lenalidomide reduces prostate stromal cell growth and modulates cytoskeletal actin organization. Here, we addressed effects of thalidomide-analogue lenalidomide on adrenergic and non-adrenergic contractions of human prostate smooth muscle.

Methods: Prostate tissues were obtained from patients undergoing radical prostatectomy for prostate cancer ( $n=33$ patients). Contractility of prostate strips was then assessed in an organ bath.

Results: Noradrenaline-induced adrenergic contractions were decreased up to over $51 \%$ with lenalidomide $(20 \mu \mathrm{M})$ for concentrations of $1-100 \mu \mathrm{M}$ $(p<0.03$ at $100 \mu \mathrm{M}$ for lenalidomide vs. control), up to $67 \%$ for $1-100 \mu \mathrm{M}$ of methoxamine-induced contractions ( $p<0.01$ at $1 \mu \mathrm{M}, 3 \mu \mathrm{M}, 10 \mu \mathrm{M}$, $30 \mu \mathrm{M}, 100 \mu \mathrm{M}$ for lenalidomide vs. control), and up to $33 \%$ for $1-100 \mu \mathrm{M}$ of phenylephrine-induced contractions $(p<0.02$ at 3 and $10 \mu \mathrm{M}$ for lenalidomide vs. control). Lenalidomide inhibited non-adrenergic contraction with endothelin- 1 up to $88 \%$ ( $p<0.05$ at $0.1 \mu \mathrm{M}, 0.3 \mu \mathrm{M}, 3 \mu \mathrm{M}$ endothelin-1, for lenalidomide vs. control) and contractions by thromboxane $A 2$ analogue U46619 up to $122 \%$ ( $p<0.01$ at $0.1 \mu \mathrm{M}, 0.3 \mu \mathrm{M}, 1 \mu \mathrm{M}, 10 \mu \mathrm{M}$, $30 \mu \mathrm{M}$ U46619, for lenalidomide vs. control). Significant inhibition up to $96 \%$ also occurred in EFS-induced neurogenic contractions for $2-32 \mathrm{~Hz}$ ( $p<0.02$, at $4-32 \mathrm{~Hz}$, for lenalidomide vs. control).

Conclusions: While Lenalidomide inhibits prostate stromal cell growth and modulates cytoskeletal development, it also inhibits adrenergic and non-adrenergic prostate smooth muscle contraction. Therefore, lenalidomide may be superior to current medical treatment.
V15.2

Alpha $_{1}$-adrenoceptor antagonism and inhibition of neurogenic smooth muscle contraction by mirabegron in the human prostate

R. Huang*, Y. Liu, A. Tamalunas, R. Waidelich, F. Strittmatter, C. G. Stief, M. Hennenberg

Urologische Klinik und Poliklinik, Klinikum der Universität München, LMU München, München, Germany

Introduction: Male lower urinary tract symptoms (LUTS) include obstructive symptoms attributed to benign prostatic hyperplasia and storage symptoms due to overactive bladder. Mirabegron is a $\beta_{3}$-adrenoceptor agonist and available for treatment of storage symptoms. Despite its clinical use in LUTS, effects in the prostate are hardly characterized. Off-target effects may include antagonism of $a_{1}$-adrenoceptors, which are an important target in obstructive symptoms. However, improvements by mirabegron did not become unequivocally obvious during clinical application. Here, we examined mirabegron effects on contractions of human prostate tissues and proliferation of prostate stromal cells.

Methods: Prostate tissues were obtained from radical prostatectomy. Contractions were studied in an organ bath, and effects on WPMY-1 cells in cell culture.

Results: $5 \mu \mathrm{M}$ and $10 \mu \mathrm{M}$ mirabegron, but not $1 \mu \mathrm{M}$ inhibited neurogenic contractions of human prostate tissues. $5 \mu \mathrm{M}$ and $10 \mu \mathrm{M}$ mirabegron, but not $1 \mu \mathrm{M}$ shifted concentration response curves for noradrenaline-, methoxamine- and phenylephrine-induced contractions to the right, including recovery of contractions at high agonist concentrations, increased $\mathrm{EC}_{50}$ values, and unchanged $E_{\max }$ values. Endothelin-1-induced contractions were not affected. U46619-induced contractions were slighly inhibited. Effects of mirabegron on proliferation and viability of stromal cells were neglectable or small (maximum decreases: $8 \%$ proliferation, $17 \%$ viability). Conclusions: Mirabegron inhibits neurogenic and $a_{1}$-adrenergic human prostate smooth muscle contractions. Effects are based on antagonism of $a_{1}$-adrenoceptors, but do not include $\beta_{3}$-adrenoceptors and require concentrations ranging $50-100$ fold higher than plasma concentrations during normal dosing.

\section{V15.3}

Neue Matrix zur Rekonstruktion und Regeneration von Harnröhrenstrikturen im Tiermodell

\author{
S. Aufderklamm*, A. Kelp, A. Stenzl, B. Amend \\ Eberhard Karls Universität Tübingen, Urologie, Tübingen, Deutschland
}

Einführung: Das Ziel dieser Studie war es, eine neue, mit humanen Urothelzellen (HUC) beschichtete Matrix (Collagen Cell Carrier-CCC) für die Harnröhrenrekonstruktion im Tiermodell zu evaluieren

Methoden: Für diese Studie wurden 14 männliche Göttinger Minischweine mit Immunsuppression (Cyclosporin A) verwendet (4 Schweine CCC mit HUC luminal vs. antiluminal; 6 Schweine mit CCC mit HUC, 2 Schweine nur CCC, 2 Schweine Sham). 6 Wochen nach Induktion der Harnröhrenstriktur und Vesikostomie wurde die Rekonstruktion mit CCC (+ - HUC) oder Sham (primäre Rekonstruktion) durchgeführt. Die HUC's wurden mit PKH26 markiert. 2 und 4 Wochen sowie 3 Monate nach der Rekonstruktion wurden die Tiere euthanasiert und urographisch sowie histologisch untersucht

Ergebnisse: Antiluminal implantiertes HUC zeigte eine stärkere PKH26Ablösung von CCC als luminal implantierte Zellen. In der endgültigen Urethrographie konnte in der 3-Monats-Gruppe keine verbleibende signifikante Striktur festgestellt werden. Im Gegensatz dazu wurde in der Sham-Gruppe bei der Abschlussuntersuchung eine anhaltende urographische Harnröhrenstriktur festgestellt. Darüber hinaus zeigte die Harnröhre in der 3-Monats-Gruppe, die CK20, E-Cadherin und ZO-1 exprimierte, intaktes und regeneriertes Urothel, während 1 von 2 SHAM-Tieren eine 
histologisch diskontinuierliche Harnröhre aufwies. Es wurden keine signifikanten Unterschiede zwischen CCC mit und ohne HUC gefunden Fazit: Im Vergleich zur Kontrollgruppe mit primärer Harnröhrenrekonstruktion scheint CCC mit oder ohne HUC die Stabilität der rekonstruierten Harnröhre zu erhöhen und das Überleben und Wachstum von ausgesäten Urothelzellen zu unterstützen, was zu einer intakten Regeneration des Urothelgewebes führt

\section{V15.4}

\section{Pentosan polysulfate sodium (PPS) affects marker expression in bladder organoids}

\author{
J. Neuhaus ${ }^{1 *}$, A. Weimann ${ }^{1}$, A. Gonsior ${ }^{2}$, M. Berndt-Paetz ${ }^{1}$ \\ 'Department of Urology, University of Leipzig, Research Laboratories, Leipzig, Germany; \\ ${ }^{2}$ Department of Urology, University Hospital Leipzig, Leipzig, Germany
}

Introduction: Interstitial cystitis/bladder pain syndrome (IC/BPS) is a disabling, poorly understood syndrome of lower urinary tract dysfunction. Since good animal models are missing, we developed an 3D-organoid model to mimic certain aspects of IC/BPS in vitro. Here we report on the effect, of PPS, the only approved oral therapeutic of IC/BPS, on the expression of marker proteins.

Material and methods: Organoids were established from human urothelial cells (HBLAK), bladder fibroblasts and smooth muscle cells in ultra-low attachment 96-well plates, grown with/without $10 \mathrm{~d}$ differentiation medium to $700-1.000 \mu \mathrm{m}$ in diameter, and treated with $150 \mu \mathrm{g} / \mathrm{ml} \mathrm{PPS} \mathrm{for} 2 \mathrm{~h}$ or $18 \mathrm{~h}$. Paraffin sections were used for immunofluorescence of cytokeratins (panCK, CKAE, CK5 +6, CK7, CK20), connexins (Cx43, Cx45), tight junction proteins (ZO-1, ZO2), muscarinic receptors (M2R, M3R), heparan sulfate (PERL), and uroplakin III (UPL-III). PPS was detected by a custom biotinylated anti-PPS antibody and streptavidin-Alexa 555 .

Results: Uptake and distribution of PPS was different depending on differentiation, indicating a barrier function of the HBLAK cell layer. Marker expression varied in organoids treated with PPS for $2 \mathrm{~h}$ or $18 \mathrm{~h}$ compared no PPS. Semi-quantitative analysis revealed upregulation of Cx43, UPL-III, M2R, while PERL was downregulated. The other markers did not show significant differential expression.

Conclusions: For the first time we showed effects of PPS treatment on marker expression in HBLAK organoids. This $3 \mathrm{D}$ in vitro-model is promising for use as complement to animal models in IC/BPS research.

Acknowledgements

The study was funded by Wissenschaftsstiftung Leipzig, Markkleeberg, Germany, and bene-pharmaChem (Geretsried, Germany), also kindly providing PPS and anti-PPS antibodies.

\section{V15.5}

\section{ADP ribosylation factor 6 is required for smooth muscle contraction and stromal proliferation in the prostate, and is specifically inhibited by NAV2729}

\section{R. Wang ${ }^{1 *}$, S. Schneider ${ }^{2}$, O.T. Keppler', B. Li', C. G. Stief', M. Hennenberg'}

'Urologische Klinik und Poliklinik, Klinikum der Universität München, LMU München, München, Germany; ${ }^{2}$ Max von Pettenkofer Institute and Gene Center, Virology, National Reference Center for Retroviruses, Faculty of Medicine, LMU Munich, München, Germany

Introduction: The presumed ARF6 inhibitor NAV2729 inhibits human prostate smooth muscle contraction and proliferation of stromal cells, which are driving factors of voiding symptoms in benign prostatic hyperplasia (BPH). However, its specificity and a confirmed role of ARF6 for smooth muscle contraction are pending. Here, we created Arf6 knockout clones of human prostate stromal cells, and characterized phenotypes of contractility, proliferation, and susceptibility to NAV2729.

Methods: Monoclonal Arf6 knockouts were generated in human prostate stromal cells (WPMY-1). Phenotypes were characterized by comparison to ARF6-expressing control clones. Effects of NAV2729 were assessed in knockout and control clones.

Results: ARF6 knockout was verified by Western blot. Knockout resulted in reduced contraction, breakdown of actin organization, reduced proliferation rate (EdU), reduced expression of the proliferation marker Ki-67, reduced viability, and increased apoptosis and cell death. In ARF6-expressing control clones, NAV2729 $(5 \mu \mathrm{M})$ reduced contraction, caused actin breakdown $(2.5-5 \mu \mathrm{M})$, reduced proliferation (EdU, Ki-67, both $5 \mu \mathrm{M}$ ), increased apoptosis and cell death $(5 \mu \mathrm{M})$, and reduced viability $\left(\mathrm{EC}_{50}\right.$ $\sim 2.5 \mu \mathrm{M}$ ). In ARF6 knockouts, effects of NAV2729 were widely reduced, represented by lacking effects on contractions ( $5 \mu$ M NAV2729), actin $(2.5-5 \mu \mathrm{M})$ and proliferation in EdU assays $(2.5-5 \mu \mathrm{M})$, only slight decreases of Ki-67 mRNA $(5 \mu \mathrm{M})$, lacking (additive) effects on apoptosis and cell death, and shifted effects on viability $\left(\mathrm{EC}_{50} \sim 5 \mu \mathrm{M}\right)$.

Conclusions: ARF6 promotes prostate smooth muscle contraction and proliferation of stromal cells. Both are inhibited by NAV2729, which shows high ARF6 specificity up to $5 \mu \mathrm{M}$ and represents an attractive compound in the context of $\mathrm{BPH}$.

\section{V15.6}

Die Sabal- und Urtica-Komponenten von WS ${ }^{\circledR} 1541$ tragen synergetisch zu anti-migratorischen und anti-proliferativen Wirkungen in humanen benignen Prostatahyperplasie-Epithelzellen bei

\author{
M.C. Michel ${ }^{2 *}$, C. Sens-Albert² ${ }^{2}$ B. König ${ }^{2}$, S. Melcher², S. Weisenburger ${ }^{2}$, \\ M. Lehner ${ }^{2}$
}

'Johannes Gutenberg Universität, Mainz, Deutschland; ${ }^{2}$ Dr. Willmar Schwabe GmbH \& Co KG, Preclinical R\&D, Karlsruhe, Deutschland

Fragestellung: Pro-migratorische und proliferative Phänotypen von Stromazellen spielen eine Rolle in der Progression der benignen Prostatahyperplasie (BPH). Wir haben den Einfluss der Sabal-Urtica-Kombination WS $^{\circledR} 1541$ und der Einzelextrakte auf die Migration, Apoptose und Proliferation in der epithelialen Zellline BPH-1, isoliert von einem BPH-Patienten, untersucht.

Material und Methoden: WS ${ }^{\circledR} 1541$ ist eine proprietäre Kombination von 160 mg Dickextrakt aus Sägepalmenfrüchten (10-14,3:1), Auszugsmittel: Ethanol $90 \%(\mathrm{~m} / \mathrm{m})$, (WS $\left.{ }^{\oplus} 1473\right)$ und $120 \mathrm{mg}$ Trockenextrakt aus Brennesselwurzeln (7,6-12,5:1), Auszugsmittel: Ethanol $60 \%(\mathrm{~m} / \mathrm{m})$ (WS $\left.{ }^{\oplus} 1031\right)$. BPH-1 Zellen wurden für 2, 24 oder 48 h mit WS ${ }^{\circledR} 1541$, WS ${ }^{\circledR} 1473$ (Sabal), WS $^{\circledR} 1031$ (Urtica) oder Finasterid behandelt. Die Migration wurde mit einem Gap-closing-Assay und die Proliferation mithilfe eines MTS-Assays untersucht. Die Apoptose wurde mit einem Annexin V/PI- und der Zellzyklus mit einem EdU-7AAD-Assay am FACS analysiert.

Ergebnisse: WS ${ }^{\circledR} 1541$ hemmte die Migration von BPH-1 Zellen, was durch Urtica $\left(\mathrm{IC}_{50}=7,5 \mu \mathrm{g} / \mathrm{ml}\right)$, aber nicht durch Sabal zu erklären ist. WS ${ }^{\circledast} 1541$ förderte die Apoptose von BPH-1 Zellen durch Sabal, aber nicht durch Urtica. Sowohl Sabal als auch Urtica hemmten die Proliferation der Zellen, wobei WS ${ }^{\circledR} 1541$ wirksamer war als jede Einzelkomponente. Dies geschah durch Blockade des Eintritts in die S-Phase. In allen drei Tests war Finasterid schwächer wirksam als der stärkere Extrakt.

Schlussfolgerung: WS ${ }^{\circledast} 1541$ hemmt die Migration und Proliferation und fördert die Apoptose von BPH-1 Zellen, wobei jede Komponente einen spezifischen Beitrag leistet. Dies könnte zur klinischen Wirksamkeit der Sabal-Urtica-Kombination WS ${ }^{\circledR} 1541$ beitragen und belegt, dass jede der beiden Komponenten eigenständig zur Gesamtwirkung beiträgt. 
Tab. 1 | V15.7 Vergleich der Ergebnisse der Druck-Fluss-Studie vor und nach Implantation eines ATOMS

\begin{tabular}{|l|l|l|l|}
\hline Variable & Mittelwert präoperativ & Mittelwert postoperativ & $\begin{array}{l}p \text {-Wert (Wilcoxon signed rank } \\
\text { test) }\end{array}$ \\
\hline $\begin{array}{l}\text { Zystometrisches maximales Bla- } \\
\text { senvolumen }(\mathrm{ml})\end{array}$ & $322(97-569)$ & $336(120-502)$ & 0,9 \\
\hline Maximaler Harnstrahl (ml/s) & $16,2(2-37)$ & $13,7(3-32)$ & 0,23 \\
\hline Restharn (ml) & $27,7(0-185)$ & $39,0(0-372)$ & 0,5 \\
\hline $\begin{array}{l}\text { Detrusordruck beim maximalen } \\
\text { Harnstrahl }\left(\mathrm{cmH}_{2} \mathrm{O}\right)\end{array}$ & $20,9(0-46)$ & $29,4(10-49)$ & 0,08 \\
\hline $\begin{array}{l}\text { Maximaler intravesikaler Druck in } \\
\text { der Entleerungsphase (cmH } \mathrm{O})\end{array}$ & $60,3(20-117)$ & $75,6(25-108)$ & 0,09 \\
\hline $\begin{array}{l}\text { BOOI (Bladder Outlet Obstruction } \\
\text { Index) }\end{array}$ & $-11,5((-69)-30)$ & $2,4((-32)-29)$ & 0,034 \\
\hline BCl (Bladder Contractility Index) & $95,9(10-213)$ & $96,8(40-199)$ & 1,0 \\
\hline
\end{tabular}

\section{V15.7}

Kompression oder Obstruktion: Prospektive Studie zur Überprüfung des Einflusses des Adjustable TransObturatoric Male System (ATOMS, A. M.I) auf den unteren Harntrakt anhand einer urodynamischen DruckFluss-Analyse vor und nach Implantation

F. Queissert ${ }^{1 *}$, B. Brücher', D. Klein', S. Ruiz², M. Virseda², A. J. Schrader'1, J. Angulo ${ }^{2}$

'Universitätsklinikum Münster, Abteilung für Urologie und Kinderurologie, Münster, Deutschland; ${ }^{2}$ Catedrático de Urología Universidad Europea de Madrid Hospital Universitario de Getafe, Getafe, Spanien

Einleitung: Diese Analyse einer prä- und postoperativen Urodynamik soll erstmals Aufschluss über den Einfluss des ATOMSystems auf den unteren Harntrakt geben.

Material und Methoden: Prospektive Untersuchung von Patienten mit einer Belastungsharninkontinenz und geplanter Implantation eines ATOMS nach Radikaler Prostatektomie. Neben der Erfassung der Kontinenzsituation (24 h pad-test, ICIQ-SF) erfolgt eine Urodynamik mit ICS-standardisierter Druck-Fluss-Analyse vor und nach Implantation/Adjustierung eines ATOMS. Die statistische Analyse erfolgte mittels Wilcoxon signed rank test. Ergebnisse: 12 Patienten aus 2 Zentren (69 Jahre) wurden inkludiert, das Follow up betrug im Mittel 246 Tage. Der mittlere Urinverlust sank von 359 (72-1250) auf postoperativ 70 (0-700) $\mathrm{g} / 24 \mathrm{~h}$ bei einer Vorlagenreduktion von 4/Tag auf 0,9 Vorlagen/Tag. In der Druck-Fluss-Analyse trat nur beim Bladder Outlet Obstruction Index (BOOI) eine signifikante Veränderung auf. Bladder Contractility Index, intravesikale Druckverhältnisse und Uroflowmetrie waren nicht signifikant beeinträchtigt. Bei keinem der Patienten zeigte sich in der ICS-Analyse postoperativ eine de novo Obstruktion. Schlussfolgerung: Das ATOMS bewirkt bei guten Kontinenzergebnissen zwar eine signifikante Erhöhung des BOOI. Eine de novo Obstruktion und somit potenzielle Gefahr für den unteren Harntrakt konnte jedoch nicht festgestellt werden.

\section{V15.8}

How strong is the correlation of voided volume with other parameters of overactive bladder syndrome?

F. Erbing ${ }^{1 * 2}$, T. Schneider ${ }^{2}$, S. Murgas ${ }^{3}$, Y. Igawa ${ }^{4}$, M. Michel ${ }^{1}$

'Universitätsmedizin der Johannes Gutenberg-Universität Mainz, Institut für Pharmakologie, Mainz, Germany; ${ }^{2}$ Praxisklinik Urologie Rhein-Ruhr, Mülheim, Germany; ${ }^{3}$ Apogepha, Dresden, Germany; ${ }^{4}$ Nagano Prefectural Shinshu Medical Center, Dept. of Urology, Suzaka, Japan
Question: The overactive bladder (OAB) syndrome is typically accompanied by a reduced bladder capacity as reflected by a lowered mean voided volume (MVV). MVV is often used in clinical trials as indicator of treatment effectcs. We have explored how well MVV and its changes occur to those of other $O A B$ parameters (urgency, incontinence, frequency, nocturia patient perception of bladder condition (PPBC), pad use).

Material and methods: Data from two previously reported, large, nonobservational studies (https://doi.org/10.3390/jcm10020311) were analyzed, in which 1335 and 745 patients had been treated with 30 or $45 \mathrm{mg}$ propiverine ER for 12 weeks. Non-parametric Spearman rank tests were used to test for pair-wise correlations between MVV on the one and age, urgency, incontinence, frequency, nocturia, PPBC and pad use on the other hand.

Results: Median MVV increased from $150 \mathrm{~mL}$ at baseline to $200 \mathrm{~mL}$ after 4 and to $220 \mathrm{~mL}$ after 12 weeks of treatment. Neither basal MVV nor treatment-associated changes thereof were correlated with age. While statistically significant correlations with $\mathrm{OAB}$ parameters were found consistently $(p \leq 0.0003)$, they were only weak to moderate (Spearman $r<0.5$, in most cases $<0.3$ ) in both datasets and were of similar extent for correlations of MVV with basal values and with treatment-associated changes thereof. Conclusion: The pathophysiologically expected correlation between MVV and other OAB-related parameters was confirmed in two large datasets. However, correlations were weak to moderate and MVV accounted for less than $25 \%$ of the variability of other $O A B$ parameters.

\section{V15.9}

Inhibition of prostate smooth muscle contraction and prostate stromal cell growth by the WNK inhibitor WNK463 and the NUAK inhibitor HTH01-015

Y. Liu*, R. Huang, B. Li, R. Wang, A. Tamalunas, R. Waidelich, F. Strittmatter, C.G. Stief, M. Hennenberg

Urologische Klinik und Poliklinik, Klinikum der Universität München, LMU München, München, Germany

Introduction: Medical treatment of lower urinary tract symptoms suggestive of benign prostatic hyperplasia targets $a_{1}$-adrenergic prostate smooth muscle contraction and prostate growth. However, the efficacy is limited as non-adrenergic contractions are not inhibited, and combination therapies are often applied. Consequently, identification of novel targets is of high demand. Recent evidence suggested procontractile roles of the kinase families WNK and NUAK. Here, we examined effects of the WNK inhibitor WNK463 and the NUAK inhibitor HTH01-015 on human prostate smooth muscle contraction and growth of stromal cells. 
Methods: Human prostate tissues were obtained from radical prostatectomy. Contractions were studied in an organ bath, and effects on WPMY-1 cells in cell culture.

Results: Neurogenic contractions of human prostate tissues were inhibited by WNK463 (500 nM) ( 50\%) and HTH01-015 (500 nM) ( 30\%). Contractions by a thromboxane $A_{2}$ analog were inhibited by WNK463 ( 50\%) and HTH01-015 (40-50\%). Endothelin-1-induced contractions were inhibited by WNK463 (35-50\%), but not HTH01-015. Both inhibitors reduced viability of stromal cells at concentrations $>1 \mu \mathrm{M}$ by, but not $<1 \mu \mathrm{M}$. Proliferation (EdU assays) was reduced by $13 \%$ and $57 \%$ by $1 \mu \mathrm{M}$ and $10 \mu \mathrm{M}$ WNK463, and by $52 \%$ by $10 \mu \mathrm{M}$ HTH01-015 (not by $2.5 \mu \mathrm{M}$ ). Growth of stromal cells (colony formation assays) was reduced by $39 \%$ and $66 \%$ by $1 \mu \mathrm{M}$ and $10 \mu \mathrm{M}$ WNK463, and by $30 \%$ and $78 \%$ by $2.5 \mu \mathrm{M}$ and $10 \mu \mathrm{M}$ HTH01-015.

Conclusions: WNK463 and HTH01-015 inhibit neurogenic and non-adrenergic contractions in the human prostate, and stromal cell growth in vitro. The translational value may be higher for WNK463, as the spectrum of inhibited non-adrenergic contractions was higher, and growth occurred at lower concentrations.

\section{V16 - Hodentumoren und Tumoren des äußeren Genitales}

17.09.2021, C4.2, 13:30-15:00

\section{V16.1}

MicroRNA-371a-3p und histologische Risikofaktoren bei Nichtseminom im klinischen Stadium 1

\section{K.-P. Dieckmann ${ }^{1 *}$, C. Dumlupinar ${ }^{2}$, A. Radtke ${ }^{2}$, C. Matthies ${ }^{3}$, R. Pichler ${ }^{4}$, G. Belge ${ }^{2}$}

'Asklepios Klinik Altona, Urologie, Hamburg, Deutschland; ${ }^{2}$ Universität Bremen, Fachbereich Biologie und Chemie, Bremen, Deutschland; ${ }^{3}$ Bundeswehrkrankenhaus Hamburg, Urologie, Hamburg, Deutschland; ${ }^{4}$ Universtätsklinik Innsbruck, Urologie, Innsbruck, Österreich

Einführung: Lymphovaskuläre Invasion (LV) und $>50 \%$ Embryonales Karzinom ( $>50 \% \mathrm{EC}$ ) sind Risikofaktoren für Progression bei testikulärem Nichtseminom (NS) im klinischen Stadium 1 (CS1). Die hochsensitive, spezifische microRNA-371a-3p (M371) kann selbst kleine NS detektieren. Die Hypothese ist, dass M371 Erhöhung nach Ablatio testis bei NS CS1 auf okkulte Metastasen deutet und ein besserer Risikomarker ist.

Patienten, Methoden: Prospektiv wurden bei 153 NS CS1 Patienten postoperative M371 Serumspiegel gemessen, präoperativ bei $n=131$. Folgende Faktoren wurden erfaßt: Alter, Tumorgröße, LV, $>50$ \% EC, Teratomkomponente, klassische Tumormarker. Die M371 Expression in den Kollektiven mit und ohne Risikofaktor wurden verglichen. Mit ROC Analyse wurde die Fähigkeit der M371 Expression zur Vorhersage von LV1 untersucht. Mit multipler Regression wurde nach Assoziationen der M371 Expression gesucht.

Ergebnisse: Postoperative M371 Erhöhung (29,4\% der Patienten) ist nicht assoziiert mit LV und $>50 \% \mathrm{EC}$, ebenso wenig der relative postoperative M371 Abfall. Die ROC Analyse ergab $A U C=0,5$ für postoperative M371 Spiegel. Aber präoperative M371 Erhöhung war signifikant mit LV1 $(p=0,003),>50 \%$ EC $(p=0,004)$ und Tumorgröße $(p=0,001)$ assoziiert. Präoperative M371 Spiegel haben eine $A U C=0,732$ für die Prädiktion von LV1.

Schlussfolgerungen: Postoperative M371 Erhöhung ist nicht assoziiert mit bekannten histologischen Risikofaktoren bei NS CS1 Patienten. Wahrscheinlich führt verlängerte Abklingrate bei großen Primärtumoren sowie vorzeitige postoperative Blutentnahme zu falsch-positiven Erhöhungen. Hingegen hat die präoperative M371 Erhöhung aufgrund signifikanter Assoziationen mit histologischen Faktoren das Potenzial zu einem neuen Risikofaktor.
V16.2

\section{Early relapse in seminoma is associated with reduced} overall survival

P. Paffenholz ${ }^{1 *}$, T. Nestler ${ }^{1,2}$, Y. Maatoug ${ }^{1}$, M. Brandenstein ${ }^{1}$, B. Köditz' ${ }^{1}$, D. Pfister ${ }^{1}$, A. Heidenreich ${ }^{1}$

'Universitätsklinikum Köln, Klinik und Poliklinik für Urologie, Uro-Onkologie, Roboterassistierte und Spezielle Urologische Chirurgie, Köln, Germany; ${ }^{2}$ Bundeswehrkrankenhaus Koblenz, Koblenz, Germany

Introduction: The characteristics and outcome associated with relapse in seminomatous testicular germ cell tumors (TGCT) are still unclear. Materials and methods: We performed a retrospective analysis including 348 patients with seminomatous TGCT, who were treated in or referred to our department from 2000 to 2020 . Early relapse was defined as tumour recurrence $<12$ months after successful treatment.

Results: 69/348 (20\%) seminoma patients relapsed during a median follow-up of 34 months [4-87]. The predominant site of relapse was the retroperitoneal space (75\%). Relapse was most commonly treated by chemotherapy (49\%), followed by chemotherapy plus RPLND (20\%) or RPLND alone (14\%). Of the 69 relapsing patients, 29 (42\%) patients had an early relapse and showed a significantly higher number of clinical stage $2 \mathrm{C}-3$ disease $(41 \%$ vs. $13 \%, p=0.006)$, S-stage $\geq 2(50 \%$ vs. $23 \%, p=0.027)$ as well as a higher IGCCCG risk group $(p=0.027)$ at diagnosis compared to patients with late relapse. Of those with numerous relapses, all patients with late relapses $(n=5)$ had clinical stage 1 at diagnosis and were treated with active surveillance $(n=4)$ or one cycle of carboplatin $(n=1)$, while the majority $(5 / 6,83 \%)$ of all patients with early relapses initially had metastatic disease and received chemotherapy. In the Kaplan-Meier estimates, early relapse was associated with a significantly reduced overall survival compared to late relapse $(p=0.013)$, however median overall survival was not reached.

Conclusion: Relapse in seminoma occurred in $20 \%$ of all patients. Of note, early relapses were associated with a higher metastatic burden and worse prognosis at diagnosis compared to late relapses, leading to a reduced overall survival in early relapsing seminoma patients compared to late relapsing patients.

\section{V16.3}

\section{Effektivität der adjuvanten Chemotherapie mit $1 \times$ PEB} beim Nichtseminom im klinischen Stadium 1

\section{K.-P. Dieckmann 1" , D. Niehaus' ${ }^{1}$, L. Geczi ${ }^{2}$, T. Pokrivcak ${ }^{3}$, C. Matthies ${ }^{4}$, M. Pichler ${ }^{5}$}

'Asklepios Klinik Altona, Urologie, Hamburg, Deutschland; ${ }^{2}$ National Institute of Oncology, Oncology, Budapest, Ungarn; ${ }^{3}$ Masaryk Memorial Cancer Institute, Clinical Oncology, Brno, Tschechische Republik; ${ }^{4}$ Bundeswehrkrankenhaus Hamburg, Urologie, Hamburg, Deutschland; ${ }^{5}$ Medizinische Universität Graz, Onkologie, Graz, Österreich

Fragestellung: Das klinische Stadium 1 (CS1) des Nichtseminoms ist praktisch bedeutsam, weil etwa $20 \%$ aller Keimzelltumoren diese Konstellation aufweisen. Die adjuvante Chemotherapie mit einem Zyklus Cisplatin, Etoposid, Bleomycin ( $1 \times \mathrm{PEB})$ ist gut verträglich und läßt nur in etwa $5 \%$ ein Rezidiv zu. Die Rezidivtherapie ist in $80 \%$ erfolgreich. Die vorliegende Studie prüft die Hypothese, dass die Erfolgsrate von $1 \times \mathrm{PEB}$, die auf nur 5 kontrollierten Studien beruht, auch in der klinischen Versorgungsrealität reproduziert werden kann.

Material und Methoden: In einer Umfrage an 45 Institutionen in 6 europäischen Ländern wurden aus 32 Kliniken insgesamt 412 Patienten gemeldet, die im CS1 des Nichtseminom mit $1 \times$ PEB behandelt wurden und $>6$ Monate Nachbeobachtung aufweisen. Die folgenden Parameter wurden registriert: Alter (Jahre), Tumorgröße $(\mathrm{mm})$, vaskuläre Invasion (ja/ nein), pT-Stadium, >50 \% Embryonales Karzinom (ja/nein), Nachsorgezeitraum (Monate), Rezidiv (ja/nein, Zeitintervall), Ergebnis der Rezidivtherapie. Die Ergebnisse wurden deskriptiv statistisch ausgewertet.

Ergebnisse: Insgesamt 15 Patienten (3,64\%) entwickelten ein Rezidiv nach einem medianen Intervall von 28 Monaten. Von den Rezidivpati- 
enten hatten 7 (47\%) eine vaskuläre Invasion, 7 (47\%) einen Anteil von $>50 \%$ Embryonales Karzinom. Ein Patient verstarb an Therapiekomplikationen. Die Rezidivtherapie war erfolgreich bei 14 Patienten (93\%).

Schlussfolgerungen: Die Rezdivrate der adjuvanten Therapie mit $1 \times$ PEB im CS1 des Nichtseminoms ist in der realen Versorgungssituation nahezu identisch mit den Ergebnissen aus kontrollierten Studien. Die Rezidive können in der überwiegenden Mehrheit der Fälle geheilt werden. Die $1 \times$ PEB Therapie ist somit eine sichere adjuvante Behandlung im CS1 des Nichtseminoms.

\section{V16.4}

Neudiagnose Hodentumor: 32-Monatsdaten aus der VERSUS-Studie von d-uo

J. Klier ${ }^{*}$, M. Johannsen'2 , F. König ${ }^{3}$, R. Schönfelder ${ }^{4}$, R. Eichenauer ${ }^{5}$, J. Schröder ${ }^{3}$, E. Hempel ${ }^{6}$, C. Doehn

'Urologische Partnerschaft Köln, Köln, Deutschland; ${ }^{2}$ Urologische Facharztpraxis Johannsen \& Laux, Berlin, Deutschland; ${ }^{3}$ ATURO, Berlin, Deutschland; ${ }^{4}$ Urologie Schönfelder \& Straßer, Hamburg, Deutschland; ${ }^{5}$ Urologikum Hamburg, Hamburg, Deutschland; ${ }^{6}$ SMG Forschungsgesellschaft, Berlin, Deutschland; ${ }^{7}$ Urologikum Lübeck, Lübeck, Deutschland

Einleitung: Eine Voraussetzung für die Erfassung und wissenschaftliche Auswertung der Versorgungsqualität urologischer Tumorerkrankungen ist deren standardisierte Dokumentation. Seit Mai 2018 dokumentieren Mitglieder von d-uo urologische Tumorerkrankungen im Rahmen der prospektiven VERSUS-Studie.

Material und Methoden: Es handelt sich bei der VERSUS-Studie um eine nicht-interventionelle, prospektive, multizentrische Registerstudie zur Dokumentation und deskriptiven statistischen Auswertung von Diagnostik, Behandlungsverlauf und Nachsorge uro-onkologischer Patienten. In der vorliegenden Arbeit wurden Patienten mit der Erstdiagnose Hodentumor untersucht.

Ergebnisse: Bis Dezember 2020 wurden 7469 Patienten mit der Erstdiagnose einer urologischen Tumorerkrankung dokumentiert. Bei 305 Männern $(4,1 \%)$ lag ein Hodentumor vor. Bei 225 Patoenten (73,8\%) wurde der Hodentumor aufgrund einer Selbstuntersuchung und bei 12 Patienten $(28,6 \%)$ wegen einer Symptomatik diagnostiziert. Ein Seminom hatten $74,8 \%$ der Patienten und ein Nichtseminom 25,2 \%. Für 225 Patienten $(73,8 \%)$ war ein TNM-Stadium verfügbar. Die Verteilung der T-Stadien war: $146 \times \mathrm{T} 1(64,9 \%), 66 \times \mathrm{T} 2(29,3 \%), 11 \times \mathrm{T} 3(4,9 \%)$ und $2 \times \mathrm{T} 4(0,9 \%)$. Bei 15 Patienten $(6,7 \%)$ lag ein primäres $\mathrm{N}(+)$-Stadium und bei 12 Patienten (5,3\%) ein primäres $M(+)$-Stadium. Bei 55 Männern (18\%) wurde eine Kryokonservierung vorgenommen und bei 122 Patienten (40\%) nicht. In den restlichen Fällen war die Information nicht bekannt.

Schlussfolgerung: Ein Hodentumor macht laut RKI 3,5\% aller urologischen Tumorerkrankungen aus. Die Ergebnisse aus der vorliegenden VERSUS-Studie sind mit 4,1 \% vergleichbar. Bei mehr als einem Drittel der Männer fiel der Tumor durch eine Selbstuntersuchung und bei mehr als jedem vierten Mann durch Symptomatik auf.

\section{V16.5}

Was wissen Jugendliche über den Hodentumor?

O. Anegg ${ }^{1 *}$, I. Schauer', S. Madersbacher ${ }^{1,2}$

${ }^{1}$ Klinik Favoriten, Wien, Österreich; ${ }^{2}$ Sigmund Freud Privatuniversität, Wien, Österreich

Einleitung: Hodentumore sind die häufigste Tumorerkrankung des jungen Mannes, weshalb die regelmäßige Selbstuntersuchung zur Früherkennung empfohlen wird. Da zum Wissensstand Jugendlicher diesbezüglich aus Österreich keine Studien vorliegen, war das Ziel dieser Untersuchung diesen zu erfassen.

Methodik: Zur Evaluierung des Wissensstandes zu Anatomie und Funktion des männlichen Geschlechtstrakts und des Hodentumors wurde ein Fragebogen eingesetzt, der kürzlich von Anheuser et al. (Urologe 2019; 58:1331) etabliert und eingesetzt wurde. Dieser Fragebogen umfasst 15 großteils multiple-choice-Fragen. Im Herbst 2020 wurde dieser an 3 Schulen eingesetzt, befragt wurden Schüler in der 11. und 12. Schulstufe Ergebnisse: 337 Jugendliche wurden befragt, f: 154, m: 183. In einer einfachen Skizze konnten $63 \%$ die Prostata, $87 \%$ den Hoden und $64 \%$ den Nebenhoden korrekt benennen. Knapp die Hälfte konnte die Funktion des Hodens beschreiben (49,3\%). Die Frage zum Altersgipfel des Hodentumors konnten $81 \%$ richtig beantworten. $18 \%$ gaben an, dass der Hodentumor durch sexuellen Kontakt entstehen würde. Aufgabe und Sinn der regelmäßigen Selbstuntersuchung des Hodens konnten nur 54,9\% richtig benennen ( $\mathrm{m}: 44,3 \%, \mathrm{f}: 67,5 \%, p=0,001$ ). Bei einem maximalen Gesamtscore von 15 erreichten die Schüler einen Durchschnittswert von 10,4, wobei insgesamt kein Unterschied zwischen beiden Geschlechtern nachweisbar war. Signifikante Unterschiede bei den korrekten Antworten fanden sich hinsichtlich Schultypus: Gymnasium $(11,2)$, Realgymnasium $(10,8)$ und höheren technischen Lehranstalt $(9,8),(p=0,001)$.

Schlussfolgerung: Diese Untersuchung bestätigt die deutsche Studie von Anheuser et al. und belegt deutliche Wissensdefizite hinsichtlich Hodentumor und Früherkennung bei Jugendlichen.

\section{V16.6 \\ Selbstuntersuchung von Hoden und Brust - eine retrospektive Kohortenstudie an Medizinstudierenden}

M. Jahnen ${ }^{1 *}$, L. Dichtl' ${ }^{1}$ N. Stirenberg ${ }^{1}$, A. Dinkel ${ }^{2}$, S. Schiele ${ }^{1}$, H. Schulwitz', J. Gschwend', K. Herkommer'

'Klinik und Poliklinik für Urologie, Klinikum rechts der Isar, Fakultät für Medizin, Technische Universität München, München, Deutschland; ${ }^{2}$ Klinik und Poliklinik für Psychosomatische Medizin und Psychotherapie, Klinikum rechts der Isar, Fakultät für Medizin, Technische Universität München, München, Deutschland

Fragestellung: Durch eine regelmäßige Selbstuntersuchung kann ein Malignom der Hoden oder Brust ggf. frühzeitiger erkannt und kurativ behandelt werden. Ziel dieser Arbeit war es, das Selbstuntersuchungsverhalten von Medizinstudierenden zu untersuchen und Faktoren, die eine regelmäBige Selbstuntersuchung beeinflussen, zu identifizieren.

Material und Methoden: Medizinstudierende wurden mittels Fragebogen bezüglich ihres Gesundheits- und Sexualverhaltens befragt. 98,8\% der Studierenden nahmen teil $(N=473)$. Die erhobenen Daten wurden mittels univariater und multivariater logistischer Regression analysiert.

Ergebnisse: $64,2 \%$ der männlichen Studierenden $(n=177)$ gaben an, regelmäßig ihre Hoden zu untersuchen und $72,2 \%$ der weiblichen Studierenden $(n=296)$ gaben an, regelmäßig ihre Brust abzutasten. Studierende, die nicht mit ihrer/ihrem Partnerln bzw. mit ihren Freunden/ Freundinnen über ihre Sexualität sprechen, führten seltener eine Selbstuntersuchung durch $(p<0,05)$. Männliche Studierende, die in den letzten vier Wochen vor Befragung keinen Geschlechtsverkehr hatten und weibliche Studierende die im gleichen Zeitraum nicht masturbierten, führten seltener eine Selbstuntersuchung durch $(p<0,05)$.

Schlussfolgerung: Der Anteil an Medizinstudierenden, der eine regelmäBige Selbstuntersuchung durchführt, ist hoch. Wissen über die Relevanz von Hodenkrebs bzw. Brustkrebs scheint grundlegend für eine regelmäßige Selbstuntersuchung zu sein. Ein belastetes Sexualleben schränkt solch ein Gesundheitsverhalten möglicherweise ein. Eine Verbesserung der Aufklärung über Hodenkrebs und die urologische Anbindung von Jungen/ junger Männer bieten daher die Möglichkeit, die Bereitschaft zur Selbstuntersuchung zu steigern. 


\section{V16.7}

\section{miRNA expression profile in different histological} subtypes in penile squamous cell carcinoma

\section{H. Ayoubian ${ }^{\text {* }}$, J. Heinzelmann², S. Hölters ${ }^{3}$, O. Khalmurzaev ${ }^{4}$, A. Pryalukhin ${ }^{5}$, P. Loertzer ${ }^{6}$, J. Heinzelbecker', S. Lohse ${ }^{7}$, C. Geppert ${ }^{8}$, H. Loertzer ${ }^{6}$, H. Wunderlich' ${ }^{9}$ R. M. Bohle ${ }^{10}$, M. Stöckle', V. B. Matveev ${ }^{4}$, A. Hartmann ${ }^{8}$, K. Junker ${ }^{1}$}

'Saarland University, Department of Urology and Paediatric Urology, Homburg, Germany; 2Universitätsklinikum Halle (Saale), Universitätsklinik und Poliklinik für Augenheilkunde, Halle/Saale, Germany; ${ }^{3}$ Ingenieurbüro für Gesundheitswesen GmbH, Leipzig, Germany; ${ }^{4}$ Federal State Budgetary Institution, N. N. Blokhin National Medical Research Center of Oncology, Moscow, Russische Föderation; ${ }^{5}$ Landesklinikum Wiener Neustadt, Department of Pathology, Wien, Austria; ${ }^{6}$ Westpfalz-Klinikum, Clinic of Urology and Paediatric Urology, Kaiserslautern, Germany; ${ }^{7}$ Saarland University, Institute of Virology, Homburg, Germany; ${ }^{8}$ University Erlangen-Nuremberg, Institute of Pathology, Erlangen, Germany; ${ }^{9}$ St. Georg Klinikum, Clinic of Urology and Paediatric Urology, Eisenach, Germany; ${ }^{10}$ Saarland University Medical Center, Institute of Pathology, Homburg, Germany

Background: Prognostic parameters for individual therapy selection in penile squamous cell carcinoma (PSCC) are still missing, and the impact of HPV infection remains unclear. We aimed to characterize the miRNA expression profiles in different histological subtypes of PSCC in the context of HPV infection.

Materials and methods: Microarray analysis was performed on RNA isolated from 30 FFPE tissue samples. Microarray data were validated by qRTPCR on an enlarged cohort.

Results: We found 876 significantly differentially expressed miRNAs between HPV-positive and HPV-negative tumors. Specific miRNAs expression patterns occurred in distinct histological subtypes such as usual PSCC (95 differentially expressed miRNAs, $p \leq 0.05$ ) and basaloid/warty subtypes (247 differentially expressed miRNAs, $p \leq 0.05$ ) as well as between distinct histological subtypes. From those, miR-99a-5p, miR-181d (usual PSCC) and miR-211-5p (basaloid/warty subtypes) have been confirmed by RT-PCR. Microarray data revealed 118 miRNAs $(p \leq 0.01)$ that were significantly differentially expressed in metastatic versus non-metastatic usual PSCC including miR-137 and miR-328-3p that were validated by RT-PCR. Conclusion: For the first time, to our knowledge, a different microRNA expression pattern has been defined in distinct PSCC histological subtypes. The identified miRNAs could serve as potential diagnostic and prognostic markers for single PSCC subtypes. Our data support that PSCC subtypes are characterized by distinct molecular alterations and should be therefore investigated separately as already shown by clinical data. The influence and degree of altered miRNAs associated with HPV infection in the different PSCC histological subtypes requires additional research in a larger cohort.

\section{V16.8 \\ Mechanismen der Resistenz gegen Cisplatin und Osimertinib beim Peniskarzinom}

A. Thomas ${ }^{1 *}$, O. Vakhrusheva' ${ }^{1}$ J. Cinat ${ }^{2}$, F. Rothweiler ${ }^{2}$, J. Cinat $\left.\right|^{2}$, M. Michaelis ${ }^{3}$, A. Haferkamp ${ }^{1}$, E. Jüngel', I. Tsaur'

'Universitätsmedizin der Johannes Gutenberg-Universität Mainz, Urologie und Kinderurologie, Mainz, Deutschland; ${ }^{2}$ Goethe Universität Frankfurt, Frankfurt, Deutschland; ${ }^{3}$ University of Kent, Canterbury, Vereinigtes Königreich

Einleitung: Resistenzbildung gegenüber systemischen Therapeutika limitiert Behandlungsfortschritte beim metastasiertem Peniskarzinom ( $\mathrm{PeCa}$ ) erheblich. In dieser Studie wurden erfolgreich PeCa-Zelllinien etabliert, die gegen Cisplatin und Osimertinib resistent sind. Resistenzmechanismen wurden untersucht und die Wirksamkeit potenzieller Medikamente getestet.

Methode: Zur Etablierung chemoresistenter adaptierter Sublinien wurde das Wachstum von der therapienaiven UKF-PeC-3-Zelllinie in $2 \mu \mathrm{g} /$ $\mathrm{ml}(2000 \mathrm{ng} / \mathrm{ml})$ Cisplatin (UKF-PeC-3rCDDP $\left.{ }^{2000}\right)$ oder $2 \mu \mathrm{M}$ Osimertinib
(UKF-PeC-3rOSIMER ${ }^{2 \mu \mathrm{M}}$ ) adaptiert. Tumorzellwachstum, Proliferation, Apoptose, Zellzyklusphasen und regulierende Proteine sowie AKT/mTOR-Signalweg-Proteine wurden in therapienaiven und -resistenten Sublinien mit dem MTT- und BrdU-Assay, FACS und Western Blot untersucht. Des Weiteren wurden die Auswirkungen der Behandlung mit Everolimus bestimmt. Ergebnisse: Der IC50-Wert für Cisplatin $(5,48 \mu \mathrm{g} / \mathrm{ml}$ vs. $61,76 \mu \mathrm{g} / \mathrm{ml})$ und Osimertinib $(5,04 \mu \mathrm{M}$ vs. $17,02 \mu \mathrm{M})$ war in den resistenten Sublinien im Vergleich zu den behandlungsnaiven Zellen signifikant erhöht, was eine erworbene Resistenz in den Linien UKF-PeC-3rCDDP2000 und UKF-PeC-3rOSIMER ${ }^{2 \mu \mathrm{M}}$ bestätigt. Dementsprechend zeigte sich die Auswirkung auf Viabilität und Proliferation in beiden resistenten Zelllinien signifikant erniedrigt. Eine Modulation der Zellzyklusphasen konnte im Zustand der Resistenz nachgewiesen werden. Weiterhin zeigten Proteinexpressionsprofile von Proteine des AKT/mTOR-Signalwegs eine Hochregulierung von pAKT, p4EBP1 und pmTOR in den resistenten Sublinien.

Schlussfolgerung: Resistenzmechanismen wurden identifiziert, die die Beteiligung des AKT/mTOR-Signalwegs unterstreichen und den Weg für die Entwicklung neuer Behandlungsstrategien bei PeCa ebnen.

\section{V16.9}

\section{Die Wertigkeit von Wnt/ $\beta$-Catenin-Signalweg Proteinen als prognostische Biomarker und therapeutisches target beim Peniskarzinom}

A. Thomas ${ }^{1 *}$, O. Vakhrusheva', P. Stenzel ${ }^{2}$, K. Tagscherer ${ }^{2}$, W. Roth ${ }^{2}$, E. Jüngel', A. Haferkamp', I. Tsaur'

'Universitätsmedizin der Johannes Gutenberg-Universität Mainz, Urologie und Kinderurologie, Mainz, Deutschland; ${ }^{2}$ Universitätsmedizin der Johannes Gutenberg-Universität Mainz, Pathologie, Mainz, Deutschland

Einleitung: Das Peniskarzinom (PeCa) ist eine Erkrankung, die sich durch einen aggressiven Verlauf gekennzeichnet ist. Noch wenig sind über die genauen molekularen Mechanismen der Tumorentstehung bekannt. Limitierte Evidenz weist darauf hin, dass der Wnt/ $\beta$-Catenin-Signalweg dysreguliert sein könnte. Der Wnt/ $\beta$-Catenin-Signalweg spielt eine entscheidende Rolle in der Karzinogenese verschiedener Entitäten. In dieser vorliegenden Studie untersuchen wir, ob der Wnt/B-Catenin-Signalweg ein prognostisches und therapeutisches Nutzen für PeCa aufweisen könnte.

Methode: Formalin-fixiertes, paraffin-eingebettetes Tumorgewebe von PeCA Patienten wurde für die Tissue Microarray (TMA)-Analyse verwendet. Immunhistochemische Färbungen wurden durchgeführt zur Bestimmung der Expression von Wnt/ $\beta$-Catenin-Signalweg-Proteine $n$-MYC, PPARg, $\beta$-Catenin, Snail, Survivin und c-MET. Die Expression wurde mit klinisch-pathologischen Merkmalen und Überlebensdaten korreliert. Weitere Analyse von selektierten Proteinen erfolgtenin in vitro Studien.

Ergebnisse: Die Gesamtkohorte betrug 90 PeCa-Patienten.Eine hohe Expression von Snail war mit HPV-positiven Tumoren assoziiert. Die Expression von $\beta$-Catenin war invers mit dem Grading assoziiert. In der univariaten COX-Regressionsanalyse und im Log-Rank-Test war die erhöhte Expression von PPARg, Snail und c-MET ein Prädiktor für ein schlechteres krankheitsspezifisches Überleben (DSS). In der multivariaten Analyse war eine höhere Expression von c-MET unabhängig mit dem schlechteren DSS assoziiert. Daten der Zellkulturen werden auf dem Kongress präsentiert. Schlussfolgerung: Wnt/ $\beta$-Catenin-Signalweg Proteinen waren assoziiert mit klinisch-pathologischen und Überlebensparametern bei PeCa-Patienten. c-MET zeigte sich als der wichtigste Biomarker. 


\section{V17 - Urothelkarzinom: Therapie fortgeschrittener und metastasierter Tumoren}

17.09.2021, H2, 13:30-15:00

\section{V17.2}

\section{Outcomes of palliative cystectomy in patients with locally advanced pT4 bladder cancer (BCa)}

P. Maisch ${ }^{1 * 2,}$, L. Lunger ${ }^{2}$, C. Düwel ${ }^{2}$, S.C. Schmid ${ }^{2}$, T. Horn' ${ }^{2}$, J. E. Gschwend ${ }^{2}$, A. Sauter ${ }^{3}$, M. Heck ${ }^{2}$

'Universitätsklinik Ulm, Klinik für Urologie und Kinderurologie, Ulm, Germany; ${ }^{2} T e c h n i-$ sche Universität München, Klinikum rechts der Isar, Klinik für Urologie, München, Germany; ${ }^{3}$ Technische Universität München, Klinikum rechts der Isar, Institut für Diagnostische und Interventionelle Radiologie, München, Germany

Background: Radical cystectomy $(\mathrm{Cx})$ is the standard of care for muscleinvasive $\mathrm{BCa}$, but the oncologic outcome is inconclusive for patients with pT4 BCa, as Cx may be necessary for palliation. Aim of this retrospective study was to evaluate the outcomes of $\mathrm{Cx}$ performed in pT4 BCa.

Methods: Between 2008-2017 we identified 76 of 905 patients who underwent $\mathrm{Cx}$ for pT4 BCa at a single tertiary referral center. Time-to-event variables with log-rank statistics were calculated with the use of the Kaplan-Meier method.

Results: Median age was 74 years (range 42-90). Preoperatively, the physical status was estimated poor (ASA score of $\geq 3$ ) in $40(52 \%)$ patients. Overall, 19 (25\%) patients had pT4b BCa, 41 (54\%) patients were lymph node positive $(\mathrm{c} / \mathrm{pN}+)$ and $14(18 \%)$ patients had distant metastases (c/ $\mathrm{pM}+$ ).

Within 30 and 90 days after surgery $21 \%$ and $30 \%$ of the patients, respectively, developed severe complications (Clavien-Dindo grade ${ }^{3} 3$ ). Overall, 30 - and 90 -day mortality rates were $9 \%$ and $11 \%$, respectively. Moreover, $86 \%$ and $75 \%$ of patients who died within 30 and 90 days after surgery, respectively, had an ASA-score $\geq 3$.

At a median postoperative follow-up of 8 months $53(70 \%)$ patients have died. During the follow-up period $46 \%$ of the patients died due to progressive disease, $16 \%$ died of a non-cancer specific cause and for $8 \%$ of the patients the reason remains unknown. Median OS and CSS were 13.0 and 16.0 months, respectively. In subgroup analyses ASA-score ${ }^{3} 3$ and hemoglobin $<11.7 \mathrm{~g} / \mathrm{dl}$ was significantly associated with poor OS.

Conclusion: Cx performed in patients with pT4 BCa is associated with an increased mortality rate within 90 days postoperatively. Our study revealed that the ASA score is a relevant and easily available tool to rate the patient's postoperative outcome.

\section{V17.3}

Next Generation Sequencing (NGS) beim metastasierten Urothelkarzinom (mUC) im klinischen AlltagErfahrungsbericht zu Qualität und Effektivität

M. Marx*, R. Claus², M. Reike ${ }^{3}$, F. Roghmann ${ }^{3}$, V. Lieb ${ }^{4}$, M. Grabbert ${ }^{5}$, S. Rausch ${ }^{6}$, M. Krebs', F. Zengerling', C. Bolenz', F. Wezel'

\begin{abstract}
'Universitätsklinikum Ulm, Klinik für Urologie und Kinderurologie, Ulm, Deutschland; ${ }^{2}$ Medizinische Fakultät Universität Augsburg, Klinik für Hämatologie und Onkologie, Augsburg, Deutschland; ${ }^{3}$ Marien Hospital Herne, Ruhr-Universität Bochum, Klinik für Urologie, Herne, Deutschland; ${ }^{4}$ Universitätsklinikum Erlangen, Klinik für Urologie und Kinderurologie, Erlangen, Deutschland; ${ }^{5}$ Universitätsklinikum Freiburg, Klinik für Urologie, Freiburg, Deutschland; ${ }^{6}$ Universitätsklinikum Tübingen, Klinik für Urologie, Tübingen, Deutschland; ${ }^{7}$ Universitätsklinikum Würzburg, Klinik für Urologie und Kinderurologie, Würzburg, Deutschland
\end{abstract}

Einleitung: NGS ermöglicht innovative, personalisierte Therapieansätze des mUC. Im klinischen Alltag wird NGS zunehmend implementiert, um neue therapeutische Zielstrukturen zu nutzen. Wir analysierten die Verwendung von NGS beim mUC und deren Nutzen und Limitationen.
Material und Methoden: Die Daten zu Gen-Panel-NGS von 7 Universitätskliniken wurden ausgewertet. Patientendaten und molekulare Charakteristika wurden mittels deskriptiver Statistik analysiert.

Ergebnisse: Insgesamt wurden 70 Patienten mittels NGS-Panels analysiert. $76 \%$ der Fälle waren UC der Harnblase, $24 \%$ UC des oberen Harntrakts. Im Median wurden $160 \mathrm{Gene} / \mathrm{Panel}$ analysiert (3-716 Gene). Die häufigsten bekannten UC-Mutationen (TCGA-Frequenz $\geq 8 \%$ ) wurden zu $73 \%$ durch die Panels abgedeckt. In den Panels zeigte sich eine heterogene Mutationslandschaft. Die häufigsten Mutationen waren TP53 (19 Fälle), FGFR3 (15 Fälle), PIK3CA (12 Fälle) und CHEK2, KMT2D, ARID1A, ERBB2 (je 4 Fälle). In $51 \%$ der Fälle konnte eine potenzielle therapeutische Zielstruktur identifiziert werden, jedoch erhielten nur $19 \%$ der Patienten eine zielgerichtete Therapie. Fehlende therapeutische Zielstrukturen, klinische Verschlechterung der Patienten oder fehlende Kostenübernahme der Krankenkassen waren Gründe für fehlende Durchführung zielgerichteter Therapieansätze.

Schlussfolgerung: Für das mUC werden häufig druggable targets identifiziert, jedoch wird auf dieser Basis eine zielgerichtete Therapie relativ selten durchgeführt. Die Implementierung von NGS in Kombination mit molekularen Tumorboards könnte einen wesentlichen Fortschritt in der personalisierten Therapie des UC bedeuten. Um die Effektivität zu steigern bedarf es UC-spezifischer NGS-Panels und innovativer Studiendesigns, um genom-getriggerte Therapien zu validieren.

\section{V17.4}

\section{Behandlungsrealität bei Patienten bei metastasiertem Urothelkarzinom: Ergebnisse einer Umfrage von d-uo}

F. König $^{1 *}$, F. Christoph ${ }^{2}$, C. Kluike ${ }^{3}$, R. Eichenauer ${ }^{4}$, R. Schönfelder ${ }^{5}$, M. Johannsen ${ }^{6}$, J. Klier ${ }^{7}$, J. Schröder ${ }^{1}$, E. Hempel ${ }^{8}$, C. Doehn ${ }^{9}$

'ATURO, Berlin, Deutschland; ${ }^{2}$ urologie citywest, Berlin, Deutschland; ${ }^{3}$ Urologie am Wasserturm, Stade, Deutschland; ${ }^{4}$ Urologikum Hamburg, Hamburg, Deutschland; ${ }^{5}$ Urologie Schönfelder \& Straßer, Hamburg, Deutschland; ${ }^{6}$ Urologische Facharztpraxis Johannsen \& Laux, Berlin, Deutschland; ' $U$ rologische Partnerschaft Köln, Köln, Deutschland; ${ }^{8}$ SMG Forschungsgesellschaft, Berlin, Deutschland; ${ }^{9}$ Urologikum Lübeck, Lübeck, Deutschland

Einleitung: Entsprechend der deutschen S3-Leitlinie ist beim metastasierten Urothel-karzinom eine Cisplatin-basierte Chemotherapie (CTx) nicht indiziert bei: GFR $<60 \mathrm{ml} / \mathrm{min}$., ECOG-PS $\geq 2$, Hörverlust $\geq$ Grad 2, peripherer Neuropathie $\geq$ Grad 2 oder einer Herzinsuffizienz $\geq$ NYHA III. In dieser Arbeit haben wir die Versorgungsrealität in Deutschland untersucht.

Material und Methoden: Es handelte sich um eine fragebogenbasierte Untersuchung unter Mitgliedern von d-uo über die Behandlung von Patienten im Zeitraum 7/2019 bis 6/2020. Aus 19 Praxen wurden insgesamt 107 Patienten dokumentiert.

Ergebnisse: Das mediane Alter der Patienten lag bei 74 Jahren. Ein ECOG-PS 0, 1, 2 bzw. 3 lag bei 18, 56, 25 bzw. 6 Patienten vor. Bei 81 Patienten $(76 \%)$ bestand die Eignung für eine Cisplatin-basierte CTx und bei 26 Patienten (24\%) nicht. Bei 18/26 Patienten gab es einen und bei 8/26 Patienten mehrere Gründe für die Nichteignung: schlechte Nierenfunktion (18x), schlechter ECOG-PS (7x), Herzinsuffizienz (2x) und Hörverlust (1x). 77 der 81 geeigneten Patienten (95\%) erhielten eine Standard-CTx mit Gemcitabine/Cisplatin (Gem/Cis). Eine PD-L1-Testung erfolgte bei 17/26 Patienten (65\%), die nicht für eine Cisplatin-basierte CTx geeignet waren. Ein positives Ergebnis lag bei 11 von 17 Patienten (65\%) vor. Eine Therapie mit einem Checkpoint-Inhibitor erfolgte bei 6 Patienten und eine Carboplatin-basierte CTx bei 11 Patienten. Ein Patient erhielt eine GemcitabineMonotherapie.

Schlussfolgerung: Die Therapie des metastasierten Urothelkarzinoms in der ambulanten Versorgung entspricht weitestgehend der Vorgabe der wissenschaftlichen Leitlinie. Dreiviertel der Patienten waren für eine Cisplatin-basierte CTx geeignet und erhielten fast immer eine Standard-CTx mit Gem/Cis.

Funding: AstraZeneca GmbH 


\section{V17.5}

\section{Immunotherapy (IC) for advanced or metastatic} urothelial carcinoma (UC): a Cochrane Review

\begin{abstract}
P. Maisch ${ }^{1 *}, 2$, E. C. Hwang ${ }^{3}$, V. Narayan ${ }^{4}$, C. J. Bakker ${ }^{5}$, F. Kunath ${ }^{6}$, P. Dahm
'Universitätsklinik Ulm, Klinik für Urologie und Kinderurologie, Ulm, Germany; ${ }^{2}$ Technische Universität München, Klinikum rechts der Isar, Klinik für Urologie, München, Germany; ${ }^{3}$ National University Hwasun Hospital, Department of Urology, Hwasun, Korea; ${ }^{4}$ Emory University, Department of Urology, Atlanta, Vereinigte Staaten von Amerika; ${ }^{5}$ University of Minnesota, Biomedical Research Services Liaison, Minneapolis, Vereinigte Staaten von Amerika; ${ }^{6}$ Universitätsklinik Erlangen, Urologische und Kinderurologische Klinik, Erlangen, Germany; ${ }^{7}$ University of Minnesota, Department of Urology, Minneapolis, Vereinigte Staaten von Amerika
\end{abstract}

Background: Immune checkpoint inhibitors are increasingly important in the treatment algorithm for metastatic bladder cancer, as a large number of ongoing studies are investigating these agents.

Methods: We performed a comprehensive search in several medical literature databases including randomized and non-randomized trials. Participants (pts) had locally advanced inoperable (pT4b and/or N+) and/or metastatic (M1) UC of the bladder or upper urinary tract. According to the Grading of Recommendations Assessment, Development and Evaluation (GRADE) approach, the certainty of evidence was rated.

Results: We identified three randomized controlled trials and seven single-armed studies including 3411 pts, comparing IC versus chemotherapy (CT). IC may have little or no effect on the risk of overall survival in first line therapy setting (HR 1.02, 95\% Cl 0.83 to 1.25 ; low certainty evidence (CE). This corresponds to 552 deaths per 1000 pts with CT and 7 more (66 fewer to 81 more) deaths per 1000 pts with IC. IC reduces the risk of overall survival in second line (HR $0.78,95 \% \mathrm{Cl} 0.69$ to 0.88 ; high CE). This corresponds to 860 deaths per 1000 pts with CT (vinflunine, paclitaxel, docetaxel) and 76 fewer ( 118 fewer to 37 fewer) deaths per 1000 pts with IC. IC reduces serious adverse events (SAEs) in pts undergoing first line therapy (RR $0.55,95 \% \mathrm{Cl} 0.49$ to 0.61 ; high $\mathrm{CE}$ ) and probably slightly reduces SAEs in pts undergoing second line ( $\mathrm{RR} 0.88,95 \% \mathrm{Cl} 0.80$ to 0.96 ; moderate $\mathrm{CE}$ ). Conclusions: To date, 6 immunotherapeutic agent are approved for UC, but only 3 randomized trials could be identified. Accordingly, more rigorous trials will be necessary to prove the high potential of immunotherapy.

\section{V17.6}

First results from the phase 3 CheckMate (CM) 274 trial of adjuvant nivolumab $(\mathrm{N})$ versus placebo $(\mathrm{P})$ in patients (pts) who underwent radical surgery for high-risk muscle-invasive urothelial carcinoma (MIUC)

J.E. Gschwend ${ }^{1 *}$, D. F. Bajorin'2, J.A. Witjes ${ }^{3}$, M. Schenker4 , B. P. Valderrama ${ }^{5}$, Y. Tomita ${ }^{6}$, A. Bamias ${ }^{7}$, T. Lebret ${ }^{8}$, S. F. Shariat ${ }^{9}$, S. H. Park ${ }^{10}$, D. Ye ${ }^{11}$, M. Agerbaek ${ }^{12}$, S. Collette ${ }^{13}$, K. Unsal-Kacmaz ${ }^{13}$, D. Zardavas ${ }^{13}$, H. B. Koon ${ }^{13}$, M.D. Galsky ${ }^{14}$

${ }^{1}$ Technical University Munich, München, Germany; ${ }^{2}$ Memorial Sloan Kettering Cancer Center, New York, Vereinigte Staaten von Amerika; ${ }^{3}$ Radboud University, Nijmegen, The Netherlands; ${ }^{4}$ Nectarie Oncology Center, Craiova, Romania; ${ }^{5}$ Hospital Universitario Virgen del Rocío, Sevilla, Spain; ${ }^{6}$ Niigata University Graduate School of Medical and Dental Sciences, Niigata, Japan; ${ }^{7}$ National and Kapodistrian University of Athens, Athens, Greece; ${ }^{8}$ Paris-Saclay University UVSQ, Urology department Hopital Foch, Paris, France; ${ }^{9}$ Medical University of Vienna, Vienna General Hospital, Vienna, Austria; ${ }^{10}$ Samsung Medical Center, Seoul, Korea; ${ }^{11}$ Fudan University Shanghai Cancer Center, Shanghai, China; ${ }^{12}$ Aarhus University Hospital, Aarhus, Denmark; ${ }^{13}$ Bristol Myers Squibb, Princeton, Vereinigte Staaten von Amerika; ${ }^{14}$ Icahn School of Medicine at Mount Sinai, New York, Vereinigte Staaten von Amerika

Background: Radical surgery \pm cisplatin (C)-based neoadjuvant chemotherapy (chemo) is the standard of care (SOC) for pts with MIUC, but many pts are C-ineligible. There is no conclusive evidence supporting adjuvant chemo in pts who did not receive neoadjuvant chemo and in those with residual disease after neoadjuvant $C$.
Methods: CM 274 is a phase 3, randomized, double-blind trial in pts with high-risk MIUC after radical surgery receiving N $240 \mathrm{mg} \mathrm{Q2} \mathrm{W}$ or P for $\leq 1$ year of adjuvant treatment. Pts had radical surgery within 120 days \pm neoadjuvant $\mathrm{C}$ or were ineligible/declined C-based chemo, evidence of highrisk UC, were disease-free by imaging after surgery, and ECOG PS $\leq 1$. Primary endpoints: disease-free survival (DFS) in all randomized pts (ITT population) and in pts with tumor PD-L1 expression $\geq 1 \%$. Non-urothelial tract recurrence-free survival (NUTRFS) in ITT pts and in pts with PD-L $\geq 1 \%$ is a secondary and safety an exploratory endpoint.

Results: 353 pts were randomized to N (PD-L1 $\geq 1 \%, n=140$ ) and 356 pts to $\mathrm{P}$ (PD-L $1 \geq 1 \%, n=142$ ). DFS was met in ITT pts and in pts with PD-L1 $\geq 1 \%$. DFS and NUTRFS were improved with $\mathrm{N} v \mathrm{P}$ in both populations. DFS improvement with $\mathrm{N}$ was generally consistent across subgroups. Grade 3-4 treatment-related adverse events occurred in $17.9 \%$ and $7.2 \%$ of pts in the $\mathrm{N}$ and $\mathrm{P}$ arms, respectively.

Conclusions: $\mathrm{N}$ demonstrated a statistically significant + clinically meaningful improvement in DFS v P for MIUC after radical surgery in ITT pts and pts with PD-L $1 \geq 1 \%$. AEs were manageable and consistent with previous reports. The results support adjuvant $\mathrm{N}$ as a new SOC for MIUC pts with high risk for recurrence despite neoadjuvant chemo or those ineligible for and/or declining C-based chemo.

(With permission from ASCO-GU 2021, Abstract 391, Bajorin DT et al.)

\section{V17.7}

\section{TITAN-TCC - Ein auf dem Ansprechen basierender Immuntherapie-Ansatz mit Nivolumab beim fortgeschrittenen Urothelkarzinom}

M.-O. Grimm ${ }^{*}$, B. J. Schmitz-Dräger², U. Zimmermann ${ }^{3}$, C. B. Gruen ${ }^{4}$, G. Baretton ${ }^{5}$, M. Schmitz ${ }^{6}$, S. Foller', M. Schostak', F. Zengerling ${ }^{8}$, U. Schumacher ${ }^{9}$, W. Loidl ${ }^{10}$, J. Meran ${ }^{11}$

${ }^{1}$ Klinik und Poliklinik für Urologie, Universitätsklinikum Jena, Jena, Deutschland; ${ }^{2}$ Klinik für Urologie, St. Theresien-Krankenhaus Nürnberg, Nürnberg, Deutschland; ${ }^{3}$ Klinik und Poliklinik für Urologie, Universitätsmedizin Greifswald, Greifswald, Deutschland; ${ }^{4}$ Medizinische Onkologie, Nationales Centrum für Tumorerkrankungen Heidelberg, Heidelberg, Deutschland; Institut für Pathologie, Universitätsklinikum Carl Gustav Carus, Dresden, Deutschland; 6 Institut für Immunologie, Universitätsklinikum Carl Gustav Carus, Dresden, Deutschland; ${ }^{7}$ Klinik für Urologie, Uroonkologie, robotergestützte und fokale Therapie, Universitätsklinikum Magdeburg, Magdeburg, Deutschland; ${ }^{8} \mathrm{Klinik}$ für Urologie und Kinderurologie, Universitätsklinikum Ulm, Ulm, Deutschland; ${ }^{9}$ Zentrum für klinische Studien, Universitätsklinikum Jena, Jena, Deutschland; ${ }^{10} \mathrm{Klinik}$ für Urologie und Andrologie, Ordensklinikum Linz Elisabethinen, Linz, Österreich; "'Klinik für Innere Medizin, Barmherzige Brüder Krankenhaus Wien, Wien, Österreich

Fragestellung: Eine Kombination aus PD-(L)1- und CTLA4-Immuncheckpoint-Inhibitoren scheint einer Anti-PD-(L)1-Monotherapie beim fortgeschrittenen Urothelkarziom überlegen, führt aber zu mehr Nebenwirkungen. TITAN-TCC untersucht eine Nivolumab-(Nivo-)Induktion und Nivo+Ipilimumab (Ipi) als Boost bei Nichtansprechen.

Material und Methoden: 86 Patienten begannen ihre Behandlung gemäß Protokoll V3 (Kohorte 1). Nach 4 Zyklen Nivo-Induktion und CTScan in Woche 8 (W8) erhielten Patienten mit partiellem oder komplettem Ansprechen (PR/CR) weiterhin Nivo und Patienten mit stabiler (SD) oder progredienter Erkrankung 2 Zyklen Nivo3+lpi1, gefolgt von 2 Zyklen Nivo1+lpi3 bei Nichtansprechen. Die mediane Nachbeobachtungszeit beträgt 7,2 Monate. Primärer Endpunkt ist die bestätigte objektive Ansprechrate (ORR) nach RECIST1.1. Sekundäre Endpunkte sind u. a. Ansprechen auf die Nivo-Induktion (W8), Remissionsrate mit Nivo+lpi Boosts, Gesamtüberleben und Sicherheit.

Ergebnisse: 42, 39 und 5 Patienten wurden in der 1., 2. bzw. 3. Linie (1L/2L/3L) behandelt. Das mediane Alter betrug 67 Jahre (45-84), $61 \mathrm{~Pa}-$ tienten waren männlich. Die ORR nach Nivo-Induktion betrug $29 \%$ (1L) bzw. $23 \%$ (2/3L). 41 Patienten erhielten Nivo+lpi Boosts nach W8, 12 erhielten diese später. Die beste Gesamtansprechrate mit Nivo-Induktion \pm Nivo+Ipi Boosts betrug $45 \%$ (1L) bzw. $27 \%$ (2/3L). Das Ansprechen durch Boost-Gabe verbesserte sich bei 7/17 Patienten mit Boost nach W8 (1L) 
bzw. 2/24 (2/3L). Bei späterem Boost wegen Progress erreichten $25 \%$ eine Verbesserung (1/12 PR, 2/12 SD).

Schlussfolgerungen: Das TITAN-TCC-Studiendesign führte in der $1 \mathrm{~L}$ zu einer signifikanten Verbesserung der ORR gegenüber einer Nivo-Monotherapie, was einen Beleg für den Mehrwert von Ipi in Kombination mit Nivo darstellt.

\section{V17.8}

Body composition measures are associated with survival of chemotherapy-treated patients with advanced urothelial carcinoma

U. Krafft", C. Olah, I. Münch, J. Hess, S. Tschirdewahn, C. Kesch, J.P. Radtke, C. Rehme, B. A. Hadaschik, T. Szarvas

Universität Duisburg-Essen, Klinik für Urologie, Essen, Germany

Objective: Advanced bladder cancer (BC) shows a heterogeneous response to both platinum and immune checkpoint inhibitor therapies. To improve clinical stratification, we aimed to identify easily accessible prognostic markers for chemotherapy-treated $\mathrm{BC}$ patients.

Material and methods: In this monocentric, retrospective analysis we included 122 bladder cancer (BC) patients who underwent platinum-containing adjuvant or palliative chemotherapy ( $n=61$ both) between 2007 and 2020. The median follow-up was 18 months (range: 1-137) and 93 patients died during the follow-up period. Among other clinicopathological parameters, core parameters were: primary versus secondary muscleinvasive $\mathrm{BC}$, body composition measures, urinary pathogen detection and antibiotic therapy. Sarcopenia was assessed by the following CT-based methods: skeletal muscle index (SMI) and total muscle area L3 (TMAL3). All parameters were correlated with patient outcome.

Results: Low BMI $(<27.75)$ correlated with shorter overall survival (HR: $0.848, p=0.046)$ for the whole cohort, while low TMAL3 $(<130 \mathrm{~cm} 2)$; was associated with shorter survival in the subgroup of male patients (HR: $0.520, p=0.035$ ). SMI tended to be associated with poor survival $(p=0.067)$ for male patients. All other parameters were not associated with patient's prognosis.

Conclusion: We found that BMI and TMA as surrogate parameter for sarcopenia predict prognosis in chemotherapy-treated $B C$ patients. These body composition measures represent easy accessible prognostic markers and therefore may improve clinical decision-making.

\section{V17.9}

Time to metastatic switch - ein Parameter für die frühe Einschätzung des Gesamtüberlebens von uroonkologischen Patienten unter Multisequenztherapie

R. Dotzauer*, V. Suleja, K. Boehm, M. Brandt, A. Thomas, R. Mager, H. Borgmann, I. Tsaur, A. Haferkamp, T. Höfner

Klinik und Poliklinik für Urologie und Kinderurologie der Universitätsmedizin Mainz, Mainz, Deutschland

Fragestellung: Im Vergleich zum prognostischen Einfluss eines spezifischen Organbefalls einer metastasierten Erkrankung, wurde der Zeitspanne bis in einem bisher nicht betroffenes Organ Metastasen auftreten, kaum Beachtung geschenkt. Da regulatorische Prozesse auf molekularbiologischer Ebene bei der Entstehung neuer Metastasen beschrieben wurden, die eine bedeutende Rolle bei der Krankheitsprogression spielen könnten war es unser Ziel, diese Zeitspanne (time to metastatic switch) als neuen prognostischen Parameter zu untersuchen.

Material und Methoden: Klinische und radiologische Daten von $203 \mathrm{~Pa}-$ tienten mit metastasierten uroonkologischen Erkrankungen unter Multisequenztherapien wurden erhoben. Die Dynamik der Metastasierung wurde mit Hilfe des neu definierten Faktors "time to metastatic switch" (TTMS - Zeit vom Start der Erstlinientherapie bis zum Auftreten von Me- tastasen in einem bisher nicht betroffenen Organsystem) untersucht. Es wurden Korrelationen und Regressionen mit dem Gesamtüberleben und dem progressionsfreien Überleben durchgeführt.

Ergebnisse: Eine Zunahme von TTMS war mit einem erniedrigten Risiko für ein Versterben assoziiert. Patienten mit einem geringeren TTMS $(\leq 12$ versus > 12 Monate) zeigten ein kürzeres Gesamtüberleben. Viszeralswitch: OS 25 vs. 45 Monate, $\mathrm{HR}=3,60,95 \% \mathrm{Cl} 1,51-8,57$; Knochenswitch: OS 37 vs. 55 Monate, $\mathrm{HR}=4,46,95 \% \mathrm{Cl}$ 1,93-10,26; Lymphknotenswitch: OS 23 vs. 62 Monate, $\mathrm{HR}=4,11,95 \% \mathrm{Cl} 1,24-13,69)$.

Schlussfolgerung: Inspiriert von den Prozessen bei der Entstehung neuer Metastasen und deren prognostischen Einfluss, definierten wir "TTMS" als neuen Parameter zur frühen Einschätzung des Gesamtüberlebens.

\section{K01 - Prostatakarzinom - Diagnostik}

15.09.2021, C6.2, 10:30-12:00

\section{K01.1:}

Comparison of the rigid and elastic registration method to detect significant prostate cancer using targeted and systematic cores in transperineal MRI/TRUS-fusion biopsy

M. Görtz" ${ }^{1 *}$, J. Nyarangi-Dix', M. Wiesenfarth², G. Hatiboglu' ' V. Schütz', P. Reimold', G. Tosev' ${ }^{1}$, V. Spies' ${ }^{1}$, C. Schwab ${ }^{3}$, A. Stenzinger ${ }^{3}$, S. Duensing', H.-P. Schlemmer ${ }^{4}$, D. Bonekamp ${ }^{4}$, M. Hohenfellner' ${ }^{1}$, J. P. Radtke ${ }^{5}$

'Universitätsklinikum Heidelberg, Urologische Klinik, Heidelberg, Germany; ${ }^{2}$ Deutsches Krebsforschungszentrum, Abteilung Biostatistik, Heidelberg, Germany; ${ }^{3}$ Universität Heidelberg, Institut für Pathologie, Heidelberg, Germany; ${ }^{4}$ Deutsches Krebsforschungszentrum, Abteilung Radiologie, Heidelberg, Germany; ${ }^{5}$ Universitätsklinikum Essen, Klinik für Urologie, Essen, Germany

Background: Multiparametric magnetic resonance imaging (mpMRI) and $\mathrm{MRI} / \mathrm{TRUS}$-fusion biopsy (FB) has excellent sensitivity in detecting significant prostate cancer ( $\mathrm{SPC}$, defined as ISUP grade group $\geq 2$ ). The available $\mathrm{FB}$ platforms can be distinguished by rigid or elastic image registration. We compared the rigid and elastic image registration methods by analysing SPC detection rates of the targeted (TB) and systematic biopsy (SB) component of FB.

Material and methods: Between 2015-2019 1384 men with suspicion of PC underwent transperineal saturation SB and TB. After excluding patients with previous $\mathrm{PC}$ diagnosis and/or negative MRI, patients undergoing rigid registration FB 2015-2017 $(n=511)$ were compared to patients undergoing elastic registration FB 2017-2019 $(n=449)$. Combination of SB and TB served as reference standard. Experience of the total 17 biopsy operators were comparable between groups.

SPC detection rates of MRI/TRUS-fusion biopsies were compared by McNemar's test on patient basis.

Results: Patient demographics (PSA-density 0.15 vs. $0.17 \mathrm{ng} / \mathrm{ml} / \mathrm{ml}$, number of TB cores 4 vs. 5) were comparable between the groups. $855 \mathrm{PI}$ RADS $\geq 3$ lesions occurred in the rigid and 781 PI-RADS $\geq 3$ lesions in the elastic FB subgroup. In the rigid biopsy subgroup 242 men (47\%) had sPC, compared to 204 (45\%) in the elastic subgroup. Rigid TB detected $91 \%$ $(n=220)$ men with SPC and elastic TB 86\% $(n=175) .22$ men (9\%) were diagnosed by the SB part alone in the rigid and 29 men (14\%) in the elastic FB subgroup. Detection rates were not significant different on McNemar's test $(p=0.09)$.

Conclusion: Rigid targeted FB showed a comparable SPC detection rate to elastic FB. In a center with experienced biopsy operators, omitting SB would come at a risk of $9-14 \%$ missing SPC, depending on the FB approach. 


\section{K01.2}

Smartglass augmented-reality assisted prostate biopsy using cognitive point-of-care fusion

\author{
P. Sparwasser ${ }^{1 *}$, M. Haack ${ }^{1}$, L. Frey ${ }^{1}$, K. Boehm ${ }^{1}$, C. Boedecker ${ }^{2}$, T. Huber ${ }^{2}$, \\ F. Jungmann ${ }^{3}$, T. Hoefner ${ }^{1}$, I. Tsaur ${ }^{1}$, A. Haferkamp ${ }^{1}$, H. Borgmann ${ }^{1}$ \\ 'Universitätsmedizin Mainz, Urologie, Mainz, Germany; ${ }^{2}$ Universitätsmedizin Mainz, \\ Allgemeinchirurgie, Mainz, Germany; ${ }^{3}$ Universitätsmedizin Mainz, Radiologie, Mainz, \\ Germany
}

Introduction: MRI guided target biopsy of the prostate improves diagnostic of prostate cancer. Several techniques for MRI supported prostate biopsy with comparable detection rates had been developed. Smartglass augmented reality assisted urological surgery has been reported to be safe and efficient in feasibility studies. We performed a smartglass augmented reality assisted prostate biopsy using cognitive point-of-care fusion technology (AR-COG TB) and investigated its operability.

Methods: Multiparametric MRI of the prostate with suspect PIRADS lesions was uploaded to smartglass (Hololens, Microsoft). Imaging was retrieved through Hololens by generation of a visual cognitive matching tool during transrectal ultrasound-guided prostate biopsy. AR-COG TB detection rate was compared to 12-core systematic biopsy. Descriptive statistic was used for data reporting and safetyness was assessed in accordance to EAUiaiC and Clavien Dindo classification. Operability (scale: $1=$ lowest to $10=$ highest) for AR-COG TB was assessed by 2 surgeons.

Results: AR-COG TB plus 12-core standard biopsy of the prostate was performed for 10 patients with suspect lesion defined as PIRADS-Score $\geq 3$. Pathological analyses demonstrated detection rates superior for AR-COG TB vs. standard biopsy. AR-COG TB was safe, with no complications detected intraoperatively and during $30 \mathrm{~d}$ follow-up. Operability scores (execution speed [9]; physical stress [6]; comfort [8]; surgery improveness [8]; multitasking [10], practicality [10], image quality [8], battery autonomy [4]; device handling [6], device weight [5]) demonstrated feasibility, safetyness and usefulness.

Conclusion: AR-COG TB demonstrated convenient operability and comparable detection rates. AR-COG TB might be a sustainable solution for targeted prostate biopsy.

\section{K01.3}

A non-inferiority comparative analysis of microultrasound and MRI targeted biopsy in men at risk of prostate cancer

S. Hofbauer ${ }^{1 *}$, F. Luger ${ }^{2}$, N. Harland ${ }^{3}$, H. Plage ${ }^{1}$, M. Reimann ${ }^{1}$, M. Hollenbach', A. Gusenleitner ${ }^{2}$, A. Stenzl $\left.\right|^{3}$, T. Schlomm', L. Wiemer', H. Cash ${ }^{4}$

'Charité - Universitätsmedizin Berlin, Klinik für Urologie, Berlin, Germany; ${ }^{2}$ Ordensklinikum Linz Elisabethinen, Linz, Austria; ${ }^{3}$ Eberhard Karls University of Tübingen, Klinik für Urologie, Tübingen, Germany; ${ }^{4}$ Prouro Berlin, Berlin, Germany

Objective: To compare the efficacy of multiparametric magnetic resonance imaging (mpMRI) directed and micro-ultrasound (micro-US) directed biopsy for detecting clinically significant (Grade Group $>1$ ) prostate cancer (csPCa).

Materials and methods: 203 patients were prospectively enrolled at 3 institutions across Germany and Austria in the period from January 2019 to December 2019. During each biopsy, the urologist was blinded to the $\mathrm{mp}-$ MRI report until after micro-US targets had been assessed. After unblinding, targets were then sampled using software-assisted fusion, followed by systematic samples. The primary outcome measure was non-inferiority of micro-US to detect csPCa with a detection ratio of at least $80 \%$ of $\mathrm{mp}$ MRI.

Results: 79 csPCa cases were detected overall (39\%). Micro-US targeted biopsy detected 58/79 (73\%), while mpMRI targeted biopsy detected 60/79 (76\%) and non-targeted (systematic) samples detected 45/79 (57\%). mpMRI targeted samples alone detected 7/79 (9\%) csPCa cases which were missed by Micro-US targets and non-targeted samples. 3/7 of these were anterior lesions with $2 / 7$ in the transition zone. Micro-US targeted samples alone detected 5/79 (6\%) and non-targeted samples alone detected 4/79 (5\%). Micro-US was noninferior to mpMRI and detected $97 \%$ csPCa compared to mpMRI targeted biopsy ( $95 \% \mathrm{Cl} 80-116 \%, p=0.023)$.

Conclusions: This is the first multi-center prospective study comparing micro-US targeted biopsy with mpMRI targeted biopsy and it provides further evidence that micro-US can reliably detect cancer lesions and suggests that micro-US biopsy might be as effective as mpMRI for detection of csPCA. This result has significant implications for increasing accessibility, reducing costs and expediting diagnosis.

\section{K01.4}

Evaluation of the Ginsburg Scheme: In which regions of the prostate gland is cancer being missed?:

\section{R. Suarez-Ibarrola1" , C. Jilg², C. Gratzke², A. Sigle}

'University of Freiburg Medical Centre, Freiburg, Germany; ${ }^{2}$ University of Freiburg Medical Centre, Klinik Urologie, Freiburg, Germany

Introduction and Objective: In prostate cancer (PC) diagnosis, adding a systematic biopsy (SB) to MRI-targeted biopsy (TB) is the current standard of care. The Ginsburg scheme (GBS) mainly focuses on the peripheral zone and systematically omits particular sectors of the prostate. We aimed to localize and classify PC that is missed by GBS.

Methods: We analyzed data from 1120 patients undergoing robot-assisted TB+SB perineal prostate biopsy according to GBS between 2015-2020. There are four inherent blind sectors where biopsies were not taken: anterior stroma (AS), central zone, and basoventral and basodorsal sectors. Performance of GBS was evaluated with histopathology of a combined biopsy. When PC was diagnosed by TB only, cancerous cores were mapped to include GBS sectors and the newly defined blind sectors. ISUP 2 or more was considered significant PC (SPC). Pearson's chi-squared test and regression analyses were performed to identify subgroups that were more likely to have SPC solely localized in a blind sector.

Results: The median age and PSA were 67.0 y $(+7.5)$ and $8.8 \mathrm{ng} / \mathrm{ml}(+$ 10.9). Median number of cores taken in total was 35 (range 12-70) and of SB cores was 31 (range: 8-62). In 29 patients (2.6\%), PC was diagnosed by TB only, 20 with sPC. In 19 of these (65.5\%), sPC was missed in a blind sector mainly the AS $(12 / 29,41.3 \%)$. The proportional distribution of index lesions localized in the AS was significant $(p=0.043)$ and, therefore, not attributed to chance. No predictive variables were found for PC solely localized in any blind sector.

Conclusions: Blind regions within the GBS may contain SPC. Few lesions diagnosed by TB only and missed by GBS were located mainly in the AS. Modifying the GBS to include this blind sector might be beneficial to improve detection rates.

\section{K01.5}

Gezielte Biopsie von mid-apikalen Prostatakarzinomverdächtigen mpMRT-Läsionen: Bedeutung extrem apikaler Stanzbiopsien

\section{S.-R. Leyh-Bannurah', S. Boiko ${ }^{2^{*}}$, M. Kachanov², D. Beyersdorff2,3, T. Maurer²,} M. Graefen², L. Budäus ${ }^{2}$

'Prostate Center Northwest, Department of Urology, Pediatric Urology and Urooncology, St. Antonius-Hospital, Gronau, Deutschland; ${ }^{2}$ Martini-Klinik Prostate Cancer Center Hamburg-Eppendorf, Hamburg, Deutschland; ${ }^{3} U$ niversity Medical Center HamburgEppendorf, Department of Radiology, Hamburg, Deutschland

Einführung: Auf Grund der schweren Erreichbarkeit in der transrektalen Biopsie stellen extrem apikal gelegene Tumornester eine Herausforderung innerhalb der Gesamtheit der mid-apikal gelegenen Läsionen dar. Methoden: Bei allen Patienten erfolgte eine MRT-gezielte (TBx) und systematische Prostatabiopsie; csPCa wurde als Gleason Score(GS) $\geq 7$ definiert. 
Klinische und pathologische Merkmale von Patienten mit mid-apikaler PI-RADS $\geq 3$ mpMRT-Läsion (Kohorte A; $n=420$ ) bzw. extrem apikaler PIRADS $\geq 3$-Läsion (Kohorte $B ; n=85$ ) wurden verglichen und PCa-Detektionsraten bei mid-apikaler mpMRT-Läsionen TBx-Stanzen, aus dem oberen (mid) Teil der Läsion bzw. aus dem Apex erhoben.

Ergebnisse: In Kohorte A lag ein maximaler PI-RADS-Score von 3, 4 und 5 in 30, 57 und $13 \%$ der Patienten vor, während in Kohorte B die PI-RADSScores von 44, 51 und 5,9\% gefunden wurden. Die Biopsie ergab keinen PCa Nachweis vs. GS6 vs. csPCa bei den Patienten mit mid-apikalen Läsionen bei 37,19 und $44 \%$ bzw. 52, 11 und $38 \%$ bei den streng apikalen Läsionen. PCa-Detektionsraten von TBx-Stanzen aus der Mid vs Apex Region innerhalb einer Läsion, ergaben bei 457 Patienten (64\%) kein csPCa. Bei $8,1 \%$ wurde csPCa nur in der apikalen TBx-Stanzen nachgewiesen, wobei $12 \%$ dieser Patienten in der apikale TBx-Stanzen keinen csPCa-Nachweis aufwiesen und die Diagnosestellung ausschließlich über Mid-Stanzen erfolgte.

Fazit: Eine zusätzliche Ausbeute an csPCa von 8,1 \% in ausschließlich apikalen TBx-Stanzen bei Patienten mit mid-apikalen mpMRT-Läsionen verdeutlicht die Notwendigkeit einer zusätzlichen apikalen Probennahme auch innerhalb der Läsion. Aufgrund der bekannten Limitationen der transrektalen Biopsie sollte bei MRT Nachweis von apikalen Läsionen ein transperinealer Biopsieansatz in Betracht gezogen werden.

\section{K01.6 \\ Detection of significant prostate cancer using target saturation in transperineal magnetic resonance imaging/transrectal ultrasonography-fusion biopsy: a prospective, randomized comparison to conventional target biopsy}

Y. Saner ${ }^{1 *}$, M. Wiesenfarth², S. Tschirdewahn', L. Püllen', D. Bonekamp³, H. Reis', U. Krafft' ${ }^{1}$ C. Kesch', C. Darr', M. Forsting ${ }^{5}$, L. Umutlu' ${ }^{5}$, B. Hadaschik', J.P. Radtke ${ }^{1,3}$

${ }^{1}$ Universitätsklinikum Essen, Klinik für Urologie, Essen, Germany; ${ }^{2}$ Deutsches Krebsforschungszentrum, Abteilung Biostatistik, Heidelberg, Germany; ${ }^{3}$ Deutsches Krebsforschungszentrum, Abteilung Radiologie, Heidelberg, Germany; ${ }^{4}$ Universitätsklinikum Essen, Institut für Pathologie, Essen, Germany; ${ }^{5}$ Universitätsklinikum Essen, Institut für Diagnostische und Interventionelle Radiologie, Essen, Germany

Introduction: Multiparametric magnetic resonance imaging (mpMRI) and targeted biopsies (TB) facilitate accurate detection of significant prostate cancer (sPC). However, it remains unclear how many cores should be applied per target. The main objective of this study was to assess SPC detection rates of TB and TS in prospectively randomized men.

Material and methods: Using a noninferiority margin of $5 \%$ and a onesided alpha level of $5 \%$, the randomization of 170 men $(n=85$ in each group) provides the trial with $80 \%$ power. All men underwent either TB or TS in addition to 24 systematic cores. Cancer and SPC (International Society of Urological Pathology grade group $>=2$ ) detection rates were analysed. Cancer detection rates were calculated for TS, TB, and SB at both lesion and patient level. Combination of SB + TB or TS served as reference. The detection difference of TS and TB was estimated by the means of a generalized linear mixed (GLM) model and a t-test for independent samples. Intrapatient statistical differences in SPC detection for patient- and lesion-level were calculated using McNemar's tests with confidence intervals.

Results: 53 men (62\%) in the TB and 69 men (81\%) in the TS group harbored PC. SPC was detected in $42 \%$ of men in the TB and $67 \%$ in the TS group. SB detected $86 \%$ (in TB group) and $82 \%$ (in TS group) of men with SPC. TB detected $92 \%$ of men and $86 \%$ of lesions harboring SPC, whereas TS detected all men and $97 \%$ of SPC lesions. Comparing detection rates, TS was $8 \%$ in favor over TB $(p=0.03)$ on patient level and $11 \%(p=0.04)$ on lesion level.
Conclusion: Overall, data of this prospective randomized study demonstrate a higher SPC detection rate using a TS approach as compared to conventional TB in MRI/TRUS-fusion biopsy.

\section{K01.7}

Comparative analysis of a novel target saturation biopsy approach in Magnetic Resonance Imaging (MRI-) Transrectal Ultrasound (TRUS)-fusion biopsy versus transperineal template saturation biopsy for the detection of significant Prostate Cancer

Y. Saner', M. Wiesenfarth², S. Tschirdewahn', L. Püllen', D. Bonekamp³, M. Görtz ${ }^{4}$, V. Schütz' ${ }^{4}$ H. Reis ${ }^{5}$, U. Krafft' ${ }^{1}$ C. Kesch', C. Darr' ${ }^{1}$ M. Forsting ${ }^{6}$, L. Umutlu ${ }^{6}$, B. Hadaschik' ${ }^{1}$ J.P. Radtke ${ }^{1 * 3}$

'Universitätsklinikum Essen, Klinik für Urologie, Essen, Germany; ${ }^{2}$ Deutsches Krebsforschungszentrum, Abteilung Biostatistik, Heidelberg, Germany; ${ }^{3}$ Deutsches Krebsforschungszentrum, Abteilung Radiologie, Heidelberg, Germany; ${ }^{4}$ Universitätsklinikum Heidelberg, Urologische Klinik, Heidelberg, Germany; ${ }^{5}$ Universitätsklinikum Essen, Institut für Pathologie, Essen, Germany; ${ }^{6}$ Universitätsklinikum Essen, Institut für Diagnostische und Interventionelle Radiologie, Essen, Germany

Introduction: Multiparametric magnetic resonance imaging (mpMRI) and targeted prostate biopsies facilitate accurate detection of significant prostate cancer (SPC). However, it remains unclear how many cores should be applied per target. The objective of this study was to assess SPC detection rates applying 9 target saturation cores per lesion compared to systematic biopsies (SB) on per-patient and per-lesion analysis.

Material and methods: Retrospective single-center outcome of transperineal MRI/TRUS-fusion biopsies of 298 men performed 2016-2020. All men underwent TS with a median of 9 cores per MRI lesion, followed by a median of 24 SB, performed by experienced urologists. SPC (ISUP grade group $\geq 2$ ) detection rates were analyzed.

Cancer detection rates were calculated for TS and SB at both lesion and patient level. Combination of SB+TS served as reference. Statistical differences in PC detection between groups were calculated using McNemar's tests with Confidence intervals $(\mathrm{Cl})$.

Results: sPC was detected in 145 men (49\%). Out of the 541 PI-RADS $\geq 3$ lesions, 197 (36\%) harbored sPC. TS detected $98 \%$ men with sPC and $95 \%$ of the SPC lesions. SB detected $88 \%$ of men with $\mathrm{SPC}$ and $80 \%$ of all SPC lesions. Using McNemar's tests, TS was on both, patient-basis (Cl 4.7-19\%, $p=0.004)$ and lesion-basis $(\mathrm{Cl} 8.9-22 \%, p<0.001)$ significantly in favor of detecting SPC over SB. However, the detection of low-risk PC was not statistically significant between TS and SB on both, patient- $(p=0.51)$ and lesion-basis $(p=0.85)$.

Conclusions: Compared to extended SB, TS alone detected significantly more SPC on patient- and lesion-basis. Compared to the reference test of combined systematic and targeted cores, TS alone detected $98 \%$ of all men and $95 \%$ of all lesions, and might have the potential to omit SB.

\section{$3 \mathrm{~K} 01.8$}

Added value of randomized biopsy to mpMRI-targeted biopsy of the prostate: 5 -year experience from a community-based urologic outpatient clinic

M. Chaloupka ${ }^{1 *}$, P. Pfitzinger', R. Bischoff', L. Rath', A. Buchner', B. Schlenker', D.-A. Clevert' ${ }^{2}$, C. G. Stief', M. Apfelbeck'

'Urologische Klinik des Klinikums der Universität München, Klinikum Großhadern, München, Germany; ${ }^{2}$ Radiologisches Institut des Klinikums der Universität München, Klinikum Großhadern, München, Germany

Intro: The added diagnostic value of systematic biopsy of the prostate $(\mathrm{SBx})$ additionally to mpMRI-fusion-guided biopsy (FBx) remains unclear. We are performing SBx and FBx until today, working with a group of 110 
external radiologists. By evaluating the results of 1168 patients, we analyzed who benefited from SBx in this real-world setting.

M\&M: 1168 patients underwent FBx and SBx from 2015 to 2020. The following clinical parameters were evaluated:Age, PSA-level, prostate volume, PSA-density (PSAD), localization and PI-RADS of mpMRI-lesions. Results: 108/1168 patients were diagnosed with clinically significant prostate cancer (csPCa) by SBx only and benefitted from SBx. These patients were significantly older (72 vs. $68, p<0.001)$ and had a higher ratio of PI-RADS 4 mpMRI-targets ( $60.34 \%$ vs. $50.76 \%, p=0.05$ ) compared to patients who did not benefit from SBx. Considering the prevalence of cSPCa (554/1168), a relative percentage of additionaly detected PCa can be determined. 108/554 of patients with csPCa were diagnosed by SBx only. In univariate analysis, these patients had a lower PSAD, higher prostate volume, higher percentage of prior biopsy, lower percentage of positive DRE, higher amount of mpMRI-targets in the transitional zone and higher amount of PI-RADS $3 \mathrm{mpMRI}$-targets compared to patients diagnosed with csPCa by FBx.

Conclusion: Of 1168 patients who underwent FBx and SBx, CsPCa was found in $9 \%$ by SBx. Age and amount of PI-RADS 4 mpMRI-targets were significantly higher in patients benefitting from SBx. Analyzing the relative percentage of additionally detected csPCa by SBx, $19.5 \%$ of patients with cSPCa were diagnosed by SBx only. PSAD, prostate volume, DRE, history of prior biopsy, mpMRI-target characteristics could represent predictors for the need of additional SBx.

\section{K01.9}

\section{Correlation of MRI-lesion targeted biopsy vs. systematic} biopsy Gleason score with final pathological Gleason score after radical prostatectomy

M. Wenzel ${ }^{1 *}$, F. Preisser', C. Wittler', B. Hoeh', P. Wild ${ }^{2}$, B. Bodelle ${ }^{3}$, C. Würnschimmel ${ }^{4}$, D. Tilki ${ }^{4}$, M. Graefen ${ }^{4}$, A. Becker', F. Chun', L. Kluth', J. Köllermann ${ }^{2}$, P. Mandel'

'University Hospital Frankfurt, Department of Urology, Frankfurt, Germany; ${ }^{2} \mathrm{Dr}$. Senckenberg Institute of Pathology, University Hospital Frankfurt, Frankfurt, Germany ${ }^{3}$ Department of Diagnostic and Interventional Radiology, University Hospital Frankfurt, Frankfurt, Germany; ${ }^{4}$ Martini-Klinik Prostate Cancer Center, University Hospital HamburgEppendorf, Hamburg, Germany

Background: To date, the impact of MRI-lesion targeted (TB) and systematic biopsy (SB) Gleason score as a predictor for final pathological Gleason score (GS) remains still unclear, although most centers routinely use both techniques in combination.

Methods: All patients with TB and additional SB, and subsequent radical prostatectomy (RP) between 01/2014 and 12/2020 at our institution were retrospectively analyzed. Spearman rank correlation coefficient predicted concordance with pathological GS for patients' TB and SB GS in separate fashions, as well as for the combined effect of SB+TB. Moreover, concordance, upgrading and downgrading rates were computed.

Results: Of eligible 159 patients with TB and SB, median age and PSA was 66 years and $7.0 \mathrm{ng} / \mathrm{ml}$. Of all, 77\% patients were biopsy naïve. For SB, a spearmen correlation of +0.33 was observed regarding final GS. The rates of concordance, upgrading, and downgrading for SB were $37.1 \%, 37.1 \%$, and $25.8 \%$, respectively. For TB, a +0.52 correlation was computed regarding final GS. The rates of concordance, upgrading and downgrading for TB biopsy GS were $45.9,33.3$, and $20.8 \%$, respectively. For the combined effect of $\mathrm{SB}+\mathrm{TB}$, a correlation of +0.59 was observed regarding final GS. The rates of concordance, upgrading and downgrading for $S B+T B G S$ were $49.7,15.1$, and $35.2 \%$, respectively. The combined effect of SB+TB resulted in a significantly lower upgrading rate but a significantly higher downgrading rate $(p=0.01)$.

Conclusion: GS obtained from TB provided higher concordance and lower upgrading and downgrading rates, relative to SB GS with regard to final pathology. The combined effect of $\mathrm{SB}+\mathrm{TB}$ led to the highest concordance rate and the lowest upgrading rate. The combined use of $S B+T B$ technique should be the standard procedure.
3K01.10

Transrektal oder transperineal? - Erfahrungen nach 1000 transperinealen Prostatabiopsien in Lokalanästhesie

K. Günzel ${ }^{*}$, S. Heinrich, H. Neubert, K. Sollik, A. Magheli, S. Hinz

Vivantes Klinikum Am Urban, Berlin, Germany

Aufgrund der Senkung des postoperativen Infektionsrisikos rückt der transperineale Zugangsweg für Prostatabiopsien in den Fokus. Transperineale Prostatabiopsien (TPBx) in Lokalanästhesie (LA) ermöglichen die ambulante Durchführung. Seit dem „TREXIT“ im April 2019 erfolgte im Vivantes Klinikum Am Urban keine transrektale Prostatabiopsie mehr.

In der retrospektiven Analyse werden die Behandlungsergebnisse (Infektionsraten, subjektives Schmerzempfinden, Prostatakarzinom(PCa)-Detektionsraten) nach 1002 TPBx in LA im Zeitraum 04/2019 bis 02/2021 dargestellt.

918 (92\%) dieser Biopsien waren MRT/Ultraschall Fusionsbiopsien (MRT/US TPBx) und 84 (8\%) systematische TPBx. Im Median war das Patientenalter 68 Jahre (62-74), der PSA-Wert vor Biopsie 6,69 ng/ml (4,8410,13) und des Prostatavolumen $45 \mathrm{ml}(32-65) .592$ (59\%) Patienten wurden vorstellig zur primären Biopsie und 115 (12\%) im Rahmen einer "Aktiven Überwachung". $10 \%$ (99/1002) der Patienten erhielten eine perioperative, antibiotische Prophylaxe. Die postoperative Infektionsrate war $0,6 \%$ (6/1002). Es zeigte sich eine PCa-Detektionsrate für die systematischen TPBx von $57 \%$ (48/84) und für die MRT/US-TPBx von $66 \%$ (606/918). Die Detektionsraten für PI-RADS 3, 4, 5 waren 39\%, $71 \%, 88 \%$. Das mediane Schmerzniveau bei der Durchführung der TPBx in LA auf einer analogen Schmerzskala war 2 (1-3).

Die Daten zeigen, dass die TPBx in LA bezüglich der niedrigen postoperativen Infektionsraten, dem moderaten, subjektiven Schmerzempfinden und der PCa-Detektionsraten eine geeignete Alternative zur transrektalen Prostatabiopsie darstellt.

\section{K01.11}

Randomisierte Untersuchung zum Vergleich der transperinealen MRT/Ultraschall Fusionsbiopsie der Prostata in Lokalanästhesie mit und ohne perioperative, antibiotische Prophylaxe - Eine Zwischenbilanz

\section{K. Günzel' ${ }^{1 *}$, E. Baco², M. Jacewicz², K. Sollik', A. Magheli', S. Hinz'}

'Vivantes Klinikum Am Urban, Berlin, Deutschland; ${ }^{2}$ Oslo University Hospital, Department of Urology, Oslo, Norwegen

Der transperineale Zugangsweg für die Durchführung von Prostatabiopsien gewinnt aufgrund der Senkung des Risikos von postoperativen Infektionen zunehmend an Bedeutung. Bisher wird laut EAU-Leitlinien eine perioperative, antibiotische Prophylaxe (AP) auch für die Durchführung von transperinealen Prostatabiopsien empfohlen.

Ziel der prospektiven, randomisiert-kontrollierten Interventionsstudie ist der Vergleich der Infektionsraten bei Patienten mit und ohne AP bei der Durchführung von transperinealen MRT/Ultraschall Fusionsbiopsie der Prostata (MRI-TRUS-TPBX) in LA.

Seit November 2020 wurden am Vivantes Klinikum Am Urban insgesamt 131 Patienten mit präoperativ Infekt-unauffälligen Urin und ohne Indikation für eine perioperative antibiotische Prophylaxe in die Studie eingeschlossen. Patienten erhielten nach Randomisierung präoperativ entweder eine Einmalgabe Cefuroxim intravenös als antibiotische Prophylaxe $(N=68)$ oder eine Infusion mit Kochsalz in der Gruppe ohne antibiotische Prophylaxe $(N=63)$. In dieser Zwischenbilanz werden beide Studiengruppen hinsichtlich der postoperativen Infektionsraten analysiert.

Hinsichtlich der Basischarakteristika (Alter, PSA-Wert, Prostatavolumen, suspekte DRU, relevante Vorerkrankungen) ergaben sich keine statistisch signifikanten Unterschiede zwischen den Patientengruppen. In beiden Studiengruppen ergaben sich keine Interventions-assoziierten postoperative Infektionen. 
Nach dem Einschluss von 131 Patienten zeigte sich bisher keine postoperative Infektion. Aufgrund der kleinen Patientengruppe ist eine endgültige Schlussfolgerung nicht möglich. Die Daten belegen aber die Tendenz, dass die Durchführung der MRI-TRUS-TPBx ohne AP möglich sein könnte.

3K01.12

Kombination von PI-RADS Score und SelectMDx ${ }^{\circledR}$-Test Ein neuer nicht-invasiver Score zur Identifizierung von Patienten mit Prostatakarzinom

O. Katzendorn ${ }^{1 *}$, C. A.-J. von Klot' ${ }^{1}$, S. Mahjoub ${ }^{1}$, P. Faraj Tabrizi ${ }^{1}$, N. N. Harke', H. Tezval', S. Hellms², J. Hennenlotter ${ }^{3}$, M.S. Baig ${ }^{3}$, A. Stenzl ${ }^{3}$, M. Lafos ${ }^{4}$, M. A. Kuczyk', S. Rausch³ I. Peters

'Medizinische Hochschule Hannover, Klinik für Urologie und Urologische Onkologie, Hannover, Deutschland; ${ }^{2}$ Medizinische Hochschule Hannover (MHH), Institut für Diagnostische Radiologie, Hannover, Deutschland; ${ }^{3}$ Universität Tübingen, Klinik für Urologie, Tübingen, Deutschland; ${ }^{4}$ Medizinische Hochschule Hannover, Institut für Pathologie, Hannover, Deutschland

Hintergrund: Verfügbare Test zur Prostatakrebsdiagnostik führen zu Überdiagnostik und Übertherapie des Prostatakarzinoms.

Methoden: In einer bi-zentrischen prospektiven Studie wurde der kommerziell verfügbare SelectMDx ${ }^{\circledR}$-Urintest bei 72 Patienten durchgeführt, die zur MRT-Fusionbiopsie zugewiesen wurden. Der SelectMDx ${ }^{\circledR}$-Test kombiniert mRNA-Levels von HOXC6 and DLX1 im Urin nach DRU mit klinischen Parametern zu einen Risikoscore für das Vorliegen eines Prostatakarzinoms. Assoziationen zwischen dem SelectMDx ${ }^{\circledR}$-Score mit klinischen und pathologischen Parametern wurden mittels T-Test und ANOVA analysiert. Sensitivität und Spezifität wurden in ROC-Analysen untersucht. Ergebnisse und Limitationen: Von 72 untersuchten Patienten wiesen $56,9 \%$ ein Prostatakarzinom und $37 \%$ ein klinisch signifikantes Prostatakarzinom (Gleason 27 ) in der MRT-Fusionsbiopsie auf. Der SelectMDx ${ }^{\circledast}$ Score war in Patienten mit Nachweis eines Prostatakarzinoms signifikant höher $(49,85 \pm 25,62$ vs. $21,29 \pm 26,28 ; p<0,01)$. Die Kombination von PIRADS-Score und SelectMDx ${ }^{\circledR}$-Score zu einem neuen Score führte zu statistisch signifikanten $(p=0,05)$ Prostatakarzinom-Detektionsraten mit einer Sensitivität von je $30 \%, 60 \%, 80 \%$, und $100 \%$. Limitationen unserer Studie beinhalten eine kleine Kohorte mit kleinen Subgruppen und einen potenziellen Bias in der Patientenauswahl.

Zusammenfassung: Die Kombination aus SelectMDx ${ }^{\oplus}$ - und PI-RADSScore hat das Potenzial unnötige Prostatastanzbiopsien zu verhindern und die Beratung der Patienten zu verbessern. Weitere prospektive Analysen mit uni- und multivariaten Regressionsanalysen und ROC-Analysen in größeren Kohorten sind nötig, um den diagnostischen Wert des neuen Scores zu überprüfen.

3K01.13

\section{External validation of two MRI-based risk calculators in prostate cancer diagnosis}

A.-L. Petersmann' ', S. Remmers'², P. Manava ${ }^{3}$, C. Hüttenbrink', S. A. Pahernik', F. A. Distler"

${ }^{1}$ Paracelsus Medizinische Privatuniversität, Urologie, Nürnberg, Germany; ${ }^{2}$ Erasmus University Medical Centre, Urology, Rotterdam, The Netherlands; ${ }^{3}$ Paracelsus Medizinische Privatuniversität, Radiologie und Nuklearmedizin, Nürnberg, Germany

Background: The diagnosis of significant prostate cancer (sPC) is impeded by overdiagnosis and unnecessary biopsy. Risk calculators (RC) have been developed to mitigate these issues. Contemporary RCs integrate clinical characteristics with mpMRI findings.

Objective: To validate two of these models: the MRI-ERSPC-RC-3/4 and the risk model of van Leeuwen.

Methods: 265 men with clinical suspicion of prostate cancer were enrolled. Every patient received a pre-biopsy mpMRI, which was reported ac- cording to PI-RADS v. 2.1, followed by stereotactic transperineal MRI/TRUS fusion-biopsy. Cancers with ISUP grade $\geq 2$ were classified as SPC. Statistical analysis was performed by comparing discrimination, calibration and clinical utility

Results and Limitations: There was no significant difference in discrimination between the two RCs. The MRI-ERSPC-RC-3/4-RC showed a nearly ideal calibration slope $(0.94 ; 95 \% \mathrm{Cl} 0.68-1.20)$ than the van Leeuwen model $(0.70 ; 95 \% \mathrm{Cl} 0.52-0.88)$. Within a threshold range up to $9 \%$ for a SPC, the MRI-ERSPC-RC-3/4-RC shows a greater net benefit than the van Leeuwen model. From $10 \%$ to $15 \%$ the van Leeuwen model showed a higher net benefit compared to the MRI-ERSP-3/4-RC. For a risk threshold of $15 \%$, the van Leeuwen model would avoid $24 \%$ vs. $14 \%$ compared to the MRI-ERSPC-RC-3/4 model; $6 \%$ vs. $5 \%$ sPC would be overlooked, respectively. Limitations include sample size and mono-central design.

Conclusion: Both risk models supply accurate results and reduce the number of biopsies and basically no SPC were overlooked. The van Leeuwen model suggests a better balance between unnecessary biopsies and overlooked SPC at a thresholds range of $10-15 \%$. The MRI-ERSPC-RC-3/4 risk model provides better overall calibration.

\section{K01.14}

\section{MRI grading for the prediction of prostate cancer aggressiveness}

L. Schimmöller ${ }^{1 *}$, T. Ullrich', M. Boschheidgen', M. Giessing ${ }^{2}$, G. Antoch', P. Albers ${ }^{2}$, C. Arsov ${ }^{2}$

'University Dusseldorf, Medical Faculty, Department of Diagnostic and Interventional Radiology, Düsseldorf, Germany; ${ }^{2}$ University Dusseldorf, Medical Faculty, Department of Urology, Düsseldorf, Germany

Purpose: To evaluate the value of multiparametric MRI (mpMRI) for the prediction of prostate cancer (PCA) aggressiveness.

Methods: In this single centre cohort study consecutive patients with histologically confirmed PCA were retrospectively enrolled. Four different biopsy ISUP grade groups (1, 2, 3, and 4-5) were defined and fifty patients per group were included. Several qualitative and quantitative clinical (age, PSA, PSAD, percentage of PCA infiltration) and mpMRI parameters (ADC value, signal increase on high $b$-value images, PCA diameter, extraprostatic extension [EPE], cross-zonal growth) were evaluated and correlated within the four groups. Based on combined descriptors, MRI grading groups (mG1-mG3) were defined to predict PCA aggressiveness.

Results: In total 200 patients (mean age 68 years, median PSA value $8.1 \mathrm{ng} / \mathrm{ml}$ ) were analysed. Between the four groups, statistically significant differences could be shown for age, PSA, PSAD, and for MRI parameters cross-zonal growth, high b-value signal increase, $E P E$, and $A D C$ $(p<0.01)$. All examined parameters revealed a significant correlation with the histopathologic biopsy ISUP grade groups $(p<0.01)$, except PCA diameter $(p=0.09)$. A mixed linear model demonstrated the strongest prediction of the respective ISUP grade group for the MRI grading system $(p<0.01)$ compared to single parameters.

Conclusions: MpMRI yields relevant pre-biopsy information about PCA aggressiveness. A combination of quantitative and qualitative parameters (MRI grading groups) provided the best prediction of the biopsy ISUP grade group and may improve treatment planning. Due to the high prevalence of higher-grade PCA in patients within $\mathrm{mG} 3$ a timely re-biopsy seems indicated in cases of negative or post-biopsy low-grade PCA. 
3K01.15

Relevanter Anstieg des Serum PSA nach Radfahren und Rudern in einer randomisierten Studie an 101 Männern - ein seltenes Phänomen

\author{
A. Lunacek ${ }^{1}$, M. Tischler ${ }^{1 *}$, D. Hebenstreit ${ }^{1}$, M. Schmudermaier ${ }^{2}$, E. Plas $^{1}$ \\ ${ }^{1}$ Hanusch Krankenhaus, Abteilung für Urologie, Wien, Österreich; ${ }^{2}$ Hanusch Krankenhaus, \\ Wien, Österreich
}

Einleitung: PSA-Testungen bilden seit vielen Jahren das Rückgrat der Prostatakrebs-Vorsorge. Vorangegangene Studien ergaben divergierende Ergebnisse hinsichtlich des Einflusses von Sport auf die Höhe des PSA.

Material und Methoden: Die Serumkonzentrationen von GesamtPSA (tPSA) und freiem PSA (fPSA) wurden in 101 gesunden Männern zwischen 20 und 80 Jahren (Durchschnitt 49,9 $\pm 15,7$ ) untersucht. Die Probanden trainierten randomisiert entweder gleich beim ersten Studientermin oder um mindestens 1 Woche zeitversetzt. Die Blutabnahmen erfolgten $15 \mathrm{~min}$ vor bzw max 60 min nachdem sie je nach Präferenz auf einem Ergometer bzw Rudergerät für $1 \mathrm{~h}$ trainierten sowie ein weiteres Mal am trainingsfreien Studientermin.

Die schief verteilten PSA Werte wurden mittels Wilcoxon-Test ausgewertet, zwischen den Gruppen wurde der Mann-Whitney-U-Test angewandt. Ergebnisse: Wir beobachteten einen zahlenmäßig geringen aber statistisch hochsignifikanten tPSA Anstieg nach Radfahren $(0,11 \pm 0,37 \mathrm{ng} / \mathrm{ml}$, $p=0,003)$ und Rudern $(0,07 \pm 0,13, p=0,001)$. Ebenso fiel ein Zuwachs des fPSA auf $(0,21$ vs. 0,$26 ; p=0,003)$. Hingegen ergab sich zwischen den Sportarten jeweils kein signifikant unterschiedlicher Anstieg ( $p=0,54$ bzw $0,18)$.

Unter den 101 Teilnehmern beobachteten wir in 2 Fällen einen deutlichen Anstieg von $>20 \%$ bei einem absoluten Wert von $>1 \mathrm{ng} / \mathrm{ml} \mathrm{tPSA}$ : von 4,5 auf 6,3 bzw. von 2,1 auf 3,9.

Schlussfolgerung: Sportliche Betätigung unmittelbar vor PSA-Bestimmungen führen gewöhnlich zu keiner relevanten Beeinträchtigung der Werte. Jedoch kann dies in Eizelfällen auftreten und sollte entsprechend der geltenden S3-Leitlinie nachgeprüft werden. Eine allgemeine Empfehlung, dass alle Männer entsprechend sportliche Betätigung vor der Untersuchung einschränken sollen, lässt sich aber nicht ableiten.

\section{K01.16}

\section{Prostate cancer specific mortality in the ERSPC trial: What is the role of screening result and adherence:}

C. Wetterauer ${ }^{1 *}$, S. Remmers ${ }^{2}$, L.W. Prause ${ }^{3}$, J. Hugosson ${ }^{4}$, T. L. J. Tammela ${ }^{5}$, M. Zappa ${ }^{6}$, V. Nelen ${ }^{7}$, M. Lujan ${ }^{8}$, L. Denis ${ }^{9}$, A. Paez ${ }^{10}$, D. Puliti ${ }^{6}$, A. Villers ${ }^{11}$, X. Rebillard ${ }^{12}$, R. Arnsrud Godtman ${ }^{13}$, C. Bangma ${ }^{14}$, F. H. Schröder ${ }^{14}$, A. Auvinen ${ }^{5}$, L. Manka' ${ }^{15}$, H. H. Seifert' ${ }^{1}$, S. F. Wyler ${ }^{16}$, M.J. Roobol ${ }^{2}$, M. Kwiatkowski ${ }^{16}$

'Universityhospital Basel, Basel, Schweiz; ${ }^{2}$ Erasmus University Rotterdam, Rotterdam, Niederlande; ${ }^{3}$ Kantonsspital Aarau, Aarau, Schweiz; ${ }^{4}$ Sahlgrenska Academy at the University of Göteborg, Götborg, Schweden; ${ }^{5}$ University of Tampere, Tampere, Finnland; ${ }^{6}$ University of Florence, Florence, Italien; ${ }^{7}$ Provinciaal Instituut voor Hygiëne Antwerp, Antwerp, Belgien; ${ }^{8}$ Hospital Infanta Cristina, Parla, Mardrid, Spanien; ${ }^{\circ}$ Europa Uomo, Oncology Centre Antwerp, Antwerp, Belgien; ${ }^{10} \mathrm{Hospital}$ Universitario de Fuenlabrada, Mardrid, Spanien; ${ }^{11}$ University Lille Nord de France, Lille, Frankreich; ${ }^{12}$ Clinique Beau Soleil, Montpellier, Frankreich; ${ }^{13}$ Sahlgrenska Academy at the University of Göteborg, Göteborg, Schweden; ${ }^{14}$ Department of Urology, Erasmus MC Rotterdam, Rotterdam, Niederlande; ${ }^{15} \mathrm{Klinikum}$ Braunschweig, Braunschweig, Deutschland; ${ }^{16}$ Cantonal Hospital Aarau, Aarau, Schweiz

With a median follow-up of 16 years the ERSPC trial shows a relative reduction of prostate cancer (PCa) specific mortality (PCSM) of $20 \%$ in favor of PSA based screening. Despite screening 520 men died from PCa.

This multicentre population-based randomised screening trial has included a total of 182,160 men. We provide descriptive analyses and visualizations of the screening history and outcome data of men who died of PCa in the ERSPC.

A total of 1313 men died of PCa in the ERSPC. $793(60 \%)$ men had been randomised to the control arm and $520(40 \%)$ to the screening arm.
$137 / 520$ (26\%) participants randomised to screening never attended (Group A). 218/520 (42\%) participants had an initial positive screening (i.e., recommendation for biopsy) (Group B). 117/520 (23\%) participants had at least one negative screening and did not follow up or had a positive screen (Group C) and 48/520 (9\%) participants completed the screening with negative screening and were diagnosed with PCa later in time (Group D). Median (IQR) age at death for the groups A-D was 72 years (69-77), 73 years (69-77), 74 years (70-78) and 75.5 years (70-80), respectively. The rate of $M+$ disease at diagnosis was $5 \%$ for Group A, 12\% for Group B, $29 \%$ for Group C, and 52\% for Group D.

This study analyses all cases of PCSM in a large population and describes scenarios in which screening failed. Adherence to screening was identified as most important contributing factors for success or failure of a screening protocol, reflected by the percentage of $\mathrm{M}+$ disease. In addition, men who completed screening with negative screenings in all rounds and died of prostate cancer should be classified as failure of screening protocol. These data should help in development and refinement of the future screening policy for $\mathrm{PCa}$.

\section{$3 \mathrm{~K} 01.17$}

Ist die totale lineare Infiltration des Prostatakarzinoms ein Prädiktor für eine ungünstige Pathologie bei Active Surveillance?

\section{Z. Al-Kailani*, S. Siemer, M. Stöckle, M. Saar}

Universität des Saarlandes, Urologie und Kinderurologie, Homburg-Saar, Deutschland

Einleitung: Gemäß den Leitlinien ist die Active Surveillance (AS) die Therapie der Wahl bei Patienten mit low-risk Prostatakarzinom (PCA). Dabei handelt es sich um Gleason 6 Tumore ohne Berücksichtigung des Tumorvolumens. Die aktuelle Studienlage deutet auf einen Zusammenhang zwischen der Tumorinfiltration in den Stanzbiopsien und einer ungünstigen Pathologie (UP) bei AS Kandidaten hin. Diese Analyse soll prüfen, ob bei Patienten unter AS, die schlussendlich eine radikale Prostatektomie (RP) erhielten, die Tumorinfiltration ein Prädiktor für UP ist.

Methoden und Methoden: Ausgewertet wurde eine AS Kohorte mit 108 Männer (<70 J.; max. T2; PSA $\leq 10 \mathrm{ng} / \mathrm{ml}$, max. 2 positive Biopsieproben und Gleason 6; Für Männer $>70$ gilt PSA $\leq 15 \mathrm{ng} / \mathrm{ml}$; Gleason $\leq 3+4)$. Der primäre Endpunkt war die UP nach Prostatekomie (Gleason Score $\geq 4+3$, $\geq \mathrm{pT3a}$, pN1 and/or R1). Es wurden die totale lineare Infiltration (TLI) der Kernbiopsie bei der Diagnosestellung und deren Einfluss auf eine UP untersucht. Eine weitere Kohorte, bei der sich 213 Männer mit low-risk PCA unmittelbar einer RP (iRP) unterzogen haben, wurde analysiert.

Ergebnisse: Nach einem medianen Follow-up von 25 Monaten wurde bei 67 Patienten der AS Kohorte eine RP durchgeführt. In der iRP Kohorte war die TLI länger (Median 1,8 vs 3,0 mm, $p=0,004$ ). Dennoch zeigte die UP mehr Übereinstimmungen mit der AS Kohorte ( $46 \%$ vs. $29 \%, P=0,011$ ). Insgesamt hat die Regressionsanalyse keinen Zusammenhang zw. TLI und der Verschlechterung der Histologie im Prostatektomiepräparat für beiden Gruppen ergeben.

Schlussfolgerung: Unabhängig von der Länge der TLI kann die AS bei Patienten mit low risk PCA empfohlen werden. Die Entscheidung zwischen der AS und der kurativen Therapie ist anhand der Tumorinfiltrationsrate allein nicht möglich. 
3K01.18

${ }^{68} \mathrm{Ga}$-PSMA PET/CT to detect pelvic lymph node metastases (LNM) in high risk prostate cancer (PCA) prior to radical prostatectomy (RP) and extended pelvic lymphadenectomy (epLND)

A. Kowalewski", D. Pfister, M. Schmautz, M. Bühler, A. Heidenreich

Uniklinik Köln, Köln, Germany

Purpose: The present study evaluates the potential role of ${ }^{68} \mathrm{Ga}-\mathrm{PSMA}$ $\mathrm{PET} / \mathrm{CT}$ to detect pelvic LNM in newly diagnosed, treatment-naïve high risk PCa patients prior to RP and EPLND.

Methods: 165 men with newly diagnosed high risk PCa (ISUP grade 4/5, PSA $>20 \mathrm{ng} / \mathrm{ml}$ or $\geq \mathrm{CT3a}$ ) were included in the retrospective study. All men underwent transperineal MR fusion biopsy, all men underwent RPE with epLND. Patients with neoadjuvant ADT, TRUS guided biopsies, previous radiation or surgery in the small pelvis were excluded. Imaging and pathohistological findings were correlated and sensitivity, specificity, positive and negative predictive values were calculated.

Results: Median PSA was $24.5(6.7-185) \mathrm{ng} / \mathrm{ml}$, median number of dissected lymph nodes was $21-5$ (14-45). 68/165 (41,2\%) pts had lymph node metastases (LNM) of which $43(63.2 \%)$ were positive on PSMA-PET/CT, 25 (36.8\%) LNM were negative. 97/165 (58.8\%) pts had pN0 disease of whom 93 (95.9\%) and 3 (4.1\%) demonstrated negative and positive PSMA PET/CT findings, resp. $n=47$ had positive PSMA PET/CT and $40(85.1 \%)$ demonstrated LNM, $7(14.9 \%)$ had pN0 disease. $\mathrm{N}=118$ had negative PSMA PET/CT of which 93 (78.8\%) and 25 (21.2\%) were true and false negative, resp. Sensitivity was $63.2 \%$, specificity was $97.0 \%$, and positive and negative predictive values were $93.5 \%$ and $78,8 \%$, resp. 3564 lymph nodes were resected, 149 (4.2\%) had LNM. 88/149 (59.1\%) were detected on PSMA PET/CT and 61 (40.9\%) were undetected. On a per lymph node base, sensitivity and specificity were $40.4 \%$ and $94.5 \%$, resp; positive and negative predictive values were $59.1 \%$ and $97.3 \%$.

Conclusions: PSMA-PET/CT has a high reliability to identify LNM in high risk PCA. If a positive lesion is detected, epLND is mandatory due to high frequency of undetected small LNM.

\section{K02 - Versorgungsforschung - Die Stimme des Patienten}

15.09.2021, C6.1, 10:30-12:00

3K02.1

Ambulant vor stationär? - Versorgungswirklichkeit bei kleinen urologischen Eingriffen in Deutschland von 2013 bis 2018

I. Leuchtweis ${ }^{1 *}$, M. Baunacke' ${ }^{1}$, C. Groeben ${ }^{1}$, C. Aksoy ${ }^{1}$, M. Schmidt ${ }^{2}$, A. Schneider ${ }^{3,4}$, C. Thomas ${ }^{1}$, J. Huber ${ }^{1,4}$

${ }^{1}$ Klinik und Poliklinik für Urologie, TU Dresden, Dresden, Deutschland; ${ }^{2}$ Coloplast GmbH, Hamburg, Deutschland; ${ }^{3}$ Urologische Gemeinschaftspraxis, Winsen/Luhe, Deutschland; ${ }^{4} \mathrm{AG}$ sektorenübergreifende fachärztliche urologische Versorgung, DGU e.V., Deutschland

Einleitung: Obwohl eine ambulanten Leistungserbringung ökonomisch erstrebenswert ist, erfolgen viele kleine urologische Eingriffe aktuell noch stationär. Ziel unserer Analyse ist zu prüfen, ob der aktuelle gesundheitspolitische Rahmen zu einer Ambulantisierung beiträgt.

Material und Methode: Datenbasis ist eine nach Alter und Regionen repräsentative Stichprobe von 4 Mio. Versichertenanonymen aus der Forschungsdatenbank des Instituts für angewandte Gesundheitsforschung $\mathrm{GmbH}$ (InGef). Wir berichten Hochrechnungen für die Anzahl ambulanter und stationärer Leistungen in ganz Deutschland zwischen 2013 und 2018.
Ergebnisse: Im Studienzeitraum fiel die Gesamtzahl der Prostatabiopsien von 184.573 auf 174.558. Der Anteil ambulanter Biopsien fiel kontinuierlich um $0,9 \%$ pro Jahr von $81 \%$ auf $76 \%(p<0,001)$. Bei der Injektion von Botulinumtoxin in die Blase stieg die Gesamtzahl von 15.630 auf 26.824. Der ambulant durchgeführte Anteil stieg dabei um 2,7 \% pro Jahr von $3 \%$ auf $19 \%(p=0,01)$. Für die übrigen untersuchten Eingriffe (Anlage suprapubischer Blasenkatheter, das Einlegen, Entfernen und Wechseln von Ureterschienen, Zystoskopien und die Harnröhrenbougierung) zeigten sich keine relevanten Veränderungen beim Anteil der ambulanten Leistungserbringung.

Schlussfolgerung: Die deutliche Zunahme ambulant erbrachter Botulinumtoxin-Injektionen zeigt den erfolgreichen Steuerungseffekt durch angepasste Vergütungsoptionen. Bei den Prostatabiopsien konnte eine Verschiebung in den stationären Sektor beobachtet werden. Möglicherweise ist dies auf höhere Anforderungen (Hygiene, MRT-Fusion) zurückzuführen. Langfristig wären Rahmenbedingungen wünschenswert, welche die Wahl des behandelnden Sektors entsprechend der Patientenbedürfnisse erlauben.

\section{$3 \mathrm{~K} 02.2$}

Nutzung von Krankenhausnavigatoren bei uroonkologischen Patienten in Deutschland: Ergebnisse der multizentrischen NAVIGATOR-Studie

\author{
C. Groeben ${ }^{1 *}$, K. Böhm² ${ }^{2}$ U. Sonntag ${ }^{3}$, T. Nestler', J. Struck', M. Heck', \\ M. Baunacke', A. Uhlig ${ }^{7}$, M. Kölker ${ }^{8}$, C.P. Meyer ${ }^{8}$, B. Becker ${ }^{9}$, J. Salem ${ }^{10}$, \\ J. Huber ${ }^{1}$, M. Leitsmann ${ }^{7}$
}

'Uniklinikum Dresden, Urologie, Dresden, Deutschland; ${ }^{2}$ Klinik und Poliklinik für Urologie und Kinderurologie der Universitätsmedizin Mainz, Urologie, Mainz, Deutschland; ${ }^{3}$ Universitätsklinikum Augsburg, Urologie, Augsburg, Deutschland; ${ }^{4}$ Bundeswehrkrankenhaus Koblenz, Koblenz, Deutschland; ${ }^{5}$ Universitätsklinikum Lübeck, Lübeck, Deutschland; ${ }^{6}$ Technische Universität München, Klinikum rechts der Isar, München, Deutschland; ${ }^{7}$ Universitätsmedizin Göttingen, Urologie, Göttingen, Deutschland; ${ }^{8}$ Universitätsklinikum Hamburg-Eppendorf, Urologie, Hamburg, Deutschland; ${ }^{9}$ Asklepios Klinik Hamburg Barmbek, Urologie, Hamburg, Deutschland; ${ }^{10}$ Klinik links vom Rhein, Urologie, Köln, Deutschland

Einleitung: Krankenhausnavigatoren (KN) bieten Patient*innen Unterstützung bei der Auswahl einer Klinik für geplante Therapien an. Welchen Einfluss diese Angebote in der Urologie haben ist bis dato unbekannt. Wir erwarteten eine maximale Nutzungsrate von $10 \%$ (95\% Cl 8,1-12,0\%) unter den uroonkologischen Patient*innen in Deutschland.

Methoden: An 10 deutschen Zentren wurden Patienten bei Aufnahme zur geplanten radikalen Prostatektomie, Zystektomie oder Nierentumoroperation mittels eines standardisierten Fragebogens befragt.

Ergebnisse: Wir erhielten $n=719$ Fragebögen (Rücklaufquote 71,9\%). Das mittlere Alter lag bei $65,0 \pm 10,4$ Jahren, $14,2 \%$ waren Frauen. Bei $47,6 \%$ waren eine Prostatektomie, bei $21,4 \%$ eine Nierentumoroperation, bei 15,3\% eine Zystektomie geplant. Von allen Befragten nutzten 54,4\% das Gespräch mit ihrem Arzt, 21,1\% vorrangegangene Erfahrungen in der Klinik, 17,1\% Empfehlungen von Angehörigen/Freunden, 10,7\% die Internet-Homepage der Klinik, 10,7\% sonstige und $7 \%$ keine Beratungsquellen um eine geeignete Klinik zu finden. 7,1\% $(n=51)$ nutzten einen KN zur Entscheidungsfindung. Dies bestätigte die erwartete Nutzungsrate von weniger als $10 \%(p=0,001)$. Am häufigsten wurden mit $20,3 \%$ die Plattform Weisse-Liste.de, mit 14,8\% der AOK-KN und mit 9,3\% der DAK-Klinikführer genutzt. 8,7\% der Nutzer*innen eines KN beschrieben, durch die Nutzung ihre ursprüngliche Klinikwahl geändert zu haben. In der Acceptability-E-Scale wurde die Nutzung eines KN durchschnittlich mit 23,7/30 Punkten überwiegend positiv bewertet.

Schlussfolgerung: Krankenhausnavigatoren spielen für uroonkologische Patient*innen in Deutschland eine geringe Rolle. Nutzer*innen änderten hierdurch zudem nur selten ihre vorherige Klinikwahl, bewerten die Nutzung jedoch überwiegend als positiv. 
3K02.3

Partizipative Entscheidungsfindung in der Urologie wie bewerten Patienten ihre Beteiligung?

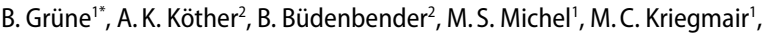
G.W. Alpers ${ }^{2}$

${ }^{1}$ Klinik für Urologie und Urochirurgie, Universitätsmedizin Mannheim, Mannheim, Deutschland; ${ }^{2}$ Lehrstuhl für Klinische und Biologische Psychologie und Psychotherapie, Fakultät für Sozialwissenschaften, Universität Mannheim, Mannheim, Deutschland

Ziel: Die Bestimmung der wahrgenommenen Beteiligung an der Partizipativen Entscheidungsfindung (PEF) urologischer Patienten und die Identifikation möglicher Einflussfaktoren.

Methoden: Es wurden 372 urologische Patienten einer universitären Ambulanz prospektiv in die Studie eingeschlossen. Vor der ärztlichen Konsultation wurden klinische und soziodemographische Parameter erhoben. Nach der Konsultation gaben die Patienten Auskunft über das Ausmaß ihrer wahrgenommenen Beteiligung, erfasst mittels des „Partizipative Entscheidungsfindung" Fragebogen (PEF-FB-9). Ein hohes Maß an Beteiligung war definiert als PEF-FB-9 Gesamtwert $>66$. Relevante Einflussfaktoren der wahrgenommenen Beteiligung wurden mit einer logistischen Regressionsanalyse identifiziert.

Ergebnisse: Insgesamt war die erlebte Beteiligung hoch (PEF-FB-9: $M=77,8, S D=20,6)$. Die Mehrheit der Patienten $(72,8 \%)$ fühlte sich in hohem Maß beteiligt. Die durchschnittliche Bewertung des PEF-FB-9 pro Item lag bei $3,9 \pm 1,4$ von 5 Punkten. Die geringste Zustimmung erhielt das Item "mein Arzt erfragt meine Beteiligungspräferenz" $(3,5 \pm 1,6)$. Migrationshintergrund (OR $3,7, p=0,05)$ und Vorstellung als Notfall (OR 2,1, $p=0,05)$ prädisponierten für eine mittlere bis geringe wahrgenommene Beteiligung (PEF-FB-9 $\leq 66$ ). Keinen Einfluss auf die Beteiligung hatten Geschlecht, Alter, Diagnose (onkologisch vs. nicht-onkologisch) und Komorbiditäten.

Schlussfolgerung: Die meisten urologischen Patienten fühlen sich in hohem $M a ß$ an ihrer Entscheidungsfindung beteiligt. Dennoch wird klar, dass Urologen die Beteiligungspräferenz ihrer Patienten ansprechen sollten. Besonders im Notfallsetting und bei Patienten mit Migrationshintergrund sollten Urologen darauf achten, ihre Patienten in den Entscheidungsprozess einzubeziehen.

\section{K02.4 \\ Vergleich zwischen G8- und ISAR-Screening in der geriatrischen Urologie}

\author{
J. Bouzan*, B. Stoilkov, S. Nellas, M. Horstmann \\ Helios St Josefshospital Uerdingen, Urologie, Krefeld, Deutschland
}

Fragestellung: Vergleich zwischen den G8- und ISAR-Screening-Fragebögen für die Einschätzung der geriatrischen Risikofaktoren bei urogeriatrischen Patienten.

Material und Methoden: Wir untersuchten retrospektiv 100 Patienten im Alter von 75 und darüber, die wegen verschiedener urologischer Erkrankung behandelt wurden. Alle Patienten wurden bei der Aufnahme sowohl einem G8- als auch einem ISAR-Screening unterzogen. Ein G8-Score $\leq 14$ und ISAR-Screening Score $>2$ wurden als positiv bewertet. Die Ergebnisse wurden zwischen beiden Tests verglichen und mit den Merkmalen des Patienten in Beziehung gesetzt.

Ergebnisse: Das Durchschnittsalter der Patienten betrug 83 Jahre (min. 75-max. 101). 78 der Patienten waren Männer und 22 Frauen. 24 waren Notfall Patienten und 76 geplante Aufnahmen. 56 der Patienten waren wegen urologischer Malignitäten und 44 wegen gutartiger urologischer Erkrankungen behandelt worden. 58 der Patienten waren G8-positiv und 42 G8-negativ. 24 waren ISAR-positiv und 76 ISAR-negativ. Alle ISAR positive Patienten waren auch G8-positiv. 34 der Patienten waren G8-positiv und ISAR-negativ. Es gab eine signifikante und starke negative Korrelation zwischen dem G8 und ISAR Score $(r=-0,77, p<0,001)$. Beide Tests korre- lierten signifikant mit dem Charlson-Komorbiditätsindex, der Verweildauer, der Anzahl der codierten Diagnosen und dem Braden-Score.

Schlussfolgerungen: Beide Tests korrelieren gleichermaßen mit klinischen Daten, die sich auf geriatrische Gebrechlichkeit beziehen. Im Vergleich weist der G8-Score eine viel höhere Rate an positiven Tests auf. Dies schränkt die Verwendung des G8-Score ein und begünstigt den ISARScore. Für geriatrische „Fitte“-Patienten ist ein negativer G8-Score für die weitere onkologische Entscheidungsfindung von großem Nutzen sein.

\section{K02.5}

Die Zukunft der Urologie: Demographie und 12-MonatsÜberlebensrate von urologischen Patienten 90+

K. Eredics' ${ }^{1}$, T. Luef ${ }^{2}$, S. Madersbacher ${ }^{2 *, 3}$

${ }^{1}$ Klinik Donaustadt, Urologie, Wien, Österreich; ${ }^{2}$ Klinik Favoriten, Urologie, Wien, Österreich; ${ }^{3}$ Sigmund Freud Privatuniversität, Wien, Österreich

Hintergrund: Der demographische Wandel wird zu einer deutlichen Zunahme von hochbetagten Patienten führen, die medizinische Versorgung benötigen.

Methoden: In einer retrospektiven Studie wurden alle 90+ Patienten analysiert, die zwischen 2014 und 2018 auf unserer urologische Abteilung aufgenommen wurden. Die Patienten wurden 12 Monate lang nachbeobachtet und Prädiktoren für die 12-Monats-Mortalität berechnet.

Ergebnisse: 152 Patienten (M: $n=86, \mathrm{~F}: n=66$ ) mit einem Durchschnittsalter von 92 Jahren (90-99 Jahre) nahmen an dieser Studie teil. Die häufigsten Indikationen für die Aufnahme waren Makrohämaturie (M $42 \%$, F $44 \%$ ), Blasenfunktionsstörungen (M 45\%, F 35\%), Harnwegsinfektionen (M $41 \%, F 70 \%)$, Hydronephrose (M $24 \%, F 22 \%$ ) und Harnverhalt (M 19\%, F 12\%). Die Häufigkeit von Blasenkrebs war $24 \%$ bei Männern und $11 \%$ bei Frauen, $6 \%$ der Männer und $4 \%$ der Frauen litten an Nierenzellkarzinomen. An Prostatakrebs litten $21 \%$ der Patienten. Die häufigsten invasiven Eingriffe waren das Einbringen eines Spülkatheters (M: $28 \%$, F: $32 \%$ ), Zystoskopie (M: 13\%, F: 17\%), Blasentumor-Resektion (M: 10,5\%, F: $3 \%$ ) und Einsetzen eines DJ-Katheters (M: $9 \%$, F: $10 \%)$. Die durchschnittliche Krankenhausaufenthaltsdauer betrug 6,5 Tage. Die Krankenhaus-Mortalität betrug 7,2 \% und die 12-Monats-Mortalität $45 \%$. Der stärkste Prädiktor für eine 12-Monats-Mortalität war der CSHA-FrailtyScore (<6: $36 \%,>6: 67 \%)$.

Fazit: Die Urogerontologie ist eine der größten Herausforderungen in unserem Bereich. Die hier untersuchte Kohorte von 90+ Patienten zeigt eine hohe Rate invasiver Interventionen und eine innerklinische Mortalität im Bereich von $7 \%$. Die 12-Monats-Sterblichkeitsrate beträgt fast $50 \%$, und Prädiktoren hierfür könnten das Managment dieser ständig wachsenden Kohorte unterstützen.

\section{K02.6}

Prospektive Versorgungsforschung zur Lebensqualität und psychosozialen Belastung nach radikaler Zystektomie wegen Urothelkarzinoms der Harnblase

G. Müller"*, M. C. Butea-Bocu', H. Bahlburg'², T. Hellmann², F. Schuster², F. Roghmann², U. Otto' ${ }^{1}$, J. Noldus ${ }^{2}$

'Urologisches Kompetenzzentrum für die Rehabilitation (UKR), Bad Wildungen, Deutschland; ${ }^{2}$ Marien Hospital Herne, Ruhr-Universität Bochum, Herne, Deutschland

Einleitung: In einem aktuellen Kollektiv werden prospektiv Patienten mit einem Urothelkarzinom der Harnblase nach radikaler Zystektomie (RZE) und Harnableitung in Form eines lleum Conduits (IC) oder einer orthotopen lleum Neoblase (NB) evaluiert.

Material und Methoden: Die Patienten wurden von 04/2018 bis 12/2019 mit Beginn der Anschlussheilbehandlung (AHB) in die Studie eingeschlossen. Es werden 6 Monate nach Entlassung aus der AHB der weitere Verlauf der Patienten, die Lebensqualität (EORTC QLQ-C30 und QLQ-BLM30) 
und die psychosoziale Belastung (Fragebogen zur Belastung Krebskranker FBK-R10) analysiert.

Ergebnisse: Von 842 Patienten erhielten $447(53,1 \%)$ ein IC und 395 $(46,9 \%)$ eine NB. Adjuvante Chemotherapie $11,4 \%$, Immuntherapie $2,1 \%$, erneute stationäre Behandlung 15,4\%, verstorben 3,8\%, Return-to-work $47,1 \%$. Die gesundheitsbezogene Lebensqualität verbesserte sich auch nach der AHB nochmals signifikant ( 55,8 vs. 62,$9 ; p<0,001)$, während sich die emotionale Funktion wieder verschlechterte $(71,6$ vs. 66,$1 ; p<0,001)$ und sich auch die Zukunftssorgen $(44,6$ vs. 49,$4 ; p<0,001)$ sowie die Unzufriedenheit mit dem eigenem Körper $(30,4$ vs. 38,$5 ; p<0,001)$ wieder verstärkten. Der Anteil von Patienten mit hoher psychosozialer Belastung stieg wieder deutlich an $(34,9 \%$ vs. $43,8 \% ; p<0,001)$. Die multivariate Regressionsanalyse konnte diesbezüglich keine unabhängigen Prädiktoren identifizieren.

Schlussfolgerung: Die vorliegende Untersuchung gibt einen Einblick in das komplexe Kollektiv der Patienten nach RZE und Anlage von IC oder NB. Diese Patientengruppe bedarf häufig einer adjuvanten Therapie und auch nach der AHB weiterer psychosozialer Unterstützung.

\section{K02.7}

Versorgungsrealität von Harnsäuresteinpatienten in Deutschland - eine Umfrage zum Therapie- und Behandlungsmanagement (MANUCA)

J. R. Wießmeyer*, T. Genske, T. Ozimek, J.P. Struck, J. Willig, M. C. Hupe, A.S. Merseburger, M.W. Kramer

Universitätsklinikum Schleswig-Holstein (Campus Lübeck), Klinik für Urologie, Lübeck, Deutschland

Einleitung: Für Harnsäuresteine (UCA) steht als eine Behandlungsoption die orale Chemolitholyse (OC) zur Verfügung. Es mangelt jedoch an wiss. Evidenz, welche Parameter in der Praxis in Hinblick auf UCA erhoben werden und in wieweit die $O C$ ins Therapieregime einbezogen wird.

Material und Methoden: Wir erstellten einen Fragebogen (21 Fragen), der u. a. Diagnostik und Therapie der UCA abfragte. Studienvorbereitung und Datenerhebung erfolgten 2020. Eine Teilnahme war online, per Fax oder postalisch möglich.

Ergebnisse: Wir erhielten 395 Fragebögen zurück (Universitätskliniken $22,7 \%$, Maximal - 19,3\%, Grund- und Regelversorger 21,6\%, Praxen $30,1 \%)$. Im Median werden 10 Steinpatienten pro Woche behandelt ( $R$ 0-200, IQR 16-5). 96,5\% würden mit einem geeigneten Prädiktionstool ihren Patienten eine OC anbieten (häufigster geforderter PPV $80 \%$ ) und $50,1 \%$ gaben an eine medikamentös expulsive Steintherapie um eine OC bei V.a. UCA zu ergänzen. $73,4 \%$ antworteten, bereits während der Diagnostik beim V.a. eine Urolithiasis nach Hinweisen auf die Zusammensetzung zu suchen. Zur Diagnostik setzen 92,3\% ein CT, 15,4\% ein Dual-Energy CT (DECT) und $32,6 \%$ ein IVP ein. Es zeiget sich ein signfikanter Zusammenhang $(p<0,001)$ mit starkem Effekt (Cramers V 0,542) zwischen der Verfügbarkeit eines DECT und der Art der Einrichtung. Eine OC basieren 82,4\% auf Blut- und Urinparametern, $59 \%$ auf den HU, $66 \%$ auf dem Röntgenverhalten, 40,4 \% auf dem BMI und 32,2\% auf dem Alter. Als Hauptproblem einer $\mathrm{OC}$ wird die Patientencompliance angesehen $(60,3 \%)$.

Schlussfolgerung: Unsere Ergebnisse zeigen die Versorgungsrealität von UCA-Patienten in Deutschland. Die Studie hilft Einblicke in Bedürfnisse und Fallstricke der OC zu gewinnen, was zur Entwicklung effektiverer Behandlungs- und Forschungsstrategien führen kann.
3K02.8

Ergebnisse nach perkutaner Nephrolitholapaxie bei Nierensteinen: Deutschlandweite Analyse von 16.201 Patienten aus der AOK-Krankenversicherungsdatenbank:

B. Becker ${ }^{1 *}$, C. Schulz², T. R.W. Herrmann ${ }^{3}$, A. J. Gross ${ }^{1}$, C. M. Rosenbaum', H.-H. König ${ }^{2}$, C. Netsch ${ }^{1}$

${ }^{1}$ Asklepios Klinik Hamburg Barmbek, Urologie, Hamburg, Deutschland; ${ }^{2}$ Universitätsklinikum Hamburg-Eppendorf, Institut für Gesundheitsökonomie und Versorgungsforschung, Hamburg, Deutschland; ${ }^{3}$ Kantonsspital Frauenfeld, Urologie, Frauenfeld, Schweiz

Einleitung: Ziel war es, die perkutane Nephrolitholapaxie (PCNL) hinsichtlich Komplikationen, Re-Interventions- und Re-Hospitalisierungsraten innerhalb von 30 Tagen anhand von Daten der allgemeinen Ortskrankenkassen (AOK) zu analysieren.

Material und Methode: Es wurden alle AOK-Versicherungsnehmer eingeschlossen, die zwischen 2008-2016 mit einer PCNL in Deutschland behandelt wurden. Die Anzahl der verschlüsselten Komplikationen innerhalb der ersten 30 Tage nach Operation sowie die Re-Interventions- und Re-Hospitalisierungsraten wurden analysiert.

Ergebnisse: Es wurden 16.201 Patienten eingeschlossen. Das Durchschnittsalter war 55,25 Jahre. Die häufigsten Komorbiditäten waren ein arterieller Hypertonus (39,62\%), ein Diabetes mellitus (19,1\%) und eine Adipositas (10,65\%). Die Re-Interventionsrate innerhalb von 30 Tagen lag bei $18,88 \%$, wobei die häufigste Maßnahme die Einlage bzw. Wechsel eines DJ-Katheters war bei je 1,951 (12,04\%) und 551 (3,40\%) Patienten. Für die Analyse der Patienten, die innerhalb des gleichen Krankenhausaufenthaltes eine zweite Steinbehandlung erhielten, wurden 15.842 Versicherungsnehmer ausgewertet. Aus dieser Gruppe, wurden 1450 (9,15\%) Patienten mittels PCNL, 543 (3,43\%) mittels URS und 430 (2,71\%) mittels ESWL erneut behandelt. Die Re-Hospitalisierungsrate lag bei insgesamt $14,13 \%$ innerhalb der ersten 30 Tage nach dem Operationszeitpunkt.

Zusammenfassung: Durch die erstmalige Analyse der AOK-Daten dieses Patientenkollektivs kann erstmals ein tiefer Einblick in sog. „big data“ der endoskopischen Steinbehandlung gewonnen werden. Es konnte gezeigt, dass die PCNL mit hohen Re-Interventions- und Re-Hospitalisierungsraten vergesellschaftet ist.

\section{K02.9}

Behandlungstrends bei muskelinvasivem Blasenkrebs in Deutschland von 2006 bis 2019

L. Flegar ${ }^{1 *}$, M. Baunacke' ${ }^{1}$ C. Groeben' ${ }^{1}$, C. Aksoy ${ }^{1}$, A. Borkowetz' ${ }^{1}$, K. Kraywinkel${ }^{2}$, N. Eisenmenger ${ }^{3}$, C. Thomas', J. Huber ${ }^{1}$

${ }^{1}$ Medizinische Fakultät Carl Gustav Carus, Technische Universität Dresden, Klinik für Urologie, Dresden, Deutschland; ${ }^{2}$ Nationales Zentrum für Krebsregisterdaten, Robert Koch-Institut, Berlin, Deutschland; ${ }^{3}$ Reimbursement Institute, RI Innovation, Hürth, Deutschland

Einleitung: Ziel der Studie war die Untersuchung von Behandlungstrends bei muskelinvasivem Blasenkrebs (MIBC) in Deutschland.

Materialien und Methoden: Hierfür nutzen wir die epidemiologischen Krebsregister (2006-2015) und die Qualitätsberichte der Krankenhäuser mithilfe von reimbursement. INFO (2006-2019). Zur regionalen Darstellung der Versorgung diente easymap $\odot$ office (Lutum+Tappert DV-Beratung $\mathrm{GmbH}$, Bonn).

Ergebnisse: Die jährliche Fallzahl der radikalen Zystektomie (RZE) in Deutschland für Patienten mit MIBC stieg von 6005 Fällen 2006 auf 7476 Fälle 2019 um 24,5\% ( $p=0,001)$. Der Anteil der zystektomierten Patienten blieb zwischen 2006 und 2015 in allen Altersgruppen konstant bei etwa $75 \%$. Bezogen auf alle RZE stieg der Anteil der Patienten $>75$ Jahre von $25 \%$ im Jahr 2006 auf $38 \%$ im Jahr $2019(p=0,03)$. Der Anteil der Patienten, die eine Kombination aus RZE und Chemotherapie erhielten, stieg von $9 \%$ im Jahr 2006 auf $12 \%$ im Jahr $2015(p=0,005)$. Die Patientengruppe ohne dokumentierte Behandlung sank von $8 \%$ im Jahr 2006 auf 
$5 \%$ im Jahr $2015(p=0,1)$. Die alleinige Behandlung mit entweder Chemotherapie oder Strahlentherapie blieb über den Studienzeitraum konstant. Im Jahr 2006 führten 11 von 295 urologischen Abteilungen (4\%) mehr als 50 RZE pro Jahr durch, wobei dieser Anteil 2019 mit 17 von 360 (5\%) auf demselben Niveau blieb. Im Jahr 2019 führten 107 Abteilungen (29\%) 25-49 RZE und 236 (66\%) Abteilungen < 25 RZE durch.

Schlussfolgerungen: In Deutschland erhalten drei von vier Patienten mit MIBC eine RZE und der Anteil der Patienten >75 Jahre steigt. Die Kombination aus Operation und Chemotherapie wird zunehmend eingesetzt. Bei insgesamt steigenden Fallzahlen zeigt sich keine Tendenz zur Zentralisierung.

\section{K02.10 \\ Auswirkung eines Arbeitszeitmodells auf den Facharzt für Urologie: Eine Ausbildung im Wandel der Zeit}

M. Bündgen ${ }^{1 *}$, D. Pfister ${ }^{2}$, M. Schmautz ${ }^{1}$, F. Hartmann ${ }^{2}$, A. Heidenrech ${ }^{3}$

'Uniklinik Köln, Urologie, Köln, Deutschland; ${ }^{2}$ Universität zu Köln, Köln, Deutschland; ${ }^{3}$ Uniklinik Köln, Köln, Deutschland

Hintergrund: Bei immer komplexer werdenden Teilbereichen der Urologie, die zunehmend in andere Fachabteilungen abzudriften drohen, liegt eine national und international zu beobachtende Unzufriedenheit unter den Weiterzubildenden vor. Der Aspekt, welcher in Umfragen repetitiv angemerkt wird, ist fehlende Zeit. Wir analysierten die zur Verfügung stehende Zeit zur Weiterbildung und den Einfluss des Arbeitszeitmodells in unserer Klinik über das letzte Viertel Jahrhundert.

Material und Methoden: In die Berechnung gingen die Arbeitszeitmodelle von 1996, 2000, 2007, und 2017 ein. Als Basis dient das Modell von 1996 ohne Ausbildungsverlust durch Freizeitausgleichstage. Alle Tage, an welchen keine Anwesenheit in der Klinik mit Beginn des Tagesgeschäft vorlagen mit regelhafter Einteilung wurden gestrichen. Zudem wurden die Richtzahlen in den jeweils gültigen Weiterbildungsordnungen und der damit verbundenen Zeitaufwand berechnet. Das zu versorgende Patientenaufkommen wurde aus den jährlichen Krankhausreporten entnommen.

Ergebnisse: Bei zunehmendem Patientenaufkommen im ambulanten und stationären Sektor in unsere Klinik kommt es zu einem kontinuierlichen Abfall der Weiterbildungszeit. Die Weiterbildungszeit ist absolut auf 3,1 Jahre gefallen. Mit Beginn der Tätigkeit muss mit dem aktuellen Arbeitszeitmodell pro Tag 80 min selbstständige Diagnostik oder Interventionen durchgeführt werden, um die Richtzahlen zu erfüllen.

Schlussfolgerung: Die begrenzte Weiterbildungszeit wurde durch eine Ausdünnung der Richtzahlen in der neuen Weiterbildungsordnung aufgelockert. Um die verschiedenen Bereiche der Urologie zu vermitteln ist ein strukturiertes Curriculum erforderlich, welches national zur Vereinheitlichung Anwendung finden muss.

\section{K02.11}

Auswirkungen der COVID-19 Pandemie auf die Ausbildung urologischer ÄrztInnen in Weiterbildung in Deutschland

C. Aksoy ${ }^{1 *}$, T. Nestler', M. Kölker ${ }^{3}$, A. Uhlig ${ }^{4}$, H. Borgmann ${ }^{5}$, J. Struck ${ }^{6}$, N. von Landenberg ${ }^{7}$, A. Mattigk ${ }^{8}$, P. Reimold ${ }^{9}$, V. Zehe ${ }^{8}$, K. Boehm $^{5}$, M. Leitsmann ${ }^{4}$, GeSRU Academics - Versorgungsforschung \& Soziale Medien

${ }^{1}$ Klinik und Poliklinik für Urologie, Medizinische Fakultät Carl Gustav Carus, TU Dresden, Dresden, Deutschland; ${ }^{2}$ Klinik für Urologie, Uniklinik Köln, Köln, Deutschland; ${ }^{3}$ Klinik und Poliklinik für Urologie, Universitätsmedizin Hamburg-Eppendorf, Hamburg, Deutschland; ${ }^{4}$ Klinik für Urologie, Universitätsmedizin Göttingen, Georg-August-Universität, Göttingen, Deutschland; ${ }^{5}$ Klinik und Poliklinik für Urologie und Kinderurologie, Universitätsmedizin Mainz, Mainz, Deutschland; ${ }^{6}$ Klinik für Urologie, Universitätsklinikum Schleswig-Holstein, Lübeck, Deutschland; ${ }^{7}$ Klinik für Urologie, Marien-Hospital Herne, Herne, Deutschland; ${ }^{8}$ Klinik für Urologie, Universitätsklinikum Ulm, Ulm, Deutschland; ${ }^{\circ}$ Urologische Universitätsklinik Heidelberg, Universitätsklinikum Heidelberg, Heidelberg, Deutschland
Fragestellung: Ziel dieser Arbeit war, die Ausbildungssituation urologischer ÄrztInnen in Weiterbildung in Deutschland während der COVID-19 Pandemie zu betrachten.

Material und Methoden: Im Mai 2020 wurde eine deutschlandweite online-Umfrage zur Weiterbildungssituation über die Mitglieder der Arbeitsgruppe, soziale Medien (Facebook, Twitter, Instagramm) und den GeSRU Newsletter verteilt. Die Umfrage erfasste 3 Teilbereiche: 1) Grundcharakteristika der Teilnehmerlnnen, 2) genereller und 3) subjektiver Einfluss der COVID-19 Pandemie auf Klinik und Weiterbildung.

Ergebnisse: Insgesamt nahmen 50 ÄssistenzärztInnen an der Umfrage teil, davon $54 \%$ Frauen. Das Durchschnittsalter betrug 30,9 Jahre. Die meisten Teilnehmerlnnen befanden sich im 2. (22\%) und 5. (26\%) Ausbildungsjahr und arbeiteten in einer Universitätsklinik (44\%) oder in einem Haus der Maximalversorgung (30\%) in Baden-Württemberg (18\%), Hamburg (16\%) oder Bayern (14\%). $38 \%$ der Befragten gaben an, aufgrund der COVID-19 Pandemie nur noch im Notfallbetrieb zu arbeiten. Für $28 \%$ bedeutete dies eine sehr starke Verzögerung der Facharztausbildung, während $28 \%$ nur eine geringe Einschränkung angaben. $66 \%$ dokumentierten Beeinträchtigungen der Ausbildung aufgrund eines reduzierten OP-Einsatzes, weniger Einsätze in der Ambulanz (50\%), sowie der Absage von Kongressen (50\%) und Weiterbildungen (44\%). $46 \%$ der Befragten gaben direkten Kontakt zu COVID-19 Patienten an. $10 \%$ wurden auf interdisziplinären IMC-Stationen eingesetzt. Insgesamt wurden zahlreiche Schritte zum „physical distancing" und Hygienemaßnahmen von den Kliniken umgesetzt.

Schlussfolgerungen: Im Durchschnitt gaben etwa $50 \%$ der urologischen Assistenzärztlnnen deutliche Einschränkungen in der Weiterbildung durch die COVID-19 Pandemie an.

\section{K02.12}

\section{Impact of the COVID-19 pandemic on urologists in Germany}

P. Paffenholz ${ }^{*}$, A. Peine ${ }^{2}$, N. Fischer ${ }^{1}$, M. Hellmich ${ }^{3}$, D. Pfister ${ }^{1}$, A. Heidenreich ${ }^{1}$, S. Loosen ${ }^{4}$

'Universitätsklinikum Köln, Klinik und Poliklinik für Urologie, Uro-Onkologie, Roboterassistierte und Spezielle Urologische Chirurgie, Köln, Germany; ${ }^{2}$ Uniklinik RWTH Aachen, Klinik für Operative Intensivmedizin und Intermediate Care, Aachen, Germany; ${ }^{3}$ Medizinische Fakultät und Uniklinik Köln, Institut für Medizinische Statistik und Bioinformatik (IMSB), Köln, Germany; ${ }^{4}$ Universitätsklinikum Düsseldorf, Klinik für Gastroenterologie, Hepatologie und Infektiologie, Düsseldorf, Germany

Background: In order to contain the COVID-19 pandemic, Germany has implemented drastic restrictions on public or social life, while health institutions are invoked to postpone elective procedures. Although urologists are less involved in the direct treatment of COVID-19 patients, the current situation strongly affects the urological work routine. The objective was to analyze the impact of the COVID-19 pandemic on aspects of work and personal life among urologists in Germany.

Material and methods: 589 urologists in Germany participated in an online survey between March 18th and April 11th 2020. Participants were stratified into subgroups according to professional characteristics.

Results: Most urologists rated Germany as "well prepared" and the increasing restrictions of social life as "very positive". Routine operation was more restricted in hospitals compared to the outpatient sector $(p=0.046)$. Moreover, urologists from the outpatient sector felt significantly less prepared for the COVID-19 pandemic $(p=0.001)$, reported a higher shortage of protective medical equipment $(p<0.001)$ and described a tendency towards a higher level of threat $(p=0.054)$. Although restrictions regarding telemedicine approaches were reported by $60 \%$ of participants, the outpatient sector used telehealth more frequently compared to hospitals ( $25.5 \%$ vs. $17.0 \%, p<0.001)$.

Conclusions: This survey systematically evaluates the impact of the COVID-19 pandemic on private and professional aspects among German urologists. We identified several issues such as a higher shortage of medical protective equipment in the outpatient sector that could trigger specific measures to further improve the quality of urological care in Germany. 
3K02.13

Einfluss der COVID-Pandemie auf die klinische Versorgung in der Urologie - eine weltweite Umfrage

R. Dotzauer*, K. Böhm, M. Brandt, P. Sparwasser, M. Haack, S. Frees, K. Gheith, R. Mager, W. Jäger, T. Höfner, I. Tsaur, A. Haferkamp, H. Borgmann

Klinik und Poliklinik für Urologie und Kinderurologie der Universitätsmedizin Mainz, Mainz, Deutschland

Fragestellung: In Anbetracht der weltweiten Bündelung der medizinischen Ressourcen zur Bewältigung der COVID-Pandemie, war unser Ziel, die durch die erste Phase der Pandemie verursachten Veränderungen in der klinischen Versorgung von urologischen Patienten zu erfassen.

Material und Methoden: Für diese Querschnittstudie wurde ein OnlineFragebogen mit 12 Items zu den globalen Veränderungen der klinischen Versorgung in der Urologie entworfen. Demographische Umfragedaten, Veränderung des klinischen Patientenversorgung, der Status der aktuell durchgeführten Operationen und die Handhabung medikamentöser onkologischer Behandlungen wurden evaluiert.

Ergebnisse: 235 Urologen aus 44 Nationen nahmen an der Umfrage teil. $93 \%$ der Befragten gaben Änderungen der klinischen Versorgung auf Grund der COVID-Pandemie an. Anhand eines 4-Stufigen-Eskalationsschemas von durchgeführten Operationen gaben $44 \%$ primäre, $23 \%$ sekundäre und $20 \%$ tertiäre Stornierung an. $13 \%$ führten lediglich noch Notfalleingriffe durch. Onkologische Operationen hatten geringe Stornierungsraten. (Neo)adjuvante/palliative Behandlungen wurden von mehr als der Hälfte der Befragten auf Grund der Pandemie nicht durchgeführt. Schlussfolgerung: Die COVID-19-Pandemie hat großen Einfluss auf die klinische Versorgung in der Urologie weltweit genommen. Welchen Einfluss Stornierung oder Verzögerungen v. a. bei onkologischen Erkrankungen auf den Krankheitsverlauf haben werden zukünftige Studien evaluieren müssen.

\section{K02.14 \\ Veränderungen im Urolithiasismanagement während der COVID-19 Pandemie}

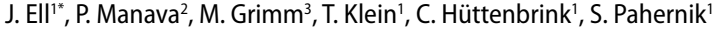

${ }^{1}$ Klinikum Nürnberg, Klinik für Urologie, Nürnberg, Deutschland; ${ }^{2}$ Klinikum Nürnberg, Institut für Radiologie und Nuklearmedizin, Nürnberg, Deutschland; ${ }^{3}$ Klinikum Nürnberg, Medizin \& Ökonomie, Nürnberg, Deutschland

Einleitung: Durch die Covid-19 Pandemie hat sich das medizinische Management verschoben. Ziel dieser Studie war es, die Versorgung von Steinpatienten in der Pandemie-Ära verglichen mit der Vor-Pandemie-Ära zu untersuchen.

Methode: Eingeschlossen wurden alle Patienten, die sich am Klinikum Nürnberg mit Verdacht auf symptomatische Urolithiasis innerhalb von zwei Zeiträumen (November 2019-Januar 2020: Prä-Pandemie; November 2020-Januar 2021: Pandemie-Lockdown) vorstellten. Klinische und sozioökonomische Parameter wurde erhoben.

Ergebnisse: Zwischen November 2019 und Januar 2020 (Prä-Pandemie) stellten sich 391 Patienten mit Verdacht auf symptomatische Urolithiasis vor. Im Vergleich dazu stellten sich zwischen November 2020 und Januar 2021 während des Pandemie-Lockdowns lediglich 314 Patienten mit derselben Diagnose vor. Mit Urolithiasis stationär aufgenommen wurden 86 Patienten in der Prä-Pandemie-Periode vs. 63 Patienten in der LockdownPeriode. Das mittlere Patientenalter veränderte sich nicht signifikant $(49,9$ vs. 52,5 Jahre), ebenso wenig der Case-Mix-Index (0,605 - Range 0,1751,288 vs. 0,597 - Range $0,175-1,33$ ). Die mittlere Verweildauer der Patienten stieg jedoch von 2,29 $\pm 2,3$ Tagen in der Vor-Pandemie-Periode auf 3,1 $\pm 6,1$ Tagen in der Lockdown-Periode, wobei ein signifikant höherer Patientenanteil länger als einen Tag stationär aufgenommen wurde $(p<0,05)$. Auch der Anteil an Langliegern mit einer Aufenthaltsdauer über der oberen Grenzverweildauer am Patientengut stieg von 3,5\% auf 6,3\%.
Schlussfolgerung: Während der Pandemie stellten sich deutlich weniger Patienten notfallmäßig mit Verdacht auf Urolithiasis vor. Gleichzeitig nahm die Schwere dieser Fälle zu, was sich in einem signifikant höheren Anteil an länger stationär aufgenommenen Patienten ausdrückte.

\section{K02.15}

Der Einfluss der SARS-CoV2-Pandemie auf die Versorgung von Patienten mit metastasierter uroonkologischer Erkrankung unter systemischer Krebstherapie - eine Bestandsaufnahme an deutschen Universitätskliniken

J.P. Struck ${ }^{1 *}$, M. Schnoor ${ }^{2}$, A. Schulze ${ }^{3}$, M.C. Hupe ${ }^{3}$, T. Ozimek ${ }^{3}$, M.W. Kramer ${ }^{3}$, I. A. Oppolzer ${ }^{4}$, M. J. Schnabel ${ }^{4}$, M. Burger ${ }^{4}$, C. Darr ${ }^{5}$, V. Grünwald ${ }^{5}$, B. Hadaschik ${ }^{5}$, M. Weinke ${ }^{6}$, H. Kübler ${ }^{6}$, J.C. Klockenbusch ${ }^{7}$, M. T. Grabbert ${ }^{7}$, C. Gratzke ${ }^{7}$, A. Katalinic ${ }^{2}$, A.S. Merseburger ${ }^{3}$

'UKSH Campus Lübeck, Lübeck, Deutschland; ${ }^{2}$ Institut für Sozialmedizin und Epidemiologie, UKSH Campus Lübeck, Lübeck, Deutschland; ${ }^{3}$ UKSH Campus Lübeck, Klinik für Urologie, Lübeck, Deutschland; ${ }^{4}$ Caritas Krankenhaus St. Josef, Universität Regensburg, Klinik für Urologie, Regensburg, Deutschland; ${ }^{5}$ Universitätsklinikum Essen, Klinik für Urologie, Kinderurologie und Uroonkologie, Essen, Deutschland; ${ }^{6}$ Universitätsklinikum Würzburg, Klinik und Poliklinik für Urologie und Kinderurologie, Würzburg, Deutschland; ${ }^{7}$ Universitätsklinikum Freiburg, Klinik für Urologie, Freiburg im Breisgau, Deutschland

Fragestellung: Bis heute wurden über 2 Mio. Deutsche mit dem SARS-CoV2-Virus infiziert. Dies führt zu erhöhten Belastungen des Gesundheitssystems. Uro-onkologische (UO) Patienten (Pat) sind besonders gefährdet, benötigen aber vielfach lebenswichtige Therapien. Mit unserer multizentrischen Studie soll die Versorgungsrealität dieser Patienten an deutschen Universitätskliniken untersucht werden.

Material und Methoden: Wir werteten klinische Parameter von insgesamt 161 UO-Patienten mit metastasierter Erkrankung unter systemischer Krebstherapie an 5 Universitätsstandorten zwischen Oktober 2019 und Ende Mai 2020 aus. Es erfolgte eine univariate Analyse mittels Fisher-Exact-Test, um eine Assoziation zwischen u.a. Therapieform und -verzögerungen zu prüfen.

Ergebnisse: Ein Großteil der Pat war männlich (87,6\%) mit einem Altersmedian von 67 Jahren. In 25/161 (15,5\%) Fällen erfolgte eine Therapieverzögerung von mehr als 2 Wochen. Ein Großteil dieser Pat erhielt eine immunonkologische (IO) (13 Pat, 18,3\%) oder eine Androgendeprivationstherapie (ADT) (5 Pat, 17,2\%, $p=0,746$ ). Bei 52 (32,3\%) Pat erfolgte eine veränderte Nachsorge. In 43 Fällen (26,7\%) erfolgte eine Verschiebung von Laboruntersuchungen, signifikant häufiger bei IO-Pat $(21,1 \%$, $p=0,042)$. Von den Auswirkungen waren Urothelkarzinome (7/32 Pat, $21,9 \%)$ am stärksten betroffen. 11 Pat $(6,8 \%)$ starben in der Progression. Schlussfolgerungen: Die Coronapandemie beeinträchtige bei einem Drittel der Pat die Nachsorge und bei knapp einem Fünftel die Therapie. Tendenziell waren dies vermehrt IO- und ADT-Therapien. Die Daten belegen, dass die Coronapandemie die Versorgung von UO-Pat an deutschen Universitätskliniken beeinträchtigt, aber bisher offensichtlich nicht zu onkologisch relevanten Therapieveränderungen führt.

\section{K02.16}

\section{Patientenveranstaltungen in der deutschen Urologie: Trend zu Hybrid-Formaten?}

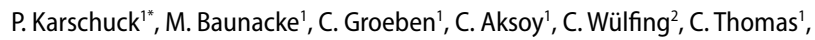
J. Huber ${ }^{1}$

'Universitätsklinikum „Carl Gustav Carus" an der Technischen Universität Dresden, Klinik und Poliklinik für Urologie, Dresden, Deutschland; ${ }^{2}$ Asklepios Klinik Altona, Hamburg, Deutschland

Einleitung: Durch das „Patientenforum" setzt sich die Deutsche Gesellschaft für Urologie e.V. auf ihren Jahreskongressen für die Patienteninformation und Öffentlichkeitsarbeit ein. Ziel der Arbeit war die Evaluation 
der Veranstaltungen in den Jahren 2017 bis 2019 (Präsenzgruppe; P) und ein Vergleich mit dem ersten digitalen Patientenforum 2020 (Onlinegruppe; 0).

Material und Methoden: Anhand eines zweiseitigen, standardisierten Fragebogens befragten wir die Besucher*innen des Präsenz-Patientenforums sowie die Nutzer*innen des digitalen Angebotes.

Ergebnisse: Für die Jahre 2017-2020 erhielten wir $n=79$ Datensätze. Das mediane Alter der Besucher*innen lag bei 64 Jahren (Spannweite 30-89). Männlich waren $66 \%(P)$ vs. $83 \%(0)$ der Teilnehmer*innen ( $p>0,05)$. Das Angebot wurde von beiden Gruppen insgesamt als gut bis sehr gut bewertet $(p>0,05)$, d. h. in Schulnoten 1,6 (P) vs. 1,5 (0). Die Möglichkeit Fragen zu stellen wurde entsprechend der geringeren Interaktion im digitalen Format deutlich schlechter bewertet $(p=0,008)$, d. h. in Schulnoten 1,5 (P) vs. 2,8 (0). Auf die Frage nach dem zukünftig gewünschten Veranstaltungsformat sprachen sich die Nutzer des digitalen Patientenforums mit zwei Dritteln für eine Hybrid-Veranstaltung vor Ort und online aus.

Schlussfolgerung: Patientenveranstaltungen werden sehr geschätzt und die Interaktion mit Expert*innen hat einen hohen Stellenwert. Präsenzformate sind mit einem hohen logistischen Aufwand verbunden und ihre Reichweite ist limitiert. Zukünftig können Hybrid-Formate eine sinnvolle Alternative sein, da sie die Vorteile von Online- und Präsenzformaten kombinieren.

3K02.17

Digitale Patientenbefragung mit dem Convalescence and recovery evaluation (CARE) Fragebogen zur Erfassung der Rekonvaleszenz nach urologischen Eingriffen

F. Wessels ${ }^{1 *}$, M. Lenhart ${ }^{1}$, M. Neuberger ${ }^{1}$, J. Mühlbauer', J. Huber ${ }^{2}$, J. Breyer ${ }^{3}$, P. Nuhn' ${ }^{1}$, M. S. Michel' ${ }^{1}$ J. König ${ }^{4,5}$, M. Kriegmair ${ }^{1}$

'Universitätsmedizin Mannheim, Klinik für Urologie und Urochirurgie, Mannheim, Deutschland; ${ }^{2}$ Universitätklinikum Carl Gustav Carus, Klinik und Poliklinik für Urologie, Dresden, Deutschland; ${ }^{3}$ Caritas Krankenhaus St. Josef, Universität Regensburg, Klinik für Urologie, Regensburg, Deutschland; ${ }^{4}$ Klinik für Kinder- und Jugendpsychairtrie, Zentrum für Psychosoziale Medizin, Universitätsklinikum Heidelberg, Sektion für Experimentelle Kinder- und Jugendpsychiatrie, Heidelberg, Deutschland; ${ }^{5}$ Universitätsklinik für Kinderund Jugendpsychiatrie und Psychotherapie, Bern, Schweiz

Fragestellung: Evaluation eines elektronischen patient-reported outcome measure (ePROM) Systems zur Erfassung des Gesundheitsstatus nach urologischen Eingriffen.

Material und Methoden: 283 Patienten (Prostatektomie, (RP), $n=146$; Zystektomie (RC), $n=67$, radikale/partielle Nephrektomie, (R/PN), $n=70$ ) wurden mit einer deutschen Übersetzung des CARE-Fragebogens (Skalen: gastrointestinal (Gl), Schmerz, Aktivität, Kognition, Gesamtscore (GS)) in digitaler Form präoperativ (IN), bei Entlassung (OUT) und 6 Wochen postoperativ (FU) befragt. Die interne Konsistenz wurde mittels Crohn's a bestimmt. Mit gemischt linearen und multivariaten Regressionsmodellen wurde der Einfluss des Befragungszeitpunkts (ZP), der Art der Operation (OP) und weiterer Faktoren sowie die Prädiktion der Lebensqualität (QoL), gemessen am QLQ-C30, evaluiert.

Ergebnisse: Die interne Konsistenz war für alle Skalen hoch bis sehr hoch $(a=0,649-0,920)$. Univariate Modell-Effekte $(p<0,005$ für alle CARE-Skalen) zeigten sich jeweils für den ZP (IN vs. OUT: sign. Punktzahlabnahme, OUT vs. FU: sign. Zunahme) und die OP (Punktzahl RP $>$ R/PN $>$ RC). Im multivariaten Modell (ZP + OP) zeigte sich nur für die RC Gruppe in den Skalen $\mathrm{GI}\left(X^{2}{ }_{(4)}=30,75, p<0,001\right)$ und $\mathrm{GS}\left(X_{(4)}^{2}=13,47, p=0,010\right)$ ein signifikanter Effekt im Sinne in einer größeren Abnahme der Punktzahl zum ZP OUT und geringerer Anstieg zum ZP FU. Patienten mit Komplikationen zeigten einen signifikant geringeren $\mathrm{GS}\left(\mathrm{X}_{(2)}^{2}=8,31, p=0,016\right)$. Ein hoher GS zum ZP Entlassung zeigte sich als unabhängiger Prädiktor für eine hohe QoL 8 Wochen postoperativ ( $O R=5,26,95 \%-K I ~ 1,42-19,37$, $p=0,013)$.
Schlussfolgerung: Der CARE zeigt als ePROM eine hohe Validität zur Erfassung des Gesundheitsstatus nach urologischer Chirurgie und eignet sich zur Vorhersage der postoperativen QoL.

\section{K02.18}

\section{Erste Daten aus einer digitalen Gesundheits-App für Erektionsstörungen}

\author{
L. Wiemer ${ }^{1 *}$, T. Bartelheimer ${ }^{2}$, R. Raschke ${ }^{3}$, K. Miller ${ }^{1}$
}

${ }^{1}$ Charité, Universitätsmedizin Berlin, Berlin, Deutschland; ${ }^{2}$ Urologie am Kurfürstendamm, Berlin, Deutschland; ${ }^{3}$ Urologische Facharztpraxis Ralph Raschke, Berlin, Deutschland

Die Digitalisierung der Medizin schreitet voran. Mit dem Inkrafttreten des Digitale-Versorgung-Gesetzes (DVG) müssen sich Ärztlnnen mehr mit digitalen Gesundheitsanwendungen auseinandersetzen. Spezielle urologische DiGA (digitale Gesundheitsanwendungen), welche BfArM geprüft sind, gibt es bisher nicht.

Bei erektiler Dysfunktion (ED) fehlt oft die Zeit um mit dem Patienten ausführlich über die zugrundeliegenden Zusammenhänge und die Notwendigkeit zur Lebensstiländerung zu reden.

Gerade bei zeitaufwändigen und kostenintensiven Therapien wie der ED könnten DiGAs unterstützend und unabhängig von medikamentöser Therapie wirken.

Methoden: Wir haben in einem Prototyp einer Anwärter-DiGA die Wirksamkeit eines Evidenz-basierten Programms für Patienten mit ED an 30 Patienten getestet.

Die Patienten durchliefen ein 12-Wochen-Programm, welches aus Beckenboden-, Aerobic- und kardiovaskulärem Training besteht. Ergänzt wurde dies durch Anleitungen zur Stressbewältigung, Achtsamkeitsmeditationen und Wissensvermittlung.

Der Altersmedian lag bei 51 Jahren (26-81 Jahre). Die Patienten wurden vor Beginn und nach Abschluss mittels IIEF-6 Fragebogen befragt.

Ergebnisse: Nach Absolvierung des Programms ergab sich eine sich eine durchschnittliche Verbesserung von 4,6 Punkten beim IIEF-6. Bei 3/4 der Patienten hat sich die Qualität der Erektionen verbessert. Insgesamt sind $2 / 3$ der Patienten zufriedener als bei Programmstart. In Anbetracht der IIEFVerbesserung sind Alter, BMI und Krankheitsdauer negativ korreliert $(-0,3$, $-0,23$ bzw. $-0,35)$, was einem schwachen linearem Zusammenhang entspricht.

Zusammenfassung: Digitale Anwendungen könnten die Versorgungsrealität in der Urologie verbessern. Wir konnten zeigen, dass ein kombiniertes Sport/Beckenbodentraining zu einer Verbesserung des IIEF-Scores führt.

\section{K03 - Urothelkarzinom - Therapie invasiver Tumoren}

$$
\text { 15.09.2021, C6.2, 13:30-15:00 }
$$

\section{K03.2}

Klinische Bedeutung der P2X7-Rezeptorfamilie und des Downstream-Parameters NFAT1c beim invasiven Urothelkarzinom der Harnblase

\section{T. Lütfrenk ${ }^{*}$, J. Hennenlotter, C. Rieger, A. Stenzl, T. Todenhöfer, S. Rausch}

Eberhard Karls Universität Tübingen, Klinik für Urologie, Tübingen, Deutschland

Hintergrund: Die Aktivierung des Plasmamembran-assoziierten P2X7 Rezeptor (P2X7R) zeigt je nach extrazellulärer ATP-Konzentration proliferative oder pro-apoptotische Effekte. Die mutierte Variante (nfP2X7) konnte als spezifisch für das Urothelkarzinom (UC) nachgewiesen werden. NFATc1 als Downstreamparapeter des nfP2X7 wird ein proliferativer Effekt zugeschrieben. In der vorliegenden Arbeit wurden die differentielle Expressi- 
on von PX2X7R, nfP2X7R und NFATc1 sowie deren prognostische Relevanz beim invasiven UC untersucht.

Methode: An einem Kollektiv von 103 UC-Patienten nach Zystektomie und 46 benignen Urothelgewebeproben wurde immunhistochemisch die Expression und zelluläre Lokalisation des P2X7-Rezeptors, des nfP2X7 und dem NFATc1 ermittelt und diese mit klinischen Daten korreliert.

Ergebnisse: Der P2X7R zeigt sich nur zytoplasmatisch exprimiert (CP). Der nfP2X7 kann zusätzlich membranständig (MEM) abgegrenzt werden. P2X7 und vor allem MEM nfP2X7 zeigen sich in den UC signifikant stärker exprimiert als in benignem Gewebe (beide $p<0,0001$ ). NFATc1 wird in benignem Urothel nicht exprimiert $(p<0,0001)$, auch nicht bei hoher CP nfP2X7 Expression $(p<0,0001)$. pT $>2$ BC exprimieren mehr NFATc1 $(p=0,0003)$. Hohe Expressionslevel von MEM nfP2X7 korrelieren mit einem verlängerten Gesamt- $(p=0,0434)$ und tumorspezifischen Überleben $(p=0,043)$.

Schlussfolgerung: Die MEM nfP2X7 und CP P2X7 Expression zeigen sich charakteristisch für das UC. Eine hohe nfP2X7 Expression zeigt einen prognostischen Effekt für das Überleben. Da die NFATc1 Überexpression mit hohen T-Stadien korreliert, könnte dies zudem als Progressionsmarker dienen. Zielgerichtete Therapien gegen $\mathrm{nfP} 2 \mathrm{X} 7$ befinden sich aktuell in der präklinischen Evaluation.

\section{K03.3}

Sentinel node mapping using near infrared fluorescence imaging in open radical cystectomy for bladder cancer: a single center experience

U. Krafft ${ }^{1 *}$, P. Fragoso Costa ${ }^{2}$, O. Mohamed ${ }^{1}$, C. Kesch' , C. Darr' ${ }^{1}$ J. Hess' ${ }^{1}$, A. Panic ${ }^{1}$, J.P. Radtke' ${ }^{1}$, B. A. Hadaschik' ${ }^{1}$ S. Tschirdewahn ${ }^{1}$

${ }^{1}$ Universität Duisburg-Essen, Klinik für Urologie, Essen, Germany; ${ }^{2}$ Universität DuisburgEssen, Klinik für Nuklearmedizin, Essen, Germany

Objective: To assess the feasibility of near-infrared fluorescence sentinel node mapping (NIRF-SNM) in open radical cystectomy (CE) for muscle invasive bladder cancer (MIBC) using a novel hand-held device and to compare this technique with standard bilateral extended lymphadenectomy. Material and methods: Monocentric analysis of 17 patients who underwent CE for MIBC with NIRF-SNM. Intraoperatively, a cystoscopic injection of indocyanine green was performed before cystectomy. Prior to lymphadenectomy, the pelvis was scanned for sentinel areas using the novel

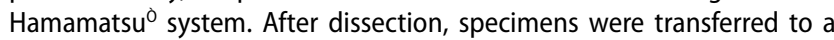
standardized template for a second ex vivo analysis. Detection rate and false negative rate was calculated.

Results: Median age was 64 (33-78) with 14 (82.35\%) male patients. Bladder specimens showed ypT0-pT3 cancers except for one pT4 tumor. Sentinel nodes were in 14 cases detected bilaterally, in 3 cases unilaterally. A total of 144 template-based lymph node areas were harvested, of which 56 showed a positive NIRF signal. 6 NIRF positive areas showed metastatic involvement, whereas no lymph node metastasis was detected in NIRFnegative template-regions, corresponding to a false-negative rate of $0 \%$ and a detection rate of $100 \%$. Of 34 lymphadenectomized hemipelves, 31 $(91.18 \%)$ showed a NIRF signal, of which $6(17.65 \%)$ were histologically proven to be metastatic. Sentinel lymphnode mapping and resection was non-inferior to standard extended lymphadenectomy in this series.

Conclusion: NIRF-SNM in open CE is feasible and identified all metastatic lymph nodes in this series. In addition, this technique may allow intraoperative detection of sentinel nodes located outside the standardized templates and does not require radiation protection measures.
3K03.4

Radical cystectomy vs. multimodality treatment in T2NOMO bladder cancer: a population-based, agematched analysis

M. Deuker ${ }^{*}$, M. Krimphove', L. F. Stolzenbach², A. Becker', L. Kluth', F. Roos'1, D. Tilki², F. Chun', P. Karakiewicz ${ }^{3}$

${ }^{1}$ Universitätsklinikum Frankfurt, Frankfurt, Germany; ${ }^{2}$ Martini-Klinik Prostate Cancer Center, University Hospital Hamburg-Eppendorf, Hamburg, Germany; ${ }^{3}$ Cancer Prognostics and Health Outcomes Unit, Division of Urology, University of Montréal Health Center, Montreal, Canada

Background: Controversy still exists regarding efficacy of multimodality treatment (MMT) vs. radical cystectomy (RC) for urothelial carcinoma of the urinary bladder (UCUB).

Methods: Within the SEER-database (2004-2016), we retrospectively identified stage T2NOMO UCUB patients. Competing-risks-regression (CRR) tested cancer-specific-mortality (CSM) and adjusted for other cause mortality after MMT vs. RC. Exact matching for age was applied. Subgroup analyses focused on differences in chemotherapy or lymph node dissection rates. In sensitivity analyses, we accounted for $40 \%$ understaging rate in MMT patients.

Results: Of $9862 \mathrm{~T}_{2} \mathrm{~N}_{0} \mathrm{M}_{0}$ UCUB patients, 2675 (27.1\%) underwent MMT vs. 5751 (58.3\%) RC vs. 1436 (14.6\%) RT without chemotherapy. MMT rate increased (annually $+3.0 \%, p<0.01$ ) and MMT patient age was significantly higher (median 77 years) than RC patient age (68 years). In exact agematched analyses, 10 year-CSM rates were 44.3 vs. $25.9 \%$ for MMT vs. RC (multivariate hazard ratio [HR] 0.48 ); 44.1 vs. $22.8 \%$ for MMT vs. RC with chemotherapy (HR 0.43 ); 40.5 vs. $31.1 \%$ for MMT vs. RC without lymph node dissection (HR 0.66 ) and 55.6 vs. $27.3 \%$ for RT without chemotherapy vs. RC (HR 0.37, all $p<0.001)$. Sensitivity analyses that addressed understaging of MMT patients, resulted in virtually the same CSM rates.

Conclusion: $\ln \mathrm{T}_{2} \mathrm{~N}_{0} \mathrm{M}_{0}$-patients, MMT or even more so RT alone, may be associated with higher CSM than RC, even in exact age-matched multivariate CRR analyses, that adjust for other cause mortality. In consequence, T2 UCUB patients should be informed of this possible CSM disadvantage outside of highly specialized centers.

\section{K03.5}

\section{Untersuchung des Zusammenhangs zwischen} Operationsdauer und Komplikationsrate nach radikaler Zystektomie

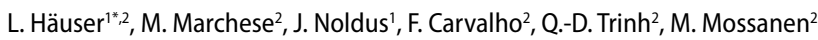

'Marien Hospital Herne, Ruhr-Universität Bochum, Klinik für Urologie und Neuro-Urologie, Herne, Deutschland; 'Brigham and Women's Hospital, Division of Urologic Surgery and Center for Surgery and Public Health, Boston, Vereinigte Staaten von Amerika

Einleitung: Ziel dieser Studie ist es, den Zusammenhang zwischen Operationsdauer und Komplikationen nach radikaler Zystektomie zu untersuchen. Unsere Hypothese war, dass die Komplikationsrate mit längerer OPDauer ansteigt.

Material und Methoden: Hierzu analysierten wir die NSQIP Datenbank, eine landesweite amerikanische Datenbank, die Komplikationen aller chirurgischen Eingriffe beinhaltet. Alle Patienten, die sich zwischen 2012-2017 einer radikalen Zystektomie unterzogen, wurden ausgewählt. Demographische Charakteristika, Operationsdauer und perioperative Komplikationen gemäß Clavien-Dindo Klassifikation (CDC) wurden abstrahiert. Um eine Abhängigkeit der Komplikationsrate von der Operationsdauer feststellen zu können, wählten wir ein generalisiertes lineares Modell mit linearen splines für die Operationszeit.

Ergebnisse: Die mittlere OP-Dauer der 10.520 eingeschlossenen Zystektomie-Patienten betrug 331 min (IQR 255-419). In $55 \%$ und 18,2 \% der Fälle trat eine Komplikation jeder Schwere ( $C D C \geq \mathrm{I})$ und eine bedeutende Komplikation (CDC $\geq$ III) innerhalb 30 Tage postoperativ auf. Das spline Regres- 
sionsmodell für jede Komplikation zeigte eine nahezu lineare Beziehung zwischen Komplikationsrate und OP-Dauer, mit $47 \%$ nach 2,5 h bis $70 \%$ nach $10 \mathrm{~h}$. Das Modell für bedeutende Komplikationen zeigte die niedrigste Komplikationsrate von $15 \%$ nach 4,5 h. Eine OP-Dauer an den Extremen der Verteilung zeigte höhere Komplikationsraten: $17,5 \%$ bei $<2,5 \mathrm{~h}$ und $28 \%$ bei $>10 \mathrm{~h}$.

Schlussfolgerung: Die OP-Dauer der Zystektomie ist assoziiert mit dem Auftreten postoperativer Komplikationen, mit niedrigsten Komplikationsraten bei Eingriffen zwischen 4-5 h. Die Beachtung von OP-Dauer beeinflussenden Faktoren erlaubt es, die chirurgische Behandlung zu optimieren und Komplikationen nach Zystektomie zu reduzieren.

\section{K03.6 \\ Sinkende konkurrierende Sterblichkeit nach radikaler Zystektomie}

M. Fröhner ${ }^{1^{*}}$, R. Koch², U. Heberling ${ }^{3}$, A. Borkowetz ${ }^{4}$, M. Hübler ${ }^{5}$, V. Novotny ${ }^{6}$, M. Wirth ${ }^{4}$, C. Thomas ${ }^{4}$

'Zeisigwaldkliniken Bethanien, Klinik für Urologie, Chemnitz, Deutschland; ${ }^{2}$ Technische Universität Dresden, Dresden, Deutschland; ' $Z$ Zeisigwaldkliniken Bethanien, MVZ Mittweida, Chemnitz, Deutschland; ${ }^{4}$ Technische Universität Dresden, Klinik für Urologie, Dresden, Deutschland; ${ }^{5}$ St. Joseph Stift Dresden, Anesthesiologie, Dresden, Deutschland; ${ }^{6}$ Städtisches Klinikum Görlitz, Görlitz, Deutschland

Einleitung: Ziel der Studie war die Untersuchung des Zusammenhanges zwischen der zunehmenden Lebenserwartung und der Sterblichkeit konkurrierenden Ursachen nach radikaler Zystektomie RCX).

Material und Methoden: Mittels proportionalen Hazard-Modellen für konkurrierende Risiken wurde der Zusammenhang zwischen dem Jahr der Operation und der konkurrierenden Sterblichkeit (Sterblichkeit an allen Ursachen außer dem Harnblasenkarzinom) in einer unizentrischen Stichprobe 1419 konsekutiven Patienten, sie sich zwischen 1993 und 2018 einer RCX unterzogen. Die Zahl der im Laufe der Jahre scheinbar gewonnenen Lebensjahre wurde basierend auf multivariaten Modellen mit einem heuristischen Modell berechnet: (Hazard-Ratio Jahr der Operation) 26 Kalenderjahre ${ }_{*}($ Hazard-Ratio Alter bei Operation $)$ gewonnene Lebensjahre $=1$. Trends wurden mittels linearer Regressionsanalyse untersucht.

Ergebnisse: Während des Beobachtungszeitraumes nahmen das mittlere Alter und der Anteil der Patienten mit einer ASA-Klasse 3 oder 4 zu, während der Anteil der Patienten mit Herzerkrankungen abnahm. Nach Altersadjustierung ging die konkurrierende Sterblichkeit in allen Subgruppen zurück (Hazard-Ratios, HR, pro Jahr 0,931-0,963) In einem optimalen Modell unter Einschluß des Alters (HR pro Jahr 1,048, $95 \%$-Konfidenzintervall, $\mathrm{KI}, 1,027-1,070), p<0,0001$, der Komorbidität, tumor-bezogener Variablen, dem Body-Mass-Index, neoadjuvanter oder adjuvanter Chemotherapie und dem Raucherstatus lag die HR pro Jahr bei 0,928 (95\%-KI $0,886-0,973), p=0,0019$.

Schlussfolgerung: Die konkurrierende Sterblichkeit nach RCX sank während des 26-jährigen Beobachtungszeitraum stärker als es durch die zunehmende Lebenserwartung in diesem Zeitraum (4 Jahre bei Frauen, 6 Jahre bei Männern) zu erwarten gewesen wäre.

\section{K03.7 \\ Onkologische Validierung umfassender Pentafecta- Qualitätskriterien nach radikaler Zystektomie bei Blasentumor-Patienten mit Langzeit-Follow-up}

M. Khonsari, P. Gild, J. Klemm, M. Kölker, R. Dahlem, M. Fisch, M. Rink, M.W. Vetterlein

Universitätsklinikum Hamburg-Eppendorf, Klinik und Poliklinik für Urologie, Hamburg, Deutschland

Kürzlich wurden Pentafecta-Kriterien (PC) zur Standardisierung uroonkologischer Versorgungsqualität nach offener radikaler Zystektomie (RC) von einem Expertenpanel definiert (https://rdcu.be/cdQJj). Bis heute wur- den diese PC nicht an Blasentumor-Patienten mit langem Follow-up validiert. Ziel unserer Studie war die kritische Evaluation der PC in Bezug auf die Vorhersagekraft von Gesamt- (OM) und krebsspezifischer Mortalität (CSM).

Einschlusskriterien:

CM0 Blasentumor, offene RC zwischen 2009-17. Ausschlusskriterien: fehlende Daten zu den PC (A: RO-Status; B: $\geq 16$ entfernte LK; C: Clavien-Dindo $\leq$ Il nach 30 Tagen; D: TURB $\rightarrow>$ RC $\leq 90$ Tage; E: kein Rezidiv $\leq 12$ Monate) sowie zensierte Patienten mit Follow-up $\leq 3$ Monaten. Prädiktoren für PC Erfüllung und der Einfluss der PC Erfüllung auf OM, CSM und konkurrierende Sterblichkeit wurde mittels Regressionsanalysen ermittelt.

Von insgesamt 420 Patienten erfüllten 108 (26\%) alle 5, 195 (46\%) 4/5, $77(18 \%) 3 / 5$ und $40(9,5 \%) \leq 2 / 5$ aller PC. Bei einem medianen Followup von 73 Monaten (IQR 48-100) waren steigendes Alter (OR 0,8) und inkontinente Ableitung $(\mathrm{OR} 0,38)$ mit Nichterfüllung der PC assoziiert (alle $p<0,001$ )

Verglichen mit Patienten, bei denen $\geq 4 / 5$ der PC erfüllt wurden, hatten Patienten mit 3/5 bzw. $\leq 2 / 5$ PC nach Adjustierung ein 2,8-bzw. 5,3-faches (2,8-bzw. 4,4-faches) Risiko für OM (bzw. CSM; alle $p<0,001$ ). PC Erfüllung war kein Prädiktor für konkurrierende Sterblichkeit $(p>0,1)$, welche vor allem vom Charlson-Komorbiditätsindex beeinflusst wurde.

Wir präsentieren die erste externe Validierung von onkologischen $\mathrm{PC}$ in einer großen kontemporären Serie nach offener RC. Die PC sind ein valides Tool zur Differenzierung des Langzeit-Risikos für OM und CSM und können als Qualitätsindikator nach RC bei Blasenkrebspatienten dienen.

\section{K03.8}

Komplikationen nach radikaler Zystektomie (RC) in der frühen Rehabilitationsphase: Ein Vergleich zwischen lleumconduit (IC) und orthotoper Neoblasenanlage (NB)

M.C. Butea-Bocu' ${ }^{1 *}$, M. Götte ${ }^{2}$, H. Bahlburg ${ }^{2}$, F. Roghmann², J. Noldus², U. Otto', G. Müller ${ }^{1}$

'UKR - Urologisches Kompetenzzentrum für die Rehabilitation, Bad Wildungen, Deutschland; ${ }^{2}$ Marien Hospital Herne, Ruhr-Univerität Bochum, Herne, Deutschland

Einleitung: Ziel dieser Studie war, in einem aktuellen Kollektiv prospektiv Komplikationen nach RC und IC- oder NB-Anlage zu analysieren.

Material und Methoden: Patienten mit Urothelkarzinom der Harnblase nach RC mit IC oder NB wurden von $04 / 2018$ bis $12 / 2019$ evaluiert. Gemäß Clavien-Dindo-Klassifikation (CDC) wurde zwischen low- (CDC 1-2, LG) und high-grade (CDC 3-5, HG) Komplikationen unterschieden.

Ergebnisse: Von 842 Patienten erhielten 447 (53,1\%) ein IC und 395 $(46,9 \%)$ eine NB. Männer (M) waren zu 81,1\% vertreten. IC-Patienten waren im Median älter, 73 Jahre (IQR 67-78) vs. NB, 64 Jahre (IQR 58-69), $p<0,001$. LG-Komplikationen waren häufiger bei NB- vs. IC-Patienten ( $82,0 \%$ vs. $68,7 \%, p<0,001)$. NB-Patienten hatten ein hohes Risiko für Harnwegsinfektionen $(67,1 \%)$ und urogenitale Komplikationen $(36,2 \%)$. Es zeigten sich keine Unterschiede in der Rate an HG-Komplikationen zwischen IC vs. NB ( $26,8 \%$ vs. $31,6 \%, p=0,126)$. Univariat wurden Harnableitung IC vs. NB (OR 0,487; $95 \% \mathrm{Cl} 0,342-0,692 ; p<0,001)$, Geschlecht $M$ vs. $\mathrm{F}(\mathrm{OR} 1,719 ; 95 \% \mathrm{Cl} 1,134-2,606 ; p=0,011)$, Tumorstadium $\leq \mathrm{pT} 2 \mathrm{~b}$ vs. $\geq \mathrm{pT3a}(\mathrm{OR} 0,700 ; 95 \% \mathrm{Cl} 0,507-0,967 ; p=0,031)$ und Lymphknotenstatus positiv vs. negativ $(\mathrm{OR} 0,561 ; 95 \% \mathrm{Cl} 0,376-0,836 ; p=0,005)$ als Prädiktoren für jeden CDC-Grad identifiziert. Multivariat wurde das männliche Geschlecht als Prädiktor für HG-Komplikationen identifiziert (OR 1,615; 95 \% Cl 1,001-2,606; $p=0,049$ ).

Schlussfolgerung: HG-Komplikationen nach RC mit IC- oder NB-Anlage treten meist innerhalb von 4 Wochen postoperativ auf. Ein hoher Anteil therapiebedürftiger LG-Komplikationen wird jedoch erst nach Entlassung aus der Primärklinik evident. Die fachspezifische stationäre Anschlussheilbehandlung (AHB) stellt die notwendige intensive Nachsorge und Edukation für diese Patientengruppe sicher. 
3K03.9

\section{Onkologisches Outcome nach robotischer versus offener radikaler Nephroureterektomie}

P. Zeuschner*, S. Grosse Vollmer, J. Linxweiler, M. Stöckle, S. Siemer, M. Saar, J. Heinzelbecker

Universitätsklinikum des Saarlandes, Klinik für Urologie und Kinderurologie, Homburg/ Saar, Deutschland

Einleitung: Die radikale Nephroureterektomie (RNU) ist die Standardbehandlung für hoch-Risiko Urothelkarzinome des oberen Harntrakts. Diese Arbeit vergleicht das onkologische Outcome robotischer (RANU) und offener (ONU) Nephroureterektomien.

Material und Methoden: Die onkologischen Ergebnisse von 131 zwischen 2009-2019 durchgeführten RNUs (66 RANU, 65 ONU) wurden mittels Kaplan Meier Analysen, Cox Regressionen und Propensity Score (PS) Matching verglichen.

Ergebnisse: In der ONU Gruppe wurden mehr pT4- (ONU 12,3\% vs. 1,5\%, $p=0,015)$ und Harnleitertumore $(58,5 \%$ vs. $36,4 \%, p=0,014)$ behandelt. Blutverlust (RANU 150 vs. $250 \mathrm{ml}, p=0,004$ ) und Komplikationsraten $(40,9 \%$ vs. $63,1 \%, p=0,011)$ waren nach RANU geringer, die Verweildauer kürzer (9 vs. 12d, $p<0,001$ ). Die Operationszeit war nicht verschieden (RANU $188 \mathrm{~min}$ vs. $178 \mathrm{~min}$ ). Diese Unterschiede, außer den Komplikationsraten, blieben in der PS gematchten Analyse bestehen.

Bei einem medianen Follow-Up von 29,2 Monaten (Range 0,4-127,7) hatten 53 Patienten eine Progression (ONU: 28, RANU: 25) ohne Nachweis atypischer Metastasierung, 38 Patienten verstarben (ONU: 22, RANU: 16). Weder das progressionsfreie Überleben (PFS, 2-Jahre: RANU 59,4\% vs. ONU 52,4\%) noch das Gesamtüberleben (OS, 2-Jahre: RANU $73 \%$ vs. ONU $67,2 \%)$ waren signifikant verschieden. In der multiplen Cox-Regression hatte das Operationsverfahren keinen Einfluss auf PFS und OS. Organüberschreitende Tumore hatten ein höheres Progressionsrisiko (HR 6,7, $p=0,003)$. Bereits vor RNU radikal zystektomierte (HR 2,8, $p=0,017)$ oder metastasierte Patienten (HR 4,0, $p=0,012$ ) hatten ein höheres Risiko, früher zu versterben.

Schlussfolgerung: Bei geringerer Komplikationsrate des Roboter-assistierten Verfahrens ist das onkologische Outcome vergleichbar zur offenen Operation.

3K03.10

\section{Outcome of kidney-sparing surgery in patients with} high-grade ureteral cancer

\section{F.P. Kirchhoff'", F. J. Koll', S. C. Foreman², S. C. Schmid', J. E. Gschwend', T. Horn' ${ }^{1}$}

${ }^{1}$ Klinikum Rechts der Isar der TU München, Urologie, München, Germany; ${ }^{2}$ Klinikum Rechts der Isar der TU München, Diagnostische und interventionelle Radiologie, München, Germany

Objectives: To evaluate the concordance of preoperative staging with postoperative pathology as well as follow-up data with emphasis on upper tract urothelial recurrences in high-grade ureteral cancer undergoing kidney-sparing surgery (KSS).

Methods: Retrospective, single center analysis with blinded radiological (contrast CT) reinterpretation of 16 high-grade ureteral cancer patients with KSS and complete upper tract tumor resection between 5/2010 and $6 / 2020$.

Results: Ureteral tumors of all stages were visible on CT with an association of contrast enhancement in all tumors $\geq \mathrm{pT} 1$. Non organ-confined tumors ( $\geq \mathrm{pT} 3$ ) were correctly staged by $\mathrm{CT}$ in 5 of $6(83 \%)$ patients. Only 1 of $4(25 \%)$ patients with regional lymph node metastases (LNM) showed suspicious regional lymph nodes $(>8 \mathrm{~mm}$ ) in preoperative imaging, while one case was falsely classified as $\mathrm{cN}+$. Postoperative upgrading occurred in 4 of $13(31 \%)$ cases. All surgical specimens had negative margins in the upper tract. In one patient there was residual CIS in the bladder cuff. Within a median follow up of 26 months recurrence occurred in 8 of 14 (57\%) patients (ipsilateral upper tract: 1, LNM: 4, distant metastasis: 5) with a median time to recurrence of 16 months. Therefore urothelial recurrence in the ipsilateral upper tract developed in only 1 of 14 (7\%) cases. Muscle-invasive tumors ( $\geq \mathrm{pT} 2$ ) had a very high likelihood of tumor recurrence $(6 / 9,67 \%)$.

Conclusion: While showing a good sensitivity for detecting non organconfined tumors, preoperative assessment in high-grade ureteral cancer remains a challenge with high proportions of understaged LNM and upgrading. The low rate of recurrences in the ipsilateral upper tract may justify KSS even in high-grade ureteral cancers to allow for an eventual cisplatin-based chemotherapy.

\section{K03.11}

Stentless Ureterreimplantation im Rahmen der radikalen Zystektomie mit Harnableitung

J. Nyarangi-Dix*, F. Yue, M. Görtz, P. Reimold, C. Pecqueux, C. Gasch, L. Hofer, G. Hatiboglu, L. Pursche, V. Schütz, M. Hohenfellner

Universitätsklinikum Heidelberg, Urologische Universitätsklinik, Heidelberg, Deutschland

Fragestellung: Goldstandard der Therapie des muskelinvasiven Harnblasenkarzinoms ist die radikale Zystektomie (RC) mit Harnableitung (HA). Ureterstents werden routinemäßig eingesetzt, um Komplikationen der ureterointestinalen Anastomose (UA) wie postoperative Hydronephrose zu vermeiden. Dabei können liegende Stents pflegeintensiv und mit Komplikationen verbunden sein. Wir präsentieren unsere Erfahrung mit der Nicht-Schienung des Ureters (Stentless-Ureterremplantation) bei RC mit HA.

Material und Methoden: Daten von Patienten, die 2016-2019 eine RC und Stentless-Ureterreimplantation an unserer Klinik erhielten, wurden ausgewertet. Die postoperative 30-Tage-Komplikationsrate wurde erfasst. Ergebnisse: Von 42 untersuchten Patienten [Durchschnittalter: 65,8 $\pm 8,9$ ] waren $61,9 \%$ Männer und $8,1 \%$ Frauen. Als HA wurde ein lleum conduit in $57,1 \%$, ein orthotoper Pouch in $35,7 \%$ und ein kontinenter heterotoper Pouch in 7,2\% der Fälle konstruiert. Als assoziierte Komplikation wurde bei $33,3 \%(n=14)$ eine Harntransportstörung postoperativ nachgewiesen. Sie löste sich mehrheitlich spontan auf. 2 Patienten wurden bei steigenden Retentionsparametern zunächst mittels Nephrostomiekatheter versorgt dann sekundär antegrad geschient. Harnwegsinfekte traten bei $19 \%$ auf. Der stationäre Aufenthalt betrug im Schnitt 13,1 $\pm 6,6$ Tage. Eine Ureterreimplantation musste bei keinem Patienten durchgeführt werden. Schlussfolgerung: Unsere Daten weisen darauf hin, dass auf die routinemäßige Schienung der Harnleiteranastomose bei Harnableitung verzichtet werden kann, ohne relevante Erhöhung der Komplikationen. Gleichzeitig, reduziert dieses Vorgehen den mit der Schienung verbundenen Pflegeaufwand und ermöglicht eine frühe physiologische Dauerirrigation, die insb. bei kontinenter Harnableitung vorteilhaft ist.

\section{K03.12}

Makrohämaturie und Antikoagulation - kritische Bewertung von Prädiktoren für das klinische Outcome bei hospitalisierten Patienten

\author{
L. Lawaczeck*, R. Slomma, S. Aufderklamm, A. Stenzl, S. Rausch \\ Universitätsklinikum Tübingen, Klinik für Urologie, Tübingen, Deutschland
}

Einleitung: Das Auftreten einer spülpflichtigen Makrohämaturie ist häufig mit der Einnahme von oralen Antikoagulantien assoziiert. Es wurde untersucht, ob die Medikation mit Antikoagulantien zu einem komplikativen stationären Verlauf oder einer höheren Tumordetektionsrate führt.

Material und Methoden: Anhand einer Analyse stationär behandelter Patienten mit spülpflichtiger Makrohämaturie zwischen 2013 und 2019 wurde der Zusammenhang zwischen einer Antikoagulation und klinischen Parametern untersucht. 
Ergebnisse: Insgesamt wurden 189 Patienten eingeschlossen. Das mittlere Patientenalter betrug 80 Jahre (Range 56 bis 100). Antikoagulantien wurden von 75,83\% der Patienten eingenommen (Acetylsalicylsäure: 45,83\%, NOAK: 29,86\%, Clopidogrel: 19,44\%, Phenprocoumon: 15,27\%, niedermolekulare Heparine: 13,19\%). 78,47\% der Fälle waren einfach, $19,44 \%$ doppelt und 2,09\% dreifach antikoaguliert. Die häufigsten Indikationen zur Antikoagulation waren die koronare Herzkrankheit und Vorhofflimmern. Die mittlere Dauer der Blasenspülung betrug 3,12 Tage. Transfusionen wurden bei $11,64 \%$ der Patienten durchgeführt. Endoskopische Eingriffe waren bei $27,51 \%$ der Patienten innerhalb von 30 Tagen und bei $35,98 \%$ der Patienten innerhalb von 90 Tagen notwendig. Bei $30,69 \%$ der Patienten war ein urogenitales Tumorleiden vorbekannt, in $8,47 \%$ der Fälle wurde es neu diagnostiziert. Die Spüldauer $(p=0,05)$ und die Menge der Spülflüssigkeit $(p=0,01)$ korrelierten signifikant mit dem Einsatz von Antikoagulantien, während die Interventionsrate, Transfusionsrate und Tumordiagnose nicht assoziiert waren.

Schlussfolgerung: Bei Patienten mit spülpflichtiger Makrohämaturie unter Antikoagulation war die de novo Tumorinzidenz nicht erhöht, jedoch der medizinische Aufwand bezüglich der Intensität der Harnblasenspülung.

\section{K04 - Urothelkarzinom: Von Progressionsmarkern zu Therapieansätzen}

16.09.2021, H2, 08:00-09:30

\section{K04.1}

Kaltes atmosphärisches Plasma in der Uroonkologie Neue Behandlungsoption für Harnblasenkrebs!?

\author{
N. Gelbrich ${ }^{1 *}$, M. Burchardt ${ }^{1}$, U. Zimmermann' ${ }^{1}$, M. Stope ${ }^{2}$, S. Bekeschus ${ }^{3}$ \\ 'Universitätsmedizin Greifswald, Klinik und Poliklinik für Urologie, Greifswald, Deutsch- \\ land; '2Universitätsklinik Bonn, Klinik für Gynäkologie und Gynäkologische Onkologie, \\ Bonn, Deutschland; ${ }^{3}$ ZIK plasmatis, Leibniz-Institut für Plasmaforschung und Technologie \\ e.V., Greifswald, Deutschland
}

Das Harnblasenkarzinom ist der zweithäufigste Tumor des Urogenitaltrakts. Aufgrund der hohen Mortalität und der therap. Nebenwirkungen sind neue Therapieoptionen erforderlich. Hierbei stellt die Behandlung mit kaltem atmosphärischen Plasma (KAP) eine vielversprechende Methode dar, die nicht nur antineoplastische, sondern auch immunstimulierende Ansätze aufweist. Diese Arbeit untersucht die Auswirkungen von KAP auf untersch. humane Krebszelllinien der Harnblase im 2D- und 3DModell.

Zur Beurteilung der KAP-Effekte wurden 2D- und 3D-Tumorzellmodelle mit KAP behandelt. Zytotoxizitäts- und durchflusszytometrische Analysen von apoptotischen Prozessen auf mit KAP-behandelten Tumorzellen wurden untersucht. Mittels Mikroskopie konnten für beide Tumorzellmodelle zellmorpholog. Veränderungen quantitativ ermittelt werden.

Die Assays wurden mit untersch. KAP-Expositionszeiten durchgeführt. Im Vergleich zu Kontrollzellen wurde in KAP-behandelten Tumorzellen eine Abnahme der Zellviabilität nachgewiesen. Die antineoplastischen Effekte von KAP gingen mit der Induktion von Apoptose und Zellzyklus-Arrest einher. Eine Internalisierung diverser Oberflächenproteine auf mit KAP-behandelten Tumorzellen verglichen zur Kontrollbehandlung wurde quantifiziert. Entsprechende Ergebnisse wurden mikroskopisch im 3D-Tumorspheroidmodell detektiert und Veränderungen der Zellmotilität und -morphologie nachgewiesen.

Diese Arbeit belegt die antineoplastischen Auswirkungen von KAP im 2Dund 3D-Tumorzellmodell. Die KAP-Behandlung führte zur Immunmodulation und Induktion von Apoptose, sodass eine KAP-Applikation nicht mit starken inflammatorischen Nebenwirkungen verbunden wäre. Demnach vermag die KAP-Anwendung eine vielversprechende Behandlungsoption und Lokaltherapie von Harnblasentumoren zu sein
3K04.3

Differenzierung pluripotenter Stammzellen in reifes Urothel mit stabiler Markerexpression: Etablierung eines neuen in vitro-Modells

M. K. Melzer" ${ }^{1 *}$, , F. Wezel', M. Breunig², M. Hohwieler' ${ }^{2}$ A. Azoitei', C. Günes', A. Kleger' ${ }^{2}$ C. Bolenz'

'Uniklinik Ulm, Klinik für Urologie und Kinderurologie, Ulm, Deutschland; ${ }^{2}$ Uniklinik Ulm, Klinik für Innere Medizin I, Ulm, Deutschland

Einleitung: Die in vitro-Differenzierung von Urothel aus patienten-eigenen induzierten pluripotenten Stammzellen (iPSCs) bietet ein hohes wissenschaftliches und therapeutisches Potenzial. Mit der vorliegenden Arbeit wird gezeigt, dass (i) eine Differenzierung von Urothel-ähnlichen Zellen möglich ist, (ii) diese Zellen Organoide bilden, auf der de-epithelialisierten Schweineharnblase (iii) zu einer Re-epithelialisierung führen und (iv) dort final maturieren.

Material und Methoden: Urothel-ähnliche Zellen wurden nach existierenden und neu entwickelten Protokollen differenziert. Genexpressionsanalysen erfolgten mittels Western Blot und qRT-PCR. Differenzierte Zellen wurden als Organoide kultiviert und immunhistochemisch (IHC) untersucht. Schweineharnblasen wurden enzymatisch und mechanisch de-epithelialisiert, als Matrix für differenzierte Zellen verwendet und mit IHC untersucht.

Ergebnisse: Aus iPSCs differenzierte Urothel-ähnliche Zellen zeigten die Expression von typischen Urothelmarkergenen (UPK1a, UPK3, KRT20). Die Zellen bildeten Organoide und komplexe Strukturen. Diese exprimierten funktionelle (ZO-1, UPK1b) und Strukturproteine (CK19) sowie Transkriptionsfaktoren (FOXA1) analog zu reifem Urothel. Der Transfer von Organoiden auf ein porcines in-vitro-Harnblasenmodell induzierte einen massiven Anstieg urothelialer Marker (UPK1b, FOXA1).

Schlussfolgerungen: Die Generierung von Urothel-ähnlichen Zellen aus iPSCs gelingt und erlaubt die Kultur als Organoide zur Untersuchung von zellulären Interaktionen und dreidimensionalen Strukturen. Der Transfer auf ein porcines in-vitro-Harnblasenmodell demonstriert die Machbarkeit des Einsatzes von iPSCs als Gewebeersatz und bietet erste Einblicke in ein potenzielles Xenotransplantationsmodell zum Harnblasenersatz.

\section{K04.4}

Loss of Connexin GJB3 promotes genome instability and the invasive capacity of urothelial cells

J. Liu' ${ }^{1 *}$, X. Wang ${ }^{1}$, S. Meessen ${ }^{1}$, A. Azoitei ${ }^{1}$, X. Zheng ${ }^{1}$, V. Zehe' ${ }^{1}$, F. Wezel', A. John', F. Zengerling ${ }^{1}$, M. Eckstein ${ }^{2}$, A. Hartmann², C. Bolenz' , C. Günes ${ }^{1}$

'Universitätsklinikum Ulm, Ulm, Germany; ${ }^{2}$ University of Erlangen-Nuremberg, Erlangen, Germany

Introduction: Connexins are a family of membrane proteins that form gap junctions between neighbouring cells. They play important roles in regulation of cell proliferation, differentiation, apoptosis and tissue development. We have previously identified connexin31 (GJB3) in a RNAi genomic screen as a ploidy-control gene. Since bladder cancer (BC) displays an increase in aneuploidy during tumor progression, we suggest that GJB3 may be involved in the progression of $B C$.

Materials und Methods: The expression of GJB3 was analysed in normal human and murine urothelial cells and tissues as well as in BC cells and tissues using immunohistochemistry, RT-qPCR and Western blot. Wound healing assay, Boyden chamber and porcine bladder organ culture were applied to evaluate the impact of GJB3 on the migratory and invasive capacity of BC cells in response to shRNA-mediated GJB3 knockdown and ectopic GJB3 expression. Immunofluorescence was used to investigate the mitotic dysregulation, aneuploidy, invadopodia formation and colocalization experiments.

Results: GJB3 is downregulated in BC cells with higher invasive capacity and in advanced tumour stages in vivo. The knockdown of GJB3 induced 
chromosomal instability by dysregulation of the accurate mitosis in normal urothelial cells. While the shRNA-mediated depletion of GJB3 improved migration and invasion capacities of $\mathrm{BC}$ cells, ectopic expression of GJB3 in cells impaired their migration and invasion through regulating invadopodia formation. Interestingly, GJB3 was found to be colocalized with cytoskeleton proteins F-actin and a-tubulin.

Conclusions: The data indicate that the loss of GJB3 promotes the initiation and progression of $B C$ by regulating cell division and invasion via interaction with cell cytoskeleton proteins.

\section{K04.5 \\ PAR1 inhibits proliferation and invasion of bladder cancer cells via AKT and Hippo-YAP signaling pathway}

C. Zhang ${ }^{1 *}$, A. John', A. Azoitei', V. Zehe', F. Wezel', F. Zengerling' ', C. Bolenz', C. Günes ${ }^{1}$

'Department of Urology, Ulm University Hospital, Ulm, Germany

Introduction: Proteinase-activated receptor-1 (PAR1), encoded by the $F 2 R$ gene, belongs to a subfamily of the $\mathrm{G}$-protein-coupled receptors. The wide distribution of PARs in a variety of cells supports the idea that they are involved in many processes, including coagulation, proliferation and adhesion.

Materials and methods: F2R/PAR1 expression was determined by RTGPCR and Western blot in primary human urothelial cells, immortalized urothelial cell strains (e.g. UROtsa and HBLAK) and bladder cancer (BC) cell lines (RT4, UMUC3 and T24). Stable ectopic PAR1 expression was used to elucidate the role of PAR1 in BC cells (UMUC3 and T24). MTT assay, Boyden chamber assay and Scratch assay experiments were used for functional experiments.

Results: PAR1 is readily detectable in immortalized Y235T and HBLAK cells, established from normal urothelial cells, while its expression was lower in bladder cancer cell lines RT4, T24, UMUC3. Overexpression of PAR1 inhibited proliferation, migration and invasion of T24 cells and impaired the proliferation and invasion of UMUC 3 cells. At the molecular level, ectopic PAR1 expression resulted in increased LATS1 and $p$-YAP levels in both cell lines. Interestingly, PAR1 expression reduced PTEN expression and resulted in increased levels of $p$-AKT ${ }^{\text {Ser473 }}, p$-AKT Thr308 in T24 cells. Conversely, expression of PAR1 resulted in reduced $p$-AKT ${ }^{\mathrm{Ser} 43}, p-\mathrm{AKT}^{\mathrm{Th} \text { r308 }} \mathrm{lev}$ els in PTEN null UMUC3 cells.

Conclusions: This study shows for the first time potential role of PAR1 in $\mathrm{BC}$ and indicates that PAR1 may impair proliferation, migration and invasion of BC cells via AKT and Hippo-YAP signaling pathways. It also remains ambiguous whether the PAR1-induced contradictory AKT phosphorylation results in T24 and UMUC3 cells are due to PTEN expression in these cells.

\section{K04.6 \\ $\mathrm{BCL}$ L and Wnt/ $\beta$-catenin signalling have an oncogenic effect in bladder cancer cell lines}

\author{
R. Kotolloshi ${ }^{* *}$, M. Hölzer², M.-O. Grimm , D. Steinbach¹ \\ ${ }^{1}$ Klinik und Poliklinik für Urologie, Universitätsklinikum Jena, Jena, Germany; ${ }^{2}$ Fakultät für \\ Mathematik und Informatik, Friedrich-Schiller Universität Jena, Jena, Germany
}

Introduction: The molecular mechanism of the progression of $\mathrm{BC}$ is not fully understood. DNA sequencing of progressive NMIBC and their corresponding MIBC identified frequent gene mutations, including BCL9L to be associated with $\beta$-catenin signalling. BCL9L, a coactivator of $\beta$-catenin, plays a crucial role in the carcinogenesis of various tumour entities. We analyzed the functional role of BCL9L and the influence on $\mathrm{Wnt} / \beta$-catenin signalling.

Material and methods: Knockdown of BCL9L using siRNA and the manipulation of Wnt/ $\beta$-catenin signalling using SKL2001 and iCRT3 were per- formed. Growth was assessed by spheroid formation and proliferation by crystal violet staining. Migration and invasion were analyzed in real-time using xCelligence RTCA system. The localization of BCL9L in bladder cancer cells was investigated by immunofluorescence. For pathway analysis, mRNA expression of wnt/ $\beta$-catenin target genes were analyzed by qRTPCR.

Results: Knockdown of BCL9L and inhibition of $\beta$-catenin significantly repress the growth of bladder cancer cells in monolayer and 3D spheroid models as well as inhibit the migration and invasion of bladder cancer cells. Interestingly, immunofluorescence data shows that BCL9L is mainly localized in the nucleus of Cal29 cells and mainly in the cytoplasm of T24 cells. Knockdown of BCL9L reduces mRNA level of Wnt/ $\beta$-catenin target genes in Cal29 but not in T24 cells.

Conclusion: $\mathrm{BCL} 9 \mathrm{~L}$ has an oncogenic role. Our data indicate the existence of the BCL9L/ $\beta$-catenin axis in bladder cancer cells, which is cell line dependent, suggesting that BCL9L could act dependently and independently from $\beta$-catenin. Our data provide new insights into the understanding of molecular mechanisms of carcinogenesis in bladder cancer, which might provide new therapeutic targets.

\section{K04.7}

Validation of the association of high androgen receptor mRNA expression with improved prognosis in high-risk non-muscle-invasive bladder cancer

D. Sikic ${ }^{*}$, H. Taubert ${ }^{1}$, R. Wirtz ${ }^{2}$, J. Breyer ${ }^{3}$, M. Eckstein ${ }^{4}$, V. Weyerer', J. Kubon', P. Erben ${ }^{5}$, C. Bolenz ${ }^{6}$, M. Burger ${ }^{3}$, A. Hartmann ${ }^{4}$, B. Wullich', S. Wach', B. Keck

'Urologische und Kinderurologische Klinik, Universitätsklinikum Erlangen, Erlangen, Germany; ${ }^{2}$ Stratifyer Molecular Pathology GmbH, Köln, Germany; ${ }^{3}$ Klinik für Urologie der Universität Regensburg, Regensburg, Germany; ${ }^{4}$ Institut für Pathologie, Universitätsklinikum Erlangen, Erlangen, Germany; ${ }^{5}$ Klinik für Urologie, Universitätsmedizin Mannheim, Medizinische Fakultät Mannheim der Universität Heidelberg, Mannheim, Germany; ${ }^{6}$ Klinik für Urologie und Kinderurologie, Universitätsklinikum Ulm, Ulm, Germany

Introduction: The role of the androgen receptor (AR) in bladder cancer remains controversial.

Methods: We retrospectively analyzed 95 patients with high-risk nonmuscle-invasive bladder cancer (NMIBC) treated with transurethral resection of the bladder. The mRNA expression of AR and the keratins KRT5 and KRT20 used as surrogate markers for basal and luminal subtypes, respectively, was measured by RT-qPCR and correlated with clinical data and recurrence-free (RFS), cancer-specific (CSS), and overall survival (OS).

Results: AR mRNA expression was positively correlated with KRT5 $\left(r_{s}=0.456 ; p<0.001\right)$. High AR $(p=0.050)$ and KRT5 $(p=0.030)$ were associated with lower tumor grade. Kaplan-Meier analysis indicated significantly prolonged CSS $(p=0.020)$ and OS $(p=0.015)$ and a trend towards longer RFS $(p=0.051)$ in patients with high AR expression. High KRT5 mRNA expression showed significantly longer RFS ( $p=0.033)$, CSS $(p=0.029)$ and OS $(p=0.030)$, while high KRT20 was associated with reduced RFS $(p=0.042)$. In multivariable analysis, none of the markers was an independent prognostic factor. When substratificating with regard to molecular subtypes, age, gender and instillation therapy, high expression of KRT20 and AR showed improved OS $(p=0.041)$ compared to patients with high KRT20 and low AR expression. Women and younger patients had significantly longer RFS $(p=0.034$ and $p=0.009)$ and OS $(p=0.011$ and $p=0.007$ ) in cases with high AR expression. High AR expression was associated with longer CSS in patients with instillation therapy $(p=0.040)$, while RFS and OS was improved regardless of instillation therapy. Conclusions: High AR mRNA expression is associated with KRT5 and improved outcome in high-risk NMIBC. The role of androgen deprivation therapies needs to be explored in future studies. 


\section{K04.8}

Absence of telomerase delays onset and progression of BBN-induced bladder cancer in mice

S. Meessen" ${ }^{*}$, A. Azoitei' ' X. Zheng' ', M. Eckstein², A. Hartmann², F. Zengerling', C. Bolenz' ${ }^{1}$ C. Günes

'Universitätsklinikum Ulm, Klinik für Urologie und Kinderurologie, Ulm, Germany; ${ }^{2}$ University of Erlangen-Nuremberg, Institute of Pathology, Erlangen, Germany

Purpose: Telomerase activity is observed in $99 \%$ of human bladder cancers (BC), indicating an essential role for telomerase for survival and sustained replicative capacity of $B C$ cells. Thus, telomerase inhibition could be a useful target for tumor therapy. The N-butyl-N-(4-hydroxybutyl)nitrosamine (BBN)-induced bladder cancer mouse model recapitulates the muscle-invasive human bladder cancer. The impact of telomerase deletion on tumor development was evaluated in vivo using the BBN- mouse model in combination with wildtype and telomerase deficient (Terc-KO) mice.

Method: WT C57/BL6 and Terc-KO mice (male/female) were treated ad libitum with $0,1 \%$ BBN from 8 weeks of age on. The mice were sacrificed at different time-points post treatment $(2,4,6$, and 8 months). The resected bladders were evaluated histologically for tumor progression. Based on previous reports from in vitro experiments showing that telomerase can promote tumor formation by alleviating replication stress-induced senescence, the bladder samples were analyzed by phospho-RPA2 (pRPA2) immunohistochemistry to evaluate the accumulation of replication stress during tumor progression.

Results: The histological evaluation of the bladders showed that the onset of BBN-induced tumor development is significantly delayed in Terc-KO mice, as well as a significant increase in survival compared to telomerase positive WT mice. The evaluation of the replication stress levels revealed an increase in Terc-KO mice, conforming the results from in vitro experiments.

Conclusion: The results of this study suggest that telomerase is a potential target for tumor therapy in $\mathrm{BC}$ and that the $\mathrm{BBN}$-induced $\mathrm{BC}$ mouse model represents a useful experimental tool to test efficacy of potential telomerase inhibiting therapeutics.

\section{K04.9}

Shorter peripheral blood telomere length is associated with worse survival of patients with bladder and kidney tumours

X. Zheng", F. Wezel, A. Azoitei, S. Meessen, W. Wang, G. Najjar, A. John, F. Zengerling, C. Bolenz, C. Günes

Department of Urology, Ulm University Hospital, Ulm, Germany

Background: Telomeres are protein-DNA complexes at the tip of linear chromosomes. It is well established that telomere shortening results in genome instability and promotes tumor formation. Recent data indicated that telomere length of PB cells may serve as a prognostic biomarker for patients with solid cancers. Although the molecular basis of this relationship is yet unknown, telomere length measurement in PB cells could be a prognostic marker for the survival in patients with bladder cancer (BC) and kidney cancer (KC).

Methods: Relative telomere length (RTL) was measured by qPCR using genomic DNA prepared from the PB cells of normal control population without malignant disease (NC, $n=73)$, patients with $\mathrm{BC}(n=144)$ or with KC $(n=144)$. Chi square test, Kaplan-Meier analysis and Cox regression analysis were performed to investigate the correlation of RTL with patients' clinical and pathological parameters and overall survival (OS).

Results: RTL was significantly shorter in PB of patients with $\mathrm{BC}(p<0.0001)$ or with $\mathrm{KC}(p<0.0001)$, compared to the age-matched control group. The cancer patients were divided into long and short RTL subgroups with the median RTL value. Both $B C$ and KC patients with shorter RTL had significantly worse OS (BC: $p=0.029 ; \mathrm{KC}: p=0.012$ ) during the 83 months' follow- up period. The multivariate analysis revealed that short $\mathrm{RTL}(\mathrm{BC}: p=0.039$; KC: $p=0.046$ ) was an independent prognostic factor for OS in BC and KC compared to long RTL.

Conclusions: $A$ reduced RTL is associated with the presence of $B C$ and $K C$. It may serve as a prognostic biomarker for the prediction of reduced survival in $B C$ and KC patients. Further prospective studies with larger sample numbers are needed for more accurate validation and for better understanding of the potential mechanisms.

3K04.10

Einfluss der präoperativen Plasmaspiegel des Urokinasetyp-Plasminogenaktivator (uPA), seines löslichen Rezeptors (SuPAR) und seines Inhibitors (PAI-1) auf den Krankheitsverlauf nach radikaler Zystektomie beim Urothelkarzinom der Blase

V. Schüttfort ${ }^{1 *}$, B. Pradere², D. D'Andrea ${ }^{2}$, N.C. Grossmann², F. Quhal' ${ }^{2}$, H. Mostafaei², E. Laukhtina' ${ }^{2}$ K. Mori², M. Rink', P.I. Karakiewicz', R. Sari Motlagh ${ }^{2}$, S. Katayama ${ }^{2}$, Y. Lotan ${ }^{4}$, D. Scherr ${ }^{5}$, H. Fajkovic ${ }^{2}$, E. Compérat ${ }^{2}$, D. Enikeev ${ }^{6}$, S. F. Shariat ${ }^{2}$

'Universitätsklinikum Hamburg-Eppendorf, Urologie, Hamburg, Deutschland; ${ }^{2}$ Medical University of Vienna, Urologie, Wien, Österreich; ${ }^{3}$ University of Montreal Health Center, Cancer Prognostics and Health Outcomes Unit, Montreal, Kanada; ${ }^{4}$ University of Texas Southwestern, Urology, Texas, Vereinigte Staaten von Amerika; ${ }^{5}$ Weill Cornell Medical College, New York Presbyterian Hospital, Urology, New York, Vereinigte Staaten von Amerika; ${ }^{6}$ Sechenov University, Institute for Urology and Reproductive Health, Moscow, Russische Föderation

Einleitung: Präoperative Plasmaspiegel des Urokinasetyp-Plasminogenaktivator (UPA), seines Rezeptors (SuPAR) und seines Inhibitors (PAI-1) wurden mit onkologischen Krankheitsverläufen beim Urothelkarzinom der Blase (UCB) assoziiert, jedoch fehlt eine Validierung für Patienten, welche mit radikaler Zystektomie (RC) für UCB behandelt wurden. Methoden: Die Plasmaspiegel von uPA, SuPAR und PAI-1 wurden bei insgesamt 1036 konsekutiven Patienten vor RC an zwei Instituten bestimmt. Es wurden logistische und Cox-Regressionsanalysen in Bezug auf verschiedene Endpunkte erstellt. Die Diskriminationsfähigkeit der Modelle und der additive Nutzen der Marker wurde durch die Berechnung der AUC unter ROC-Curves und des C-Index analysiert. Der zusätzliche prädiktive Nutzen der Marker wurde mit Hilfe von Decision curve analysis (DCA) untersucht.

Ergebnisse: Die medianen Spiegel von uPA, SuPAR- und PAI-1 waren bei Patienten mit ungünstigen pathologischen Merkmalen signifikant erhöht. Alle drei Biomarker waren mit einem erhöhten Risiko für pN+-Tumore assoziiert; erhöhte uPA-Level auch mit einer erhöhten Wahrscheinlichkeit von $\geq \mathrm{pT}$ T-Tumoren. $\mathrm{UPA}$ und SuPAR waren mit dem Tumor-freien Überleben (RFS) und dem krebsspezifischen Überleben (CSS) assoziiert. Die Addition zu etablierten prä- und postoperativen Modellen verbesserte die Diskriminationsfähigkeit für $\mathrm{pN}+$ und $\geq \mathrm{pT} 3$-Tumoren, RFS und CSS bei der DCA

Diskussion: Erhöhte präoperative Plasmaspiegel von UPA, SuPAR und PAI-1 waren mit schlechteren onkologischen Krankheitsverläufen assoziiert. Alle Marker haben das Potenzial die Diskriminationsfähigkeit von prädiktiven Modellen verbessern und Patienten zu identifizieren, welche von einer multimodalen Therapie profitieren könnten und somit individuelle Therapieentscheidung zu ermöglichen. 
3K04.11

Prädiktive Bedeutung des Neutrophilen-zuLymphozyten Ratio in Patienten mit muskelinvasiven Urothelkarzinom der Blase die mit neoadjuvanter Chemotherapie und radikaler Zystektomie behandelt wurden

V. Schüttfort ${ }^{*}$, N.C. Grossmann ${ }^{2}$, B. Pradere ${ }^{2}$, H. Mostafaei ${ }^{2}$, F. Quhal ${ }^{2}$, E. Laukhtina ${ }^{2}$, K. Mori², M. Rink', R. Sari Motlagh'², S. Katayama ${ }^{2}$, H. Fajkovic ${ }^{2}$, E. Compérat ${ }^{2}$, M. Abufaraj', J. Yuen-Chun Teoh ${ }^{3}$, M. Moschini ${ }^{4}$, S. F. Shariat ${ }^{2}$

'Universitätsklinikum Hamburg-Eppendorf, Urologie, Hamburg, Deutschland; ${ }^{2}$ Medical University of Vienna, Urologie, Wien, Österreich; ${ }^{3}$ The Chinese University of Hongkong, S. H. Ho Urology Centre, Department of Surgery, Prince of Wales Hospital, Hongkong, Hongkong; ${ }^{4}$ Luzerner Kantonsspital, Urologie, Luzern, Schweiz

Einleitung: Ziel war es, den prädiktiven Nutzen des präoperativen Neutrophilen-zu-Lymphozyten-Ratio (NLR) in Patienten mit Urothelkarzinom der Harnblase (UCB) zu untersuchen, die mit neoadjuvante Chemotherapie (NAC) und radikaler Zystektomie (RC) behandelt wurden.

Methoden: Es erfolgte eine retrospektive Analyse von 404 UCB-Patienten (Stadium CT2-4N0-3M0). Die Kohorte wurde in zwei Gruppen hinsichtlich des Youden-Index vom NLR eingeteilt. Es wurden logistische und Cox-Regressionsanalysen in Bezug auf verschiedene Endpunkte erstellt. Die Diskriminationsfähigkeit der Modelle und der additive Nutzen des NLR wurde durch die Berechnung der AUC unter ROC-Curves und des C-Index analysiert. Der zusätzliche prädiktive Wert des NLR wurde mit Hilfe von Decision curve analysis (DCA) untersucht.

Resultate: 169 Patienten $(41,3 \%)$ hatten einen erhöhten NLR. Dieser war mit einer verringerten Wahrscheinlichkeit für eine komplette Remission (CR, OR: 0,27 [95\%Cl 0,15-0,48], $p<0,001$ ) und partieller Remission (PR, OR: $0,36[95 \% \mathrm{Cl} 0,23-0,56], p<0,001)$ nach NAC assoziiert. Die Addition des NLR zu prädiktiven Modellen verbesserte die Diskriminationsfähigkeit bezüglich CR und PR (AUC $+5,7, p=0,012$ bzw. AUC $+4,1, p=0,04)$. In der präoperativen Cox-Analyse war ein erhöhter NLR mit schlechteren Überlebenserwartung (Tumor-freies Überleben, Krebs-spezifisches Überleben und Gesamtüberleben) assoziiert, ermöglichte aber keine relevante Verbesserung des C-Index (Änderung $<2 \%$ ).

Diskussion: Der NLR ist mit dem Ansprechen auf NAC und der Überlebenserwartung bei UCB-Patienten assoziiert, welche mit NAC + RC behandelt werden. Der NLR verbesserte die Diskriminationsfähigkeit etablierter Modelle zur Prädiktion von CR und PR signifikant und kann so individuelle Therapieentscheidungen ermöglichen.

3K04.12

Die Chondrotinase HYAL4-V1 - Auswirkungen und Einfluss auf Chemotherapieresistenz und Gemcitabin/ Cisplatin-Versagen bei Urothelkarzinomen

M. J.P. Hennig ${ }^{1 *}$, M.C. Hupe ${ }^{1}$, M.W. Kramer ${ }^{1}$, S. Lokeshwar ${ }^{2}$, S. Hasanali ${ }^{3}$, M. Terris' ${ }^{2}$ A. S. Merseburger ${ }^{1}$, V. Lokeshwar ${ }^{3}$

'Universität zu Lübeck, Klinik für Urologie, Lübeck, Deutschland; ${ }^{2}$ Augusta University, Department of Surgery: Urology, Augusta, Vereinigte Staaten von Amerika; ${ }^{3}$ Augusta University, Department of Biochemistry and Molecular Biology, Augusta, Vereinigte Staaten von Amerika

Einleitung: $\mathrm{Gem} / \mathrm{Cis}(\mathrm{G}+\mathrm{C})$ ist die bevorzugte Systemtherapie bei fortgeschrittenen Urothelkarzinomen (UC), wobei es keine geeignete Möglichkeit zur Vorhersage des Ansprechens gibt. V1, Splicevariante von HYAL-4, zeigt sich in UC hochreguliert und unterhält den malignen Phänotyp. Wir untersuchten, ob V1 die Chemoresistenz in UC beeinflusst.

Methodik: 2 Kohorten (K1: 86 Proben (normal = 34; UC=52); K2: 44 Proben von Patienten mit MIBC, welche $\mathrm{G}+\mathrm{C}$ zur Behandlung eines UC erhielten). Die V1 Expression wurde mittels RT-qPCR und IHC bestimmt. HYAL-4-Wildtyp (Wt) und V1 wurden stabil exprimiert oder unterdrückt in normalen und UC Zelllinien. Transfizierte Zellen wurden hinsichtlich ihrer
Sensitivität gegenüber einer Behandlung mit $\mathrm{G}+\mathrm{C}$ beurteilt. Die Chemosensitivität von $\mathrm{G}+\mathrm{C}$ resistenten Tumoren, gegenüber einer kombinierten Behandlung mit Tetrahydrouridine (TU) und G wurde in einem UC-Xenograft Modell untersucht

Ergebnisse: In K1 zeigten sich die V1 Transkriptions- und IHC Level signifikant erhöht $(6-13 \mathrm{x})$ in UC-Gewebe gegenüber Kontrollproben $(p<0,001)$ und $7 \times$ erhöht in MIBC $(P=0,0087)$. In K2, konnte eine 3,5 $\times$ Erhöhung in MIBC-Proben gezeigt werden, welche ein Therapieversagen gegenüber $\mathrm{G}+\mathrm{C}$ zeigten. V1-exprimierende urotheliale Zellreihen und UC-Zellreihen zeigten sich resistent gegenüber $\mathrm{G}$. Bei Einsatz des CDA Inhibitors TU zeigte sich eine Sensitivitätssteigerung. Im Xenograft-Modell zeigte G (25$50 \mathrm{mg} / \mathrm{kg}$ ) eine UC-Wachstumsinhibierung, jedoch nicht in V1-expremierenden Tumoren. Die Kombination aus G( $25 \mathrm{mg} / \mathrm{kg})$ und TU $(20 \mathrm{mg} / \mathrm{kg})$ stoppte das Tumorwachstum in V1-expremierenden Tumoren.

Schlussfolgerung: V1 ist ein Einflussfaktor der G Resistenz in UC und ist ein Prädiktor für das $\mathrm{G}+\mathrm{C}$ Versagen. Ein möglicher Ansatzpunkt dieses zu überwinden scheint die kombinierte Gabe mit TU.

\section{K04.13}

\section{Epigenetic priming to enhance CAR T-cell cytotoxicity in bladder cancer}

C.M. Grunewald ${ }^{1 *}$, C. Haist' ${ }^{2,3}$, C. König' ${ }^{1}$, P. Petzsch' ${ }^{4}$, E. Nößner ${ }^{5}$, C. Wiek², K. Scheckenbach ${ }^{2}$, K. Köhrer ${ }^{4}$, G. Niegisch' ${ }^{1}$ H. Hanenberg' ${ }^{2,3}$, M. J. Hoffmann ${ }^{1}$

'Heinrich-Heine-Universität Düsseldorf, Klinik für Urologie, Düsseldorf, Germany; ${ }^{2} \mathrm{Hein}$ rich-Heine-Universität Düsseldorf, Klinik für Hals-Nasen-Ohrenheilkunde, Düsseldorf, Germany; ${ }^{3}$ Universität Duisburg-Essen, Klinik für Kinderheilkunde III, Essen, Germany; ${ }^{4}$ Heinrich-Heine-Universität Düsseldorf, Biologisch-Medizinisches Forschungszentrum (BMFZ), Düsseldorf, Germany; ${ }^{5} \mathrm{Helmholtz} \mathrm{Zentrum} \mathrm{München-Deutsches} \mathrm{Forschungs-}$ zentrum für Gesundheit und Umwelt, Immunoanalytics: Tissue Control of Immunocytes, München, Germany

Introduction: Epigenetic inhibitors of DNA methyltransferases (DNMTi) and histone deacetylases (HDACi) show broad gene induction making them potential combination partners for immune-oncological approaches. We therefore investigated whether pretreatment of bladder cancer cell lines with DNMTi decitabine (DEC) or HDACi romidepsin (ROM) might improve the lytic capacity of CAR T-cells.

Materials and methods: Several bladder cancer cell lines and HBLAK pretreated with $3 \mathrm{nM}$ ROM or $100 \mathrm{nM}$ DEC were co-incubated with CAR Tcells directed against EGFR or CD44v6 and subsequent cytotoxicity assays were performed. Surface expression of target antigens and T-cell ligands was assessed by flow cytometry. For further analysis, we performed next generation RNA sequencing and siRNA mediated knockdown of potential regulators of CART-cells lysis.

Results: Pretreatment with DEC, but not with ROM enhanced CAR-T cell lysis towards all bladder cancer cell lines, but not towards benign HBLAK. Differential effects could not be attributed to target antigen induction nor to changes in T-cell interaction molecules. Alternately, regulators of cell survival and apoptosis were differentially modulated by the two treatments. DEC shifted the balance between survival and apoptosis towards a state prone to apoptosis associated with increased CAR T-cell lysis, ROM altered this balance to the opposite. Subsequent siRNA experiments supported BID and BCL2L1 as two important factors in this context. Conclusion: We propose DEC pretreatment in combination with CART-cell therapy as a new therapeutic option for treatment of bladder cancer. Beyond, targeting of BID and BCL2L1 as key factors of CAR T-cell lysis might be suitable for combination with immune-oncological approaches in other malignancies as well. 
3K04.14

Establishing of a new nanoparticle-based immunotherapy for treatment of high-grade nonmuscle invasive bladder cancer

B. Kind ${ }^{1 *}$, S. Tietze ${ }^{2}$, D. Nahhas ${ }^{1}$, N. Wetterling ${ }^{2}$, D. Appelhans ${ }^{3}$, A. Temme², C. Thomas', S. Füssel ${ }^{1}$

'Uniklinikum Dresden, Department of Urology, Dresden, Germany; ${ }^{2}$ Uniklinikum Dresden, Department of Neurosurgery, Section Experimental Neurosurgery/Tumor Immunology, Dresden, Germany; ${ }^{3}$ Leibniz Institute of Polymer Research Dresden, Dresden, Germany

Purpose: BCG therapy reduces the risk of recurrence and progression in patients with high-grade non-muscle invasive bladder cancer (BCa) after transurethral resection and is in use for long-term therapy. There are common adverse effects including cystitis and fever after admission of BCG and $\sim 30 \%$ of non-responders. To overcome these problems, we evaluate a new nanoparticle-based immunotherapy (Nano:BICs) for BCa.

Materials and methods: The Nano:BICs used in this study contain short single-stranded DNA molecules (ODN) as specific Toll-like receptor 9 (TLR9) ligands and antibodies targeting prostate stem cell antigen (PSCA) on the surface of BCa cells as functional components. Both are shielded by transfection-incompetent polypropylenimine dendrimers (PPIs) to prevent unspecific cellular uptake. After developing a successful assembly protocol, activation of endosomal TLR9 was proven using $\mathrm{mTLR9}^{+} / \mathrm{PSCA}^{+}$ HEK-Blue reporter cells co-expressing murine TLR9 and an inducible alkaline phosphatase (AP) reporter gene for colorimetric assay. Furthermore, cytokine production was analyzed by cytometric bead array.

Results: Nano:BICs designed in this study activated mTLR9 ${ }^{+} /$PSCA $^{+}$HEKBlue cells specifically. Nano:BICs containing 1 equivalent anti-PSCA-antibody, 2 equivalents PPI containing 18\% Maltose and $1 \mu$ M ODN1668 (partly phosphorothioate-modified) induced a $2.9 \pm 0.07$ fold induction of AP activity. Furthermore, $1.07 \pm 0.07 \mathrm{ng} / \mathrm{ml}$ of the cytokine IL- 8 were secreted to the medium in vitro.

Conclusion: Our Nano:BICs are suited to induce a proinflammatory cytokine response specifically in reporter cells. Further studies using a syngeneic orthotopic immunocompetent $\mathrm{BCa}$ mouse model are ongoing to prove if this cytokine induction results in an appropriate immune response causing tumor shrinkage in vivo.

Funding: This project is funded by the European Union and the European Regional Development Fund (EFRE) and the Free State of Saxony (SAB; project no. 100379619).

3K04.15

Evaluation of immunostimulatory nucleic acids in a reporter cell model for the potential therapy of NMIBC

D. Nahhas ${ }^{1 *}$, B. Kind ${ }^{1}$, S. Tietze ${ }^{2}$, A. Temme ${ }^{2}$, C. Thomas ${ }^{1}$, S. Füssel ${ }^{1}$

'Uniklinikum Dresden, Department of Urology, Dresden, Germany; ${ }^{2}$ Uniklinikum Dresden, Department of Neurosurgery, Section Experimental Neurosurgery/Tumor Immunology, Dresden, Germany

Purpose: Alternatives for BCG-refractory cases of non-muscle invasive bladder cancer (NMIBC) are lacking as high-risk NMIBC frequently recurs despite guideline-based therapy. Toll-like receptor 9 (TLR9), a pattern recognition receptor of the innate immune system, is under investigation as an anti-tumour immune response mediator. Here, we examined TLR9 and different agonists (CpG ODNs) in vitro.

Material and methods: Expression analysis ( $\mathrm{PPCR}$ ) was performed in human bladder cancer (BCa) cell lines. HEKBlue reporter cells expressing human or murine TLR9 secrete an alkaline phosphatase for photometric assessment (QUANTIBlue assay) after stimulation of TLR9. They were treated by CpG ODNs 1668, 2006 or $2395(0.01-1 \mu \mathrm{M})$. Secreted cytokines were analysed by cytometric bead array (CBA).

Results: In 5 out of 14 BCa cell lines (Cal29, KU1919, RT112, SW780, UMUC-16), hTLR9 mRNA was detected. In $\mathrm{h} / \mathrm{mTLR9}^{+}$HEKBlue reporter cells, TLR9 was activated in a concentration-dependent and species-specific manner. ODN 2006 specifically activated hTLR9 with a 1.8-fold induction over unstimulated control. The ODNs 1668, 2006 and 2395 activated mTLR9 with a $4.9,2.6$ or 3.5 -fold induction, respectively. After stimulation of HEKBlue $\mathrm{h} / \mathrm{mTLR}^{+}$reporter cells, the proinflammatory cytokines IL-8 $(70 \pm 8 / 2907 \pm 182 \mathrm{pg} / \mathrm{ml})$ and IP-10 $(22 \pm 0.1 / 89 \pm 8 \mathrm{pg} / \mathrm{ml})$ were increased in CBA.

Conclusion: The proof of hTLR9 expression in several BCa cell lines revealed TLR9 to be a beneficial target for immunotherapies. ODN 2006 potently stimulates hTLR9 and, therefore, is a candidate for a cancer immunotherapy. ODN 1668 might be helpful to evaluate the therapy in a mouse BCa model. The specific secretion of proinflammatory cytokines in vitro suggests TLR9 to be a potential mediator of anti-tumour immune response.

Funding: This project is funded by the European Union and the European Regional Development Fund (EFRE) and the Free State of Saxony (SAB; project no. 100379619) and it is supported by Deutsche Krebshilfe.

\section{K04.16}

Downregulation of cell cycle and checkpoint genes by class I HDAC inhibitors impairs synergism with G2/M checkpoint inhibitor MK-1775 in bladder cancer cells

\section{S. Meneceur*, K. Hommel, M. Hoffmann, G. Niegisch}

Dept. of Urology, Medical Faculty, Heinrich-Heine-University Duesseldorf, Düsseldorf, Germany

Objectives: Epigenetic regulators like class I histone deacetylases (HDAC1,2,3,8) are frequently deregulated in urothelial cancers (UC) and may thus represent promising targets for new therapy approaches. In this study, we characterized the cytotoxic effect of three class I HDAC targeting inhibitors (HDACi) with different isoenzyme specificity, namely romidepsin (HDAC1/2), entinostat (HDAC1/3) and RGFP966 (HDAC3). Since $\mathrm{HDACi}$, as a mono-treatment, do not sufficiently induce apoptosis in UC cells (UCC), but promote accumulation in the G2/M-phase, we also analysed the combination of romidepsin with the G2/M checkpoint inhibitor MK-1775 for synergistic action.

Material and methods: The UCC VM-CUB1 and UMUC-3 were treated with $\mathrm{HDACi}$ for $24 \mathrm{~h}$ and $48 \mathrm{~h}$. Cell cycle changes and apoptosis induction were analysed by flow cytometry. HDACi induced expression changes of cell cycle- and DNA damage response-proteins were evaluated by western blot. The Chou-Talalay method was used to assess synergism for the combination of romidepsin with MK-1775 in UCC and normal HBLAK cells.

Results: Inhibition of HDAC1/2, but not of HDAC3 impeded transition of UCC into M phase. Likewise, HDACi targeting HDAC1 or HDAC2, but not HDAC3 induced DNA damage. At the same time these compounds impaired DNA damage response by downregulation of checkpoint control proteins like CHK1. Since HDAC1/2 inhibition also downregulated G2/M checkpoint regulators like CDK1, CDC25C, WEE1, AURKB and CCNB1, the WEE1 inhibitor MK-1775 could not overcome G2-arrest and did not synergize with romidepsin.

Conclusion: Targeting HDAC1 and HDAC2, but not HDAC3 is the most promising approach for HDACi based therapy in UC. Since they induce DNA damage, we suggest their combination with DNA damage inhibitors. DFGHO6448/NI1398

\section{K04.17}

\section{mTOR alterations in muscle-invasive bladder cancer}

K. Meisterhofer ${ }^{1 *}$, J. Hennenlotter ${ }^{1}$, C. Wandel ${ }^{1}$, U. Kühs ${ }^{1}$, M. Scharpf ${ }^{2}$, S. Baisch', S. Rausch', A. Stenzl', S. Aufderklamm

'Eberhard Karls University Tübingen, Departement of Urology, Tübingen, Germany; ${ }^{2}$ Eberhard Karls University Tübingen, Departement of Pathology, Tübingen, Germany 
Background: In muscle-invasive bladder cancer (MIBC) mTOR inhibition has proven to be less effective in previous clinical trials. Aim of this study was to evaluate hypotheses for the failure and to find a possible new therapeutic approach.

Methods: The study comprised a tissue microarray of 103 patients ( $79 \mathrm{~m} / 24 \mathrm{f}$, median age $69 \mathrm{y}, 31 \times \mathrm{pT} 2,72 \mathrm{x}>\mathrm{pT} 2$ ) who underwent radical cystectomy due to MIBC. Of 46 patients, corresponding normal urothelium of the bladder was included. Samples were immunohistochemically stained for mTOR, phosphorylated (p-)mTOR and 4E-BP1 as downstream effector. Results were determined histologically and correlated to clinical data and outcome.

Results: MIBC tissue showed clearly higher mTOR (medians 184/140, $p=0.02)$, lower \%mTOR $(0.78 / 1.00,0.0009)$ and higher 4E-BP1 (104/35, $<0.0001)$ than urothelium. T $>2$ BC showed lower mTOR and $p$-mTOR $(157 / 200,0.032$ and 104/135, 0.010), G>2 BC showed higher 4E-BP1 (119/100, 0.048). P-mTOR correlated strongly positive with mTOR in MIBC as well as in normal urothelium (both $<0.0001, r^{2}=0.25$ and 0.39 ). Only in MIBC downstream 4E-BP1 correlated positively with $\operatorname{mTOR}(p=0.0011$, $\left.r^{2}=0.11\right)$ and $p-m T O R(0.007,0.07)$. Survival analysis showed clear tendencies for worse outcome in case of lower mTOR, lower $p$-mTOR, higher \%-mTOR and higher 4E-BP1, whereby overall survival was significantly shorter in case of lower $p$-mTOR $(p<0.05)$.

Conclusion: The activation of the mTOR system seems to be an event which decreases at a certain stage of $\mathrm{BC}$ progression and may be replaced by other oncologic mechanisms. Hence, these results may indicate the relevance of mTOR inhibition in early tumor stages.

\section{K05 - Prostatakarzinom: experimentell}

$$
\text { 16.09.2021, C6.2, 13:30-15:00 }
$$

\section{K05.1}

\section{First identification and validation of prostate cancer} specific tumor endothelial cell markers by multi-omic profiling

I. Heidegger ${ }^{1 *}$, A. Offermann ${ }^{2}$, H. Timmer-Bosscha ${ }^{3}$, G. Schäfer ${ }^{4}$, J. Goveia ${ }^{5}$, S. Daum 6 , A. Walenkamp ${ }^{3}$, S. Perner ${ }^{2}$, Z. Trajanoski', A. Krogsdam ${ }^{7}$, J. Haybaeck', C. Plattner ${ }^{7}$, S. Salcher ${ }^{6}$, S. Thaler ${ }^{1}$, H. Klocker ${ }^{1}$, D. Wolf ${ }^{6}$, A. Pircher ${ }^{6}$

${ }^{1}$ Medizinische Universität Innsbruck, Urologie, Innsbruck, Austria; ${ }^{2}$ Universität Schleswig Holstein, Campus Lübeck, Pathologie, Lübeck, Germany; ${ }^{3}$ University Medical Center Groningen, Medical Oncology, Groningen, The Netherlands; ${ }^{4}$ Medizinische Universität Innsbruck, Pathologie, Innsbruck, Austria; ${ }^{5}$ Unicle, Biomedical Data Science, Leuven, Belgium; ${ }^{6}$ Medizinische Universität Innsbruck, Innere Medizin V; Hämatologie und Onkologie, Innsbruck, Austria; ${ }^{7}$ Medizinische Universität Innsbruck, Institut für Bioinformatik, Biocenter, Innsbruck, Austria

Introduction: Tumor endothelial cells (TEC) are essential components of the tumor microenvironment (TME). We isolated for the first time TEC from prostate cancer (PCa) patients to identify novel targets.

Methods: Normal endothelial cells (NEC) and TEC were isolated from 65 fresh prostatectomy specimens, selected by the endothelial cell (EC) marker CD31 and surveyed for EC characteristics using Immunofluorescence (IF) and FACS. Functional properties were analyzed by $3 \mathrm{H}$-thymidine and scratch assays. To identify molecular differences between TEC and NEC, we performed bulk RNA-sequencing. For validation, immunohistochemistry (IHC) was performed on human and murine samples, IF was used for cultured NEC/TEC.

Results: Compared to NEC, cultured TEC have an increased cell and nucleus area, more abundant discontinuous cell junctions and show increased migration and proliferation. Differential gene expression analyses revealed an upregulation of genes associated with tumor vasculature and cytokine signaling. Complementary, we confirmed an increased protein expression of transcriptionally upregulated genes, such as VDR and
CXCL12 in cultured TECs. Increased expression of the novel prostate TEC markers PTGIR, PLAC9, CXCL12 and VDR was validated in an independent cohort of primary and metastatic PCa samples. For first in vivo validation of CXCL12 as a potentially actionable TEC marker, a subcutaneous xenograft mouse model of human PCa was used. Indeed, targeting CXCR4 by AMD3100 decreases vessel number and density in the TME when compared to solvent-exposed mice.

Conclusion: We identified and validated novel prostate-specific TEC markers. In addition, in vivo validation suggest that blockade of the CXCL12/ CXCR4 interaction is a novel promising vasculature targeting therapeutic option.

\section{K05.2}

Effektivität und Selektivität von 1,4-NaphthoquinonGlukose-Konjugaten durch Nutzung des Warburg-Effekts beim fortgeschrittenen Prostatakarzinom

T. Busenbender', S. Dyshlovoy², M. Kaune', L. Boeckelmann' ${ }^{1}$, T. Lange $^{3}$, U. Schumacher ${ }^{3}$, D. N. Pelageev ${ }^{4}$, Y.E. Sabutskiii, K. Borisova ${ }^{4}$, V. Anufriev ${ }^{4}$, M. Graefen ${ }^{5}$, C. Bokemeyer ${ }^{6}$, G. von Amsberg ${ }^{2 *}$

'Universitätsklinikum Hamburg-Eppendorf, Onkologisches Zentrum, II. Medizinische Klinik, Hamburg, Deutschland; ${ }^{2}$ Universitätsklinikum Hamburg-Eppendorf, Martini-Klinik Prostatakrebszentrum und Onkologisches Zentrum, Hamburg, Deutschland; ${ }^{3}$ Universitätsklinikum Hamburg-Eppendorf, Institut für Anatomie, Hamburg, Deutschland; ${ }^{4}$ Pacific Institute of Bioorganic Chemistry, Vladivostok, Russische Föderation; ${ }^{5}$ Martini-Klinik Prostatakrebszentrum, Hamburg, Deutschland; ${ }^{6}$ Universitätsklinikum Hamburg-Eppendorf, Hamburg, Deutschland

Hintergrund: Der Warburg-Effekt beschreibt die Fähigkeit von Krebszellen durch Überexpression von Glukosetransportern (z. B. GLUT1) vermehrt Glukose im Vergleich zu normalem Gewebe zu verwerten. Dieser Effekt kann genutzt werden, um die Selektivität zytotoxischer Substanzen durch Konjugation an Zuckerreste zu erhöhen.

Material und Methoden: Wir synthetisierten 35 neuartige Moleküle, basierend auf einem 1,4-Naphthochinonelement und daran konjugiertem Glukosemolekül. Im Rahmen von Screening-Untersuchungen wurden die aktivsten Verbindungen ausgewählt und in Prostatakarzinom (PCa)-Zelllinien evaluiert.

Ergebnisse: Zwei vielversprechende Derivate mit IC50s im niedrigen mikro- und nanomolaren Bereich wurden identifiziert. Eine Glukose-Reduktion im Medium führte zu erhöhter Zytotoxizität und eine simultane Behandlung mit einem GLUT1-Inhibitor zu antagonistischen Effekten, ein Indiz für eine konkurrierende Aufnahme mit Glukose und damit eine erfolgreiche Nutzung des Warburg-Effekts. Beide Derivate zeigten eine hohe zytotoxische Aktivität in PCa-Zellen mit unterschiedlichem Resistenzprofil. Dabei wurde die Wirkung vermittelt über einen Verlust des mitochondrialen Membranpotentials, eine Freisetzung von Cytochrom C und AIF in das Zytosol sowie eine Hochregulation von Caspase-9, Caspase-3 und gespaltenem PARP und somit einer Aktivierung der intrinsischen Apoptose. Frühe intrazelluläre Effekte umfassten eine gesteigerte ROS-Produktion und zytosolische Kalziumfreisetzung als Indikatoren für ER-Stress. Eine vielversprechende Aktivität konnte in einem 22Rv1-Xenograft-Maus-Modell beobachtet werden.

Zusammenfassung: Glukose-konjugierte 1,4-Naphthochinone zeigen eine hohe in vitro und in vivo Effektivität und Selektivität in humanen $\mathrm{PCa}$ unter Nutzung des Warburg-Effekts. 


\section{K05.3}

\section{Establishment of an ex-vivo model to study} the interaction between tumor cells and their microenvironment

\author{
M. Saponaro ${ }^{1 *}$, A. Schmidt ${ }^{1}$, N. Klümper ${ }^{1,2}$, M. Hölzel ${ }^{2}$, J. Ellinger ${ }^{1}$, M. Ritter ${ }^{1}$, \\ A. Alajati ${ }^{1}$ \\ 'Universitätsklinikum Bonn, Klinik und Poliklinik für Urologie und Kinderurologie, Bonn, \\ Germany; ${ }^{2}$ Universitätsklinikum Bonn, Institut für Experimentelle Onkologie, Bonn, \\ Germany
}

Introduction \& Objectives: A deeper characterization of the non-epithelial factors involved in prostate cancer became critical for the development of novel therapies. It has been stated that the tumor microenvironment (TME) plays a central role in the prostate cancer progression and resistance to therapies. We recently showed that the overexpression of CDCP1 in the Pten-null background induces metastatic prostate cancer. We hypothesized that $C D C P 1+/ P t e n-n u l l$ tumors could be associated with protumoral macrophages. Our objective is to establish a novel organoid exvivo model to study the interaction between tumor cells and the TME. Materials \& Methods: We performed immunohistochemistry (IHC) analyses in metastatic CDCP1+/Pten-null compared to non-metastatic Pten-null mouse prostate tumors to assess their TME. We set up an ex-vivo organoid model from the tumors of CDCP1+/Pten-null and Pten-null mice to study the interaction between macrophages and tumor cells. Conditioned media was collected from organoids and used to stimulate murine bone marrow derived macrophages (BMDMs). Flow cytometry analyses for CD206 were performed.

Results: The IHC analyses performed on $C D C P 1+/$ Pten-null tumors reported a higher level of macrophages when compared to Pten-null tumors. We observed an enrichment of CD206+ pro-tumoral macrophages among BMDMs harvested with conditioned media from our established $C D C P 1+/$ Pten-null organoid model.

Conclusions: Our results show that $C D C P 1+/$ Pten-null advanced prostate tumors are infiltrated by pro-tumoral macrophages associated with prostate cancer progression. These results were confirmed through an ex-vivo organoid model from mice prostate tumors, where the interactions between tumor cells and the TME can be further investigated.

\section{K05.4}

Prostate cancer-specific transcripts isolated from urinary exosomes show diagnostic potential in patients scheduled for prostate biopsy

\section{K. Erdmann 1"2,2, A. Borkowetz ${ }^{2,3}$, A. Lohse-Fischer ${ }^{2}$, C. Thomas ${ }^{1,2}$, S. Füssel2,3}

${ }^{1}$ National Center for Tumor Diseases (NCT), Dresden, Germany; ${ }^{2}$ Univ.-Klinikum Carl Gustav Carus d.T.U.Dresden, Klinik und Poliklinik für Urologie, Dresden, Germany; ${ }^{3}$ German Cancer Consortium (DKTK), Dresden, Germany

Objective: The diagnostic potential of selected messenger RNAs (mRNAs) and long non-coding RNAs (IncRNAs) in comparison to serum PSA levels was explored by using urinary exosomes from patients scheduled for prostate biopsy.

Materials and methods: After digital-rectal examination, urine samples from 88 patients with suspected prostate cancer ( $\mathrm{PCa}$ ) were collected prebiopsy. Urinary exosomes were obtained by centrifugation following precipitation. After RNA isolation, multiplexed reverse transcription followed by a preamplification step was conducted. Twenty PCa-associated mRNAs and IncRNAs as well as KLK2 as reference were quantified by qPCR and then evaluated for their diagnostic ability by receiver operating characteristic (ROC) curve analyses and determination of the area under the curve (AUC) value.

Results: PCa was detected in 42 patients (47.8\%) by prostate biopsy. Using $4 \mathrm{ng} / \mathrm{ml}$ as cutoff value, serum PSA showed an insufficient diagnostic ability (AUC $=0.569, p=0.267$ ) in the present cohort with a sensitivity, speci- ficity and accuracy of $81.0 \%, 15.2 \%$ and $46.6 \%$, respectively. ROC curve analyses revealed a potential for non-invasive urine-based $P C$ a detection for AMACR, DLX1, ERG, HOXC6, PCA3, PCAT14 and PSGR with AUC values ranging from 0.632 to $0.756(p<0.05)$. The combination of the five best performing transcript markers (AMACR, DLX1, ERG, PCA3, PCAT14) resulted in an AUC of $0.834(p<0.001)$ as well as a sensitivity, specificity and accuracy of $76.2 \%, 78.3 \%$ and $77.3 \%$, respectively, and thus, surpassed the diagnostic power of serum PSA and individual markers.

Conclusion: These findings highlight the potential of urinary exosomal mRNAs and IncRNAs as molecular markers with high clinical performance. Overall, these results need to be validated in an independent patient cohort.

\section{K05.5}

Therapeutic resistance of prostate cancer cells in vitro to second- and third-generation antiandrogens depends on androgen receptor splicing, is regulated by H3K27me3, and can be affected by modifying the lysine demethylase UTX

M. Bertlich', S. Asdjodi',2, G. E. Schmidt', N. Artysh', J.C. R. Becker', M. R. Lüdtke' ${ }^{1}$ M. C. Hasselluhn ${ }^{3}$, L. Trojan', O. Hahn" ${ }^{*}$

'Universitätsmedizin Göttingen, Klinik für Urologie, Göttingen, Germany; ${ }^{2}$ Georgetown University School of Medicine, Washington DC, Vereinigte Staaten von Amerika; ${ }^{3}$ Universitätsmedizin Göttingen, Klinik für Gastroenterologie und Gastrointestinale Onkologie, Göttingen, Germany

Background: Androgen deprivation therapy (ADT) is the foundation of prostate cancer (PCA) treatment in advanced stages. Therapeutic resistance is an emerging problem and the sequence of drugs to be used for optimal outcome remains unclear. Here, we assessed the role of the trimethylated lysine 27 residue of histone 3 (H3K27me3) in therapeutic resistance. Methods: VCaP and LNCaP cells were cultivated with increasing concentrations of different anti-androgens. Resistance was verified using imagebased cytometry. Global H3K27me3 levels were assessed and their impact was measured by RNA sequencing (RNAseq) as well as by qRT-PCR and Western blot. Its regulators were manipulated using siRNA knockdown and small molecule inhibitors. We analyzed Androgen Receptor (AR) splicing by Western blot and qRT-PCR. Chromatin immunoprecipitation (ChIP) of H3K27me3 was performed to identify a possible direct impact on AR expression. The public Stand Up To Cancer (SU2C) data set was used to validate our findings in a large patient cohort.

Results: Significant decrease of H3K27me3 levels occurred in cells resistant to abiraterone but not to other drugs. RNAseq confirmed several H3K27me3 dependent gene sets to be differentially regulated. Knockdown as well as overexpression of H3K27me3 demethylase UTX and treatment with its inhibitor GSK-J4 lead to changes both in AR levels and in the expression of its constitutively active variant AR-V7. Treatment with GSK-J4 affected cellular proliferation. ChIP assay showed different binding patterns of H3K27me3 in resistant and wildtype cells. The SU2C dataset confirmed UTX amplification to be correlated with abiraterone resistance. Conclusions: $\mathrm{H} 3 \mathrm{~K} 27 \mathrm{me} 3$ could serve as a predictive biomarker as well as a therapeutic target in castration resistant PCA. 
3K05.6

\section{Clinical validation of EPI CE, a urine exosomal RNA test for risk stratification of patients under suspicion of prostate cancer}

\author{
A. Kretschmer ${ }^{* *}$, G. Stoll ${ }^{2}$, C. Flinspach ${ }^{2}$, C. Fischer ${ }^{2}$, D. Enderle², R. Müller ${ }^{2}$, \\ A. Reichert ${ }^{2}$, L. Meyer ${ }^{2}$, A. Atterbury ${ }^{3}$, P. Torkler ${ }^{2}$, E. Margolis $^{4}$, R. Tutrone ${ }^{5}$, \\ J. Skog ${ }^{6}$, M. Noerholm² \\ 'Urologische Klinik und Poliklinik, Klinikum der Universität München, LMU München, \\ München, Germany; ${ }^{2}$ Exosome Diagnostics GmbH, Martinsried, Germany; ${ }^{3}$ Bio-Techne, \\ Manchester, Vereinigtes Königreich; ${ }^{4}$ Hackensack Meridian School of Medicine, Depart- \\ ment of Urology, Hackensack, Vereinigte Staaten von Amerika; ${ }^{5}$ Chesapeake Urology \\ Associates, Division of Urology, Baltimore, Vereinigte Staaten von Amerika; ${ }^{6}$ Exosome \\ Diagnostics, Inc., Waltham, Vereinigte Staaten von Amerika
}

Background: The ExoDx Prostate test (EPI) is a non-invasive urine exosomal RNA test for risk assessment prior to prostate biopsy and has been available in the US as a laboratory developed test (LDT) for several years. Here we present the clinical validation of an CE-IVD version of the EPI test (EPI CE), developed as a distributed test for clinical laboratories, in compliance with in-vitro diagnostic devices (IVD) requirements and required to make the test available to patients and clinicians in Europe.

Methods: Subjects, $\geq 50$ years with PSA $2-10 \mathrm{ng} / \mathrm{mL}$, scheduled for systematic prostate biopsy due to suspicion of prostate cancer were enrolled in the study after informed consent at 11 sites in EU and US. First catch urine $<50 \mathrm{~mL}$ was collected without prior digital rectal examination (DRE) analyzed at Exosome Diagnostics according to the Instructions For Use (IFU) of the EPI test. EPI test score performance around the 15.6 EPI cutpoint was compared to the previously published performance characteristics of the EPI LDT assay.

Results: A total of $N=109$ patients, with median (IQR) age of 66 (62-71) years, median PSA $5.88(4.8-7.5) \mathrm{ng} / \mathrm{mL}, 80 \%$ Caucasian, and $54 \%$ positive biopsy rate (36\% Gleason Grade (GG) $1,34 \%$ GG2, and $30 \% \geq G G 3)$ was included. Using the EPI score cut-point 15.6 would avoid $34 \%$ (95\%Cl: $23-$ $46 \%)$ of unnecessary prostate biopsies and $25 \%(95 \% \mathrm{Cl}: 17-34 \%)$ of all biopsies, with negative predictive value (NPV) $89 \%$ (95\%Cl: $71-98 \%)$ and missing $8 \%(95 \% \mathrm{Cl}: 2-21 \%)$ of $\geq \mathrm{GG} 2 \mathrm{PCa}$.

Conclusion: The EPI CE is a non-invasive urine exosomal RNA CE-IVD test validated for predicting high grade prostate cancer $(\geq G G 2)$ in patients with suspected prostate cancer.The clinical performance of EPI CE is equivalent to previously published results of the US CLIA laboratory developed test.

\section{K05.7 \\ Cerenkov Luminescence (CLI) and autoradiography imaging (ARI) in a prostate cancer mouse model using 18-Fluorine and to 68-Gallium-PSMA small ligands}

C. Darr ${ }^{*}$, L. Püllen ${ }^{1}$, J. Iking ${ }^{2}$, J. Klose², P. Sandach², M. Staniszewska², K. Herrmann², J.P. Radtke', S. Tschirdewahn¹, B. A. Hadaschik', W.P. Fendler², P. Fragoso Costa ${ }^{2}$

'Universitätsmedizin Essen, Klinik für Urologie, Essen, Germany; ${ }^{2}$ Universitätsmedizin Essen, Klinik für Nuklearmedizin, Essen, Germany

Background: ${ }^{68} \mathrm{Ga}-\mathrm{PSMA} \mathrm{CLI}$ is a novel imaging modality for the assessment of resection margins in radical prostatectomy (RP). ${ }^{18} \mathrm{~F}$ has a lower light yield and minimum detection limit (MDL), but a significantly longer half-life. Does a flexible scintillator improve the imaging of ${ }^{18} \mathrm{~F}$ by using ARI?

Methods: A total of 10 mice bearing subcutaneous RM1-PGLS tumors (PC) were examined. First, CLI and ARI were performed in the LightPath System. Afterwards, repeat imaging of $\mathrm{PC}$ was performed ex vivo. Due to strong renal PSMA expression, imaging of the kidneys was performed for correlation to activity levels. Median time to imaging of PC was $5.7 \mathrm{~h}(4.7 ; 7.1)$. Imaging was performed with acquisition times of 300 and $120 \mathrm{~s}$. Based on the PET data, respective tracer concentration was decay corrected to the time of CLI and ARI. Activity levels at imaging are stated as $\mathrm{kBq} / \mathrm{mL}$.

Results: A median of $4.3 \mathrm{MBq}(4.1 ; 4.7 \mathrm{MBq}){ }^{68} \mathrm{Ga}$ and $2.6 \mathrm{MBq}(2.3 ; 2.9$ $\mathrm{MBq})$ of ${ }^{18} \mathrm{~F}$ were injected into 5 mice each. At time of $\mathrm{CLI}$, median activity levels of ${ }^{68} \mathrm{Ga}$ was $0.9(0.6 ; 1.3)$ in $\mathrm{PC}$ and $8.7(7.3 ; 10.5)$ in kidneys. Median activity levels of ${ }^{18} \mathrm{~F}$ was $9.02(8.2 ; 10.2)$ in PC and $106.7(95 ; 121.8)$ in kidneys. For both ${ }^{68} \mathrm{Ga}$ and ${ }^{18} \mathrm{~F}$, tracer activity showed a significant Pearson correlation for contrast-to-noise ratio (68Ga: $r=0.55, p<0.001$ and 18F: $r=0.68, p<0.001)$. In CLI, MDL for ${ }^{68} \mathrm{Ga}$ was 1.4 and 73.8 for ${ }^{18} \mathrm{~F}$. ARI significantly improved the representation of low activity levels for ${ }^{18} \mathrm{~F}(p<0.001)$. The lowest imaged activity present was 7.3.

Conclusion: Using ARI, it is possible to detect low signals that are not visible by CLI. AR significantly improves the use of ${ }^{18} \mathrm{~F}$, lowering the MDL to levels comparable, but still higher than 68Ga. Intraoperatively, this may provide an advantage of ${ }^{18} \mathrm{~F}$ over ${ }^{68} \mathrm{G}$ a due to a longer half-life.

\section{K05.8 \\ High fibroblast-activation-protein (FAP) expression in castration resistant prostate cancer supports the use of FAPI-molecular theranostics}

C. Kesch'", L. Yirga', K. Dendl², A. Handke', C. Darr', U. Krafft', J.P. Radtke', S. Tschirdewahn' ${ }^{1}$, T. Szarvas ${ }^{1,3}$, L. Fazil ${ }^{4}$, M. Gleave ${ }^{4}$, F. L. Giesel2, ${ }^{2,56}$, U. Haberkorn ${ }^{2,5}$, B. Hadaschik

'Department of Urology, University of Duisburg-Essen, and German Cancer Consortium (DKTK), University Hospital Essen, Essen, Germany; ${ }^{2}$ Department of Nuclear Medicine, University Hospital Heidelberg, Heidelberg, Germany; ${ }^{3}$ Department of Urology, Semmelweis University, Budapest, Hungary; ${ }^{4}$ Vancouver Prostate Center, Vancouver General Hospital and Department of Urologic Sciences, University of British Columbia, Vancouver Canada; ${ }^{5} \mathrm{Clinical}$ Cooperation Unit Nuclear Medicine, German Cancer Research Center (DKFZ), Heidelberg, Germany; ${ }^{6}$ Department of Nuclear Medicine, University Hospital Düsseldorf, Düsseldorf, Germany

Purpose: To evaluate fibroblast-activation-protein (FAP) expression in different clinical stages of prostate cancer (PC) with regards to utility of ${ }^{68} \mathrm{Ga}$ FAPI PET/CT imaging in patients with castration resistant PC (CRPC). Methods: Tissue microarrays (TMAs) were constructed from prostatic tissue from 94 patients at different stages of PC (primary PC, patients undergoing neoadjuvant androgen deprivation therapy, CRPC and neuroendocrine PC (NEPC)) and were stained with anti-FAPa monoclonal antibody. A positive pixel count algorithm ( $\mathrm{H}$-Index) was use to compare FAP expression between the groups. Additionally, three men with advanced CRPC or NEPC underwent ${ }^{68} \mathrm{Ga}-\mathrm{FAPI} \mathrm{PET} / \mathrm{CT}$ and PET positivity was analyzed.

Results: The mean $\mathrm{H}$-index for benign tissue, primary PC, neoadjuvant androgen deprivation therapy before radical prostatectomy, CRPC and NEPC was $0.018,0.031,0.042,0.076$ and 0.051 , respectively, indicating a significant rise in FAP expression with advancement of disease. Corroborating these findings ${ }^{68} \mathrm{Ga}$-FAPI PET/CT was highly positive in men with advanced CRPC.

Conclusion: Increasing fibroblast-activation-protein tissue expression supports the use of FAPI-molecular theranostics in castration resistant prostate cancer.

\section{K05.9}

\section{Novel Androgen receptor truncation in Cologne collective}

E. Spahic, M. von Brandenstein*, M. Huerta, B. Koeditz, A. Heidenreich

Uniklinik Köln, Urologie, Köln, Germany

Introduction: The HSD3B1 SNP at position 1245 is responsible for resistance to androgen-deprivation therapy (ADT) in prostate cancer. According to the literature it seems, that not only the mutation is responsible for resistance to ADT in prostate cancer. A further possible explanation of failed ADT can be a truncation or mutation of the androgen receptor (AR). 
Several different mutations of the AR are already known, nevertheless, we identified a novel truncated $A R$, called AR/TC. It was possible to identify a hypothetical miR/DNA binding site.

Method: We isolated the cfRNA from blood $(n=40)$ and performed SNP PCR and qRT-PCR for the identification of the novel truncated AR. We analyzed our collective on the presences and distribution of heterozygotes vs homozygotes $(n=45)$. Therefore, we isolated the cfDNA from blood samples and established a SNP PCR. Since the hypothesized truncation of the AR is only present on RNA level, we isolated the RNA form blood and performed qRT-PCR.

Results: The distribution of heterozygotes to homozygotes was $50 \%$. Even in our group of castration-resistant PCa there was a distribution of $50 \%$. Furthermore, the novel truncated AR was present in all patients in the group of castration-resistance. Significant differences were detectable by comparing the group of castration-resistance patients with patients who were diagnosed with high risk or intermediate prostate cancer.

Conclusion: It seems to be of great importance to screen all patients regarding the HSD3B1 mutation. According to the identification of a novel truncated AR further experiments needed. Whether the newly identified $\mathrm{AR} / \mathrm{TC}$ is responsible for castration-resistance or whether the ADT increases the miR and therefore leads to an overproduction of the AR/TC needs to be proven in detail.

\section{K05.10 \\ Glutamine deprivation as a potential therapy in docetaxel resistant prostate cancer}

\section{A.-M.K. Beier ${ }^{*}$, M. Puhr², B. Guezguez ${ }^{3}$, A. Dubrovska ${ }^{4}$, S. Füssel5 ${ }^{5}$, C. Thomas', H.H.H. Erb \\ 'Universitätsklinikum Carl Gustav Carus, Klinik und Poliklinik für Urologie, Dresden, Ger- many; ${ }^{2}$ Medical University of Innsbruck, Department of Urology/Division Experimental Urology, Innsbruck, Austria; ${ }^{3}$ Universitätsmedizin der Johannes Gutenberg-Universität Mainz, Deutsches Konsortium für Translationale Krebsforschung (DKTK); Deutsches Krebsforschungszentrum, Mainz, Germany; ${ }^{4}$ Faculty of Medicine and University Hospital Carl Gustav Carus, OncoRay-National Center for Radiation Research in Oncology, Dresden, Germany; ${ }^{5}$ Univ.-Klinikum Carl Gustav Carus d.T. U.Dresden, Dresden, Germany}

Introduction: Docetaxel is one therapy option for metastatic prostate cancer (PCa). Although initial remission, acquired docetaxel-resistance is inevitable. The mechanisms behind docetaxel-resistance are not clarified yet; however, a cancer stem cell phenotype with altered metabolic features is associated with docetaxel-resistance. Metabolic analysis revealed that docetaxel-resistant (DR) cell lines obtain most ATP production by oxidative phosphorylation, powered substantially by glutamine (Gln). Likewise, Gln is indispensable in redox homeostasis. Thus, we investigated the influence of GIn deprivation on PCa cell models and determined its therapeutic value in DR cells.

Methods: Docetaxel sensitive and DR PC3 and DU145 cells were screened regarding their Gln dependency. Proliferation and migration were examined using an InCucyte live-cell imager. siRNA transfection was used for Glutaminase (GLS) 1/2 knock-down. Clonogenic assays were carried out as published by Franken et al. 2006. Reactive oxygen species (ROS) induction was determined using the ROS indicator $\mathrm{CM}-\mathrm{H}_{2}$ DCFDA.

Results: In general, lower GIn concentrations significantly decreased cell proliferation, clonogenic potential, and migratory behaviour of the selected PCa cell models. Especially DR cell sub-lines were susceptible to GIn deprivation. GLS 1/2 knock-down experiments revealed that observed effects are mainly mediated by GLS1. In addition, only DU145 DR exhibited in formation of ROS.

Conclusion: Gln availability highly influences PCa cell proliferation, clonogenic potential, and migration. These findings highlight the potential of blocking the Gln metabolism as a therapeutic strategy to target DR cells and thereby delay accelerated tumor progression and metastatic spread.
3K05.11

Mechanistic analysis of androgen receptor dimerization

J. Guzman*, H. Taubert, S. Wach, B. Wullich

Universitätsklinik Erlangen, Molekulare Urologie, Erlangen, Germany

Introduction: Androgen-regulated gene expression is a highly coordinated dynamic process mediated by androgen receptor (AR) ligand binding by specific AR protein-protein interactions. The constitutively active androgen receptor splice variant 7 (AR-V7) lacking the ligand-binding domain has been implicated in the pathogenesis of castration-resistant prostate cancer and in mediating resistance to newer drugs that target the androgen axis. The purpose of the present project is to investigate the kinetics of the androgen receptor dimerization with its androgen receptor splice variant 7.

Methods: NanoLuc Binary Technology (NanoBiT) is a system based on two small subunits, Large BiT and Small BiT, of the very bright NanoLuc luciferase, allowing to detect protein interactions using structural complementation. HEK-293 cells were transfected with generated AR-FL and AR-V7 NanoBiT constructs and luminescence readings were obtained with a microplate reader. To investigate co-localization, cells were transfected with the indicated plasmids on Poly-D-Lysine-coated coverslips. Confocal images were obtained by using a Leica SP5 II system.

Results: We found that AR-V7 homodimerizes in a ligand independent manner with nuclear co-localization. Homodimerization of AR-V7 cannot be androgen-stimulated nor inhibit with enzalutamide. As expected, AR-FL homodimirizes in the cytoplasm upon dehydrotestosterone (DHT) stimulation and translocates into the nucleus. AR-FL-AR-V7 heterodimerization occurs in the nucleus only upon DHT stimulation.

Conclusions: Our results elucidate important steps in the mechanism by which AR-V7 and AR-FL heterodimers mediate gene regulation and provide a pivotal pathway for rational drug design for the effective treatment of advanced prostate cancer.

\section{K05.12}

Relevanz des Insulinsignalwegs für die Tumorbiologie des Prostatakarzinoms am Beispiel der IRS1/2

\section{Aktivierung}

S. Walz ${ }^{*}$, C. Wandel ${ }^{1}$, J. Hennenlotter ${ }^{1}$, L. Ulrich ${ }^{1}$, L. Jobst ${ }^{1}$, M. Heni ${ }^{2,3,4}$ A. Wittan' ${ }^{1}$, M. Scharpf ${ }^{5}$, A. Stenzl' ${ }^{1}$ S. Rausch ${ }^{1}$

'Universitätsklinik Tübingen, Abteilung für Urologie, Tübingen, Deutschland; ${ }^{2}$ Universitätsklinik Tübingen, Abteilung für Endokrinologie, Diabetologie und Nephrologie, Tübingen, Deutschland; ${ }^{3}$ University of Tuebingen, Institute for Diabetes Research and Metabolic Diseases, Helmholtz Centre Munich, Tübingen, Deutschland; ${ }^{4}$ German Center for Diabetes Research (DZD), Tübingen, Deutschland; ${ }^{5}$ Universitätsklinik Tübingen, Institut für Pathologie, Tübingen, Deutschland

Hintergrund: Die unterschiedlich hohe Insulinrezeptor(IR)-Expression sowie das veränderte Verhältnis der IR-substrat(IRS)-isoformen im Prostatakarzinom (PCa) legen eine Beteiligung an der Tumorentstehung und Progression durch Veränderungen im down-stream signaling nahe. In dieser Studie wurde normales und PCa Gewebe auf IR- und IGFR1-Expression, IRS1, IRS2 sowie deren Einfluss auf den proonkogenen PI3K-AKT Signalweg untersucht.

Material und Methoden: PCa und normales Prostata-Gewebe aus Operationspräparaten von Patienten mit nmPCa $(n=53)$ und benigner (BEN) Prostatahyperplasie $(n=26)$ wurden mittels Tissue Microarray Technik aufgearbeitet und immunhistochemisch die Proteinexpressionen des IRß und IGFR1 sowie IRS1 und IRS2 denen von Akt gegenübergestellt. Mittels multivariater Analysen wurde der Einfluss des IRß und IGFR1 auf IRS1, IRS2 und Akt untersucht.

Ergebnisse: IRß und IGFR1 exprimieren beide im PC höher als im BEN Gewebe. IRS1 und IRS2 korrelieren beide mit der Akt-Expression. Sowohl im BEN als auch PCa ist multivariat der Einfluss von IRß sowohl auf IRS1 und IRS2 als auch auf Akt dabei erhalten und der Einfluss von IGFR1 nicht 
mehr unabhängig vorhanden. (im BEN: IRß vs. IGFR1 auf IRS1, IRS2 undAkt: $p<0,0001$ vs. $0,71,<0,0001$ vs. 0,43 und 0,0002 vs. 0,67 , im PC: 0,0013 vs. $0,17,0,0002$ vs. 0,89 und 0,0051 vs. 0,07$)$.

Schlussfolgerung: Ein Zusammenhang der Insulinkaskade und der proonkogenen Aktivierung des PI3K-AKT Signalwegs kann nachgewiesen werden. Daran scheint der IRß einen wesentlich höheren Anteil zu haben, als bisher angenommen. Weitere Untersuchungen zur Einordnung der diagnostischen und therapeutischen Relevanz im PCa werden benötigt.

\section{K05.13}

Inzidentelles Prostatakarzinom zeigt unterschiedliche miRNA-Profile bei Detektion via radikaler Zystektomie und via TUR-P

K. Richter", M. von Brandenstein, B. Köditz, J. Fries, A. Heidenreich

Uniklinik Köln, Köln, Deutschland

Einleitung: Das inzidentelle Prostatakarzinom (iPCA) wird entweder via radikaler Zystektomie oder TUR-P diagnostiziert. Ziel dieser Studie war es, Unterschiede in miRNA-Profilen zu bestimmen.

Material und Methoden: Wir untersuchten 86 miRNAs (miR) in 25 Patienten davon 5 Patienten, bei denen ein iPCa via radikaler Zystektomie entdeckt wurde (iPCa-Cyst) und 10 Patienten, bei denen ein iPCA via TUR-P gefunden wurde (iPCa-TUR). Als Kontrollgruppe zogen wir 10 Patienten heran, die sich einer radikalen Prostatektomie (RPE) wegen eines stanzbioptisch gesicherteten Prostatakarzinoms unterzogen. Das Pca-Gewebe wurde makrodisseziert, die miRNA mit dem miScript PCR Array Prostate Cancer (Qiagen) quantifiziert.

Ergebnisse: Insgesamt wurden 13 miR identifiziert, die bei iPCa-Cyst überexprimiert sind, nicht aber bei iPCA-TUR. Das Expressionsniveau in der Hochrisikogruppe wurde als Kontrolle verwendet. Die Niedrigrisikogruppe diente als Normalisierungskohorte. Das Expressionsniveau der beiden miR-92a-3p und miR-223-3p war signifikant erhöht bei iPCa-Cyst gegenüber sowohl iPCa-TUR als auch gegenüber dem der Kontrolle (RPE). Die miR-7-5p, miR-142-3p und miR-374a-5p zeigten einen signifikanten Unterschied gegenüber iPCa-TUR und nicht jedoch gegenüber der Kontrolle (RPE). Zusätzlich fanden wir acht weitere miRs, die bei iPCa-Cyst signifikant überexprimiert sind, die allerdings auch mit einem Urothelkarzinom assoziiert sein können: miR-21-5p, miR-27b-3p, miR-29b-3p, miR-32-5p, miR-101-3p, miR-142-5p, miR-150-5p und miR-155-5p.

Schlussfolgerung: Es fanden sich unterschiedliche Expressionsmuster für miR im IPCA je nach Detektionsmethode TUR-P versus radikaler Zystektomie. Weitere Studien werden notwendig sein, um ihre Rolle als Tumorsuppressoren oder Onkogene zu bestimmen.

\section{K05.14}

Non-virale Etablierung primärer Prostatalinien als uroonkologisches Forschungsobjekt präklinischer Stadien

\section{S. Lange ${ }^{1 *}$, V. Humberg ${ }^{1}$, L. Esch ${ }^{1}$, A. Kuntze ${ }^{2}$, W. G. Dirks ${ }^{3}$, S. Huss ${ }^{4}$, C. Bernemann ${ }^{1}$}

${ }^{1}$ Universitätsklinikum Münster, Forschungslabor Urologie, Münster, Deutschland; ${ }^{2}$ Universitätsklinikum Münster, Gerhard-Domagk-Institut, Münster, Deutschland; ${ }^{3}$ Leibnitz Institut DSMZ, Braunschweig, Deutschland; ${ }^{4}$ Institut für Pathologie am Clemenshospital, Münster, Deutschland

Einleitung: Derzeit fehlen frühe, präklinische Modelle des Prostatakarzinoms, während etablierte Zelllinien meist kein Abbild des hormonsensitiven Stadiums bieten. Daher sollen primäre Linien von RPE-Patienten ohne vorangegangene Medikation im Labor etabliert und untersucht werden. Material und Methoden: RPE-OP-Material ( $n=4$ Patienten; GS $\geq 7$ ) wird mechanisch und enzymatisch dissoziiert und die Zellen in Kultur gebracht. Mittels Sleeping-Beauty-Transposase (SBT) werden 2 Immortalisierungsfaktoren stabil in den Zellen exprimiert. Die weitere molekular- und zellbiologische Charakterisierung umfasst in-vitro-Studien, wie
Assays zum Migration- und Invasionspotential sowie in-vivo-Studien zum Tumorbildungspotential.

Ergebnisse: Von drei aus vier ausgewählten RPE-Patienten konnten immortalisierte Linien abgeleitet und dauerhaft kultiviert werden. Trotz fehlender PCa-Marker sind einige der Linien in der Lage sowohl in-vitro in 3D-Matrices als auch in-vivo zu proliferieren und Tumore auszubilden. Die tumorbildenden Linien zeigen in beiden Fällen ein heterogenes Bild aus p40 Basalzellen und p40-Zellen, die im Tumor das gestreifte Plattenepithel der Prostata abbilden.

Schlussfolgerung: Wir präsentieren hier die erste Immortalisierung humaner Primärkulturen durch Einsatz der SBT. Auch ohne die Expression der klassischen Prostatamarker sind die isolierten Linien in der Lage, in Kultur dauerhaft zu proliferieren und prostata-ähnliche Strukturen in Mäusen zu entwickeln. Der Einsatz von RNA-Sequenzierung und in-vitro-Differenzierung wird das weitreichende Potenzial dieser Zelllinien für Grundlagenforschung und pharmazeutische Entwicklung zeigen.

\section{K05.15}

\section{Shikonin inhibiert das progressive Wachstumsverhalten Docetaxel-resistenter Prostatakarzinomzellen}

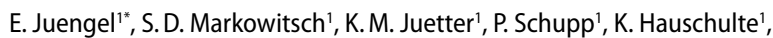
O. Vakhrusheva' ${ }^{1}$, K. S. Slade', A. Thomas' ${ }^{1}$, I. Tsaur', J. Cinatl Jr.', M. Michaelis ${ }^{3}$, T. Efferth ${ }^{4}$, A. Haferkamp ${ }^{1}$

'Universitätsmedizin Mainz, Klinik und Poliklinik für Urologie und Kinderurologie, Mainz, Deutschland; ${ }^{2}$ Universitätsklinikum Frankfurt, Institut für Medizinsche Virologie, Frankfurt/Main, Deutschland; ${ }^{3}$ University of Kent, Industrial Biotechnology Centre and School of Biosciences, Kent, Vereinigtes Königreich; ${ }^{4}$ Institut für Pharmazie und Biochemie, Abt. Pharmazeutische Biologie, Mainz, Deutschland

Einleitung: In der vorliegenden Studie wurde der Einfluss von Shikonin (SHI) aus der Traditionellen Chinesischen Medizin auf das Wachstumsverhalten Docetaxel (DX)-resistenter Prostatakarzinom (PCa)-Zellen untersucht.

Material und Methoden: DX-resistente PCa-Zellen, PC3, DU145, LNCaP und 22Rv1, wurden für 12-72 $\mathrm{h}$ mit SHI $[0,1-1,5 \mu \mathrm{M}]$ behandelt. Therapiesensitive (parentale) und SHI-unbehandelte PCa-Zellen dienten als Kontrollen. Evaluiert wurden das Tumorzellwachstum, die Proliferation, die Zellzyklusphasen, apoptotische, nekrotische und nekroptotische Ereignisse, der Glutathion-Gehalt sowie die metabolische Aktivität. Weiterhin wurde die Expression der entsprechenden regulatorischen Proteine analysiert.

Ergebnisse: Die Behandlung mit SHI resultierte zeit- und dosisabhängig in einer signifikanten Inhibition des Wachstums und der Proliferation parentaler und DX-resistenter PCa-Zellen. Die Wachstumshemmung war mit einem Zellzyklusarrest in der G2/M- oder S-Phase und Veränderungen zellzyklusregulierender Proteine assoziiert. Die SHI-Gabe führte weiterhin zum Zelltod parentaler und DX-resistenter PCa-Zellen. In allen parentalen und DX-resistenten PCa-Zellen vermochte SHI dabei signifikant die Nekroptose zu induzieren. Diese ging mit einer Hemmung von Caspase- 8 und erhöhter Aktivität von pRIP1 und pRIP3 einher. Parallel rief SHI eine Reduktion des Glutathion-Gehalts hervor, kennzeichnend für einen Anstieg reaktiver Sauerstoffspezies. Die metabolische Aktivität der PCa-Zellen wurde durch die SHI-Behandlung hingegen nicht beeinflusst.

Schlussfolgerungen: Aufgrund unserer Daten postulieren wir, dass SHI ein vielversprechendes Additivum in der Therapie fortgeschrittener auch Therapie-resistenter - PCa darstellen könnte. Weiterführende Studien sollen dies verifizieren. 
3K05.16

Kleine RNAs als Biomarker zur Bewertung der Dignität von Prostataerkrankungen - BPH und PCa im Patientenurin differenzieren.

L. Markert' ${ }^{1}$ J. Holdmann ${ }^{1 *}$, C. Klinger', M. Kaufmann', K. Schork², M. Turewicz ${ }^{2}$, M. Eisenacher ${ }^{2}$, A. Savelsbergh ${ }^{1}$

'Universität Witten/Herdecke, Lehrstuhl für Biochemie und Molekulare Medizin, Witten, Deutschland; ${ }^{2}$ Ruhr-Universität Bochum, Computional Quantitative Proteomics, Bochum, Deutschland

Hintergrund: Prostatakrebs (PCa) ist die häufigste Krebserkrankung und dritthäufigste Krebstodesursache des Mannes in Deutschland. MicroRNAs (miRNA) scheinen an Entstehung und Krankheitsverlauf des PCa beteiligt zu sein. Eine diagnostische Abgrenzung zur benignen Prostatahyperplasie (BPH) gelingt oft erst durch transrektale Stanzbiopsien. Dieses Verfahren wird als schmerzhaft beschrieben und birgt Risiken.

Ziel: Es wurde untersucht, ob Micro-RNAs und piwi-interacting RNAs (piRNAs) aus Urin als Biomarker zur Unterscheidung der Dignität obiger Prostataerkrankungen herangezogen werden können.

Methode: Urinproben urologischer Patienten beider Erkrankungen (15 $\mathrm{BPH}, 18$ PCa) wurden mittels Next-Generation Sequencing (NGS) auf ihr Gesamt-miRNA-Expressionsprofil hin untersucht. Die Ergebnisse wurden mittels 20 weiterer Proben (10 BPH, 10 PCa) zudem bioinformatisch validiert.

Ergebnisse: Es zeigten sich 79 miRNAs, sowie 5 piwi-interacting-RNAs (piRNAs) signifikant differentiell exprimiert (adjust. $p$-Wert $<0,05$ und log2-FoldChange $>1$ oder $<-1$ ), folgend dargestellt als Volcano-Plot. Davon konnten 6 miRNAs und 2 piRNAs zusätzlich statistisch validiert werden. Überdies konnte mit Methoden des Maschinellen Lernens ein Satz von 22 weiteren miRNAs identifiziert werden, deren Zusammenspiel ebenfalls eine Unterscheidung der beiden Gruppen ermöglicht. Dieses Muster kann als Heatmap grafisch dargestellt werden.

Schlussfolgerung: Es ergeben sich aussichtsreiche Einzelkandidaten für eine potenzielle Verwendung als Biomarker beim Prostatakarzinom. Durch die Nutzung von Methoden des Maschinellen Lernens könnten weitere, bislang unbeachtete, miRNAs ins wissenschaftliche Blickfeld geraten. Die Entwicklung eines kommerzialisierbaren Tests könnte eine Alternative zur Prostatastanzbiopsie liefern.

\section{K05.17}

TP53-dependent release of extracellular vesicles (EVs) from urological malignancies affects functional status of tumor associated macrophages and therapy response

B. Köditz ${ }^{1 *}$, E. Izquierdo ${ }^{2}$, T. Nestler ${ }^{1}$, M. Hallek ${ }^{2}$, A. Heidenreich ${ }^{1}$, M. Von Brandenstein ${ }^{1}$, C. Pallasch ${ }^{2}$

'Universitätsklinikum Köln, Köln, Germany; ${ }^{2}$ Universitätsklinikum Köln, Innere Medizin I, Köln, Germany

Introduction: Immune evasion is one of the hallmarks of cancer and one of the most important strategies for tumor survival. One mediator, which can induce immune evasion and therefore tumor survival, are extracellular vesicles (EVs). The question was if EVs derived from tumor cells with different TP53 status can have an impact on macrophage activation and therefore on phagocytosis of tumor cells.

Materials and methods: EVs isolated from prostate cancers (PC3 and LNCap), bladder carcinoma (HTB-9) and seminoma (TCam2) were investigated. These cell lines differ in their TP53 status. Impact of EVs on phagocytosis was analyzed by an antibody dependent cellular phagocytosis (ADCP). EVs were checked for the expression of PD-L1 and CD47. In order to understand the role of PD-L1 and CD47 in this mechanism, EVs were pretreated with Anti-PD-L1 and Anti-CD47 and further investigated in an ADCP. To proof the principle CRISPR-KO of PD-L1 and RAB27A in PC3 cells were established and isolated EVs analyzed via an ADCP.
Results: EVs from cells with different TP53 status can have an impact on macrophage activation and therefore on phagocytosis of tumor cells. EVs derived from TP53 null cell line cause a significant decrease of phagocytosis, compared to TP53 wild type and to the control. In the case of blockage of PD-L1 on PC3 derived EVs cause significant increase on phagocytosis performed by macrophages. Furthermore, the blockage of PD-L1 and Rab27A in PC3 cells cause a significant increase in macrophage activation. Conclusion: Therefore it could be concluded that EVs derived from tumor cells with different TP53 status can have an impact on macrophage activation in the presence of exosomal PD-L1 and therefore on the therapy response

\section{K06 - Nierenkarzinom: operative und medikamentöse Therapie}

16.09.2021, C6.1, 13:30-15:00

\section{K06.1}

Kleine Nierentumore: eine neue therapeutische Herausforderung:

\section{K. Elkaial", P. Zeuschner, S. Siemer, M. Stöckle, K. Junker}

Universitätskliniken des Saarlandes, Homburg Saar, Deutschland

Fragestellung: Die zunehmende Inzidenz kleiner Nierentumore(SRM) erfordert ein differenziertes therapeutische Vorgehen. Im Rahmen dieser Studie wurden SRM über einen Zeitraum von 30 Jahren charakterisiert. Material und Methoden: Patienten, die zwischen 1990 und 2019 wegen einer SRM operiert wurden, konnten hinsichtlich klinischer, histopathologischer und Follow-Up Daten analysiert werden.

Ergebnisse: 1048 Patienten mit SRM(mediane Tumorgröße: $2,5 \mathrm{~cm}$ ) wurden erfasst. Die Fallzahl stieg von 98 (1990-1994) auf 335 (2015-2019). $21 \%$ der Tumore waren benigne, bei Frauen häufiger als bei Männern. ( $30 \%$ vs. $16,6 \%, p<0,001$ ). Der Anteil maligner Tumore stieg mit der Tumorgröße von $52 \%(0,1-1 \mathrm{~cm})$ auf $81 \%(3,1-4 \mathrm{~cm}, p<0,001)$. Klarzellige $(67,4 \%)$, papilläre $(15,2 \%)$ und chromophobe $(5,3 \%)$ Nierenzellkarzinome stellten die häufigsten malignen, Onkozytome $(61,3 \%)$ und Angiomylipome $(19,6 \%)$ die häufigsten benignen Tumore dar. pT3 Tumore (7\%) waren mit höherer Tumorgröße assoziiert ( $p=0,018)$. 27 (2,6\%) Patienten hatten synchrone $(n=12)$ oder metachrone Metastasen $(n=15)$. Der Anteil an pT3-Tumoren war bei metastasierten Patienten signifikant höher $(22,2 \%$ vs. $6,4 \%, p=0,006)$. Das Gesamtüberleben (Nachbeobachtung: 64 Monate (1-278)) unterschied sich zwischen benignen und malignen Tumoren nicht, und war in den malignen Tumoren bei Frauen besser als Männer $(p=0,037)$. Das metastasenfreie Überleben (Mittelwert: 268,4 Monate) nahm mit zunehmender Tumorgröße signifikant $\mathrm{ab}(\leq 3 \mathrm{~cm}$ : 273,7 Monate, vs. $>3 \mathrm{~cm}$ : 118,5 Monate, $p=0,001$ ).

Schlussfolgerung: Der große Anteil benigner SRM unterstreicht die Empfehlung einer Nierentumorbiopsie. Bei vergleichbarem Gesamtüberleben könnte eine aktive Überwachung bei kleinen Tumoren auch bei einer längeren Lebenserwartung diskutiert werden, insbesondere bei Frauen. 
Tab. 1 | 3K06.3 Vergleich der FBK-Werte unauffällig (<34) und auffällig (>34) - Anzahl der Patienten die ein psychologisches Einzelgespräch wahrgenommen haben

\begin{tabular}{|l|l|l|l|l|l|l|}
\hline & $N$ & FBK<34 MW (SD) & $N$ & FBK>34 MW (SD) & $N$ & $\begin{array}{l}\text { Psychologisches } \\
\text { Einzelgespräch } \\
\text { FBK MW (SD) }\end{array}$ \\
\hline Niere & 367 & $14,2(8,7)$ & 55 & $48,9(13,4)$ & 21 & $43,9(7,6)$ \\
\hline
\end{tabular}

Tab. 2 | 3K06.3 Vergleich der FBK-Werte zwischen Männer und Frauen - Arbeitnehmer und Rentner

\begin{tabular}{|l|l|l|l|l|l|l|l|l|}
\hline & $N$ & $\begin{array}{l}\text { FBK (Männer) } \\
\text { MW (SD) }\end{array}$ & $\boldsymbol{N}$ & $\begin{array}{l}\text { FBK (Frauen) } \\
\text { MW (SD) }\end{array}$ & $\boldsymbol{N}$ & $\begin{array}{l}\text { FBK (Arbeit- } \\
\text { nehmer) MW } \\
\text { (SD) }\end{array}$ & $\begin{array}{l}\boldsymbol{N} \\
\text { FBK (Rent- } \\
\text { ner) MW (SD) }\end{array}$ \\
\hline Niere & 250 & $15,9(14,7)$ & 172 & $21,0(16,0)$ & 209 & $20,4(16,7)$ & 213 & $15,5(13,6)$ \\
\hline
\end{tabular}

\section{K06.2}

Die roboterassistierte Nierenteilresektion bei multiplen Nierentumoren - eine multizentrische Analyse

N. N. Harke' ${ }^{1 *}$, C. von Klot' ${ }^{1}$, M. Wolters' ${ }^{1}$, F. Schiefelbein ${ }^{2}$, G. Schön ${ }^{3}$, M. Kriegmair ${ }^{4}$, N. Gilbert ${ }^{5}$, V. Zimmermanns ${ }^{6}$, I. Paramythelli ${ }^{6}$, C. Wiesinger ${ }^{7}$, J. Pfuner ${ }^{7}$, E. Falkensammer ${ }^{7}$, O. Katzendorn' ${ }^{1}$, C. Darr ${ }^{8}$, A. Eraky', J.P. Radtke ${ }^{8}$, M. A. Kuczyk' D. Osmonov ${ }^{9}$

${ }^{1}$ Medizinische Hochschule Hannover, Hannover, Deutschland; ${ }^{2}$ KWM-Klinikum Würzburg Mitte, Standort Missioklinik, Würzburg, Deutschland; ${ }^{3}$ Urologische Klinik München-Planegg, Planegg, Deutschland; ${ }^{4}$ Universitätsmedizin Mannheim, Mannheim, Deutschland; ${ }^{5}$ Universitätsklinikum Schleswig-Holstein (Campus Lübeck), Lübeck, Deutschland; ${ }^{6}$ Siloah St. Trudpert Klinikum, Pforzheim, Deutschland; ${ }^{7}$ Klinikum Wels-Grieskirchen $\mathrm{GmbH}$, Wels, Österreich; ${ }^{8}$ Universitätsklinikum Essen, Essen, Deutschland; ${ }^{9}$ Universitätsklinikum Schleswig-Holstein (Campus Kiel), Kiel, Deutschland

Einleitung: Mit zunehmendem Einsatz der roboterassistierten partiellen Nephrektomie steigt die Rate anspruchsvoller Tumorkonstellationen. Diese Studie untersucht die Machbarkeit der robotischen Resektion multipler Nierentumore.

Material und Methoden: Die Daten aus acht robotischen Zentren wurden retrospektiv ausgewertet. Hierbei wurden 97 Patienten mit mehr als einem Tumor (RF) im histopathologischen Befund identifiziert. Zur Qualitätskontrolle wurden die Kriterien der Trifecta überprüft: negative Schnittränder, Ischämiezeit zur Resektion aller Tumore (WIT) $<25$ min, keine Komplikationen.

Ergebnisse: $16 \%$ der Tumore waren pathologische Zufallsbefunde ohne radiologisches Korrelat. 67 der verbleibenden 80 Patienten mit 182 RF zeigten zwei Tumore, $9 \%$ drei Tumore, $6 \%$ vier bzw. sieben Tumore $(n=1)$. Die mediane Größe der größten und zweitgrößten RF lag bei $31 \mathrm{~mm}$ und $15 \mathrm{~mm}$ jeweils mit einem PADUA Score von 8. Die mediane Schnitt-NahtZeit war 173 min mit drei Konversionen (zwei robotische Nephrektomien, eine offene Nierenteilresektion). Die mediane Ischämiezeit zur Resektion aller Tumore betrug $14 \mathrm{~min}$; in $30 \%$ Resektion aller RF in einer WIT, $24 \%$ mit mehreren Abklemmungen, $15 \%$ Off-clamp-Resektionen und in $31 \%$ Ischämie für lediglich die erste RF. In $21 \%$ der Fälle traten postoperative Komplikationen auf mit fünf Transfusionen und $10 \%$ Majorkomplikationen. Bei Entlassung zeigte sich ein medianer GFR-Verlust von $11,8 \mathrm{ml} /$ min. Die Qualitätskriterien der Trifecta konnten bei $48 / 80$ Patienten erreicht werden.

Schlussfolgerung: Die Resektion multipler Tumore ist auch roboterassistiert unter Verwendung unterschiedlicher Herangehensweisen zur Hilusund Blutungskontrolle mit einer kurzen Ischämie- und Operationszeit und guten onkologischen und funktionellen Ergebnissen machbar.

\begin{tabular}{|l|l|l|}
\hline Tab. 3 | 3K06.3 Vergleich der FBK-Werte bezüglich des Alters \\
\hline $\begin{array}{l}\text { Alterseinteilung in } \\
\text { Jahren }\end{array}$ & $\mathbf{N}$ & FBK MW (SD) \\
\hline $30-49$ & 19 & $22,6(17,7)$ \\
\hline $50-69$ & 221 & $19,6(17,2)$ \\
\hline $70-99$ & 182 & $15,4(12,3)$ \\
\hline
\end{tabular}

\section{K06.3}

Psychoonkologische Belastungssituation nach Therapie des Nierenzellkarzinoms

M. Heydenreich", D.-H. Zermann

Vogtland-Klinik Bad Elster, Bad Elster, Deutschland

Fragestellung: Diagnose und Therapie einer Krebserkrankung führen häufig zu einer erheblichen psychosozialen Belastung der Betroffenen und Angehörigen. Zur ganzheitlichen rehabilitativen Betreuung gehört deshalb deren Erfassung und Behandlung bzw. psychosoziale Unterstützung.

Die vorliegende Studie befasst sich mit der psychoonkologischen Situation bei Patienten mit einem operativ behandelten Nierenzellkarzinom. Methode: 422 Patienten mit einem durchschnittlichen Alter von 67,7 Jahren wurden nach Nephrektomie am Anfang einer AHB bzgl. der psychosozialen Belastung mit dem FBK-R23-Fragebogen untersucht.

Ergebnisse: Die Daten von 422 Patienten konnten ausgewertet werden. $13 \%$ der untersuchten Patienten hatten auffällige FBK-23 Fragebogenwerte und somit einen signifikanten psychoonkologischen Behandlungsbedarf. Frauen und jüngere/berufstätige Patienten sind hierbei häufiger betroffen. Nur $38 \%$ haben eine indizierte psychoonkologische Betreuung wahrgenommen.

Schlussfolgerung: Psychosoziale Angebote für Nierentumorpatienten müssen weiterentwickelt und angepasst werden. Auch dem Urologen kommt in der Nachsorge eine entsprechende Verantwortung in der psychosozialen Betreuung des Patienten zu.

\section{K06.4}

Primär metastasiertes Nierenzellkarzinom in Deutschland: d-uo meets RKI:

C. Doehn ${ }^{1 *}$, K. Kraywinkel2 ${ }^{2}$ R. Eichenauer ${ }^{3}$, J. Klier ${ }^{4}$, F. König ${ }^{5}$, R. Schönfelder ${ }^{6}$, J. Schröder ${ }^{5}$, E. Hempel', M. Johannsen ${ }^{8}$

'Urologikum Lübeck, Lübeck, Deutschland; ${ }^{2}$ Robert Koch-Institut, Berlin, Deutschland; ${ }^{3}$ Urologikum Hamburg, Hamburg, Deutschland; ${ }^{4}$ Urologische Partnerschaft Köln, Köln, Deutschland; ${ }^{5}$ ATURO, Berlin, Deutschland; ${ }^{6}$ Urologie Schönfelder \& Straßer, Hamburg, Deutschland; ${ }^{7}$ SMG Forschungsgesellschaft, Berlin, Deutschland; ${ }^{8}$ Urologische Facharztpraxis Johannsen \& Laux, Berlin, Deutschland 
Einleitung: Urologische Tumorerkrankungen machen in Deutschland etwa $37 \%$ und $5 \%$ aller Krebserkrankungen bei Männern bzw. Frauen aus (RKI 2016). Wir stellten uns die Frage, wie häufig das Nierenzellkarzinom (NZK) heutzutage primär metastasiert diagnostiziert wird.

Material und Methoden: Seit Mai 2018 dokumentieren Mitglieder von d-uo urologische Tumorerkrankungen im Rahmen der prospektiven VERSUS-Studie. In vielen Publikationen werden Tumorstadien nach der UICC-Klassifikation angegeben. Dieses Stadium umfasst beim NZK alle Fälle mit einem Stadium T4M0 oder T1-4M1. Wir verglichen aktuelle Daten von d-uo mit denen des RKI.

Ergebnisse: In einer RKI-Analyse für die Jahre 2012-14 lagen für $90 \%$ der Patienten mit einem NZK Informationen zum Tumorstadium vor (Fiebig und Kraywinkel 2019). Der Anteil eines UICC IV (T4M0) wurde für Männer und Frauen mit 0,8\% bzw. 0,9\% und der Anteil UICC IV (T1-4M1) mit $11,2 \%$ bzw. 10,2 \% angegeben. Aktuelle Zahlen vom RKI liegen auch für das Jahr 2016 vor: es wurden insgesamt 15.640 NZK diagnostiziert (www. rki.de). Für etwa $48 \%$ der Frauen und $52 \%$ der Männer war dabei ein Tumorstadium verfügbar. Ein Stadium UICC IV lag bei $15 \%$ aller Frauen und $18 \%$ aller Männer vor. d-uo hat im Zeitraum 2018-20 insgesamt $594 \mathrm{~Pa}-$ tienten mit der Erstdiagnose NZK dokumentiert. Für 73,3\% der Patienten war ein Tumorstadium verfügbar. Das Stadium UICC IV betraf 9,6\% aller Fälle. Dabei entfielen 1,3\% auf das Stadium UICC IV (T4M0) und 8,3 \% auf das Stadium UICC IV (T1-4M1).

Schlussfolgerung: Das NZK wird in etwa $10 \%$ aller Fälle primär im UICCStadium IV diagnostiziert. Das primär metastasierte NZK wird anteilig deutlich weniger häufig als früher diagnostiziert. Dabei besteht eine gute Übereinstimmung zwischen den RKI-Daten und den Ergebnissen von d-uo.

\section{K06.5}

\section{Metastasektomie bei metachron metastasierten} Nierenzellkarzinompatient ${ }^{*}$ innen - Wer, wann \& wie?

M. Seles ${ }^{1 *}$, M. Smolle ${ }^{2}$, A. Molnar ${ }^{3}$, J. Riedl' ${ }^{4}$, D. Barth ${ }^{4}$, A. Terbuch ${ }^{4}$, C. Rossmann ${ }^{4}$, S. Mannweiler', G. C. Hutterer', R. Zigeuner', K. Pummer', F.-M. Smolle-Juettner ${ }^{6}$, J. Lindenmann ${ }^{6}$, M. Stotz ${ }^{4}$, A. Gerger ${ }^{4}$, M. Pichler ${ }^{4,7,8}$, F. Posch ${ }^{4}$

${ }^{1}$ Medizinische Universität Graz, Universitätsklinik für Urologie, Graz, Österreich; ${ }^{2}$ Medizinische Universität Graz, Universitätsklinik für Orthopädie und Traumatologie, Graz, Österreich; ${ }^{3}$ Medizinische Universität Graz, Klinische Abteilung für Endokrinologie und Diabetologie, Universitätsklinik für Innere Medizin, Graz, Österreich; ${ }^{4}$ Medizinische Universität Graz, Universitätsklinik für Innere Medizin, Abteilung für Onkologie, Graz, Österreich; ${ }^{5}$ Medizinische Universität Graz, Diagnostik und Forschungsinstitut für Pathologie, Graz, Österreich; ${ }^{6}$ Medizinische Universität Graz, Universitätsklinik für Chirurgie, Klinische Abteilung für Thorax- und hyperbare Chirurgie, Graz, Österreich; ${ }^{7}$ The University of Texas MD Anderson Cancer Center, Department of Experimental Therapeutics, Houston, Vereinigte Staaten von Amerika; ${ }^{8}$ Medizinische Universität Graz, Research unit for Non-Coding RNAs and Genome Editing in Cancer, Graz, Österreich

Einleitung: Die Metastasektomie stellt ein mögliches Verfahren in der Behandlungskaskade des metastasierten Nierenzellkarzinoms (mRCC) dar. Diese Behandlungsoption kann Patienten mitunter lang andauernde Remissionen bescheren; die Selektion muss jedoch sorgfältig gewählt werden.

Material und Methoden: Für diese retrospektive Analyse wurden aus den 1190 zwischen Januar 2005 und November 2018 an der Universitätsklinik für Urologie Graz operierten Patienten jene 106 mit metachroner Metastasierung ausgewählt. Wir führten eine propensity-score basierte Analyse unter der Verwendung multipler statistischer Verfahren und Modelle durch.

Resultate: 36 (34\%) wurden in der Therapiesequenz zumindest einer Metastasektomie unterzogen während 70 (66\%) eine alleinige Systemtherapie erhielten.

Die häufigste Prozedur stellt die Lungenresektion gefolgt von Kraniotomien dar. Die mittlere Zeit bis zur Progression nach Metastasektomie betrug 0,7 Jahre [25.-75. Perzentile: 0,3-2,7].
Nach einem medianen Follow-Up von 6,2 Jahren und 63 Todesfällen betrugen das geschätze 5-Jahresüberleben $41 \%$ in der Metastasektomieund $22 \%$ in der Systemtherapiegruppe (log-rank $p=0,00007$; Hazard ratio $(\mathrm{HR})=0,38,95 \% \mathrm{Cl}: 0,21-0,68)$.

Patienten, die einer Metastasektomie unterzogen wurden, hatten einen signifikant höhere Prävalenz von günstigen Prognosefaktoren. Nach propensity-score Adjustierung Unterschieden und Korrektur der immortaltime bias wurde diese Assoziation schwächer ( $\mathrm{HR}=0,62,95 \% \mathrm{Cl}$ : 0,39$1,00, p=0,050$; propensity-score-gewichtetes 5-Jahres Gesamtüberleben $24 \%$ vs. $20 \%$ (log-rank $p=0,001)$.

Konklusion: Das Therapiekonzept der Metastasektomie eignet sich für mRCC Patient*innen mit günstigem Risikoprofil mit max. 2 Metastasen, bei denen eine gleichzeitige und kompletter Resektion erreicht werden kann.

\section{K06.6}

Prognostische Bedeutung der kurativen

Metastasenresektion beim metastasierten

Nierenzellkarzinom im Zeitalter der IO-basierten Kombinationstherapien

\section{Stühler ${ }^{1 *}$, L. Herrmann², S. Rausch² ${ }^{2}$ A. Stenzl ${ }^{2}$, J. Bedke ${ }^{1}$}

'Universitätsklinikum Tübingen, Tübingen, Deutschland; ${ }^{2}$ Universitätsklinikum Tübingen, Urologie, Tübingen, Deutschland

Fragestellung: Die Metastasenresektion (MR) des Nierenzellkarzinoms (NZK) gerät durch den Fortschritt der IO-Kombinationen in der Systemtherapie (ST) in den Hintergrund. Der prognostische Einfluss einer Erstlinientherapie (FL) mittels MR in kurativer Intention vs einer sofortigen Checkpoint- (IO) oder Tyrosinkinase-Inhibition (TKI) auf das tumorspezifische Überleben (CSS) wurde untersucht.

Material und Methoden: 205 Patienten mit einer synchronen bzw. metachronen Metastasierung erhielten als FL eine kurative MR $(n=80)$ oder eine ST ( $n=125$, TKI:87, IO-TKI:13, IO-IO:25). Der prognostische Einfluss der Therapie wurde mittels Cox-Regression- \& Kaplan-Mayer-Analysen untersucht.

Ergebnisse: Das mediane PFS war signifikant durch eine IO-basierte Therapie (TKI-IO/IO-IO) vs einer TKI Monotherapie (18,4 vs 10,7 Monate, HR $0,61, p=0,05)$ verbessert, mit maximalem Benefit der IO-TKI Kombination gegenüber einer TKI-Monotherapie (HR 0,27, $p=0,01$ ), als auch vs einer kurativen MR (11,3 Monate, HR 0,34, $p=0,035)$. Die kurative FL-MR vs TKIMonotherapie (medianes CSS 6,1 vs 2,6 Jahre, HR 0,45, $p<0,001$ ), als auch die FL-MR vs IO-IO/TKI-IO Therapie (CSS 6,1 vs 3,5 Jahre, HR 0,28, $p=0,007$ ) verbesserte das CSS signifikant. Das mediane CSS bei alleiniger MR ohne spätere ST war signifikant verlängert vs der direkten ST in der FL (11,3 vs 3,1 Jahre, HR 0,34, $p=0,002$ ). Eine kurative FL-MR und bei Progress folgende ST war mit einem signifikanten Überlebensvorteil vs einer ST ab der FL verbunden $(5,8$ vs 3,1 Jahre, HR $0,53, p=0,003)$, auch wenn diese IO-basiert erfolgte $(5,8$ vs 3,5 Jahre, HR $0,30, p=0,017)$.

Schlussfolgerungen: Trotz des Fortschrittes der IO-basierten Kombinationstherapien in der FL bleibt die MR in kurativer Intention integraler Bestandteil der multimodalen Behandlung des metastasierten NZK. 
3K06.7

Ist die TKI-Monotherapie out? - Entscheidungsfaktoren

für die Wahl der Erstlinientherapie bei Patienten

mit fortgeschrittenem oder metastasiertem

Nierenzellkarzinom: Analysen aus der deutschen

Registerplattform CARAT

P. Goebell ${ }^{*}$, C. Grüllich², L. Müller ${ }^{3}$, M. Bögemann ${ }^{4}$, U. Martens ${ }^{5}$,

E. von der Heyde ${ }^{6}$, D. Reichert ${ }^{7}$, S. Dörfel ${ }^{8}$, A. Schlenska-Lange ${ }^{9}$, M. Merling ${ }^{10}$, M. Koska ${ }^{10}$, M. Jänicke ${ }^{10}$, N. Marschner ${ }^{11}$, M. Staehler ${ }^{12}$, V. Grünwald ${ }^{13}$

'Urologische und Kinderurologische Klinik, Universitätsklinikum Erlangen, Erlangen, Deutschland; ${ }^{2}$ Urologsiche Klinik Gustav-Carus Universität, Dresden, Deutschland; ${ }^{3}$ Onkologie UnterEms Leer-Emden-Papenburg, Leer, Deutschland; ${ }^{4}$ Urologische Universitätsklinik, Münster, Deutschland; ${ }^{5}$ SLK Kliniken Heilbronn, Klinik für Innere Medizin III, Heilbronn, Deutschland; ${ }^{6}$ Onkologische Schwerpunktpraxis, Hannover, Deutschland; ${ }^{7}$ Gemeinschaftspraxis für Hämatologie und Onkologie, Westerstede, Deutschland; ${ }^{8}$ Onkozentrum Dresden/Freiberg, Dresden, Deutschland; ${ }^{9} \mathrm{Krankenhaus} \mathrm{Barmherzige}$ Brüder, Onkologie und Hämatologie, Regensburg, Deutschland; ${ }^{10}$ iOMEDICO AG, Freiburg, Deutschland; ${ }^{11}$ Praxis für interdisziplinäre Onkologie \& Hämatologie, Freiburg, Deutschland; ${ }^{12}$ Klinikum der Universität München Campus Großhadern, Urologische Klinik, München, Deutschland; ${ }^{13}$ Universitätsklinik, Urologische Klinik, Essen, Deutschland

Einleitung: Die TKI-Monotherapie in der Erstlinie ist zunehmend von $\mathrm{CPI} / \mathrm{CPI}$ bzw. CPI/TKI-Kombinationen abgelöst worden. Die Entscheidungskriterien für die ein oder andere Therapieoption stehen im Vordergrund dieser Analyse.

Methoden: CARAT (NCT03374267) ist eine prospektive, offene, multizentrische Datensammlung, die die Arbeit des Nierentumorzell-Registers (RCC Register) fortsetzt. Bis 06/2020 konnten hier 1884 Patienten eingeschlossen werden. Mit Beginn der Erstlinientherapie - und unabhängig von der eingesetzten Substanz - werden die Patienten prospektiv verfolgt. Details über Patientencharakteristika werden genauso erfasst, wie Tumorbiologie und klinische Verläufe. In dieser Analyse fokussieren wir auf die Faktoren, die die Entscheidung des Therapeuten beeinflusst haben. Datensätze von 159 Pat., die zwischen 01/2019 und 12/2019 behandelt worden waren wurden in der ersten Analyse inkludiert. Ein up-date vor dem Hintergrund der Pandemie wird inkludiert.

Ergebnisse: Von 159 Pat. erhielten $52 \%$ einen CPI (z. B. 55 Nivo+lpi; 13 Pembro/Axi) und $47 \%$ einen TKI (z. B. 30 Pazo; 23 Cabo; 16 Sunitinib; 4 Tivo). In beiden Gruppen waren "Leitlinienempfehlung" und "gute Effizienz" unter den häufigsten Entscheidungskriterien. In der CPI-Gruppe war "schnelle Remission notwendig" - in der TKI-Gruppe „Verträglichkeit" und "orale Applikation" wichtiges Kriterium. Die CPI-Patienten waren jünger (Median 65 vs. 72 Jahre) und hatten häufiger einen schlechteren Prognose-Score nach IMDC ( $23 \%$ vs. $16 \%)$.

Schlussfolgerung: CPI-Behandlung wurde für Jüngere und für Patienten mit schlechterem IMDC-Score oder hohem Remissionsdruck eingesetzt. Die Übersetzung dieser Entscheidung in einen unterschiedlichen klinischen Verlauf oder ein das Überleben dieser Patienten ist Gegenstand weiterer Analysen.

\section{K06.8}

Nebenwirkungen und etablierte Einflussfaktoren auf die VEGFi oder mTOR Erstlinientherapie des metastasierten Nierenzellkarzinoms

\section{N. Biernath", B. Erber, B. Ralla, K. Miller, T. Schlomm, J. Busch \\ Charité - Universitätsmedizin Berlin, Klinik für Urologie, Berlin, Deutschland}

Fragestellung: Analyse von etablierten Prognose- und Prädiktionsfaktoren für Therapieansprechen und Gesamtüberleben (OS) sowie weiteren Faktoren im Bereich Nebenwirkungen beim metastasierten Nierenzellkarzinom unter Erstlinientherapie mit VEGF - sowie mTOR-Inhibitoren.
Material und Methoden: Retrospektive Analyse an 151 Patienten (20062013) in zwei Gruppen mit einem progressionsfreien Überleben (PFS) ${ }^{3} 6$ Monaten zwecks Analyse der Prognose-und Prädiktionsfaktoren.

Kaplan-Meier Überlebensanalyse von PFS und OS, Cox-Regressionsanalyse der Einflussfaktoren.

Ergebnisse: Hand-Fuß-Syndrom ( $p=0,0003)$, Hypertonie $(p=0,046)$, Leukopenie $(p=0,013)$, Hypothyreose $(p=0,022)$, Diarrhoe $(p<0,0001)$ und Reflux $(p=0,021)$ konnten als Einflussfaktoren bei einem Ansprechen $>6$ Monate dargestellt werden.

Unabhängiger Prognosefaktoren für ein verlängertes PFS war die „Disease control" Rate (SD, PR/CR) mit einer Hazard Ratio (HR) von 0,05 (95\% KI $0,023-0,108, p<0,0001)$. Bei diesem Therapieansprechen war das PFS im Median bei 13,2 vs 2,9 Monaten. Eine Mukositis wurde als prädiktiver Faktor für ein verlängertes PFS mit 12,8 vs 7,43 Monaten (HR 0,48; $95 \%$ KI $0,294-0,785 ; p=0,003)$ identifiziert. Eine supportive medikamentöse Therapie führte zu einer Verlängerung des PFS von im Median 12,90 vs. 7,43 Monaten als unabhängiger Einflussfaktor (HR 0,59; $95 \%$ KI 0,379$0,924, p=0,0021$ ).

Als unabhängiger Prognosefaktor für ein verlängertes OS von 38,9 vs. 15,8 Monaten wurde die disease control rate der Erstlinie (HR 0,28; $95 \% \mathrm{KI}$ $0,131-0,393, p<0,0001)$ identifiziert, für ein kürzeres OS eine primäre Metastasierung sowie kardiovaskuläre Toxizität der Erstlinie.

Schlussfolgerungen: Es konnten neue Prognose- und prädiktive Faktoren für das PFS und OS unter Targeted-Therapie der Erstlinie ermittelt werden.

\section{K06.9}

Thrombospondin-2 und LDH: zwei potenzielle prädiktive Biomarker zur Behandlung des metastasierten Nierenzellkarzinoms mit Everolimus in der Zweitlinie (MARC-2 Studie)

P. Zeuschner ${ }^{1 *}$, S. Hölters ${ }^{1,2}$, M. Stöckle' ${ }^{1}$ B. Seliger ${ }^{3}$, A. Müller ${ }^{3}$, H. S. Bachmann ${ }^{4}$, V. Grünwald ${ }^{5,6}$, D. C. Christoph ${ }^{7,8}$, A. Stenzl $\left.\right|^{9}$, M.-O. Grimm ${ }^{10}$, F. Brüning ${ }^{11}$, P.J. Goebell ${ }^{12}$, M. Augustin ${ }^{13}$, F. Roos ${ }^{14,15}$, J. Harde ${ }^{16}$, I.-B. Rüd ${ }^{16}$, M. Stähler ${ }^{17}$, K. Junker ${ }^{1}$

'Universitätsklinikum des Saarlandes, Klinik für Urologie und Kinderurologie, Homburg/ Saar, Deutschland; ${ }^{2}$ Ingenieurbüro für Gesundheitswesen $\mathrm{GmbH}$, Leipzig, Deutschland; ${ }^{3}$ Martin Luther Universität Halle, Institut für Medizinische Immunologie, Halle/Saale, Deutschland; ${ }^{4}$ Universität Witten/Herdecke, Institut für Pharmakologie und Toxikologie, Zentrum für Biomedizinische Bildung und Forschung (ZBAF), Witten/Herdecke, Deutschland; ${ }^{5}$ Medizinische Hochschule Hannover (MHH), Klinik für Hämatologie, Hannover, Deutschland; ${ }^{\circ}$ Universitätsklinikum Essen, Klinik für Innere Medizin (Tumorforschung) und Klinik für Urologie, Essen, Deutschland; ${ }^{7}$ Universitätsklinikum Essen, Institut für Medizinische Onkologie, Essen, Deutschland; ${ }^{8}$ Evangelische Kliniken Essen Mitte, Abteilung für Medizinische Onkologie \& Hämatologie, Essen, Deutschland; ${ }^{2}$ Universitätsklinikum Tübingen, Klinik für Urologie, Tübingen, Deutschland; ${ }^{10}$ Universitätsklinikum Jena, Klinik für Urologie, Jena, Deutschland; ${ }^{11}$ Philipps-Universität Marburg, Klinik für Urologie und Pädiatrische Urologie, Marburg, Deutschland; ${ }^{12}$ Universitätsklinikum Erlangen, Ambulante Uro-onkologische Therapie Einheit Erlangen (AURONTE), Klinik für Urologie und Klinik für Hämatologie und Internistische Onkologie, Erlangen, Deutschland; ${ }^{13} \mathrm{Klinikum}$ Nürnberg, Klinik für Hämatologie und Onkologie, Nürnberg, Deutschland; ${ }^{14}$ Universitätsmedizin Mainz, Klinik für Urologie und Pädiatrische Urologie, Mainz, Deutschland; ${ }^{15}$ Universitätsklinikum Frankfurt, Klinik für Urologie, Frankfurt, Deutschland; ${ }^{16}$ iOMEDICO, Medizinisches Department, Freiburg im Breisgau, Deutschland; ${ }^{17}$ Ludwig-MaximiliansUniversität (LMU), Medizinische Fakultät, Klinik für Urologie, Interdisziplinäres Zentrum für Nierentumoren, München, Deutschland

Einleitung: Bis heute liegen keine prädiktiven Biomarker für die Therapie metastasierter Nierenzellkarzinome (mNZK) vor. Im Rahmen der prospektiven multizentrischen MARC-2 Studie wurden potenzielle Biomarker aus Blutproben für das Therapieansprechen auf Everolimus in der Zweitlinie untersucht.

Material und Methoden: Blutproben von 54 Patienten wurden vor Beginn der Therapie und nach 15 Tagen asserviert. 55 Angiogenese-assoziierte Proteine wurden mit Antikörper-Arrays analysiert und ausgewählte Proteine sowie metabolische Moleküle (LDH, SOD1, ENO2) mittels ELISA quantifiziert. Polymorphismen im mTOR Gen wurden mittels Pyrosequenzierung untersucht. 
Ergebnisse: Thrombospondin-2 (TSP-2) vor Therapiebeginn war bei Langansprechern signifikant niedriger und für ein längeres progressionsfreies Überleben prädiktiv (PFS, $\leq 665$ parts per billion, 6,9 vs. 1,8 Monate, $p=0,005)$. An Tag 15 war eine erhöhte Serum-LDH $(>27,14 \mathrm{nmol} / \mathrm{l}) \mathrm{mit}$ längerem PFS (3,8 vs. 2,2 Monate, $p=0,013$ ) und Gesamtüberleben (OS, 31,0 vs. 14,0 Monate, $p<0,001$ ) verbunden. In der multiplen Cox Regression war das baseline TSP-2 ein stärkerer unabhängiger Prädiktor für das PFS (HR 0,22, $p=0,001)$ als klinische Patientencharakteristika, wie auch die $\mathrm{LDH}$ an Tag 15 für das OS (HR 0,15, $p<0,001)$. mTOR Polymorphismen waren tendenziell mit dem Therapieansprechen verbunden, jedoch nicht signifikant.

Schlussfolgerung: Everolimus hat in der Zweitlinie einen relevanten klinischen Nutzen für einen Teil der Patienten mit mNZK. Diese Patienten könnten primär durch TSP-2 identifiziert werden und LDH könnte der frühzeitigen Differenzierung des Therapieansprechens dienen. Diese Ergebnisse belegen, dass Biomarker wesentlich zur Individualisierung der systemischen Therapie bei Patienten mit NZK beitragen können.

\section{K06.10 \\ Einfluss der Pharmakogenomik auf die Behandlung des metastasierten Nierenzellkarzinoms - Eine systematische Übersichtsarbeit}

V. Stühler ${ }^{1 *}$, S. Rausch ${ }^{1}$, V. Boviatsis ${ }^{1}$, S. Winter ${ }^{2}$, A. Stenzl' ${ }^{1}$ J. Bedke', M. Schwab ${ }^{2}$, E. Schaeffeler ${ }^{2}$

${ }^{1}$ Universitätsklinikum Tübingen, Tübingen, Deutschland; ${ }^{2}$ Dr. Margarete Fischer-Bosch Institut für Klinische Pharmakologie, Stuttgart, Deutschland

Fragestellung: Obwohl das molekularbiologische Wissen beim metastasierten Nierenzellkarzinom (mNZK) deutlich zugenommen hat, fehlen validierte prädiktive Biomarker hinsichtlich des Therapieansprechens und des individuellen Nebenwirkungsrisikos.

Material und Methoden: Es wurde eine systematische Suche zu pharmakogenetischen Markern im Zusammenhang mit Systemtherapien des mNZK in PubMed, EMBASE und Cochrane Library im März 2020 gemäß dem PRISMA-Statement durchgeführt. Insgesamt wurden 65 von 4659 gescrennten Publikationen in die vorliegende Analyse einbezogen.

Ergebnisse: Die interindividuelle Variabilität der TKI-Exposition ist mit Variationen in Zielgenen verbunden, die an der Absorption, Metabolismus, Verteilung und Ausscheidung (ADME) beteiligt sind. Die Daten der Metaanalyse identifizierten funktionell relevante Polymorphismen in $A B C B 1$, $A B C G 2$, CYP3A5, UGT1A1, VEGFA, VEGFR \& IL8 für die Vorhersage der TKIResistenz sowie -Toxizität. Daten zur Pharmakogenetik hinsichtlich der Checkpointinhibitoren sind bisher nur im begrenzen Umfang verfügbar. Der Evidenzgrad der identifizierten pharmakogenomischen Marker bleibt begrenzt, da die Daten auf retrospektiven Studien oder kleinen Fallserien mit zum Teil widersprüchlichen Ergebnissen beruhen. MicroRNA- und DNA-Methylierungsmuster können als zusätzliche prädiktive Biomarker für die Systemtherapie in Betracht gezogen werden.

Schlussfolgerungen: Die Implementierung der Pharmakogenomik in die klinische Praxis erfordert eine prospektive Validierung der identifizierten genetischen Varianten in ADME-Genen in größeren Kohorten. Neuartige genomweite Assoziationsstudien oder Next Generation Sequencing-Ansätze können zur Identifizierung bisher unbekannter Erkenntnisse führen. Förderung: Gefördert durch die Robert Bosch Stiftung, Stuttgart, Deutschland

\section{K06.11}

Analyse von immunologischen Markern im Primärtumor und korrespondierenden Metastasengewebe von Patienten mit einem metastasierten Nierenzellkarzinom

V. Stühler ${ }^{1 *}$, L. Herrmann' ${ }^{1}$, S. Winter ${ }^{2}$, A. Reustle², J. Hennenlotter ${ }^{3}$, S. Rausch', A. Stenzl' ${ }^{1}$ E. Schaeffeler ${ }^{2}$, M. Schwab ${ }^{2}$, J. Bedke ${ }^{1}$

'Universitätsklinikum Tübingen, Urologie, Tübingen, Deutschland; ${ }^{2}$ Dr. Margarete FischerBosch - Institut für Klinische Pharmakologie, Stuttgart, Deutschland; ${ }^{3}$ Universitätsklinikum Tübingen, Tübingen, Deutschland

Fragestellung: Die Suche nach prädiktiven Biomarkern zur Vorhersage des Therapieansprechens von Patienten mit metastasiertem Nierenzellkarzinom ist klinisch relevant. Ziel der Analysen war es die Expression von immunologischen Markern in Primärtumoren und korrespondierenden Metastasen systematisch zu untersuchen.

Material und Methoden: Es wurden 79 Primärtumore sowie 176 Metastasen (FFPE) von 135 Patienten untersucht. Bei 56 Patienten lag Primärtumor- und korrespondierendes Metastasengewebe, bei 47 Patienten Material aus mehreren Metastasen unterschiedlicher Lokalisation vor. Die Proben wurden immunhistochemisch unter Verwendung von validierten Antikörpern gegen BTLA, hTim3 und PD-L1 untersucht, standardisiert mit der Software Definiens Tissue Studio ${ }^{\circledR}$ ausgewertet und zu klinisch-pathologischen Daten korreliert.

Ergebnisse: Nur für PD-L1 zeigte sich unabhängig von der Lokalisation eine höhere Proteinexpression im Metastasen- vs. korrespondierendem Primärtumorgewebe $(p<0,01)$. BTLA war am höchsten in Lokalrezidiven $(n=12)$, Lymphknoten $(n=23)$ und der Nebenniere $(n=14)$ exprimiert. In Lunge $(n=37)$ und Knochen $(n=24)$ zeigte sich eine signifikant niedrigere Expression. Eine hohe PD-L1 Expression im Primärtumor war mit einem schlechteren Überleben (CSS HR 6,3, 95 \%Cl: 2,6-15,3, $p=0,004$ \& OS HR $5,6,95 \% \mathrm{Cl}: 2,1-15,3, p<0,001)$ assoziiert. Für BTLA und hTim3 zeigte sich kein signifikanter Zusammenhang zum Überleben.

Schlussfolgerung: Die vorliegenden Ergebnisse zeigen eine heterogene intertumorale Expression von immunologischen Markern mit unterschiedlichen Auswirkungen auf das Überleben.

geteilte Autorenschaft, gefördert durch ein IZKF-Promotionskolleg, Universität Tübingen und die Robert Bosch Stiftung, Stuttgart

\section{K06.12}

Early CRP dynamics as an easy-to-implement surrogate biomarker for therapy success after initiation of antiPD-1 based first line therapy in metastatic renal cell carcinoma

N. Klümper ${ }^{1 *}$,

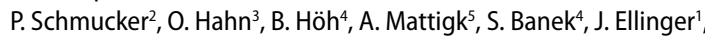
J. Heinzelbecker ${ }^{6}$, A. Strauß ${ }^{3}$, F. Zengerling ${ }^{5}$, P. Zeuschner ${ }^{6}$, C. Kalogirou ${ }^{2}$, on behalf of the GeSRU Academics Renal Cell Carcinoma Working Group

'Universitätsklinikum Bonn, Klinik und Poliklinik für Urologie und Kinderurologie, Bonn, Germany; ${ }^{2}$ Universitätsklinikum Würzburg, Klinik und Poliklinik für Urologie und Kinderurologie, Würzburg, Germany; ${ }^{3}$ Universitätsklinikum Göttingen, Klinik für Urologie, Göttingen, Germany; ${ }^{4}$ Universitätsklinikum Frankfurt, Klinik für Urologie, Frankfurt, Germany; ${ }^{5}$ Universitätsklinikum Ulm, Klinik für Urologie und Kinderurologie, Ulm, Germany; ${ }^{6}$ Universitätsklinikum des Saarlandes, Klinik für Urologie und Kinderurologie, Homburg, Germany

Background: Immune checkpoint blockade combining aPD-1 and aCTLA-4 (IO+IO) vs. aPD-1 in combination with VEGFR-targeting tyrosine-kinase inhibitors $(\mathrm{IO}+\mathrm{TKI})$ are considered equivalent first line therapies for metastatic renal cell carcinoma (mRCC). Unfortunately, there is sparse data on direct comparison of these therapies and precise biomarkers for outcome prediction have yet to be defined.

Methods: 100 mRCC from 6 different German tertiary referral centers receiving either first-line $10+10$ (nivolumab + ipililumab, $n=64$ ) or IO+TKI 
(pembrolizumab + axinitb, $n=36$ ) were included in this retrospective study by reviewing all relevant clinical and therapy outcome parameters. Results: At comparable baseline patient characteristics and a median follow-up of 9 months (range $0-37$ months), patients receiving $10+10$ combination experienced significantly less adverse events (AEs, $64 \%$ vs. $86 \%$, $p=0.021$ ). However, overall survival (mean 26.9 vs. 20.2 months) and progression-free survival (median 11.0 months for both groups) did not differ between $\mathrm{IO}+\mathrm{IO}$ vs. IO+TKI patients. Of note, patients with a decrease of CRP (CRP ratio $<1$ ) during the first 3 months after treatment initiation showed better therapy responses with regard to target lesion change $(-31.1 \%$ vs. $+5.6 \%, p=0.0003)$, irrespective of the applied IO combination, and favorable outcome.

Conclusion: In one of the largest German multicenter cohorts comparing $10+10$ vs. IO+TKI in mRCC to date, we highlight the potential role of early CRP dynamics to predict oncological outcomes, which were comparable between the two groups despite different $A E$ profiles. Since CRP is collected in many hospitals as a standard laboratory parameter, early CRP dynamics could be an interesting and easy-to-implement predictive biomarker for therapy success.

\section{K06.13}

Final results and response pattern of the randomized phase II trial comparing switch-maintenance from TKI to nivolumab in metastatic renal cell carcinoma (mRCC) patients (NIVOSWITCH)

C. Darr ${ }^{*}$, C. Grüllich², P. Ivanyi ${ }^{3}$, M. Wirth ${ }^{4}$, P. Staib ${ }^{5}$, M. Schostak ${ }^{6}$, P. Dargatz ${ }^{7}$, L. Müller ${ }^{8}$, M. Metz ${ }^{9}$, L. Bergmann ${ }^{10}$, T. Steiner ${ }^{11}$, M. Welslau' ${ }^{12}$, A. Lorch ${ }^{13}$, P. Schütt ${ }^{14}$, M.-R. Rafiyan ${ }^{15}$, E. Hellmis ${ }^{16}$, A. Hinke ${ }^{17}$, M. Mänz ${ }^{18}$, J. Meiler ${ }^{19}$, T. Kretz ${ }^{20}$, W. Loid ${ }^{21}$, A. Flörcken ${ }^{22}$, V. Grünwald ${ }^{1,23}$

${ }^{1}$ Klinik für Urologie, Universitätsmedizin Essen, Essen, Germany; ${ }^{2}$ Medizinische Onkologie, Nationales Zentrum für Tumorerkrankungen (NCT), Heidelberg, Germany; ${ }^{3}$ Klinik für Hämatologie, Hämostaseologie und Onkologie, Medizinische Hochschule Hannover, Hannover, Germany; ${ }^{4}$ Klinik und Poliklinik für Urologie, Uniklinikum Dresden, Dresden, Germany; ${ }^{5}$ Klinik für Hämatologie/Onkologie, St. Antonius Hospital, Eschweiler, Germany; ${ }^{6}$ Urologischen Klinik, Universitätsklinikum Magdeburg, Magdeburg, Germany; ${ }^{7} \mathrm{Klinik}$ für Hämatologie/Onkologie, Johannes Wesling Klinikum Minden, Minden, Germany; ${ }^{8}$ Onkologie Leer, Studienzentrum Unter Ems, Leer, Germany; ${ }^{9} \mathrm{Hämatologie/Onkologie}$ OSP Göttingen, Göttingen, Germany; ${ }^{10}$ Medical Clinic li, Universitätsklinikum Frankfurt, Frankfurt, Germany; ${ }^{11}$ Klinik für Urologie, Helios Klinikum Erfurt, Erfurt, Germany; ${ }^{12}$ Onkologie, Klinikum Aschaffenburg, Aschaffenburg, Germany; ${ }^{13}$ Department of Medical Oncology and Haematology, University Hospital Zurich, Zürich, Switzerland; ${ }^{14}$ Onkologische Schwerpunktpraxis, Onkologie Gütersloh, Gütersloh, Germany; ${ }^{15} \mathrm{Klinik}$ für Onkologie und Hämatologie, Krankenhaus Nordwest, Frankfurt, Germany; ${ }^{16}$ Praxis Walsum, Urologicum Duisburg, Duisburg, Germany; ${ }^{17} \mathrm{Hematology}$ and Oncology, CCRC, Düsseldorf, Germany; ${ }^{18} \mathrm{AlO}$-Studien gGmbH, Berlin, Germany; ${ }^{19} \mathrm{Mvz}$ Onkologie, Klinik Dr. Hancken, Stade, Germany; ${ }^{20}$ Onkologischer Schwerpunkt und Studienzentrum, Urologische Gemeinschaftspraxis Heinsberg, Heinsberg, Germany; ${ }^{21}$ Abteilung für Urologie und Andrologie, Ordensklinikum Linz, Linz, Austria; ${ }^{22} \mathrm{Hematology,} \mathrm{Oncology} \mathrm{and} \mathrm{Tumor}$ Immunology, Universitätsklinik Charité, Campus Virchow Klinikum, Berlin, Germany; ${ }^{23}$ Innere Klinik (Tumorforschung), Westdeutsches Tumorzentrum, Universitätsmedizin Essen, Essen, Germany

Background: Combinations of tyrosine kinase inhibitors (TKI) and checkpoint inhibitors $(\mathrm{CPI})$ are considered standard options in $\mathrm{mRCC}$ patients (pts.). Our study investigated a maintenance switch approach in 1st line mRCC.

Methods: Pts. with measurable clear cell mRCC, ECOG 0-2, adequate organ function and partial remission or stable disease to TKI therapy were eligible. 49 patients were randomized to early study termination between December 2016 and August 2018. After 12 weeks, 1:1 randomization to TKI continuation (24 pts.) or nivolumab (NIVO; 25 pts.; 240 or $480 \mathrm{mg}$ IV q2-4wk) was performed. With MSKCC risk, type of TKI (sunitinib, pazopanib) and response as strata. Objective response rate (ORR) was assessed according to RECIST 1.1. KM/log-Rank analyses were used for survival analyses.

Results: Median age was 65 years (range 35-79), 82\% were male and $4 \%$ had ECOG PS 2 . With metastases predominantly in lung $(47 \%)$, lymph nodes (27\%) and liver (24\%). 55\% received sunitinib. ORR for NIVO vs. TKI differed when assessed from start of induction therapy (64 vs. $70 \%$, $P=0.76$ ) or from randomization ( 16 vs. $48 \% ; P=0.03$ ). Accordingly, progression free survival (PFS) from randomization was 3.0 vs. 11.9 mo. $(\mathrm{HR}=2.57$ [95\% Cl: 1.36-4.89]) in favor for TKI continuation. With a 2-year OS of $64 \%$ for NIVO vs. $66 \%$ for TKI ( $\mathrm{HR}=1.12$ [ $95 \% \mathrm{Cl}: 0.43-2.89$ ]; $P=0.82$ ). All grades adverse events (AE) for NIVO vs. TKI occurred in $96 \%$ vs. $100 \%$, grade $3-5: 48 \%$ vs. $71 \%$ and serious AE (SAE): $40 \%$ and $46 \%$, respectively. Conclusion: Continuation of TKI is more efficacious than early switch to NIVO. The major limitation of our trial is the premature closure and its limited sample size.

Authoring Group Name: IAG-N of the German Cancer Society

Sponsor, funding source: AIO-Studien-gGmbH, financial support BMS

\section{K06.14}

Nephrotoxizität unter Immuncheckpoint-InhibitorTherapie: eine Arzneimittelüberwachungsstudie

\author{
L. Häuser*, M. Marchese', E. B. Cone', J. Noldus², G. Bayliss³, K. L. Kilbridge ${ }^{4}$ \\ Q.-D. Trinh
}

'Brigham and Women's Hospital, Division of Urologic Surgery and Center for Surgery and Public Health, Boston, Vereinigte Staaten von Amerika; ${ }^{2}$ Marien Hospital Herne, RuhrUniversität Bochum, Klinik für Urologie und Neuro-Urologie, Herne, Deutschland; ${ }^{3}$ Rhode Island Hospital, Division of Kidney Diseases and Hypertension, Providence, Vereinigte Staaten von Amerika; ${ }^{4}$ Dana Farber Cancer Institute, Lank Center for Genitourinary Oncology, Boston, Vereinigte Staaten von Amerika

Einleitung: Die Immuncheckpoint-Inhibitor (ICI) Therapie weist beeindruckende klinische Ergebnisse in einer Vielzahl von Krebserkrankungen auf. Jedoch kann es, häufig aufgrund Autoimmunsyndromen, zu unerwünschten Arzneimittelwirkungen (UAW) kommen. Ziel der Studie war es, eine Assoziation zwischen ICI Therapie und Nephrotoxizität mithilfe einer Arzneimittelüberwachungs-Datenbank zu untersuchen.

Material und Methoden: VigiBase, die Arzneimittelüberwachungs-Datenbank der WHO, wurde analysiert, um renale UAW (rUAW; Nephritis, Nephropathie, vaskuläre Störungen), die unter laufender ICI Therapie auftraten, zu filtern. Wir führten eine Disproportionalitätsanalyse durch, um zu untersuchen, ob rUAW in anderer Häufigkeit - verglichen mit der gesamten Datenbank - unter ICI Therapie angegeben wurden. Hierzu wurde eine empirische Bayes Signifikanz-Screeningmethode und eine reporting odds ratio (ROR) zur Definition der Effektgröße angegeben.

Ergebnisse: Unter 2341 rUAW für alle untersuchten ICI Medikamente zeigte sich lediglich für die Nephritis ein Disproportionalitätssignal (ROR 3,67, $95 \% \mathrm{Cl}$ : 3,34-4,04). Untersucht man die Medikamente separat, weisen Pembrolizumab, Nivolumab und Kombination aus Ipilimumab+Nivolumab signifikant höhere ROR für Nephritis auf als die anderen ICl Medikamente (ROR 4,54, $95 \% \mathrm{Cl}$ : 3,81-5,4; ROR 3,94, $95 \% \mathrm{Cl}$ : 3,40-4,56; ROR 3,59, $95 \% \mathrm{Cl}: 2,71-4,76$; respektive).

Schlussfolgerung: Eine Arzneimittelüberwachungsmethodik nutzend, fanden wir erhöhte Wahrscheinlichkeiten eine Nephritis zu entwickeln während ICI Therapie. Pembrolizumab, Nivolumab und Kombinationstherapie aus Ipilimumab und Nivolumab zeigten die höchsten Wahrscheinlichkeiten. Kliniker sollten diese Ergebnisse beachten und sich des erhöhten Risikos einer Nephritis bei Patienten mit ICI Therapie bewusst sein. 
3K06.15

Häufigkeit, Diagnostik und Therapie der Hypophisitis unter Immuntherapie mit Checkpointinhibitoren im uroonkologischen Zentrum der Universität Regensburg

\section{A. Oppolzer*, M. Burger, M.J. Schnabel}

Caritas Krankenhaus St. Josef, Universität Regensburg, Urologie, Regensburg, Deutschland

Fragestellung: Die Hypophysitis unter Therapie mit Checkpointinhibitoren $(\mathrm{CPi})$ ist aufgrund der unspezifischen Symptomatik und komplexen Diagnostik eine herausfordernde Nebenwirkung. In einer retrospektiven Analyse wurden Inzidenz und Outcome an einer universitären Klinik für Urologie evaluiert.

Material und Methoden: In dieser retrospektiven monozentrischen Analyse wurden laborchemische und klinische Daten von 104 Patienten ausgewertet, die zwischen 01/2017 und 11/2020 aufgrund eines metastasierten Urothel- oder Nierenzellkarzinoms mit CPi behandelt wurden.

Ergebnisse: 77 Patienten erhielten eine Monotherapie (mCPi) (15 Atezolizumab, 1 Avelumab/Axitinib, 26 Nivolumab, 25 Pembrolizumab, 10 Pembrolizumab/Axitinib) und 27 eine Kombination (kCPi) aus Ipilimumab/Nivolumab. Bei 4 Patienten (14,8 \%) unter Ipi/Nivo und keinem unter mCPi trat eine Hypophysitis auf. Die Nebenwirkung trat 3 bis 17 Wochen (median 10) nach Therapiestart auf. Die Symptomatik umfasste Fatigue, Schwindel, Kopfschmerzen, Sehstörungen. Laborchemisch auffällig waren eine Hyponatriämie (75\%), eine Hyperkaliämie (50\%), TSH-Erniedrigung (75\%), TSH-Erhöhung ( $25 \%)$, fT4-Erniedrigung (50\%). Cortisol und ACTH war bei allen erniedrigt. Ein MRT der Hypophyse wurde bei einem Patienten durchgeführt. Alle Patienten wurden initial mit Hochdosis-Glukocorticoiden behandelt und auf eine Erhaltungstherapie mit $5 \mathrm{mg}$ Prednisolon Äquivalenzdosis eingestellt. $75 \%$ erhielten eine Substitution mit L-Thyroxin. Nach einer Therapiepause von 42 Tagen (median) konnte ein mCPi mit Nivolumab bei allen Patienten fortgeführt werden.

Schlussfolgerung: Die Hypophysitis ist eine häufige Nebenwirkung unter einer kCPi mit CTLA-4 und PD1 Inhibitor, bei frühzeitiger Diagnose und Therapie ist sie gut behandelbar und nicht zwingend therapielimitierend.

3K06.16

Patient-reported outcomes (PRO) of patients (pts) with advanced renal cell carcinoma (aRCC) treated with first-line (1L) nivolumab (N) plus cabozantinib (C) versus sunitinib (S): the CheckMate (CM) 9ER trial

J. Bedke ${ }^{*}$, D. Cella ${ }^{2}$, T. K. Choueiri ${ }^{3}$, S.I. Blum ${ }^{4}$, F. Ejzykowicz ${ }^{4}$, M. Hamilton ${ }^{4}$, J. Zhang ${ }^{4}$, C. Ivanescu ${ }^{5}$, R. J. Motzer ${ }^{6}$

'Eberhard Karls University of Tübingen, Department of Urology, Tübingen, Germany; ${ }^{2}$ Northwestern University Chicago, Robert H. Lurie Comprehensive Cancer Center, Chicago, Vereinigte Staaten von Amerika; ${ }^{3}$ Dana-Farber Cancer Institute, The Lank Center for Genitourinary Oncology, Boston, Vereinigte Staaten von Amerika; ${ }^{4}$ Bristol Myers Squibb, Princeton, Vereinigte Staaten von Amerika; ${ }^{5} \mathrm{IQVIA}$, Herikerbergweg, The Netherlands; ${ }^{6}$ Memorial Sloan Kettering Cancer Center, New York, Vereinigte Staaten von Amerika

Background: In the phase 3, open-label CM 9ER trial (NCT03141177), aRCC pts were randomized 1:1 to N $240 \mathrm{mg}$ IV Q2 W + C $40 \mathrm{mg}$ PO QD $(\mathrm{N}+\mathrm{C} ; n=323)$ or $\mathrm{S} 50 \mathrm{mg}$ PO (4 weeks of 6-week cycles; $\mathrm{n}=328)$ for $1 \mathrm{~L}$ treatment until disease progression/unacceptable toxicity. $\mathrm{N}+\mathrm{C}$ met primary and secondary efficacy endpoints by significantly improving progression-free survival, overall survival (OS), and objective response rate vs $\mathrm{S}$. We present in-depth health-related quality of life (HRQLL) PRO results. Methods: PROs in all randomized pts were an exploratory endpoint assessed using FKSI-19 and EQ-5D-3L instruments at baseline, on-treatment and follow-up visits. Changes from baseline were assessed using mixedmodel repeated measures. Time to confirmed deterioration (TCD) was calculated from Kaplan-Meier estimates and Cox proportional hazards models.
Results: Median follow-up for OS was 18.1 months. PRO completion rates were $\geq 80 \%$ at all on-treatment assessments ( $\geq 10$ pts) through week 91 in both arms. The overall least squares mean difference in change from baseline favored N+C vs S in FKSI-19 (all domains) and in EQ-5D-3L. Pts treated with $\mathrm{N}+\mathrm{C}$ experienced less treatment burden, with improved TCD across most measurements vs S, including FKSI-19 (in all domains except treatment side effects), and EQ-5D-3L visual analog scale scores.

Conclusions: Pts reported statistically significant HRQoL benefits with $\mathrm{N}+\mathrm{C}$ vs $\mathrm{S} . \mathrm{N}+\mathrm{C}$ treatment significantly reduced the risk of deterioration in $\mathrm{HRQ}$ oL scores. These results suggest that the superior efficacy of $\mathrm{N}+\mathrm{C}$ vs $\mathrm{S}$ comes with the additional benefit of improved HRQoL.

(Reused with permission from ASCO-GU 2021, Abstract 285, Cella D et al.)

\section{K06.17}

The natural history of sarcomatoid renal-cell carcinoma-a stage-by-stage analysis

K. Tully ${ }^{1 * 2}$, S. Berg ${ }^{1}$, M. Paciotti ${ }^{3}$, F. Janisch ${ }^{4}$, S.W. Reese ${ }^{2}$, G. Lughezzani ${ }^{3}$, J. Noldus', S. F. Shariatt ${ }^{4}$, S. L. Chang' ${ }^{2}$, Q.-D. Trinh ${ }^{2}$, M. Mossanen ${ }^{2}$

'Marien Hospital Herne, Ruhr-Universität Bochum, Herne, Germany; ${ }^{2}$ Brigham and Women's Hospital, Boston, Vereinigte Staaten von Amerika; ${ }^{3} \mathrm{Humanitas}$ Clinical and Research Center IRCCS, Rozzano, Italy; ${ }^{4}$ Medical University of Vienna, Wien, Austria

Introduction \& objectives: Sarcomatoid differentiation in renal cell carcinoma imply aggressive behavior and often metastatic disease at the time of the diagnosis. We aim to evaluate the impact of the sarcomatoid differentiation on the overall survival (OS) using the National Cancer Database (NCDB).

Material and methods: We identified patients diagnosed with sRCC using the NCDB for the period 2010-2015. We employed Kaplan-Meier curves and multivariable Cox proportional hazards regression models to examine the impact of sarcomatoid differentiation on OS.

Results: In total, 8582 patients with renal cancer were found to have sarcomatoid differentiation at the time of surgery. The median OS was 8.3 months (IQR 3.3, 22.7 months). Compared to patients who did not undergo surgery, OS was significantly longer in patients undergoing partial or total nephrectomy across all stages. This result remained consistent on multivariable Cox proportional hazards regression adjusting for patient and tumor characteristics (Surgery: Hazard ratio 0.61 95\%Confidence interval $0.43-0.88, p=0.008$ ).

Conclusion: In our cohort of patients diagnosed with SRCC, nephrectomy followed by systemic therapy was associated with favorable OS across all stages. This study supports the notion surgical therapy provides a survival benefit in patients with SRCC. 
3K06.18

Wirksamkeit von Nivolumab/lpilimumab bei Patienten mit initialer oder später Progression unter Nivolumab: aktualisierte Analyse eines auf dem Ansprechen basierenden Ansatzes beim fortgeschrittenen Nierenzellkarzinom (TITAN-RCC)

M.-O. Grimm ${ }^{1 *}$, E. Esteban², P. Barthélémy ${ }^{3}$, M. Schmidinger ${ }^{4}$, J. Busch ${ }^{5}$, B.P. Valderrama ${ }^{6}$, M. Schmitz ${ }^{7}$, U. Schumacher ${ }^{8}$, G. Baretton ${ }^{9}$, S. Foller ${ }^{1}$, I. Duran ${ }^{10}$, G. de Velasco ${ }^{11}$, F. Priou ${ }^{12}$, P. Maroto ${ }^{13}$, G. Schinzari' ${ }^{14}$, L. Albiges ${ }^{15}$

${ }^{1}$ Klinik und Poliklinik für Urologie, Universitätsklinikum Jena, Jena, Deutschland; ${ }^{2} \mathrm{Ab}$ teilung für Medizinische Onkologie, Hospital Universitario Central de Asturias, Oviedo, Spanien; ${ }^{3}$ Abteilung für Medizinische Onkologie, Institut de Cancérologie Strasbourg Europe, Straßburg, Frankreich; ${ }^{4}$ Universitätsklinik für Innere Medizin I, Klinische Abteilung f. Onkologie, AKH Wien, Medizinische Universität Wien, Wien, Österreich; ${ }^{5} \mathrm{Klinik}$ für Urologie, Charité - Universitätsmedizin Berlin, Berlin, Deutschland; ${ }^{6} A b t e i l u n g$ für Medizinische Onkologie, Hospital Universitario Virgen del Rocío, Sevilla, Spanien; ${ }^{7}$ nstitut für Immunologie, Universitätsklinikum Carl Gustav Carus, Dresden, Deutschland; ${ }^{8}$ Zentrum für klinische Studien, Universitätsklinikum Jena, Jena, Deutschland; ' 1 nstitut für Pathologie, Universitätsklinikum Carl Gustav Carus, Dresden, Deutschland; ${ }^{10} \mathrm{Hospital}$ Universitario Marqués de Valdecilla, IDIVAL, Santander, Spanien; ${ }^{11}$ Abteilung für Onkologie, Hospital 12 de Octubre, Madrid, Spanien; ${ }^{12}$ Centre Hospitalier Départemental Vendee-Hopital Les Oudairies, La Roche Sur Yon, Frankreich; ${ }^{13}$ Abteilung für Medizinische Onkologie, Hospital de la Santa Creu I Sant Pau, Barcelona, Spanien; ${ }^{14}$ Policlinico Universitario A. Gemelli, Università Cattolica del Sacro Cuore, Rom, Italien; ${ }^{15}$ Abteilung für Onkologie, Gustave Roussy Cancer Campus, Universität Paris Sud, Villejuif, Frankreich

Fragestellung: TITAN-RCC untersucht Nivolumab (Nivo) und, bei Nichtansprechen, Nivo+Ipilimumab (Ipi) beim Nierenzellkarzinom (NCC). Wir berichten das Ansprechen auf Nivo+Ipi nach initial progredienter Erkrankung (PD) gegenüber dem initialen Ansprechen auf Nivo mit späterer PD. Material und Methoden: 207 NCC-Patienten (intermediäres/ungünstiges IMDC-Risiko) begannen die Nivo-Induktion. Bei früher PD (Woche (W) 8) oder ohne Ansprechen in W16 folgten 2-4 Nivo+lpi Boostzyklen. Patienten mit partiellem oder komplettem Ansprechen (PR/CR) erhielten weiter Nivo und Nivo+Ipi bei späterer PD. Primärer Endpunkt ist die bestätigte objektive Ansprechrate (ORR) nach RECIST in 1. und 2. Linie (1L, 2L). Sekundäre Endpunkte sind Ansprechen auf die Nivo-Induktion, Remissionsrate mit Nivo+lpi Boosts, Gesamtüberleben und Sicherheit.

Ergebnisse: Das mediane Alter der $1091 \mathrm{~L}$ und 98 2L Patienten (nach TKI) betrug 65 Jahre (20-87). $71 \%$ hatten ein intermediäres, $25 \%$ ein ungünstiges Risiko. Die bestätigte ORR mit Nivo betrug $28 \%$ (1L) bzw. $17 \%$ (2L). Nach medianem Follow-up von 12,8 Monaten lag das beste Gesamtansprechen (Nivo \pm Nivo+lpi) bei $36 \%$ (1L) bzw. $30 \%$ (2L). 38 Patienten erhielten Boosts nach stabiler Erkrankung (SD, W16), $13 \%$ davon erreichten CR/PR. 28 (1L) und 43 (2L) Patienten erhielten Nivo+Ipi nach initialer PD, $11 \%$ davon erreichten PR, $29 \%$ SD (1L) bzw. $7 \%$ CR, $14 \%$ PR und $30 \%$ SD (2L). 16 (1L) bzw. 10 (2L) Patienten erhielten Boosts bei PD nach initialem Ansprechen auf Nivo. Davon erreichten $19 \%$ PR und $31 \%$ SD (1L) bzw. $20 \%$ PR und $30 \%$ SD (2L).

Schlussfolgerung: Nivo+lpi Boosts führten zu verbessertem Ansprechen im Vergleich zu Nivo. Etwa die Hälfte der Patienten haben einen klinischen Benefit unabhängig davon, ob Nivo+Ipi nach früher PD oder initialem Ansprechen gegeben wurde.

Förderung: BMS
3K07 - Urothelkarzinom: Neues zur Therapiesteuerung und -überwachung

16.09.2021, C6.2, 16:00-17:30

3K07.1

BTA stat ${ }^{\oplus}$, Alere NMP22 ${ }^{\circledR}$ BladderChek ${ }^{\circledR}$, UBC $^{\circledR}$ rapid test/visual, uromonitor ${ }^{\circledast}$ und Zytologie beim Harnblasenkarzinom: Up-date der deutschen multicenter-Studie

T. Ecke ${ }^{1 *}$, C. Meisl ${ }^{2}$, F. Friedersdorff ${ }^{2}$ T. Schlomm², A. Rabien², S. Hofbauer ${ }^{2}$, F. Labonté ${ }^{2}$, A. Gössl ${ }^{3}$, D. Barski ${ }^{3}$, T. Otto ${ }^{3}$, C. Grunwald ${ }^{4}$, G. Niegisch ${ }^{4}$, M. Hennig ${ }^{5}$, M. Kramer', S. Hallmann'

'HELIOS Klinikum Bad Saarow, Bad Saarow, Deutschland; ${ }^{2}$ Charité - Universitätsmedizin Berlin, Urologie, Berlin, Deutschland; ${ }^{3}$ Rheinland Klinikum Neuss, Urologie, Neuss, Deutschland; ${ }^{4}$ Universitätsklinik Düsseldorf, Urologie, Düsseldorf, Deutschland; ${ }^{5}$ Universität Schleswig Holstein, Campus Lübeck, Urologie, Lübeck, Deutschland

Einleitung: BTA stat ${ }^{\oplus}$, Alere NMP22 ${ }^{\circledR}$ BladderChek $^{\circledast}, \mathrm{UBC}^{\circledast}$ rapid test und $\mathrm{UBC}^{\oplus}$ rapid visual sind urinbasierte Schnelltests zur Detektion von Harnblasenkarzinomen; uromonitor ${ }^{\circledast}$ ist ein urinbasierter Test zur Bestimmung der Mutationen FGFR3, TERT und KRAS im Urin. Die vorliegende multicenter-Studie ist die erste Studie, die all diese Tests im Vergleich zur Zytologie untersucht.

Material und Methoden: Es wurden klinische Urinproben von 265 Patienten mit Urothelkarzinom der Harnblase (113 low grade und 152 high grade Tumore), sowie von 146 gesunden Individuen untersucht. An diesen Urinproben wurden Messungen von BTA stat ${ }^{\oplus}$, Alere NMP22 ${ }^{\circledR}$ Bladder$\mathrm{Chek}^{\circledast}, \mathrm{UBC}^{\circledast}$ rapid visual, UBC ${ }^{\circledast}$ rapid test point-of-care (POC) System mittels concile ${ }^{\circledR}$ Omega 100 POC reader und uromonitor ${ }^{\circledR}$ durchgeführt. Es erfolgte die zytologische Bewertung nach Paris Klassifikation. Sensitivitäten und Spezifitäten wurden entsprechend berechnet.

Ergebnisse: Bei allen untersuchten Urinmarkern wurden erhöhte Werte im Urin der Tumorpatienten nachgewiesen. Die berechnete diagnostischen Sensitivitäten für BTA stat ${ }^{\oplus}$, Alere NMP22 ${ }^{\circledR}$ BladderChek $^{\circledast}, \mathrm{UBC}^{\circledR}$ rapid test, UBC ${ }^{\circledast}$ rapid visual, uromonitor ${ }^{\circledast}$ und Zytologie bertrugen $58,4 \%$, $11,6 \%, 62,8 \%, 29,2 \%, 50,0 \%, 36,1 \%$ für low grade, und $83,6 \%, 40,4 \%$, $77,0 \%, 47,4 \%, 63,5 \%, 70,8 \%$ für high grade Tumore der Harnblase. Die berechneten Spezifitäten betrugen entsprechend $77,6 \%, 97,3 \%$, 79, $1 \%$, $91,9 \%, 87,2 \%$ und 93,9\%. Pathologische Werte aller Tumormarker waren höher bei Patienten mit Harnblasenkarzinom im Vergleich mit den Kontrollen.

Schlussfolgerungen: BTA stat ${ }^{\oplus}, \mathrm{UBC}^{\circledR}$ rapid test und uromonitor ${ }^{\circledR}$ zeigten die höchsten Sensitivitäten, die höchsten Spezifitäten zeigten NMP22, $\mathrm{UBC}^{\circledR}$ rapid visual, uromonitor ${ }^{\circledR}$ und die Zytologie. Weitere Ergebnisse dieser Studie mit einer größeren Probenanzahl werden folgen.

\section{K07.2}

UroQuant-Studie: Entwicklung eines neuen Biomarkerpanels zur nicht-invasiven Diagnostik des Harnblasenkarzinoms aus Urin mittels QconCAT-PRMMassenspektrometrie

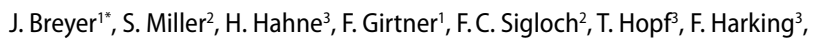
M. Forchheim ${ }^{2}$, A. Bhangu-Uhlmann ${ }^{2}$, M. Burger ${ }^{1}$

${ }^{1}$ Klinik für Urologie der Universität Regensburg am Caritas Krankenhaus St. Josef, Regensburg, Deutschland; ${ }^{2}$ Polyquant $\mathrm{GmbH}$, Regensburg, Deutschland; ${ }^{3} \mathrm{OmicS}$ couts $\mathrm{GmbH}$, Freising, Deutschland

Einleitung: Die Urethrozystoskopie ist der Goldstandard sowohl in der Diagnosestellung, als auch in der Nachsorge des Urothelkarzinoms der Harnblase (UBC). Ziel war es, ein Biomarkerpanel aus Spontanurin zu iden- 
tifizieren, mit dem nicht-invasiv mit hoher Genauigkeit ein UBC detektiert werden kann.

Material und Methoden: Es erfolgte der prospektive Einschluss von Patienten mit zystoskopischem Verdacht auf (V.a.) UBC zur transurethralen Resektion der Harnblase und von Patienten zur radikalen Zystektomie. Als Kontrollgruppe dienten Patienten, die eine subvesikale Desobstruktion erhielten. Von allen Patienten wurde bei Aufnahme Spontanurin asserviert. Nach Zentrifugation und proteolytischem Verdau von $30 \mu \mathrm{g}$ Protein/ Urinprobe und Zugabe von synthetischen Referenzpeptiden (QconCATs) erfolgte die targetierte massenspektrometrische Messung. Mittels maschinellen Lernens wurden Vorhersagemodelle basierend auf der Proteinexpression von 141 Biomarkerkandidaten errechnet.

Ergebnisse: Insgesamt konnten 561 Patienten prospektiv eingeschlossen werden (medianes Alter: 70 Jahre, $78 \%$ männlich). Hiervon waren 469 $(83,6 \%)$ mit V. a. UBC, histologisch konnte in 280 Fällen $(49,9 \%)$ ein UBC nachgewiesen werden, davon $80 \%$ nicht-muskelinvasive UBC. Mit der Kombination aus klinischen Parametern und einem Biomarkerpanel von 33 Proteinen konnte mit $87 \%$ Sensitivität (SENS), $92 \%$ Spezifität (SPEC) und $88 \%$ Genauigkeit (ACC) UBC von benignen Läsionen unterschieden werden. Zudem war anhand der Kombination aus klinischen Parametern und 28 Proteinen die korrekte Vorhersage des Tumorgradings mit $79 \%$ SENS, $84 \%$ SPEC und $82 \%$ ACC möglich.

Schlussfolgerung: Mit dem UroQuant-Assay kann UBC mit hoher Genauigkeit nicht-invasiv im Urin identifiziert werden. Dies könnte zukünftig die Diagnostik und Nachsorge unterstützen.

\section{K07.3}

Evaluierung von nicht-invasiven Biomarkern anderer Tumorentitäten zur Detektion von Urothelkarzinomen im Urinsediment und die Suche nach neuen Methylierungsmarkern durch genomweite Sequenzierung methylierter DNA-Regionen im Urinsediment

\section{Steinbach ${ }^{1 *}$, M. Sperling ${ }^{1}$, M. Kaufmann ${ }^{1}$, E. Barth ${ }^{2}$, M.-O. Grimm ${ }^{1}$}

'Klinik und Poliklinik für Urologie, Universitätsklinikum Jena, Jena, Deutschland; ${ }^{2}$ Friedrich-Schiller-Universität Jena, Bioinformatics Core Facility, Jena, Deutschland

Einleitung: Für die Diagnostik des Urothelkarzinoms und in der Nachsorge sind invasive Verfahren auf Grund fehlender nicht-invasiver Marker unerlässlich. Wir identifizieren und validieren vielversprechende nicht-invasive Urinmarker auf Basis der DNA-Methylierung für den Nachweis des Urothelkarzinoms.

Material und Methoden: Urinsedimente von NMIBC-Patienten und von Patienten mit benignen urologischen Erkrankungen wurden mit dem GynTect Test, einem diagnostischen Test zum Nachweis von Gebärmutterhalskrebs in zervikalen Abstrichen, untersucht. Mittels genomweiter Tiefensequenzierung methylierter Genregionen in Urinsedimenten identifizierten wir neue nicht-invasive Marker, welche durch quantitative methylierungsspezifische PCR validiert werden.

Ergebnisse: Drei GynTect-Marker konnten ein Urothelkarzinom mit hoher Spezifität und einer Sensitivität von $40 \%$ bis $60 \%$ im Urinsediment nachweisen. Die beste Kombination (Spez. 100\%) war ITGA4 + ZNF671 + SOX17 mit einer Sensitivität von $68 \%$. Mit dem Marker DLX1 + ITGA4 konnte eine Sensitivität von bis zu $90 \%$ erreicht werden (Spezifität $73,3 \%$ ). Durch die genomweite Methylierungsanalyse konnten wir neue Marker mit einer Sensitivität von bis zu $80 \%$ und einer Spezifität von $100 \%$ im Urinsediment nachweisen.

Schlussfolgerungen: Methylierungsmarker anderer Tumorentitäten können auch für den Nachweis von Urothelkarzinomen in Urinsedimenten nützlich sein. Spezifische Biomarker zum Nachweis des Urothelkarzinoms, insbesondere von Ta low-grade Tumoren, müssen jedoch durch genomweites Screening direkt im Urinsediment identifiziert werden. Es muss zukünftig gelingen die hohe Anzahl der Zystoskopien bei Verdacht auf ein
Urothelkarzinom und in der Nachsorge durch Ausschluss eines Urothelkarzinoms mittels nicht-invasiver Biomarker zu verringern.

\section{K07.4}

Ist die Präzisionsonkologie beim Urothelkarzinom angekommen? Eine Querschnittstudie zu Biomarkertestungen in klinischen Studien

F. Kunath ${ }^{1 * 2,2,}$, M. Eckstein ${ }^{3,4}$, S. Schmidt ${ }^{2}$, D. Sikic ${ }^{1,3}$, F. Wezel ${ }^{3,5}$, F. Zengerling ${ }^{5}$, B. Wullich ${ }^{1,2,3}$, A. Hartmann ${ }^{3,4}$, C. Bolenz ${ }^{3,5}$

'Urologische und Kinderurologische Klinik, Universitätsklinikum Erlangen, Erlangen, Deutschland; ${ }^{2}$ UroEvidence@DGU, Berlin, Deutschland; ${ }^{3}$ Bladder Cancer Research Initiative for Drug Targets Deutschland (BRIDGE) Consortium e.V., Mannheim, Deutschland; ${ }^{4}$ Institut für Pathologie, Universitätsklinikum Erlangen, Erlangen, Deutschland; ${ }^{5}$ Klinik für Urologie und Kinderurologie, Universitätsklinikum Ulm, Ulm, Deutschland

Fragestellung: Die personalisierte Onkologie hat das Ziel, Patienten*innen anhand einer molekularen und zellulären Tumoranalyse eine individualisierte Therapie anzubieten. Wir untersuchten, inwiefern eine Biomarkertestung beim Urothelkarzinom Voraussetzung für einen klinischen Studieneinschluss war.

Material und Methoden: Es erfolgte eine systematische Recherche in ClinicalTrials.gov nach interventionellen Studien zur systemischen Tumortherapie beim fortgeschrittenen Urothelkarzinom (Januar 2020). Es wurde evaluiert, ob eine Biomarkertestung (am archivierten oder frisch entnommenen Gewebe) zur Therapieentscheidung für eine systemische Therapie genutzt wurde. Zwei Reviewer (FK und ME) haben unabhängig voneinander die Studien durchsucht und Daten extrahiert.

Ergebnisse: Es wurden insgesamt 827 Studien identifiziert und schließlich 356 in die Datenauswertung eingeschlossen. Eine Biomarkertestung war bei 313 (88\%) Studien keine Voraussetzung zum Studieneinschluss (z. B. ,targeted therapy', ,immun checkpoint inhibition', antibody-drug conjugates'). Von 43 (12\%) Studien mit vorausgesetzter Biomarkertestung gab es bezüglich des zu testenden Gewebes bei $24(6,7 \%)$ keine spezifische Anforderung im Studienprotokoll. Bei 16 Studien (4,5\%) reichte das archivierte Gewebe des Primärtumors aus und nur bei 3 Protokollen $(0,8 \%)$ wurde eine erneute aktuelle Gewebeentnahme gefordert.

Schlussfolgerungen: Eine aktuelle Biomarkertestung wird bei den bisherigen Studien zum Urothelkarzinom kaum durchgeführt. Einige wenige Protokolle fordern eine Biomarkertestung am Primärtumor. Zukünftige innovativere Studien sollten eine Biomarkertestung durch Biopsie unmittelbar vor Studieneinschluss voraussetzen, um der Tumorevolution und potenziellen "druggable Targets" optimal gerecht zu werden.

\section{K07.5}

Bewertung eines neuen mRNA-basierten Urintests (Xpert ${ }^{\circledast}$ Bladder Cancer Detection) bei der Beurteilung von Patienten mit Hämaturie - Ergebnisse einer Kohorten-Studie (138)

C. Schmitz-Dräger' ${ }^{1}$ P.J. Goebell2* ${ }^{*}$, T. Ebert ${ }^{1}$, E. Bismarck', D. Grammenos ${ }^{1}$, S. Zhang ${ }^{3}$, M. Gergondey ${ }^{4}$, A. Jöcker ${ }^{5}$, P. Balakrishnann', J. Chen 6 , E. Paxinos ${ }^{4}$, M. Bates ${ }^{4}$, N. Benderska-Söder ${ }^{1}$

'Urologie 24, Nürnberg, Deutschland; ${ }^{2}$ Urologische und Kinderurologische Klinik, Universitätsklinikum Erlangen, Erlangen, Deutschland; ${ }^{3}$ Department of Clinical Research and Biostatistics, Cepheid, Sunnyvale, Vereinigte Staaten von Amerika; ${ }^{4}$ Medical and Scientific Affairs and Strategy, Oncology, Cepheid, Sunnyvale, Vereinigte Staaten von Amerika; ${ }^{5}$ Government Affairs and Market Access, Cepheid GmbH, Krefeld, Deutschland; ${ }^{6}$ Department of Clinical Research and Biostatistics, Cepheid, Sunnyvale, Sunnyvale, Vereinigte Staaten von Amerika

Hintergrund: Die richtige Beurteilung der asymptomatischen Hämaturie (aMh) bleibt eine Herausforderung in der Routine. Diese Studie evaluiert einen neuen Urin-basierten mRNA-Signatur-Tests (Xpert ${ }^{\circledR}$ Bladder Cancer 
Detection, $C E-I V D)$, der 5 verschiedene mRNA-Zielstrukturen detektiert (ABL1, CRH, IGF2, UPK1B, ANXA10).

Material \& Methoden: Es konnten 187 Pat. (113 $\delta, 74$ क; med. Alter: $60 \mathrm{~J}$.) mit neu diagnostizierter schmerzloser Hämaturie eingeschlossen werden. 128 Pat. mit asymptomatischer Mikrohämaturie oder Hämaturie $(n=48)$ erhielten eine urologische Aufarbeitung mit Xpert ${ }^{\oplus}$ Bladder Cancer Detection-Test, Urinzytologie, Zystoskopie und Bildgebung des oberen Harntraktes.

Ergebnisse: 16/26 Pat., die aufgrund der Zystoskopie als verdächtig/positiv für einen Blasentumor eingeschätzt worden waren, wurden histopathologisch bestätigt: 4 pTa low grade; 1 Tumor unklarer Graduierung, und 11 high grade Läsionen. Xpert ${ }^{\circledast}$ BC-Detection-Test zeigte eine hohe Sensitivität $(93,8 \%)$ und Spezifität $(85,3 \%)$ und entdeckte $100 \%(11 / 11)$ der high-grade Tumore. Der positive prädiktive Wert lag bei 39,5\% - der negative prädiktive Wert bei $99,3 \%$. Der Xpert ${ }^{\oplus}$ BC Detection-Test war signifikant sensitiver als die Urinzytologie für das Erkennen positive Fälle $(p<0,05)$ basierend auf der besseren Sensitivität bei low-grade Läsionen. Die Daten zeigen erhöhte Risiko-Raten (RR) für Makrohämaturie ( $\mathrm{RR}=6,03 ; 95 \% \mathrm{Kl}: 2,21-16,41)$, Zytologie (RR=7,49; $95 \% \mathrm{Kl}: 2,6-21,56)$, und ein positives $\mathrm{Xpert}^{\oplus} \mathrm{BC}$ Detection-Testergebnis ( $\mathrm{RR}=52,89 ; 95 \% \mathrm{KI}$ : 3,87-87,72).

Schlussfolgerung: Der histopathologische Befund war in $40 \%$ negativ, was für eine niedrige Spezifität der Zystoskopie sprechen könnte. Die Ergebnisse unterstützen die Rolle des Xpert ${ }^{\oplus}$ Bladder Cancer Detection-Test bei vor-selektionierten Patienten mit Hämaturie.

\section{K07.6 \\ Drug testing using patient derived organoids from upper tract urothelial carcinoma and bladder cancer}

Y. Wei ${ }^{1 *}$, T. Todenhöfer' ${ }^{1}$ L. Schwaibold' ${ }^{1}$ A. Stenzl' ', W. K. Aicher', N. Harland ${ }^{1}$

'Eberhard Karls Universität Tübingen, Klinik für Urologie, Tübingen, Germany

Aim: A major breakthrough in cell culture technologies facilitates drug response analyses in $3 \mathrm{D}$ organoid systems when compared to previous standard 2D cultures thus mimicking the 3D situation in tissues.

Materials: Organoids were established from upper tract urothelial carcinoma (UTUC) and bladder cancer (BC). For cytotoxicity testing [cis-platin

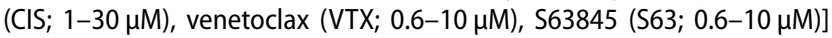
were used over 24,48 and $72 \mathrm{~h}$ of incubation. Cell viability was determined GloMax and 2D/3D-specific chemistry. Untreated cells or solvent only samples (DMSO) served as controls. Normal urothelial cells and bladder cancer lines RT4 and HT1197 were included. Data obtained were processed by Two-way ANOVA statistical tests.

Results: Normal urothelial cells were sensitive to CIS $\left(p<0.5, I C 50_{\mathrm{d} 3}\right.$ $3.5 \mu \mathrm{M})$, VTX $\left(p<0.5, \mathrm{IC} 50_{\mathrm{d} 3} 0.6 \mu \mathrm{M}\right)$, and S63 $\left(p<0.5, \mathrm{IC} 50_{\mathrm{d} 2} 2.1 \mu \mathrm{M}\right)$ dose/ time dependently. RT4 (CIS: $p<0.5$, IC50 $12.1 \mu \mathrm{M}$; VTX: $p<0.5$, IC50 $\mathrm{d}_{\mathrm{d} 3}$ $12.8 \mu \mathrm{M})$ and HT1197 (CIS: $\left.p<0.5, \mathrm{IC} \mathrm{d}_{\mathrm{d} 3} 12 \mu \mathrm{M}\right)$; VTX: $p<0.5, \mathrm{IC} \mathrm{d}_{\mathrm{d} 3} \sim$ $10.7 \mu \mathrm{M} ; \mathrm{S} 63 ; p<0.5$, IC $\left.50_{\mathrm{d} 3} \sim 11.5 \mu \mathrm{M}\right)$ were less sensitive. UTUC organoids were sensitive to CIS $\left(p<0.5, \mathrm{IC} \mathrm{d}_{\mathrm{d} 3} 15.5 \mu \mathrm{M}\right)$ and $\mathrm{S} 63\left(p<0.5, \mathrm{IC} 50_{\mathrm{d} 3}\right.$ $\sim 10 \mu \mathrm{M})$ dose/time dependently. The $\mathrm{BC}$ organoids were sensitive to CIS $\left(p<0.5, \mathrm{IC}_{\mathrm{d} 3} 2 \mu \mathrm{M}\right)$ and VTX $\left(p<0.5, \mathrm{IC} 50_{\mathrm{d} 3} 9.3 \mu \mathrm{M}\right)$. Preliminary data suggest that VTX yielded with UTUCO an IC50 $\mathrm{d}_{3}$ of about $10 \mu \mathrm{M}$.

Conclusions: Patient-derived organoids present with individual sensitivities to the different drugs included in this study. Comparably, healthy urothelial cells undergo cell death by all 3 drugs used, while tumor lines present with distinct sensitivities. UTUC and BC organoids are therefore an interesting model to investigate the individual drug responses to specific active components.
3K07.7

Development and characterization of bladder organoids by ultra-low attachment microplate method

S. Han", M. Berndt-Paetz, A. Weimann, J. Neuhaus

Department of Urology, Research Laboratories, University of Leipzig, Leipzig, Germany

Introduction: Organoids consisting of several different cell types better mimic solid tumors in terms of 3D structure, proliferation, cell-cell interaction and ECM deposition. We developed five organoids aiming to find models for bladder cancer (BCa) research and anti-cancer drug development.

Material and methods: We generated organoids from RT4, RT112, T24 and CAL29 cell lines or non-malignant HBLAK with human bladder fibroblasts and bladder smooth muscle cells in ultra-low attachment 96-well plates. Paraffin sections were stained for cytokeratins (panCK, CK7, CK13, CK20), Ki67, and fibronectin. Immunoreactivity (IR) was analyzed using ImageJ.

Results: After $96 \mathrm{~h}$, the organoids were $650-1000 \mu \mathrm{m}$ in diameter mimicking the structure of an inverse bladder wall with outside urothelial cells and a core of supportive cells. HBLAK were smaller than BCa organoids, which formed lumina and were negatively size correlated with cell line grading. In line with the progenitor status of HBLAK panCK, CK7, CK13 and CK20-IR was significant lower. CK-IR was higher in RT4 and RT112 than in T24. RT112 showed a stratified layering: CK7/CK13-IR in basal and intermediate cells; CK20-IR in superficial cells. The proliferation rate was 7-8\% in HBLAK and $2 \%$ in the low-grade RT4 compared to $35-50 \%$ in higher grade BCa. Fibronectin-IR was highest in G3/G4 organoids.

Conclusion: Bladder organoids can be generated in large numbers using the ULA plate method. They form a bladder-like structure and reproduce in-vivo features as stratified urothelium and fibronectin deposition. Thus, they can be useful tools in cancer biology research and anti-cancer drug evaluation.

Acknowledgements

HS received scholarship from China Scholarship Council; JN was funded by Dr. Siegfried Krüger Stiftung, Leipzig, Germany.

\section{K07.8}

\section{Cisplatin-resistant urothelial carcinoma cells are} sensitive to BET- and PARP-inhibition

\section{A.L. Bartkowiak*, M.J. Hoffmann, G. Niegisch}

Dept. of Urology, Medical Faculty, Heinrich-Heine-University, Düsseldorf, Germany

Objective: Treatment of advanced invasive urothelial carcinoma (UC) with cisplatin chemotherapy is only moderately efficient due to cisplatin resistance. Epigenetic inhibitors (Epi-i) can alter expression of DNA damage response (DDR) components and may sensitize UC cells (UCC) towards PARP inhibitors (PARPi). As cisplatin-resistant sublines of UCC (LTTs) are highly dependent on DDR, we analysed in this study their response towards combined treatment with Epi-i and PARPi.

Material and methods: UCC RT-112, T24, 253J and J82 and their LTTs were treated with the Epi-i PLX51107 (bromodomain protein (BET) inhibitor) and the PARPi Olaparib. We used MTT assays to analyse effects of monoand combined treatment on viability, synergistic effects were calculated. Cell cycle changes and apoptosis induction were determined by flow cytometry. Gene expression changes in DDR pathways were measured by RT-q-PCR.

Results: LTTs were more sensitive to mono-treatment with both drugs than parental UCC (IC $C_{50}$ range PARPi LTTs: $5.0-80.9 \mu \mathrm{M} ; \mathrm{IC}_{50}$ range BETi LTTs: 0.8-3.1 $\mu \mathrm{M})$. Combination treatment resulted in synergistic effects on all parental UCC and LTTs with tolerable toxicity in benign HBLAK cells. The combination reduced long-term proliferation capacity and forced them more strongly into apoptosis (e. g. T24 LTT 26\% viable cells) than the mono-treatment (e. g. T24 LTT 70\% viable cells). Expression of DNA repair 
genes, particularly FANCD2, NHEJ1, PARP2 and POLE2 was altered by the combination which may explain its synergistic action.

Conclusions: Synergistic treatment with PLX51107 and Olaparib strongly reduced viability of cisplatin-resistant LTTs but spared normal cells. Thus, this combination could be a promising therapeutic option for UC, also in the second line after chemotherapy.

\section{K07.9 \\ Cisplatin-resistant urothelial carcinoma cells are dependent on upregulation of chromatin regulators HDAC9 and HAT1}

\author{
L. Breuer ${ }^{*}$, P. Petzsch², K. Köhrer ${ }^{2}$, G. Niegisch¹, M. J. Hoffmann ${ }^{1}$ \\ 'Dept. of Urology, Medical Faculty, Heinrich-Heine-University, Düsseldorf, Germany \\ ${ }^{2}$ Genomics Transcriptomics Lab, Biomedical Research Center, Heinrich Heine University, \\ Düsseldorf, Germany
}

Objective: Aberrant gene expression due to alterations in histone acetylation mediated by histone acetyl transferases (HATs) and histone deacetylases (HDACs) plays an important role in cancer. Transcriptome analysis of long-term cisplatin resistant sublines (LTT) of three different urothelial carcinoma cell lines (UCC) revealed that genes encoding for HDAC9 and HAT1 were upregulated in LTTs as compared to their parental UCCs. Thus, we analyzed the function of these epigenetic enzymes in cisplatin resistance.

Material and methods: We investigated expression of HDAC9 and HAT1 in four UCC (RT112, J82, 253J, T24) and their respective LTT sublines by qRTPCR and western blotting. Modulation of their expression by siRNA knockdown as well as treatment with enzyme inhibitors was analyzed regarding the effect on cell proliferation (clonogenic assays), cell cycle and apoptosis induction (flow cytometry) and cisplatin sensitivity.

Results: Knockdown of HDAC9 or HAT1 resulted in inhibited proliferation and increased apoptosis for HDAC9. We performed dose-response curve analysis with the HAT-inhibitors L-Moses and A-485 and the HDAC9-inhibitor BRD43543. While LTTs were less sensitive to BRD4354 compared to parental UCCs (1.25 to 2-fold), they were more sensitive to L-Moses. However, combined treatment of LTTs with BRD4354 (IC ${ }_{50}$ range 20-50 $\left.\mu \mathrm{M}\right)$ and cisplatin reduced viability of LTTs more efficiently than mono-treatment with cisplatin and allowed an $\mathrm{IC}_{50}$ reduction of up to $30 \%$. Further, induction of apoptosis was stronger (e. g., 2-fold in T-24 LTT).

Conclusion: Resistant LTT cells evade cisplatin stress by upregulation of HDAC9 and HAT1. Thus, their inhibition "episensitizes" cisplatin resistant UC cells to chemotherapy.

3K07.10

Epigenetic treatment of urothelial carcinoma cells with BET inhibitor PLX51107 sensitizes to PARP inhibitors and Cisplatin chemotherapy

\section{S. Thy ${ }^{1 *}$, A. Hommel ${ }^{1}$, P. Petzsch² ${ }^{2}$ K. Köhrer ${ }^{2}$, G. Niegisch', M. Hoffmann}

'Dept. of Urology, Medical Faculty, Heinrich-Heine-University Duesseldorf, Düsseldorf, Germany; ${ }^{2}$ Genomics Transcriptomics Lab, Biomedical Research Center, Heinrich Heine University, Düsseldorf, Germany

Objective: Urothelial carcinoma (UC) has one of the highest prevalence of alterations in epigenetic enzymes. Therefore, the use of epigenetic inhibitors (Epi-I) is considered as a new therapeutic approach. We investigated the cytotoxic impact of the second-generation Bromodomain protein inhibitor (BETi) PLX51107 (PLX) on UC cells (UCC). We also analyzed, how the treatment with BETi could be applied to episensitize UCC towards approved treatments.

Material and methods: UCCs VM-CUB1 and UM-UC-3 and normal HBLAK control cells were treated with Epi-I PLX and PARP inhibitor (PARPi) Talazoparib or the chemotherapy drug Cisplatin. Effects on proliferation, cell cycle and apoptosis induction were analyzed by viability and colony formation assays and flow cytometry. Effects on DNA damage signaling were investigated by $\mathrm{qPCR}$, Western Blot and immunocytochemistry. Synergy of combination treatment was evaluated by the Chou-Talalay method. Results: Treatment with PLX induced DNA damage, reduced cell proliferation in UCC, disturbed the cell cycle regulation and induced apoptosis. PLX altered gene expression contributing to DNA repair deficiency. Thus, combination treatment of PLX and Cisplatin acted strongly synergistic in UCC, especially in PLX-resistant UM-UC-3 cells, but not in normal HBLAK cells. Even better synergism was obtained in UCC by combining PLX with Talazoparib. Concurringly, cell death induction was 6 -fold more increased compared to mono-treatment.

Conclusion: The BETi PLX can be used to episensitize UCC towards Cisplatin-based chemotherapy. Further, this study established a promising new combination therapy with PARPi like Talazoparib for non BRCA1/2 mutated cancers.

\section{K07.11}

Vesical Imaging-Reporting and Data System (VI-RADS) eine monozentrische Korrelation des VI-RADS Scores mit dem histopathologischen Tumor (pT)-Stadium

V. Norz ${ }^{1 *}$, F. Hagen ${ }^{2}$, A. Mair ${ }^{2}$, W. Thaiss ${ }^{2,3}$, S. Rausch', J. Bedke', K. Nikolaou², S. Kruck ${ }^{4}$, T. Hepp ${ }^{5}$, S. Kaufmann ${ }^{2,6}$, A. Stenzl ${ }^{1}$, A. Estler ${ }^{2}$

'Universitätsklinik Tübingen, Urologie, Tübingen, Deutschland; ${ }^{2}$ Universitätsklinik Tübingen, Abteilung für Diagnostische und Interventionelle Radiologie, Tübingen, Deutschland; ${ }^{3}$ Uniklinik Ulm, Nuklearmedizin, Ulm, Deutschland; ${ }^{4}$ Siloah St. Trudpert Klinikum, Urologie, Pforzheim, Deutschland; ${ }^{5}$ Max Planck Institute for Intelligent Systems, Tübingen, Deutschland; ${ }^{6}$ Siloah St. Trudpert Klinikum, Abteilung für Diagnostische und Interventionelle Radiologie, Pforzheim, Deutschland

Einleitung: Die Vesical Imaging-Reporting and Data System (VI-RADS) Klassifikation dient der standardisierten Befundung von Blasenkarzinomen $(\mathrm{BCa})$ in der multiparametrischen Magnetresonanztomographie (mpMRT). Die 5 Punkte Skala des VI-RADS Scores klassifiziert die Wahrscheinlicht einer Detrusormuskelinfiltration. In unserer Analyse erfolgt eine Korrelation des präoperativen VI-RADS Scores mit dem histopathologischen Tumor (pT)-Stadium.

Material und Methoden: Im Zeitraum von Juli 2019 bis August 2020 durchgeführte mpMRT nach VI-RADS Kriterien wurden retrospektiv erhoben. Nur Patienten mit anschließender Tumorresektion wurden in die Auswertung eingeschlossen. Es erfolgte ein Abgleich des VI-RADS Scores mit dem pT-Stadium. Die Performance von VI-RADS für die Detektion einer Muskelinvasion wurde mittels „receiver Operating curve“ analysiert. Der VI-RADS Score wurde von zwei unabhängigen Radiologen erhoben und das Cohen's Kappa ermittelt.

Ergebnisse: Von 40 durchgeführten mpMRT der Blase fanden 33 vor einer Tumoroperation statt. In 16 Fällen wurde eine radikale Zystektomie, in 17 Fällen eine transurethrale Resektion durchgeführt. Das mittlere Patientenalter waren 70 Jahre, $87,8 \%$ waren männlich. Im mpMRT wurden 10 Tumore als nicht-muskelinvasives (nmi) $(30 \%)$ und 23 als muskel-invasives (mi) BCa (70\%) eingestuft. Sensitivität und Spezifität für das Erkennen einer Muskelinvasion und lymphatischen Metastasierung lagen zwischen 70-86\%. Die Intrarater-Reliabilität des VI-RADS Scores war hoch $(\mathrm{K}=0,966)$.

Schlussfolgerung: Die VI-RADS Klassifikation ermöglicht eine gute bildgebende Differenzierung zwischen miBCa und nmiBCa mit hoher Reproduzierbarkeit. Diese Information stellt eine wertvolle Ergänzung der klinischen und pathologischen Diagnostik vor Therapieentscheidung dar. 
3K07.12

\section{Ex-vivo Evaluierung miniaturisierter OCT-Sonden zum Einsatz in der Endourologie}

D. S. Schoeb ${ }^{1 *}$, C. Wollensak ${ }^{2}$, S. Kretschmer ${ }^{3}$, C. Ataman³ , G. Kayser ${ }^{4}$, F. F. Dressler ${ }^{5}$, H. Zappe ${ }^{3}$, A. Miernik ${ }^{2}$

'Universitätsklinikum Freiburg, Freiburg, Deutschland; ${ }^{2}$ Universitätsklinikum Freiburg, Urologie, Freiburg, Deutschland; ${ }^{3}$ Universität Freiburg, IMTEK, Gisela and Erwin Sick Chair of Micro-optics, Freiburg, Deutschland; ${ }^{4}$ Universitätsklinikum Freiburg, Institut für Pathologie, Freiburg, Deutschland; ${ }^{5}$ nniversitätsklinikum Schleswig-Holstein (Campus Lübeck), Pathologie, Lübeck, Deutschland

Einleitung: Derzeit ist der Goldstandard in der Diagnostik des Urothelkarzinoms die Weißlichtzystoskopie (WLC) in Kombination mit der transurethralen Resektion. OCT basiert auf der Weißlicht-Interferometrie und ermöglicht Querschnittsansichten der Gewebestruktur. In dieser Studie bewerten wir zwei miniaturisierte OCT-Sonden, die für den endoskopischen Einsatz entwickelt wurden.

Methoden: Insgesamt wurden 33 Patienten, die sich einer Zystektomie unterzogen hatten eingeschlossen. Zusätzlich wurden Schweineblasenproben als gesundes Referenzgewebe verwendet. Es wurden Messungen mit zwei miniaturisierten OCT-Sonden durchgeführt: einer bimodalen Sonde und einer reinen OCT-Sonde. Als Referenz wurde ein nicht miniaturisierter Standard-OCT-Scanner verwendet. Alle Bilder wurden mit dem Referenzbild verglichen und bewertet.

Resultate: Insgesamt wurden 133 Messungen an Schweinegewebeproben ausgewertet. Ein Vergleich mit der HE-Färbung ergab für alle Messungen eine klare Unterscheidung zwischen den Urothelschichten. Darüber hinaus konnten wir durch Dehnung des Gewebes eine Verbesserung der Bildqualität erreichen. In menschlichen Gewebeproben führten wir 128 Referenzmessungen durch, 104 Messungen mit der bimodalen Sonde und 39 Messungen mit der reinen OCT-Sonde. Während im gesunden Gewebe die Unterscheidung der Schichten möglich war, zeigte Krebsgewebe ein inhomogenes Bild. Eine Unterscheidung zwischen histologischen Tumorstadien war nicht möglich.

Schlussfolgerungen: Wir zeigen, dass die Anwendung endoskopischer Sonden für die OCT-Bildgebung technologisch machbar ist und miniaturisierte Sonden eine akzeptable Bildqualität liefern. Während OCT eine Unterscheidung zwischen gesundem und abnormalem Gewebe ermöglicht, ist die Infiltrationstiefe ein begrenzender Faktor.

\section{K07.13}

\section{Tumorbudding ist beim pT1 nicht-muskelinvasiven} Harnblasenkarzinom (NMIBC) mit schlechterem Überleben assoziiert

M. Eckstein', C. Kimmel ${ }^{2}$, J. Bründl ${ }^{2}$, F. Weber ${ }^{3}$, S. Denzinger ${ }^{2}$, M. Gierth², M. Burger' ${ }^{2}$ A. Hartmann', W. Otto ${ }^{2}$, J. Breyer ${ }^{2 *}$

${ }^{1}$ Institut für Pathologie der Universität Erlangen-Nürnberg, Erlangen, Deutschland; ${ }^{2}$ Klinik für Urologie der Universität Regensburg am Caritas Krankenhaus St. Josef, Regensburg, Deutschland; ${ }^{3}$ Institut für Pathologie der Universität Regensburg, Regensburg, Deutschland

Fragestellung: Tumorbudding ist charakterisiert durch eine Tumorzelle oder ein Zellnest von 2-5 Tumorzellen im Stroma an der Invasionsfront und beim kolorektalen Karzinom ein unabhängiger prognostischer Parameter. Ziel war es, den Einfluss von Tumorbudding auf das Überleben des pT1 NMIBC zu untersuchen.

Material und Methoden: Retrospektiv wurden alle Patienten mit einem pT1 NMIBC in der transurethralen Resektion der Blase, die blasenerhaltend therapiert wurden, eingeschlossen. Nach panCK-Färbung am FFPE-Gewebe wurden die Tumorbuds in 5 high power fields (HPF) gezählt und der mediane bud-count pro HPF berechnet. Das Tumorbudding wurde mit klinischen und pathologischen Parametern sowie mit dem RFS, PFS und CSS korreliert.
Ergebnisse: Es konnten 92 Patienten in die Auswertung eingeschlossen werden, von denen $65 \mathrm{BCG}$ erhielten. Tumorbudding korrelierte statistisch signifikant mit multifokalen Tumoren in der $\mathrm{Chi}^{2}$-Analyse $(p=0,003)$ sowie mit dem EORTC recurrence risk ( $\rho: 0,262, p=0,012$ ) und progression risk score $(\rho: 0,264, p=0,011)$ in der Spearman-Analyse. In der Kaplan-MeierAnalyse war ein medianer bud-count von $\geq 0,9$ statistisch signifikant mit schlechterem RFS $(p=0,005)$, PFS $(p=0,017)$ und CSS $(p=0,002)$ assoziiert. In der multivariablen Cox-Regressions-Analyse war ein medianer bud-count von $\geq 0,9$ der beste prädiktive Parameter für ein Rezidiv (HR: 2,94, $95 \%$-Cl: 1,15-7,52; $p=0,025)$. Bei den BCG-therapierten Patienten war ein medianer bud-count von $\geq 0,9$ ebenfalls mit schlechterem RFS $(p=0,012)$, PFS $(p=0,011)$ und CSS $(p=0,022)$ assoziiert.

Schlussfolgerungen: Die Implementierung des einfach zu erhebenden Tumorbuddings in die pathologische Aufarbeitung des TUR-Gewebes könnte helfen, pT1 Hochrisikopatienten zu identifizieren, die von einer Frühzystektomie profitieren.

\section{K07.14}

\section{Validierung zweier Subklassifikationen des T1 Urothelkarzinoms der Blase und Evaluation der prognostischen Wertigkeit}

S. Schöpfer ${ }^{1}$, J. Gleissner ${ }^{1}$, G. Hutterer ${ }^{1}$, M. Leoni² ${ }^{2}$ S. Mannweiler ${ }^{2}$, K. Pummer ${ }^{1}$, R. Zigeuner ${ }^{1}$, M. Geyer ${ }^{1}$, G. Pichler ${ }^{1}$, M. Seles ${ }^{1}$, H. Zurl ${ }^{1 *}$, J. Mischinger ${ }^{1}$

'Universitätsklinik Graz, Urologie, Graz, Österreich; ${ }^{2}$ Universitätsklinik Graz, Pathologie, Graz, Österreich

Ziel dieser Arbeit ist die bisher unzureichende Validierung der T1 m/T1ebzw. ROL-Subklassifizierung (SK) und die Evaluierung ihrer prognostischen Relevanz bezüglich Rezidiv- (RZ) und (PG) Progressionsrisiko zur Vereinfachung der Therapieentscheidung bei high risk (HR) pT1-Blasenkarzinomen (BC).

Es wurden 130 PatientInnen mit pT1-BC und erfolgter Nachresektion (NR) in die retrospektive Studie eingeschlossen. Für alle Erstresektate erfolgte die pT1-Reevaluation anhand der T1 m/T1e- bzw. ROL1/2-SK. Weiters wurden (HR-)Rezidivauftreten, pT2-Progress, Fernmetastasen, Alter, $\mathrm{CCl}$, Art und Dauer der Instillationstherapien (IT), adjuvante Therapien, krebsspezifisches und Gesamtüberleben erhoben.

Medianes Follow-up betrug 2,3 Jahre (IQR 1,2-4,2). RZ wurden bei 43 PatientInnen festgestellt, davon $40 \mathrm{HR}-\mathrm{RZ}$. Bei 13 PatientInnen kam es zu einer PG in ein Muskel-invasives (MI) BC. Die Subklassifizierungssysteme (SKS) zeigten keinen signifikanten Einfluss auf RZ und PG. Die Stadien T1e und ROL2 zeigten signifikant häufiger Residualtumor in der NR. Der Prognosefaktor Alter ergab ein signifikant erhöhtes Risiko für HR-RZ, MIBC oder Fernmetastasenprogress, vor allem bei PatientInnen $\geq 70$ Jahres sowie bei $\mathrm{CCl}>3$. Die BCG-IT hingegen zeigte eine Reduktion des Gesamt- und HRRezidiv- sowie Progressrisikos zu einem MIBC um $80 \%$.

Die prognostische Wertigkeit der PT1-SK nach van Rhijn et al. und Colombo et al. wurde nicht bestätigt. Verschiedene klinische Einflussfaktoren und die Kollektivzusammensetzung scheinen Einfluss auf die Aussagekraft der SK zu haben und sollten in größeren Kollektiven untersucht werden. Alter und CCI habe einen Einfluss auf das RZ-Auftreten bzw. PG und könnten in Risikostratifizierungen einfließen. Die IT wurde in ihrer therapeutischen Wertigkeit beim HR NMIBC bestätigt. 
3K07.15

Hexaminolevurinate $\left(\right.$ Hexvix $\left.^{\circledast}\right)$ induced Protoporphyrin IX in the ekstracorporal photodynamic detection of bladder cancer cells in urin

\author{
S. Jersinovic ${ }^{1 *}$, Y. Nakai ${ }^{2}$, S. Aufderklamm ${ }^{1}$, N. Harland ${ }^{1}$, A. Stenzl ${ }^{1}$ \\ ${ }^{1}$ University of Tuebingen, Department of Urology, Tuebingen, Germany; ${ }^{2}$ Nara Medical \\ University, Department of Urology, Kahihara, Japan
}

Objective: Tools for examining voided urine in patients with bladder cancer (BC) lack accuracy, cost-effectiveness, objectiveness, or simplicity. Our objective is to evaluate the accuracy of photodynamic procedures for detecting $B C$ cells in voided urine using Hexaminolevurinate(HAL).

Materials and methods: Voided urine was collected preoperatively from 121 patients undergoing transurethral resection of bladder tumor (BC: $n=42$, no BC: $n=29)$, and transurethral resection of prostate and transurethral lithotripsy (Control group: $n=50$ ). Half of urine samples was incubated with $\mathrm{HAL}$, and the rest was incubated without treatment. The intensity of fluorescence at $635 \mathrm{~nm}$ (emission wave length) by $430 \mathrm{~nm}$ (exiting wave length) was evaluated using a spectrophotometer. The difference between the intensity of HAL-treated and the HAL-untreated samples was calculated.

Results: Area under the curve, sensitivity, and specificity of HFC were 0.83 , $69.1 \%$ (29/42), and 94.0\% (47/50), respectively. The sensitivities and specificities of fluorescence in situ hybridization (FISH) and PDD-HAL were $57.1 \%(4 / 7)$ and $57.1 \%(4 / 7)$ and $72.7 \%(8 / 11)$ and $63.6 \%(7 / 11)$, respectively. The intensity of PDD-HAL was significantly correlated with the number of abnormal chromosomes $(r=0.5, p=0.02)$. The sensitivities and specificities of conventional cytology and PDD-HAL were 67\% (20/30) (low grade: $44 \%(7 / 16)$, high grade: $93 \%(13 / 14))$ and $73.3 \%(22 / 30)$ and $78.9 \%$ (14/18) (low grade: $56 \%(9 / 16)$, high grade: $93 \%(13 / 14))$ and $66.7 \%$ $(12 / 18)$, respectively.

Conclusion: HFC had higly accuracy. HFC was more effective in detecting LG tumors than cytology. Therefore, PDD-HAL can be used as a diagnostic tool for $\mathrm{BC}$ using voided urine.

Keywords

Bladder cancer

Cytology

Hexaminolevulinate

FISH

Cost-effectiveness

3K07.16

Blue light $(\mathrm{BL})$ versus white light $(\mathrm{WL})$ for transurethral resection of non-muscle invasive bladder cancer (NMIBC): a Cochrane Review

\footnotetext{
P. Maisch ${ }^{1 * 2}$, A. Koziarz ${ }^{3}$, J. Vajgrtt ${ }^{4}$, V. Narayan ${ }^{5}$, M. H. Kim ${ }^{6}$, P. Dahm ${ }^{7}$

'Universitätsklinik Ulm, Klinik für Urologie und Kinderurologie, Ulm, Germany; ${ }^{2}$ Technische Universität München, Klinikum rechts der Isar, Klinik für Urologie, München, Germany; ${ }^{3}$ University of Toronto, Faculty of Medicine, Toronto, Canada; ${ }^{4}$ University of Minnesota, Medical School, Minneapolis, Vereinigte Staaten von Amerika; ${ }^{5}$ Emory University, Department of Urology, Atlanta, Vereinigte Staaten von Amerika; ${ }^{6} Y$ Yonsei University Wonju College of Medicine, Yonsei Wonju Medical Library, Wonju, Korea; ${ }^{7}$ University of Minnesota, Department of Urology, Minneapolis, Vereinigte Staaten von Amerika
}

Background: Disease recurrence and progression remain major challenges in the treatment of NMIBC. BL enhanced transurethral resection of bladder cancer (TURBT) is an approach to increase accurate staging as well as complete resection.

Methods: We performed a comprehensive search in several medical literature databases including randomized trials. Participants (pts) included had high level of suspicion or 'visible diagnosis' for primary or recurrent urothelial carcinoma of the bladder. According to the Grading of Rec- ommendations Assessment, Development and Evaluation (GRADE) approach, the certainty of evidence was rated.

Results: We identified 16 randomized controlled trials including 4325 pts, comparing BL versus WL TURBT. BL may reduce the risk of disease recurrence over time (hazard ratio (HR) $0.66,95 \%$ confidence interval $(\mathrm{Cl}) 0.54$ to 0.81 ; low certainty of evidence (CoE). For pts with low, intermediate and high risk NMIBC this corresponds to 150 ( 66 fewer to 27 fewer), 380 (152 fewer to 59 fewer) and 610 (211 fewer to 76 fewer) fewer recurrences per 1000 pts when compared to WL TURBT, respectively. BL may have little or no effect on the risk of disease progression over time (HR $0.65,95 \% \mathrm{Cl} 0.50$ to 0.84 ; low $\mathrm{CoE}$ ). For patients with low, intermediate and high risk NMIBC this corresponds to 2 ( 1 fewer to 0 fewer), 50 ( 25 fewer to 8 fewer) and 170 (81 fewer to 25 ewer) fewer progressions per 1000 pts.

Conclusions: Although this review identified 16 randomized controlled trials addressing the objective of this review, the certainty of evidence on the results is low to very low. In the future methodological rigorous trails should be conducted.

\section{K07.17}

The "COVID-19 Pandemic Gap" and its influence on oncologic outcomes of primary and recurrent bladder cancer

G. Tulchiner ${ }^{1 *}$, N. Staudacher', J. Fritz², C. Radmayr' ${ }^{1}$, Z. Culig' ${ }^{1}$, W. Horninger'1, R. Pichler'

${ }^{1}$ Med. Universität Innsbruck, Urologie, Innsbruck, Austria; ${ }^{2}$ Med. Universität Innsbruck, Department of Medical Statistics, Informatics and Health Economics, Innsbruck, Austria

Introduction: Effect of deferred diagnosis and treatment of bladder cancer (BC) patients due to the coronavirus-19 (COVID-19) pandemic is currently not clarified. The objective of this study was to evaluate outcomes of COVID-19 pandemic resulting from of delayed diagnosis, staging and treatment of primary and recurrent $\mathrm{BC}$ and to create feasible triage decisions.

Material and methods: A retrospective single center analysis of all patients, who underwent diagnostic procedures and surgical treatment because of BC during January 2019 and December 2020. Comparison between year 2019 and 2020 were assessed with Poisson-test. Categorical variables are reported as frequencies and percentages and were compared using chi-square or Fisher's exact tests, as appropriate to show differences between 2019 and 2020.

Results: Due to COVID-19 lockdown significantly fewer (diagnostic and therapeutic) endoscopic procedures were performed in the first half of the year 2020 compared with $2019(p=0.002)$. In patients with primary diagnosis of $\mathrm{BC}$, a significant increase of high-grade tumors $(p<0.001)$ as well as advanced tumor stages $(p=0.014)$ was noticed during 2020 . On the contrary, patients with recurrent $B C$ undergoing surveillance at our institution showed no adverse outcomes regarding tumor stage and grade comparing between 2020 and 2019.

Discussion and conclusions: The COVID-19 pandemic led to a deferred oncological diagnosis and treatment of BC. Adverse outcomes with increased rates of advanced and aggressive tumors in patients with primary $B C$ requires more awareness in clinical urologic practice and should be timely treated. However, in recurrent $B C$ an individual risk stratification in order to avoid worse outcome during COVID-19 pandemic seems to be justified. 


\section{K08 - Benigne Prostatahyperplasie und unterer Harntrakt}

$$
\text { 17.09.2021, H2, 08:15-09:45 }
$$

\section{K08.1}

Prostatic artery embolisation versus transurethral resection of the prostate for benign prostatic hyperplasia: 2-yr outcomes of a randomised, open-label, single-centre trial:

\section{Abt ${ }^{*}$, G. Müllhaupt ${ }^{1}$, L. Hechelhammer ${ }^{2}$, S. Markart ${ }^{2}$, S. Güsewell ${ }^{3}$,} H.-P. Schmid', L. Mordasini', D. Engeler' ${ }^{1}$

${ }^{1}$ Kantonsspital St. Gallen, Klinik für Urologie, St. Gallen, Schweiz; ${ }^{2}$ Kantonsspital St. Gallen, Klinik für Radiologie und Nuklearmedizin, St. Gallen, Schweiz; ${ }^{3}$ Kantonsspital St. Gallen, Biostatistik, Clinical Trials Unit, St. Gallen, Schweiz

Einleitung: Prostatic artery embolisation (PAE) for the treatment of lower urinary tract symptoms secondary to benign prostatic obstruction (LUTS/BPO) still remains under investigation. This study compares efficacy and safety of PAE and TURP in the treatment of LUTS/BPO at $2 \mathrm{yr}$ of follow-up.

Material und Methoden: A randomised, open-label trial randomized 103 participants aged $\geq 40 \mathrm{yr}$ with refractory LUTS/BPO to PAE or TURP. Outcomes included IPSS and other questionnaires, functional measures, prostate volume, and adverse events. Changes from baseline to $2 \mathrm{yr}$ were tested for differences between the two interventions with standard twosided tests.

Ergebnisse: The mean reduction in IPSS after 2 yr was 9,21 points after PAE and 12,09 points after TURP (difference of 2,88 [95\% confidence interval $0,04-5,72] ; p=0,047)$. Superiority of TURP was also found for most other patient-reported outcomes except for erectile function. PAE was less effective than TURP regarding the improvement of maximum urinary flow rate $(3,9 \mathrm{vs} 10,23 \mathrm{ml} / \mathrm{s}$, difference of $-6,33[-10,12$ to $-2,54] ; p<0,001)$, reduction of postvoid residual urine $(62,1$ vs $204,0 \mathrm{ml} ; 141,91$ [43,31$240,51] ; p=0,005)$, and reduction of prostate volume $(10,66 \mathrm{vs} 30,20 \mathrm{ml}$; $19,54[7,70-31,38] ; p=0,005)$. Adverse events were less frequent after PAE than after TURP (total occurrence $n=43$ vs $78, p=0,005$ ). Ten patients (21\%) who initially underwent PAE required TURP within $2 \mathrm{yr}$ due to unsatisfying clinical outcomes.

Schlussfolgerung: Inferior improvements in LUTS/BPO and a relevant retreatment rate are found $2 \mathrm{yr}$ after PAE compared with TURP. PAE is associated with fewer complications than TURP. The disadvantages of PAE regarding functional outcomes should be considered for patient selection and counselling.

\section{K08.2}

\section{REZUM Water Vapor Therapy under intravenous} sedation: 1-year experience at the University Hospital Zurich:

M. Adank ${ }^{1}$, M. Meier ${ }^{2}$, C. Poyet ${ }^{2}$, D. Schmid², D. Eberli², T. Sulser², T. Hermanns², E.X. Keller ${ }^{2 *}$

'Universitätsspital Zürich, Urologie, Zürich, Switzerland; ${ }^{2}$ Universitätsspital Zürich, Zürich, Switzerland

Introduction: REZUM Water Vapor Therapy has recently become available in Switzerland. This study evaluates efficacy and safety of this therapy 1 year after its introduction at the University Hospital Zurich.

Methods: All patients undergoing REZUM therapy since June 2019 were included. Primary outcome was time to catheter withdrawal. Secondary outcomes were anesthesia-related complications, hospital stay length, continuous bladder irrigation $(\mathrm{CBI})>24 \mathrm{~h}$, postoperative urinary tract in- fection (UTI), maximal urinary flow (Qmax), post-void residual volume (PVR) and continence at 3 months after surgery.

Results: A total of 47 patients were included. Median age was 78 years (range 54-92). ASA-score was $\geq 3$ in 29/47 (62\%) patients. Before surgery, $16 / 47$ (34\%) patients had a permanent indwelling catheter. Median prostate volume was $50 \mathrm{ml}$ (range 30-160). Median operative time was 8 min (range 4-27). A median 5 water vapor injections (range 3-18) were applied. Prostate volume significantly correlated with injections count $\left(\mathrm{R}^{2}=0.57 ; p<0.001\right)$, and operative time $\left(\mathrm{R}^{2}=0.38 ; p<0.001\right)$. Postoperative delirium occurred in 1 patient (2\%). Anaphylactic shock occurred in 1 patient (2\%). Median hospital stay was 2 days (range $0-7$ ). $C B I>24 \mathrm{~h}$ was necessary in $3(6 \%)$ patients. UTI occurred in $4(9 \%)$ patients. Bladder tamponade occurred in 1 (2\%) patient. Median time to catheter withdrawal was 9 days (range 5-67). A significant improvement of Qmax (median $2.8 \mathrm{ml} / \mathrm{s}$ higher; $p=0.036$ ) and PVR (median $26 \mathrm{ml}$ lower; $p<0.008$ ) was found, and continence was preserved.

Conclusions: REZUM water vapor therapy under intravenous sedation is applicable to patients with severe comorbidities. Complications occur seldom, but require close monitoring of patients after surgery.

\section{K08.3}

Aquablation for benign prostatic hyperplasia in large prostates (80-150cc): 3-year results

K. Zorn ${ }^{1 *}$, N. Bhojani', C. Roehrborn², M. Desai ${ }^{3}$, D. Elterman ${ }^{4}$, S. Kaplan ${ }^{5}$, P. Gilling ${ }^{6}$, WATER 2 Aquablation Working Group

${ }^{1} \mathrm{CHUM}$ - University of Montreal Hospital Center, Montreal, Canada; ${ }^{2}$ UT Southwestern Medical Center, Department of Urology, University of Texas Southwestern, Dallas, US, TX, Virgin Islands (U.S.); ${ }^{3}$ Keck Hospital of USC, Los Angeles, CA, USA, CA, Virgin Islands (U.S.); ${ }^{4}$ University of Toronto - University Health Network, Toronto, CAN, Ontario, Canada; ${ }^{5}$ cahn School of Medicine at Mount Sinai, New York, US, Virgin Islands (U. S.); ${ }^{6}$ Urology Bay of Plenty, Tauranga, New Zealand, Tauranga

Objective: To report 3 year safety and efficacy outcomes of the Aquablation procedure for the treatment of men with symptomatic BPH and largevolume prostates.

Methods: 101 men with moderate-to-severe BPH symptoms and prostate volumes of $80-150 \mathrm{cc}$ underwent a robotic-assisted Aquablation procedure in a prospective multicenter international clinical trial with scheduled follow-up at 6, 12, 24 and 36 months.

Results: Mean prostate volume was $107 c c$ (range 80-150). Mean operative time was $37 \mathrm{~min}$ and mean Aquablation resection time was $8 \mathrm{~min}$. IPSS scores improved from 23.2 at baseline to 5.2 at 36 months (change of -16.7 points, $p<0,0001)$. Qmax improved from $8.7 \mathrm{cc} / \mathrm{sec}$ at baseline to $19.0 \mathrm{cc} / \mathrm{sec}$ at 36 months. Improvements in both IPSS, IPSS Quality of Life, Qmax, and PVR were immediate and sustained throughout follow-up. Three subjects (3\%) have required surgical retreatment over the course of three years post-Aquablation.

Conclusions: In 3-year prospective follow-up, the Aquablation procedure was shown to be safe and effective in men with large prostates (80150cc). ClinicalTrials.gov number, NCT03123250.

\section{K08.4}

Wasserstrahlablation zur Behandlung der BPH: Erfahrungen während der Lernkurve:

\section{S. Foller*, M. Keil, M.-O. Grimm}

Universitätsklinikum Jena, Klinik und Poliklinik für Urologie, Jena, Deutschland

Fragestellung: Die Wasserstrahlablation ist ein minimal-invasives Verfahren zur Behandlung der BPH. Ein hochfokussierter Wasserstrahl trägt obstruktives Prostatagewebe ab. Grenzen werden mittels TRUS und integriertem Zystoskop definiert. Wir berichten unsere Ergebnisse während der Lernkurve anhand einer heterogenen Gruppe an BPH-Patienten. 
Material und Methoden: Die ersten $120 \mathrm{BPH}-$ Patienten mit einem PV bis zu $200 \mathrm{ml}$ wurden zw. 05/2019 u. 10/2020 an unserer Klinik mit der Methode behandelt. Das mittl. Alter betrug $71 \mathrm{~J}$.. Die meisten Pat. waren mit Alphablockern u/o 5a-Reduktasehemmern vorbehandelt. 38\% waren nach Harnverhalt mit einem DK versorgt. $28 \%$ der Patienten waren antikoaguliert. In allen Fällen erfolgten zum Ende der Prozedur eine Koagulation am Blasenhals und Anlage eines Spülkatheters auf Zug.

Ergebnisse: Der mittl. präop. Flow (Qmax) betrug $11 \mathrm{ml} / \mathrm{s}$; mittl. RH $117 \mathrm{ml}$; mittl. PV $74 \mathrm{ml}(20-200 \mathrm{ml} ;<60 \mathrm{ml} n=39,60-100 \mathrm{ml} n=61$, $>100 \mathrm{ml} n=20)$; medianer präop IPSS 20 Pkt. Die mittl. OP-Zeit lag bei 26 min (8-58). Der mittl. Hb-Abfall betrug 1,3 mmol/l; zwei Patienten erhielten EK. In vier Fällen beobachteten wir Komplikationen >Grade 2 (n. Clavien-Dindo): bei drei Patienten erfolgte eine Nachkoagulation, bei einem Patienten kam es zu einer Läsion am Rektum. Nachbeobachtungen zeigten eine Verbesserung des IPSS auf 8 Pkt, des Qmax auf $19 \mathrm{ml} / \mathrm{s}$ und einen Rückgang des RH-Vol. auf $33 \mathrm{ml}$.

Schlussfolgerungen: Die Verbesserung der Miktionsparameter im Versorgungsalltag unterstützt den Einsatz der Wasserstrahlablation sogar bei PV bis zu $200 \mathrm{ml}$. Dennoch beobachteten wir während der Lernkurve vier höhergradige Komplikationen bedingt durch Setup u. Methode. Unsere Erfahrungen verdeutlichen den hohen Stellenwert eines standardisierten Ablaufs insbesondere im Hinblick auf die Hämostase.

\section{K08.5 \\ Routine use of focal bladder neck cautery in 1116 consecutive Aquablation controls postoperative bleeding}

S. Gloger ${ }^{*}, 2$, B. Ubrig ${ }^{1,2}$, D. Elterman ${ }^{3}$, S. Foller ${ }^{4}$, A. Al-Ahni ${ }^{5}$, A. Kugler ${ }^{6}$, V. Misrai ${ }^{7}$, A. Porreca ${ }^{8}$, D. Abt ${ }^{9}$, K.C. Zornn ${ }^{10}$, N. Bhojani ${ }^{10}$, L. Kriteman ${ }^{11}$, R. Mehan ${ }^{12}$, M. McDonald ${ }^{13}$, S. Kaplan ${ }^{14}$

'Augusta Kliniken Bochum, Bochum, Germany; ${ }^{2}$ Universität Witten/Herdecke, Witten, Germany; ${ }^{3}$ University of Toronto - University Health Network, Toronto, Canada; ${ }^{4}$ Universitätsklinikum Jena, Jena, Germany; ${ }^{5}$ Eichsfeld Klinikum, Niederorschel, Germany; ${ }^{6}$ Klinikum Fichtelgebirge, Marktredwitz, Germany; ${ }^{7}$ Clinique Pasteur, Toulouse, France; ${ }^{8}$ Policlinico Abano Terme, Abano Terme, Italy; ${ }^{9}$ Kantonsspital St. Gallen, St. Gallen, Switzerland; ${ }^{10}$ University of Montreal, Montreal, Canada; ${ }^{11}$ Northside Forsyth Hospital, Atlanta, Vereinigte Staaten von Amerika; ${ }^{12}$ East Valley Urology Center, Mesa, Vereinigte Staaten von Amerika; ${ }^{13}$ AdventHealth Celebration, Celebration, Vereinigte Staaten von Amerika; ${ }^{14}$ Mount Sinai Medical Center, New York, Vereinigte Staaten von Amerika

Introduction and Objective: To determine if focal bladder neck cautery effectively prevents blood transfusions across various prostate volumes following prostate tissue resection for benign prostatic hyperplasia using Aquablation.

Methods: Consecutive patients between late 2019 and August 2020 undergoing Aquablation followed by focal bladder neck cautery from 11 countries from Asia, Europe, and North America were evaluated for transfusions.

Results: 1,116 Aquablation cases were performed using focal bladder neck cautery with a mean prostate size of $81 \mathrm{cc}$ (range 20 to $300 \mathrm{cc}$ ). The average time spent after removing the handpiece to inserting the urinary catheter was $18 \mathrm{~min}$. This segment of the procedure includes flushing, transitioning to the resectoscope, and cauterizing at the bladder neck. Postoperative bleeding requiring transfusion occurred in seven cases $(0.6 \%, 95 \%$ $\mathrm{Cl} 0.3-1.3 \%)$. This result compares favorably $(p<0,0001)$ to the previously published hemostasis aggregate transfusion rate of 31/801 (3.9\%) using methods performed in the years 2014 to 2019.

Conclusions: Routine use of additional focal bladder neck cautery subsequent to aquablation will bring down the risk of postoperative bleeding to a level known from TURP or HoLEP while preserving the main strategic goals of aquablation: reliable desobstruction of the prostatic urethra, high safety profile for protection of the urinary sphincter, high efficacy in preserving antegrade ejaculation, minimizing and standardizing the ablative procedure.
3K08.6

In-hospital cost analysis of aquablation compared with transurethral resection of the prostate in the treatment of benign prostatic enlargement

G. Müllhaupt ${ }^{1}$, P. Lyatoshinsky ${ }^{1}$, A. Neuenschwander ${ }^{1 *}$, S. Güsewell², H.-P. Schmid ${ }^{1}$, D. Abt ${ }^{1}$

${ }^{1}$ Klinik für Urologie Kantonsspital St. Gallen, St.Gallen, Switzerland; ${ }^{2}$ Clinical Trials Unit School of Medicine Universität St.Gallen, St.Gallen, Switzerland

Objectives: To compare in-hospital treatment costs of aquablation and transurethral resection of the prostate (TURP) in the treatment of benign prostatic enlargement.

Patients and methods: Patient data and procedural details were derived from a prospective database. In-hospital costs were calculated using detailed expenditure reports provided by the hospital accounts department. Total costs including those arising from surgical procedures, consumables, personnel, and accommodation were analysed for 24 consecutive patients undergoing aquablation and compared to 24 patients undergoing TURP during the same period. Mean total costs and mean costs for individual expense items were compared between treatment groups with t-tests.

Results: Mean total costs per patient $( \pm \mathrm{SD})$ were higher for aquablation at $€ 10,994 \pm 2,478$ than for TURP at $€ 7,445 \pm 2,354$. The mean difference (md) of $€ 3,549$ was statistically significant $(p<0.001)$. While the mean procedural costs were significantly higher for aquablation ( $m € € 3,032$ $(p<0.001))$, costs apart from the procedure were also lower for TURP, but the md of $€ 1,627$ was not significant $(p<0.327)$. Medical supplies were mainly responsible ( $\mathrm{md}$ of $€ 2,057 ; p<0.001$ ) for the difference in procedural costs.

Conclusions: In-hospital costs are significantly higher for aquablation than for TURP, mainly due to higher costs of medical supplies of the procedure. This difference should be taken into consideration, at least in patients for whom the different side effect profiles of both treatments are irrelevant.

\section{K08.7}

\section{Pooled analysis of bladder function post-aquablation}

D. Elterman' ${ }^{1}$, P. Gilling ${ }^{2}$, C. Roehrborn ${ }^{3}$, N. Barber ${ }^{4}$, V. Misrai ${ }^{5}$, K. C. Zorn' ${ }^{6}$,

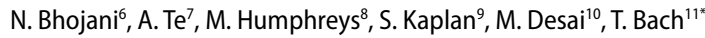

'University of Toronto, Department of Urology, Toronto, Canada; ${ }^{2}$ Tauranga Urology Research, Department of Urology, Tauranga, New Zealand; '3niversity of Texas Southwestern, Department of Urology, Dallas, Vereinigte Staaten von Amerika; ${ }^{4}$ Frimley Park Hospital, Frimley Health Foundation Trust, Department of Urology, Surrey, Vereinigtes Königreich; ${ }^{5}$ Clinique Pasteur, Department of Urology, Toulouse, France; ${ }^{6}$ University of Montreal Hospital Center, Department of Urology, Montreal, Canada; ${ }^{7}$ Weill Cornell Medical College, New York Presbyterian, Department of Urology, New York, Vereinigte Staaten von Amerika; ${ }^{8}$ Mayo Clinic Arizona, Department of Urology, Scottsdale, Vereinigte Staaten von Amerika; ${ }^{9}$ Mount Sinai Medical Center, Department of Urology, New York, Vereinigte Staaten von Amerika; ${ }^{10}$ University of Southern California, Department of Urology, Los Angeles, Vereinigte Staaten von Amerika; "Asklepios Westklinikum Hamburg, Urologie, Hamburg, Germany

Introduction: Aquablation Therapy (AQUABEAM Robotic System, PROCEPT BioRobotics, Inc., USA) is an ultrasound-guided, robotically executed waterjet ablative procedure used to treat men with lower urinary tract symptoms (LUTS) due to benign prostatic hyperplasia (BPH). It has demonstrated treatment in a wide range of prostate sizes while minimizing irreversible complications (erectile dysfunction, ejaculatory dysfunction, incontinence). This analysis explores the bladder function following Aquablation in various prostate volume and anatomical subgroups. Methods: Four prospective, global, clinical studies have been conducted with Aquablation with a minimum follow up of one year; WATER, WATER II, FRANCAIS WATER, and OPEN WATER. The focus of the analysis is the seven individual questions from IPSS and post-operative incontinence symptom index (ISI). 
Results: 425 men with prostates ranging in size from $20-150 \mathrm{cc}$ were treated with Aquablation Therapy. Outcomes from the seven questions from the IPSS questionnaire were analyzed for prostates $<100 \mathrm{cc}$, prostates $>100 \mathrm{cc}$, prostate anatomy with median lobe, and prostate anatomy without median lobe. Regardless of subgroup, all outcomes are consistent and a significant improvement from baseline. Specifically, improvements in frequency, urgency, and nocturia demonstrate bladder function improvement. Patients entering treatment with severe incontinence, ISI score $>4$, and regardless of prostate size, showed a reduction in incontinence during patient follow-up.

Conclusions: Aquablation Therapy showed remarkable bladder function improvement following the index procedure. Additionally, men with severe incontinence showed a reduction in incontinence post-procedure.

\section{K08.8}

\section{Einfluss der Energiedichte auf Früh- und Langzeitergebnisse der High-Power (100 W) Holmium Laser Enukleation der Prostata (HoLEP)}

P. Gild", K. Breunig, M. W. Vetterlein, T. A. Ludwig, A. Soave, P. Marks, R. Dahlem', M. Fisch, M. Rink, C.P. Meyer

Universitätsklinikum Hamburg-Eppendorf, Klinik und Poliklinik für Urologie, Hamburg, Germany

Der Einfluss der Energiedichte $(\mathrm{kJ} / \mathrm{g})$ auf die Früh- und Langzeitergebnisse der high-Power HoLEP ist kaum untersucht.

1515 Patienten, die zwischen 2006-2017 eine HoLEP (70 W;1,4J;50 Hz) erhielten, wurden retrospektiv anhand der Energiedichte/Enukleatgewicht in Quartilen (Q) stratifiziert (<1,9 kJ/g (1.Q), 2-2,7 kJ/g (2. Q), 2,8-3,8 kJ/g (3.Q), 3,9-16 kJ/g (4. Q)), und anhand perioperativer Charakteristika und des Querschnitt Follow-ups ( $\mathrm{F} / \mathrm{u}$ ) verglichen.

Präoperativ unterschieden sich die Pat. signifikant hinsichtlich des PSA $(8,5 \mathrm{mg} / \mathrm{dl}$ (Interquartilsabstand (IQR) 4,9-14,8) vs. 3,2 mg/dl (IQR 1,7$5,7), 1$. vs. 4. Q), und des Prostatavolumens (108,5 ml (IQR $85-145)$ vs. $58 \mathrm{ml}$ (IQR 46-75), 1. vs. 4. Q). Perioperativ boten sich signifikante Unterschiede hinsichtlich des Enukleatgewichts ( $90 \mathrm{~g}$ (IQR 70-114) vs. $25 \mathrm{~g}$ (IQR 18-35), 1. vs. 4. Q), Clavien-Dindo $\geq 3$ Komplikationen (8\% $(n=34)$ vs. $1,4 \%(n=5), 1$. vs. 4 . Q), und inzidentellen Prostatakarzinomen $(12 \%(n=52)$ vs. $27 \%(n=93), 1$. vs. 4.Q)(alle $p<0,01)$. Unter 576 (38\%) zur Verfügung stehenden Patienten mit medianem F/u von 40 Monaten (IQR 26-59) zeigten sich signifikante Unterschiede hinsichtlich des IPSS (2 (IQR $1-4)$ vs. $4(2-7,5), 1$. vs. $4 . Q)$ und der QoL (1 (IQR 0-1) vs. 1 (IQR 1-2), 1. vs. 4.Q) (beide $p<0,01$ ), aber nicht Dauer des F/u, aktuellem PSA, IIEF-5, Vorhandensein einer Inkontinenz, oder Folgeeingriffen (alle $p>0,08$ ). Die positive Assoziation aus steigender Energiedichte und IPSS/QoL bestätigte sich im multivariablen linearen Regressionsmodell, adjustiert für Alter, ASA, Prostatavolumen, Anzahl Operationen/Operateur (alle $p<0,01$ ). Eine steigende Energiedichte hat einen negativen Einfluss auf IPSS/QoL nach HoLEP. Die Modulation der Energiedichte bietet eine Möglichkeit das funktionelle Ergebnis der HoLEP weiter zu verbessern.

\section{K08.9}

The impact of preoperative LUTS medication on the technical performance of holmium laser enucleation of the prostate

A. Tamalunas", T. Westhofen, M. Schott, P. Keller, M. Atzler, C. Stief, G. Magistro Urologische Klinik und Poliklinik, Klinikum der Universität München, LMU München, München, Germany

Purpose: Medical treatment of lower urinary tract symptoms(LUTS) secondary to benign prostatic obstruction(BPO) targets prostate size, to prevent disease progression, and prostate smooth muscle tone for rapid relieve of LUTS. Holmium laser enucleation of the prostate(HoLEP) is a size-independent method for surgical treatment of LUTS/BPO in medication-refractory patients and offers durable long-term results with reduced perioperative morbidity. As up to $50 \%$ of patients receive medical treatment for LUTS/BPO prior to surgery, we analyzed the impact of alphablockers and 5-alpha-reductase-inhibitors(5-ARI) on outcomes and perioperative morbidity in patients undergoing HoLEP for LUTS.

Materials and methods: We retrospectively collected data of 1,057 patients who underwent HoLEP for LUTS secondary to BPO between 2013-2018. Patients were divided into group 1 (no medication), group 2 (a-blockers), group 3 (5-ARI and a-blockers). Perioperative parameters, safety and short-term functional outcomes were assessed and analyzed.

Results: Patients in group 3 had significantly lower IPSS and PSA compared to patients in group 1 and 2. Perioperative Clavien-Dindo grade $\geq$ II complications were seen in $4.0 \%$ of all patients $(42 / 1,057)$. There was no difference in perioperative complications between all groups $(p=0.943)$. Functional outcome was assessed 30 days post-surgery. There was improvement in median IPSS of 9, 8 and 7 points for groups 1-3, with improvement of QoL for all groups. Median $\mathrm{Q}_{\max }$ showed improvement of 10 , 12 and $9.5 \mathrm{ml} / \mathrm{s}$ for groups $1-3$.

Conclusions: Although preoperative LUTS medication does not impair efficacy of HoLEP with acceptable perioperative morbidity, the time gap between medical therapy and surgical treatment may favor an earlier response.

\section{K08.10}

Chirurgische Effizienz der „Ein-Lappen“-Technik vs. „DreiLappen“-Technik für die Holmium Laser Enukleation der Prostata (HoLEP)

\author{
T. Westhofen*, M. Schott, K. Patrick, A. J. Tamalunas, M. Atzler, C. G. Stief, \\ G. Magistro
}

Klinik für Urologie, Ludwig-Maximilians-Universität München, München, Deutschland

Hintergrund: Holmium-Laser-Enukleation der Prostata (HoLEP) ist sicher und effektiv. Unklarheit herrscht hinsichtlich, verschiedener Operationstechniken. Unser Ziel war es, die Drei-Lappen-Technik(TL) mit der neueren Ein-Lappen-Technik(OL) hinsichtlich chirurgischer Effizienz zu vergleichen.

Methoden: Es wurde eine retrospektive Analyse von 1475 Patienten durchgeführt, die zwischen Januar 2017 und Juni 2020 mittels HoLEP bei BPH aufgrund von BPO unterzogen. Propensity-Score-Matching ergab eine Kohorte von $n=528$ ( $n=264$ HoLEP in Drei-Lappen-Technik (TL), $n=264$ HoLEP in Ein-Lappen-Technik (OL)). Primärer Endpunkt: chirurgische Effizienz des OP-Technik. Sekundärer Endpunkt: perioperatives Outcome, frühe funktionelle Ergebnis und perioperative Komplikationen (nach Clavien Dindo).

Ergebnisse: Baseline-Charakteristika beider Subkohrten waren vergleichbar. Mediane Operationszeit ( 52,0 min vs. $83,5 \mathrm{~min} ; p<0,001)$, Enukleationszeit $(18,0 \mathrm{~min}$ vs. $35,0 \mathrm{~min} ; p<0,001)$ und Morcellationszeit $(9,0 \mathrm{~min}$ vs. 12,0 min; $p<0,001)$ waren signifikant kürzer für $\mathrm{OL}$. Die chirurgische Effizienz war zugunsten von OL in Bezug auf eingesetzte Laserenergie, Operationsgeschwindigkeit, Enukleationsgeschwindigkeit, Enukleationseffizienz und Operationsleistung (jeweils $p<0,001$ ). OL zeigte eine signifikant höhere Korrelation von PV zur Enukleationseffizienz als TL $(p<0,001)$. Das frühfunktionelle Outcome (IPSS und Qmax) war besser nach OL (jeweils $p<0,05)$. Die Rate perioperative Komplikationen war vergleichbar $(p=0,485)$

Schlussfolgerung: Die Ein-Schleifen-Technik ist schneller und effizienter als die klassische Drei-Schleifen-Technik. Im Gegensatz zur TL zeigte OL mit zunehmender PV eine konstant verbesserte chirurgische Effizienz. OL ist daher insbesondere bei Riesenprostata eine wertvolle Alternative. 
3K08.11

Einfluss der "early release" Technik während der Holmiumlaser-Enukleation der Prostata (HoLEP) auf frühe postoperative funktionelle Ergebnisse

M. Deuker", M. Welte, F. Chun, F. Roos, L. Kluth, P. Mandel, S. Banek, A. Becker Universitätsklinikum Frankfurt, Frankfurt, Deutschland

Hintergrund: Die Reduzierung der postoperativen Stressinkontinenz nach Holmium-Laser-Enukleation der Prostata (HoLEP) ist eine große Herausforderung. Die early release Technik (ER) stellt eine chirurgische Modifikation des Enukleationsverfahrens dar und könnte die frühe Kontinenz verbessern.

Material und Methoden: In unserer prospektiven institutionelle Datenbank von 07/2019 bis 10/2020 wurden Patienten, bei denen die ER-Technik durchgeführt wurde mit Patienten, bei denen eine Standardenukleation durchgeführt wurde retrospektiv verglichen. Das Follow-up umfasste Patient-reported outcomes (PROMS) sowie standardisierte Fragebögen und Komplikationsraten. Deskriptive Statistiken, Chi-Quadrat- und t-Test wurden angewandt.

Ergebnisse: Von 193 Patienten wurden 89 (46,1\%) mit ER-Technik operiert, während 104 Patienten (53,9\%) eine Standardenukleation erhielten. Vier Wochen nach der Operation zeigte sich im Follow-up eine statistisch signifikante Verringerung der Verwendung von Vorlagen (0,6 Pads nach ER-modifiziertem Verfahren gegenüber 0,9 Pads nach Standardverfahren, $p=0,026)$. Der Symptomscore (IPSS), die Lebensqualität (QoL), die maximale Harn-Flussrate und der Restharn waren im Vergleich zu präoperativen Werten unabhängig vom operativen Verfahren statistisch signifikant verbessert. Beim Follow-up nach drei Monaten zeigte sich kein statistisch signifikanter Unterschied mehr zwischen den chirurgischen Verfahren in Bezug auf alle untersuchten Ergebnisse.

Fazit: Trotz gleicher Inkontinenzraten drei Monate nach der Operation sprechen die vier-Wochen Follow-up-Ergebnisse für das ER-modifizierte Verfahren. Diese Ergebnisse könnten durch die weniger traumatische Enukleation und die schnellere Rekonvaleszenz durch das modifizierte Verfahren erklärt werden.

3K08.12

Prostatakarzinom beeinflusst nicht das peri- oder postoperative Outcome: Eine prospektive MulticenterAnalyse der Thulium-Vapoenukleation der Prostata von 1256 Patienten

T. Lamersdorf', C. Netsch', B. Benedikt', S. Tauber², C. Wülfing ${ }^{3}$, T. Bach ${ }^{4}$ O. Engel ${ }^{5}$, A. Gross' ${ }^{1}$, C. Rosenbaum ${ }^{*}$

${ }^{1}$ Asklepios Klinik Hamburg Barmbek, Urologie, Hamburg, Deutschland; ${ }^{2}$ Asklepios Klinik Wandsbek, Urologie, Hamburg, Deutschland; ${ }^{3}$ Asklepios Klinik Altona, Urologie, Hamburg, Deutschland; ${ }^{4}$ Asklepios Westklinikum Hamburg, Urologie, Hamburg, Deutschland; ${ }^{5}$ Asklepios Klinik Harburg, Urologie, Hamburg, Deutschland
Ziel war Ergebnisse der Thulium-Vapoenukleation der Prostata (ThuVEP) bei Patienten (Pt) mit LUTS und Prostata-Karzinom (PCa) zu evaluieren. Prospektive Multicenter-Analyse von $1256 \mathrm{Pt}$, mit ThuVEP operiert. Vergleich des Outcomes von PCa- und Nicht-PCa-Patienten.

$994 \mathrm{Pt}$ mit vollständigen Daten, $708 \mathrm{Pt}$ ohne und $286(28,8 \%)$ mit PCa. 141 D'Amico-Niedrig- (49,3\%), 110 -Intermediär- $(38,5 \%)$ und 25 -HochRisiko-Pt (8,7\%). PCa-Pt waren älter, hatten kleinere Prostatae und höhere PSA-Werte (alle $p<0,001$ ). Keine Unterschiede intra- und perioperativ, bei Komplikationen oder Re-OPs. IPSS, QoL, RH und Qmax verbesserten sich in beiden Gruppen (alle $p<0,001$ ). Langzeit-Outcome s. D Tab. 1. Niedrigvs Intermediär-/Hoch-Risiko-Pt: Keine Unterschiede.

ThuVEP ist sicher bei LUTS, unabhängig vom Vorliegen eines Pca. Inkontinenzraten sind bei Pca-Pt im Langzeitverlauf höher.

\section{K08.13}

Extraperitoneal Extravesical Robotic-Assisted Simple

Prostatectomy (EE-RASP) with vesico-urethral

anastomosis excluding the prostatic fossa: a new operative technique to treat large adenomas

\section{O. Burkhardt", M. Tutal, C. Padevit, B. Förster, H. John}

Kantonsspital Winterthur, Urologie, Winterthur, Switzerland

Introduction: Robotic assisted prostate adenomectomy (RASP) was first demonstrated by John et al. 2007 at the AUA. Simple robotic prostatectomy has been modified using different techniques. We propose a new operative technique with extraperitoneal approach, extravesical prostate adenomectomy and reconstruction of the prostatic urethra by running suture of the bladder neck with the intraprostatic urethra (EE-RASP).

Surgical techniques: Extraperitoneal access is performed with placement of a 4-arm daVinci $\mathrm{X}^{\circledR}$ System. The bladder neck and the proximal prostatic urethra are prepared and dissected.

The enucleation of the prostate gland is performed. The urethral tract is reconstructed according to van Velthoven of the bladder neck with the intraprostatic urethral stump excluding the prostatic fossa totally. Suprapubic and transurethral catheters are placed.

Results: We performed EE-RASP in 25 patients with a median age of 72 and a prostate size of $120 \mathrm{ml}$. The operative time of 175 min was observed with a blood loss of $200 \mathrm{ml}$. The median preoperative residual urine and $\mathrm{Q}_{\max }$ were $125 \mathrm{ml}$ and $6.7 \mathrm{ml} / \mathrm{sec}$ respectively compared to postoperative $0 \mathrm{ml}$ and $19 \mathrm{ml} / \mathrm{sec}$. The transurethral catheter was removed on the first postoperative day, the suprapubic catheter on the eighth. Two months after the operation, no incontinence-pads were used.

Conclusion: The EE-RASP is a minimal invasive technique with low complication rate and good functional outcome. The reconstruction of the prostatic urethra, thus excluding the prostatic fossa completely, prevents postoperative complications from the prostatic fossa as postoperative prostate fossa bleeding, urgency, frequency, bladder neck and urethral strictures. In plus, even transurethral irrigation has become obsolete.

Tab. 1 | 3K08.12 Erst- und Zweit-Jahres-Follow-up nach ThuVEP

\begin{tabular}{|l|l|l|l|l|}
\hline & Alle & Kein PCa & PCa & $p$-Wert \\
\hline 1. Jahr: IPSS; mean (SD) & $7,1( \pm 6,8)$ & $6,9( \pm 6,8)$ & $7,5( \pm 6,7)$ & 0,37 \\
\hline 1. Jahr: QoL; mean (SD) & $1,8( \pm 2,1)$ & $1,8( \pm 2,2)$ & $1,9( \pm 1,7)$ & 0,38 \\
\hline 1. Jahr: $\leq 1$ Vorlage/Tag; $n(\%)$ & $443(87,7)$ & $317(89,0)$ & $126(84,6)$ & 0,11 \\
\hline 1. Jahr: $\geq 2$ Vorlagen/Tag; $n(\%)$ & $62(12,3)$ & $39(11,0)$ & $23(15,4)$ & $7,9( \pm 7,2)$ \\
\hline 2. Jahr: IPSS; mean (SD) & $7,0( \pm 6,6)$ & $6,8( \pm 6,4)$ & $1,9( \pm 1,7)$ & 0,29 \\
\hline 2. Jahr: QoL; mean (SD) & $1,8( \pm 1,6)$ & $1,7( \pm 1,6)$ & $40(75,5)$ & 0,45 \\
\hline 2. Jahr: $\leq 1$ Vorlage/Tag; $n(\%)$ & $212(84,8)$ & $172(87,3)$ & $13(24,5)$ & 0,05 \\
\hline 2. Jahr; $\geq 2$ Vorlagen/Tag; $n(\%)$ & $38(15,2)$ & $25(12,7)$ & \\
\hline
\end{tabular}


3K08.14

Standardisierte Erfassung postoperativer Komplikationen: ein Vergleich zwischen offener und laparoskopisch, roboterassistierter (DaVinci) Adenomenukleation

\section{J. Weber*, M.-O. Grimm, S. Foller}

Universitätsklinikum Jena, Klinik und Poliklinik für Urologie, Jena, Deutschland

Fragestellung: Zur Behandlung der BPH stehen bei großen Prostatavolumina (PV) verschiedene OP-Methoden zur Verfügung. Die offene Adenomenukleation (0) war lange Goldstandard. Aktuell werden u. a. die Laserenukleation, Wasserstrahlablation $u$. laparoskopische, roboterassistierte Adenomenukleation eingesetzt. Seit 2011 ist das DaVinci-Operationssystem in unserer Klinik etabliert; seit 2017 wird die Adenomenukleation mit dem DaVinci (DV) durchgeführt. Prä- und intraop. Parameter und postop. Komplikationen wurden standardisiert nach Clavien-Dindo-Klassifikation (CDC) erfasst, um beide Verfahren zu vergleichen.

Material und Methoden: Zwischen 08/2012 und 06/2020 wurden an unserer Klinik 115 Pat. mit den o.g. Verfahren operiert ( $n=59$; DV $n=56)$. Das mittl. Alter der Patienten betrug 72 J.. Das PV lag zwischen $45 \mathrm{u}$. $250 \mathrm{ml}$.

Ergebnisse: $\ln 17$ Fällen ( $n=10$; DV $n=7$ ) war eine höhergradige Komplikation (Grad 3a/b n. CDC) zu beobachten (0: 6 Blasentamp./Bltg., 2 Wundinfekte, 2 Hydronephrosen; DV: 5 Blasentamp., 1 Hydronephrose. 1 relev. Restadenom). $49 \mathrm{Grad} 1 / 2 \mathrm{Kompl}$. wurden unter den robot. und 67 unter den offenen OPs beobachtet (O/DV: 34/22 HWI, 6/3 Hb-Abfall, 2/7 hypertensive Episoden u. a.). 29 Pat. waren ohne Kompl. ( $0 n=11$, DV $n=18), 53$ Pat. hatten 1 Kompl. (O $n=30, \mathrm{DV} n=23)$; übrige Pat. mit 2 u. mehr Kompl. (O $n=17, \mathrm{DV} n=16)$.

Schlussfolgerung: Re-Intervention (CDC Grad 3) wurden in beiden Gruppen beobachtet (vornehmlich b. Nachblutungen). Grad 4/5 Kompl. traten nicht auf. Grad 1/2 Kompl. traten nach offener OP häufiger auf. In der robot. Gruppe fanden sich mehr Patienten bei denen keine Komplikationen beobachtet wurden. Robotisch operierte Pat. profitierten von einem sign. geringeren Blutverlust ( 318 vs $538 \mathrm{ml}, p<0,001$ ); die OP dauerte jedoch sign. länger (219 vs $133 \mathrm{~min}, p<0,001)$.

\section{K08.15}

Modifikation der YV-Plastik in der offen-chirurgischen Salvage-Therapie rezidivierender Blasenhalsstenosen: Langzeitergebnisse der T-Plastik

F. König*, R. Dahlem, P. Marks, L. Kühnke, M. Khonsari, M. Fisch, M.W. Vetterlein Universitätsklinikum Hamburg-Eppendorf, Klinik und Poliklinik für Urologie, Hamburg, Deutschland

Die Blasenhalsstenose (BHS) stellt ein bekanntes Problem nach transurethraler Desobstruktion bei benigner Prostatahyperplasie (BPH) dar. Zur offen-chirurgischen Therapie bei rezidivierenden BHS etablierten wir die TPlastik, eine Modifikation der YV-Plastik.

Wir identifizierten Männer mit rezidivierender BHS, die sich von 2008-19 einer T-Plastik unterzogen. Über einen retropubischen Zugang wird die Blasenwand T-förmig inzidiert, die Narbe exzidiert und zwei gut vaskularisierte Lappen aus gesunder Blasenwand mit der prostatischen Harnröhre vernäht. Klinische und chirurgische Parameter sowie funktionelle Ergebnisse wurde mittels validierter Fragebögen (ICIQ-UI SF, 6-item LUTS Score) erfasst. Das Rezidiv wurde als Re-Intervention bei erneuter BHS definiert. 48 Männer erhielten eine T-Plastik bei im Median 3 (IQR 2-4) vorangegangen endoskopischen Sanierungen. Bei Aufnahme waren 36 Patienten (75\%) SPDK-versorgt, der mediane präoperative Qmax lag bei 7,3 ml/s und verbesserte sich zu $25 \mathrm{ml} / \mathrm{s}$ postoperativ. Der Behandlungserfolg nach medianen Followup von 67 Monaten lag bei $94 \%$. 3 Patienten erlitten ein Rezidiv. Gemäß ICIQ-UI SF waren 27 (63\%) vollständig kontinent, der mediane Score (0-21) lag bei 0 (IQR 0-4). Insgesamt waren 37 Männer $(86 \%)$ mit dem OP-Ergebnis zufrieden. Der mediane 6-item LUTS Score (0-24) betrug 2 (IQR 2-3), was eine normalisierte postoperative Miktion widerspiegelt.

In der Salvage-Situation bei therapierefraktären BHS kann durch T-förmige Inzision und bilaterale, gut vaskularisierte Lappen ein spannungsfreier Blasenhals etabliert werden, welcher beständige, gute Miktionsverhältnisse ermöglicht. Somit stellt die T-Plastik eine valide Alternative zur permanenten Harnableitung dar. Eine robotisch-assistierte Adaptation erscheint zudem praktikabel.

\section{K08.16}

Die Langzeitergebnisse der Urethrotomia Interna bei primären Harnröhrenstrikturen - Eine populationsbasierte Analyse

K. Eredics' , F. Röthlin ${ }^{2}$, D. Wachabauer ${ }^{2}$, S. Sevcenco ${ }^{3,4}$, M. Marszalek', K. Mock ${ }^{3}$, S. Madersbacher ${ }^{5,6}$

'Klinik Donaustadt, Wien, Österreich; ${ }^{2}$ Gesundheit Österreich GmbH, Wien, Österreich; ${ }^{3}$ Klinik Donaustadt, Urologie, Wien, Österreich; ${ }^{4}$ Paracelsus Medizinische Privatuniversität, Salzburg, Österreich; ${ }^{5}$ Klinik Favoriten, Urologie, Wien, Österreich; ${ }^{6}$ Sigmund Freud Privatuniversität, Urologie, Wien, Österreich

Einleitung: Ziel unserer Arbeit war die Ermittlung des Langzeitergebnisses der endoskopischen Urethrotomie bei primären Harnröhrenstrikturen anhand einer populationsbasierten Analyse.

Methoden: Analyse einer bundesweiten Datenbank aller Patienten mit Harnröhrenstrikturen, bei denen zwischen Januar 2006 und Dezember 2007 eine endoskopische Urethrotomie als primäre Intervention durchgeführt wurde. Alle Patienten wurden 7 bis 9 Jahre lang nachverfolgt. Reinterventionen wurden in drei Behandlungstypen unterteilt: Urethrotomie, Augmentationsurethroplastie und Strikturresektion mit End-zuEnd-Harnröhrenanastomose.

Ergebnisse: Insgesamt wurden 1203 Männer wurden im Indexzeitraum behandelt. Das mittlere Patientenalter betrug 63 Jahre $(S D \pm 15,7)$ und lag zwischen 20 und 85 Jahren. Insgesamt 136 Patienten (11\%) starben während der Beobachtungszeit. Innerhalb der Nachbeobachtungszeit benötigten 932 Patienten (78\%) keine weitere chirurgische Intervention aufgrund eines Rezidivs und 176 Patienten (14,6\%) benötigten ein, 53 (4,5\%) zwei und 41 (3,4\%) drei oder mehr Eingriffe. Die mittlere Anzahl der ReInterventionen betrug 1,5 pro Patient, die niedrigste Re-Interventionsrate war bei Patienten $>80$ Jahren (13,9\%). In 236 Fällen (68\%) wurde mindestens eine wiederholte Urethrotomie durchgeführt. In 87 Fällen (32\%) erfolgte eine offene Rekonstruktion der Urethra, mit einer Augmentationsurethroplastie bei 21 Patienten (24\%) und einer Strikturresektion mit End-zu-End-Anastomose bei 66 Patienten (76\%). Die mittlere Dauer bis zur Reintervention betrug 29,5 Monate.

Schlussfolgerung: Die Reinterventionsrate nach primärer Urethrotomie innerhalb eines Beobachtungszeitraums von 8 Jahren beträgt $22 \%$ und ist am niedrigsten bei Patienten mit fortgeschrittenem Alter.

\section{K08.17}

Salvage-Therapie komplexer Harnröhrenstrikturen: Technik und Ergebnisse der zweizeitigen MeshgraftUrethroplastik unter Verwendung eines SpalthautAutotransplantats

L. Kühnke*, R. Dahlem, P. Marks, M. Khonsari, F. König, M. Fisch, M.W. Vetterlein

Universitätsklinikum Hamburg-Eppendorf, Klinik und Poliklinik für Urologie, Hamburg, Deutschland

Es existieren begrenzte Optionen für Patienten mit komplexen Harnröhrenstrikturen. Die Anlage einer Boutonnière oder suprapubischen Harnableitung ist bei rezidivierenden Strikturen oft unvermeidlich. Wir 
präsentieren Technik und funktionelle Ergebnisse der zweizeitigen Harnröhrenrekonstruktion mittels Spalthaut-Autotransplantation (MeshgraftUrethroplastik, MGU) im Sinne eines Salvage-Therapieansatzes.

Einschlusskriterien:

Männer mit Harnröhrenstrikturen zwischen 2011-17, die einer MGU unterzogen wurden. Nach ventraler Inzision der Striktur auf gesamter Länge und Exzision der Narbe wird ein freies Spalthauttransplantat als Neourethralbett fixiert und mit den skrotalen und penilen Hauträndern vernäht. Der erste Verbandswechsel erfolgt nach 7 Tagen Bettruhe. Zweite Sitzung zur Tubularisierung der Harnröhre nach 3 Monaten. Funktionelle Ergebnisse wurden anhand validierter PROMs erhoben. Das Rezidiv wurde als Re-Intervention definiert.

83 Patienten wurden rekonstruiert, 37 (45\%) und 9 (11\%) Patienten mit 1- bzw. 2-zeitiger offener Rekonstruktion in der Anamnese. $30 \%$ der Strikturen waren idiopathisch, $28 \%$ hypospadieassoziiert. Mediane Transplantatlänge und Intervall zwischen 1. und 2. Sitzung waren $15 \mathrm{~cm}$ und 98 Tage. Harnröhrenkalibrierung vor 2. Sitzung durchschnittlich $18 \mathrm{CH}$. Uroflowmetrisch deutliche Verbesserung von Qmax 9,6 ml/s auf $26 \mathrm{ml} / \mathrm{s}$. PROMs waren von 53 (64\%) Patienten verfügbar, nach medianem Followup von 59 Monaten waren $60(72 \%)$ rezidivfrei. Der mediane 6-item LUTS Score (0-24) betrug 3, 41 Männer (77\%) waren vollständig kontinent nach ICIQ-UI SF. Insgesamt 40 (75\%) waren mit der Miktionslage postoperativ (sehr) zufrieden.

Die MGU ist ein valider, kurativer Ansatz in der Salvage-Therapie komplexer Harnröhrenstrikturen mit beständigem, funktionellem Outcome.

3K08.18

Ist ein postoperatives Miktionscystourethrogramm nach Urethraplastik mit Mundschleimhauttransplantation (OMG) wirklich notwendig?

\section{J. Aich", T. Klein, C. Hüttenbrink, S. Pahernik, A. Pandey}

Klinikum Nürnberg, Klinik für Urologie, Nürnberg, Deutschland

Fragestellung: Der Goldstandard zur Behandlung einer rezidivierenden Harnröhrenstriktur ist die Urethraplastik mit Mundschleimhaut (OMG). Es besteht allerdings kein Konsens über das postoperative Management und vor allem über die postoperative Bildgebung. Wir untersuchten die Fragestellung, ob ein Miktionscystourethrogramm (MCU) nach Urethraplastik erforderlich ist.

Methoden: In dieser retrospektiven Kohortenstudie untersuchten wir 78 Patienten, bei denen von 09/2018 bis 10/2020 eine einzeitige ventrale Onlay-OMG-Urethraplastik durchgeführt wurde. Alle Patienten erhielten einen transurethralen Dauerkatheter (DK) für 3 Wochen und anschließend ein MCU.

Ergebnisse: Die mittlere Strikturlänge bertug $6,75 \mathrm{~cm}(2,5-20)$ In nur 3 von 78 (3, $85 \%)$ Fällen zeigte das MCU am 21. Tag eine Extravasation. Ein weiteres MCU wurde nach 2 Wochen durchgeführt und war bei allen $3 \mathrm{~Pa}-$ tienten unauffällig, sodass der DK entfernt werden konnte.

Die Komplikationen waren:

oberflächliche Wundheilungsstörung $(2,53 \%)$, eine Katheterdislokation $(1,28 \%)$ und Fieber $(1,28 \%)$ sowie Epididymitis $(1,28 \%)$.

Schlussfolgerungen: Unsere Studie zeigt, dass die Rate der Extravasation nach der einzeitigen Harnröhrenplastik sehr gering ist. Sollten sich unsere Ergebnisse auch in einem größeren Patientenkollektiv bestätigen, kann auf eine routinemäßige Bildgebung nach der einzeitigen Harnröhrenplastik ohne weiteren Risikofaktoren (z. B. Radiatio, ausgedehnte Wundheilungsstörung) verzichten werden.

Schlüsselwörter: Harnröhre

Striktur

BMG

MCU

Urethroplastik

\section{K09 - Fortgeschrittenenes Prostatakarzinom}

$$
\text { 17.09.2021, C5.2, 13:30-15:00 }
$$

\section{K09.1}

Verlängerung der Hormonsensitivität und Verzögerung der Kastrationsresistenz - eine monozentrische Analyse nach radikaler Prostatektomie bei T4 Prostatakarzinom

\section{Saar", C. Maßmann, J. Linxweiler, K. Junker, S. Siemer, M. Stöckle}

Universität des Saarlandes, Klinik für Urologie und Kinderurologie, Homburg, Deutschland

Einleitung: Immer mehr klinische Daten suggerieren einen Vorteil der Therapie des Prostatatumors auch bei oligometastasierten Patienten. Dabei ist bisher nicht geklärt, warum der Primarius einen Einfluss auf das Therapieansprechen hat. Wir haben das Therapieansprechen unserer Patienten nach Prostatektomie eines T4 Lokalbefundes nachverfolgt.

Material und Methoden: Eine monozentrische Kohorte mit Langzeitüberleben nach induktiver Therapie und radikaler Prostatektomie bei T4 Prostatakarzinom wurde auf ihr Therapieansprechen auf die unterschiedlichsten Arten der Hormonmanipulation nachuntersucht.

Ergebnisse: Es konnte ein biochemisch rezidivfreies, karzinomfreies und Gesamtüberleben nach 200 Monaten von $20 \%$, $65 \%$ und $47 \%$ festgestellt werden. Das mediane Gesamtüberleben lag bei erstaunlichen 156 Monaten. Dabei zeigten die Patienten, obwohl sie zumeist nicht vom Tumor kuriert waren ein Langzeitüberleben. Sogar die Patienten, die ein Rezidiv aufwiesen, zeigten nach 150 Monaten ein PCa spezifisches und ein Gesamtüberleben von $61 \%$ bzw. $44 \%$. Diese Überlebensdaten ergaben sich hauptsächlich aus einem Langzeitansprechen auf die hormonmanipulativen Therapien.

Schlussfolgerung: Aufgrund eines Langzeitansprechens auf die primäre und sekundäre Hormontherapie zeigen Patienten nach radikaler Prostatektomie, auch wenn sie durch die Operation nicht geheilt werden, ein dauerhaftes Überleben. Diese Ergebnisse legen nahe, dass durch die Behandlung der tumortragenden Prostata eine Kastrationsresistenz verzögert wird und der Effekt der Androgendeprivation verstärkt wird. Dabei sind die zellulären und molekularen Ursachen dieses Phänomens unbekannt, ihre weitere Aufklärung könnte aber die Behandlung des fortgeschrittenen Prostatakarzinoms maßgeblich beeinflussen.

\section{K09.2}

\section{Einfluss der PSA-Persistenz auf das onkologische} Outcome nach Salvage radikaler Prostatektomie

\section{F. Preisser ${ }^{1 *}$, R. M. Pose ${ }^{2}$, A. Heinze ${ }^{2}$, T. Steuber ${ }^{2}$, U. Michl², G. Salomon ${ }^{2}$,} F. K.-H. Chun', M. Graefen², D. Tilki ${ }^{2}$

${ }^{1}$ Abteilung für Urologie, Universitätsklinikum Frankfurt, Frankfurt, Deutschland; ${ }^{2}$ MartiniKlinik Prostate Cancer Center, Universitätsklinikum Hamburg-Eppendorf, Hamburg, Deutschland

Ziel: Prostataspezifische Antigen (PSA) Persistenz stellt einen schlechten Prognosefaktor nach radikaler Prostatektomie dar. Der Einfluss einer PSA Persistenz auf das onkologische Outcome nach Salvage Prostatektomie (SRP) ist jedoch unbekannt.

Methoden: Aus der Datenbank eines High-Volume Centers wurden Patienten, bei denen zwischen 2004 und 2020 eine SRP aufgrund eines Prostatakarzinom Lokalrezidivs durchgeführt wurde, identifiziert. Nur Patienten mit verfügbarem PSA nach SRP wurden eingeschlossen. Kaplan-Meier-Analysen und multivariate Cox-Regressionsmodelle wurden verwendet, um die Auswirkung eines persistierenden PSA-Werts, definiert als PSA $\geq 0,1 \mathrm{ng} / \mathrm{ml}$ postoperativ, auf das Risiko eines biochemisches Rezidivs (BCR), einer Metastasierung und Tod nach SRP zu testen. 
Ergebnisse: Insgesamt wurden 145 Patienten identifiziert von denen $38,6 \%(n=56)$ eine PSA Persistenz hatten. Die mediane Nachbeobachtungszeit betrug 47 Monate, die mediane Zeit bis zum ersten PSA-Wert nach der SRP betrug 13,7 Wochen. 72 Monate nach SRP betrug das BCRfreie, metastasenfreie und Gesamtüberleben 77,6 vs. $13,4 \%, 100$ vs. $78,6 \%$ und 96,3 vs. $80,0 \%$ bei Patienten mit persistierendem vs. nicht nachweisbarem PSA nach SRP (alle $p$-Werte $<0,01$ ). In der multivariaten Analyse war ein persistierender PSA-Wert ein unabhängiger Prädiktor für ein BCR (HR: 8,83, $p<0,001)$. In der multivariaten logistischen Regression war ein höherer präoperativer PSA-Wert ein unabhängiger Prädiktor für eine PSA-Persistenz nach SRP (OR: 1,08, $p=0,02$ ).

Schlussfolgerung: PSA Persistenz nach SRP ist häufig und stellt einen unabhängigen Prädiktor für ein schlechteres onkologisches Outcome dar. SRP Patienten sollten nach der Operation engmaschig überwacht werden, um Patienten mit PSA Persistenz zu identifizieren.

\section{K09.3}

Feasibility of radical salvage prostatectomy (RSP) in men with radiorecurrent prostate cancer ( $\mathrm{rPCA}$ ) following multiple lines of radiation therapy (RT)

\section{Schmautz*, J. Heidenreich, D. Pfister, A. Heidenreich}

Uniklinik Köln, Köln, Germany

Purpose: RSP represents a secondary curative approach in the management of rPCA with organ confined disease. Its role in the treatment of rPCA following multiple lines of RT is unclear with regard to oncological and functional outcome and complications.

Patients and methods: A case-control study of $n=15$ with rPCA following one type of RT (group 1) compared to $n=15$ with 3 lines of RT (group 2) was performed. Group 2 received IMRT, LDR-BT and HDR-BT in different sequences. All men underwent PSMA-PET/CT, mpMRT and transperineal prostate biopsy prior to open retropubic RSP. We compared pathohistology, bNEDI, overall survival and complications according to Clavien Dindo. Results: Median age was 67.5 (42-79) and 59.2 (43-65) years, median PSA at RSP was $4.93(0,9-41,9)$ and $4.32(1.1-23.4) \mathrm{ng} / \mathrm{ml}$. In group $1,46.7 \%$ pts exhibited pT2a-c, $20 \%$ and $33.9 \%$ demonstrated pT3a or pT3b, resp. $\mathrm{pN}+$ was identified in $26.7 \%$, positive surgical margins were present in $26.7 \%$. bNED was $60 \%$ for the total cohort and $85.7 \%, 66.7 \%$, and $60 \%$ for pT2, pT3a, pT3b. PFS for pN+ was $25 \%$. In group 2, $40 \%, 13.3 \%$ and $46.7 \%$ had pT2a-c, pT3a or pT3b, resp. pN+ was identified in $40 \%$, positive surgical margins were present in 30\%. bNED was $40 \%$ for the total cohort and $83.3 \%, 50 \%, 42.8 \%$ for pT2, pT3a, and pT3b. PFS for pN+ was $25 \%$. Median follow-up was 45 (31-67) and 40 (34-62) months, OS was $86.7 \%$ for both groups. Grad III \& IV complications developed in $13.3 \%$ and $26.7 \%$, resp. Complete continence was achieved in $66.7 \%$ and $53.3 \%$, resp., severe incontinence developed in $13.3 \%$ and $26.7 \%$, resp.

Conclusion: RSP following multiple lines RT is technically feasible but with an inferior oncological and functional outcome. These data must be conseidered when counselling the patient for redo-RT or RSP.

\section{K09.4}

\section{Einfluss der Lymphadenektomie und} Lymphknoteninfiltration im Rahmen der Salvage radikalen Prostatektomie auf das onkologische Outcome

F. Preisser ${ }^{1 *}$, R. M. Pose ${ }^{2}$, A. Heinze ${ }^{2}$, T. Steuber ${ }^{2}$, U. Michl², G. Salomon², F. K.-H. Chun', M. Graefen², D. Tilki ${ }^{2}$

${ }^{1}$ Abteilung für Urologie, Universitätsklinikum Frankfurt, Frankfurt, Deutschland; ${ }^{2}$ MartiniKlinik Prostate Cancer Center, Universitätsklinikum Hamburg-Eppendorf, Hamburg, Deutschland
Ziel: Die Lymphknoteninfiltration (LNI) stellt einen schlechten Prognosefaktor nach Prostatektomie dar. Der Einfluss der Lymphadenektomie (LND) und LNI auf das onkologische Outcome bei Salvage-Prostatektomie (SRP) Patienten ist jedoch unklar.

Methoden: Aus der Datenbank eines High-Volume Centers wurden Patienten, bei denen 2004-2020 eine SRP bei Prostatakarzinom-Lokalrezidiv durchgeführt wurde, identifiziert. Kaplan-Meier-Analysen und multivariate Cox-Modelle wurden verwendet, um die Auswirkung von LNI und LND auf das biochemische Rezidiv (BCR), Metastasierung und Tod nach SRP zu testen.

Ergebnisse: Insgesamt wurden 201 SRP Patienten identifiziert, von denen $91,0 \%$ eine LND und 21,3\% eine LNI hatten. Es wurden keine Unterschiede in den Komplikationsraten zwischen Patienten mit und ohne LND festgestellt. Die mittlere Anzahl entfernter Lymphknoten betrug 14 in der LND-Kohorte. 60 Monate nach SRP war das BCR-freie Überleben 75,0 vs. 70,1 vs. $14,9 \%$ bei Patienten ohne LND vs. ohne LNI vs. LNI $(p<0,001)$. 108 Monate nach SRP war das metastasenfreie und Gesamtüberleben 100 vs. 85,3 vs. $14,7 \%(p<0,001)$ und 67,0 vs. 92,1 vs. $17,3 \%(p<0,01)$ bei Patienten ohne LND vs. ohne LNI vs. LNI. In der multivariaten Analyse stellte die LNI ein unabhängigen Prädiktor für ein BCR (HR: 3,77, $p<0,001)$ und Tod nach SRP (HR: 5,61, $p<0,01)$ dar. 120 Monate nach SRP wurden keine Unterschiede im BCR-freien, metastasenfreien und Gesamtüberleben zwischen Patienten mit und ohne LND festgestellt (alle $p$-Werte $>0,1$ ). Die Anzahl an entfernten Lymphknoten war kein Prädiktor für ein BCR oder Tod nach SRP.

Fazit: Die LND im Rahmen der SRP ist eine sichere diagnostische Prozedur. Ihr klinischer Nutzen bleibt umstritten. Die LNI im Rahmen der SRP stellt einen unabhängigen schlechten Prognosefaktor dar.

\section{K09.5}

Efficacy of enzalutamide (ENZA)+androgen deprivation therapy (ADT) in men with de novo (M1) metastatic hormone-sensitive prostate cancer ( $\mathrm{mHSPC}$ ) vs progression to $\mathrm{mHSPC}(\mathrm{M} 0)$ : post hoc analysis of the Phase 3 ARCHES trial

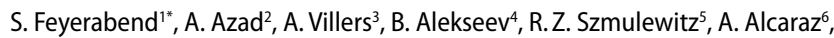
N. D. Shore ${ }^{7}$, D. P. Petrylak', J. Holzbeierlein ${ }^{9}$, F. Gomez-Veiga ${ }^{10}$, B. Rosbrook ${ }^{11}$, F. Zohren ${ }^{11}$, H.-J. Lee ${ }^{12}$, G. P. Haas ${ }^{12}$, T. Iguchi ${ }^{13}$, A. Stenzl ${ }^{14}$, A. J. Armstrong ${ }^{15}$

${ }^{1}$ Studienpraxis Urologie, Nürtingen, Germany; ${ }^{2}$ Monash Health, Melbourne, Victoria, Australia; ${ }^{3}$ University Hospital Centre, Lille University, Lille, France; ${ }^{4}$ Hertzen Moscow Cancer Research Institute, Moscow, Russische Föderation; ${ }^{5}$ The University of Chicago, Chicago, IL Vereinigte Staaten von Amerika; ${ }^{6} \mathrm{H}$ ospital Clinic de Barcelona, Barcelona, Spain; ${ }^{7}$ Carolina Urologic Research Center, Myrtle Beach, SC, Vereinigte Staaten von Amerika; ${ }^{8}$ Yale Cancer Center, New Haven, CT, Vereinigte Staaten von Amerika; ${ }^{9}$ The University of Kansas Medical Center, Kansas City, KS, Vereinigte Staaten von Amerika; ${ }^{10} \mathrm{Hospital}$ Universitario de Salamanca, GITUR-IBSAL, Salamanca, Spain; ${ }^{11}$ Pfizer Inc., San Diego, CA, Vereinigte Staaten von Amerika; ${ }^{12}$ Astellas Pharma Inc., Northbrook, IL, Vereinigte Staaten von Amerika; ${ }^{13}$ Osaka City University Graduate School of Medicine, Osaka, Japan; ${ }^{14}$ University Hospital, Eberhard Karls University, Tübingen, Germany; ${ }^{15}$ Duke Cancer Institute Center for Prostate \& Urologic Cancers, Durham, NC, Vereinigte Staaten von Amerika

Introduction: Exploratory analysis to assess the efficacy of ENZA+ADT in patients (pts) from ARCHES (NCT02677896) who progressed to M1 HSPC following initial diagnosis (M0) vs pts who presented with de novo $\mathrm{mHSPC}$ at diagnosis (M1).

Material and methods: $\mathrm{mHSPC}$ pts $(n=1150)$ were randomized 1:1 to ENZA ( $160 \mathrm{mg} /$ day)+ADT or placebo (PBO)+ADT, stratified by disease volume and prior docetaxel use. In this post hoc analysis, pts previously centrally categorized as unknown metastasis at initial diagnosis $(n=213)$ were adjudicated as either M0 or M1 disease following medical profile review; efficacy outcomes were compared according to M0 vs M1 disease at initial diagnosis.

Results: 246 pts (ENZA, $n=117 ; \mathrm{PBO}, n=129)$ had M0 and 890 pts (ENZA, $n=448 ;$ PBO, $n=442$ ) had M1 disease at initial diagnosis. At baseline, a greater proportion of $\mathrm{M} 1 \mathrm{pts}$ had high disease volume $(68.1 \%$ vs $47.2 \%$ 


\begin{tabular}{|c|c|c|c|c|c|c|}
\hline & $\begin{array}{l}\text { rPFS' events, } n \\
\text { (\%) }\end{array}$ & $\begin{array}{l}\text { rPFS, } \\
\text { HR }(95 \% \mathrm{Cl})^{d}\end{array}$ & $\begin{array}{l}\text { Time to PSA } \\
\text { progression, HR } \\
(95 \% \mathrm{Cl})^{d}\end{array}$ & $\begin{array}{l}\text { Time to new } \\
\text { antineoplastic } \\
\text { therapy, } \\
\text { HR }(95 \% \mathrm{Cl})^{d}\end{array}$ & $\begin{array}{l}\text { PSA undetectable } \\
\text { rate } \\
(<0.2 \mathrm{ng} / \mathrm{mL}))^{e} \\
\% \text { difference } \\
(95 \% \mathrm{Cl})\end{array}$ & $\begin{array}{l}\text { Objective respon- } \\
\text { se rate, } \\
\% \text { difference } \\
(95 \% \mathrm{Cl})\end{array}$ \\
\hline 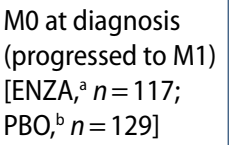 & $\begin{array}{l}16(13.7)_{i}^{a} \\
34(26.4)^{b}\end{array}$ & $\begin{array}{l}0.42 \\
(0.23,0.76)\end{array}$ & $\begin{array}{l}0.12 \\
(0.04,0.34)\end{array}$ & $\begin{array}{l}0.32 \\
(0.15,0.66)\end{array}$ & $\begin{array}{l}45.4 \\
(33.9,56.9)\end{array}$ & $\begin{array}{l}18.5 \\
(-7.4,44.4)\end{array}$ \\
\hline $\begin{array}{l}\text { M1 at diagnosis } \\
\text { (de novo) [ENZA, } \\
n=448 ; \text { PBO, }^{\text {b }} \\
n=442 \text { ] }\end{array}$ & $\begin{array}{l}73(16.3)_{i}^{\mathrm{a}} \\
166(37.6)^{\mathrm{b}}\end{array}$ & $\begin{array}{l}0.38 \\
(0.29,0.50)\end{array}$ & $\begin{array}{l}0.20 \\
(0.14,0.28)\end{array}$ & $\begin{array}{l}0.27 \\
(0.18,0.40)\end{array}$ & $\begin{array}{l}53.6 \\
(48.1,59.1)\end{array}$ & $\begin{array}{l}20.1 \\
(10.9,29.4)\end{array}$ \\
\hline \multicolumn{7}{|c|}{$\begin{array}{l}\text { CI confidence interval; } H R \text { hazard ratio. } \\
\text { aENZA+ADT; bPBO+ADT; ' Assessed by independent central review or death within } 24 \text { weeks of treatment discontinuation; }{ }^{\text {a } H R}<1 \text { favors ENZA; }{ }^{\circ} \text { Of those with detectab- } \\
\text { le PSA or measurable soft tissue disease at baseline; Difference }>0 \text { favors ENZA. } \\
\text { This study was funded by Astellas Pharma Inc. and Pfizer Inc., the co-developers of enzalutamide. Medical writing and editorial assistance were provided by Lianne } \\
\text { Young, BSC (Hons), and Jane Beck, MA, from Complete HealthVizion, funded by the study sponsors. } \\
\text { ( } 2021 \text { American Society of Clinical Oncology, Inc. Reused with permission. This abstract was accepted and previously presented at the } 2021 \text { Genitourinary Cancers } \\
\text { Symposium. All rights reserved }\end{array}$} \\
\hline
\end{tabular}

[M0]) and prior docetaxel (19.4\% vs $11.8 \%$ [M0]). ENZA+ADT improved radiographic progression-free survival (rPFS) vs PBO+ADT irrespective of M0 or $\mathrm{M} 1$ disease at diagnosis; similar improvements were observed for secondary endpoints including prostate-specific antigen (PSA) and objective responses, time to PSA progression, time to new antineoplastic therapy (Table). Safety profiles were generally similar between subgroups and the overall population; exceptions include higher fatigue in MO ENZA and PBO arms.

Conclusions: This post hoc analysis demonstrates clinical benefit of ENZA+ADT vs PBO+ADT based on rPFS and secondary endpoints in men who progressed from M0 to M1 HSPC and those with de novo M1 HSPC.

\section{K09.6}

Analysis of the effect of crossover from placebo (PBO) to darolutamide (DARO) on overall survival (OS) benefit in the ARAMIS Trial

M. Bögemann ${ }^{1 *}$, N.D. Shore ${ }^{2}$, K. Fizazi ${ }^{3}$, T. L. Tammela ${ }^{4}$, M. Luz ${ }^{5}$, M.P. Salas ${ }^{6}$ P. Ouellette ${ }^{7}$, S. Lago ${ }^{8}$, D. A. Bastos ${ }^{9}$, G. K. Jansz ${ }^{10}$, F. M. Carcano ${ }^{11}$, L. Andrade ${ }^{12}$, M. Pliskin ${ }^{13}$, N. Lazaretti ${ }^{14}$, L. De Arruda ${ }^{15}$, J. J. Correa ${ }^{16}$, O. Petrenciuc ${ }^{17}$, C. Kappeler ${ }^{18}$, T. Sarapohja ${ }^{19}$, M. R. Smith ${ }^{20}$

'Universitätsklinikum Münster, Urologie, Münster, Germany; ${ }^{2}$ carolina Urologic Research Center, Myrtle Beach, Vereinigte Staaten von Amerika; ${ }^{3}$ Institut Gustave Roussy, University of Paris Sud, Villejuif, France; ${ }^{4}$ Tampere University Hospital and Tampere University, Tampere, Finland; ${ }^{5} \mathrm{Hospital}$ Erasto Gaertner, Curitiba, PR, Brazil; ${ }^{6}$ Instituto de Oncología y Radioterapia Clínica Ricardo Palma, Lima, Peru; ${ }^{7}$ Recherches Cliniques TheraDev, Granby, QC, Vereinigte Staaten von Amerika; ${ }^{8} \mathrm{Hospital}$ São Lucas da PUCRS, Porto Alegre, Brazil ${ }^{9}$ Hospital Sirio-Libanes, São Paulo, Brazil; ${ }^{10} \mathrm{G}$. Kenneth Jansz Medicine Professional Corporation, Burlington, ON, Canada; ${ }^{11}$ Hospital de Câncer de Barretos, Barretos, Brazil; ${ }^{12 S a n t a}$ Casa de Misericordia de Salvador, Oncologia, Salvador, Brazil; ${ }^{13}$ The Urology Group, Cincinnati, $\mathrm{OH}$, Vereinigte Staaten von Amerika; ${ }^{14} \mathrm{Hospital}$ de Clínicas de Passo Fundo, Rio Grande Do Sul, Brazil; ${ }^{15}$ Instituto do Câncer do Ceará, Fortaleza, Brazil; ${ }^{16} \mathrm{Hospital}$ Pablo Tobon Uribe, Medellin, Brazil; ${ }^{17}$ Pharmaceuticals Division of Bayer, Whippany, NJ, Vereinigte Staaten von Amerika; ${ }^{18}$ Bayer AG, Berlin, Germany; ${ }^{19}$ Orion Corporation Orion Pharma, Espoo, Finland; ${ }^{20}$ Massachusetts General Hospital Cancer Center and Harvard Medical School, Urologic Oncology, Boston, MA, Vereinigte Staaten von Amerika

Background: DARO is a structurally distinct androgen receptor inhibitor approved for the treatment of non-metastatic castration-resistant prostate cancer (nmCRPC) based on significantly prolonged metastasis-free survival compared with PBO (median 40.4 vs 18.4 months; hazard ratio [HR] $0.41 ; 95 \% \mathrm{Cl} 0.34-0.50 ; \mathrm{P}<0.0001$ ) and a favorable safety profile in the phase III ARAMIS trial. Following unblinding at the primary analysis, crossover from PBO to DARO was permitted.

Methods: Patients (pts) with nmCRPC receiving ADT were randomized 2:1 to DARO $(n=955)$ or PBO $(n=554)$. Iterative parameter estimation (IPE) and rank-preserving structural failure time (RPSFT) analyses were performed as pre-planned sensitivity analyses and generated a Kaplan-Meier curve for the PBO arm that predicts what would have been observed in the absence of crossover.

Results: After unblinding, 170 pts (30.7\%) crossed over from PBO to DARO. Final analysis of the combined double-blind and open label periods was conducted after 254 deaths (15.5\% of DARO and $19.1 \%$ of PBO pts) and showed a statistically significant OS benefit for DARO vs PBO (HR 0.69; 95\% Cl 0.53-0.88; $P=0.003$ ). Results from the IPE (HR 0.66; 95\% Cl 0.51$0.84 ; P<0.001)$ and RPSFT (HR $0.68 ; 95 \% \mathrm{Cl} 0.51-0.90 ; P=0.007$ ) analyses were similar to those from the intention-to-treat population, showing that the impact of PBO-DARO crossover was small. Additional analyses will be presented.

Conclusions: Early treatment with DARO in men with nmCRPC is associated with significant improvement in OS regardless of pts crossing over from PBO to DARO. The safety profile of DARO continued to be favorable at the final analysis, and discontinuation rates at the end of the doubleblind period remained unchanged ( $8.9 \%$ with DARO and $8.7 \%$ with PBO). 
3K09.7

Safety of darolutamide (DARO) for nonmetastatic castration-resistant prostate cancer (nmCRPC) from extended follow-up in the phase III ARAMIS trial

G. Niegisch ${ }^{*}$, M. R. Smith ${ }^{2}$, K. Fizazi ${ }^{3}$, T.L. Tammela ${ }^{4}$, F.M. Cruz ${ }^{5}$, L.T. Nordquist ${ }^{6}$, D. S. Aleman Polanco ${ }^{7}$, U. Emmenegger ${ }^{8}$, G. C. Silveira ${ }^{9}$, R. S. Concepcion ${ }^{10}$, A. Paula ${ }^{11}$, C. A. Mendonça Beato ${ }^{12}$, N. Fleshner ${ }^{13}$, M. E. Richardet ${ }^{14}$, I. Kuss ${ }^{15}$, M.-A. Le Berre ${ }^{16}$, G. Borghesi ${ }^{15}$, T. Sarapohja ${ }^{17}$, N. D. Shore ${ }^{18}$

'Universitätsklinikum Düsseldorf, Heinrich Heine Universität, Klinik für Urologie, Düsseldorf, Germany; ${ }^{2}$ Massachusetts General Hospital Cancer Center, Boston, Vereinigte Staaten von Amerika; ${ }^{3}$ Institut Gustave Roussy, University of Paris Sud, Villejuif, France; ${ }^{4}$ Tampere University Hospital and Tampere University, Tampere, Finland; ${ }^{5}$ Instituto Brasileiro de Controle do Câncer, Sao Paulo, Brazil; ' 6 GU Research Network, Omaha, Vereinigte Staaten von Amerika; ${ }^{7}$ Centro Médico Monte Carmelo, Arequipa, Peru; ${ }^{8}$ Sunnybrook Health Sciences Centre, University of Toronto, Toronto, Canada; ${ }^{9} \mathrm{C}$ entro Oncológico do Triângulo, Uberlandia, Brazil; ${ }^{10}$ Urology Associates, PC, Nashville, Vereinigte Staaten von Amerika; ${ }^{11}$ Setor Leste Universitário, Goiânia, Brazil; ${ }^{12}$ Hospital Amaral Carvalho, São Paulo, Brazil; ${ }^{13}$ Princess Margaret Cancer Centre, University Health Network, Toronto, Canada; ${ }^{14}$ Sanatorio Aconcagua, Cordoba, Argentina; ${ }^{15}$ Bayer AG, Berlin, Germany; ${ }^{16}$ Bayer HealthCare SAS, Loos, France; ${ }^{17}$ Orion Corporation Orion Pharma, Espoo, Finland; ${ }^{18}$ Carolina Urologic Research Center, Myrtle Beach, Vereinigte Staaten von Amerika

Background: DARO is a structurally distinct androgen receptor inhibitor (ARI) approved for treating nmCRPC. In ARAMIS, DARO significantly reduced the risk of death by $31 \%(\mathrm{HR}=0.69 ; 95 \% \mathrm{Cl}: 0.53-0.88 ; p=0.003)$ and prolonged median metastasis-free survival vs placebo (PBO; $\mathrm{HR}=0.41 ; 95 \% \mathrm{Cl}: 0.34-0.50 ; p<0.001)$. In the final analysis of the doubleblind (DB) period of the ARAMIS trial, DARO had a favorable safety profile. The incidence of permanent discontinuation due to AEs was also similar between DARO and PBO (8.9\% vs $8.7 \%$ ). Here we present safety data for prolonged treatment with DARO from the final analysis of the DB + openlabel (OL) period.

Methods: Patients (pts) with nmCRPC $(\mathrm{N}=1509)$ were randomized 2:1 to DARO or PBO while continuing ADT. Study unblinding occurred on November 30, 2018, after which pts in the DARO arm continued with OL DARO. The data cut-off for final analysis of the DB+OL period was November 15, 2019.

Results: The increase in the incidence of any-grade AEs ( $85.7 \%$ vs $89.8 \%$ ) and serious $A E s$ ( $26.1 \%$ vs $32.1 \%$ ) between the $\mathrm{DB}$ and $\mathrm{DB}+\mathrm{OL}$ period was small and only minor changes for ARI-associated AEs were observed. Fatigue remained the only $A E$ of interest that exhibited $>10 \%$ incidence in the $\mathrm{DARO}$ arm during the $\mathrm{DB}+\mathrm{OL}$ period. The incidence of permanent discontinuation of DARO due to AEs increased slightly from $8.9 \%$ during the $\mathrm{DB}$ period to $10.5 \%$ during the $\mathrm{DB}+\mathrm{OL}$ period.

Conclusions: With longer treatment exposure, DARO remained well-tolerated and no new safety signals were observed. The expected increases in incidence of $\mathrm{AEs}$ between the $\mathrm{DB}$ and $\mathrm{DB}+\mathrm{OL}$ periods largely disappeared when adjusted for the longer exposure, confirming the favorable safety profile of DARO with prolonged treatment.
3K09.8

Final analysis results from TITAN: A phase III study of apalutamide (APA) versus placebo (PBO) in patients (pts) with metastatic castration-sensitive prostate cancer (mCSPC) receiving androgen deprivation therapy (ADT):

K. N. Chi', S. Chowdhury', A. Bjartell ${ }^{3}$, B. H. Chung ${ }^{4}$,

A.J. Pereira de Santana Gomes ${ }^{5}$, R. Given ${ }^{6}$, A. J. Soto ${ }^{7}$, A. Merseburger ${ }^{{ }^{*}}$, M. Özgüroglu ${ }^{9}$, H. Uemura ${ }^{10}$, D. Ye ${ }^{11}$, S. Triantos ${ }^{12}$, S. Mundle ${ }^{13}$, S. A. McCarthy ${ }^{13}$, J.S. Larsen ${ }^{14}$, W. Sun ${ }^{14}$, K. Bevans ${ }^{15}$, K. Zhang ${ }^{16}$, N. Bandyopadhyay ${ }^{13}$, N. Agarwal ${ }^{17}$

'BC Cancer and Vancouver Prostate Centre, Vancouver, Canada; ' ${ }^{G}$ uy's, King's and St. Thomas'Hospitals and Sarah Cannon Research Institute, London, Vereinigtes Königreich; ${ }^{3}$ Skane University Hospital, Lund University, Malmö, Sweden; ${ }^{4}$ Yonsei University College of Medicine and Gangnam Severance Hospital, Seoul, Korea; ${ }^{5}$ Liga Norte Riograndense Contra O Cancer, Natal, Brazil; ${ }^{6}$ Urology of Virginia, Eastern Virginia Medical School, Norfolk, Vereinigte Staaten von Amerika; ${ }^{7}$ Hospital Universitario de Jerez de la Frontera, Cadiz, Spain; ${ }^{8}$ University Hospital Schleswig-Holstein, Campus Lübeck, Lübeck, Germany; ${ }^{9}$ Istanbul University-Cerrahpasa, Cerrahpasa School of Medicine, Istanbul, Turkey; ${ }^{10} \mathrm{Kindai}$ University Faculty of Medicine, Osaka, Japan; ${ }^{11}$ Fudan University Shanghai Cancer Center, Shanghai, China; ${ }^{12}$ Janssen Research \& Development, Spring House, Vereinigte Staaten von Amerika; ${ }^{13}$ Janssen Research \& Development, Raritan, Vereinigte Staaten von Amerika; ${ }^{14}$ Janssen Research \& Development, Los Angeles, Vereinigte Staaten von Amerika; ${ }^{15}$ Janssen Research \& Development, Horsham, Vereinigte Staaten von Amerika; ${ }^{16}$ Janssen Research \& Development \& Development, San Diego, Vereinigte Staaten von Amerika; ${ }^{17}$ Huntsman Cancer Institute, University of Utah, Salt Lake City, Vereinigte Staaten von Amerika

Background: TITAN evaluated APA or PBO added to ADT in pts with mCSPC (high- and low-volume, prior docetaxel, prior treatment for localized disease, and prior ADT ( $\leq 6 \mathrm{mos})$ ). At the first interim analysis $(22.7 \mathrm{mos}$ median follow-up) APA significantly improved dual primary end points of OS (hazard ratio [HR] 0.67) and rPFS (HR 0.48) compared with PBO.

Methods: $1052 \mathrm{mCSPC}$ pts were randomized 1:1 to receive APA (240 mg QD) or PBO plus ADT. Time-to-event end points were analyzed by KaplanMeier method and Cox proportional hazards model. A preplanned sensitivity analysis for OS, accounting for crossover using inverse probability censoring weighted (IPCW) log-rank test, was conducted. No formal statistical retesting was performed; nominal $p$ values were reported without multiplicity adjustment.

Results: With 44 mos median follow-up, 405 OS events had occurred. After unblinding, 208 PBO pts (39.5\%) crossed over to APA. Median treatment duration was 39.3 mos for the APA group, 20.2 mos for the entire PBO group, and 15.4 mos for the PBO $\rightarrow$ APA crossover group. OS was superior in the APA group compared with the $\mathrm{PBO}$ group despite crossover. 48-mo survival rates were $65 \%$ (APA) vs $52 \%$ (PBO). Other end points also favored APA vs PBO. HRQoL, per total FACT-P, was maintained in the APA group and was not different from the PBO group. Safety was consistent with previous reports.

Conclusions: With close to 4 yrs of follow-up, the final analysis of TITAN demonstrated that in a broad population of pts with mCSPC, APA plus ADT provides an improvement in OS (35\% reduction in risk of death, which increased to $48 \%$ after adjusting for pts who crossed over from PBO to APA). There was consistent benefit with APA in other end points. NCT02489318 


\section{K09.9}

Impact of time to castration resistance on survival in metastatic hormone sensitive prostate cancer patients in the era of combination therapies

M. Wenzel ${ }^{1 *}$, F. Preisser ${ }^{1}$, B. Hoeh ${ }^{1}$, C. Würnschimmel ${ }^{2}$, T. Steuber ${ }^{2}$, H. Heinzer ${ }^{2}$, S. Banek', M. Ahrens ${ }^{3}$, A. Becker ${ }^{1}$, F. Chun'1, L. Kluth'1, P. Mandel ${ }^{1}$

${ }^{1}$ Goethe University Frankfurt, Frankfurt, Deutschland, ${ }^{2}$ Martini-Klinik Prostate Cancer Center, University Hospital Hamburg-Eppendorf, Hamburg, Deutschland, ${ }^{3}$ Department of Hematology and Oncology, University Hospital Frankfurt, Frankfurt, Deutschland

Background: To evaluate the impact of time to castration resistance (TTCR) in metastatic hormone-sensitive prostate cancer ( $\mathrm{mHSPC}$ ) patients on overall survival (OS) in the era of combination therapies for mHSPC.

Material and methods: Of $213 \mathrm{mHSPC}$ patients diagnosed between $01 / 2013-12 / 2020$ and subsequent development of metastatic castration resistant prostate cancer (mCRPC), 204 eligible patients were analyzed after applying exclusion criteria. $\mathrm{mHSPC}$ patients were classified into TTCR $<12$ vs. $12-18$ vs. $18-24$ vs. $>24$ months and analyzed regarding OS. Moreover, further OS analyses were performed after developing mCRPC status according to TTCR. Logistic regression models predicted the value of TTCR on OS.

Results: Median follow-up was 34 months. Among 204 mHSPC patients, $41.2 \%$ harbored TTCR $<12$ months vs. $18.1 \% 12-18$ months vs. $15.2 \% 18-$ 24 months vs. $25.5 \%>24$ months. Median age and PSA at prostate cancer diagnosis was respectively 67 years and $61 \mathrm{ng} / \mathrm{ml}$. No differences in patient characteristics were observed (all $p>0.05$ ). According to OS, TTCR $<12$ months patients had the worst OS, followed by TTCR 12-18 months, $18-24$ months and $>24$ months, in that order $(p<0.001)$. After multivariable adjustment, a 4.07-, 3.31- and 6.40-fold higher mortality was observed for TTCR 18-24 months, $12-18$ months and $<12$ months patients, relative to TTCR $>24$ months (all $p<0.05$ ). Conversely, OS after developing mCRPC was not influenced by TTCR stratification (all $p>0.05$ ).

Conclusion: Patients with TTCR $<12$ months are at the highest OS disadvantage in $\mathrm{mHSPC}$. This OS disadvantage persisted even after multivariable adjustment. Interestingly, TTCR stratified analyses did not influence OS in MCRPC patients.

\section{K09.10}

Biochemisches Ansprechen auf eine Radioligandentherapie mit ${ }^{177}$ Lu-PSMA- 617 bei mCRPC Patienten mit geringer PSMA-Expression im ${ }^{68} \mathrm{Ga}$ PSMA-11 PET/CT

\section{K. Seitzer ${ }^{1 *}$, K. Schlack', R. Seifert ${ }^{2}$, K. Kessel ${ }^{3}$, A. J. Schrader', M. Bögemann ${ }^{1}$, K. Rahbar ${ }^{3}$}

'Universitätsklinikum Münster, Klinik für Urologie und Kinderurologie, Münster, Deutschland; ${ }^{2}$ Uniklinik Essen, Klinik für Nuklearmedizin, Essen, Deutschland; ${ }^{3}$ Universitätsklinikum Münster, Klinik für Nuklearmedizin, Münster, Deutschland

Fragestellung: Das biochemische Ansprechen auf ${ }^{177}$ Lu-PSMA-617 konnte in mehreren Studien belegt werden. Aus Einigen ging hervor, dass Patienten mit einer höheren PSMA-Expression auch besser auf eine Radioligandentherapie ansprechen. Dies wurde bei Patienten mit niedrigen PSMAExpression bisher nicht untersucht. Daher analysierten wir in einer kleinen Kohorte das Ansprechen von Patienten mit geringer PSMA-Expression im Vergleich zu Patienten mit hoher Expression.

Material und Methoden: Wir behandelten $86 \mathrm{mCRPC}$ Patienten mit ${ }^{177} \mathrm{Lu}$ PSMA-617. Verschiedene biochemische Parameterwurden erhoben, retrospektiv analysierten wir PSA, LDH und AP. Anhand der semiautomatisch ausgewerteten ${ }^{68} \mathrm{Ga}$-PSMA-11 PET/CT, wurden die Patienten in eine Lowund High-PSMA Gruppe eingeteilt. Der Einfluss der Dynamik von PSA, AP und LDH unter Therapie wurde für beide Gruppen analysiert.

Ergebnisse: Eine PSA-Reduktion $\geq 50$ und $\geq 90 \%$, eine LDH-Normalisierung sowie eine AP-Normalisierung unter Therapie waren prognostisch für ein längeres OS. Die High-PSMA Gruppe zeigte ein bemerkenswert besseres Ansprechen des PSA-Wertes, besonders bezüglich der Reduktion $\geq 50$ und $\geq 90 \%$ (jeweils $p=0,01$ ). Auch bei der Normalisierung der AP war ein Unterschied zwischen den Gruppen feststellbar $(p=0,03)$. Kein signifikanter Unterschied zeigte sich bei LDH-Normalisierung. Dennoch hatten in der Low-PSMA Gruppe $90 \%$ einen Abfall des PSA-Wertes und $27 \%$ einen Abfall über $50 \%$. In der High-PSMA Gruppe waren es $89 \%$ bzw. $56 \%$. Schlussfolgerungen: Eine niedrige PSMA-Expression geht mit einem schlechteren PSA-Ansprechen, sowie mit einer schlechteren Reduktion des prognostischen Markers AP, einher. Auf LDH hatte dies keinen Einfluss. Dennoch scheinen einige Patienten mit niedriger Expression auf diese Therapie ausreichend anzusprechen.

\section{K09.11}

Erhöhte PSMA-Expression als positiver Prognostikator des Gesamtüberlebens bei mCRCP Patienten unter ${ }^{177} \mathrm{Lu}$ PSMA-617 Radioligandentherapie

\author{
K. Seitzer ${ }^{1 *}$, K. Schlack ${ }^{1}$, R. Seifert ${ }^{2}$, K. Kessel ${ }^{3}$, A. J. Schrader ${ }^{1}$, M. Bögemann' ${ }^{1}$, \\ K. Rahbar ${ }^{3}$
}

'Universitätsklinikum Münster, Klinik für Urologie und Kinderurologie, Münster, Deutschland; ${ }^{2}$ Uniklinik Essen, Klinik für Nuklearmedizin, Essen, Deutschland; ${ }^{3}$ Universitätsklinikum Münster, Klinik für Nuklearmedizin, Münster, Deutschland

Fragestellung: In verschiedenen Studien konnte für ${ }^{177}$ Lu-PSMA-617 Radioligandentherapie ein verlängertes Gesamtüberleben nachgewiesen werden. PSA-Ansprechen, baseline ALP und LDH, vorherige Taxane-Chemotherapie, sowie das Vorhandensein von viszeralen Metastasen konnten als prognostische Parameter identifiziert werden. Ob und bei welchen PET/CT-Parametern und ab welchem Grenzwert die PSMA-Expression eine prognostische Aussagekraft hat, ist noch nicht abschließend geklärt. Material und Methoden: Retrospektiv wurden das Überleben von 85 Patienten unter ${ }^{177}$ Lu-PSMA-617 RLT analysiert. Verschiedene erhobene PET/CT-Parameter der Metastasen wurden mithilfe einer Cox-RegressionsAnalyse auf deren Einfluss aufs Gesamtüberleben untersucht. Anhand dieser Ergebnisse wurden die Patienten in 2 Gruppen eingeteilt werden. Ergebnisse: Einer, der im PET/CT ermittelten Parameter, mit Einfluss aufs Gesamtüberleben war der läsionale mittlere SUV ${ }_{\max }$ identifiziert werden. Ein signifikanter Unterschied im Gesamtüberleben konnte ab einem mittleren SUV $V_{\max }$ von über 17 festgestellt werden. Wir teilten die Patienten daraufhin in 2 Gruppen, oberhalb und unterhalb dieses Grenzwertes, ein. Das mediane Gesamtüberleben in diesen beiden Gruppen unterschied sich signifikant (7 vs. 15 Monate $(p=0,01)$ ).

Schlussfolgerungen: Ein erhöhter mittlerer SUV $_{\max }$ also eine erhöhte PSMA-Expression der Metastasen im PET/CT, geht mit einem verlängertem medianen Gesamtüberleben einher. 
3K09.12

Association of co-occurring gene alterations and clinical activity of the PARP inhibitor rucaparib in patients with $B R C A 1$ or $B R C A 2$ mutated (BRCA+) metastatic castrationresistant prostate cancer (mCRPC)

A. S. Merseburger ${ }^{1 *}$, A. Patnaik ${ }^{2}$, D. Campbell ${ }^{3}$, J.D. Shapiro ${ }^{4}$, A. H. Bryce ${ }^{5}$ R. McDermott ${ }^{6}$, B. Sautois ${ }^{7}$, N. J. Vogelzang ${ }^{8}$, R. M. Bambury ${ }^{9}$, E. Voog ${ }^{10}$, J. Zhang ${ }^{11}$, J.M. Piulats ${ }^{12}$, C. J. Ryann ${ }^{13}$, K. Fizazi ${ }^{14}$, D. Despain ${ }^{15}$, A. Loehr ${ }^{15}$, M. Dowson ${ }^{16}$, T. Golsorkhi ${ }^{15}$, S. Chowdhury ${ }^{17}$, W. Abida ${ }^{18}$

'Lübeck University Hospital, Lübeck, Germany; ${ }^{2}$ University of Chicago, Chicago, Vereinigte Staaten von Amerika; ${ }^{3}$ Barwon Health, University Hospital Geelong, Geelong, Australia; ${ }^{4}$ Cabrini Hospital, Malvern, Australia; ${ }^{5}$ Mayo Clinic, Phoenix, Vereinigte Staaten von Amerika; ${ }^{6}$ Adelaide and Meath Hospital (Incorporating the National Children's Hospital), Dublin Ireland; ${ }^{7}$ University Hospital of Liège, Liège, Belgium; ${ }^{8}$ Comprehensive Cancer Centers of Nevada, Las Vegas, Vereinigte Staaten von Amerika; ${ }^{9}$ Cork University Hospital, Wilton, Ireland; ${ }^{10} \mathrm{Clinique} \mathrm{Victor} \mathrm{Hugo} \mathrm{Centre} \mathrm{Jean} \mathrm{Bernard,} \mathrm{Le} \mathrm{Mans,} \mathrm{France;}{ }^{11} \mathrm{H}$. Lee Moffitt Cancer Center, Tampa, Vereinigte Staaten von Amerika; '12Institut Català d'Oncologia, Barcelona, Spain; ${ }^{13}$ University of Minnesota, Minneapolis, Vereinigte Staaten von Amerika; ${ }^{14} \mid$ nstitut Gustave Roussy, University of Paris Saclay, Villejuif Cedex, France; ${ }^{15} \mathrm{Clovis}$ Oncology, Inc., Boulder, Vereinigte Staaten von Amerika; ${ }^{16}{ }^{6} \mathrm{Clovis}$ Oncology UK, Ltd., Cambridge, Vereinigtes Königreich; ${ }^{17}$ Guy's Hospital and Sarah Cannon Research Institute, London, Vereinigtes Königreich; ${ }^{18}$ Memorial Sloan Kettering Cancer Center, New York, Vereinigte Staaten von Amerika

Introduction: The phase 2 TRITON2 (NCT02952534) and phase 3 TRITON3 (NCT02975934) studies are evaluating rucaparib in patients with BRCA+ $\mathrm{mCRPC}$. The TP53 tumour suppressor gene is among the most frequently mutated genes in human cancers, and alterations in TP53, PTEN, and RB1 are associated with poor prognosis in $\mathrm{MCRPC}$. We present data on Co-occurring alterations in TRITON2 patients with BRCA+ mCRPC treated with rucaparib.

Materials and methods: Patients received rucaparib after progressing on 1-2 lines of androgen receptor-directed and 1 taxane-based therapy. Objective response rate (ORR) and prostate-specific antigen (PSA) response rate were assessed. Tissue and/or cell-free DNA assays were used for comprehensive genomic profiling.

Results: Genomic data were available for $114 / 115$ patients with BRCA+ mCRPC (visit cutoff: 23.12.2019), of whom 36.8\% (42/114) had a co-occurring alteration in TP53 and 34.2\% (39/114) in PTEN. RB1 loss was observed in $12.3 \%(14 / 114)$ and more frequent in patients with measurable disease $(18.0 \%, 11 / 61)$ than in those without $(5.7 \%, 3 / 53)$.

Patients with and without TP53 mutations had similar demographic and disease characteristics, but visceral disease was more prevalent in patients with TP53 mutations $(54.8 \% ; 23 / 42)$ than in those without $(29.2 \% ; 21 / 72)$. ORR and PSA response rates were similar in BRCA+ patients with or without TP53 mutation, with a non-significant trend towards lower response rates in patients with TP53 alterations.

Conclusions: Results from TRITON2 showed antitumor activity of rucaparib in patients with BRCA+ $m C R P C$ with or without co-occurring alterations in TP53. Additional demographics and efficacy analyses in subgroups with co-occurring alterations in TP53, PTEN, and RB1 will be reported. Funding: Study funded by Clovis Oncology.
3K09.13

Salvage-Chemotherapie mit Cisplatin, Ifosfamid und Paclitaxel beim metastasierten, kastrationsresistenten Prostatakarzinom

G. von Amsberg ${ }^{1 *}$, M. Zilles ${ }^{2}$, P. Gild ${ }^{3}$, W. Alsdorf ${ }^{2}$, L. Boeckelmann ${ }^{2}$, C. Langebrake ${ }^{4}$, S. Oh-Hohenhorst ${ }^{5}$, D. Tilki ${ }^{5}$, M. Graefen ${ }^{5}$, S. Dyshlovoy', C. Bokemeyer ${ }^{6}$

'Universitätsklinikum Hamburg-Eppendorf, Martini-Klinik Prostatakrebszentrum und Onkologisches Zentrum, Hamburg, Deutschland; ${ }^{2}$ Universitätsklinikum HamburgEppendorf, Onkologisches Zentrum, II. Medizinische Klinik, Hamburg, Deutschland; ${ }^{3}$ Universitätsklinikum Hamburg-Eppendorf, Klinik und Poliklinik für Urologie, Hamburg, Deutschland; ${ }^{4}$ Universitätsklinikum Hamburg-Eppendorf, Institut für Pharmakologie, Hamburg, Deutschland; ${ }^{5}$ Martini-Klinik Prostatakrebszentrum, Hamburg, Deutschland; ${ }^{6}$ Universitätsklinikum Hamburg-Eppendorf, Hamburg, Deutschland

Hintergrund: Jüngste Entwicklungen in der Behandlung des metastasierten, kastrationsresistenten Prostatakarzinoms (mCRPC) führten zu einem Revival platinbasierter Chemotherapien, insbesondere bei aggressiven Krankheitsverläufen. Hier berichten wir über die Ergebnisse einer kombinierten Salvage-Therapie mit Cisplatin, Ifosfamid und Paclitaxel (TIP).

Material und Methoden: Wir analysierten retrospektiv Patienten mit mCRPC, die zwischen 11/13 und 09/20 am UKE TIP erhielten. Begleitend erfolgten in vitro-Analysen mit humanen mCRPC-Zelllinien.

Ergebnisse: Insgesamt wurden 17 Patienten untersucht. Bei Therapieeinleitung lagen bei $82 \%$ Lebermetastasen, bei $47 \%$ viszerale Metastasen in anderen Lokalisationen und bei $76 \%$ ossäre Metastasen vor. Die mediane LDH betrug $903 \mathrm{U} / \mathrm{l}$, der PSA-Wert lag bei $77 \mathrm{ng} / \mathrm{ml}$. Eine erhöhte NSE wurde bei $83 \%$ nachgewiesen. Die Patienten waren mit durchschnittlich vier Vortherapien intensiv vorbehandelt. Im Median wurden 3,5 Zyklen TIP verabreicht, wobei $29 \%$ der Patienten alle 6 Zyklen erhielten. Vier Patienten brachen die Behandlung aufgrund von Nebenwirkungen ab. In der Zwischenanalyse zeigten $60 \%$ der Patienten ein radiologisches Ansprechen oder eine stabile Erkrankung. Nur ein Patient entwickelte im Folgenden einen Krankheitsprogress. Das mediane PFS betrug 2,5 Monate, das mediane OS 6 Monate. Ein Rückgang des PSA $>30 \%$ und der LDH $>50 \%$ wurde bei $41 \%$ bzw. $35 \%$ der Patienten beobachtet. In vitro Untersuchungen zu TIP zeigten additive Effekte in mCRPC-Zelllinien mit unterschiedlichem Resistenzprofil. Bemerkenswert war eine erhöhte Effektivität bei Docetaxel-resistenten Zellen im Vergleich zu den Docetaxelsensitiven Ursprungszellen.

Zusammenfassung: Die Kombinationstherapie mit TIP zeigt bei aggressiven $\mathrm{mCRPC}$ eine vielversprechende Aktivität.

\section{K09.14}

Real-Life Daten zu Carboplatin und Cabazitaxel beim metastasierten, kastrationsresistenten Prostatakarzinom

G. von Amsberg ${ }^{1 *}$, N. Strewinsky ${ }^{2}$, C. Langebrake ${ }^{3}$, P. Gild ${ }^{4}$, S. Oh-Hohenhorst ${ }^{5}$, D. Tilki ${ }^{5}$, M. Peters' ${ }^{2}$ S. Dyshlovoy', M. Graefen ${ }^{5}$, C. Bokemeyer ${ }^{2}$

'Universitätsklinikum Hamburg-Eppendorf, Martini-Klinik Prostatakrebszentrum und Onkologisches Zentrum, Hamburg, Deutschland; ${ }^{2}$ Universitätsklinikum Hamburg-Eppendorf, Onkologisches Zentrum, II. Medizinische Klinik, Hamburg, Deutschland; ${ }^{3}$ Universitätsklinikum Hamburg-Eppendorf, Institut für Pharmakologie, Hamburg, Deutschland; ${ }^{4}$ Universitätsklinikum Hamburg-Eppendorf, Klinik und Poliklinik für Urologie, Hamburg, Deutschland; ${ }^{5}$ Martini-Klinik Prostatakrebszentrum, Hamburg, Deutschland

Hintergrund: Die Kombinationstherapie mit Carboplatin und Cabazitaxel ist der Cabazitaxel-Monotherapie insbesondere bei klinisch oder molekularpathologischem Nachweis einer aggressiven Variante des metastasierten, kastrationsresistenten Prostatakarzinoms (mCRPC) überlegen.

Material und Methoden: In einer retrospektiven Analyse wurde die Effektivität von Carboplatin und Cabazitaxel bei Patienten überprüft, die zwischen 12/2017 und 09/2020 am UKE behandelt wurden. Begleitende in-vitro-Analysen erfolgten an humanen mCRPC-Zelllinien mit unterschiedlichem Resistenzprofil. 
Ergebnisse: Insgesamt wurden 16 Patienten analysiert. Davon wiesen $94 \%$ ossäre und $75 \%$ viszerale Metastasen auf. Der mediane PSA-Wert betrug $180 \mathrm{mg} / \mathrm{dl}$. Die Männer hatten zuvor durchschnittlich 3,5 Vortherapien erhalten, einschließlich einer Cabazitaxel-Monotherapie in $69 \%$ der Fälle. Ein PSA-Rückgang > $50 \%$ bzw. $>30 \%$ wurde bei $31 \%$ bzw. $44 \%$ der Patienten verzeichnet. Das mediane progressionsfreie Überleben betrug 6 Monate. $56 \%$ der Patienten, die alle sechs Zyklen Carboplatin/Cabazitaxel abschlossen, wiesen eine anhaltende Stabilisierung der Erkrankung auf. In-vitro wurden synergistische Effekte von Carboplatin/Cabazitaxel in den Andorgenrezeptor (AR)-positiven Zelllinien LNCaP und 22Rv1 (AR-V7+) sowie in den AR-negativen, neuroendokrinen LASCPC-01-Zellen nachgewiesen. Die Docetaxel-resistente Sublinie DU145-DR wies eine moderate Kreuzresistenz gegenüber Cabazitaxel auf, zeigte jedoch eine erhöhte Empfindlichkeit für Carboplatin.

Zusammenfassung: Die Effektivität von Carboplatin und Cabazitaxel kann im Behandlungsalltag bestätigt werden. Präklinische Daten zeigen eine synergistische Wirkung der beiden Chemotherapeutika.

\section{K09.15 \\ Neuroendocrine Prostate Cancer (NEPC): A single-center experience}

\section{C. Rehlinghaus", C. M. Grunewald, J. Lakes, G. Niegisch \\ Uniklinik Düsseldorf, Urologie, Düsseldorf, Germany}

Background: There is a rising number of men diagnosed with NEPC associated with poor prognosis and limited treatment options. This may be caused by improved histological diagnosis, increasing number of therapy lines and the advent of new antiandrogens.

Methods: We retrospectively analyzed all NEPC patients (pts) treated between 2012 and 2020 according to age, prior therapy, NSE and PSA levels, progression free survival (PFS), overall survival (OS) and overall response rate (ORR) following chemotherapy (CTx), calculated using Kaplan Meier method.

Results: Of 138 prostate cancer (PCa) pts undergoing systemic therapy, 17 pts with NEPC (12.3\%) were identified. 9 pts presented with treatment induced t-NEPC and 8 with de novo-NEPC. Median age was 70 years (IQR 13.5). In pts with t-NEPC the median number of prior therapies was 2 with median time from first PCa diagnosis to neuroendocrine differentiation being 5.5 years. Besides lymph node and bone metastases, pts presented hepatic $(n=7)$, pulmonary $(n=5)$ and cerebral $(n=2)$ metastases. At time of NEPC diagnosis, mean levels of NSE and PSA were $160 \mu \mathrm{g} / \mathrm{l}$ and $2.86 \mathrm{ng} /$ $\mathrm{ml}$, respectively. Following NEPC diagnosis, all pts were treated with platinum-based CTx as first-line treatment (11 received carboplatin/etoposide, 3 cisplatin/etoposide and 3 docetaxel/carboplatin). Median PFS was 6.3 months ( $95 \% \mathrm{Cl} 3.9-12)$, median OS after diagnosis of NET was 13 months (95\% Cl 7-NR), median OS after start of platin-based CTx was 12.3 months (95\% Cl 5.0-NR) and ORR was 47\%. Best response was observed for pts being treated with carboplatin/etoposide.

Conclusion: In PCa pts with visceral metastases, low PSA values and elevated NSE, the presence of a t-NEPC should be considered. Platin-based $\mathrm{CTX}$ is the treatment of choice. However, prognosis is poor.

\section{K09.16 \\ ${ }^{177}$ Lu-PSMA-617 Radioligandentherapie und Analyse von zirkulierenden Tumorzellen in Patienten mit metastasiertem kastrationsresistenten Prostatakarzinom}

\author{
K. Kessel ${ }^{1 *}$, K. Schlack ${ }^{2}$, M. Bögemann ${ }^{2}$, C. Bernemann ${ }^{2}$, K. Rahbar ${ }^{1}$ \\ 'Uniklinik Münster, Nuklearmedizin, Münster, Deutschland; ${ }^{2}$ Universitätsklinikum Müns- \\ ter, Klinik und Poliklinik für Urologie, Münster, Deutschland
}

Fragestellung: Die Radioligandentherapie mit ${ }^{177}$ Lu-PSMA (PSMA-RLT) hat sich in den letzten Jahren zu einer vielversprechenden Behandlungs- methode für das fortgeschrittene metastasierte kastrationsresistente Prostatakarzinom (mCRPC) entwickelt. Für eine Prognose unter einer PSMA-RLT fehlen validierte Parameter und Biomarker. In dieser Studie wurden mCRPC Patienten im Progress untersucht, die eine PSMA-RLT erhalten haben. Wir haben PSMA Expression und Marker möglicher neuroendokrine Differenzierung (NED), hichsichtlich eines Ansprechen auf die PSMA-RLT analysiert.

Material und Methoden: Es wurden 19 mCRPC Patienten mit einem durchschnittlichen Alter von 68,8 Jahren untersucht. Anhand zirkulierender Tumorzellen (CTCs), wurde mittels qRT-PCR das Genexpressionslevel von PSMA, der Androgenrezepor (AR) Splicevariante AR-V7 und weiterer, für die NED relevanter Gene bestimmt (XX).

Ergebnisse:Verglichen mit gesunden Kontrollen $(\mathrm{HC})$ exprimieren Patienten mit fortgeschrittenem mCRPC FOXA1 und weisen signifikant stark erhöhte SYP und ENO2 Geneexpressionslevel auf $(p<0,001$ und $p<0,0001)$. Unterteilt man die Patientengruppe in $A R-V 7^{\text {pos }}$ und $A R-V 7^{\text {neg, }}$, war kein Unterschied bezüglich der Expression von PSMA, SYP und ENO2 festzustellen. $A R-V 7^{\text {neg }}$ Patienten wiesen jedoch signifikant höhere FOXA1 Level auf $(p<0,001)$.

Schlussfolgerung: Sinkendes FOXA1 bei gleichzeitig erhöhtem SYP und ENO2 Level gilt als begünstigender Faktor für NED. Patienten mit einem vergleichbaren Genexpressionsmuster unterliegen dem Risiko einer NED. Daher sollte eine zusätzliche Biotherapie gegen neuroendokrine Tumoren diskutiert werden. Genexpressionsanalysen aus CTCs stellen hiermit ein sinnvolles diagnostisches Vorgehen bei fortgeschrittenem $\mathrm{mCRPC}$ und für die Prognose der PSMA-RLT dar.

\section{K09.17}

CTCs und ihr prognostisches Potenzial im Vergleich zur AR-V7-Expression bei mCRPC Patienten unter Androgendeprivationstherapie

K. Seitzer ${ }^{*}$, K. Schlack', V. Humberg', N. Wüstmann' ${ }^{1}$, N. Grundmann², J. Steinestel', D. Tiedje', K. Rahbar', L.-M. Krabbe', M. Bögemann',

\section{A.J. Schrader', C. Bernemann}

'Universitätsklinikum Münster, Klinik für Urologie und Kinderurologie, Münster, Deutschland; ${ }^{2}$ Westfälische Wilhelms-Universität Münster, Institut für Bioinformatik, Münster, Deutschland; ${ }^{3}$ Universitätsklinikum Augsburg, Klinik für Urologie, Augsburg, Deutschland; ${ }^{4}$ Universitätsklinikum Münster, Klinik für Nuklearmedizin, Münster, Deutschland

Fragestellung: Biomarker, die das Ansprechen auf beim mCRPC vorhersagen, sind selten. CTCs und der AR-V7-Status wurden als potenzielle Prognostikatoren (Prog.) diskutiert.

Material und Methoden: Wir untersuchten 64 Patienten, die mit Abi oder Enza behandelt wurden, bestimmten CTCs und analysierten den AR-V7-Status in Korrelation mit dem PSA PFS, PFS und OS.

Ergebnisse: Für das PSA-Ansprechen unterschieden sich CTC- vs. CTC+ nicht, während der AR-V7-Status prädiktiv war (68,2 \% AR-V7- und 33,3\% AR-V7+ $(p=0,01))$

Das mediane PSA-PFS betrug 17 Monate für CTC- und $6 \mathrm{Mo}$. für CTC+ Patienten $(p<0,01)$ und 9 Mo. für CTC+/AR-V7- und 5 Mo. für CTC+/AR-V7+ Patienten $(p=0,04)$. In der multivariaten Analyse blieben für CTC+ Patienten, AR-V7+ $(p=0,02)$, PSA-Abfall $\geq 50 \%(p=0,02)$ und viszerale Metastasen $(p=0,02)$ unabhängige Prog..

Die Analyse für das PFS ergab 22 Mo. für CTC- im Vergleich zu 9 für CTC+ $(p=0,01)$ und 10 Mo. für CTC+/AR-V7- vs. 6 für CTC+/AR-V7+ $(p=0,07)$. In MV der CTC+ Patienten blieben viszerale Metastasen $(p=0,02)$, PSA-Abfall $\geq 50 \%(p=0,02)$ und $\mathrm{Hb}<12(p=0,05)$ unabhängige Prog., wohin gegen AR-V7+ dies nicht blieb.

Das mediane OS wurde für CTC- nicht erreicht und 17 Mo. für CTC+ $(p<0,01)$ mit 27 vs. 14 Mo. für AR-V7- bzw. AR-V7+ $(p=0,06)$. UV für den AR-V7-Status ergaben ebenfalls keinen signifikanten Unterschied für das OS. In MV blieben sowohl der CTC-Status als auch der $\mathrm{Hb}<12$ unabhängige Prog. ( $p=0,04$ bzw. $p<0,01)$. Für MV von CTC+ waren viszerale Metastasen $(p=0,01), \mathrm{Hb}<12(p<0,01)$ und vorheriges Docetaxel $(p=0,01)$ unabhängige Prog. für OS. 
Schlussfolgerung: CTCs scheinen bei mCRPC-Patienten, die sich einer ADT unterziehen, das PFS und OS zu prognostizieren, während das Vorhandensein von AR-V7 trotz seines prädiktiven Potenzials keine Rolle spielt.

Fi01 - Filmsitzung I

15.09.2021, H1, 10:30-12:00

Fi01.1

Die Roboterassistierte Nierenteilresektion: Tipps

und Tricks für OP-Technik und Reduktion der

Komplikationsrate. Update 2021

\section{G. Schön ${ }^{1 * 2}$, M. Kriegmair ${ }^{1}$, T. Egner ${ }^{3}$, C. Kempkensteffen ${ }^{2}$}

'Urologische Klinik München-Planegg, Planegg, Deutschland; ${ }^{2}$ Franziskus-Krankenhaus Berlin, Urologie, Berlin, Deutschland; ${ }^{3}$ KWM-Klinikum Würzburg Mitte, Standort Missioklinik, Urologie, Würzburg, Deutschland

Hintergrund: Die roboterassistierte Nierenteilresektion ist an einigen Zentren auch bei komplexen Tumoren die Therapie der Wahl. Um diese Methode weiter zu etablieren ist es notwendig, diese Technik zu standardisieren und innovativ weiterzuentwickeln. In diesem Video soll gezeigt werden, dass durch Verbesserung der einzelnen OP-Schritte der Funktionserhalt deutlich verbessert werden kann bei gleichzeitiger Senkung der Komplikationsrate.

Methode: Im 1. von 5 wesentlichen Operationsschritten wird die Bedeutung der Doppler- und KM-Sonographie im Zusammenhang mit der Indocyaningabe bei selektiver Gefässabklemmung gezeigt. In weiteren Schritten die Verbesserung der Exzisionstechnik, der Urinomprophylaxe, der Verbesserung der Nahttechnik sowie die Möglichkeit des retroperitonealen Zugangs.

Ergebnisse: Von 1/2009 bis 12/2020 wurden 950 roboterassistierte Nierenteilresektionen durchgeführt. Die ersten 800 Patienten wurden mit den letzten 150 Patienten verglichen, bei denen eine Urinomprophylaxe bei komplexen Tumoren und eine spezielle Nahttechnik zum Parenchymverschluss eingeführt wurde. In der ersten Gruppe traten ca. 5 \% Urinome auf, bei $4 \%$ kam es zu Komplikationen wie Nachblutung, bei denen eine Bluttransfusion bzw. Nephrektomie nötig war. Bei den letzten 150 Patienten war weder ein Urinom noch eine transfusionspflichtige Nachblutung zu verzeichnen.

Zusammenfassung: Ständige Verbesserung der Operationstechnik und zunehmende Erfahrung bei der roboterassistierten Nierenteilresektion kann die Komplikationsrate auf ein Minimum reduzieren. Standardisierte Technik, hohe Bildauflösung und feine Instrumente können mit Doppleroder KM-Sonografie und Indocyaningrün gut funktionierendes Nierengewebe optimal erhalten bei gleichzeitig präziser Exzision des Nierentumors.

\section{Fi01.2}

Robotic assisted closure of urethro-rectal fistula with omental flap interposition following laparoscopic prostate adenomectomy

\section{J.-U. Stolzenburg, V. K. A. Arthanareeswaran*}

Universitätsklinikum Leipzig, Leipzig, Germany

Introduction: Urethrorectal fistula is an uncommon complication resulting from surgery, radiation or trauma. In this video we present our experience in managing a patient with urethro-rectal fistula following laparoscopic prostate adenomectomy.

Materials and methods: A 71 year old male developed a large urethrorectal fistula one month following laparoscopic prostate adenomectomy in different hospital. An attempt to close the fistula with a OTSC clip in the previous hospital was unsuccessful. Rectoscopy showed a $3.5 \mathrm{~cm}$ fistula opening at the level of the prostatic cavity with OTSC clip in situ. We demonstrate our robot assisted surgical technique of closure of urethrorectal fistula with omental flap interposition. A diversion colostomy was performed in the same sitting.

Results: The patient was placed in supine position in a 20 degree Trendelenburg position. A typical 5 trocar setup was used. The bladder neck was opened ventrally and the clip was removed. A modified radical prostatectomy was performed followed by omental flap mobilization. The large rectal defect was closed using interrupted sutures. The omental flap was fixed posterior to urethra in a tension free manner. The urethrovesical anastomosis was performed in standard manner including lateral narrowing of the bladder neck. Postoperative cystography showed a water tight anastomosis on the 8th postoperative day. Rectoscopy and colostomy closure was performed 3 months later.

Conclusions: Interposition of omental flap during the treatment of complicated fistulas supports the healing process because of its rich vascular and lymphatic supply, together with its resistance to infection. The maneuverability and flexibility of the DaVinci instruments helps the surgeon to perform these fine steps precisely.

\section{Fi01.3}

\section{DaVinci-Blasenhalssphinkterimplantation nach Epispadie-Ekstrophie Komplex}

\author{
M. Arndt" ${ }^{*}$, T. Gebhardt' ${ }^{1}$ U. Humke' ${ }^{2}$ M. Gerber ${ }^{1}$, M. Stöckle' ${ }^{1}$ S. Siemer ${ }^{1}$
}

'Universitätsklinikum des Saarlandes, Klinik für Urologie und Kinderurologie, Homburg, Deutschland; ${ }^{2}$ Klinikum Stuttgart-Katharinenhospital, Urologische Klinik, Stuttgart, Deutschland

Fragestellung: Bei dem Epispadie-Ekstrophie-Komplex handelt es sich um eine embryonale Entwicklungsstörung mit fehlendem Verschluss der Harnröhre bis hin zur Blase mit oder ohne Schließmuskelbeteiligung. Bei penopubischer Epispadie liegt meist eine Stressinkontinenz vor, die nach peniler Rekonstrukion auch einen rekonstruktiven Eingriff am Blasenhals benötigt. Hierzu stehen die Bandsupension, ein adjustierbares Schlingen/ Sphinkterersatzsystem sowie die Implantation einer Blasenhalsmanschette zur Verfügung.

Material und Methoden: Ein 17-jähriger Patient stellte sich mit III'Harninkontinenz nach angeborenem Epispadie-Ekstrophie-Komplex vor. Im Säuglingsalter hatte sich eine penopubische Epispadie gezeigt. Nach Harnröhrenrekonstruktion in tunnel tube-Technik ex domo erfolgte bei Unzufriedenheit ein Complete disassembling mit Ventralverlagerung der Harnröhre, Penisschaftaufrichtung und Rekonstruktion in domo. Bei zufriedenstellendem kosmetischem Ergebnis zeigte sich mit Beginn der Pubertät trotz Ausschöpfung konservativer Therapien eine ausgeprägte Inkontinenz. Bei kaum ausgebildetem und vernarbtem Penisschaft wurde die Implantation eines Sphinktersytems mit Blasenhalsmanschette roboterassistiert durchgeführt.

Ergebnisse: Nach unauffälligem Verlauf konnte der Patient am 3. postoperativen Tag entlassen werden. Nach 6 Wochen wurde der Blasenhalssphinkter aktiviert. Im Verlauf konnten eine Blasenkapazität von $350 \mathrm{ml}$ sowie eine Kontinenz auch unter Belastung erreicht werden.

Schlussfolgerung: Wichtig ist die individuelle Auswahl der möglichen Rekonstruktionsverfahren der Epispadie/Ekstrophie sowie der ausgeprägten Inkontinenz. In diesem Fall konnte mit der roboterassistierten Implantation eines Blasenhalssphinkters ein sehr zufriedenstellender Verlauf erreicht werden. 
Fi01.4

Komplett extraperitoneale Nephroureterektomie: Roboterassistierte Technik ohne Positionsveränderung von Patient und Trokaren

\section{G. Schön ${ }^{1 *}, 2$ M. Kriegmair ${ }^{1}$, R. Oberneder ${ }^{1}$, T. Egner $^{3}$}

'Urologische Klinik München-Planegg, Planegg, Deutschland; ${ }^{2}$ Franziskus-Krankenhaus Berlin, Urologie, Berlin, Deutschland; ${ }^{3}$ KWM-Klinikum Würzburg Mitte, Standort Missioklinik, Urologie, Würzburg, Deutschland

Hintergrund: Eine neue roboterassistierte Technik der komplett extraperitonealen Nephroureterektomie mit Blasenmanschette wurde entwickelt, um die Nachteile der bisherigen offenen Technik (Muskeldurchtrennung, Umlagerung), der laparoskopischen Technik (schwieriger Zugang zum distalen Harnleiter und zur Blasenmanschette sowie schwierige Blasennaht) und der roboterassistierten Technik (erschwerter Zugang zur Niere und gleichzeitig zum distalen Ureter/Blasenmanschette) auszugleichen.

Methode: In dem Video wird die Technik des komplett extrperitonealen Zugangs beim Urothelkarzinom des oberen Handwerks mit vollständiger Entfernung der Niere, des Harnleiters und der Blasenmanschette in toto dargestellt. Der große Vorteil besteht nach kurzem Umdocken des Roboters (nur bei SI und XI) im komfortablen Zugang zur Blase mit simpler Blasennaht.

Ergebnisse: Die Operationszeit betrug im Durchschnitt $130 \mathrm{~min}$. Die Entfernung des Blasenkatheters war bei $90 \%$ der Patienten nach fünf Tagen möglich. Komplikationen traten nicht auf.

Zusammenfassung: Verglichen mit traditionellen chirurgischen Techniken (offen, laparoskopisch und robotisch-transperitoneal) bietet die komplett extraperitoneale robotische Technik folgende Vorteile: keine Umlagerung des Patienten, komfortabler Zugang zur Blasenmanschette mit sicherer Naht und Entfernung des Präparats in toto, keine mögliche transperitoneale Tumoraussaat. Die Technik ist sicher und reproduzierbar für urotheliale Tumore des oberen Harntrakts.

\section{Fi01.5}

Morbus Ormond (MO) - Indikation für eine roboterassistierte laparoskopische Ureterolyse?

\section{Abdeen ${ }^{*}$, T. Gebhardt, J. Linxweiler, S. Siemer, M. Stöckle}

Universität des Saarlandes/Klinik für Urologie und Kinderurologie, Homburg, Deutschland

Einleitung: $\mathrm{MO}$ ist eine Erkrankung, die mit Fibrose des Retroperitoneums und Kompression der retroperitonealen Strukturen einhergeht. Fälle von sekundärem MO als Folge von Interventionen im Becken sind beschrieben. Standardtherapie ist eine offene Ureterolyse und Intraperitonealisierung (IP) des Harnleiters (HL).

Methoden: 59jähriger Patient mit Z.n. interventionell eingelegter aortobiiliakaler Gefäßprothese stellte sich mit Harnstauungsniere rechts vor, welche bereits mit einem DJ-Katheter versorgt worden war. Die extern durchgeführte Ureterorenoskopie zeigte eine Stenose im mittleren HL bedingt durch einen sekundären MO. Es sollte eine roboterassistierte Ureterolyse und IP erfolgen. Das Peritoneum wird im kleinen Becken eröffnet, und der HL relativ problemlos medial der lliakalgefäße dargestellt. Es folgen die Mobilisation des rechten HLs nach kranial, wo er unterhalb der Gefäßkreuzung immer tiefer in eine massive Narbe hineinzieht. Dieses Narbengewebe wird gespalten und der HL mit scharfer Präparation herausgelöst bis man wieder in gesundes Gewebe kommt. Nun ist der $\mathrm{HL}$ in seinem gesamten stenosierten Verlauf freigelegt. Anschließend wird das Peritoneum unterhalb des $\mathrm{HL}$ verschlossen, um den $\mathrm{HL}$ zu intraperitonealisieren.

Ergebnisse: Die OP-Dauer betrug 104 min. ohne signifikanten Blutverlust. Der Blasen- und der DJ-Katheter wurden nach 5 bzw. 10 Tagen entfernt. Abschließend zeigte sich sonographisch keine relevante Nierenektasie.
Schlussfolgerung: Die robotische Methode ist ein vielversprechender Weg, um einen durch MO extrinsisch komprimierten $\mathrm{HL}$ freizulegen und zu intraperitonealisieren. Die Invasivität ist gegenüber dem offen-chirurgischen Vorgehen dramatisch reduziert und die optimalen Sichtverhältnisse ermöglichen die subtile HL-präparation und Blutstillung.

\section{Fi01.6}

Vorstellung einer modifizierten orthotopen Neoblasentechnik dem I-Pouch - Illustration der chirurgischen Schritte und Tricks

\author{
V. Norz ${ }^{1 *}$, J.S. Izquierdo-Luna ${ }^{1,2}$, J. Bedke', S. Aufderklamm', B. Amend ${ }^{1}$, \\ J. Mischinger ${ }^{3}$, G. Gakis ${ }^{4}$, A. Stenzl', S. Rausch'
}

'Universitätsklinik Tübingen, Urologie, Tübingen, Deutschland; ${ }^{2}$ Hospital Central Militar, Mexiko City, Mexiko; ${ }^{3}$ Universitätsklinik Graz, Abteilung für Urologie, Graz, Österreich; ${ }^{4}$ Universitätsklinikum Würzburg, Abteilung für Urologie, Würzburg, Deutschland

Einleitung: Verschiedenste Techniken der orthotopen Neoblase (ONB) werden momentan mit zufriedenstellenden onkologischen und funktionellen Ergebnissen verwendet. Die ONB Technik des I-Pouches vereint moderaten Bedarf an Ileumentnahme mit antirefluxiver Ureterimplantationstechnik und bietet zudem eine für die Endoskopie leicht erreichbare ureterointestinale Anastomose.

Material und Methoden: Das vorgestellte Video illustriert die Schlüsselschritte der Operation und weist auf Fallstricke des Eingriffs hin. Funktionelle Resultate des I-Pouches im Vergleich zu einer intrainstitutionellen Kontrollgruppe der Studer ONB werden vorgestellt.

Ergebnisse: Für die Bildung der ONB in I-Pouch Technik werden $40 \mathrm{~cm}$ lleum entnommen und es wird eine U-förmige lleumplatte modelliert. Die Ureteren werden zu einer Wallace-Platte vereint und über eine zuvor gebildete Ureterenrinne mit der ONB vernäht. Die lleumplatte wird abschließend gefaltet und fortlaufend vernäht. Zuletzt erfolgt die Anastomosierung der ONB mit dem Blasenhals unter Sicht. Eine retrospektive Untersuchung von $33 \mathrm{I}$-Pouch und 23 Studer-Pouch Patienten zeigte keine Unterschiede der 30 Tage Major $(P=0,33)$ und Minor $(P=0,96)$ Komplikationsraten zwischen den beiden Techniken.

Schlussfolgerung: Der I-Pouch stellt eine alternative ONB-Technik dar, welche vereinfachten Zugang zum oberen Harntrakt und verminderten Bedarf an lleumentnahmelänge bei einem dem Studer-Pouch vergleichbaren Komplikationsprofil bietet.

\section{Fi01.7}

Erosion of inflatable penile prothesis reservoir into the bladder: managed by reservoir placement at a higher level of sub-rectus abdominal wall

M. Mahdi i", R. Talib ${ }^{1}$, M. Alwani', O. Aboumarzouk', R. Al-Zoubi', A. Qudimat ${ }^{1}$, A. Yassin ${ }^{1,3}$

'Hamad Medical Corporation, Doha, Qatar; ${ }^{2} J o r d a n$ University of Science and Technology, Irbid, Jordan; ${ }^{3}$ Segeberger Kliniken, Norderstedt, Norderstedt b. Hamburg, Germany

Objective: A 64 year old diabetic patient, presented to our clinic suffering from erectile dysfunction (ED). A 3-pieces of inflatable penileprosthesis (IPP) was inserted. He was satisfied and used the device efficiently. Patient suffered from a minor lower abdominal blunt trauma. Followed by a suddenonset of lower abdominal pain and gross hematuria, the pain subsided later. Also, he suffered from irritative and obstructive lower urinary tract symptoms (LUTS)associated with intermittent hematuria for 2 months, before seeking medical care. During that period he was using the device without any difficulty. On examination, no signs of infection was discovered, with normal device inflation and deflation. A flexible cystoscopy showed the reservoir is completely inside the bladder

Methods: A revision procedure was done, staring with lower midline abdominal incision, identifying the bladder, cystostomy and removing of the 
erodedreservoir, then a cystorrhaphy, and finally insertion of a concealed reservoir between the anterior rectus sheath and rectus muscle at a higher level of theabdominal wall contralaterally due to inflamed retzius space at the contralateral side, as the video demonstrates.

Results: Postoperatively, the device was working seamlessly with normal inflating and deflating, recovery was uneventful. At the 10th day, a cystogram wasdone with no contrast extravasation. At the follow-up, the patient was satisfied and used the device efficiently with no observed complications.

Conclusions: Eroded Inflatable Penile Prothesis (IPP) reservoir can be safely replaced in a single procedure with the absence of complications. Nontraditional placement of IPP reservoir is a good alternative especially in case of hostile pelvis or retzius space.

\section{Fi02 - Filmsitzung II}

$$
\text { 18.09.2021, C5.2, 09:00-11:15 }
$$

\section{Fi02.1}

(Neo)Vesiko-vaginale Fistel (VVF) - Indikation für einen roboterassistierten laparoskopischen Verschluss?

\author{
M. Abdeen*, T. Gebhardt, J. Linxweiler, S. Siemer, M. Stöckle \\ Universität des Saarlandes/Klinik für Urologie und Kinderurologie, Homburg, Deutsch- \\ land
}

Einleitung: VVF ist eine seltene Komplikation nach Beckenchirurgische. Standardtherapie ist eine offene Fistelresektion mit Scheiden- und Blasenverschluss sowie Interponatanlage. Es handelt sich um einen invasiven Eingriff, mit abdominellem Zugang.

Methoden: Fall 1:

47jährige Patientin mit Z.n. vaginaler Hysterektomie und Z.n. auswärtigem laparoskopischem Fistelverschluss. Hiernach kam es zu einem rezidiv, welches unter konservativen Maßnahmen nicht abheilte. Es wird ein roboterassistierter Verschluss der Rezidiv-VVF vorgestellt.

Nach Blaseneröffnung erfolgen die Mobilisation der Blasenhinterwand, Resektion des Fistelkanals samt Narbengewebe und fortlaufender Verschluss der Scheide mit Vicryl-Naht. Ein Peritoneallappen wird mobilisiert und vor der Scheide platziert. Die Blase wird mit fortlaufender V-Loc-Naht verschlossen.

Fall 2:

56jährige Patientin mit Z.n. radikaler Zystektomie und Neoblasenanlage (Urothelkarzinom pT2, pN0, R0, G3) stellte sich mit einer VVF bei uns vor. Die Neoblase wird von der Scheide abpräpariert. Es folgen die Mobilisation der Neoblase, Resektion der Fistel und fortlaufender Verschluss der Neoblase mit einem Stratafix-Faden und der Scheide mit einer Vicryl0-Naht. Ein Omentumstreifen wird mobilisiert und zwischen der Scheide und der Neoblase fixiert.

Ergebnisse: Die OP-Dauer betrug 190 bzw. 183 min ohne signifikanten Blutverlust. Der Blasenkatheter wurde nach 2 bzw. 4 Wochen nach unauffälligem Zystogramm entfernt. Prompte komplette Wiederherstellung der Kontinenz ohne Fistelrezidiv.

Schlussfolgerung: Der robotische Fistelverschluss stellt eine sichere OPMethode auch nach Voroperationen oder in der Rezidivsituation dar. Die Prinzipien der offenen Fisteloperation können bei exzellenter Sicht und minimalinvasivem Vorgehen komplett übernommen werden.
Fi02.2

\section{Robotic assisted radical prostatectomy of a very large} $(700 \mathrm{ml})$ Adenocarcinoma of the prostate

\section{J.-U. Stolzenburg, V. K. A. Arthanareeswaran*, O. Espig}

Universitätsklinikum Leipzig, Leipzig, Germany

Introduction: In this video we present our experience in managing a patient with unusually large prostate measuring of $700 \mathrm{ml}$ diagnosed with prostate carcinoma.

Materials and methods: A 75-year-old patient presented with PSA $670 \mathrm{ng} / \mathrm{dl}$. Ultrasound revealed a large prostate measuring $700 \mathrm{ml}$. Prostate biopsy revealed Adenocarcinoma of prostate with Gleason Score $4+4=8$. Staging CT and PET scan showed no metastasis. Rectoscopy was performed to rule out rectum infiltration. The patient was started on anti-hormone therapy for one month. We demonstrate our robot assisted surgical technique of radical prostatectomy with peritoneal flap fixation.

Results: The patient was placed in supine position in a 25 degree trendelenburg position. A typical 6 trocar setup was used. The Retzius space was dissected and pelvic lymphadenectomy was performed on both sides. The ureters were looped on both sides. Inspite the abnormal size of the prostate, the plane between the prostate and rectum was intact and radical prostatectomy was performed successful. A watertight, urethrovesical anastomosis was performed with the single knot technique described as Van Velthoven technique. The peritoneum flap was fixed to the pelvic rim using 2/0 Vicryl. Final histopathology showed Gleason 5 $+5=10$ tumour without lymph node metastasis. Cystography on the 7th postoperative day and the catheter was removed subsequently.

Conclusion: Non-metastatic prostate carcinomas with above-average prostate volume and very high PSA level are rarely described in the available literature. Despite the monstrous size and the advanced tumour stage, we were successfully able to perform radical prostatectomy. The patient recovered normally.

\section{Fi02.3}

\section{Robotic assisted partial nephrectomy in a central totally} intraparenchymal kidney tumour

\section{J.-U. Stolzenburg, V. K. A. Arthanareeswaran*, D. Thomalla}

Universitätsklinikum Leipzig, Leipzig, Germany

Introduction: Recent publications have shown that partial nephrectomy $(\mathrm{PN})$ can be a safe treatment option even for complex tumours that would otherwise undergo a radical nephrectomy. Careful pre/intra-operative planning is crucial for these complex operations. In this video we present our experience in managing a patient with a central, completely intraparenchymal kidney tumour with the help of cognitive 3D guidance. Materials and methods: A 69 year old male patient presented with newly diagnosed microhematuria. MRT abdomen revealed a $3 \mathrm{~cm}$ central kidney tumour on the left side. A 3D model was reconstructed using the MRT images. We demonstrate our robot assisted surgical technique of PN.

Results: The patient was placed on a right lateral position. The trocars were placed in a typical manner for transperitoneal PN. The Gerota's fascia was opened and the hilus was dissected. The kidney was completely mobilized following looping of renal vessels. Cognitive fusion based on 3D model and intraoperative ultrasound was used to locate the tumour and mark the resection margins. The tumour was enucleo-resected successfully and the frozen section revealed tumour free margins of a hypernephroma. Haemostasis was achieved by inner layer renorraphy suturing along with placement of haemostatic agents at the end of the procedure. Conclusion: Robot assisted PN is feasible even in case of totally intrarenal tumours. The maneuverability and flexibility of the DaVinci instruments along with ultrasound and 3D cognitive guidance helps the surgeon to perform these fine steps precisely. 
Fi02.4

\section{Salvage-Operation bei Patienten mit Lokalrezidiven nach radikaler Prostatektomie}

S. Knipper ${ }^{1 *}$, L. Ascalone', B. Ziegler', J. L. Hohenhorst ${ }^{1}$, J. Maurer', R. Simon², C. Berliner ${ }^{3}$, F.W. B. van Leeuwen ${ }^{4}$, H. van der Poel ${ }^{5}$, F. Giesel ${ }^{6}$, M. Graefen ${ }^{1}$ M. Eiber ${ }^{7}$, M. M. Heck' ${ }^{2}$, T. Horn' ${ }^{2}$, T. Maurer ${ }^{1,8}$

'Martini-Klinik am Universitätsklinikum Hamburg-Eppendorf, Hamburg, Deutschland; ${ }^{2}$ Klinik für Urologie, Technische Universität München, München, Deutschland; ${ }^{3} \mathrm{Klinik}$ für Nuklearmedizin, Universitätsklinikum Essen, Essen, Deutschland; ${ }^{4}$ Interventional Molecular Imaging Laboratory, Department of Radiology, Leiden University Medical Centre, Leiden, Niederlande; ${ }^{5}$ Department of Urology, Antoni van Leeuwenhoek Hospital-the Netherlands Cancer Institute, Amsterdam, Niederlande; ${ }^{6}$ Klinik für Nuklearmedizin, Universitätsklinikum Heidelberg, Heidelberg, Deutschland; ${ }^{7}$ Klinik für Nuklearmedizin, Technische Universität München, München, Deutschland; ${ }^{8} \mathrm{Klinik}$ für Urologie, Universitätsklinikum Hamburg-Eppendorf, Hamburg, Deutschland

Einleitung: Seit der Einführung der PSMA-PET Bildgebung können Lokalrezidive nach radikaler Prostatektomie (RP) präziser entdeckt werden. Das Ziel der Arbeit war die Auswertung des biochemischen Ansprechens und therapiefreien Intervalls nach Salvage-Operation von Patienten mit Rezidiven in der Samenblasenloge.

Material und Methoden: Es wurden 40 Patienten aus zwei Zentren (11/2014-02/2020) analysiert, die eine PSMA-radioguided surgery (PSMA-RGS) erhielten. Alle Patienten hatten ein biochemisches Rezidiv (BCR) nach RP sowie ein singuläres Samenblasenlogenrezidiv in der PSMA-PET Bildgebung. 33 (82,5\%) Patienten waren vorbestrahlt. Der Anteil an Patienten mit kompletten biochemischen Ansprechen (cBR, PSA $<0,2 \mathrm{ng} / \mathrm{ml}$ ) nach 6-16 Wochen wurden erfasst. Das BCR-freie Überleben und das therapiefreie Überleben wurden mittels Kaplan-Meier berechnet. Komplikationen wurden nach Clavien-Dindo ausgewertet.

Ergebnisse: Vor PSMA-RGS lag der mediane PSA bei $0,9 \mathrm{ng} / \mathrm{ml}$ (Interquartilsabstand [IQR]: 0,5-1,7 ng/ml). Nach PSMA-RGS war der mediane PSA-Nadir ohne weitere Therapie bei 0,1 ng/ml (IQR: 0-0,4 ng/ml). Bei 31 Patienten (77,5\%) wurde ein CBR beobachtet. Während des medianen Follow-ups von 24,4 Monaten (IQR: 11,8-41,9 Monate) erlebten 22 (55,0\%) Patienten ein BCR und 12 (30,0\%) Patienten erhielten eine weiterführende Therapie. Nach einem Jahr lag das BCR-freie Überleben bei $62,2 \%$ und das therapiefreie Überleben bei 88,3\%. Drei (7,5\%) Clavien-Dindo Grad III Komplikationen wurden beobachtet. Hauptlimitation ist das retrospektive Design.

Schlussfolgerung: Die Salvage-Operation eines PSMA-PET positiven Samenblasenlogenrezidivs ist mittels PSMA-RGS gut machbar und kann möglicherweise bei hochselektierten Patienten das BCR-freie Überleben und damit das therapiefreie Überleben verlängern.

\section{Fi02.5}

Step-by-step Video einer penoskrotalen Implantation einer Rigicon Infla10-Penisprothese

\footnotetext{
A. Ragheb ${ }^{1 *}$, D. Osmonov

'Universitätsklinikum Schleswig-Holstein, Campus Kiel, Klinik für Urologie und Kinderurologie, Kiel, Deutschland; ${ }^{2}$ Universitätsklinikum Schleswig Holstein, Campus Kiel, Kiel, Deutschland

Einleitung: Wir führten die deutschlandweit erste Implantation einer Infla 10 Penisprothese durch. In diesem Lehr-Video wird die Implantation der Infla 10 Prothese Step-by-Step vorgestellt.

Material und Methoden: Wir stellen den Fall eines 71 Patienten vor. Der Patient litt unter einer therapieresistenten erektilen Dysfunktion, in der Vorgeschichte war 2006 eine radikale Prostatektomie durchgeführt worden. Der Patient war Non-responder auf PDE 5-Hemmer, Vakuum-Pumpen und SKAT. Nach präoperativer Gabe von Cephalosporinen der III. Generation wurde eine penoskrotale Prothesenimplantation vorgenommen. Die Operation dauerte 45 min und verlief ohne Komplikationen.
}

Ergebnisse: Auch der postoperative Verlauf verlief komplikationslos. Die antibiotische Therapie wurde für 3 Tage fortgesetzt und die Drainage am 2. postoperativen Tag entfernt. Der Patient wurde am 3. Tag p. o. entlassen. Die Aktivierung der Prothese erfolgte 6 Wochen nach dem Eingriff. Dabei konnte eine regelrechte Infla10-Funktion festgestellt werden.

Zusammenfassung: Die Implantation der Infla 10 Prothese ist in Handhabung und Funktion vergleichbar mit anderen penilen Implantaten.

\section{Fi02.6}

Igloo-technique for robot-assisted radical prostatovesiculectomy (RARP): maximum nerve sparing for early recovery of continence and sexual function

C. Malkmus*, F. Aschwanden, J. Cornelius, P. Viktorin, P. Baumeister, L. Mordasini, A. Mattei

Luzerner Kantonsspital, Klinik für Urologie, Luzern, Switzerland

Introduction: Preservation of the anatomical suspension of the prostate including the neurovascular structures might accelerate early continence and erectile function rates. Here we present a complete circumferential intrafascial dissection technique with a single lateral approach in RARP for low-risk prostate cancer: the Igloo-technique.

Methods: Operation was standardized into 10 steps

1. Exposition of right lateral prostate

2. Incision of endo-/periprostatic fascia

3. Mobilization of right neurovascular bundle

4. Dissection of seminal vesicles and dorsal prostate plane

5. Dissection of bladder neck

6. Mobilization of left neurovascular bundle

7. Mobilization of dorsal venous complex

8. Dissection of apex

9. Vesico-urethral-anastomosis

10. Closure of endopelvic fascia

Results: 10 patients underwent Igloo-technique since March 2020. Median operation time was $197 \mathrm{~min}$ [160-316 min]. Transurethral catheter was removed in median at $3 \mathrm{rd}$ [3-11d] postoperative day (POD). Postoperative histology showed pT2a $(n=2), \mathrm{pT} 2 \mathrm{c}(n=6), \mathrm{pT} 3 \mathrm{a}(n=1)$, pT3b $(n=1)$. Low and intermediate risk Gleason scores were confirmed in 9 of 10 patients. In 2 cases positive surgical margins $(0,5-2 \mathrm{~mm}$, Gleason 3 ) were found. Early continence was evaluated using pad tests. In the first $24 \mathrm{~h}$ after catheter removal the median loss was $5,5 \mathrm{~g} / 24 \mathrm{~h}[0-25 \mathrm{~g} / 24 \mathrm{~h}]$. At 10th POD and 12 weeks control dry pads were reported. 12 weeks postoperatively a median IIEF-15 of 52,5 points [27-65] was achieved using PDE-5-inhibitors.

Conclusion: The Igloo-technique as a complete circumferential nerve sparing with a single lateral approach is feasible, safe but technically demanding. Excellent early continence and midterm erectile function can be achieved. Nevertheless, the Igloo-technique is only to be used for patients with low-risk-profile cancer.

\section{Fi02.7}

\section{Befestigung eines Mono-J-Katheters an einem Dauerkatheter mit Flötenspitze}

\section{A. Reicherz , J. Noldus, P. Bach \\ Marien Hospital Herne, Ruhr-Universität Bochum, Herne, Deutschland}

Fragestellung: Deutsche und europäische Leitlinien empfehlen nach unkomplizierter Ureterorenoskopie keine routinemäßige Harnleiterschienung. Die gängige Praxis weicht jedoch insbesondere in Deutschland oftmals von den Empfehlungen ab. Als Alternative gibt die europäischen Leitlinie an, dass die Ergebnisse bei einer kurzfristigen Harnleiterschieneneinlage mit einer konventionellen Doppel-J-Einlage vergleichbar sind. Da die Befestigung einer Mono-J Schiene durch Knoten oder Kleben unkomfortabel ist, demonstrieren wir eine simple Technik der Befestigung. 
Material und Methoden: Eingeschlossen wurden Patienten bei denen im Rahmen der FaST 1 und 2-Studien, prospektiv randomisierte Studien zur Lebensqualität bei postoperativer Harnableitung, nach sekundärer Ureterorenoskopie ein Mono-J-Katheter (Coloplast ${ }^{\oplus}$, VORTEK ${ }^{\circledR} 6 \mathrm{Ch}$ ) eingelegt wurde. Ein Dauerkatheter mit Flötenspitze (UROMED, $18 \mathrm{Ch}$ ) wurde über den Mono-J-Katheter aufgefädelt eingelegt. Beide Katheter wurden nach $6 \mathrm{~h}$ auf der Station durch eine/n Krankenpfleger/in entfernt. Endpunkte waren eine Dislokation oder Schwierigkeiten bei der Entfernung.

Ergebnisse: Zwischen August 2014 und April 2018 wurden bei 245 randomisierten Patienten bei 121 Patienten nach sekundärer URS ein MonoJ-Katheter eingelegt. Eine Dislokation des Katheters oder Schwierigkeiten bei der Entfernung traten nicht auf.

Schlussfolgerungen: Die beschriebene Technik der Befestigung des Mono-J-Katheters ist simpel, erhöht den Patientenkomfort und verbessert die Mobilität, da nur ein Katheterbeutel benötigt wird.

\section{Fi02.8}

\section{Symptomatic nephroptosis of the transplant: first report of successful minimal-invasive treatment}

J. Huber*, E. Nikitin, J. Putz, C. Thomas

Universitätsklinikum Carl Gustav Carus, TU Dresden, Dresden, Germany

Introduction: Symptomatic nephroptosis of a kidney transplant is a rare and potentially fatal complication and requires fast diagnosis and treatment. In this report we describe a case in which intermittent symptomatic urinary obstruction and increased kidney retention parameters were the leading symptoms of nephroptosis. Increasing creatinine necessitated reinstertion of DJ-ureter stent and another removal attempt was unsuccessful. There was no stenosis, but hypermobility of the kidney as the suspected cause. We describe the diagnostic procedures and the successful minimal-invasive treatment.

Materials and methods: The operation was performed with the da Vinci Si-Surgical-System ${ }^{\circledast}$ (Intuitive Surgical) in a light Trendelenburg position. We chose a transperitoneal approach and fixed the upper kidney pole to the lateral peritoneum. We further performed an arched incision into the ventral peritoneum and flapped it over the transplant with a cranial fixation. Then we attached this "saftey belt" to the ventral aspect of the kidney transplant.

Results: Total surgery time was $86 \mathrm{~min}$ and estimated blood loss was $20 \mathrm{ml}$. The ureteral stent and the bladder catheter were removed on postoperative day 1 and the patient was discharged on postoperative day 3 . Eight months later the patient is still asymptomatic with stable renal function.

Conclusion: To our knowledge this is the first report of a symptomatic transplant nephroptosis with consecutive intermittent urinary obstruction and without complications of perfusion solved with a minimal-invasive approach. Given the rarity of this event, prophylactic nephropexy could only be discussed in very special constellations. The treatment as described is straight forward, easy to perform and bears little stress for the patient. 


\section{Autorenregister}

\begin{tabular}{|c|c|c|c|c|c|}
\hline A & & Asdjodi S. & 3К05.5 & Bedke J. & Fi01.6, V02.2, V03.2, V04.9, \\
\hline Abdeen M. & Fi01.5, Fi02.1 & Ataman C. & $3 \mathrm{~K} 07.12$ & & 3К06.6, 3К06.10, 3К06.11, \\
\hline Abdelkareem M. & V13.8 & Atassi N. & V08.8 & & 3К06.16, 3К07.11 \\
\hline Abdelwahab F. & V13.8 & Athanasiou A. & V10.8 & Beier A.-M.K. & $3 \mathrm{~K} 05.10$ \\
\hline Abida W. & 3K09.12 & Attenberger U. & V02.9 & Beier J. & V04.5 \\
\hline Aboumarzouk 0. & Fi01.7 & Atterbury A. & 3K05.6 & Bekeschus S. & 3K04.1 \\
\hline Abruzzese T. & V11.8 & Atzler M. & 3К08.9, 3К08.10 & Belge G. & V16.1 \\
\hline Abt D. & 3К08.1, 3К08.5, 3К08.6 & Aufderklamm S. & Fi01.6, V02.2, V04.9, V08.4, & Bellut L. & V02.7 \\
\hline Abufaraj M. & 3К04.11 & & V15.3, 3К03.12, 3К04.17, & Benderska-Söder N. & 3К07.5 \\
\hline Adank M. & $3 \mathrm{~K} 08.2$ & & $3 \mathrm{~K} 07.15$ & Benedikt B. & $3 \mathrm{~K} 08.12$ \\
\hline Agarwal N. & 3К09.8 & Augustin M. & 3К06.9 & Benusch T. & V05.6 \\
\hline Agerbaek M. & V17.6 & Authenrieth $\mathrm{M}$. & V03.9 & Berg S. & $3 \mathrm{~K} 06.17$ \\
\hline Ahrens M. & 3К09.9 & Auvinen A. & 3K01.16 & Bergmann J. & V08.6 \\
\hline Aich J. & V06.4, 3K08.18 & Ayoubian $\mathrm{H}$. & V16.7 & Bergmann L. & $3 \mathrm{~K} 06.13$ \\
\hline Aicher W.K. & V11.8, 3K07.6 & Ayub A. & V02.5 & Berliner C. & $\mathrm{Fi02.4}$ \\
\hline Aksoy C. & 3К02.1, 3К02.9, 3К02.11, & Azad A. & 3K09.5 & Berndt-Paetz M. & V15.4, 3K07.7 \\
\hline & $3 \mathrm{~K} 02.16$ & Azoitei A. & 3К04.3, 3К04.4, 3К04.5, & Bernemann C. & 3К05.14, 3К09.16, 3К09.17 \\
\hline Al-Ahni A. & 3К08.5 & & 3К04.8, 3К04.9 & Bertlich M. & $3 \mathrm{~K} 05.5$ \\
\hline Alajati A. & V03.1, V03.3, V03.6, V12.8, & & & Besser V. & V12.2 \\
\hline & 3К05.3 & & & Bevans K. & 3К09.8 \\
\hline Alansari A. & V13.8 & B & & Beyersdorff D. & 3К01.5 \\
\hline Albers P. & V05.2, V05.8, V12.2, V12.3, & Bach P. & Fi02.7, V08.5 & Bhangu-Uhlmann A. & $3 \mathrm{~K} 07.2$ \\
\hline & V12.4, V12.5, V12.7, V12.9, & Bach T. & 3К08.7, 3К08.12 & Bhojani N. & 3К08.3, 3К08.5, 3К08.7 \\
\hline & $3 К 01.14$ & Bachanek S. & V07.5 & Bier S. & V13.2 \\
\hline Albiges L. & $3 \mathrm{~K} 06.18$ & Bachmann H.S. & 3К06.9 & Bieri U. & V06.3 \\
\hline Albrecht J. & V03.1 & Baco E. & 3К01.11 & Biernath N. & 3К06.8 \\
\hline Alcaraz A. & 3К09.5 & Bahlburg H. & $3 \mathrm{~K} 02.6,3 \mathrm{~K} 03.8$ & Bischoff R. & 3К01.8 \\
\hline Alekseev B. & 3К09.5 & Baig M.S. & 3К01.12 & Bismarck E. & 3К07.5 \\
\hline Aleman Polanco D.S. & 3К09.7 & Baisch S. & 3K04.17 & Bjartell A. & 3К09.8 \\
\hline Alexa R. & V06.6 & Bajorin D.F. & V17.6 & Blum S.I. & $3 \mathrm{~K} 06.16$ \\
\hline Al-Kailani Z. & $3 \mathrm{~K} 01.17$ & Bakker C.J. & V17.5 & Böck S. & V14.6 \\
\hline Alkubaisi K. & V13.8 & Balakrishnan P. & 3К07.5 & Bodelle B. & 3К01.9 \\
\hline Alpers G.W. & V14.1, V14.3, 3K02.3 & Bamarni A. & V03.1 & Boeckelmann L. & 3К05.2, 3К09.13 \\
\hline Al-Qudimat A. & V13.4, V13.8 & Bambury R.M. & $3 \mathrm{~K} 09.12$ & Boedecker C. & $3 \mathrm{~K} 01.2$ \\
\hline Alsdorf W. & 3К09.13 & Bamias A. & V17.6 & Boehm K. & V02.6, V17.9, 3К01.2, \\
\hline Alves-Avelar L. A. & V12.7 & Bandyopadhyay N. & 3К09.8 & & $3 \mathrm{~K} 02.11$ \\
\hline Alwani M. & Fi01.7, V13.4, V13.8 & Banek S. & 3К06.12, 3К08.11, 3К09.9 & Bögemann M. & 3К06.7, 3К09.6, 3К09.10, \\
\hline Al-Zoubi R. & Fi01.7 & Bangma C. & $3 K 01.16$ & & ЗК09.11, ЗК09.16, ЗК09.17 \\
\hline Al-Zoubi R.M. & V13.4 & Bannert H. & V02.3 & Bohle R.M. & V16.7 \\
\hline Ameli G. & V11.6, V11.7 & Bannowsky A. & V13.7, V13.9 & Böhm K. & $3 \mathrm{~K} 02.2,3 \mathrm{~K} 02.13$ \\
\hline Amend B. & Fi01.6, V04.9, V08.4, V11.5, & Barber N. & 3K08.7 & Boiko S. & 3К01.5 \\
\hline & V15.3 & Baretton G. & V17.7, 3К06.18 & Bokemeyer $\mathrm{C}$. & 3К05.2, 3К09.13, ЗК09.14 \\
\hline Amiel T. & V10.3 & Barski D. & 3К07.1 & Bolenz C. & 3К04.3, 3К04.4, 3К04.5, \\
\hline Andrade L. & 3K09.6 & Bartelheimer T. & $3 \mathrm{~K} 02.18$ & & 3К04.7, 3К04.8, 3К04.9, \\
\hline Anegg 0. & V16.5 & Barth D. & $3 \mathrm{~K} 06.5$ & & 3K07.4, V17.3 \\
\hline Angulo J. & V15.7 & Barth E. & 3К07.3 & Bonekamp D. & 3К01.1, 3К01.6, 3К01.7 \\
\hline Ankerst D.P. & V10.2 & Barthélémy $P$. & $3 \mathrm{~K} 06.18$ & Bonkat G. & V01.9 \\
\hline Antoch G. & $3 K 01.14$ & Bartkowiak A. L. & 3К07.8 & Borghesi G. & 3К09.7 \\
\hline Anufriev V. & $3 \mathrm{~K} 05.2$ & Baschek R. & V04.8 & Borgmann $\mathrm{H}$. & 3К01.2, 3К02.11, 3К02.13, \\
\hline Apfelbeck M. & 3К01.8 & Bastos D. A. & 3К09.6 & & V17.9 \\
\hline Appelhans D. & $3 K 04.14$ & Bates M. & 3К07.5 & Borisenkov M. & V04.5 \\
\hline Armbrust F. & V13.9 & Baumeister P. & Fi02.6 & Borisova K. & 3K05.2 \\
\hline Armstrong A.J. & 3K09.5 & Baunacke M. & V05.6, 3K02.1, 3K02.2, & Borkowetz A. & V05.7, V10.6, V10.9, 3K02.9, \\
\hline Arndt M. & Fi01.3 & & 3К02.9, 3К02.16 & & 3К03.6, 3К05.4 \\
\hline Arnold C. & V05.5 & Bayliss G. & $3 \mathrm{~K} 06.14$ & Boschheidgen M. & $3 \mathrm{~K} 01.14$ \\
\hline Arnold H. & V02.7 & Beck A. & V02.7 & Bouzan J. & 3К02.4 \\
\hline Arnsrud Godtman R. & $3 \mathrm{~K} 01.16$ & Becker A. & V05.9, V10.7, V14.5, 3K01.9, & Boviatsis V. & $3 \mathrm{~K} 06.10$ \\
\hline Arsov C. & 3К01.14 & & 3К03.4, 3К08.11, 3К09.9, & Braissant 0. & V01.9 \\
\hline Arthanareeswaran V. & Fi01.2, Fi02.2, & Becker A.J. & V13.7 & Brandenstein M. & V16.2 \\
\hline & $\mathrm{Fi} 02.3$ & Becker B. & V08.6, 3K02.2, 3K02.8 & Brandt A.S. & V08.9 \\
\hline Artysh N. & 3K05.5 & Becker J.C.R. & 3K05.5 & Brandt M. & V17.9, 3K02.13 \\
\hline Ascalone L. & $\mathrm{Fi} 02.4$ & & & Brauers $C$. & V08.2 \\
\hline Aschwanden F. & Fi02.6 & & & Braun K.-P. & V02.8 \\
\hline
\end{tabular}




\begin{tabular}{|c|c|c|c|c|c|}
\hline Brehmer M. & V08.5 & Dahlem R. & V04.7, 3K03.7, 3K08.8, & Ellinger J. & V02.9, V03.1, V03.3, V03.6, \\
\hline Breuer L. & 3К07.9 & & $3 \mathrm{~K} 08.15,3 \mathrm{~K} 08.17$ & & V07.2, V12.8, 3K05.3, \\
\hline Breunig K. & 3К08.8 & Dahm P. & V17.5, 3K07.16 & & 3K06.12 \\
\hline Breunig M. & $3 \mathrm{~K} 04.3$ & Dargatz P. & $3 K 06.13$ & Elsässer J. & V02.3 \\
\hline Breyer J. & $\begin{array}{l}\text { V02.4, 3K02.17, 3K04.7, } \\
\text { 3K07.2, 3К07.13 }\end{array}$ & Darr C. & $\begin{array}{l}\text { 3К01.6, 3К01.7, 3К02.15, } \\
\text { 3К03.3, 3К05.7, 3К05.8, }\end{array}$ & $\begin{array}{l}\text { Elterman D. } \\
\text { Emmenegger U. }\end{array}$ & $\begin{array}{l}\text { 3К08.3, 3К08.5, 3K08.7 } \\
\text { 3К09.7 }\end{array}$ \\
\hline Brücher B. & V15.7 & & $3 \mathrm{~K} 06.2,3 \mathrm{~K} 06.13$ & Enderle D. & $3 \mathrm{~K} 05.6$ \\
\hline BrummeisI W. & V04.3 & Daum S. & 3K05.1 & Enderle $\mathrm{M}$. & V11.8 \\
\hline Bründl J. & $3 \mathrm{~K} 07.13$ & De Arruda L. & 3K09.6 & Engel 0. & 3К08.12 \\
\hline Brüning F. & 3К06.9 & De Velasco G. & 3К06.18 & Engeler D. & 3К08.1 \\
\hline Brunner A. & V03.8 & De Visschere P. & V07.5 & Engler T. & V12.8 \\
\hline Bryce A.H. & $3 K 09.12$ & Degener S. & V08.9 & Enikeev D. & 3К04.10 \\
\hline Buchner $\mathrm{A}$. & V14.5, V14.6, 3K01.8 & Deininger $\mathrm{S}$. & V08.4 & Eraky A. & $3 K 06.2$ \\
\hline Budäus L. & V10.3, 3K01.5 & Dendl K. & $3 \mathrm{~K} 05.8$ & Erb $\mathrm{H}$. & V10.9 \\
\hline Buddensieck C. & V12.2 & Denis L. & 3К01.16 & Erb H.H.H. & 3К05.10 \\
\hline Büdenbender B. & V14.1, V14.3, 3K02.3 & Denzinger $\mathrm{S}$. & $3 K 07.13$ & Erben $\mathrm{P}$. & 3К04.7 \\
\hline Bühler M. & $3 \mathrm{~K} 01.18$ & Desai M. & $3 K 08.3,3 K 08.7$ & Erber B. & $3 \mathrm{~K} 06.8$ \\
\hline Bündgen $\mathrm{M}$. & 3К02.10 & Deshpande H. & V07.6 & Erbing $\mathrm{F}$. & V15.8 \\
\hline Burchardt M. & $3 \mathrm{~K} 04.1$ & Despain D. & 3К09.12 & Erdmann $\mathrm{K}$. & V10.9, 3K05.4 \\
\hline \multirow[t]{2}{*}{ Burger M. } & V02.4, 3K02.15, 3K04.7, & Deuker M. & $3 K 03.4,3 K 08.11$ & Eredics K. & V01.6, 3K02.5, 3К08.16 \\
\hline & $3 \mathrm{~K} 06.15,3 \mathrm{~K} 07.2,3 \mathrm{~K} 07.13$ & Dichtl A. & V13.3 & Erlmeier $\mathrm{F}$. & V03.9 \\
\hline Bürk B. & V05.7 & Dichtl L. & V16.6 & Erne E. & V08.4 \\
\hline Burkhardt 0. & $3 K 08.13$ & Dieckmann K.-P. & V16.1, V16.3 & Esch L. & 3К05.14 \\
\hline Burmeister $\mathrm{A}$. & V12.7 & Dieffenbacher S. & V05.1 & Espig 0. & $\mathrm{Fi} 02.2$ \\
\hline Busch J. & 3К06.8, 3К06.18 & Dietrich D. & V07.2 & Esteban E. & $3 К 06.18$ \\
\hline Busenbender T. & $3 K 05.2$ & Dinkel A. & V16.6 & Estler A. & $3 \mathrm{~K} 07.11$ \\
\hline \multirow[t]{3}{*}{ Butea-Bocu M.C. } & $3 \mathrm{~K} 02.6,3 \mathrm{~K} 03.8$ & Dirks W.G. & 3K05.14 & Eul K. & V12.5 \\
\hline & & Distler F. & V06.4 & & \\
\hline & & Distler F.A. & $3 K 01.13$ & & \\
\hline C & & Dittmar F. & V13.6 & $\mathbf{F}$ & \\
\hline Campbell D. & 3К09.12 & Dlugosch J. & V08.8 & Fahlteich F. & V10.9 \\
\hline Carcano F.M. & 3К09.6 & Doehn C. & V02.1, V16.4, V17.4, 3K06.4 & Fahr C. & V11.3 \\
\hline Carvalho F. & 3К03.5 & Dörfel S. & $3 \mathrm{~K} 06.7$ & Fajkovic $\mathrm{H}$. & 3К04.10, 3К04.11 \\
\hline Cash $\mathrm{H}$. & 3К01.3 & Doros G. & V13.5 & Falkensammer $\mathrm{E}$. & $3 \mathrm{~K} 06.2$ \\
\hline Cella D. & $3 \mathrm{~K} 06.16$ & Dotzauer R. & V02.6, V17.9, 3K02.13 & Fangerau $\mathrm{H}$. & V09.6 \\
\hline Chaloupka M. & V14.5, 3K01.8 & Dowson M. & 3K09.12 & Faraj Tabrizi P. & V07.4, 3K01.12 \\
\hline Chang S.L. & $3 \mathrm{~K} 06.17$ & Dräger D. & V06.5 & Fassbach M. & V02.7 \\
\hline CheY. & $\mathrm{V} 12.4, \mathrm{~V} 12.2, \mathrm{~V} 12.3$ & Dräger D.L. & V14.2 & Fazil L. & $3 K 05.8$ \\
\hline Chen J. & $3 \mathrm{~K} 07.5$ & Dreger N.M. & V08.9 & Fendler W.P. & 3К05.7 \\
\hline Chi K.N. & 3К09.8 & Dressler F.F. & 3К07.12 & Feyerabend $\mathrm{S}$. & 3K09.5 \\
\hline Choueiri T.K. & $3 K 06.16$ & Dubrovska A. & 3К05.10 & Fiebig C. & V02.3 \\
\hline Chowdhury S. & 3К09.8, 3К09.12 & Dubrowinskaja N. & V07.4 & Fisang C. & V10.5 \\
\hline Christoph D.C. & $3 \mathrm{~K} 06.9$ & Duensing S. & 3K01.1 & Fisch M. & V04.7, 3К03.7, 3К08.8, \\
\hline Christoph F. & V17.4 & Dugas M. & V13.1 & & 3К08.15, 3К08.17 \\
\hline \multirow[t]{2}{*}{ Chun F. } & V10.7, 3К01.9, 3К03.4, & Dumlupinar $\mathrm{C}$. & V16.1 & Fischer C. & 3K05.6 \\
\hline & 3К08.11, 3К09.9 & Duran I. & 3К06.18 & Fischer N. & 3К02.12 \\
\hline Chun F.K.-H. & 3К09.2, 3К09.4 & Düwel C. & V17.2 & Fizazi K. & 3К09.6, 3К09.7, ЗК09.12 \\
\hline Chung B.H. & $3 \mathrm{~K} 09.8$ & Dyshlovoy S. & 3К05.2, 3К09.13, 3К09.14 & Flegar L. & V05.7, 3K02.9 \\
\hline Cinatl J. & V16.8, V16.8 & & & Fleshner N. & 3К09.7 \\
\hline Cinatl Jr.J. & $3 \mathrm{~K} 05.15$ & & & Flinspach C. & 3К05.6 \\
\hline Ciotkowska A. & V15.1 & E & & Flörcken A. & $3 K 06.13$ \\
\hline Claus R. & V17.3 & Eberli D. & V06.3, 3K08.2 & Foerster B. & V08.3 \\
\hline Clevert D.-A. & $3 \mathrm{~K} 01.8$ & Ebert T. & V02.6, 3K07.5 & Folchini D.M. & V02.3 \\
\hline Collette S. & V17.6 & Ecke T. & $3 K 07.1$ & Foller S. & V17.7, 3K06.18, 3K08.4, \\
\hline Compérat E. & 3К04.10, 3K04.11 & Eckstein M. & V10.4, 3K04.4, 3K04.7, & & 3К08.5, 3К08.14 \\
\hline Concepcion R.S. & 3K09.7 & & 3K04.8, 3К07.4, 3К07.13 & Forchheim M. & $3 \mathrm{~K} 07.2$ \\
\hline Cone E. B. & 3К06.14 & Eder A. & V01.6 & Foreman S.C. & 3К03.10 \\
\hline Cornelius J. & $\mathrm{Fi} 02.6$ & Efferth T. & $3 \mathrm{~K} 05.15$ & Förster B. & $3 \mathrm{~K} 08.13$ \\
\hline Correa J.J. & 3К09.6 & Egner T. & Fi01.1, Fi01.4 & Forsting $\mathrm{M}$. & 3К01.6, 3К01.7 \\
\hline Cox A. & V03.6 & Eiber $\mathrm{M}$. & 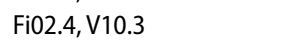 & Fragoso Costa P. & $3 \mathrm{~K} 03.3,3 \mathrm{~K} 05.7$ \\
\hline Cruz F.M. & $3 \mathrm{~K} 09.7$ & Eichenauer R. & V02.1, V16.4, V17.4, 3K06.4 & Frees $\mathrm{S}$. & $3 \mathrm{~K} 02.13$ \\
\hline \multirow[t]{3}{*}{ Culig Z. } & V03.8, 3К07.17 & Eisenacher M. & $3 \mathrm{~K} 05.16$ & Frey L. & V03.3, 3К01.2 \\
\hline & & Eisenmenger $\mathrm{N}$. & 3К02.9 & Friedersdorff $\mathrm{F}$. & $3 \mathrm{~K} 07.1$ \\
\hline & & Eismann L. & V14.6 & Fries J. & V07.3, 3К05.13 \\
\hline D & & Ejzykowicz F. & 3К06.16 & Fries $\mathrm{P}$. & V04.1 \\
\hline D’Andrea D. & $3 \mathrm{~K} 04.10$ & Elkaial K. & $3 \mathrm{~K} 06.1$ & Fritz J. & $3 \mathrm{~K} 07.17$ \\
\hline Daemi Attaran P. & V11.2 & Ell J. & V06.4, 3К02.14 & Fröhner M. & V10.6, 3K03.6 \\
\hline
\end{tabular}




\begin{tabular}{|c|c|c|c|c|c|}
\hline Fünfgeld C. & V11.4 & Gross A.J. & V08.6, 3K02.8 & Harland N. & V11.8, 3K01.3, 3К07.6, \\
\hline Funk K. & V02.2 & Große Siemer R. & V12.3 & & 3К07.15 \\
\hline \multirow[t]{4}{*}{ Füssel S. } & V06.1, V10.9, 3K04.14, & Grosse Vollmer S. & $3 \mathrm{~K} 03.9$ & Hartmann A. & V03.9, V10.4, V16.7, 3K04.4 \\
\hline & 3K04.15, 3K05.4, 3К05.10 & Grossmann N.C. & V06.3, 3К04.10, 3К04.11 & & 3K04.7, 3К04.8, 3К07.4, \\
\hline & & Gruen C. B. & V17.7 & & $3 \mathrm{~K} 07.13$ \\
\hline & & Grüllich C. & 3К06.7, ЗК06.13 & Hartmann F. & $3 \mathrm{~K} 02.10$ \\
\hline $\mathbf{G}$ & & Grundmann N. & $3 \mathrm{~K} 09.17$ & Harz N. & V04.2 \\
\hline Gakis G. & Fi01.6 & Grüne B. & V01.3, V01.7, V14.1, V14.3, & Hasanali S. & $3 K 04.12$ \\
\hline Ganzer R. & V04.3 & Grunewald C.M. & 3К04.13, 3К09.15 & Hasselluhn M.C. & $3 \mathrm{~K} 05.5$ \\
\hline Gasch C. & 3К03.11 & Grunwald C. & $3 \mathrm{~K} 07.1$ & Hatiboglu G. & 3К01.1, 3К03.11 \\
\hline Gaßmann K.-G. & V02.3 & Grünwald V. & V07.6, 3K02.15, 3К06.7, & Hauschulte K. & $3 \mathrm{~K} 05.15$ \\
\hline Gebhard I. & V02.4 & & 3К06.9, 3К06.13 & Häuser L. & V02.5, 3K03.5, 3К06.14 \\
\hline Gebhardt T. & Fi01.3, Fi01.5, Fi02.1 & Grütter A. & V01.9 & Haybaeck J. & $3 \mathrm{~K} 05.1$ \\
\hline Geczi L. & V16.3 & Grzella C.I. & V05.2 & Hebenstreit D. & $3 K 01.15$ \\
\hline Geisel D. & V07.5 & Gschwend J. & V03.9, V13.3, V16.6 & Heberling U. & V10.6, 3K03.6 \\
\hline Geng R. & V11.8 & Gu A. & V06.3 & Heck M. & V10.3, V17.2, 3K02.2 \\
\hline Genske T. & $3 \mathrm{~K} 02.7$ & Guezguez B. & $3 K 05.10$ & Heck M. M. & $\mathrm{Fi} 02.4$ \\
\hline Geppert C. & V10.4, V16.7 & Günes C. & 3К04.3, 3К04.4, 3К04.5, & Heesakkers J. & V11.2 \\
\hline Gerber M. & Fi01.3 & & 3К04.8, 3К04.9 & Heidegger I. & 3К05.1 \\
\hline Gerger A. & $3 \mathrm{~K} 06.5$ & Günzel K. & 3К01.10, 3К01.11 & Heidenrech A. & $3 \mathrm{~K} 02.10$ \\
\hline Gergondey M. & 3К07.5 & Gusenleitner A. & $3 \mathrm{~K} 01.3$ & Heidenreich A. & V07.3, V12.4, V12.6, V16.2, \\
\hline Geyer M. & $3 \mathrm{~K} 07.14$ & Güsewell S. & 3К08.1, 3К08.6 & & 3К01.18, 3К02.12, 3К05.9, \\
\hline Gheith K. & $3 K 02.13$ & Güttlein M. & V05.1 & & 3К05.13, ЗК05.17, ЗК09.3 \\
\hline Gierth M. & $3 К 07.13$ & Guzman J. & $3 K 05.11$ & Heidenreich J. & $3 \mathrm{~K} 09.3$ \\
\hline Giesel F.L. & $3 \mathrm{~K} 05.8$ & & & Heinrich S. & $3 \mathrm{~K} 01.10$ \\
\hline Giesel F. & Fi02.4 & & & Heinze A. & 3К09.2, 3К09.4 \\
\hline Giessing M. & $3 \mathrm{~K} 01.14$ & $\mathrm{H}$ & & Heinzelbecker J. & V16.7, 3К03.9, 3К06.12 \\
\hline Gilbert N. & $3 \mathrm{~K} 06.2$ & Haack M. & 3К01.2, 3К02.13 & Heinzelmann J. & V16.7 \\
\hline \multirow[t]{2}{*}{ Gild P. } & 3К03.7, 3К08.8, ЗК09.13, & Haas G.P. & $3 \mathrm{~K} 09.5$ & Heinzer $\mathrm{H}$. & V05.5, 3K09.9 \\
\hline & $3 K 09.14$ & Haberkorn U. & 3К05.8 & Hellmann T. & $3 \mathrm{~K} 02.6$ \\
\hline Given R. & 3К09.8 & Hadaschik B. A. & V04.6, V17.8, 3K03.3, & Hellms S. & $3 \mathrm{~K} 01.12$ \\
\hline Gleave M. & $3 \mathrm{~K} 05.8$ & & $3 \mathrm{~K} 05.7$ & Hempel E. & V02.1, V16.4, V17.4, 3K06.4 \\
\hline Gleissner J. & $3 \mathrm{~K} 07.14$ & Haese A. & V10.8 & Heni M. & $3 \mathrm{~K} 05.12$ \\
\hline Gloger S. & $3 \mathrm{~K} 08.5$ & Haferkamp A. & V08.2, V08.7, V16.8, V16.9, & Henkel A. & V04.6 \\
\hline Goebell P. & 3К06.7 & & V17.9, 3K01.2, 3K02.13, & Hennenberg M. & V15.1,V15.2, V15.5, V15.9 \\
\hline Goebell P.J. & 3К06.9, 3К07.5 & & $3 \mathrm{~K} 05.15$ & Hennenlotter J. & V02.2, V07.4, 3K01.12, \\
\hline Golsorkhi T. & 3К09.12 & Hafez O. & V07.6 & & 3К03.2, 3К04.17, 3К05.12, \\
\hline Gomez-Veiga F. & 3К09.5 & Hagen F. & $3 \mathrm{~K} 07.11$ & & $3 \mathrm{~K} 06.11$ \\
\hline Gonsior A. & V15.4 & Hahn 0. & $3 \mathrm{~K} 05.5,3 \mathrm{~K} 06.12$ & Hennig M. & 3К07.1 \\
\hline \multirow[t]{2}{*}{ Görtz M. } & V05.1, 3K01.1, 3K01.7, & Hahne $\mathrm{H}$. & $3 \mathrm{~K} 07.2$ & Hennig M.J.P. & $3 K 04.12$ \\
\hline & $3 K 03.11$ & Haider A. & V13.5 & Henning $\mathrm{A}$. & V01.6 \\
\hline Gössl A. & 3K07.1 & Haider K. & V13.4 & Нерр Т. & 3K07.11 \\
\hline Götte M. & $3 \mathrm{~K} 03.8$ & Haider K.S. & V13.5 & Herden J. & V02.6, V07.3 \\
\hline Goveia J. & 3К05.1 & Haisch C. & V01.5 & Herkommer K. & V10.2, V13.3, V16.6 \\
\hline Grabbert M. & V11.3, V17.3 & Haist C. & $3 \mathrm{~K} 04.13$ & Hermanns T. & V06.3, 3K08.2 \\
\hline Grabbert M.T. & $3 \mathrm{~K} 02.15$ & Hakenberg 0. & V06.5, V14.2 & Herrmann K. & 3K05.7 \\
\hline \multirow[t]{4}{*}{ Graefen M. } & Fi02.4, V05.5, V10.1, V10.7, & Hakenberg O.W. & V01.1 & Herrmann L. & 3K06.6, 3K06.11 \\
\hline & 3К01.5, 3К01.9, 3К05.2, & Hallek M. & $3 К 05.17$ & Herrmann T. R.W. & $3 \mathrm{~K} 02.8$ \\
\hline & 3К09.2, 3К09.4, 3К09.13, & Halling T. & V09.5, V09.6 & Herzog P. & V02.5 \\
\hline & $3 K 09.14$ & Hallmann S. & 3К07.1 & Heß J. & V04.6 \\
\hline Graf S. & V02.3 & Hamilton M. & $3 \mathrm{~K} 06.16$ & Hess J. & V17.8, 3К03.3 \\
\hline Grammenos D. & $3 \mathrm{~K} 07.5$ & Hammer S. & V02.4 & Heydenreich M. & V14.4, V14.7, 3K06.3 \\
\hline \multirow[t]{2}{*}{ Gratzke C. } & V11.3, V15.1, 3K01.4, & Hammes J. & V04.9 & Hiester A. & V12.2, V12.3, V12.4 \\
\hline & $3 \mathrm{~K} 02.15$ & Han S. & $3 \mathrm{~K} 07.7$ & Himbert D. & V03.4, V03.5 \\
\hline Grilli M. & V14.8 & Handke A. & $3 \mathrm{~K} 05.8$ & Himmler M. & V14.8 \\
\hline \multirow[t]{3}{*}{ Grimm M.-O. } & V17.7, 3K04.6, 3K06.9, & Hanenberg $\mathrm{H}$. & $3 K 04.13$ & Hinke A. & $3 \mathrm{~K} 06.13$ \\
\hline & 3К06.18, 3К07.3, 3К08.4, & Haney C.M. & V05.2 & Hinz S. & 3К01.10, 3К01.11 \\
\hline & $3 K 08.14$ & Hanke D. & V13.2 & Hoefner T. & $3 \mathrm{~K} 01.2$ \\
\hline Grimm M. & $3 \mathrm{~K} 02.14$ & Hansson $\mathrm{N}$. & V09.5 & Hoeh B. & V10.7, 3К01.9, 3К09.9 \\
\hline Groeben C. & V05.6, 3K02.1, 3K02.2, & Harde J. & 3К06.9 & Hofbauer S. & 3К01.3, 3К07.1 \\
\hline
\end{tabular}




\begin{tabular}{|c|c|c|c|c|c|}
\hline \multirow[t]{2}{*}{ Hoffmann M.J. } & \multirow{2}{*}{$\begin{array}{l}\text { V07.2, 3К07.8, 3К07.9, } \\
\text { 3К04.13 }\end{array}$} & \multirow{2}{*}{$\begin{array}{l}\text { Janisch F. } \\
\text { Janssen J. }\end{array}$} & \multirow{2}{*}{$\begin{array}{l}3 \mathrm{~K} 06.17 \\
\mathrm{~V} 11.2\end{array}$} & \multicolumn{2}{|c|}{ Kirschner-Hermanns R. V01.8 } \\
\hline & & & & Kleger A. & $3 K 04.3$ \\
\hline Höfner T. & V17.9, 3K02.13 & Jansz G.K. & 3К09.6 & Klein D. & V15.7 \\
\hline Höh B. & 3К06.12 & Jaschkowitz G. & V03.4, V03.5 & Klein F. & V10.5 \\
\hline \multirow[t]{2}{*}{ Hohenfellner M. } & V05.1, V05.2, V05.8, 3K01.1, & Jersinovic S. & $3 \mathrm{~K} 07.15$ & Klein T. & V06.4, 3K02.14, 3К08.18 \\
\hline & $3 K 03.11$ & Jessen J. & V08.8 & Klemm J. & $3 \mathrm{~K} 03.7$ \\
\hline Hohenhorst J.L. & $\mathrm{Fi} 02.4$ & Jilg C. & 3К01.4 & Klier J. & V02.1, V16.4, V17.4, 3K06.4 \\
\hline Hohwieler M. & $3 K 04.3$ & Jobst L. & $3 K 05.12$ & Kliesch S. & V13.1, V13.2 \\
\hline Holbach S. & V14.3 & Jöcker A. & $3 \mathrm{~K} 07.5$ & Klinger $\mathrm{C}$. & 3К05.16 \\
\hline Holdmann J. & $3 К 05.16$ & Johannsen M. & V02.1, V16.4, V17.4, 3K06.4 & Klockenbusch J.C. & $3 K 02.15$ \\
\hline Hollenbach M. & 3К01.3 & John A. & 3К04.4, 3К04.5, 3К04.9 & Klocker H. & $3 \mathrm{~K} 05.1$ \\
\hline Hölters S. & V16.7, 3К06.9 & John H. & V08.3, 3K08.13 & Klopf C. & V05.6 \\
\hline Holzbeierlein J. & 3К09.5 & Jokisch J.-F. & V14.6 & Klose J. & 3К05.7 \\
\hline Holze S. & V05.2, V05.8 & Jones J. & V02.6 & Kluike C. & V17.4 \\
\hline Hölzel M. & V03.1, V07.2, 3K05.3 & Juengel E. & $3 K 05.15$ & Klümper N. & V02.9, V03.1, V03.3, V03.6, \\
\hline Hölzer M. & 3К04.6 & Juetter K.M. & $3 K 05.15$ & & V07.2, 3К05.3, 3К06.12 \\
\hline Homann S. & V04.2 & Jüngel $\mathrm{E}$. & V16.8, V16.9 & Kluth L. & V10.7, 3K01.9, 3K03.4, \\
\hline Hommel A. & $3 \mathrm{~K} 07.10$ & Jungmann F. & 3К01.2 & & 3К08.11, 3К09.9 \\
\hline Hommel K. & 3К04.16 & Junker K. & V03.1, V03.4, V03.5, V03.7, & Knipper S. & Fi02.4, V05.5, V10.1, V10.3 \\
\hline Hopf T. & 3К07.2 & & V03.9, V16.7, 3K06.1, & Knoefel W.T. & V12.2 \\
\hline Höppner D. & V11.1 & & 3К06.9, 3К09.1 & Knoll J. & V11.8 \\
\hline \multirow[t]{2}{*}{ Horn T. } & Fi02.4, V10.3, V17.2, & & & Knoll T. & V08.8 \\
\hline & $3 \mathrm{~K} 03.10$ & & & Knüpfer S. & V01.8 \\
\hline Horninger W. & V03.8, 3K07.17 & K & & Koch R. & V05.6, V10.6, 3K03.6 \\
\hline Horstmann M. & $3 \mathrm{~K} 02.4$ & Kachanov M. & 3К01.5 & Köditz B. & V07.3, 3К05.13, 3К05.17, \\
\hline Huang R. & V15.1, V15.2, V15.9 & Kahlmeyer A. & V02.3 & & V16.2 \\
\hline \multirow{3}{*}{ Huber J. } & Fi02.8, V05.6, V05.7, 3K02.1, & Kalogirou C. & 3К06.12 & Koeditz B. & 3К05.9 \\
\hline & 3К02.2, 3К02.9, 3К02.16, & Kaltenecker K. & V05.1 & Köhler M. & V07.5 \\
\hline & $3 \mathrm{~K} 02.17$ & Kaplan S. & 3К08.3, 3К08.5, 3К08.7 & Köhrer K. & V12.5, V12.7, V12.9, \\
\hline Huber T. & $3 \mathrm{~K} 01.2$ & Kappeler C. & 3К09.6 & & 3К04.13, 3К07.9, 3К07.10 \\
\hline Hübler M. & 3K03.6, V10.6 & Karagiotis T. & V05.3 & Kolbenschlag J. & V04.9 \\
\hline Hübner W. A. & V11.6, V11.7 & Karakiewicz P. & V10.7, 3К03.4 & Kölker M. & 3К02.2, 3К02.11, 3К03.7 \\
\hline Huerta M. & V07.3, 3К05.9 & Karakiewicz P.I. & $3 \mathrm{~K} 04.10$ & Koll F.J. & $3 \mathrm{~K} 03.10$ \\
\hline Hugosson J. & $3 \mathrm{~K} 01.16$ & Karbech S. & V13.8 & Köllermann J. & 3К01.9 \\
\hline Humberg V. & 3К05.14, 3К09.17 & Karschuck P. & V05.6, V14.3, 3K02.16 & Kommoss S. & V04.9 \\
\hline Humke U. & Fi01.3 & Kaspar C. & V04.6 & Koneval L. & V02.3 \\
\hline Humphrey P. & V07.6 & Kässer M. & V11.5 & König B. & V15.6 \\
\hline Humphreys M. & $3 \mathrm{~K} 08.7$ & Katalinic A. & $3 \mathrm{~K} 02.15$ & König C. & $3 \mathrm{~K} 04.13$ \\
\hline Hupe M.C. & 3К02.15, 3К02.7, 3К04.12 & Katayama S. & 3К04.10, 3К04.11 & König F. & V02.1, V04.7, V16.4, V17.4, \\
\hline Hurwitz M. & V07.6 & Katzendorn 0. & V07.4, 3К01.12, 3К06.2 & & 3К06.4, 3К08.15, 3К08.17 \\
\hline Hüsch T. & V11.4 & Katzenwadel A. & V11.3 & König H.-H. & $3 \mathrm{~K} 02.8$ \\
\hline Huss S. & 3K05.14 & Kaufmann B. & V06.3 & König J. & V02.7, V04.3, 3K02.17 \\
\hline \multirow[t]{2}{*}{ Hüttenbrink C. } & V06.4, 3K01.13, 3K02.14, & Kaufmann M. & 3К05.16, 3К07.3 & König P. & V10.4 \\
\hline & $3 \mathrm{~K} 08.18$ & Kaufmann S. & $3 \mathrm{~K} 07.11$ & Koon H.B. & V17.6 \\
\hline Hutterer G. & 3К07.14 & Kaune M. & $3 \mathrm{~K} 05.2$ & Korte A. & V13.3 \\
\hline Hutterer G.C. & $3 \mathrm{~K} 06.5$ & Kayser G. & 3К07.12 & Koska M. & $3 \mathrm{~K} 06.7$ \\
\hline \multirow[t]{3}{*}{ Hwang E.C. } & V17.5 & Keck B. & $3 \mathrm{~K} 04.7$ & Köther A.K. & V14.1, V14.3, 3K02.3 \\
\hline & & Keil M. & 3К08.4 & Kotolloshi R. & 3К04.6 \\
\hline & & Keller E.X. & V06.3, 3K08.2 & Kowalewski A. & 3К01.18 \\
\hline I & & Keller P. & 3К08.9 & Koziarz A. & $3 \mathrm{~K} 07.16$ \\
\hline Igawa Y. & V15.8 & Kelp A. & V15.3 & Krabbe L.-M. & 3К09.17 \\
\hline Iguchi T. & $3 \mathrm{~K} 09.5$ & Kempkensteffen C. & Fi01.1 & Krafft U. & V04.6, V17.8, 3K01.6, \\
\hline Ihrig A. & V05.6 & Keppler O.T. & V15.5 & & 3К01.7, 3К03.3, 3К05.8 \\
\hline lking J. & $3 \mathrm{~K} 05.7$ & Kesch C. & V17.8, 3K01.6, 3K01.7, & Kramann R. & V06.2 \\
\hline Ivanescu C. & $3 К 06.16$ & & 3К03.3, 3К05.8 & Kramer M. & $3 K 07.1$ \\
\hline Ivanov G. & V04.5 & Kessel K. & 3К09.10, 3К09.11, ЗК09.16 & Kramer M.W. & ЗК02.7, ЗК02.15, 3К04.12 \\
\hline Ivanyi P. & $3 \mathrm{~K} 06.13$ & Khaljani E. & V02.6 & Kranz J. & V01.1, V01.2, V06.2 \\
\hline Izquierdo E. & $3 K 05.17$ & Khalmurzaev 0. & V16.7 & Krausewitz P. & V02.9 \\
\hline \multirow[t]{3}{*}{ Izquierdo-Luna J.S. } & Fi01.6 & Khonsari M. & V04.7, 3K03.7, 3К08.15, & Kraywinkel K. & 3К02.9, 3К06.4 \\
\hline & & & 3К08.17 & Krebs J. & V11.9, V14.9 \\
\hline & & Kilbridge K. L. & 3К06.14 & Krebs M. & V17.3 \\
\hline J & & Kim H.S. & V07.6 & Krege S. & V04.8 \\
\hline Jacewicz M. & 3К01.11 & Kim M.H. & 3К07.16 & Krenz H. & V13.1 \\
\hline Jaekel A. K. & V01.8 & Kimmel C. & 3К07.13 & Kress A. & V04.2 \\
\hline Jäger W. & $3 K 02.13$ & Kind $B$. & $3 \mathrm{~K} 04.14,3 \mathrm{~K} 04.15$ & Kretschmer A. & V14.5, 3K05.6 \\
\hline Jahnen M. & V13.3, V16.6 & Kinner S. & V07.5 & Kretschmer S. & 3К07.12 \\
\hline Jänicke M. & 3К06.7 & Kirchhoff F.P. & 3K03.10 & KretzT. & 3К06.13 \\
\hline
\end{tabular}




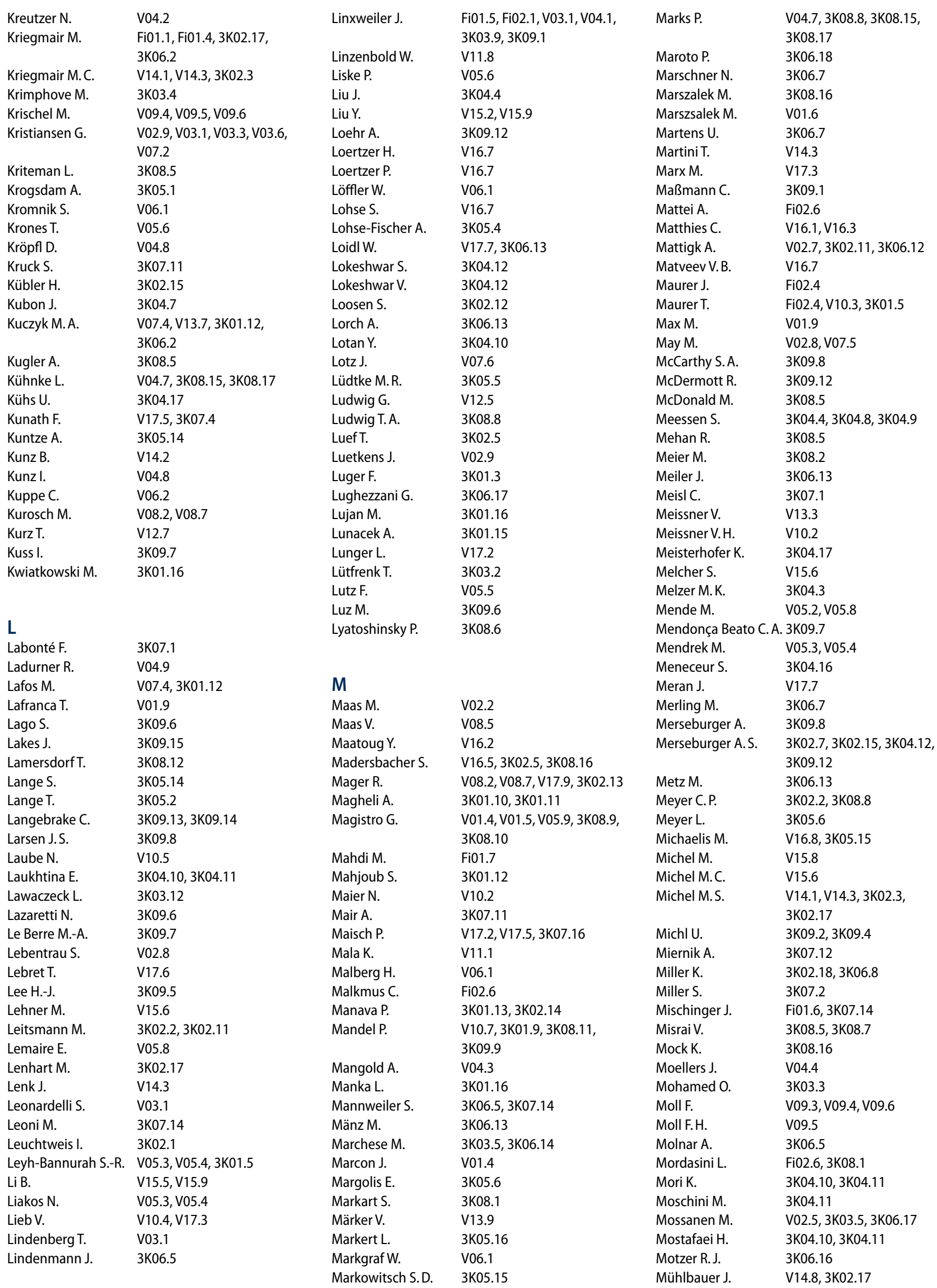




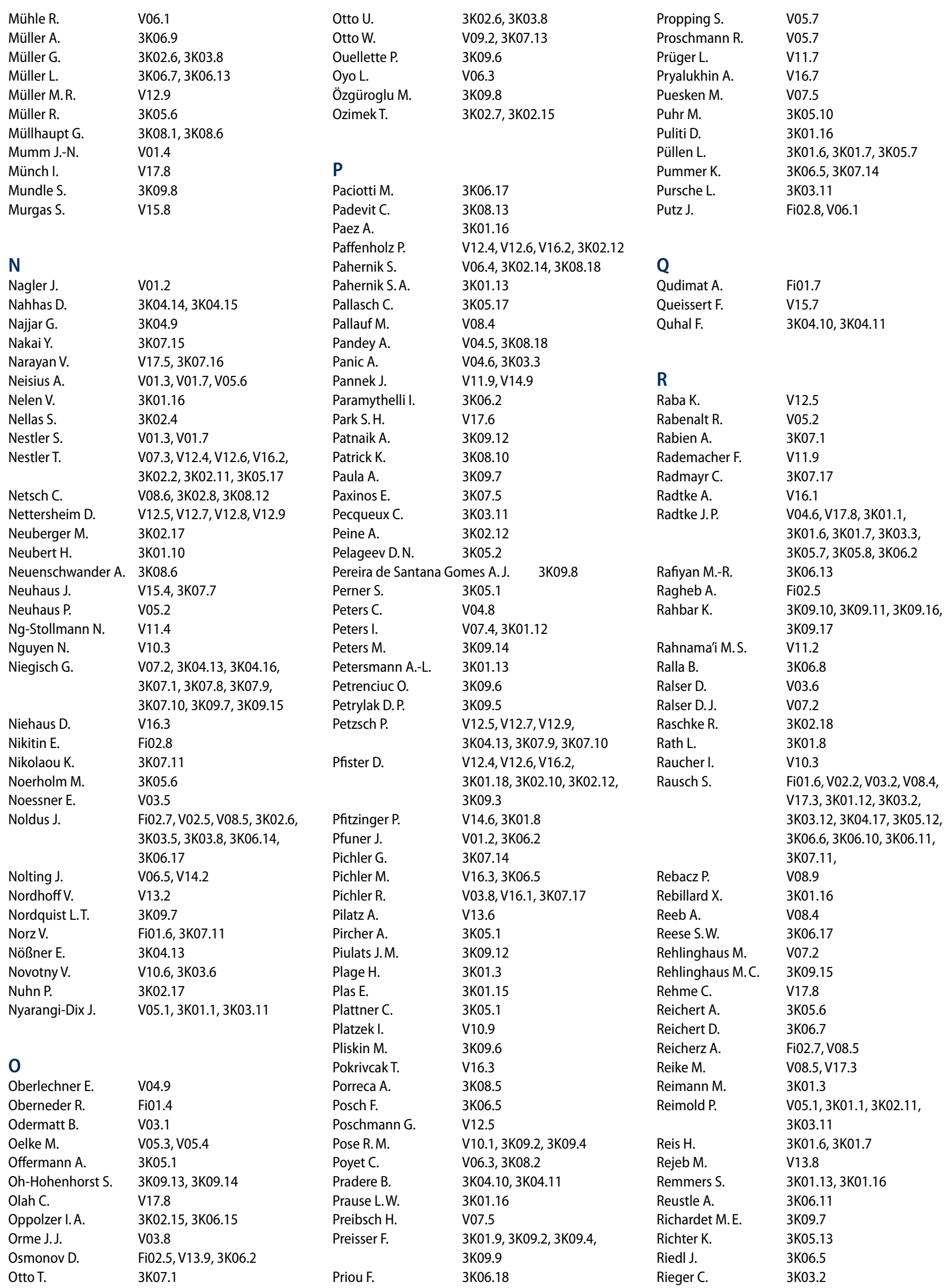




\begin{tabular}{|c|c|c|c|c|c|}
\hline Rieken M. & V01.9 & Schlack K. & V07.2, 3K09.10, 3К09.11, & Seifert R. & 3К09.10, 3К09.11 \\
\hline \multirow[t]{2}{*}{ Rink M. } & 3К03.7, 3К04.10, 3К04.11, & & 3К09.16, 3К09.17 & Seitzer K. & 3К09.10, 3К09.11, 3К09.17 \\
\hline & $3 \mathrm{~K} 08.8$ & Schlemmer H.-P. & 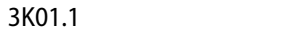 & Seles M. & 3К06.5, 3К07.14 \\
\hline Ritt M. & V02.3 & Schlenker B. & V14.5, V14.6, 3К01.8 & Seliger B. & 3К06.9 \\
\hline \multirow[t]{2}{*}{ Ritter M. } & V02.9, V03.1, V03.3, V03.6, & Schlenska-Lange A. & 3К06.7 - = & Sens-Albert C. & V15.6 \\
\hline & V07.2, V12.8, 3K05.3 & Schlomm T. & V11.1, 3K01.3, 3К06.8, & Serrero G. & V10.4 \\
\hline Rodler S. & V14.6 & & $3 \mathrm{~K} 07.1$ & Serth J. & V07.4 \\
\hline Roehrborn C. & 3К08.3, 3К08.7 & Schmautz M. & 3К01.18, 3К02.10, 3К09.3 & Sevcenco S. & 3К08.16 \\
\hline Roghmann F. & V17.3, 3К02.6, 3К03.8 & Schmees C. & V03.2 & Shaar M. & V02.8 \\
\hline Roobol M.J. & $3 \mathrm{~K} 01.16$ & Schmid D. & 3К08.2 & Shapiro J.D. & 3К09.12 \\
\hline Roos F. & $\begin{array}{l}\text { V10.7, 3К03.4, 3К06.9, } \\
\text { 3К08.11 }\end{array}$ & $\begin{array}{l}\text { Schmid H.-P. } \\
\text { Schmid M. }\end{array}$ & $\begin{array}{l}\text { 3K08.1, 3K08.6 } \\
\text { V02.6 }\end{array}$ & Shariat S.F. & $\begin{array}{l}\text { V17.6, 3K04.10, 3K04.11, } \\
\text { 3K06.17 }\end{array}$ \\
\hline Rosbrook B. & 3К09.5 & Schmid S.C. & V17.2, 3К03.10 & Shore N.D. & 3К09.5, 3К09.6, 3К09.7 \\
\hline Rosenbaum C. & $3 \mathrm{~K} 08.12$ & Schmidinger M. & V03.8, 3K06.18 & Siebels M. & V05.6 \\
\hline Rosenbaum C.M. & V08.6, 3K02.8 & Schmidt A. & 3К05.3 & Siech C. & V02.7 \\
\hline Rossmann C. & $3 \mathrm{~K} 06.5$ & Schmidt D. & V03.3 & Siemer S. & Fi01.3, Fi01.5, Fi02.1, V04.1, \\
\hline Roth S. & V08.9 & Schmidt G.E. & $3 \mathrm{~K} 05.5$ & & V06.6, 3K01.17, 3K03.9, \\
\hline Roth W. & V16.9 & Schmidt M. & $3 K 02.1$ & & 3К06.1, 3К09.1 \\
\hline Röthlin F. & $3 \mathrm{~K} 08.16$ & Schmidt S. & 3К07.4 & Sievert K.-D. & V11.5 \\
\hline Rothweiler F. & V16.8 & Schmitz M. & V17.7, 3K06.18 & Sigg A.P. & V01.9 \\
\hline Rüd I.-B. & 3К06.9 & Schmitz-Dräger B.J. & V17.7 & Sigle A. & 3К01.4 \\
\hline Ruhi Onur M. & V07.5 & Schmitz-Dräger C. & 3К07.5 & Sigloch F.C. & 3К07.2 \\
\hline Ruiz S. & V15.7 & Schmucker P. & 3К06.12 & Sikic D. & 3К04.7, 3К07.4 \\
\hline Rutkowski M. & V11.6, V11.7 & Schmudermaier M. & 3К01.15 & Silveira G.C. & 3К09.7 \\
\hline \multirow[t]{3}{*}{ Ryan C.J. } & 3К09.12 & Schnabel M. & V02.4 & Simon R. & $\mathrm{Fi} 02.4$ \\
\hline & & Schnabel M.J. & 3К02.15, 3К06.15 & Skog J. & 3К05.6 \\
\hline & & Schneider A. & $3 \mathrm{~K} 02.1$ & Skowron M.A. & V12.5, V12.7, V12.9 \\
\hline S & & Schneider S. & V15.5 & Slade K.S. & 3К05.15 \\
\hline Saad F. & V13.4 & Schneider T. & V15.8 & Slomma R. & 3К03.12 \\
\hline \multirow[t]{2}{*}{ Saar M. } & V04.1, 3K03.9, V06.6, & Schneidewind L. & V01.1, V01.2, V14.2 & Smith M.R. & 3К09.6, 3К09.7 \\
\hline & 3К01.17, 3К09.1 & Schnoor M. & $3 \mathrm{~K} 02.15$ & Smolle M. & 3K06.5 \\
\hline Sabutskii Y.E. & $3 \mathrm{~K} 05.2$ & Schoeb D.S. & 3К07.12 & Smolle-Juettner F.-M. & 3К06.5 \\
\hline Salas M.P. & 3К09.6 & Schön G. & Fi01.1, Fi01.4, 3K06.2 & Soave A. & 3К08.8 \\
\hline Salcher S. & 3К05.1 & Schönfelder R. & V02.1, V16.4, V17.4, 3K06.4 & Söhner F. & V09.3 \\
\hline Salem J. & 3К02.2 & Schöpfer S. & $3 K 07.14$ & Sollik K. & 3К01.10, 3К01.11 \\
\hline Salman M. & V13.4 & Schork K. & $3 \mathrm{~K} 05.16$ & Sommer U. & V10.9 \\
\hline Salomon G. & 3К09.2, 3К09.4 & Schorle H. & V12.8 & Sonnleithner J. & V03.4 \\
\hline Sandach P. & 3К05.7 & Schostak M. & V05.6, V17.7, 3К06.13 & Sonntag U. & $3 \mathrm{~K} 02.2$ \\
\hline Saner Y. & 3К01.6, 3К01.7 & Schott M. & 3K08.9, 3K08.10 & Soto A.J. & 3К09.8 \\
\hline Saponaro M. & 3К05.3 & Schrader A.J. & V07.2, V15.7, 3K09.10, & Spahic E. & ЗК05.9 \\
\hline Sarapohja T. & 3К09.6, 3К09.7 & & 3К09.11, 3К09.17 & Sparwasser P. & $3 \mathrm{~K} 01.2,3 \mathrm{~K} 02.13$ \\
\hline Sari Motlagh R. & 3К04.10, 3К04.11 & Schramm D. & V07.5 & Sperling M. & 3К07.3 \\
\hline Sauckel C. & V15.1 & Schregel C. & V08.3 & Spiegelhalder P. & V05.6 \\
\hline Sauter A. & V17.2 & Schröder F.H. & $3 \mathrm{~K} 01.16$ & Spies V. & 3К01.1 \\
\hline Sauter G. & V05.5, V10.1 & Schröder J. & V02.1, V16.4, V17.4, 3K06.4 & Sponholz S. & V12.2 \\
\hline Sautois B. & 3К09.12 & Schubert M. & V13.1 & Staehler M. & 3К06.7 \\
\hline Savelsbergh A. & $3 \mathrm{~K} 05.16$ & Schuette A. & V05.3, V05.4 & Stähler M. & 3К06.9 \\
\hline Savko 0 & V08.7 & Schulte-Baukloh H. & V11.1 & Staib P. & 3К06.13 \\
\hline Schaeffeler E. & V03.2, 3К06.10, 3К06.11 & Schultheiss D. & V09.7 & Staniszewska M. & 3К05.7 \\
\hline Schäfer G. & $3 \mathrm{~K} 05.1$ & Schulwitz H. & V13.3, V16.6 & Stapelmann D. & V08.9 \\
\hline Schaffner S. & V03.9 & Schulz C. & $3 \mathrm{~K} 02.8$ & Staudacher N. & V03.8, 3K07.17 \\
\hline Schagdarsurengin U. & V13.6 & Schulz G. & V14.6 & Steffens J. & V01.1, V01.2, V06.2 \\
\hline Scharpf M. & 3К04.17, 3К05.12 & Schulze A. & $3 K 02.15$ & Steffens S. & V03.9 \\
\hline Schauer A. M. & V12.2 & Schulze-Seemann W. & V02.6 & Stein J. & V02.9, V03.6, V05.6 \\
\hline Schauer I. & V16.5 & Schumacher U. & V17.7, 3К05.2, 3К06.18 & Stein R. & V14.8 \\
\hline Scheckenbach K. & $3 \mathrm{~K} 04.13$ & Schupp P. & $3 \mathrm{~K} 05.15$ & Steinbach D. & 3К04.6, 3К07.3 \\
\hline Schenker M. & V17.6 & Schuster F. & 3К02.6 & Steiner T. & 3К06.13 \\
\hline Scherr D. & $3 \mathrm{~K} 04.10$ & Schütt P. & 3К06.13 & Steinestel J. & V07.2, 3K09.17 \\
\hline Schiefelbein F. & 3К06.2 & Schüttfort V. & 3К04.10, 3К04.11 & Steinestel K. & V07.2 \\
\hline Schiele S. & V10.2, V13.3, V16.6 & Schütz V. & V05.1, 3K01.1, 3K01.7, & Steinhauser $\mathrm{C}$. & V06.1 \\
\hline Schiess R. & V10.8 & & $3 \mathrm{~K} 03.11$ & Stellwag C. & V08.8 \\
\hline Schilchegger L. & V01.3, V01.7 & Schwab C. & $3 K 01.1$ & Stenzel P. & V16.9 \\
\hline Schimmöller L. & 3K01.14 & Schwab M. & V03.2, 3K06.10, 3К06.11 & Stenzinger A. & 3К01.1 \\
\hline Schinzari G. & $3 \mathrm{~K} 06.18$ & Schwaibold L. & 3К07.6 & Stenzl A. & Fi01.6, V02.2, V03.2, V04.9, \\
\hline Schirren J. & V12.2 & Schwarzburger I. & V09.3 & & V08.4, V11.5, V11.8, V15.3, \\
\hline Schirren M. & V12.2 & $\begin{array}{l}\text { Schwarzer N. } \\
\text { Seifert H.H. }\end{array}$ & $\begin{array}{l}\text { V14.8 } \\
\text { 3K01.16 }\end{array}$ & & $\begin{array}{l}3 \mathrm{~K} 01.3,3 \mathrm{~K} 01.12,3 \mathrm{~K} 03.2, \\
\text { 3К03.12, 3К04.17, 3К05.12, }\end{array}$ \\
\hline
\end{tabular}




\begin{tabular}{|c|c|c|c|c|c|}
\hline & 3К06.6, 3К06.9, 3К06.10, & Thiele C. & V06.1 & Van Leeuwen F.W. B. & Fi02.4 \\
\hline & 3К06.11, 3К07.6, 3К07.11, & Thomalla D. & Fi02.3 & Vendl J. & V11.6, V11.7 \\
\hline & 3К07.15, 3К09.5 & Thomas A. & V16.8, V16.9, V17.9, 3K05.15 & Vetterlein M.W. & V04.7, 3K03.7, 3K08.8, \\
\hline Stephan A. & V12.5, V12.7 & Thomas $\mathrm{C}$. & Fi02.8, V05.6, V05.7, V06.1, & & $3 \mathrm{~K} 08.15,3 \mathrm{~K} 08.17$ \\
\hline \multirow[t]{2}{*}{ Steuber T. } & V10.8, 3K09.2, 3К09.4, & & V10.6, V10.9, 3К02.1, & Viktorin P. & Fi02.6 \\
\hline & 3К09.9 & & 3К02.9, 3К02.16, 3К03.6, & Villers A. & 3К01.16, 3К09.5 \\
\hline Stief $C$ & V14.6, V15.1, 3K08.9 & & 3К04.14, 3К04.15, 3К05.4, & Virseda M. & V15.7 \\
\hline \multirow[t]{3}{*}{ Stief C.G. } & V01.4, V01.5, V05.9, V14.5, & & $3 \mathrm{~K} 05.10$ & Vögeli T.A. & V11.2 \\
\hline & V15.2, V15.5, V15.9, 3K01.8, & Thurnher M. & V03.8 & Vogelzang N.J. & 3К09.12 \\
\hline & $3 K 08.10$ & Thy S. & $3 \mathrm{~K} 07.10$ & VolzY. & V05.9, V14.6 \\
\hline Stirenberg N. & V16.6 & Tiedje D. & 3К09.17 & Von Ahn S. & V05.6 \\
\hline \multirow[t]{3}{*}{ Stöckle M. } & Fi01.3, Fi01.5, Fi02.1, V03.4, & Tietze S. & 3К04.14, 3K04.15 & Von Amsberg G. & 3К05.2, 3К09.13, 3К09.14 \\
\hline & $\begin{array}{l}\text { V03.5, V03.7, V04.1, V06.6, } \\
\text { V16.7, 3K01.17, 3K03.9, }\end{array}$ & Tilki D. & $\begin{array}{l}\text { V10.7, 3K01.9, 3К03.4, } \\
\text { 3К09.2, 3К09.4, 3К09.13, }\end{array}$ & Von Brandenstein M. & $\begin{array}{l}\text { V07.3, 3K05.9, 3K05.13, } \\
\text { 3K05.17 }\end{array}$ \\
\hline & 3К06.1, 3К06.9, 3К09.1 & & 3K09.14 & Von der Heyde E. & $3 \mathrm{~K} 06.7$ \\
\hline Stöhr C. & V03.9 & Timmer-Bosscha $\mathrm{H}$. & 3K05.1 & Von Klot C. & V07.4, 3К06.2 \\
\hline Stöhr R. & V10.4 & Tischler M. & $3 \mathrm{~K} 01.15$ & Von Klot C. A.-J. & $3 \mathrm{~K} 01.12$ \\
\hline Stoilkov B. & 3К02.4 & Todenhöfer T. & V10.9, 3К03.2, 3К07.6 & Von Landenberg N. & V14.3, 3K02.11 \\
\hline Stoll G. & 3К05.6 & Toma M. & V03.1, V03.3, V03.6, V07.2 & Von Rundstedt F.-C. & V08.9 \\
\hline Stolzenbach F. & V10.1 & Tomita Y. & V17.6 & Voog E. & 3К09.12 \\
\hline Stolzenbach L.F. & $3 \mathrm{~K} 03.4$ & Torkler P. & 3К05.6 & Vrijens D. & V11.2 \\
\hline \multirow[t]{2}{*}{ Stolzenburg J.-U. } & $\mathrm{Fi} 01.2, \mathrm{Fi} 02.2, \mathrm{Fi} 02.3, \mathrm{~V} 05.2$, & Törzsök P. & V08.4 & \multirow[t]{3}{*}{ Vynnytska-Myronovska } & V03.7 \\
\hline & V05.8 & Tosev G. & V05.1, V05.6, 3K01.1 & & \\
\hline Stope M. & 3К04.1 & Trachsel Y. & V08.3 & & \\
\hline Stotz M. & 3К06.5 & Traish A. & V13.5 & \multicolumn{2}{|l|}{ W } \\
\hline Strauß A. & $3 K 06.12$ & Trajanoski Z. & 3К05.1 & \multirow[t]{2}{*}{ Wach S. } & V02.3, V10.4, 3K04.7, \\
\hline Strewinsky N. & 3К09.14 & Triantos S. & 3К09.8 & & 3K05.11 \\
\hline Strieth S. & V07.2 & Trinh Q.-D. & V02.5, 3K03.5, 3K06.14, & Wachabauer D. & $3 \mathrm{~K} 08.16$ \\
\hline Strittmatter F. & V15.2, V15.9 & & 3К06.17 & Wagenlehner $\mathrm{F}$. & V01.2, V13.6 \\
\hline Ströbel P. & V07.6 & Trojan L. & V07.2, V07.6, 3K05.5 & Wagenlehner F.M.E. & V01.1 \\
\hline Struck J. & 3К02.2, 3К02.11 & Troost J. & V14.6 & Wagner $\mathrm{C}$ & V05.3, V05.4 \\
\hline Struck J.P. & $3 \mathrm{~K} 02.7,3 \mathrm{~K} 02.15$ & Truß M.C. & V04.2 & Waidelich R. & V14.6, V15.2, V15.9 \\
\hline Stühler K. & V12.5 & Truss M.C. & V05.2, V05.8 & Wakileh G. A. & V12.5 \\
\hline \multirow[t]{2}{*}{ Stühler V. } & V02.2, V03.2, 3K06.6, & \multirow[t]{2}{*}{ Tsaur I. } & V16.8, V16.9, V17.9, 3K01.2, & Walenkamp A. & $3 K 05.1$ \\
\hline & 3К06.10, 3К06.11 & & 3К02.13, 3К05.15 & Walz S. & V02.2, 3K05.12 \\
\hline Suarez-Ibarrola R. & $3 \mathrm{~K} 01.4$ & \multirow[t]{3}{*}{ Tschirdewahn S. } & V04.6, V17.8, 3К01.6, & Wandel C. & 3К04.17, 3К05.12 \\
\hline Suleja V. & V17.9 & & 3К01.7, ЗК03.3, 3К05.7, & Wang $\mathrm{H}$. & V10.3 \\
\hline Sulser T. & V06.3, 3K08.2 & & $3 \mathrm{~K} 05.8$ & Wang R. & V15.5, V15.9 \\
\hline Sun W. & 3К09.8 & Tsikas D. & V13.7 & Wang W. & $3 \mathrm{~K} 04.9$ \\
\hline Suna A. & V01.3, V01.7 & Tulchiner G. & V03.8, 3K07.17 & Wang $X$. & 3К04.4 \\
\hline Surov A. & V07.5 & Tully K. & $3 K 06.17$ & Waskow C. & V11.1 \\
\hline Syring-Schmandke I. & V12.8 & Turewicz M. & 3K05.16 & Weber F. & 3К07.13 \\
\hline Szarvas T. & V17.8, 3K05.8 & Tutal M. & 3K08.13 & Weber J. & 3К08.14 \\
\hline Szmulewitz R.Z. & 3К09.5 & \multirow[t]{2}{*}{ Tutrone R. } & \multirow[t]{3}{*}{$3 \mathrm{~K} 05.6$} & Weber M. A. & V07.5 \\
\hline \multirow[t]{3}{*}{ Szyper L.M. } & V04.3 & & & Wedel C. & V13.9 \\
\hline & & & & Wehrberger $C$. & V01.6 \\
\hline & & U & & Wei Y. & $3 \mathrm{~K} 07.6$ \\
\hline $\mathrm{T}$ & & Ubrig B. & $3 \mathrm{~K} 08.5$ & Weib P. & V02.6 \\
\hline Tagscherer K. & V16.9 & Ückert S. & V13.7, V13.9 & Weibl P. & V11.6, V11.7 \\
\hline Talhofer P. & V06.1 & Uemura $\mathrm{H}$. & $3 \mathrm{~K} 09.8$ & Weichert W. & V03.9 \\
\hline Talib R. & Fi01.7, V13.8 & Uhlig A. & V07.2, V07.5, V07.6, 3K02.2, & Weikert S. & V05.6 \\
\hline Tamalunas A. & V15.1, V15.2, V15.9, 3K08.9 & & $3 \mathrm{~K} 02.11$ & Weimann A. & V15.4, 3K07.7 \\
\hline Tamalunas A.J. & $3 \mathrm{~K} 08.10$ & Uhlig J. & V07.5, V07.6 & Weinberger S. & V11.1 \\
\hline Tammela T.L.J. & $3 K 01.16$ & Ullrich T. & $3 \mathrm{~K} 01.14$ & Weinke M. & 3K02.15 \\
\hline Tammela T.L. & 3К09.6, 3К09.7 & Ulrich L. & 3К05.12 & Weisenburger $\mathrm{S}$. & V15.6 \\
\hline Tauber S. & 3K08.12 & Umbach R. & V08.8 & Weißflog C. & V05.6 \\
\hline Taubert H. & V02.3, V10.4, 3K04.7, & Umutlu L. & 3К01.6, 3K01.7 & Weiten R. & V12.8 \\
\hline & $3 \mathrm{~K} 05.11$ & Unsal-Kacmaz K. & V17.6 & Welslau M. & 3К06.13 \\
\hline Te A. & $3 \mathrm{~K} 08.7$ & Urbanova K. & V05.3, V05.4 & Welte M. & 3К08.11 \\
\hline Teber D. & V05.2 & & & Wenker K. & V04.4 \\
\hline Temme A. & $3 \mathrm{~K} 04.14,3 \mathrm{~K} 04.15$ & & & Wenzel M. & V10.1, V10.3, V10.7, 3K01.9, \\
\hline Tennstedt P. & V10.1, V10.8 & V & & & 3К09.9 \\
\hline Terbuch A. & $3 \mathrm{~K} 06.5$ & Vajgrt J. & 3K07.16 & Wessels F. & $3 \mathrm{~K} 02.17$ \\
\hline Terris M. & $3 \mathrm{~K} 04.12$ & Vakhrusheva O. & V16.8, V16.9, 3K05.15 & Westhofen T. & V14.5, 3K08.9, 3K08.10 \\
\hline Tezval H. & V07.4, 3K01.12 & Valderrama B.P. & V17.6, 3K06.18 & Wetterauer C. & 3K01.16 \\
\hline Thaiss W. & $3 \mathrm{~K} 07.11$ & Van der Poel H. & $\mathrm{Fi} 02.4$ & Wetterling N. & 3К04.14 \\
\hline Thaler S. & 3К05.1 & Van Koeveringe G. & V11.2 & Wettstein M.S. & V06.3 \\
\hline
\end{tabular}


Abstracts

\begin{tabular}{|c|c|c|c|}
\hline Weyerer V. & 3К04.7 & Ziegler B. & $\mathrm{Fi} 02.4$ \\
\hline Weyler M. & V01.8 & Zigeuner R. & 3К06.5, 3К07.14 \\
\hline \multirow[t]{2}{*}{ Wezel F. } & V17.3, 3K04.3, 3K04.4, & Zilles M. & $3 \mathrm{~K} 09.13$ \\
\hline & 3К04.5, 3К04.9, 3К07.4 & Zimmermann K. & V12.4 \\
\hline Widmer A. & V14.9 & Zimmermann U. & V17.7, 3К04.1 \\
\hline Wiek C. & $3 K 04.13$ & Zimmermanns V. & $3 \mathrm{~K} 06.2$ \\
\hline Wiemer L. & 3К01.3, 3К02.18 & Zitzelsberger H. & V03.9 \\
\hline Wiesenfarth M. & 3К01.1, 3К01.6, 3К01.7 & Zitzmann M. & V13.2 \\
\hline Wiesinger $C$ & V01.2, 3K06.2 & Zohren F. & 3К09.5 \\
\hline Wießmeyer J.R. & $3 \mathrm{~K} 02.7$ & Zorn K. & 3К08.3 \\
\hline Wild P. & ЗК01.9 & Zorn K.C. & 3К08.5, 3К08.7 \\
\hline Willig J. & 3К02.7 & Zurl H. & 3К07.14 \\
\hline Winter C. & V12.3 & & \\
\hline Winter S. & V03.2, 3К06.10, 3К06.11 & & \\
\hline Wirth M. & V10.6, 3К03.6, 3К06.13 & & \\
\hline Wirtz R. & 3К04.7 & & \\
\hline Wirtz R.M. & V07.2 & & \\
\hline Witjes J.A. & V17.6 & & \\
\hline Witt J.H. & V04.4, V05.3, V05.4 & & \\
\hline Wittan A. & $3 \mathrm{~K} 05.12$ & & \\
\hline Wittler C. & 3К01.9 & & \\
\hline Wolf D. & 3К05.1 & & \\
\hline Wollensak C. & $3 \mathrm{~K} 07.12$ & & \\
\hline Wöllner J. & V11.9, V14.9 & & \\
\hline Wolters M. & $3 \mathrm{~K} 06.2$ & & \\
\hline Wülfing C. & 3К02.16, 3К08.12 & & \\
\hline Wullich B. & $\begin{array}{l}\text { V02.3, V10.4, 3K04.7, } \\
\text { 3К05.11, 3К07.4 }\end{array}$ & & \\
\hline Wunderlich $\mathrm{H}$. & V16.7 & & \\
\hline Wundrack F.-M. & V02.7 & & \\
\hline Würkner D. & V05.1 & & \\
\hline Würnschimmel C. & $\begin{array}{l}\text { V10.1, V10.3, V10.7, 3K01.9, } \\
\text { 3К09.9 }\end{array}$ & & \\
\hline Wüstmann N. & 3К09.17 & & \\
\hline Wyler S.F. & 3К01.16 & & \\
\hline \multicolumn{4}{|l|}{$Y$} \\
\hline Yakac A.E. & V06.1 & & \\
\hline Yassin A. & Fi01.7, V13.4 & & \\
\hline Ye D. & V17.6, 3K09.8 & & \\
\hline Yirga L. & 3К05.8 & & \\
\hline Younsi N. & V14.8 & & \\
\hline Yue F. & 3К03.11 & & \\
\hline Yuen-Chun Teoh J. & 3К04.11 & & \\
\hline
\end{tabular}

Z

Zaccagnino A. V03.4, V03.5, V03.7

Zappa M. $\quad 3 K 01.16$

Zappe H. 3K07.12

Zarbl R. V07.2

Zardavas D. $\quad$ V17.6

Zehe V. $\quad 3$ K02.11, 3K04.4, 3K04.5

Zeng L. V13.3

Zengerling $\mathrm{F} . \quad \mathrm{V} 17.3, \mathrm{~V} 17.7,3 \mathrm{~K} 04.4$,

3K04.5, 3K04.8, 3K04.9,

3K06.12, 3K07.4

Zermann D.-H. $\quad$ V14.4, V14.7, 3K06.3

Zeugner S. V10.9

Zeuschner P. V03.1, V03.4, V03.5, 3K03.9,

3К06.1, 3K06.9, 3K06.12

Zhang C. $\quad 3$ K04.5

Zhang J. $\quad 3 K 06.16,3$ K 09.12

Zhang K. $\quad 3$ K09.8

Zhang S. $\quad 3$ KO 07.5

Zheng X. 3K04.4, 3K04.8, 3K04.9

S114 Der Urologe · Suppl 1 2021 